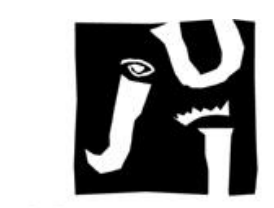

UNIVERSITAT

JAUME•I

UNIVERSITAT JAUME I

FACULTAD DE CIENCIAS DE LA SALUD

DEPARTAMENTO DE PSICOLOGÍA EVOLUTIVA, EDUCATIVA,

SOCIAL Y METODOLOGÍA

\title{
CIBERBULLYING Y ORIENTACIÓN EDUCATIVA. DISEÑO Y EVALUACIÓN DE UN PROGRAMA DE PREVENCIÓN PARA ALUMNADO DE EDUCACIÓN PRIMARIA
}

TESIS DOCTORAL

Presentada por:

Mercedes Romero Oliver

DIRECTORES:

Dra. Raquel Flores Buils

Dr. José Manuel Gil Beltrán

Dr. Antonio Caballer Miedes

Castellón, 2017 

CIBERBULLYING Y ORIENTACIÓN EDUCATIVA. DISEÑO Y EVALUACIÓN DE UN PROGRAMA DE PREVENCIÓN PARA ALUMNADO DE EDUCACIÓN PRIMARIA 

A mi padre Fernando y a José Manuel, quienes además de transmitirme su vocación investigadora, me orientaron, ayudaron y estimularon constantemente $y$ directamente en todos los aspectos de la tesis durante estos años. Sois un fiel ejemplo a seguir. 



\section{AGRADECIMIENTOS}

Deseo expresar mi agradecimiento en primer lugar a mis directores de tesis, los doctores; Raquel Flores, José Manuel Gil y Antonio Caballer. Por su paciencia, dedicación, entusiasmo y criterio. No hubiese podido elegir mejores directores, ha sido un privilegio poder contar con vuestra guía y ayuda. A Miguel Martínez, por su inestimable ayuda a lo largo de toda la tesis.

A los centros educativos de la localidad de Nules que han participado en esta tesis y a todos sus docentes. A los equipos directivos del CEIP Pio XII y CEIP Lope de Vega, en especial a sus directoras, Soledad y Carmen. Y por supuesto, a los docentes tutores del CEIP Pio XII, por su confianza y dedicación hacía nuestro proyecto; Mari Carmen, Rosa, Vicent y Rosa.

Gracias a Conselleria de Educación por su disposición hacia este proyecto, en especial a Vicent Domenech, Inspector Jefe de la Inspección Técnica de Castellón, y a Gisela Morales, Inspectora de Educación de Castellón.

A mis padres, Fernando y Merche, por ser el pilar fundamental en todo lo que soy, por la educación y los valores que me habéis inculcado y por vuestro incondicional apoyo. No hay palabras suficientes para agraceros todo lo que significáis para mí.

A mi hermano Ferran, por acompañarme cada día y transmitirme tanta felicidad. Ahora te toca a ti.

A mis abuelos, por dejar en mi esa huella y vocación por la educación.

A Jorge, por su apoyo y comprensión incondicional, por transmitirme valores de superación y esfuerzo, y confiar siempre en que lograría alcanzar esta meta. Esta tesis es también tuya. 



\section{ÍNDICE}

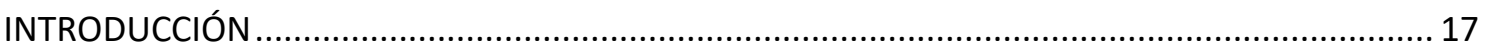

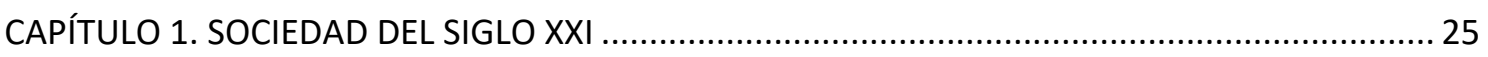

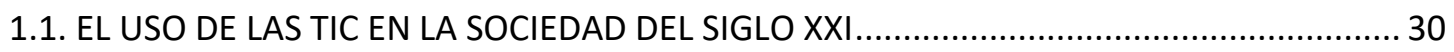

1.1.1. Uso de las TIC en Europa y España......................................................................... 31

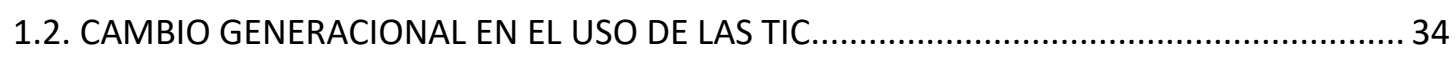

1.2.1. Generación Z: los estudiantes de la sociedad actual ................................................ 36

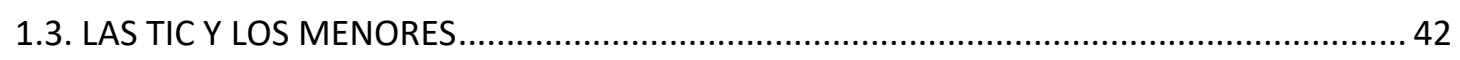

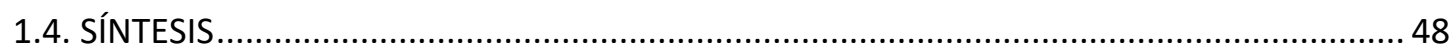

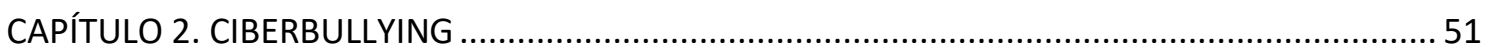

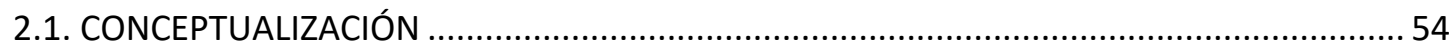

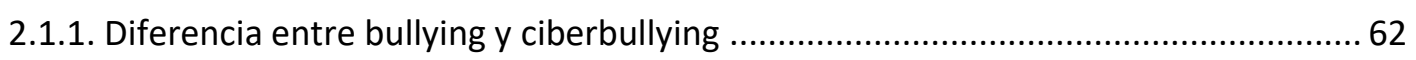

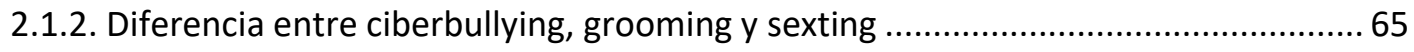

2.2. CIBERBULLYING EN EL CONTEXTO CLÍNICO, EDUCATIVO Y FAMILIAR ............................. 68

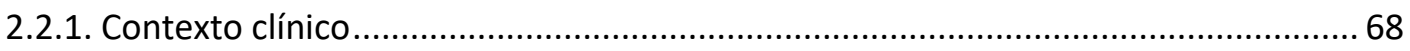

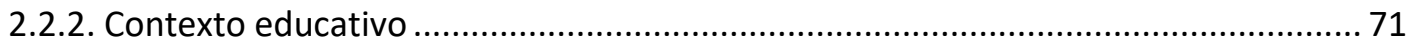

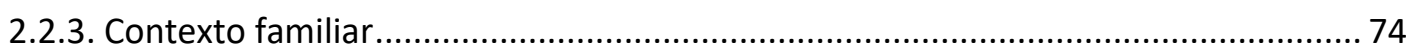

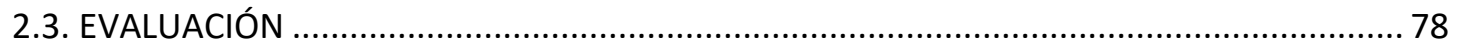

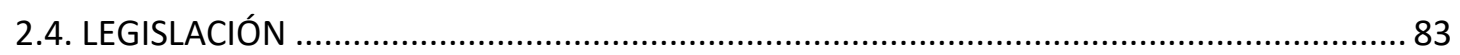

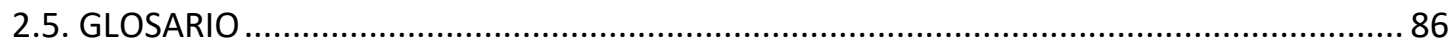

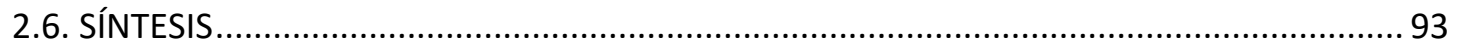

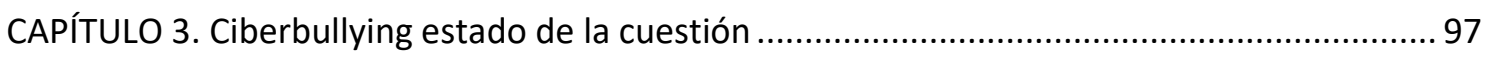

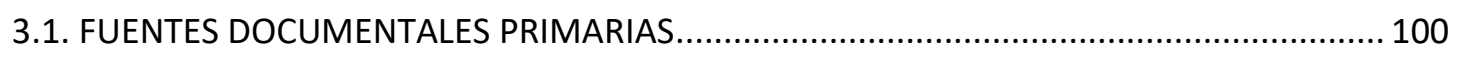

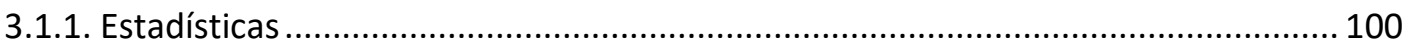

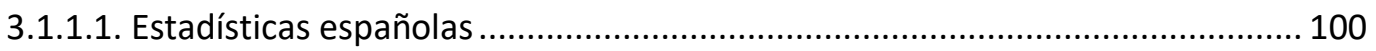

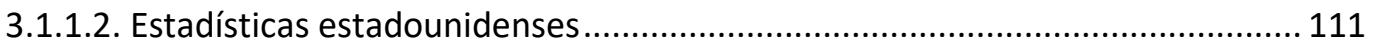

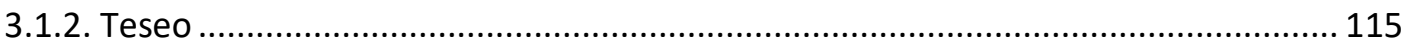

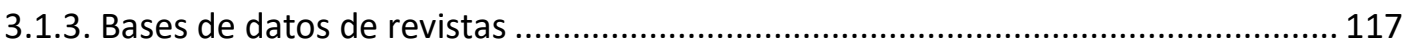

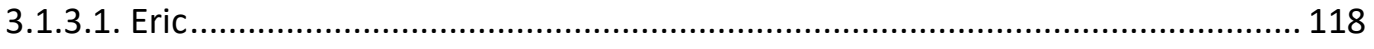

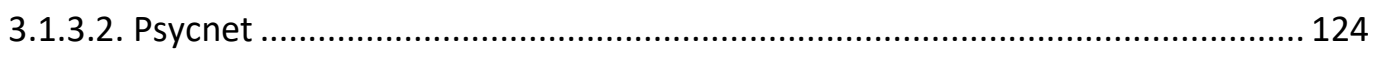

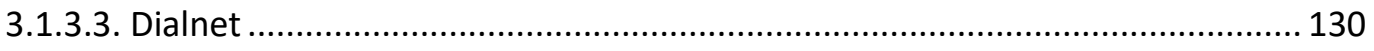


3.2.1. Libros ISBN

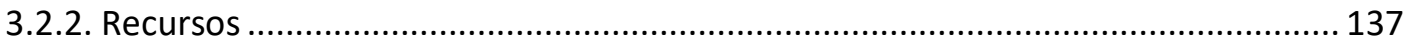

3.2.2.1. Programas ................................................................................... 137

3.2.2.2. Guías......................................................................................... 140

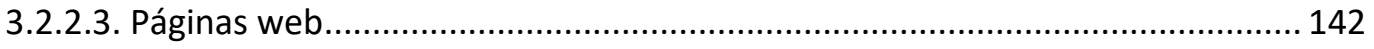

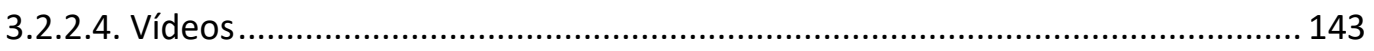

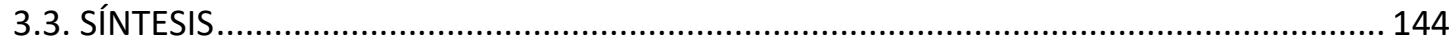

CAPÍTULO 4. ROL DEL PSICÓLOGO EDUCATIVO EN SITUACIONES DE CIBERBULLYING ............ 149

4.1. PSICÓLOGO EDUCATIVO. ¿QUÉ DEBE SABER? ..................................................... 153

4.2. PSICÓLOGO EDUCATIVO Y COMUNIDAD EDUCATIVA. ¿QUÉ HACER? ........................... 156

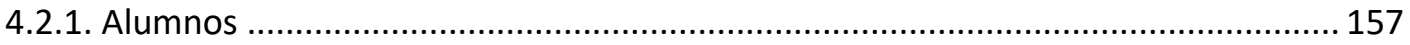

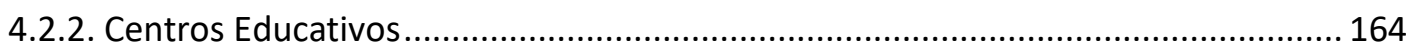

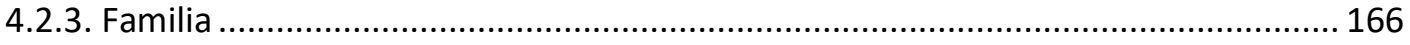

4.3. PLAN DE ACTUACIÓN EN UN CENTRO DE EDUCACIÓN INFANTIL Y PRIMARIA.............. 170

4.4. PLAN DE PREVENCIÓN DE LA VIOLENCIA Y PROMOCIÓN DE LA CONVIVENCIA (PREVI) 176

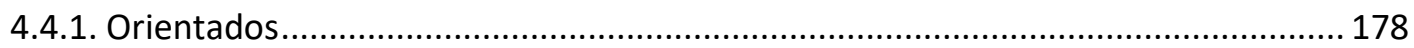

4.4.2. El ciberbullying en el PREVI ................................................................. 180

4.4.2.1. Medidas de prevención dirigidas al sistema educativo ............................. 180

4.4.2.2. Medidas de prevención dirigidas a la población de riesgo ............................ 184

4.4.2.3. Medidas de prevención dirigidas a toda la sociedad valenciana ................... 185

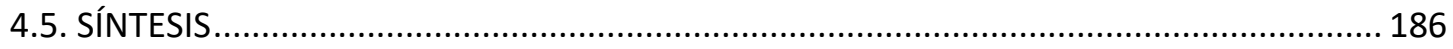

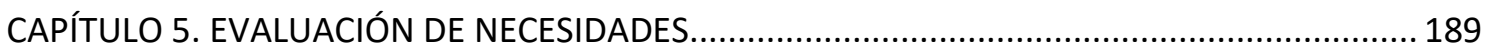

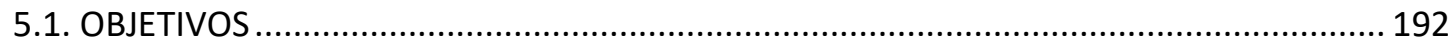

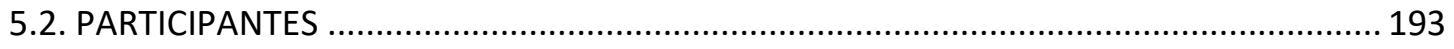

5.2.1. Participantes: profesorado................................................................. 193

5.2.2. Participantes: familias ...................................................................... 194

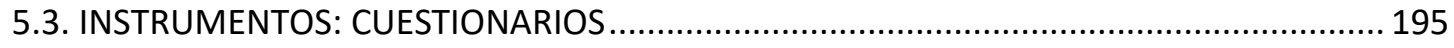

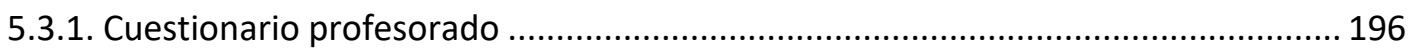

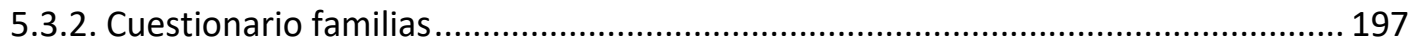

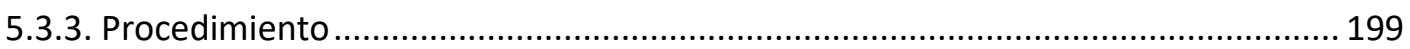


5.4. RESULTADOS Y VALORACIÓN DE LAS NECESIDADES................................................. 200

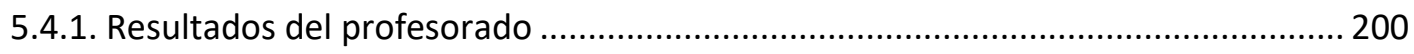

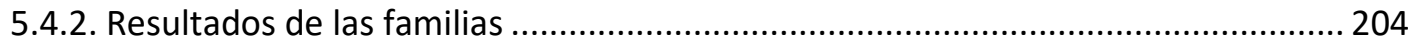

5.4.3. Análisis de los resultados y valoración de necesidades .......................................... 206

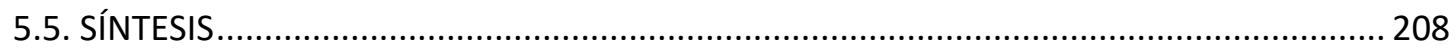

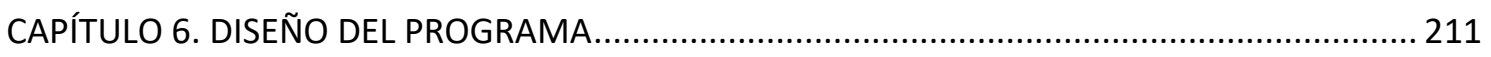

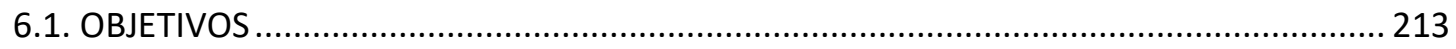

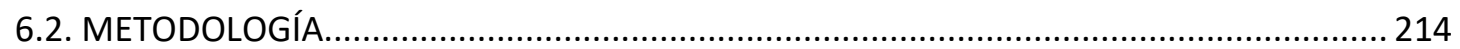

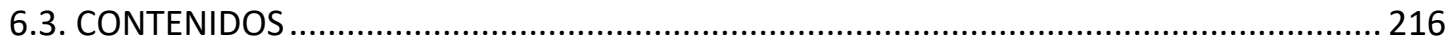

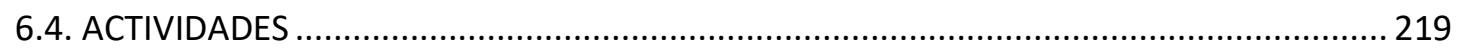

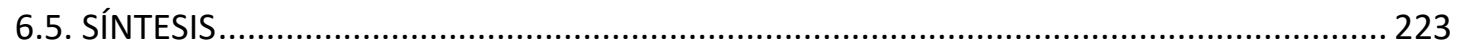

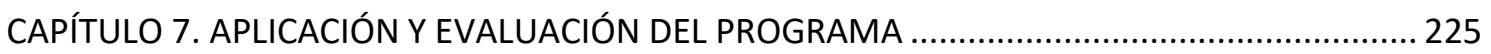

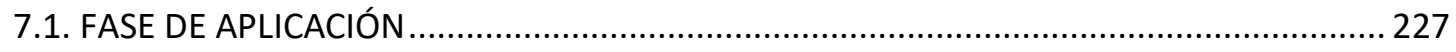

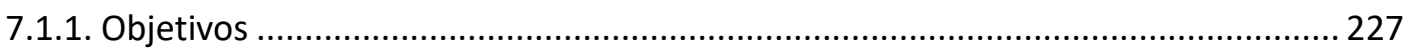

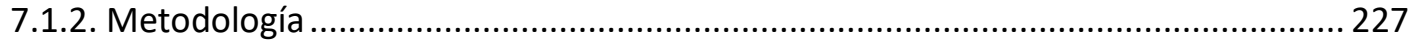

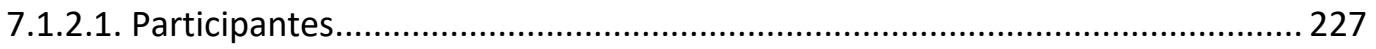

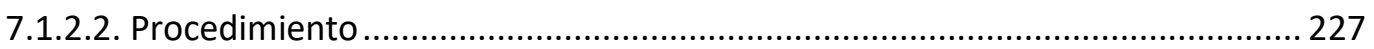

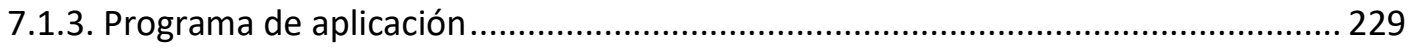

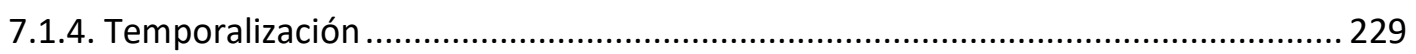

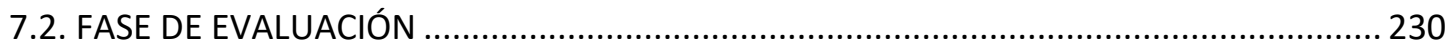

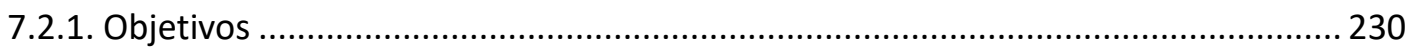

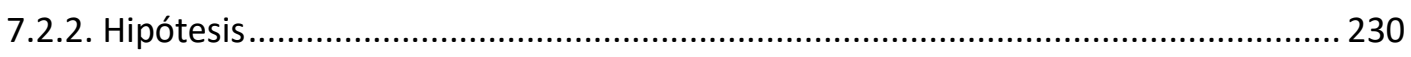

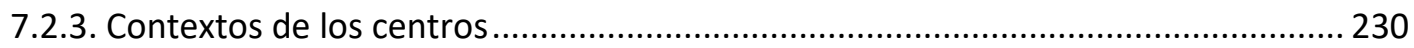

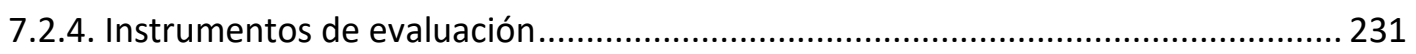

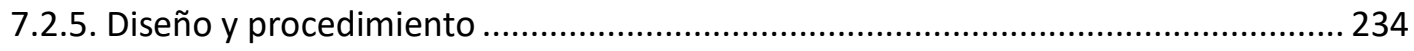

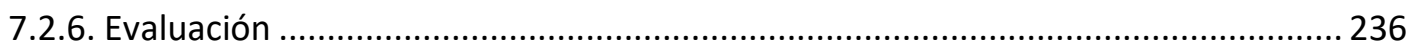

7.2.6.1. Evaluación en el segundo ciclo (3ํy 4으) de Educación Primaria ...................... 237

7.2.6.1.1. Evaluación CEE en el segundo ciclo Educación Primaria............................. 237

7.2.6.1.2. Evaluación Escaciber en el segundo ciclo Educación Primaria................... 241

7.2.6.2. Evaluación en el tercer ciclo (5ㅇ y 6으) de Educación Primaria .......................... 245

7.2.6.2.1. Evaluación CEE en el tercer ciclo Educación Primaria............................... 245 


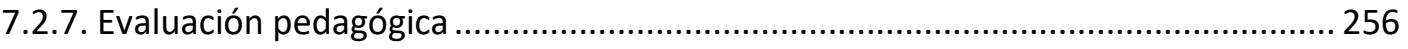

7.2.7.1. Resultados de la evaluación de los alumnos ........................................... 256

7.2.7.2. Resultados de la evaluación de los profesores ...................................... 260

7.2.7.3. Análisis de los resultados ............................................................. 262

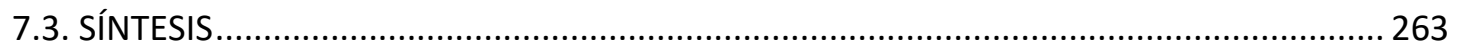

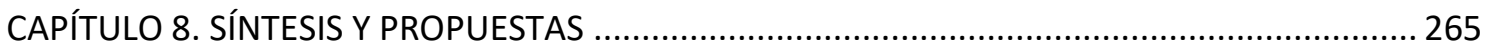

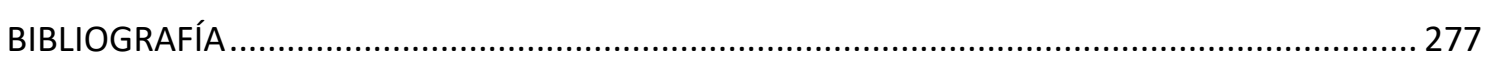

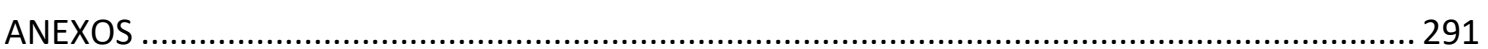

\section{ÍNDICE DE TABLAS}

Tabla1. Comparación entre las distintas generaciones ..................................................... 36

Tabla 2. Resumen de experiencias negativas online, según la edad (Garmendia et al., 2016)... 46 Tabla 3. Resumen de experiencias de daño de los/as menores, según la edad (Garmendia et al., 2016).

Tabla 4. Descripciones del fenómeno ciberbullying (Dalla, Di Prieto, Morel \& Psaila, 2016) ..... 55

Tabla 5.1. Principales características de las definiciones de los estados ................................. 57

Tabla 5.2. Aspectos característicos que incluyen diferentes autores en las definiciones de

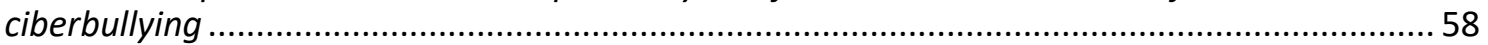

Tabla 6. Características del bullying y del ciberbullying respecto a variables que los integran .. 63

Tabla 7. Estudios en relación a las consecuencias del ciberbullying

Tabla 8.Instrumentos nacionales para evaluar el Ciberbullying: Características conceptuales y psicométricas (Lucas et al., 2016).

Tabla 9. Instrumentos internacionales para evaluar el cyberbullying: Características conceptuales y psicométricas (Lucas et al., 2016)................................................................ 81

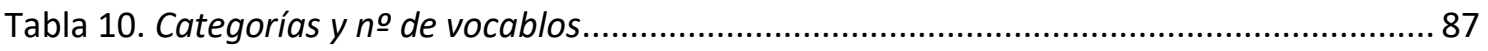

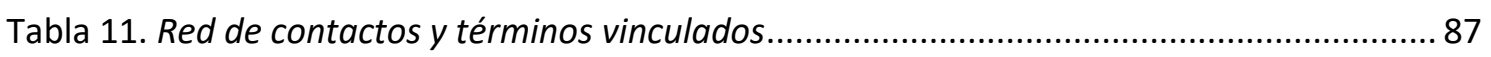

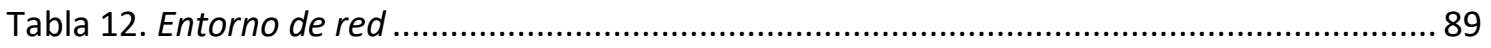

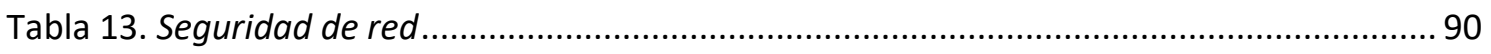

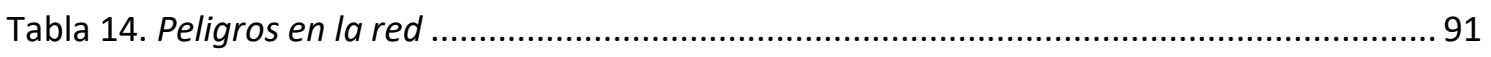

Tabla 15. Herramientas y dispositivos tecnológicos................................................................ 92

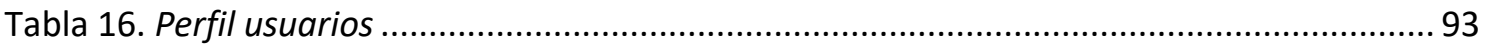

Tabla 17. Porcentaje de niños y niñas víctimas según motivos y según tipo de victimización. Promedio España (\%) (Calmaestra et al., 2016).......................................................... 108

Tabla 18. Motivos de ciberagresión por género, ciclo educativo y origen y promedio España (\%) (Calmaestra et al., 2016). 
Tabla 19. Las estrategias de afrontamiento según grado de acuerdo de las víctimas de acoso $o$ ciberacoso. (Calmaestra et al. ,2016).

Tabla 20. Características de la personalidad (autoestima, empatía y habilidades sociales) tanto de la víctima como del agresor (Calmaestra et al., 2016). 110

Tabla 21. Tesis Doctorales relacionadas con el Ciberbullying publicadas en España. 117

Tabla 22. Datos recogidos en cada una de las bases de datos 118

Tabla 23. № de artículos por años y país de procedencia de la institución que realiza el estudio(Base de datos ERIC). 120

Tabla 24. № de autores que publican sobre Ciberbullying(Base de datos ERIC)

Tabla 25. № de autores que participan en una misma publicación(Base de datos ERIC).

Tabla 26. Revistas en las que se han publicado artículos relacionados con Ciberbullying (Base de datos ERIC)

Tabla 27. № de artículos que se han publicado por año y el número de revistas que los publican(Base de datos ERIC)

Tabla 28. № de artículos por años y país de procedencia de la institución que realiza el estudio (Base de datos PSYCNET)

Tabla 29. № de autores que publican sobre Ciberbullying (Base de datos PSYCNET)

Tabla 30. № de autores que participan en una misma publicación (Base de datos PSYCNET). 127

Tabla 31. Revistas en las que se han publicado artículos relacionados con Ciberbullying (Base de datos PSYCNET)

Tabla 32. № de artículos que se han publicado por año y el número de revistas que los publican

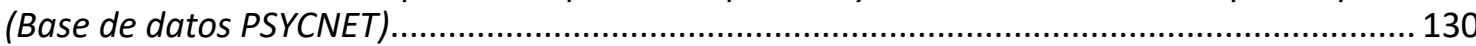

Tabla 33. № de artículos por institución que realiza el estudio (Base de datos DIALNET) ........ 132

Tabla 34. № de autores que publican sobre Ciberbullying (Base de datos DIALNET) ................ 132

Tabla 35. № de autores que participan en una misma publicación (Base de datos DIALNET) 133

Tabla 36. Revistas en las que se han publicado artículos relacionados con Ciberbullying (Base de datos DIALNET). 134

Tabla 37. № de artículos que se han publicado por año y el número de revistas que los publican

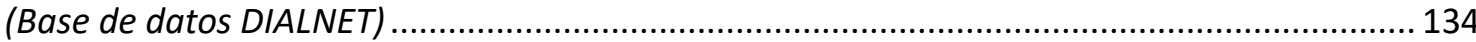

Tabla 38. Libros publicados en España sobre ciberacoso, ciberbullying y cyberbullying. .......... 136

Tabla 39. Síntesis análisis Revistas Científicas......................................................................... 146

Tabla 40. Protocolo de actuación para el Centro Educativo en casos de ciberbullying ............. 173

Tabla 41. Protocolo de actuación para la familia en casos de ciberbullying.............................. 175

Tabla 42. Muestra de los docentes participantes por nivel en el que imparten docencia. ........ 193

Tabla 43. Descripción de la muestra de los docentes participantes........................................... 193

Tabla 44. Muestra de los padres y madres participantes. ....................................................... 194

Tabla 45. Descripción de la muestra de los padres y madres participantes.............................. 195

Tabla 46. Datos de las medias y desviaciones típicas de los resultados de los ítems del bloque I

Tabla 47. Datos de las medias y desviaciones típicas de los resultados de los ítems del bloque II 202

Tabla 48. Datos de las medias y desviaciones típicas de los resultados de los ítems del bloque III 
Tabla 49.Datos de las medias y desviaciones típicas de los resultados de los ítems del bloque IV

Tabla 50. Datos de las medias y desviaciones típicas de los resultados de los ítems del bloque $V$

Tabla 51. Datos de los porcentajes de los resultados de los ítems del bloque I ...................... 204

Tabla 52. Datos de los porcentajes de los resultados de los ítems del bloque II ...................... 205

Tabla 53. Datos de los porcentajes de los resultados de los ítems del bloque III ....................... 206

Tabla 54. Datos de los porcentajes de los resultados de los ítems del bloque IV ..................... 206

Tabla 55. Resumen cuaderno contenidos tercero curso de Educación Primaria ...................... 219

Tabla 56. Resumen cuaderno contenidos cuarto curso de Educación Primaria ........................ 220

Tabla 57. Resumen cuaderno contenidos quinto curso de Educación Primaria ........................ 220

Tabla 58. Resumen cuaderno contenidos sexto curso de Educación Primaria......................... 221

Tabla 59.Actividades incluidas en cada curso y clasificadas por temáticas ............................. 221

Tabla 60. Características contextuales de ambos centros. ................................................. 231

Tabla 61. Número de participantes según género en CEE en el segundo ciclo de primaria...... 237

Tabla 62. Número de participantes según curso escolar en CEE en el segundo ciclo de primaria.

Tabla 63. Número de participantes según edad en CEE en el segundo ciclo de primaria......... 238

Tabla 65. Resultados CEE segundo ciclo pretest grupo experimental y prestest grupo control 239

Tabla 66.Resultados CEE segundo ciclo pretest y postest del grupo experimental.................. 240

Tabla 67.Resultados CEE segundo ciclo pretest y postest del grupo control............................ 240

Tabla 68. Resultados CEE segundo ciclo postest del grupo control y experimental.................. 241

Tabla 69. Número de participantes según curso escolar en Escaciber en el segundo ciclo de primaria.

Tabla 70. Número de participantes según género en Escaciber en el segundo ciclo de primaria.

Tabla 71.Uso de las redes sociales y mensajería instantánea en el segundo ciclo de primaria.243

Tabla 72. Resultados Escaciber segundo ciclo pretest grupo experimental y prestest grupo

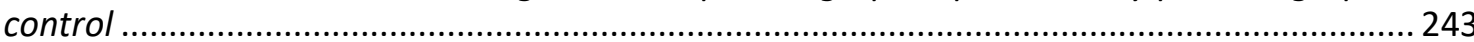

Tabla 73.Resultados Escaciber segundo ciclo pretest y postest del grupo experimental.......... 244

Tabla 74. Resultados Escaciber segundo ciclo pretest y postest del grupo control.................. 244

Tabla 75.Resultados Escaciber segundo ciclo postest del grupo control y experimental.......... 245

Tabla 76.Número de participantes según género en CEE en el tercer ciclo de primaria........... 246

Tabla 77.Número de participantes según curso escolar en CEE en el tercer ciclo de primaria. 246

Tabla 78.Número de participantes según edad en CEE en el tercer ciclo de primaria..............246

Tabla 79. CEE tercer ciclo. Prueba de normalidad de Kolmogorov-Smirnov, significación de la prueba.

Tabla 80. Resultados CEE tercer ciclo, pretest grupo experimental y prestest grupo control... 248

Tabla 81.Resultados CEE tercer ciclo, pretest y postest del grupo experimental ..................... 248

Tabla 82. Resultados CEE tercer ciclo, pretest y postest del grupo control.............................. 249

Tabla 83. Resultados CEE tercer ciclo, postest grupo experimental y postest grupo control..... 250 
Tabla 84.Número de participantes según curso escolar en Escaciber en el tercer ciclo de primaria.

Tabla 85.Número de participantes según género en Escaciber en el tercer ciclo de primaria. 251 Tabla 86. Uso de las redes sociales y mensajería instantánea en el tercer ciclo de primaria. ... 251 Tabla 87.Resultados Escaciber tercer ciclo, pretest grupo experimental y pretest grupo control

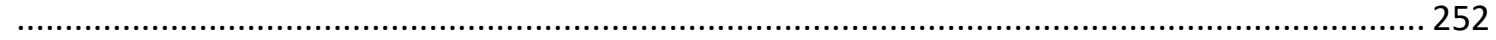

Tabla 88. Resultados Escaciber tercer ciclo, pretest-postest grupo experimental ................... 253

Tabla 89.Resultados Escaciber tercer ciclo, pretest-postest grupo control. 253

Tabla 90. Resultados Escaciber tercer ciclo, postest grupo experimental y postest grupo control

\section{ÍNDICE DE FIGURAS}

Figura 1. Hogares con acceso a Internet 2014 y 2015

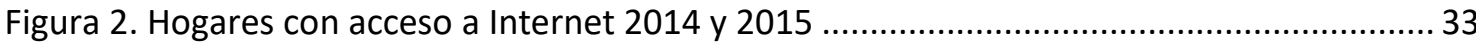

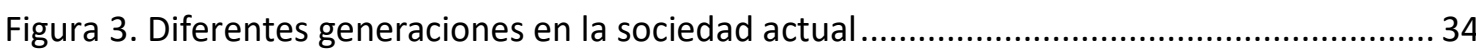

Figura 4. Porcentaje de niños y niñas víctimas de acoso y ciberacoso según género. Promedio España (Calmaestra et al., 2016). 102

Figura 5. Porcentaje de niños y niñas que han sido víctimas de ciberacoso por CCAA. Promedio España (Calmaestra et al., 2016).

Figura 6. Porcentaje de niños y niñas víctimas de acoso y ciberacoso según género. Promedio España (Calmaestra et al., 2016).

Figura 7. Porcentaje de niños y niñas víctimas de acoso y ciberacoso según ciclo educativo.

Promedio España (Calmaestra et al., 2016).

Figura 8.Porcentaje de niños y niñas que han vivido de forma ocasional o frecuente situaciones de violencia en internet o con el teléfono móvil en los últimos dos meses. Promedio España

(Calmaestra et al., 2016).

Figura 9.Porcentaje de niños y niñas agresores de acoso y ciberacoso según ciclo educativo.

Promedio España (Calmaestra et al., 2016).

Figura 10. Porcentaje de niños y niñas agresores de acoso y ciberacoso según ciclo educativo.

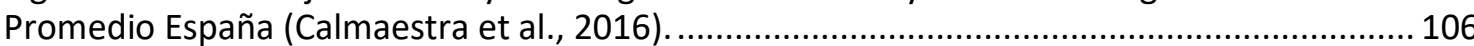

Figura 11. Porcentaje de niños y niñas agresores de acoso y ciberacoso según género.

Promedio España (Calmaestra et al., 2016). 106

Figura 12.Porcentaje de estudiantes que han provocado de forma ocasional o frecuente situaciones de agresión en internet o con el teléfono móvil en los últimos dos meses. Promedio España (Calmaestra et al., 2016).

Figura 13.Uso de las tecnologías por parte de los adolescentes (12-17 años). Actividades semanales (Hinduja \& Patchin, 2016b)

Figura 14.Victimización ciberbullying (Hinduja \& Patchin, 2016a)

Figura 15.Prevalencia en relación al género (Hinduja \& Patchin, 2016b).

Figura 16.Tasas de victimización por ciberbullying a lo largo de estos últimos años (Hinduja \& Patchin, 2016c)......

Figura 17. Tasas de victimización por ciberbullying a lo largo de estos últimos años (Hinduja \&

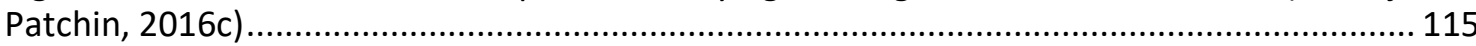

Figura 18.Número de artículos por año (Base de datos ERIC) 119 
Figura 19.Número de artículos por año (Base de datos PSYCNET)

Figura 20. Número de artículos por año (Base de datos DIALNET)

Figura 21. Protocolo de Intervención en situaciones que afectan la convivencia (Félix, Soriano, Godoy \& Martínez, 2008)

Figura 22. Diseño cuasi experimental con un grupo de control no equivalente pretest y postest, adaptado a nuestro estudio.

Figura 23.Porcentaje de respuestas correctas en cada pregunta en la evaluación pedagógica de 3ㅇ de Ed. Primaria.

Figura 24.Porcentaje de respuestas correctas en cada pregunta de la evaluación pedagógica de 4을 de $d$. Primaria.

Figura 25.Porcentaje de respuestas correctas en cada pregunta de la evaluación pedagógica de 5ㅇ de Ed. Primaria.

Figura 26. Porcentaje de respuestas correctas en cada pregunta en la evaluación pedagógica de 6ㅇ de Ed. Primaria.

Figura 27. Resultados de la evaluación pedagógica a los docentes del segundo ciclo de Ed. Primaria.

Figura 28. Resultados de la evaluación pedagógica a los docentes del tercer ciclo de Ed. Primaria. 


\section{INTRODUCCIÓN}

A lo largo de nuestra vida académica y sobre todo profesional, nos hemos preguntado una serie de cuestiones y también hemos reflexionado sobre cuál es nuestra labor en el ámbito educativo, y cómo el abordaje de estas situaciones que se nos presentan podría mejorar significativamente la calidad educativa de nuestros centros.

Día tras día, los docentes comparten sus pensamientos e inquietudes; son conscientes de las dificultades que se encuentran en su labor docente, muchas veces valoran las situaciones y se dan cuenta que les faltan recursos para abordarlos, y es entonces cuando nos muestran su preocupación por ello.

$Y$ es que, las respuestas a los problemas que suceden en los centros escolares surgen mayoritariamente como reacciones a casos graves que tienen repercusiones mediáticas. Todo ello, se debe a que estas situaciones que se producen en los centros educativos permanecen invisibles a los ojos de quienes no están día a día en las aulas, bien sea por la escasez de datos, y ello se traduce en una ausencia de respuestas institucionales sistemáticas, cuando lo que realmente se requiere es la puesta en marcha de estrategias más amplias de lucha integral cuyo enfoque principal se debe basar en el interés superior de los niños y niñas.

Son muchas las problemáticas que podríamos englobar dentro de esta visión de la realidad educativa y docente sobre la que acabamos de reflexionar, sin embargo a nosotros hay un fenómeno que nos preocupa especialmente, pues cumple a la perfección las características anteriormente citadas; el ciberbullying.

Cada vez que la humanidad ha sido capaz de realizar un salto cualitativo y significativo en la tecnología y en la capacidad de comunicarse, esto ha conllevado profundas consecuencias culturales, sociales y económicas (Roca, 2015).

La sociedad actual en la que nos encontramos, afronta una nueva revolución; la revolución digital basada en las nuevas formas de generar y hacer circular información. Las TIC, que es así como denominamos a las tecnologías de la información y la comunicación, entraron en nuestra sociedad para quedarse y para seguir evolucionando, y lo han hecho a un ritmo vertiginoso en tan solo una generación.

Todo ello nos hace plantearnos a dónde nos van a llevar las TIC, qué impacto tendrán en nosotros y cómo cambiarán nuestro día a día. Esta reflexión nos lleva a pensar que tal vez las tecnologías influyen sobre nosotros, pero no debemos olvidar que nosotros también influimos en ellas, sin saber qué es la causa y qué la consecuencia. Y es que las TIC surgen de las necesidades que nosotros creamos. Y por supuesto, todo cambio que llega a nuestras vidas requiere un tiempo de adaptación y un trabajo de prueba error.

Así, la incorporación de las TIC en nuestra sociedad se ha producido en tan solo una generación, pero ha conllevado que todas las generaciones presentes en nuestra sociedad hayan visto modificados sus hábitos e incorporado las TIC en su día a día, tanto 
en España como en Europa, como podremos ver en los datos ofrecidos en informes publicados en este último año (INTEF, 2016).

Por tanto, bien sabemos que el uso de las TIC influye en la sociedad en su conjunto, pero, ¿cómo están afectando las TIC a la llamada Generación Z? Esta generación es la formada por todos aquellos niños y jóvenes que hoy en día encontramos en nuestros centros educativos, y que junto con otras generaciones se les conoce como nativos digitales (Prensky, 2001) ya que han nacido y crecido con las TIC. A pesar de ello, no siempre disponen de la información necesaria para hacerlo responsablemente y siendo conscientes de las posibles amenazas y riesgos que su uso implica. Ante todo esto, se hace necesario preguntarnos, ¿cuál es el papel de la educación para esta Generación Z? Para ello es necesario conocer bien cuáles son las características de esta generación, así como las necesidades concretas que requieren sobre todo en el ámbito educativo, y por tanto hay que conocer el uso real que hacen de las TIC y los riesgos a los que se exponen.

$Y$ es que cuando hacemos uso de las TIC y con ello de internet, aspectos que actualmente no se pueden desvincular, nos encontramos una gran diversidad de dificultades $y$ riesgos; gente desconocida con malas intenciones, otros con fines perversos, acceso a información inadecuada, riesgos técnicos, pérdida de privacidad, suplantación de identidad, adicción a los dispositivos, etc.

Pero si hay un riesgo realmente peligroso para los menores, este es el ciberbullying. Podemos afirmar que es uno de los tipos de maltrato entre iguales que más se está detectando en estos últimos años, más recientes debido a los avances tecnológicos y que va en aumento, siendo uno de los problemas más complejos con los que nos encontramos, ya que suele tener repercusiones indeseables (Avilés, 2013).

Por ello abordaremos el fenómeno del ciberbullying en esta investigación, siendo conscientes de la actualidad del fenómeno. Así, el primer estudio realizado sobre ciberbullying fue realizado por Finkelhor, Mitchell \& Wolak (2000) en Estados Unidos, y a partir de ahí, tal y como ponen de manifiesto Lucas, Pérez \& Giménez (2016), han sido abundantes las investigaciones que se han llevado a cabo sobre el ciberbullying, tanto fuera como dentro de nuestro país. Sin embargo, aún conociéndose principalmente la prevalencia del ciberbullying y su relación con otras variables psicosociales, sigue sin existir una definición universalmente consensuada. A pesar de los muchos los intentos en definir este fenómeno, tanto por parte de organizaciones internacionales, como de instituciones de la Unión Europea (Dalla, Di Prieto, Morel \& Psaila, 2016) y del mundo académico (Aftab, 2010; Ferro, 2013; Smith, 2000; Willard, 2005, entre otros).

Entre todas ellas, podemos considerar la definición de Smith (2000) una de las más adecuadas, aunque algo incompleta, pues define el ciberbullying como acto agresivo e intencional realizado por un grupo o un individuo, usando las formas electrónicas de contacto, repetidamente y contra una víctima que no puede defenderse fácilmente. De ahí la necesidad de elaborar una definición que contemple todas las características 
propias del ciberbullying, diferenciándolo de otros tipos de acoso como el bullying, o fenómenos como el sexting y el grooming; así como también de disponer de una categorización de conceptos relacionados con este fenómeno con la finalidad de clarificarlo.

En cuanto a la evaluación en el ciberbullying, este es un aspecto muy relevante puesto que, como cualquier otro fenómeno, una evaluación eficaz facilita la detección precoz y la correcta intervención. A pesar de su importancia y necesidad, autores como Lucas et al. (2016) destacan que debido a la inestabilidad de la conceptualización se han utilizado diferentes metodologías en la evaluación, y en lo que respecta a los instrumentos españoles todos ellos dirigidos a la etapa de Educación Secundaria, evaluando dimensiones diversas en base a una falta de definición única del ciberbullying.

Todo ello ha llevado a generar una gran cantidad de investigaciones y publicaciones sobre el ciberbullying, existiendo una gran dispersión entre ellas, y con ello surge la necesidad de saber cuál es el estado de la cuestión actual, a partir del análisis de diferentes fuentes documentales.

Fenómenos tan peligrosos como el ciberbullying van haciendo que cada vez la sociedad sea más consciente de lo que conlleva en los menores el uso de las TIC, y es por ello que trabajamos para combatirlos y minimizarlos, porque sabemos que la tecnología implica riesgos pero también nos ofrece muchas oportunidades.

Así, el abordaje del ciberbullying implica que los menores desarrollen ciertas habilidades y competencias que les permitan aprender a gestionar la gran cantidad de información de la que disponen, a relacionarse por medio de las TIC, a proteger su privacidad, previniendo así nuevos tipos de exclusión y violencia entre iguales. Todo ello lleva la necesidad de modificar todo nuestro entorno, y con ello nuestros centros escolares.

$\mathrm{Y}$, ¿quiénes somos los responsables de enseñar a desarrollar estas habilidades y competencias en los menores, y con ello normalizar los usos de esta poderosa tecnología? Por mi formación como maestra y como psicopedagoga, profesión que ejerzo con gran vocación, consideramos que aunque la escuela no es la causante ni el único lugar donde nace el ciberbullying, sí forma parte de su solución, ya que la educación y el entorno educativo en su conjunto son claves para combatir este tipo de acoso entre iguales. A pesar de ello, remarcamos la necesidad de una implicación común de la sociedad en la lucha contra el acoso, en concreto una concienciación en los equipos directivos y en las familias, puesto que sólo conseguiremos terminar con el acoso trabajando en equipo de modo coordinado (García, Joffre, Martínez \& Llanes, 2011).

Así, consideramos que la escuela, aún siendo el ciberbullying un modo de acoso entre iguales que no se produce normalmente en el entorno escolar, toma una especial relevancia puesto que el ciberbullying sí se establece a partir de relaciones que suelen emerger en la vida escolar. Y es que la escuela debe ofrecer una educación de calidad que promueva la capacidad de comprender términos como el respecto a uno mismo, el 
respecto a los demás, la importancia de la privacidad, la existencia de información sensible que no debe ser revelada, o de información que no se adecua a su edad, etc. (Hidalgo, 2015), ya que estas habilidades no las han desarrollado aún los menores que hacen uso de las TIC de manera habitual, y por todo ello es muy complicado que el menor por si solo aprenda a navegar de forma segura.

En concreto es el psicólogo educativo el que debe asumir un papel relevante en cuanto al desarrollo de estrategias para reducir este tipo de violencia (NASP, 2006), y para ello nos planteamos cuestiones como ¿qué debe saber sobre este fenómeno? y ¿qué debe hacer al respecto? Todo ello teniendo en cuenta que el orientador debe atender a los tres grandes grupos que están relacionados con las situaciones de ciberbullying: familia, centro y alumno, y trabajará con ellos aspectos como son la sensibilización, prevención, detección, intervención y seguimiento.

De este modo, nuestra investigación se va a centrar en la prevención, puesto que nuestra sociedad así lo demanda, y en concreto los centros educativos y sus docentes. Las iniciativas, programas y proyectos llevados a cabo por la Unión Europea con respecto al ciberbullying y que existen en la actualidad a nivel europeo, entre los que encontramos; "Better internet for Kids programme", "Safer Internet programme" o "Daphne Programme" (Dalla et al., 2016), no se centran en los aspectos que nosotros consideramos oportunos para una prevención realmente eficaz de este fenómeno en menores, por su metodología y porque se centran en la Educación Secundaria. Líneas de trabajo que coinciden con los proyectos desarrollados por los dos grandes grupos de investigación sobre el ciberbullying de nuestro país, encabezados por las doctoras Garaigordobil y Ortega.

Por todo ello, y teniendo en cuenta uno de los últimos estudios publicados por Save the Children (Calamestra et al., 2016), se plantea y desarrolla una serie de retos y recomendaciones acerca de las acciones necesarias para hacer frente al ciberbullying. Respecto a los retos indican, entre otros:

- España carece de un abordaje integral de lucha contra todas las formas de violencia en la infancia.

- Hay que tratar el tema con confidencialidad, y la respuesta debe ser educativa y socializadora.

- Involucrar a los niños es la mejor forma de sensibilizarles contra estas formas de violencia.

- El trabajo de prevención de la violencia con los niños y niñas es la mejor manera de acabar con otras formas de violencia en la sociedad.

- Es necesario que los centros escolares estén dotados de los profesionales adecuados, con una formación específica y adecuada para llevar a cabo las estrategias de detección e intervención en los casos de acoso y ciberacoso.

- El ciberacoso implica a numerosos agentes (profesores, padres y madres, compañeros, incluso agentes de la autoridad llegado el caso). 
- Una de las claves de éxito de la lucha contra el acoso y el ciberacoso es la implicación de todos los agentes del ámbito educativo, el entorno familiar y los propios niños y niñas.

- Es necesario contar con protocolos de actuación dentro de la escuela que establezcan mecanismos claros y conocidos por todos.

A estas recomendaciones, le siguen los siguientes retos:

- Elaboración de una estrategia integral contra la violencia contra la infancia.

- Toma de conciencia generalizada en la sociedad.

- Formación en acoso y ciberacoso de los profesionales.

- Educación y formación a los niños y niñas en prevención de la violencia. Es importante la educación en valores, como la tolerancia o el respeto a la diversidad; la formación en ciudadanía digital, no limitándose al conocimiento de las tecnologías y a las técnicas de protección online, sino también extendiéndose a las normas de civismo y respeto en el mundo virtual; y la educación emocional dirigida a trabajar la asertividad, la empatía o el pensamiento crítico.

- Elaboración de protocolos y planes de actuación eficaces.

Datos actuales que nos presentan prestigiosos investigadores de la temática y que nos ofrecen una visión de la situación y de las demandas actuales, aspectos que fueron precedidos por otros como los planteados por Orjuela, Cabrera de los Santos, Calmaestra, Mora-Merchán, \& Ortega-Ruiz (2014), quienes indicaron cuáles eran los elementos clave para un buen programa de prevención, entre los que destacamos:

- Formar a toda la comunidad educativa en ciberacoso: directivas, profesores, equipo de orientación, padres y madres y niños y niñas.

- Promover el uso adecuado de las Tecnologías de la Información y la Comunicación promoviendo un uso seguro y responsable.

- Fomento de habilidades como la empatía, la asertividad, la cohesión entre pares, las relaciones basadas en la solidaridad, el respeto mutuo y el rechazo de todas las actitudes violentas.

- Evaluar el impacto de las estrategias de prevención para detectar fortalezas y debilidades de las actuaciones.

- Incluir materiales curriculares donde se aborde el problema del acoso entre escolares.

- Tomar medidas desde edades tempranas para evitar que se establezcan dinámicas de relaciones basadas en el desequilibrio de poder. 
Todas estas aportaciones nos hacen reflexionar, siendo conscientes de nuestra realidad más cercana en los centros escolares de nuestro entorno, consideramos iniciar nuestro proyecto con la finalidad dar respuesta a la necesidad real, y es que si hablamos de prevención en el ciberbullying ésta se debe hacer desde edades más tempranas, teniendo en cuenta que los menores empiezan a hacer uso de las TIC en el primer año de vida.

Prevención que se realizará mediante el diseño y evaluación del programa de prevención del ciberbullying "Conviure en un món real i digital", insertado en el currículo escolar en los dos últimos ciclos de la Educación Primaria, siguiendo el modelo teórico de Hilda, que pone énfasis en la necesidad de que en los programas escolares se incluyan aquellos aspectos que den respuestas efectivas a las necesidades y problemáticas que la sociedad nos plantea en cada momento. El contenido de este programa está centrado en contenidos tecnológicos y humanísticos como son; autoestima, emociones, autocontrol, empatía, asertividad, ciberbullying, prevención y resolución de conflictos, y buen uso de las TIC. Estos contenidos se insertan en el currículo de las asignaturas de ciencias sociales, ciencias de la naturaleza y lengua castellana y literatura, y por ello toma especial relevancia el rol del docente y el del orientador educativo, dos figuras esenciales en la formación de los menores y en la prevención de fenómenos como el ciberbullying. Todo ello sin olvidarnos del entorno cercano del menor, quienes forman parte de la clave del éxito de cualquier acción prevención en el ciberbullying.

Para ello, estructuramos esta tesis en tres partes:

- La primera parte teórica, donde situamos el contexto actual en relación al ciberbullying.

- La segunda parte, correspondiente al estudio de campos: búsqueda de necesidades, diseño, aplicación y evaluación de un programa de prevención de ciberbullying para alumnos del segundo y tercer ciclo de educación primaria.

- Y para finalizar realizaremos una síntesis del estudio, destacando las aportaciones más relevantes que habíamos realizado, las limitaciones de la tesis y las propuestas de diversas líneas de investigación futuras.

Todos estos contenidos se desarrollaron en los siguientes capítulos:

En el capítulo 1 "Sociedad del siglo XXI" trataremos aspectos sobre el uso de las TIC por parte de la sociedad actual, a partir de datos estadísticos españoles así como también europeos. Después de estos datos veremos cómo este uso afecta a las diferentes generaciones actuales, cuáles son estas generaciones, y nos centraremos sobre todo en la generación Z. Presentaremos datos del uso de las TIC por parte de los menores y qué implicaciones conlleva su uso.

En el capítulo 2 "Ciberbullying", nos detendremos en primer lugar en el análisis de la definición del concepto en sí, adentrándonos a continuación en las diferencias que 
existen entre ciberbullying y bullying, y también entre el ciberbullying y otros fenómenos tan actuales como son el grooming y el sexting. A continuación, nos detendremos en los diferentes contextos en los que se debe atender al ciberbullying, siendo éstos el contexto clínico, educativo y familiar, y cómo se debe abordar en cada uno de ellos. Presentaremos datos sobre los instrumentos de evaluación para la detección del fenómeno, así como la legislación actual que lo ampara. Por último daremos un paso más, ofreciendo un glosario de términos relacionados con el ciberbullying debidamente clasificados.

En el capítulo 3 "Ciberbullying estado de la cuestión", ofreceremos datos e información sobre la situación actual del ciberbullying, tanto a nivel nacional como internacional. Para ello presentaremos los datos atendiendo a los tipos de fuentes de información, siendo éstas primarias o secundarias. Respecto a las fuentes primarias, analizaremos datos estadísticos sobre estudios españoles y estadounidenses que nos aportarán una visión actual del fenómeno a nivel internacional, que se completará con el análisis de la base de datos Teseo para ver las tesis publicadas en España hasta el momento sobre el ciberbullying, así como también con el análisis de prestigiosas bases de datos de revistas para conocer las publicaciones realizadas a lo largo de los años. En las fuentes documentales secundarias nos detendremos en los libros publicados en España sobre el ciberbullying, así como también todos aquellos recursos publicados como pueden ser programas, guías, páginas web o vídeos.

En el capítulo 4 "Rol del psicólogo educativo en situaciones de ciberbullying", damos especial relevancia al rol del psicólogo educativo en el fenómeno del ciberbullying, aportando una visión clara sobre qué es lo que este profesional debe saber sobre el ciberbullying, y por supuesto qué debe hacer enfocando su función a la comunidad educativa en su conjunto; a los alumnos, al centro educativo y a la familia especialmente. $Y$ es que su función no termina aquí, puesto que aportamos un plan de actuación ante situaciones de ciberbullying, uno específico para centros educativos y otro para las familias. Finalizaremos este capítulo con importantes propuestas y recomendaciones de mejora del Plan de Prevención de la Violencia y Promoción de la Convivencia (PREVI) de la Conselleria de Educación de la Comunidad Valenciana, relacionadas con la necesidad de incluir en él medidas para la prevención del ciberbullying.

El capítulo 5 dará paso a la "Evaluación de necesidades", y así comenzaremos la segunda parte de esta tesis. En este capítulo identificaremos las necesidades de las familias y docentes; mostraremos los instrumentos de recogida de esa información, a través de dos cuestionarios, uno para familiares y otros para docentes, a partir de los cuales pudimos priorizar las necesidades manifestadas y qué cobertura iba a tener en el programa. 
En el capítulo 6 "Diseño del programa”, mostraremos el cuerpo del programa donde señalaremos los objetivos propuestos, cual ha sido la metodología que hemos seguido, así como los contenidos de los materiales y actividades realizadas para ello.

En el capítulo 7 "Aplicación y evaluación del programa", abordaremos las fases de aplicación y evaluación del programa. En la fase de aplicación especificaremos los objetivos propuestos, la metodología utilizada, así como los materiales necesarios y la temporalización seguida. En la fase de evaluación concretaremos los objetivos y la hipótesis planteada; definiremos los diferentes contextos de los centros así como el diseño de la investigación y el procedimiento seguido. En esta fase se detallarán los datos resultantes de los pertinentes análisis de datos, y los haremos por ciclos educativos, en primer lugar el segundo ciclo de Educación Primaria y a continuación los del tercer ciclo de Educación Primaria, realizando un análisis de todos los datos. Mención a parte requiere la evaluación pedagógica de la asimilación de contenidos del programa, mostrando los datos de la evaluación realizada a los alumnos y a los docentes, así como su posterior análisis de resultados.

En el capítulo 8 se encuentra la "Síntesis final y propuestas", donde evidenciamos cuales han sido nuestras aportaciones a la comunidad científica, las limitaciones encontradas en nuestro estudio y las líneas futuras de investigación que nos planteamos.

Esta tesis se completa con una Bibliografía que permite ampliar contenidos. También en un Anexo final están desarrollados todos los instrumentos de evaluación de la tesis, los materiales creados para el alumnado y docentes, entre otros, que son aportación más práctica.

Finalmente, señalar que en la presente tesis se incorpora un CD en el que se contempla todo el trabajo presentado en papel y los anexos. 


\section{CAPÍTULO 1. SOCIEDAD DEL SIGLO XXI}

1.1. EL USO DE LAS TIC EN LA SOCIEDAD DEL SIGLO XXI

1.1.1. Uso de las TIC en Europa y España

1.2. CAMBIO GENERACIONAL EN EL USO DE LAS TIC

1.2.1. Generación Z: los estudiantes de la sociedad actual

1.3. LAS TIC Y LOS MENORES

1.4. SÍNTESIS 



\section{CAPÍTULO 1. SOCIEDAD DEL SIGLO XXI}

Hoy en día el concepto de sociedad post-industrial es identificado por muchos autores con el desarrollo de las tecnologías de la información y la comunicación (TIC), y otros términos digitales que caracterizan a esta sociedad de la información. Otros se refieren a ella como una sociedad programada, o como la era de la discontinuidad. De Masi (2000), señala que hay más de 300 expresiones que se refieren a la sociedad postindustrial, cada una da prioridad a un conjunto específico de factores. Sin embargo, sostiene que la sociedad post-industrial no puede reducirse a un único factor. De hecho, dice que lo que puede caracterizar este nuevo sistema social y lo diferencian de los anteriores es su policentrismo. En otras palabras, el sistema social está determinado por una variedad de formas, y es el resultado de varios factores combinados, ya que ninguno de ellos es capaz de determinar la totalidad de la misma. Así algunas de las características más destacadas de esta nueva etapa post-industrial serían (De Masi, 2000):

- Integración de los países en grandes bloques políticos y económicos. Disminución de las políticas nación-estado, y cada vez mayor creación de regímenes democráticos. Aumentan los enfoques neoliberales a favor de un libre flujo de comercio e inversión y se reduce el papel del Estado, principalmente a través de la privatización. Hay una creciente globalización de los mercados, organizaciones, normativas y de culturas

- La propiedad de los conocimientos técnico-científica determina la situación económica. Universidades, laboratorios, telecomunicaciones, informática, y empresas de entretenimiento, son las instituciones vitales de esta época de alta tecnología. El sector de los servicios se convierte en la fuerza predominante en la formación de la economía nacional.

- El considerable crecimiento del tercer sector. Esto se expresa en términos de diversidad, importancia de los voluntarios y organizaciones sin ánimo de lucro.

- Grandes cambios en el mundo del trabajo, la educación y el ocio. El paso a una sociedad de servicios se caracteriza por una gran expansión en la educación, salud y otros servicios de bienestar. La esperanza de vida se incrementa en gran medida por estas mejoras. Por un lado, el crecimiento de la población disminuye e incluso llega a detenerse en los países desarrollados, dando lugar al envejecimiento de estas poblaciones. Por otro lado, la población aumenta en los países en desarrollo poniendo una presión sin precedentes sobre la educación, la salud y otros sistemas. También aumentan las presiones migratorias, lo que contribuye a la creciente diversidad social y cultural en muchos países. Un creciente número de trabajadoras entran en el mercado laboral formal. Los roles de los hombres y las mujeres, los ancianos y la familia también han experimentado grandes cambios. El conflicto entre las clases tradicionales se 
sustituye por los conflictos entre una multiplicidad de grupos con diferentes ideologías, intereses y estilos. Los movimientos sociales tienen cada vez más apoyos debido a la presión que ejercen las organizaciones no gubernamentales. Al mismo tiempo hay un gran desarrollo del llamado tiempo libre o la industria del ocio.

- Las nuevas tecnologías de la información y la comunicación (TIC) permiten la interacción instantánea a distancia y la creación de un espacio de vida virtual en el espacio urbano (por ejemplo, comunidades electrónicas, oficinas virtuales, las escuelas y las universidades virtuales). El trabajo, la educación, el ocio y la vida doméstica se van entrelazando y se van convirtiendo en inseparables. El tiempo libre, supera al tiempo de trabajo, apareciendo nuevos conceptos, tales como el aprendizaje permanente, la educación de personas mayores, y el tradicional cambio desde el punto de vista de la vida como una secuencia lineal "educacióntrabajo-jubilación".

- El progresivo aumento de los valores femeninos como consecuencia de la creciente presencia de las mujeres en las esferas sociales, tradicionalmente ocupadas por hombres. Existe una creciente valorización de la calidad de vida, y cada vez más los aspectos éticos, sociales y ecológicos se refieren a los efectos de las nuevas tecnologías.

- Una sociedad donde los individuos tienen que hacer frente a una multiplicidad de roles e identidades sociales, y donde los ambientes de trabajo son más perennes e inestables, las comunidades y redes personales adquieren una importancia creciente en relación a la estabilidad personal.

- Cambios en las características demográficas de la mano de obra. EI envejecimiento de la población (en los países más desarrollados), el creciente número de mujeres trabajadoras, y la globalización de la mano de obra, causan una multiplicidad de nacionalidades y contribuyen a aumentar la diversidad cultural y social, transformando las relaciones sociales en los entornos de trabajo.

- Uno de los mayores problemas de la era post-industrial es el problema del desempleo tecnológico. De manera similar a lo que ocurrió en el momento de la transición entre la era pre-industrial y la era industrial, cuando la mecanización de las explotaciones agrícolas condujo a una reducción de la fuerza del trabajo agrícola, la automatización de los procesos de trabajo obliga a una masa creciente de trabajadores que emigran del sector industrial al de servicios, y dentro de este sector, a los servicios rutinarios de producción (que implican simples tareas repetitivas) a los servicios en persona (servicios rutinarios de las personas) y de los servicios de análisis simbólico (las que implican la resolución de problemas, la planificación y la innovación). Un gran número de esos 
trabajadores no pueden ser re-empleados, ya sea porque carecen de los conocimientos y habilidades necesarias o porque no hay plazas suficientes para ellos. Muchos de los que son expertos son contratados solamente para períodos limitados de tiempo.

- Cambios en las organizaciones y el empleo. En todos los sectores, el empleo se ha visto afectados por una reorganización de los siguientes factores:

- Las relaciones entre las organizaciones y el entorno macroeconómico: compiten en los mercados mundiales; nueva normativa generada por políticos, económicos, sociólogos, ecológicos, etc.

- Tiempo de distribución: la reducción de la semana de trabajo y el retroceso de la edad de jubilación se están discutiendo en todo el mundo; los puestos de trabajo de toda la vida están siendo reemplazados por otros más temporales, reformando los empleos a tiempo parcial y los contratos de trabajo temporal, etc.

- Distribución espacial: un gran lugar de trabajo flexible y descentralizado, con la proliferación del trabajo a distancia y organizaciones virtuales.

- Trabajo: cambios en la organización, estructura y jerarquía de trabajo, nuevos conceptos de gestión y prácticas que afectan a los procesos de trabajo.

- Uso de nuevas tecnologías: el uso creciente de las nuevas técnicas de información y el uso de tecnologías de la comunicación en las organizaciones.

- Habilidades: nuevas necesidades de cualificación que suponga la formación y el reciclaje de los trabajadores, y que afecten a la adquisición de los recursos humanos.

- Relaciones entre empleadores y empleados: redistribución de los beneficios y responsabilidades; los trabajadores han de ser responsables en su trayectoria profesional, atención de la salud, fondos de jubilación, etc.

- Calidad de la vida laboral: hay que proporcionar puestos de trabajo creativos, donde se pueda trabajar en colaboración con otros compañeros, donde haya un buen clima de trabajo etc., ya que la fuerte competencia en el mercado mundial genera altos niveles de tensión y estrés.

- Los cambios en las cualificaciones. Mientras que millones de personas no pueden encontrar trabajo debido a que sus competencias han quedado obsoletas, ciertos empleos de alta tecnología que se están creando, sufren de una escasez de personal de alta cualificación. Algunos autores sostienen que a largo plazo el trabajo que realizan las personas relacionados con tareas de algoritmos se 
llevará a cabo por máquinas inteligentes, dejando espacio sólo para el trabajo creativo Estos cambios pueden tener consecuencias más directas en los paradigmas y teorías de la elección de la carrera y en las prácticas de orientación y asesoramiento profesional. De modo que, en los entornos de trabajo nuevos, los trabajadores necesitan tomar decisiones, resolver problemas y operar con mayor independencia, pensar de forma creativa; tener una mayor comprensión de los sistemas en los que operan, tienen que adquirir, organizar e interpretar la información de mejor manera, desarrollar habilidades sociales como la solución colectiva de problemas y la negociación para mejorar la interacción con de sus compañeros de trabajo.

Por otro lado, debido a la creciente inestabilidad del empleo, los trabajadores deben saber cómo moverse con eficacia de un empleo a otro y a administrar sus propios fondos de jubilación, prestar atención a su salud, y tener en cuenta otros aspectos personales previamente atendidos por los empleadores. De ahí la importancia de la orientación para facilitar un correcto desarrollo de la carrera y potenciar el desarrollo de habilidades y competencias que faciliten la integración de las personas en la sociedad en que viven.

\subsection{EL USO DE LAS TIC EN LA SOCIEDAD DEL SIGLO XXI}

La sociedad del siglo XXI es el resultado de varios factores, como ya hemos indicado en el anterior apartado, y se caracteriza por la relación que se ha ejercido entre ellos. A pesar de ello, y de la certeza del policentrismo como característica central en dicha sociedad, en este apartado nos vamos a adentrar en una de las características nombradas; las nuevas tecnologías de la información y la comunicación, de ahora en adelante TIC.

Desde mediados de la década de los setenta, las sociedades se han visto progresiva e irreversiblemente abocadas a un proceso de transformación tecnológico que dará lugar, en la década de los noventa, a la conceptualización de una nueva era, la "era de la información"; caracterizada por estructuras sociales postindustriales conectadas cada vez más en redes globales (Castells, 2001).

Haciendo referencia a este cambio, y centrándonos en nuestra sociedad, podemos afirmar que el progreso tecnológico y el desarrollo que ello ha traído, ha logrado un desenvolvimiento económico y un estado de bienestar que permite que se estimule positivamente la atención de la sociedad hacia aspectos de la vida de sus ciudadanos y ciudadanas que hasta hace unos años no podíamos imaginar (Ortega, Del Rey \& Sánchez, 2012).

Así, las nuevas TIC han pasado de ser sólo herramientas facilitadoras del día a día, a ser fundamentales en el desarrollo personal de los ciudadanos, utilizándolas tanto como 
medio de ocio como de desarrollo personal. Pero además, como ya avanzábamos, la inclusión y el uso masivo de las TIC está modificando los ecosistemas de relación de los grupos y las comunidades humanas a gran escala (Ortega et al., 2012), y también están contribuyendo al vertiginoso desuso de los conocimientos y al surgimiento de nuevos valores, suscitando así cambios continuos en nuestras estructuras sociales, culturales y económicas (Marquès, 2000).

Es por ello que, en la sociedad actual, la presencia de las nuevas tecnologías en todos los ámbitos, tanto laboral como de ocio, es algo que está creciendo de forma exponencial, siendo conscientes de que esto es solo el comienzo de los muchos cambios que están por llegar (Cáceres, 2010).

\subsubsection{Uso de las TIC en Europa y España}

Con la finalidad de conocer cuál es la situación real actual en cuanto al uso de las TIC vamos a analizar los datos obtenidos en diferentes estudios tanto a nivel europeo como español.

Siguiendo los datos presentados en noviembre de 2016 por el Instituto Nacional de Tecnologías Educativas y de Formación del Profesorado (INTEF, 2016), obtenidos del último estudio publicado por Eurostat, uno de los datos más relevantes en cuanto a las TIC hace referencia al número de hogares con acceso a Internet en Europa en 2015. Dichos datos indican que el $83 \%$ de los hogares europeos tienen acceso a internet, lo que significa un aumento de dos puntos respecto a los datos que obtuvieron en 2014. Como se puede observar en el Figura 1, superando la media europea, y en los primeros puestos, encontramos países como Luxemburgo y Países Bajos, seguidos de Dinamarca, Suecia, Reino Unido, Alemania y Finlandia. Por el contrario; Bulgaria, Rumanía, Grecia y Lituania, fueron los países con menores cifras en cuanto a la conexión en internet en los hogares. La tendencia general indica que el número de hogares con acceso a Internet de un año a otro suele aumentar o mantenerse.

Respecto a los datos de España, el porcentaje es del 79\% de hogares con acceso a Internet en 2015, siendo esta cifra cinco puntos superior a la de 2014 y nueve puntos más que en 2013. 


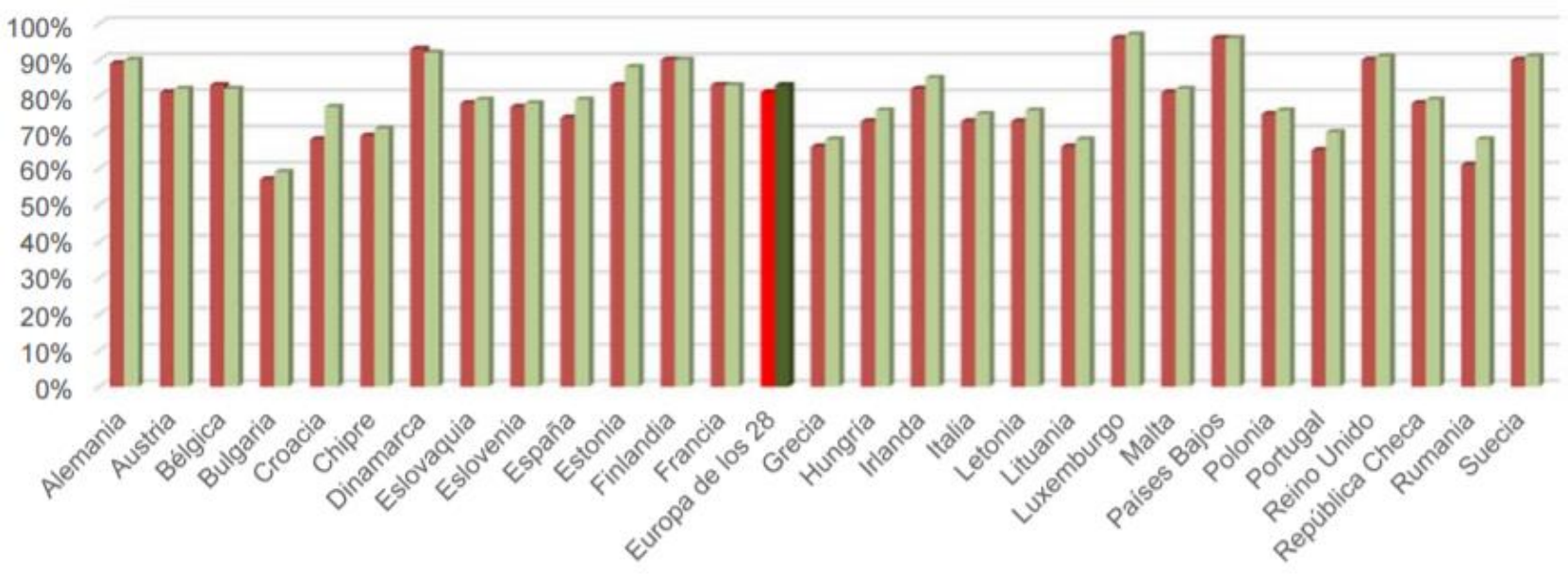

\section{4 | 2015}

Figura 1. Hogares con acceso a Internet 2014 y 2015

Fuente: Instituto Nacional de Tecnologías Educativas y de Formación del Profesorado (INTEF, 2016)

Otro de los datos presentados en este informe nos aporta información en cuanto al uso que hacemos de internet en la Unión Europea. Los datos del 2015 indican que un 79\% de los ciudadanos hizo uso de internet, lo que significa un aumento de catorce puntos respecto al año 2009. Encabezan esta lista países como Luxemburgo y Dinamarca. Las cifras más bajas se dan en Rumanía y Bulgaria. Respecto a España, el aumento del uso de internet en los últimos años ha sido considerable, puesto que supera en veinte puntos los datos de 2009, situándose así en 2015 en un 79\% de usuarios de internet.

Como podemos apreciar en la Figura 2, además del aumento en el número de usuarios a internet, también se da un aumento progresivo, en la Unión Europea, desde los primeros datos recogidos en el año 2007 a los últimos datos obtenidos en 2015 en cuanto a la frecuencia de uso. Por el contrario, disminuye la cifra de personas que nunca han usado internet, situándose la cifra más baja en el año 2015 en menos de un 20\%. 


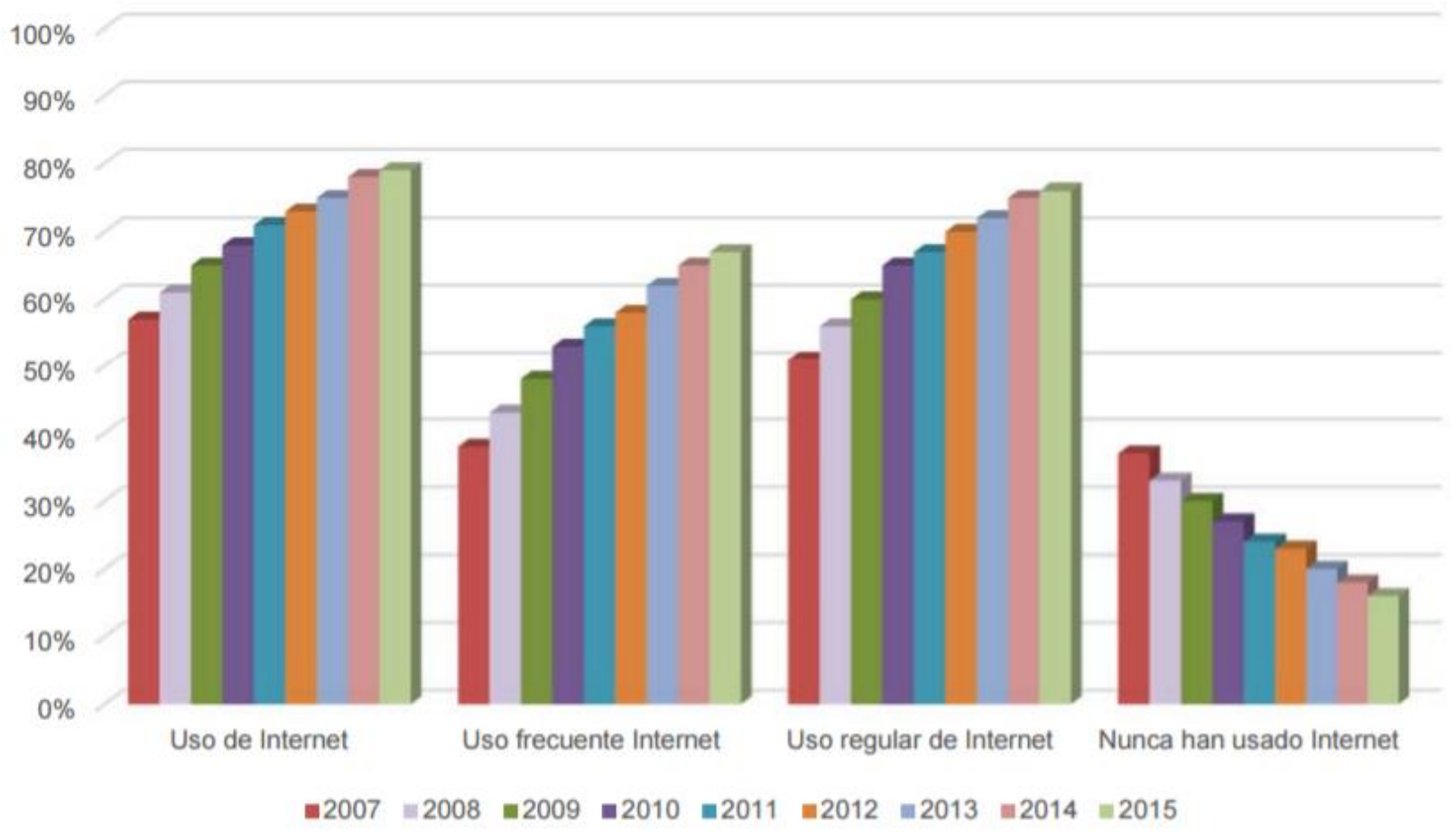

Figura 2. Hogares con acceso a Internet 2014 y 2015

Fuente: Instituto Nacional de Tecnologías Educativas y de Formación del Profesorado (INTEF, 2016)

El mismo informe presentado por INTEF recoge datos obtenidos por el Instituto Nacional de Estadística (INE), relativos al año 2016, donde se analiza el equipamiento y uso de tecnologías de información y comunicación en los hogares españoles (INE, 2016).

Este estudio indica que en el 2016 el 77'1\% de los hogares de España, con algún miembro entre los 16 y los 74 años, dispone de algún tipo de ordenador. Esta cifra es superior a la obtenida en 2015. Además, todas las Comunidades Autónomas mostraron cifras superiores al $65 \%$ de hogares con ordenador, lista encabezada por; Madrid, Cataluña, País Vasco y Navarra.

En cuanto a los hogares con teléfonos móviles, los datos son aún más significativos, puesto que todas las Comunidades obtuvieron datos de más de un $90 \%$.

Otro dato relevante en nuestro país, respecto al uso de las TIC es que, en 2016, 13.031.849 de viviendas disponen de conexión a internet, siendo la banda ancha el método más común para acceder a la red.

Si nos detenemos en datos de utilización de productos TIC en España, el mismo estudio nos dice que el $82^{\prime} 7 \%$ de personas han utilizado alguna vez internet. Por rango de edad, el colectivo que lidera en cifras en cuanto a la frecuencia de acceso a internet con un $99^{\prime} 2 \%$ son los ciudadanos de entre 16 y 24 años, seguidos por los que tienen entre 25 y 34 años con un $96^{\prime} 8 \%$, y en tercer lugar con un $94^{\prime} 9 \%$ las personas entre 35 y 44 años de edad. Como se puede apreciar, a menor edad más se accede a internet. 


\subsection{CAMBIO GENERACIONAL EN EL USO DE LAS TIC}

Los humanos nos diferenciamos de las otras especies en dos aspectos; la tecnología y el lenguaje. Por ese motivo, cuando se ha producido un cambio significativo en algún aspecto relacionado con la tecnología o con el modo de comunicarse, ha hecho que se produzcan otros cambios en el ámbito cultural, social y económico. Este fenómeno es lo que muchos historiadores llaman cambio de era, pues son hitos que marcan un antes y un después en la sociedad (Roca, 2015).

Actualmente, como hemos visto en los datos presentados anteriormente, estamos viviendo un momento donde el uso de la tecnología ha aumentado significativamente, y por tanto el acceso a estas tecnologías ha hecho que gran parte de la ciudadanía tenga acceso a la misma. Este hecho, indudablemente, provoca una modificación de la sociedad.

Así, nuestros adolescentes y menores viven conectados, siendo ésta una característica de esta generación y un aspecto que retrata la realidad de su entorno debido al momento social y cultural en el que viven; la Sociedad de la Información y la Comunicación.

Sin embargo, tal y como reflejan las estadísticas, no son sólo los jóvenes los que han incorporado las TIC en sus vidas, sino que todas las generaciones anteriores han modificado sus hábitos y han integrado el uso de las TIC en su día a día.

Grail Research (2011) presenta la siguiente imagen (ver Figura 3) que muestra gráficamente las diferentes generaciones con las que nos encontramos en la sociedad actual, y el término con el que se les denomina según el año de nacimiento.

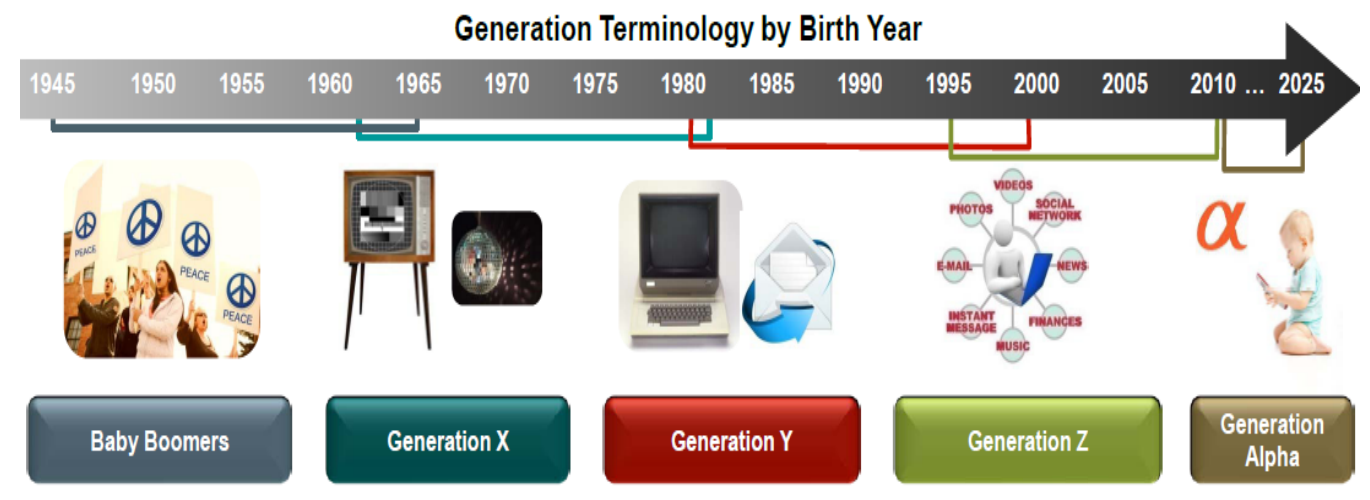

Figura 3. Diferentes generaciones en la sociedad actual

Fuente: Grail Research (2011)

La primera de las generaciones que nombra Grail Research (2011) es la Baby Boomers, y los define como los nacidos después de la Segunda Guerra Mundial, en un mundo cada vez más optimista y financieramente estable. Han sido testigos de varios cambios sociales importantes como son el Movimiento de Mujeres, Movimiento por los Derechos Civiles, Movimiento para la Paz de Vietnam, etc. Además, el aumento de la prosperidad 
les llevó al creciente consumismo. Es una generación caracterizada por ser idealistas y competitivos.

La siguiente generación que define el estudio es la llamada Generación X. Nacidos en un mundo atestiguando una fuerte tendencia hacia el divorcio y la incertidumbre económica. Fueron los primeros en observar la popularidad de la cultura discoteca y hiphop, y las tecnologías tales como TV por cable y videojuegos. Se caracterizan como individualistas y escépticos de la autoridad.

A continuación encontramos la Generación $Y$, también conocidos como millennials, siendo estos los nacidos en un mundo marcado por los crecientes conflictos interregionales e intercomunitarios. Ellos son los testigos de las emergentes tecnologías digitales como la comunicación instantánea a través de correo electrónico y mensajería de texto (SMS). Se les puede definir como optimistas y que se sienten cómodos con el uso de las TIC.

La Generación Z se caracteriza por haber nacido en un mundo que afronta desafíos como el terrorismo y preocupaciones ambientales. Han sido testigos desde su nacimiento del uso de dispositivos electrónicos y tecnologías digitales como Internet y redes sociales. Respecto al uso de las TIC, se trata de una generación competente y experta en su uso, flexible y más inteligente, además de mostrarse más tolerante con la diversidad de culturas.

Finalizamos con la Generación Alpha que es la última de esta sociedad. Nacidos en un mundo recién emergente de una desaceleración económica generalizada. Se espera de ellos que sean una generación más adaptada a las TIC, más culta y también más materialista que las anteriores generaciones.

Estas son pues las generaciones de la sociedad actual. Conociendo ya sus características, algunos autores además los agrupan y los definen utilizando términos relacionados con el uso que éstos hacen de las TIC. Así, a la Generación Baby Boomers se les conoce como análogos. La Generación X, por su parte, es denominada como Inmigrantes digitales. Al nombrar a las últimas generaciones, la Y, Z y Alpha, hablamos ya de los nativos digitales.

Nos centramos pues en los Nativos Digitales, puesto que estos son la generación que encontramos en la actualidad en nuestras aulas escolares. Esta expresión fue acuñada por primera vez por Prensky (2001) quien los identificaba como aquellas personas que han crecido con la Red, siendo éstos los nacidos a partir de 1980, y los diferencia de los inmigrantes digitales, quienes se han adaptado a la tecnología resultado de un proceso de migración digital que supone un acercamiento hacia un entorno TIC teniendo así que adaptarse a una sociedad cada día es más tecnificada.

Los Nativos Digitales, son la parte de la sociedad menor de 40 años caracterizada por haber crecido con la tecnología y, por ello, tienen una habilidad innata en el lenguaje y en el entorno digital. Estas generaciones sienten atracción por las TIC, pues han nacido y crecido sumidos en ellas. 
Comparando ambas generaciones, las diferencias pueden ser significativas en cuanto a la importancia y confidencialidad que dan a la información que poseen, ya que los inmigrantes tienden a considerarla como algo poderoso, por su parte los nativos la comparten. También cabe remarcar la capacidad de abordar procesos paralelos de los nativos, cuya apariencia es caótica y aleatoria, por su parte los inmigrantes actúan de un modo reflexivo, y con ello más lento. Si nos centramos en la relación de estos con los juegos electrónicos, los que fueron utilizados por los inmigrantes se pueden definir como lineales, tanto en funcionamiento como en objetivos. Por su parte los utilizados por los nativos son más complejos e implican la participación y coordinación de más jugadores. Los Nativos Digitales, además de utilizar la TIC, son capaces de crear sus propios recursos y apropiarse de la tecnología (García, Portillo, Romo \& Benito, 2007).

\subsubsection{Generación Z: los estudiantes de la sociedad actual}

En apartados anteriores hemos visto los cambios surgidos en el tiempo y los cambios que generan éstos en la sociedad. Dichos cambios muestran el creciente uso de las TIC en las generaciones presentes en la sociedad actual, pero si destacamos una generación en concreto en este trabajo, ésta es la Generación Z. Niños y jóvenes nacidos a partir de 1993, que aunque no hay una unanimidad entre los académicos en cuanto al cohorte de edad que componen esta generación, sí sabemos que hablamos de aquella generación que encontramos en las aulas de los colegios, institutos de secundaria y universidades, junto a la nueva denominada generación Alpha.

Para definir a esta Generación Z, vamos a seguir a Ortega, Soto \& Cerdán (2016) quienes presentan una comparación entre las últimas generaciones (ver Tabla 1) que permite ver a la perfección las diferencias entre ellas en relación a diferentes aspectos relacionados con el uso de las TIC, así como también ciertos aspectos sociales.

Tabla1. Comparación entre las distintas generaciones

\begin{tabular}{cccc}
\hline & $\begin{array}{c}\text { Generación Z } \\
\mathbf{( 2 0 1 3 )}\end{array}$ & $\begin{array}{c}\text { Millennials } \\
\mathbf{( 2 0 0 0 )}\end{array}$ & $\begin{array}{c}\text { Generación X } \\
\text { (1992) }\end{array}$ \\
\hline $\begin{array}{c}\text { Dispositivos } \\
\text { populares }\end{array}$ & $\begin{array}{c}\text { Smatphone, tableta, } \\
\text { whatsApp }\end{array}$ & $\begin{array}{c}\text { Telefonía 2G, PC } \\
\text { portátil, SMS }\end{array}$ & $\begin{array}{c}\text { Walkman, PC } \\
\text { sobremesa, Game Boy }\end{array}$ \\
\hline $\begin{array}{c}\text { Desarrollo de } \\
\text { Internet }\end{array}$ & $\begin{array}{c}672 \text { millones de páginas } \\
\text { Web }\end{array}$ & $\begin{array}{c}17 \text { millones de } \\
\text { páginas Web }\end{array}$ & 10 páginas Web \\
\hline $\begin{array}{c}\text { Tasa de paro } \\
\text { juvenil }\end{array}$ & $55.1 \%$ & $26 \%$ & $34.4 \%$ \\
\hline Política & $\begin{array}{c}\text { Falta de legitimación de } \\
\text { los grandes partidos } \\
\text { Partidos emergentes }\end{array}$ & $\begin{array}{c}\text { Estabilidad } \\
\text { Bipartidismo }\end{array}$ & $\begin{array}{c}\text { Estabilidad } \\
\text { Bipartidismo }\end{array}$ \\
\hline $\begin{array}{c}\text { Población } \\
\text { extranjera }\end{array}$ & 5.023 .487 & 923.879 & 393.100 \\
\hline
\end{tabular}


Como se puede apreciar en la tabla anterior, las diferencias entre las generaciones son significativas. Hay un aspecto que muestra la clara diferencia del cambio, y es en relación a los dispositivos tecnológicos que han marcado la época. Encontramos por una parte la Generación X que ha crecido con el walkman, el PC de sobremesa o la GameBoy, mientras que la Generación $\mathrm{Z}$ lo ha hecho con un smartphone y tableta, además del uso intensivo de canales de comunicación como el WhatsApp.

Todos estos cambios se deben a los cambios anteriormente citados, como son el número de webs existentes en 1992 con un total de 10 páginas web, en comparación con la cifra de webs en 2013 cuando ya se contabilizan 672 millones de páginas web. Esta información afianza más si cabe el salto tecnológico que se ha producido en estos últimos años.

Otros datos, que hacen referencia al contexto social, permite ver una clara diferencia entre las distintas generaciones, y es que entre 1992 y 2013 la tasa juvenil ha aumentado más de un $20 \%$, además la población extranjera se ha multiplicado casi por 13 y la estabilidad del bipartidismo ha dado paso al surgimiento de partidos emergentes y la falta de legitimación de los grandes partidos.

Pero, ¿qué aspectos son característicos de la Generación Z? Los datos evidencian ciertas particularidades de la Generación Z, nacida en la era digital. En concreto Grail Research (2011) define a esta generación como la generación que se caracteriza como:

- Más cómoda e incluso dependiente de la tecnología, habiendo crecido en un mundo digital donde la tecnología estaba siempre presente.

- Multitarea, con una gran variedad de productos en línea y dispositivos electrónicos sofisticados a su disposición, y quienes aprecian diseños sencillos e interactivos.

- Más socialmente responsables, debido a un mayor acceso a un gran grupo de información en línea, son más conscientes de los desafíos modernos como el terrorismo y del cambio climático.

- Siempre conectados, comunicándose a través de varios canales de redes sociales, a menudo entre países y culturas que influyen significativamente en su proceso de decisión.

- Nacidos en un mundo que enfrenta desafíos como el terrorismo y las preocupaciones ambientales.

A estas características, Gallardo (2013) añade haciendo referencia al International Learning Advisory Board (2008), una serie de aspectos que, junto a los comentados anteriormente, nos ayudarán a conocer mejor a esta generación:

- Les gusta tener el control. No les gusta estar sometidos a horarios tradicionales, y además no valoran positivamente el estar en un aula para aprender o en una oficina para trabajar. Por el contrario, prefieren utilizar la tecnología para 
estudiar en cualquier momento del día o de la noche y trabajar desde cualquier lugar del mundo.

- Les gusta escoger. Utilizan la tecnología para realizar tareas de maneras nuevas y creativas. Su necesidad por métodos alternativos para realizarlas presenta retos cuando se usan mediciones tradicionales para definir la productividad.

- Son orientados al grupo y a lo social. Expuestos al mundo a través de los medios de comunicación, ellos constantemente están conectados a través de las redes sociales. En línea, buscan oportunidades de identificarse con otras personas, uniéndose a las comunidades y las asociaciones con sus pares en todo el mundo. Son altamente colaborativos; comparten lo que han aprendido con otras personas lo que contribuye a crear sus propias identidades personales.

- Son inclusivos. Fueron enseñados a ser tolerantes con todas las razas, religiones y orientaciones sexuales. No están limitados por las informaciones disponibles en su biblioteca local o por búsquedas lineales sobre temas específicos en las enciclopedias. En cambio, utilizan el Internet para buscar información a nivel mundial y utilizan los hipervínculos para desviar la atención de sus búsquedas originales y aprender sobre nuevos temas.

- Son usuarios expertos de la tecnología digital. Esta generación es la primera en estar rodeada por los medios digitales de comunicación. Las TIC siempre han sido parte de sus vidas y debido al acceso, ellos se sienten atraídos a ellas. De hecho, pueden realizar muchas funciones con los teléfonos móviles, dispositivos portátiles y otros equipos inalámbricos que los que pueden realizar con los ordenadores tradicionales. Además de utilizar las funciones de calendario de estos dispositivos para planificar sus vidas, a menudo prefieren la comunicación mediada por el ordenador y han desarrollado su propio lenguaje, que consta de acrónimos.

- Piensan de manera diferente. La tecnología en sí no les sorprende como a las generaciones anteriores que primero tratan de comprender cómo funciona la nueva tecnología; esta generación la acepta, la adapta y la utiliza.

A pesar de todas estas características, hay un rasgo que consideramos que los sintetiza todos y que los define a la perfección; y es la hiperconectividad permanente. Las redes sociales y servicios de mensajería instantánea permiten que se alimente de forma constante una cualidad fundamental, la sociabilidad. Esta conexión constante genera en el ser humano una evolución a un nuevo tipo de individuo al que Reig (2015) denomina "Hiperindividuo" o "Individuo conectado". Así este se diferencia de sus predecesores en ciertos aspectos importantes de su proceso de socialización, desarrollo cognitivo, proceso de individualización y desarrollo moral. Ya que como indican autores como Castells (2011), desde que hacemos uso de las redes sociales no somos los mismos. 
De este modo, el nuevo concepto de socialización supone también un reto para la Generación Z, quienes deberán aprender a equilibrar su vida real con la cibernética, para así combatir con el riesgo de adicción tecnológica y otros peligros relacionados con la privacidad, el acoso y el cibercrimen (Ortega et al., 2016).

Por ello, es importante que psicólogos, educadores y otros colectivos interesados en el desarrollo de los jóvenes, aborden en tema, describiéndolo y orientándolo, desde los aspectos negativos al entendimiento de internet, entendiéndolos como entornos que permiten el desarrollo humano y social, y que por tanto habría que abordar y dejar de temer (Reig, 2015).

En cuanto a la implicación de la Generación $Z$ en el mundo laboral, los nacidos en los primeros años ya empiezan a salir de las universidades y con ello se incorporan al mundo del trabajo. Al igual que ocurrió con el resto de generaciones, su incorporación en el mundo laboral genera un cambio también en este sector.

Una de las características fundamentales que hemos ido comentando a lo largo del capítulo es el uso intensivo de las TIC en la Generación Z, aunque lo comparten en cierto grado con la generación anterior, parece que es la $Z$ la que destaca más en este aspecto por su inmersión desde la edad temprana. Aspecto que debe tenerse en cuenta en su inserción laboral.

Pero, ¿qué les preocupa en concreto a esta generación? Principalmente no encontrar trabajo acorde con su personalidad, que las oportunidades que se les ofrezcan no les permita crecer profesionalmente o no conseguir alcanzar las metas fijadas por ellos mismos. Con ello, lo que solicitan son entornos laborales flexibles, que permitan compaginar su vida personal con la profesional, y que se fomente su creatividad (Ortega et al., 2016).

A diferencia de los millennials, la Generación Z apuesta por la autonomía laboral, por la inmediatez y por la eficiencia derivada del uso de la tecnología, lo que provoca que las empresas se vean obligados a facilitarles cierta libertad que les permita compaginar sus intereses con los de la empresa, así como también a reexaminar sus procedimientos y esforzarse en su mejora. Con ello, los jóvenes que forman parte de la Generación Z dan por finalizado el concepto de trabajo fijo, les resulta normal el cambiar de empleo, sector y categoría profesional e incluso se alejan de la educación formal para focalizar su empleo en proyectos de aprendizaje más vocacional (Ortega et al., 2016).

Por todo ello, se hace necesario preparar a la Generación Z para una realidad laboral que estará vinculada a su capacidad de trabajar en red, junto con personas de culturas diferentes y en empleos asociados a la creatividad y la innovación.

Ante todo esto, se hace necesario preguntarnos, ¿̇uál es el papel de la Educación para esta Generación? 
Este importante cambio en cuanto al uso de las TIC de las nuevas generaciones provoca la necesidad de una implementación de cambios a nivel formativo para atender así las nuevas demandas de estos jóvenes, que por supuesto afectarán a otros ámbitos como el social, económico y político (Martín, 2015).

Así, la educación debe evolucionar al mismo ritmo que lo hacen las nuevas generaciones, y con ello adaptarse a los cambios sociales y a las necesidades de aprendizaje de los nativos digitales, y así lo está haciendo puesto que está adaptándose a los cambios sociales surgidos con la finalidad de ajustarse a la forma de aprender de las nuevas generaciones (Ortega et al., 2016).

Entre las propuestas educativas orientadas a las nuevas generaciones, la Fundación Telefónica (2013) recoge datos obtenidos del debate producido entre 50.000 docentes de 14 países iberoamericanos. En dicho informe se mantiene que la educación en el siglo $\mathrm{XXI}$ debe seguir las siguientes premisas:

1. Hay que formar al ciudadano del siglo XXI: la sociedad del siglo XXI requiere individuos creativos, emprendedores, críticos, competentes con el mundo digital, con altos dotes sociales y que se adapten a ambientes laborales diversos.

2. La inclusión social como eje: es trascendental el establecimiento de políticas públicas regionales para el desarrollo sostenible en el que uno de los pilares sea la inclusión social.

3. Se requiere liderazgo institucional: la cultura digital lleva años instaurada en la sociedad. Las instituciones educativas no pueden permanecer ajenas, por lo que se torna fundamental un liderazgo institucional basado en la construcción de un sentimiento de comunidad sólido, unido a un uso de las TIC desde y para la pedagogía y el currículo del centro.

4. Extraer la Inteligencia colectiva: en una sociedad cada vez más compleja sobrevivir en ella depende cada vez más de una inteligencia colectiva. El ser humano es social por naturaleza, por lo que ha de aprovechar las posibilidades abiertas de la sociedad digital.

5. Contenidos + Pedagogía + Tecnología: la intersección entre tres factores fundamentales son claves para la introducción de las TIC en los procesos educativos: sólidos conocimientos de los contenidos, dominio de competencias pedagógicas y manejo de herramientas tecnológicas y sus posibles aplicaciones. La tecnología no reinventa a la pedagogía, sólo amplía sus posibilidades.

6. Las TIC implican nuevos métodos de evaluación: aprender utilizando las TIC requiere un planteamiento metodológico distinto al de adquisición de meros contenidos. Evaluar este tipo de aprendizajes no debe centrarse, por tanto, en determinar el éxito en adquisición de contenidos sino en el dominio de las competencias del siglo XXI.

7. Hay que romper el mito de los nativos digitales, es decir, la consideración de que todos los jóvenes son nativos digitales y dominan las TIC para usos de provecho en el siglo XXI. 
8. Fomento de la creatividad: existe una inminente necesidad de repensar los sistemas educativos para evitar ahogar la creatividad de los aprendices. Es decir, enterrar un sistema educativo basado en el control e instaurar uno de empoderamiento. El alumno nace siendo creativo y el sistema educativo ha de generar las condiciones para que pueda seguir desarrollando esa creatividad.

9. Importancia de la Educación Emocional: la finalidad principal de la Educación es que cada sujeto pueda alcanzar un grado óptimo de bienestar social y emocional, por lo que la educación emocional debe ocupar un lugar privilegiado en los sistemas educativos. Para ello los programas de formación docente deben dedicar una mayor atención a tales competencias.

10. Cooperación necesaria entre familia, escuela y comunidad: la educación no es exclusiva de las instituciones educativas: es posible aprender en cualquier lugar de la sociedad. Para ello debe existir conexión y cooperación entre familia, escuela y comunidad. La Educación es una cuestión de toda la sociedad.

11. Liderazgo sin burocracia: el liderazgo en una institución educativa debe tener como finalidad principal la mejora educativa de los discentes, con un liderazgo centrado en la pedagogía y alejado de la pura burocracia. Todos los agentes de la comunidad educativa deben estar implicados en la consecución de las metas del centro.

12. Objetivo: desarrollo de competencias. Los cambios de sistema educativo deben orientarse hacia la mejora competencial de los estudiantes. La sociedad digital requiere de competencias que los sistemas educativos han de desarrollar (autonomía, adaptación, tratamiento de la información, etc.), reformando el currículo. Se requerirá de unidades didácticas más simples basadas en tales competencias útiles para la inserción social, aprendiendo de forma conectada en red.

13. Foco en los intereses del aprendiz: el aprendizaje debe producirse de forma natural, partiendo de los intereses del aprendiz, teniendo en cuenta lo que ya sabe, desde la práctica y de cometer errores para ser reorientado por el docente.

14. Un nuevo rol del profesor y su formación: desde la transmisión de contenidos a la orientación y apoyo del alumno, generando las condiciones para que sea éste el que, de manera activa y experimental, construya su propio conocimiento. Ello comporta que la formación docente se reconfigure, contemplando de forma más sólida el uso pedagógico de los entornos digitales para la sociedad del siglo XXI.

15. Nueva ecología del aprendizaje: existe una nueva ecología del aprendizaje que está reconfigurando la educación. Volvemos a entenderla en su sentido amplio, más allá de su simple consideración como escolarización.

16. El reto de considerar todos los ámbitos educativos posibles: existe una necesidad de disrupción en el sistema educativo planteado como ente aislado de la sociedad. Los aprendizajes producidos en ambientes no formales e informales crecen a un ritmo 
vertiginoso y no quedará más remedio que considerar los beneficios de todos estos ámbitos educativos.

17. Interactuación sobre los contenidos: el aprendizaje no está en los contenidos sino en las interacciones que se producen alrededor de ellos. El aprendizaje en red a través de interacciones debe consistir en agregar, remezclar y poner en práctica los conocimientos.

18. Una formación adaptada a las demandas: la construcción del currículo que deberá configurar los nuevos perfiles que demanda la sociedad tendrá que hacerse entre todos los agentes involucrados en su desarrollo. La sociedad y las escuelas deben colaborar para adaptar la formación a las demandas sociales del siglo XXI.

19. Se trata de formar a ciudadanos, no solo a profesionales eficientes: un sistema educativo abierto a la comunidad y basado en aprendizajes colaborativos que implican a toda la sociedad. La labor de este sistema no es formar a ciudadanos únicamente para ser útiles a un mercado, sino formar a ciudadanos capaces de desenvolverse en todos los niveles sociales.

20. Evitar la ansiedad tecnológica: la tecnología avanza a un ritmo vertiginoso, es imposible predecir qué tipo de tecnología habrá en un futuro próximo. Lo que sí tendrá que hacer la sociedad, es diseñar cómo quiere que sea la educación del siglo XXI, la tecnología que acompañará será la que esté disponible llegado el momento de la implantación.

Enfocar y centrar la formación de las nuevas generaciones en estos aspectos permitirá formar a los nuevos ciudadanos, educación que se adaptará a sus características y con la que conseguiremos formar a las nuevas generaciones como personas críticas, conscientes de sus responsabilidades, emprendedoras y capaces de enfrentarse a la incertidumbre que genera la globalización (Fundación Telefónica, 2013).

El marcado contraste de generaciones entre el profesorado y los alumnos, junto con otros aspectos como la competencia de los primeros en habilidades digitales, habilidades sociales relacionadas con el uso de las tecnologías y la inexcusable necesidad de nuevos aprendizajes para una sociedad variable, hace que nos planteemos una cuestión; la preparación del profesorado actual para liderar los procesos de enseñanzaaprendizaje de los alumnos de la Generación Z (Fernández \& Fernández, 2016).

\subsection{LAS TIC Y LOS MENORES}

El uso de las TIC en nuestra sociedad ha cambiado sustancialmente en los últimos años debido a los avances tecnológicos, como hemos visto en los datos presentados anteriormente. Así, son las últimas generaciones las que hacen más uso de ellas, y al tratarse de menores de edad, los que debemos formar en un buen uso de ellas. 
Por tanto, consideramos relevante conocer la realidad en cuanto a la relación existente entre los menores y las TIC. Para ello, siguiendo los datos presentados por Garmendia, Jiménez, Casado \& Mascheroni (2016) relativos a menores entre 9 y 16, vamos a presentar una serie de datos que muestran la situación actual.

En cuanto al acceso y uso de las TIC por parte de los menores encontramos diferentes datos.

Así, a mayor edad más acceden los menores a internet diariamente y lo hacen mayoritariamente en todos los rangos de edad desde alguna habitación del hogar. También el estatus socio-económico (ESE) influye en estos datos, puesto que cuanto más elevado es éste más se accede a internet diariamente.

Los dispositivos más utilizados en todos los grupos de edad son los smartphones (59\%), luego los ordenadores portátiles (32\%) y a continuación las tabletas (26\%).

Respecto a la propiedad de dispositivos móviles, no está directamente relacionado el dato de uso de dispositivos con tener uno para su uso privado. Los smartphones son los dispositivos que más frecuentemente poseen los menores de todos los grupos de edad (63\%) seguidos de los portátiles (28\%) y de las consolas (16\%).

Otro dato relevante que presentan estos autores respecto al uso de las TIC por los menores, es la edad media de inicio en el acceso a internet. Esta cifra se está modificando a la baja en los últimos años, y actualmente está en los 7 años. El dato significativo respecto a la edad de inicio lo encontramos al revisar los datos por grupos de edad, ya que los niños y niñas que ahora tienen 9 ó 10 años empezaron a usar internet cuando tenían 7 años, mientras los adolescentes que tienen ahora 15 ó 16 se iniciaron con 10 años. Este dato nos deja ver lo que se afirmaba al principio, y es que a generación más joven, edad más temprana en el uso de las TIC.

En relación a los datos anteriores, la edad de pertenencia del primer teléfono móvil es de 10 años, es decir, que antes hacen uso de internet que poseen un dispositivo propio. Del mismo modo que ocurría anteriormente, cambia la edad de inicio respecto al grupo de edad del que hablemos, así los menores que ahora tienen 9 ó 10 años tuvieron su primer móvil con ocho años y los que ahora tienen 15 ó 16 años lo tuvieron a los once años.

En lo que se refiere al modo de comunicación de los menores, la comunicación a través del teléfono sigue siendo el modo de contacto más habitual con sus iguales, aunque cada día se hace un uso más frecuente de la mensajería instantánea como modo de contactar con los amigos; es más, el $46 \%$ de los niños y niñas la utilizan varias veces al día. En total, el 78\% de los niños las utiliza al menos casi todos los días.

Las actividades online es otro aspecto a analizar. De este modo, algunas de las actividades que desarrollan los menores se relacionan con las redes sociales, siendo facebook la red social más utilizada, dato que ha variado respecto a los obtenidos por 
la encuesta EU Kids en 2010 que indicaba que la más utilizada era tuenti. Por su parte Twitter aumenta su popularidad con la edad y con el estado socio-económico.

En cuanto al modo de uso de las redes sociales, estos expertos determinan que el número de contactos en las redes sociales es con frecuencia considerado un indicador de comportamiento de riesgo. A pesar de ello, se tiende a sobre-estimar el riesgo de que los menores contacten con círculos sociales cada vez más amplios.

El $17 \%$ de los menores tiene entre 51 y 100 contactos, es decir, algo más de ocho de cada 10 niños y niñas tiene menos de 100 contactos.

El 19\% de los menores tienen más de 100 contactos, cifra que crece sutilmente entre los niños (22\%), los adolescentes de 15-16 años (21\%) y, sobre todo, entre los de 13-14 años (25\%).

Un dato relevante es el que hace referencia a la reducida proporción de menores con más de 300 contactos (6\%), este grupo es relativamente más numeroso entre los niños (6\%) y los adolescentes más jóvenes de 13-14 años (10\%).

Otro aspecto a destacar es que siete de cada diez niños y niñas aceptan nuevos contactos solo si los conocen (52\%) o los conocen muy bien (17\%), menos de uno de cada cuatro (23\%) acepta peticiones de personas con las que comparte amistades, mientras solo el $9 \%$ dice aceptar todas las peticiones. Por tanto, es poco significativo el dato de menores que acepta todas las peticiones.

Relativo a la privacidad de sus perfiles, se detecta que va en aumento el número de perfiles privados conforme aumenta la edad. A pesar de ello resulta significativo el dato de la incidencia de los perfiles públicos entre los menores de 9 a 10 años y entre los de 13 a 14 , con un $35 \%$ y $38 \%$ respectivamente. Por el contrario, en el grupo de 15 a 16 años el perfil parcialmente privado tiene un peso superior a los demás grupos de edad. Esto podría relacionarse con niveles superiores de habilidades digitales para la gestión de la privacidad de los menores.

En relación a la privacidad de sus datos personales, la mayoría de los menores incluye una foto que muestra su rostro y su apellido en sus perfiles. Casi tres de cada diez muestran el nombre de su escuela, y esta tendencia es más relevante en los adolescentes, y nueve de cada diez comparten su número de teléfono y uno de cada cien su dirección postal. Otro dato, más curioso, es que el $44 \%$ de los menores indica una edad que no es la suya en sus perfiles.

Un aspecto a tener presente es el que hace referencia a cómo se sienten ellos mismos. Así, nos indica que el $24 \%$ de los y las menores dice que para ellos es algo más fácil ser ellos mismos en internet que cuando están cara a cara; mientras el $67 \%$ dice que esto no es cierto en su caso. Relacionando estos datos con los obtenidos en el estudio anterior en 2010, afirman que el número de niños que perciben internet como el lugar donde se produce la auténtica comunicación se ha reducido, dato que indica que la 
distinción entre el entorno online y offline se está diluyendo, posiblemente porque ven internet como parte integral de su vida cotidiana.

Así mismo, el $18 \%$ de los menores dicen que se han sentido molestos por algo que han visto en internet a lo largo del año pasado, dato que ha aumentado respecto a los presentados en años anteriores. Respecto a estas experiencias desagradables, las diferencias entre franjas de edad también son mencionables, ya que hasta los 14 años la mayoría de éstas experiencias del uso del Smartphone. Por su parte, en los menores de 15 y 16 años la mayor proporción de problemas están relacionados con el uso de la tableta, dato que resulta curioso.

El $12 \%$ de los menores han experimentado alguna forma de bullying online. A mayor edad mayor porcentaje. El modo por el que experimentan acoso por medio de las TIC es en mayor frecuencia la mensajería instantánea, prácticamente vinculada mayormente al Whatsapp (53\%), seguido de las redes sociales (4\%) y los chats $(4 \%)$.

También el uso excesivo de internet provoca en los menores más probabilidad de experimentar "muy" o "bastante a menudo" la sensación de sentirse aburridos cuando no pueden conectarse (39\%), seguida por la sensación de pasar tiempo online sin estar realmente interesados en ello (25\%), sentir que están pasando menos tiempo que el adecuado con la familia y los amigos o haciendo tareas escolares (18\%), y la incapacidad percibida para reducir el tiempo que pasan conectados a internet (10\%).

Finalmente presentamos aquellos datos que hacen referencia a los dos contextos más cercanos a los menores, el familiar y el educativo. Así, respecto a la importancia de padres y madres como fuente primaria de apoyo en caso de experiencias desagradables, las cifras indican que ésta disminuye con la edad, de modo que los adolescentes son más propensos a recurrir a su grupo de pares para buscar apoyo.

Por su parte, la información relacionada con el uso de los smartphones en las escuelas, está cada vez más regulado. El $84 \%$ de los y las menores no están autorizados a utilizar su smartphone en el centro escolar, un $15 \%$ asegura que puede utilizarlo con restricciones, y un solo $1 \%$ afirma que puede utilizar su dispositivo sin limitación. Respecto a la edad, el uso del smartphone en la escuela se incrementa con la edad, es más, uno de cada diez menores de 9 a 12 años está autorizado a utilizarlo, mientras que entre los menores de 13 a 16 años la proporción se eleva hasta casi uno de cada cinco.

Además, el profesorado se implica en una serie de actividades de mediación, incluyendo la de ofrecer asesoramiento práctico y restringir el acceso a ciertos contenidos. El $80 \%$ de los profesores tienen reglas respecto a lo que les está permitido hacer en internet a sus alumnos en la escuela, y más de la mitad del profesorado está implicado en la mediación del uso seguro de internet que hacen los menores.

Todos estos datos nos pueden alarmar y plantearnos la gravedad de la situación actual en cuanto al uso de las TIC por parte de los menores, pero ¿cuáles podríamos determinar que son experiencias de riesgo? y ¿todo riesgo implica daño? 
Para dar respuesta a estas cuestiones vamos analizar los siguientes datos (ver Tabla 2) sobre las experiencias negativas según la edad, teniendo en cuenta que las experiencias de riesgo online no siempre causan daño, puesto que los menores que se exponen a más riesgos no son siempre los que experimentan más daño, aunque sí son los que terminan desarrollando más su resiliencia (Garmendia et al., 2016).

De estos datos se desprende que el riesgo más habitual entre los menores en cuanto al uso de internet es la visualización de imágenes sexuales puesto que un $52 \%$ de los menores afirman haber visto imágenes de esta índole. El siguiente riesgo al que se exponen con más frecuencia es la recepción de mensajes sexuales, siendo casi uno de cada tres menores los que afirman haber recibido este tipo de mensajes. Por su parte, las formas de acoso online $u$ offline se han dado en un $31 \%$ de los menores mientras que la frecuencia de haber sufrido el ciberbullying es del $12 \%$.

Otros riesgos frecuentes son los virus o el mal uso de los datos personales (29\%), así como la dependencia de internet (26\%) o la comunicación online con otro menor al que no conoce personalmente (21\%).

Con menor frecuencia encontramos riesgos como ir a citas con personas con las que contactan por internet (11\%).

Tabla 2. Resumen de experiencias negativas online, según la edad (Garmendia et al., 2016).

\begin{tabular}{|c|c|c|c|c|c|}
\hline \multirow{2}{*}{ Porcentaje (\%) en los últimos 12 meses } & \multicolumn{4}{|c|}{ Edad } & \multirow[b]{2}{*}{$\stackrel{\bar{\pi}}{\stackrel{0}{0}}$} \\
\hline & 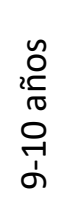 & 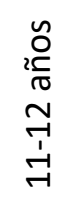 & 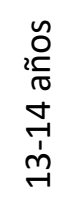 & 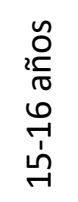 & \\
\hline Me han tratado mal online u offline & 32 & 32 & 33 & 28 & 31 \\
\hline Sufrido cualquier forma de ciberbullying & 8 & 13 & 14 & 15 & 12 \\
\hline He tratado a otros/as mal online u offline & 7 & 6 & 9 & 13 & 9 \\
\hline He tratado a otros mal a través de Internet o el teléfono móvil & 5 & 6 & 14 & 8 & 8 \\
\hline He recibido mensajes sexuales (solo +11 ) & $\mathrm{n} / \mathrm{a}$ & 18 & 34 & 42 & 32 \\
\hline He contactado con alguien que no conocía antes cara a cara & 11 & 10 & 27 & 39 & 21 \\
\hline He ido a una cita con alguien contactando online & 2 & 2 & 18 & 25 & 11 \\
\hline He visto imágenes sexuales online u offline & 36 & 50 & 57 & 70 & 52 \\
\hline $\begin{array}{l}\text { He visto cualquier tipo de contenido potencialmente dañino } \\
\text { generado por el usuario }(\text { solo }+11)\end{array}$ & $\mathrm{n} / \mathrm{a}$ & 23 & 32 & 42 & 32 \\
\hline He tenido otras experiencias negativas online & 15 & 26 & 39 & 39 & 29 \\
\hline Uso excesivo de Internet (dos de cinco ítems) & 16 & 20 & 31 & 42 & 26 \\
\hline
\end{tabular}


Nos cuestionábamos anteriormente si todas las situaciones de riesgos implican daño, al respecto podemos afirmar que entendemos por riesgo la probabilidad de un individuo de sufrir un daño, mientras que el daño haría referencia al estado que causa en los menores el haber visto o experimentado cierta situación.

Por tanto, una vez analizados los datos que hacen referencia al riesgo, vamos a detenernos en el daño (ver Tabla 3), y es que un 18\% de los menores han afirmado haber visto o experimentado molestia por algo observado o experimentado en internet.

Tabla 3. Resumen de experiencias de daño de los/as menores, según la edad (Garmendia et al., 2016).

\section{Edad}

\begin{tabular}{|c|c|c|c|c|c|}
\hline Porcentaje (\%) en los últimos 12 meses & 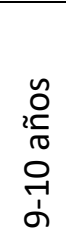 & 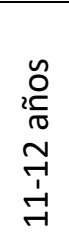 & 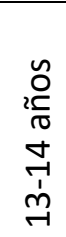 & 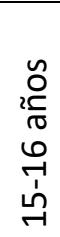 & 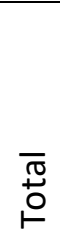 \\
\hline $\begin{array}{l}\text { He visto o experimentado algo en Internet que me ha } \\
\text { molestado }\end{array}$ & 17 & 19 & 18 & 18 & 18 \\
\hline Me han tratado mal online u offline & 27 & 25 & 25 & 17 & 23 \\
\hline $\begin{array}{l}\text { He recibido mensajes sexuales y estado disgustado/a } \\
(\text { solo }+11)\end{array}$ & 0 & 11 & 20 & 10 & 13 \\
\hline $\begin{array}{l}\text { He ido a una cita cara a cara con alguien contactado } \\
\text { online y he estado disgustado/a }\end{array}$ & 0 & 0 & 4 & 1 & 1 \\
\hline He visto imágenes sexuales y he estado disgustado/a & 17 & 22 & 23 & 16 & 19 \\
\hline
\end{tabular}

Las experiencias que los menores determinan como más dañinas son hechos como el que les traten mal (23\%), seguidos de acciones como haber visto imágenes sexuales (19\%) o recibir imágenes sexuales (13\%).

Todos estos datos nos ofrecen una información actual del uso de las TIC en los menores, aspectos que sin duda nos van a proporcionar información muy valiosa en cuanto a las características de esta generación.

De ellas se extrae que los menores son conscientes muchas veces de los peligros asociados al uso de las TIC, pero aún así sigue estando presente la necesidad de promover un uso de las TIC que sea más seguro y responsable.

Para ello, sería recomendable el aumento de la conciencia sobre aspectos relacionados con la privacidad, cómo denunciar o bloquear, entre otros. Dicho rol se podría ejercer desde los centros escolares, siendo agentes activos puesto que la mayor parte de las veces los problemas se producen entre iguales o compañeros de una misma clase. 


\subsection{SÍNTESIS}

La sociedad post-industrial se caracteriza por muchos factores. Entre ellos encontramos el papel que ejercen las nuevas tecnologías de la información y la comunicación (TIC).

La inclusión y el uso masivo de las TIC están modificando los ecosistemas de relación de los grupos y las comunidades humanas a gran escala y también están contribuyendo al vertiginoso desuso de los conocimientos y al surgimiento de nuevos valores, suscitando así cambios continuos en nuestras estructuras sociales, culturales y económicas.

Así, se observa en nuestra sociedad actual un aumento en el uso de las TIC. Los datos obtenidos en estos últimos años en Europa y España muestran que la cifra de hogares con acceso a internet está aumentando vertiginosamente, situándose en un $83 \%$ de hogares europeos con acceso a internet y un 79\% en España. En cuanto a la posesión de dispositivos tecnológicos en los hogares españoles, un 77'1\% dispone de alguno, siendo el teléfono móvil el más frecuente.

Estos cambios sufridos en nuestra sociedad han modificado los hábitos de todas las generaciones presentes, pues no sólo nuestros niños y jóvenes que han nacido en la era digital hacen uso de ellas, sino que toda la sociedad en su conjunto ha incorporado las TIC en sus vidas, modificando con ello sus hábitos del día a día.

A pesar de ello, diferenciamos entre dos generaciones en cuanto al uso de las TIC, los inmigrantes digitales y los nativos digitales, siendo estos últimos los menores de 40 años.

Entre ellos destaca la Generación Z, siendo estos los menores y jóvenes que encontramos actualmente en las aulas de los centros educativos.

A pesar de todas las características que diferencian a esta generación de las anteriores, hay un rasgo que los consideramos que los sintetiza todos y que los define a la perfección; y es la hiperconectividad permanente.

Datos a destacar son los presentados por Garmendia et al. (2016), que indican que a mayor edad más acceden los menores a internet diariamente y lo hacen mayoritariamente en todos los rangos de edad desde alguna habitación del hogar, siendo los smartphones (59\%) los dispositivos más utilizados en todos los grupos de edad. En cuanto a la edad media de inicio en el acceso a internet, esta cifra se está modificando a la baja en los últimos años, y actualmente está en los 7 años, cifra que ha disminuido respecto a menores de mayor edad. También disminuye la edad de pertenencia del primer teléfono móvil que es a los 10 años. Todo ello conlleva riesgos, y es que el $18 \%$ de los menores dicen que se han sentido molestos por algo que han visto en internet y el $12 \%$ de los menores han experimentado alguna forma de bullying online mayormente al Whatsapp (53\%). Además, existen otras experiencias que los menores determinan como más dañinas como son hechos como el que les traten mal (23\%), seguidos de acciones como haber visto imágenes sexuales (19\%) o recibir imágenes sexuales (13\%). 
Los datos presentados este último año muestran que la edad en la que empiezan los menores a hacer uso de las TIC ha disminuido, así como la edad de posesión del primer dispositivo electrónico propio. Ello conlleva asociado un aumento en el uso de redes sociales y otros canales de comunicación online, aspecto directamente relacionado con el aumento de los riesgos que conlleva su uso y por tanto del daño que ello puede implicar en los menores.

Esta conexión constante genera en el ser humano una evolución a un nuevo tipo de individuo, que se diferencia de las generaciones anteriores en ciertos aspectos importantes de su proceso de socialización, desarrollo cognitivo, proceso de individualización y desarrollo moral.

Todo ello supone un reto para la Generación Z, quienes deberán aprender a equilibrar su vida real con la cibernética, para así combatir con el riesgo de adicción tecnológica y otros peligros relacionados con la privacidad, el acoso y el cibercrimen.

Entre las propuestas educativas orientadas a las nuevas generaciones, la Fundación Telefónica (2013) presenta algunas como; formar al ciudadano del siglo XXI, la inclusión social como eje, extraer la Inteligencia colectiva, las TIC implican nuevos métodos de evaluación, romper el mito de los nativos digitales, fomento de la creatividad, entre otras.

Así, es importante que psicólogos, educadores y otros colectivos interesados en el desarrollo de los jóvenes, aborden en tema, describiéndolo y orientándolo, desde los aspectos negativos al entendimiento de internet. 



\section{CAPÍTULO 2. CIBERBULLYING}

\subsection{CONCEPTUALIZACIÓN}

2.1.1. Diferencia entre bullying y ciberbullying

2.1.2. Diferencia entre ciberbullying, grooming y sexting

2.2. CIBERBULLYING EN EL CONTEXTO CLÍNICO, EDUCATIVO Y FAMILIAR

2.2.1. Contexto clínico

2.2.2. Contexto educativo

2.2.3. Contexto familiar

2.3. EVALUACIÓN

2.4. LESGISLACIÓN

2.5. GLOSARIO

2.6. SÍNTESIS 



\section{CAPÍTULO 2. CIBERBULLYING}

La sociedad actual en la que nos encontramos se ha visto modificada sustancialmente en los últimos años, entre otros aspectos, debido al uso de la tecnología. Ello implica el uso, a veces masivo, de los dispositivos tecnológicos y con ello también el fácil acceso a los medios de comunicación lo que permiten una rápida difusión y acceso a la información.

Día a día vemos en los informativos, redes sociales, periódicos digitales, etc., es decir, en diferentes medios de comunicación, información relacionada con el acoso escolar.

Esto se debe a una mayor concienciación social con el fenómeno del acoso escolar y con la importancia y el papel tan fundamental que toman los medios de comunicación en cuanto a la concienciación y con ello la implicación de todos en su prevención y rápida y eficaz intervención.

Esta concienciación de la que hablamos ha llegado también, por supuesto, a los centros escolares y son especialmente los psicólogos educativos los que muestran cierta inquietud en cuanto a la problemática y a la alarma social que ésta está provocando en los ciudadanos.

Por mi experiencia profesional puedo constatar que muchos psicólogos que desempeñan su función en los centros escolares ponen en manifiesto la necesidad de una implicación común de la sociedad en la lucha contra el acoso, en concreto una concienciación en los equipos directivos y en las familias, puesto que sólo conseguiremos terminar con el acoso trabajando en equipo de modo coordinado. De no ser así, ocurren casos como los que recientemente hemos visto en las noticias, el caso de una niña de 13 años de Murcia que se suicidó supuestamente por estar sufriendo un caso de acoso escolar en el que al parecer no se intervino siguiendo el protocolo de acoso adecuado y por el que los padres tuvieron que luchar mucho con el centro con recursos externos de profesionales de la psicología para conseguir que se tomaran medidas en el caso.

Habló con uno de los profesores, que le describió la mala suerte de su hija al tocarle en el grupo de la ESO más conflictivo del instituto. "Se quedó aislada de sus amigas, que iban a otra aula, y fue terrible para ella», lamenta. Varios profesores indicaron entonces a los progenitores que se debía cambiar a la chiquilla de aula, pero no se hizo. Los padres de Lucía se sintieron desamparados desde el primer instante. «Fuimos a pedir ayuda a su instituto, el Ingeniero de la Cierva, en Patiño, y nos dijeron que ya se había activado el protocolo de protección contra el acoso escolar... Pero no funcionó», denuncia Joaquín García. «Fui yo quien tuvo que solicitar el traslado al instituto Francisco Cascales, situado en el centro de Murcia, a través de la Inspección y con un informe psicológico. Me dijeron que me buscara la vida, que lo hiciera a título particular, que ellos habían hecho lo correcto y que no se contemplaba el cambio de escuela». La Inspección Educativa no tenía conocimiento de los hechos cuando le trasladaron las quejas en persona, según afirman los padres, pero sí actuó para facilitar el cambio de instituto. $Y$ eso pese a que los presuntos 
responsables del acoso también se habían metido con otros compañeros de clase, se quejan. (Adán, 2017).

Como bien hemos visto, el fenómeno de la violencia entre iguales está muy presente en nuestra actualidad, sin embargo no es un fenómeno nuevo, ya que en los años 70 el noruego Olweus se inició en el estudio de la violencia entre escolares mundialmente conocido con la expresión bullying. Fue concretamente en el año 1973 cuando Olweus empezó a estudiar el maltrato entre iguales en el ámbito escolar. Desde aquel momento han sido muchos los investigadores que se han centrado en el estudio de este fenómeno y en la realización de infinidad de programas de prevención y de intervención.

Con el paso de los años, las formas de materialización del maltrato entre iguales han ido evolucionando, ideando nuevas formas de llevarla a cabo (Hernández \& Solano, 2007). Es así como van apareciendo nuevas modalidades de acoso, actualmente haciendo uso de las nuevas tecnologías de la información y comunicación como mecanismo con el cual hostigar y acosar a los iguales. Este es el llamado ciberbullying.

Así, podemos afirmar que uno de los tipos de maltrato entre iguales que más se está detectando en estos últimos años es el ciberbullying, siendo uno de los problemas más complejos con los que nos encontramos, ya que suele tener repercusiones indeseables en la convivencia escolar (Avilés, 2013).

El ciberbullying es uno de los fenómenos de maltrato entre iguales más recientes debido a los avances tecnológicos, y con ello al aumento de uso de blogs, correos, páginas web, redes sociales, chats, aplicaciones de móvil, etc. Fue en el año 2000 cuando oímos hablar por primera vez de él en un trabajo realizado por Finkelhor et al. sobre "El riesgo de internet entre los jóvenes", aunque en aquel entonces hacían referencia a él como "online". Años después, en el 2006, en el Congreso de la Sociedad de Psicólogos Londinenses, el equipo de investigación de Peter K. Smith presentó los primeros datos sobre ciberbullying.

\subsection{CONCEPTUALIZACIÓN}

Tal y como ponen de manifiesto Lucas et al. (2016), desde el primer estudio realizado sobre ciberbullying por Finkelhor et al., (2000) en Estados Unidos, han sido abundantes las investigaciones que se han llevado a cabo sobre el ciberbullying, tanto fuera como dentro de nuestro país. Sin embargo, a pesar de conocer principalmente la prevalencia del ciberbullying y su relación con otras variables psicosociales, sigue sin existir una definición universalmente consensuada.

Otro aspecto a destacar, es que en la literatura tanto nacional como internacional encontramos una gran variedad de términos que hacen referencia a un mismo fenómeno. Entre ellos encontramos términos como Ciber-Aggression (Grigg, 2010), Internet-bullying, Internet Harrasment (acoso a través de internet), Electronicaggression (agresión 
electrónica) (David \& Feldman, 2007), Ciber-moobing, Virtual, Cyber-Bullyingbullying electrónico, bullying a través de la red, acoso online y acoso a través de internet (David \& Feldman, 2007). Al igual que en otros países, en España tampoco se ha consensuado la utilización de un término común para el fenómeno del ciberbullying, haciendo referencia a este fenómeno de diferentes modos: ciberacoso, acoso electrónico o tecnológico, ebullying, ciberbullying y cyberbullying (Calmaestra, Ortega, Maldonado \& Mora- Merchán, 2010). En concreto en nuestro trabajo utilizaremos el término ciberbullying por ser uno de los más utilizados en nuestro país, junto con ciberacoso.

Respecto a la definición del fenómeno, como adelantábamos, no existe una definición única de ciberbullying acordada internacionalmente o a nivel europeo. Sin embargo, han sido muchos los intentos de definir este fenómeno, tanto por parte de organizaciones internacionales, como de instituciones de la UE y del mundo académico.

Aunque se reconoce la necesidad de una definición más clara y más amplia del ciberbullying en toda Europa, sólo catorce Estados miembros de la UE proporcionan una definición oficial. A pesar de ello, las definiciones varían de país a país.

Siguiendo a Dalla et al. (2016), las descripciones del fenómeno ciberbullying según el país son las siguientes (ver Tabla 4):

Tabla 4. Descripciones del fenómeno ciberbullying (Dalla, Di Prieto, Morel \& Psaila, 2016)

\begin{tabular}{ll}
\hline \multicolumn{1}{c}{ País } & \multicolumn{1}{c}{ Definición } \\
\hline Alemania & Cyber-mobbing es " insultar, avergonzar o acosar deliberadamente a la gente a \\
& través de nuevos medios de comunicación tales como redes sociales, sitios web \\
& o chat. \\
\hline Austria & Cyber-mobbing y cyberbullying significan insultar, amenazar, denunciar o acosar \\
& intencionalmente mediante el uso de herramientas de comunicación \\
& electrónicas como el teléfono móvil o internet. \\
\hline Bulgaria & El cyberbullying es un tipo específico de intimidación que consiste en acosar a \\
& los niños mediante nuevas tecnologías electrónicas, principalmente los \\
& teléfonos móviles e Internet. \\
\hline Chipre & El acoso cibernético ocurre cuando alguien envía a través de medios de \\
& comunicación electrónicos públicos un mensaje o cualquier otra comunicación \\
& cuyo contenido sea manifiestamente ofensivo y / o obsceno o vergonzoso o \\
& amenazante o que pueda causar molestia, acoso y / o tensión injustificada, \\
& sabiendo que dicho mensaje es falso. Del mismo modo, el acoso cibernético \\
& también se describe como un fenómeno que suele adoptar la forma de un \\
& mensaje electrónico, foto o video intimidante, racista, ofensivo o sexualmente \\
& sugestivo.
\end{tabular}


Tabla 4. Descripciones del fenómeno ciberbullying (Dalla, Di Prieto, Morel \& Psaila, 2016) (Continuación)

\begin{tabular}{|c|c|}
\hline País & Definición \\
\hline Francia & $\begin{array}{l}\text { El acoso cibernético es un acto agresivo e intencional realizado a través del uso } \\
\text { de medios digitales, por un grupo o un individuo repetidamente sobre una } \\
\text { víctima que no puede defenderse fácilmente. }\end{array}$ \\
\hline Hungría & $\begin{array}{l}\text { Cyberbullying significa la transferencia o publicación de un texto o contenido } \\
\text { visual a través de Internet, teléfonos móviles u otras tecnologías de información, } \\
\text { lo que podría ser humillante o podría causar vergüenza. El acoso se dirige a una } \\
\text { víctima, que no puede protegerse regularmente. }\end{array}$ \\
\hline Irlanda & $\begin{array}{l}\text { El cyberbullying ocurre cuando el comportamiento de intimidación se lleva a } \\
\text { cabo a través del uso de sistemas de TIC como correo electrónico, teléfonos } \\
\text { móviles, mensajería instantánea, sitios web de redes sociales, aplicaciones y } \\
\text { otras tecnologías en línea. }\end{array}$ \\
\hline Italia & Cyberbullying es la manifestación en línea de la intimidación, utilizando las TIC. \\
\hline Luxemburgo & $\begin{array}{l}\text { Cyberbullying ocurre cuando las nuevas tecnologías se utilizan para acosar, } \\
\text { humillar o amenazar a una persona, ya sea por mensajería instantánea (SMS), } \\
\text { correo electrónico, chat o en una red social. Bullying con otros medios. }\end{array}$ \\
\hline Malta & $\begin{array}{l}\text { El acoso cibernético es el acoso a través del uso de tecnología y / o medios en } \\
\text { línea. El acoso cibernético puede ser manifiesto o encubierto. Aunque la mayoría } \\
\text { de los incidentes de intimidación cibernética ocurren dentro del ambiente } \\
\text { doméstico, sin embargo, las repercusiones de estos actos a menudo se esparcen } \\
\text { en el contexto escolar. }\end{array}$ \\
\hline Países Bajos & $\begin{array}{l}\text { El cyberbullying es una forma de intimidación tradicional, que requiere el uso de } \\
\text { medios electrónicos. }\end{array}$ \\
\hline $\begin{array}{l}\text { República } \\
\text { Checa }\end{array}$ & $\begin{array}{l}\text { El cyberbullying es una forma de acoso psicológico con el uso indebido de las TIC, } \\
\text { especialmente los teléfonos móviles e Internet, a actividades que } \\
\text { deliberadamente amenazan, dañan a alguien. Al igual que la intimidación cara a } \\
\text { cara, el acoso cibernético es un comportamiento deliberado en el que la víctima } \\
\text { es atacada por un atacante o atacantes. La naturaleza y el modo en que se lleva } \\
\text { a cabo determinan la gravedad de los ataques. }\end{array}$ \\
\hline
\end{tabular}

Como podemos deducir de las definiciones anteriores, a pesar de la variedad de términos utilizados en sus definiciones, encontramos algunos elementos característicos en las definiciones de estos países como; utilización de medios electrónicos o digitales, la intención de causar daño, comportamientos encubiertos y la relación directa con el bullying, entre otros (ver Tabla 5.1). 
Tabla 5.1. Principales características de las definiciones de los estados

\begin{tabular}{|c|c|c|c|c|c|c|c|}
\hline País & Intencionalidad & Repetición & $\begin{array}{l}\text { Desequilibrio } \\
\text { de poder }\end{array}$ & $\begin{array}{l}\text { Uso de } \\
\text { las TIC }\end{array}$ & Anonimato & $\begin{array}{c}\text { Comportamientos } \\
\text { encubiertos }\end{array}$ & $\begin{array}{l}\text { Relación } \\
\text { directa con } \\
\text { el bullying }\end{array}$ \\
\hline Alemania & $x$ & & & $x$ & & $x$ & \\
\hline Austria & $x$ & & & $x$ & & $x$ & \\
\hline Bulgaria & $x$ & & & $x$ & & & $x$ \\
\hline Chipre & $x$ & & & $x$ & & $x$ & \\
\hline Finlandia & & & & & & $x$ & \\
\hline Hungría & $x$ & & $x$ & $x$ & & & \\
\hline Irlanda & & & & $x$ & & $x$ & $x$ \\
\hline Italia & & & & $x$ & & & $x$ \\
\hline Luxemburgo & $x$ & & & $x$ & & $x$ & $x$ \\
\hline
\end{tabular}

Como se puede apreciar en la tabla anterior, los aspectos característicos con los que coinciden al definir el fenómeno del ciberbullying son sobre todo la intención de hacer daño y el uso de las TIC. También se puede apreciar que la mayoría de las definiciones relacionan directamente el ciberbullying con el bullying, así como también detallan ciertos comportamientos encubiertos. Por el contrario, en ninguna definición se hace referencia a la repetición de las acciones en el tiempo o al anonimato de los implicados, y pocas referencias encontramos en las definiciones en cuanto al desequilibrio de poder existente entre la víctima y el agresor.

En el plano académico, también son muchos los autores que lo definen, sin llegar tampoco hasta el momento a una definición consensuada por todos. Por ello vamos a recoger una serie de definiciones que se han ido publicando a lo largo de estos últimos años para ver la evolución del término, así como las semejanzas y discrepancias en cuanto a los aspectos que determinan el ciberbullying.

Una de las primeras definiciones que encontramos en la literatura es la de Smith (2000) quien define el ciberbullying como un acto agresivo e intencional, utilizando formas electrónicas de contacto, desarrollado por un individuo o grupo de forma repetida y mantenida en el tiempo sobre una víctima que no puede defenderse fácilmente por sí misma.

Por otra parte, Willard (2005) lo definió remarcando la dimensión social del problema, ya que considera que el ciberbullying consiste en ser cruel con otra persona mediante el envío o publicación de material dañino o la implicación en otras formas de agresión social usando Internet u otras tecnologías digitales. Shariff (2005), muy en relación con esta definición, lo considera como una forma psicológicamente devastadora de crueldad social entre adolescentes.

El mismo año, Belsey (2005) atribuyó el término al uso vejatorio de algunas TIC, como el correo electrónico, los mensajes del teléfono móvil, la mensajería instantánea, los sitios 
personales, y/o el comportamiento personal en línea difamatorio, de un individuo o un grupo, que deliberadamente, y de forma repetitiva y hostil, pretende dañar a otra persona.

Otros autores, como Patchin \& Hinduja (2006) lo definen como un daño intencional y repetitivo infligido a través de medios de texto electrónico; definición similar a la de Erdur\& Tanrikulu (2010), quienes lo consideran un acto intencional, repetido y dañino uso de las tecnologías de la información. También, Ybarra \& Mitchell (2004) y Ferro (2013) hacen una clara alusión a características del ciberbullying, como un acto evidente e intencional de agresión online hacia otra persona. Siguiendo la misma línea, Aftab (2010) añade a la intencionalidad y deseo de hacer daño, la implicación únicamente de menores y la característica de que suelen ser compañeros de colegio y se relacionan en la vida física.

Sin embargo, Mishna, Saini \& Solomon (2009) lo definían señalando factores únicos del ciberbullying, como es la posibilidad de producirse en cualquier momento y en cualquier lugar y el anonimato o la percepción de anonimato del agresor.

Con la finalidad de analizar, al igual que con las definiciones de los diferentes países de la UE, los aspectos característicos que incluyen los diferentes autores que hemos escogido, vamos a presentar la Tabla 5.2 en la que se distinguen aspectos como; daño/agresión, intencionalidad, repetición, desequilibrio de poder, uso de las TIC, carácter social, anonimato, así como el hecho de que se produzca con independencia del lugar.

Tabla 5.2. Aspectos característicos que incluyen diferentes autores en las definiciones de ciberbullying

\begin{tabular}{|c|c|c|c|c|c|c|c|c|}
\hline Autor & $\begin{array}{c}\text { Daño/ } \\
\text { agresión }\end{array}$ & Intencional & Repetición & $\begin{array}{l}\text { Desequilibrio } \\
\text { de poder }\end{array}$ & Tic & Social & Anonimato & $\begin{array}{c}\text { Independiente } \\
\text { del lugar }\end{array}$ \\
\hline $\begin{array}{l}\text { Smith } \\
(2000)\end{array}$ & $x$ & $x$ & $x$ & $x$ & $x$ & & & \\
\hline \multicolumn{9}{|l|}{ Ybarra \& } \\
\hline $\begin{array}{l}\text { Mitchell } \\
\text { (2004) }\end{array}$ & & $x$ & & & $x$ & & & \\
\hline $\begin{array}{l}\text { Belsey } \\
\text { (2005) }\end{array}$ & $x$ & $x$ & $x$ & & $x$ & & & \\
\hline $\begin{array}{l}\text { Shariff } \\
(2005)\end{array}$ & & & & & & $x$ & & \\
\hline $\begin{array}{l}\text { Willard } \\
\text { (2005) }\end{array}$ & $x$ & & & & $x$ & $x$ & & \\
\hline \multicolumn{9}{|l|}{ Patchin e } \\
\hline $\begin{array}{l}\text { Hinduja } \\
\text { (2006) }\end{array}$ & & $x$ & $x$ & & $x$ & & & \\
\hline \multicolumn{9}{|l|}{ MishnaSaini } \\
\hline $\begin{array}{l}\text { \& Solomon } \\
\text { (2009) }\end{array}$ & & & & & & & $x$ & $x$ \\
\hline $\begin{array}{l}\text { Aftab } \\
(2010)\end{array}$ & $x$ & $x$ & & & $x$ & & & \\
\hline \multicolumn{9}{|l|}{ Erdur-Baker } \\
\hline $\begin{array}{l}\text { \& Tanrikulu } \\
\text { (2010) }\end{array}$ & $x$ & $x$ & $x$ & & $x$ & & & \\
\hline $\begin{array}{l}\text { Ferro } \\
\text { (2013) }\end{array}$ & $x$ & $x$ & & & $x$ & & & \\
\hline
\end{tabular}


De este modo, y tomando como referencia las definiciones anteriores, se puede ver la clara relación que se establece con el fenómeno del bullying puesto que muchos de los autores mantienen en sus definiciones aspectos como el carácter intencional, repetitivo y dañino.

A estos aspectos, se les añade en prácticamente todas las definiciones el aspecto tecnológico, sin embargo son pocos los que lo definen desde una dimensión social, así como también pocos son los que destacan el anonimato y la independencia física como rasgo fundamental del ciberbullying.

Por todo ello, consideramos que el hecho de no existir una definición única hace complicada la comparación de los estudios realizados hasta el momento sobre esta temática (David \& Feldman, 2007; Vandebosch \& Van Cleemput, 2009), lo que hace necesaria la elaboración de una definición común de ciberbullying.

Así, podemos considerar la definición de Smith (2000) una de las más adecuadas, aunque algo incompleta, pues define el ciberbullying como acto agresivo e intencional realizado por un grupo o un individuo, usando las formas electrónicas de contacto, repetidamente y contra una víctima que no puede defenderse fácilmente.

Sin embargo, y pese a estar de acuerdo con los diferentes autores que el ciberbullying es una forma de bullying, hay ciertos aspectos que lo diferencian y que no se tienen en cuenta a la hora de elaborar la definición de este fenómeno, tal y como veremos en posteriores apartados. Entre estas características propias del ciberbullying encontramos aspectos como pueden ser la inseguridad que provoca en la víctima el hecho de poder ser agredido en cualquier lugar con independencia del lugar físico en el que se encuentre. Además, la acción puede ser observada por un número elevado de espectadores durante mucho tiempo, debido a la rápida difusión de la información por el uso de la tecnología y a la permanencia en el tiempo de esta información. También el posible anonimato del agresor aumenta el daño potencial de la agresión (Campbell, 2005; Mora \& Ortega, 2007; Smith, 2006).

Por tanto, tomando en cuenta las características específicas del ciberbullying lo definiríamos como: una nueva forma de bullying, que se ejerce entre menores o adolescentes, mediante el uso de la tecnología con la finalidad de acosar, amenazar o intimidar a otra persona intencionalmente, pudiéndose dar en cualquier lugar con independencia del lugar físico en el que se encuentre la víctima. Para que sea considerado ciberbullying se debe mantener en el tiempo y debe existir un desequilibrio de poder entre el agredido y el agresor. Esta acción se puede ver maximizada por el anonimato del agresor, así como también por la rápida y amplia difusión junto con la permanencia en el tiempo de la acción debido al uso de la tecnología.

En el ciberbullying, al igual que el bullying son dos los roles principales implicados; el agresor y la víctima (Grigg, 2010). Además de éstos, muchos autores hablan también en estos últimos años del agresor pasivo o espectador (Slonje, Smith\& Frisen, 2012) dada la importancia de su rol como el soporte de la agresión. 
El primer perfil que determinan los investigadores es el del agresor, aunque no han determinado claramente un perfil exacto sí coinciden a la hora de indicar aspectos característicos de estos participantes como pueden ser rasgos de personalidad dominante, agresiva y con escasa empatía, impulsivos, dificultad para aceptar límites, se irritan con facilidad y no tienen problemas de autoestima (Olweus, 1993; Kowalski, Limber\& Agatston, 2010).

El segundo perfil principal que encontramos en el ciberbullying hacer referencia a la víctima, y respecto a estos participantes destacan una serie de características entre las que se encuentran una personalidad insegura, ansiosa, cauta, sensible y tranquila, con una baja autoestima, autoconcepto negativo, escasa red social y probablemente más débiles físicamente que otros compañeros (Álvarez, 2015).

Por último, se añade a estos dos perfiles principales un tercero que denominan como agresores pasivos o espectadores, definiéndolo como un grupo poco homogéneo, que suele rodear al agresor muchas veces mostrándole su apoyo y simpatía con él. Algunos autores los definen como inseguros y ansiosos (Olweus, 1993).

Siguiendo con la conceptualización de este fenómeno en el que nos estamos adentrando, el ciberbullying, existe otro aspecto que ha sido estudiado y sobre el que tampoco se llega a un consenso; los tipos de ciberbullying existentes. Son muchos los autores que han tratado de clasificarlo según el modo de actuar de los agresores mediante el uso de las tecnologías.

Así, Smith et al., (2006) cataloga los tipos de ciberbullying según la vía por la que se produce el acoso y diferencia siete tipos:

- Mensajes de texto recibidos al teléfono móvil.

- Fotografías o videos realizados con las cámaras de los móviles y posteriormente enviadas o usadas para amenazar a la víctima con hacerlo.

- Llamadas al teléfono móvil acosadoras.

- Correos insultantes o amenazantes.

- Salas de chat en las que se agrede a uno de los participantes o se le excluye socialmente.

- Programas de mensajería instantánea.

- Páginas web donde se difama a la víctima.

Willard (2006), por su parte, realiza una categorización que no atiende a la vía por la que se produce puesto que no la considera muy precisa y por ello su clasificación se basa en la acción que se realiza. Los tipos de ciberbullying que determina son:

- Insultos electrónicos referidos a un intercambio breve y acalorado entre dos o más personas.

- Hostigamiento contemplado como una modalidad de acoso cibernético que incluye mensajes ofensivos reiterados enviados a la persona. 
- Denigración entendida como una información despectiva y falsa respecto a otra persona.

- Suplantación que se da cuando el acosador se hace pasar por la víctima.

- Desvelamiento y sonsacamiento por revelar información a menudo comprometida a otras personas a las que jamás se habría pensado en revelar nada semejante.

- Exclusión y ostracismo provocado por la exclusión online puede ser llevada a cabo en cualquier entorno protegido por una clave de acceso o por la eliminación de la víctima de las listas de contactos.

- Ciberpersecución en cuanto al uso de las comunicaciones electrónicas para perseguir a otra persona a través de comunicaciones reiteradas hostigadoras y amenazantes.

Una vez ya conocemos mejor el fenómeno del ciberbullying, sus características, los perfiles de los implicados, así como sus tipologías, es importante conocer las posibles causas de esta problemática (Collell \& Escudé, 2008a) que empezó a emerger con el uso masivo de las tecnologías, tratándose de un fenómeno emergente y en crecimiento. Así, son muchos los factores que lo han podido favorecer, pero entre ellos destacaríamos aspectos como:

- Mayor disponibilidad de acceso a internet y las características que ésta ofrece como la rápida distribución de información.

- Minimización del daño causado a la víctima o la sensación de impunidad, aunque no sea cierta del todo puesto que la navegación por la red deja rastro.

- Fácil adopción de roles ficticios por la facilidad que ofrece la red de enmascararse detrás de un perfil que no es real.

- Las víctimas jóvenes no suelen denunciar el acoso que están sufriendo por temor a perder el uso de los dispositivos tecnológicos que están siendo usados como medio de acoso.

Pero, ¿cómo se manifiesta el ciberbullying en los niños y adolescentes? Siguiendo a Álvarez et al. (2015), las manifestaciones del ciberbullying en niños y adolescentes son especialmente importantes, sobre todo en el estado de ánimo y en la red social se pueden detectar estas situaciones que deben ser claras para el profesorado y su familia si estos están alerta a ellos.

Las manifestaciones más significativas pueden ser en primer lugar, cambios en sus hábitos, es decir, en el uso de dispositivos móviles o de Internet, asistencia a clase, ausencia en actividades hasta ese momento preferidas, altibajos en los tiempos de estudio y en el rendimiento escolar, variaciones en sus actividades de ocio habituales, regularidad en la cantidad de comida y maneras de comer y también se ve afectada su capacidad de concentración y mantenimiento de la atención. 
En segundo lugar, cambios en el estado de ánimo, fundamentalmente en el humor, momentos de tristeza y/o apatía e indiferencia, actitudes de relajación y tensión e incluso de reacción agresivas anormales y excesiva prudencia en la comunicación.

En tercer lugar, cambios en su red social, es decir, intercambios extraños de red social y/o por repentina pobreza, ausencia de amistades y de relaciones sociales, falta de defensa ante supuestas bromas públicas u observaciones públicas, inofensivas a ojos de los adultos y, miedo y resistencia a salir de casa.

En cuarto lugar, cambios físicos o en sus pertenencias, o sea, en su lenguaje corporal (hombros encorvados, cabeza gacha, falta de contacto en ojos, rechazo de la presencia pública, etc.), en la ocupación de espacios escolares (cercanía a adultos, miedo a recreos, ocupación de rincones y espacios protegidos y controlables, etc.), ocultamiento especial cuando se comunica por Internet o móvil, arrebatos agresivos momentáneos, manifestaciones de enfermedad o dolencias frecuentes y pérdida y/o deterioro de pertenencias físicas, lesiones físicas frecuentes sin explicación razonable.

Por último, cambios somáticos, como aumento o pérdida de peso rápido debido a cambios en el comportamiento ante la comida (falta de apetito o comidas compulsivas), mareos frecuentes con síntomas no comunes y dolor de cabeza o estómago que no ocasionan insomnio pero que impiden llevar a cabo actividades normales como el ir al colegio.

Todo ello nos pone de manifiesto que el ciberbullying es un fenómeno complejo.

\subsubsection{Diferencia entre bullying y ciberbullying}

Kowalski \& Limber (2007) y Olweus (1993), señalan que el ciberbullying compartiría los tres rasgos característicos del bullying tradicional al tratarse de conductas agresivas intencionadas, repetidas y fundamentadas en una relación irregular de control y podersumisión sobre otro. Sin embargo, Menesini \& Nocentini (2009) han puesto en duda la posibilidad de evaluar estos tres aspectos en el ciberespacio, puesto que éste implica además el uso de las nuevas tecnologías (Lucas et al., 2016), pero como se indica a continuación, a pesar de la dificultad de su evaluación son rasgos comunes a ambos.

En cuanto a la intencionalidad de estos dos fenómenos, el ciberbullying tiene en común con el bullying esta intencionalidad, aunque el bullying tradicional se entiende como toda acción u omisión con la cual se causa un daño o un perjuicio de manera intencionada (Álvarez, Rodríguez, González, Núñez \& Álvarez, 2010). En cambio, la violencia a través del uso de las nuevas tecnologías debe definirse como aquella conducta intencionada con la que se causa un daño o un perjuicio a través de las TIC, principalmente el teléfono móvil e Internet (Álvarez, Núñez, Álvarez, Dobarro, Rodríguez \& González, 2011).

Por otra parte, también se ha puesto en duda la necesidad del carácter reiterativo del ciberbullying para ser considerado como tal (Gairagordobil, 2014). Sin embargo, Menesini \& Nocentini (2009) indican que un único acto, como la publicación de una foto 
comprometida (ya sea real o resultado de un montaje) en una red social puede conllevar a una difusión inmediata y con ello cumplir el criterio de ser repetitivo y frecuente.

Respecto al tercer rasgo, resulta más fácil evaluar el desequilibrio de poder en el bullying, por la mayor fortaleza física o psicológica del agresor o por simplemente un criterio numérico (varios agresores en a diferencia de una sola víctima), pero resulta más complicado en el caso del ciberbullying (Lucas et al., 2016). Esta dificultad se debe a que mal el uso de Internet permite a las personas mandar mensajes violentos manteniendo su anonimato desencadenando aspectos peligrosos (Williams \& Guerra, 2007).Por ello, Garaigordobil (2011) apunta que este desequilibrio de poder en el ciberbullying podría ser debido a que la información ofensiva está disponible para todo el mundo, los acosadores normalmente son anónimos, el proceso de victimización es continuo e inevitable, la mayoría de las veces es muy difícil eliminar el material publicado y suele estar accesible de forma pública durante largos períodos de tiempo.

A pesar de estos rasgos característicos en ambos fenómenos, Avilés (2013) cita en su artículo a Mora \& Ortega (2007) los cuales indican que los dispositivos móviles e Internet presentan características y componentes específicos que lo diferencian del bullying presencial. Algunas peculiaridades modulan y condicionan las dinámicas de acoso y las consecuencias sobre los perfiles de quienes participan en ellas (Avilés, 2012; Burges, Patchin \& Hinduja, 2006, Willard, 2006).

En la siguiente Tabla 6 presentamos a modo de síntesis las características del bullying y del ciberbullying respecto a las distintas variables que los integran.

Tabla 6. Características del bullying y del ciberbullying respecto a variables que los integran

\begin{tabular}{|c|c|c|}
\hline & Bullying & Ciberbullying \\
\hline Mostrabilidad & $\begin{array}{l}\text { Espacios de convivencia habitual } \\
\text { como la clase, el patio o la calle. }\end{array}$ & $\begin{array}{l}\text { Da una sensación de } \\
\text { invisibilidad y de anonimato } \\
\text { que no siempre es real. }\end{array}$ \\
\hline Escenario & $\begin{array}{l}\text { Suele suceder en el centro escolar o } \\
\text { en sus inmediaciones. }\end{array}$ & $\begin{array}{l}\text { Puede presentarse fuera de } \\
\text { los espacios escolares, } \\
\text { aunque tenga un origen } \\
\text { escolar. }\end{array}$ \\
\hline Medio de ejecución & Presencia física. & Tecnológico. \\
\hline Riesgo físico & $\begin{array}{l}\text { Es menor, sobre todo para agresor } \\
\text { que no se expone menos. }\end{array}$ & $\begin{array}{l}\text { Mayor riesgo por la } \\
\text { exposición presencial. }\end{array}$ \\
\hline Detección & Más visible y fácil de detectar. & Más difícil por el anonimato. \\
\hline Perfiles escolares & $\begin{array}{l}\text { Perfiles escolares de fracaso y } \\
\text { conflictividad. }\end{array}$ & $\begin{array}{l}\text { No suelen observarse perfiles } \\
\text { determinados. }\end{array}$ \\
\hline
\end{tabular}


Tabla 6. Características del bullying y del ciberbullying respecto a variables que los integran (Continuación)

\begin{tabular}{cll}
\hline & \multicolumn{1}{c}{ Bullying } & \multicolumn{1}{c}{ Ciberbullying } \\
\hline Vigencia del maltrato & $\begin{array}{l}\text { Está activo mientras se produce y } \\
\text { sucede. }\end{array}$ & $\begin{array}{l}\text { Suele mostrarse de forma } \\
\text { más prolongada. }\end{array}$ \\
\hline Quienes contemplan & $\begin{array}{l}\text { Los que están presentes en ese } \\
\text { momento. }\end{array}$ & $\begin{array}{l}\text { Todos tienen acceso a la } \\
\text { información, incluso aunque } \\
\text { no correspondan al círculo de } \\
\text { convivencia de quien lo } \\
\text { recibe. }\end{array}$ \\
\hline Procedencia de las & $\begin{array}{l}\text { Tanto el agresor como el acto están } \\
\text { agresiones. }\end{array}$ & $\begin{array}{l}\text { La víctima no siempre conoce } \\
\text { de dónde vienen los ataques } \\
\text { ni quién los produce }\end{array}$ \\
\hline Prestación de la ayuda & $\begin{array}{l}\text { Al ser la detección más fácil, } \\
\text { también se facilita la ayuda que se } \\
\text { pueda proporcionar. }\end{array}$ & $\begin{array}{l}\text { Detectamos más difícilmente } \\
\text { por lo que se requiere } \\
\text { información de quien lo } \\
\text { padece. }\end{array}$ \\
\hline
\end{tabular}

Por lo que hace referencia al ciberbullying, es más de carácter público que las agresiones tradicionales e incrementa el sentimiento de vulnerabilidad de la víctima, puesto que no se siente segura en ningún momento ni lugar (Kowalski \& Limber, 2007).

Según Buelga, Cava \& Musitu (2010) apuntan, con un solo click un alumno puede difundir un falso rumor a gran cantidad de personas en la red, mientras que en el acoso tradicional, por su carácter presencial, la repercusión de dicho rumor está mucho más limitada.

Por otro lado, se diferencia en la imposibilidad de la víctima de escapar de la situación de intimidación. Sin embargo, el acoso tradicional se restringe simplemente al tiempo que la víctima pasa en el entorno escolar y sus alrededores. No obstante, en el ciberbullying, el hostigamiento puede continuar las 24 horas del día durante los 7 días de la semana esté o no el alumno en el centro educativo, ya que puede seguir recibiendo mensajes en su móvil u ordenador.

Por otra parte, el ciberbullying frente al bullying tradicional no es una experiencia "cara a cara", el agresor no tiene que exponerse físicamente a la víctima y, además, puede utilizar pseudónimos en la red. Todo esto le establece cierta invisibilidad y permite actuar al acosador desde el anonimato.

Por último, el contenido del acoso electrónico puede ser perpetuo o difícil de eliminar, por lo que la víctima puede estar reviviendo una y otra vez la situación de victimización, situándola en una situación de mayor fragilidad (Lucas et al., 2016). 


\subsubsection{Diferencia entre ciberbullying, grooming y sexting}

Es importante conocer también la diferencia entre los diferentes riesgos del uso de las TIC como son el ciberbullying, grooming y sexting.

El grooming hace referencia a una situación de acoso ejercida por un adulto hacia el menor con una finalidad sexual, tanto explícita como implícita.

En cambio, el sexting consiste en la publicación o envío de contenidos sexuales por medio de las TIC, produciendo una serie de peligros para el adolescente como es sufrir riesgos psicológicos, amenazas a su privacidad y chantaje.

Según Christine Kormann, Directora en la Comisión Europea del Área de la Sociedad de la Información, tanto el ciberbullying como el grooming y sexting son los fenómenos que más incidencia tienen en la actualidad entre el conjunto de comportamientos inapropiados de los adolescentes en los contextos digitales. En muchas ocasiones, el bullying puede ir acompañado de ciberbullying, siendo menos frecuente que la situación se produzca a la inversa.

Según Álvarez et al. (2015), el grooming se caracteriza por tener inicio en la fase de amistad, es decir, una toma de contacto con el menor para conocer sus gustos, preferencias y crear una relación de amistad con la finalidad de alcanzar la confianza del posible afectado. Seguidamente, un inicio de la fase de relación que incluye en muchas ocasiones confesiones personales e íntimas entre el menor y el acosador. De manera que se consolida la confianza obtenida del menor y se profundiza en información sobre su vida, sus gustos y costumbres. Y por último, un componente sexual, incluyendo una descripción detallada de términos sexuales y la petición a los menores de su participación en actos de naturaleza sexual, grabación de imágenes o toma de fotografías.

Además, en el grooming se determinan una serie de fases por la que el adulto consigue hacerse con la confianza del menor y finalizar el abuso. De este modo, aparecen las siguientes fases (Álvarez et al., 2015):

- En primer lugar, contacto y acercamiento, el ciberacosador contacta con el menor a través de Internet y lleva a cabo una estrategia preconcebida con el fin de ganarse su confianza poco a poco.

- En segundo lugar, sexo virtual, consigue en el transcurso de dicha relación, que el menor le envíe alguna fotografía comprometida, logrando que encienda la webcam o que pose desnudo.

- En tercer lugar, ciberbullying, es decir, si el menor no accede a sus intenciones sexuales, el ciberacosador le amenaza con difundir la imagen que haya capturado con mayor carga sexual a través de Internet y/o enviarla a los contactos personales del menor. 
- Por último, abuso y agresiones sexuales, ante las amenazas del ciberacosador, el menor accede a todos sus caprichos sexuales, llegando, incluso, en algún caso, a contactar físicamente con el menor y abusar sexualmente de él.

Según indica la Guía clínica de ciberacoso para profesionales de la salud (Curell, 2015), un $2,1 \%$ de los padres y un $1,3 \%$ de los hijos afirman que los menores han estado expuestos a situaciones identificadas como grooming o acoso sexual. Desde el punto de vista legal el tipo penal más próximo al grooming se encuentra en el artículo 183 bis del Código Penal, en el que, se determinan los actos dirigidos al contacto por cualquier medio con menores, acompañados de actos físicos de acercamiento y con el fin de cometer delitos de agresiones y abusos sexuales o relativos a la corrupción y prostitución de menores (Álvarez et al., 2015).

Por lo que se refiere al sexting, es considerado como el envío, especialmente a través del teléfono móvil, de fotografías y vídeos con contenido de cierto nivel sexual, cogidos o grabados por el protagonista de los mismos. Sin embargo, relacionado con el sexting se encuentra el llamado sex-casting, que consiste en la grabación de contenidos sexuales a través de la webcam y difusión de los mismos por e-mail, redes sociales o cualquier canal que permitan las TIC (Pérez et al., 2011).

Para describir este fenómeno, Pérez et al. (2011) plantean la voluntariedad inicial, ya que por norma general estos contenidos son originados por los protagonistas de los mismos o con su consentimiento y no es necesaria la amenaza ni la insinuación, puesto que son contenidos que normalmente alguien crea como regalo para su pareja o como una herramienta de flirteo y por ello son los responsables del primer paso en su difusión. También sugieren, lo sexual frente a lo atrevido, dado que el protagonista de las imágenes posa de manera erótica o sexual en una situación de sexting y, por tanto, quedarían fuera del ámbito de este fenómeno las fotografías que simplemente resultan atrevidas o sugerentes, pero no tienen un contenido sexual manifiesto. Por último, expresan la importancia de la edad, porque este fenómeno no es propio de los adolescentes.

Las últimas investigaciones indican que el sexting es una forma relativamente común de interacción sexual entre los adolescentes. Aproximadamente el 15\% de los adolescentes, de 12 a 17 años de edad, admitió haber enviado algunos contenidos sexuales en línea, el porcentaje aumenta hasta el $36 \%$ a los 17 años de edad. En este sentido, el envío de contenido sexual aumentó progresivamente a lo largo de la adolescencia, especialmente a los 14 ya los 17 años de edad. Una posible explicación de estos hallazgos es que con el aumento de la edad también aumenta la probabilidad de establecer relaciones de citas (contexto en el que se producen muchos comportamientos sexuales) y el uso de las redes sociales. El contenido sexual fue la mayoría de las veces información escrita (cerca del $11 \%)$, seguido de envío de fotos sexuales (7\%) y, finalmente, el envío de imágenes o videos, por ejemplo, a través de webcam (2\%) (Gámez-Guadiz, Santisteban \& Resett, 2017). 
A pesar de estos datos, las tasas de prevalencia de Sexting entre adolescentes son más bajas que entre adultos españoles (Agustina \& Gómez-Durán, 2012; Gámez-Guadix, Almendros, Borrajo \& Calvete, 2015). Este dato también coincide con los datos obtenidos en estudios internacionales (Döring, 2014).

Por todo ello, y debido a que los niños pueden ser más vulnerables a las posibles consecuencias negativas del sexting, al igual que con el ciberbullying, se hace especialmente importante educarlos desde el inicio de la adolescencia en el uso responsable de las TIC. Además, debemos informar correctamente a los menores sobre el sexting y ofrecerles pautas de actuación para su prevención (Hinduja \& Patchin, 2016a):

- Elimina las imágenes explícitas que te envíen. Simplemente el hecho de tener estas imágenes en tu teléfono podría acarrearte en un montón de problemas.

- No distribuyas imágenes explícitas. Si alguien te envía una imagen explícita de sí mismo o de otra persona, no lo pases a nadie más. Trata de pensar en cómo se sentiría si alguien enviara fotos similares tuyas o de otra persona que no conocía o no querrías ver.

- Ignora o rechaza todas las solicitudes que te envíen otros con imágenes inapropiadas. No vale la pena, no importa cuánto te guste la otra persona, incluso si crees que puede confiar en ellos. El riesgo potencial es demasiado alto. $\mathrm{Si}$ realmente se preocupan por ti, lo entenderán.

- Bloquea a las personas que te hacen sentir incómodo por la forma en que te hablan (o con por lo que te envían).

- Distrae a la persona que solicita alguna foto inapropiada tuya. Involúcrales en una conversación sobre otra cosa, o envíales un video de YouTube que acabas de ver o a una aplicación que crees que le gustaría. Si sigue preguntando por las fotos, hazle saber que deberían relajarse.

- No apoyes tu propia objetivación. No eres un trozo de carne. No quieras que a la gente les gustes por tu cuerpo, sino por tu mente y corazón. Dar y enviar imágenes explícitas simplemente alimenta su apetito, devaluando tu valor.

- El sexting no define una relación saludable, funcional y romántica. Se puede considerar divertido, pero recuerda que estas imágenes podrían ser vistas por un público más amplio (incluyendo tus padres, profesores o la policía).

- Envía imágenes que sean sugerentes, pero no explícitas. Mantén las partes privadas cubiertas en todo momento. Está bien enviar a tu pareja una imagen, sólo asegúrate que es PG-13 y no X-rated. Aun así, éstos también pueden ser transmitidos a otros.

- Si recibes (o alguien te muestra) una imagen explícita de alguien que conoces, ponte en contacto con esa persona para decirle que sus imágenes están circulando. 
Tú también querrías que alguien te dijera si una imagen tuya como esa estaba dando vueltas.

- Informa a un adulto de tu confianza sobre lo que te preocupa, y sobre el bienestar de la persona de la imagen. Si estás preocupado por la persona que está en la foto, si es un amigo o no, es posible que necesites la ayuda de un adulto.

Estos datos nos dejan ver que los tres fenómenos están presentes en los adultos, en mayor o menor medida, y que hay que actuar e intervenir con los menores y jóvenes para tratar de prevenir y erradicar estas problemáticas surgidas a partir del uso de las TIC por los menores.

\subsection{CIBERBULLYING EN EL CONTEXTO CLÍNICO, EDUCATIVO Y FAMILIAR}

La práctica del ciberbullying, tanto para las escuelas como para los hogares, está siendo hoy en día una problemática grave y relevante, y por ello debe tratarse de forma integral, siendo la prevención y la identificación de éste el aspecto esencial (García et al., 2011). Todo ello contando siempre con la participación de las familias, las autoridades escolares y los profesionales de la salud.

\subsubsection{Contexto clínico}

Los centros sanitarios, al igual que los centros educativos, cada día reciben más consultas de familias y menores. En concreto en lo que respecta al ciberbullying, los centros educativos cuentan con la dirección del centro y con profesionales especializados en orientación educativa quienes son suficientemente eficaces a la hora de actuar en un caso de ciberbullying, tanto en aspectos de detección como de intervención. Por ello, es muy importante que los centros sanitarios conozcan la existencia de los protocolos de ciberbullying para dar una rápida respuesta ante este tipo de situaciones (Luengo, 2014) relacionadas con el uso no adecuado de los dispositivos digitales.

Pero su labor no es simplemente la de conocer la existencia de estos protocolos, sino que es necesario que sepan detectar en sus consultas a aquellos menores que pueden estar siendo víctimas o agresores de ciberbullying. Esta detección debe ser temprana para evitar efectos negativos en la salud física y psicológica de los menores. Por todo ello, es importante que el pediatra esté alerta ante cualquier síntoma que pueda ser psicosomático puesto que cualquier síntoma recurrente y sin explicación clara puede ser un signo que nos esté indicando que el menor está implicado en una situación de ciberbullying (Gini \& Pozzoli, 2013).

Además de los síntomas psicosomáticos, es importante que los sanitarios indaguen sobre la utilización y relación que ese menor mantiene con los dispositivos tecnológicos (Salmerón, Campillo \& Casas, 2013), pues es importante constatar si ha sido intimidado o, en el caso contrario, ha sido participe de alguna agresión (Inteco, 2012). 
Dada la importancia de la detección precoz, presentamos a continuación una tabla que recoge las consecuencias derivadas del ciberbullying que recogen diferentes autores en sus estudios, puesto que estos síntomas psicosomáticos pueden dejar ver al sanitario que pueda existir un problema como el ciberbullying.

Partiendo de Curell (2015), hemos elaborado la siguiente Tabla 7 en la que se analizan los diferentes estudios en relación a las consecuencias del ciberbullying en las víctimas, agresores y testigos.

Tabla 7. Estudios en relación a las consecuencias del ciberbullying

\begin{tabular}{|c|c|c|c|}
\hline Estudio & Víctima & Agresor & Testigos \\
\hline $\begin{array}{l}\text { Emociones de agresores y } \\
\text { víctimas de cyberbullying: un } \\
\text { estudio preliminar en } \\
\text { estudiantes de secundaria. } \\
\text { Ortega, Elipe \& Calmaestra } \\
\text { (2009) }\end{array}$ & $\begin{array}{l}\text { Más emociones negativas } \\
\text { (sentirse mal, tristes e } \\
\text { indefensos) que los agresores- } \\
\text { víctimas; } 20 \% \text { no se sienten } \\
\text { afectados. }\end{array}$ & $\begin{array}{l}\text { Reconocen que la agresión } \\
\text { podía causar emociones } \\
\text { negativas en las víctimas }\end{array}$ & \\
\hline $\begin{array}{l}\text { Bullying, Cyberbullying, and } \\
\text { Suicide. } \\
\text { Hinduja \& Patchin (2010) }\end{array}$ & $\begin{array}{l}\text { Ideación suicida en } 20 \% \text { de } \\
\text { casos, casi el doble que los que } \\
\text { no habían sufrido ciberacoso. }\end{array}$ & $\begin{array}{l}\text { Mayor tasa de ideación } \\
\text { suicida }(1,5: 1) \text { que jóvenes no } \\
\text { implicados. }\end{array}$ & \\
\hline $\begin{array}{l}\text { Prevalencia y consecuencias } \\
\text { del cyberbullying: una } \\
\text { revisión. } \\
\text { Garaigordobil (2011) }\end{array}$ & $\begin{array}{l}\text { Ansiedad, depresión, ideación } \\
\text { suicida, estrés, miedo, baja } \\
\text { autoestima, falta de confianza } \\
\text { en sí mismos, ira, frustración, } \\
\text { indefensión, nerviosismo, } \\
\text { irritabilidad, somatizaciones, } \\
\text { trastornos del sueño, baja } \\
\text { concentración y rendimiento } \\
\text { escolar. }\end{array}$ & $\begin{array}{l}\text { Mayor desconexión moral, } \\
\text { falta de empatía, dificultad de } \\
\text { acatamiento de normas, } \\
\text { agresividad, conductas } \\
\text { delictivas, absentismo } \\
\text { escolar, abuso de tóxicos o de } \\
\text { las tecnologías. }\end{array}$ & $\begin{array}{l}\text { Síntomas } \\
\text { psicosomáticos. }\end{array}$ \\
\hline $\begin{array}{l}\text { Bullying and cyberbullying: } \\
\text { Overlapping and predictive } \\
\text { value of the co-occurrence. } \\
\text { Del Rey, Elipe \&Ortega-Ruiz } \\
\text { (2012) }\end{array}$ & $\begin{array}{l}\text { Baja autoestima, depresión, } \\
\text { esquema de maltrato, } \\
\text { exposición a la violencia; riesgo } \\
\text { de victimización y de } \\
\text { convertirse, a su vez, en } \\
\text { acosadores. }\end{array}$ & & \\
\hline $\begin{array}{l}\text { Psychological, Physical, and } \\
\text { Academic Correlates of } \\
\text { Cyberbullying and Traditional } \\
\text { Bullying. } \\
\text { Kowalsky \& Limber (2013) }\end{array}$ & $\begin{array}{l}\text { Baja autoestima, ansiedad } \\
\text { social, depresión, debilidad, } \\
\text { indefensión, rabia, tristeza, } \\
\text { distanciamiento, problemas } \\
\text { psicosomáticos, problemas } \\
\text { académicos, ideación suicida. }\end{array}$ & $\begin{array}{l}\text { Síntomas psicosomáticos y } \\
\text { problemas académicos; } \\
\text { agresividad, deseo de } \\
\text { venganza, felicidad, } \\
\text { satisfacción. }\end{array}$ & \\
\hline $\begin{array}{l}\text { Suicidal Thinking and } \\
\text { Behaviour Among Youth } \\
\text { Involved in Verbal and Social } \\
\text { Bullying: Risk and Protective } \\
\text { factors. } \\
\text { Borowsky, Taliaferro \& } \\
\text { McMorris (2013) }\end{array}$ & $\begin{array}{l}\text { Ideación suicida en } 29 \% \text {; } \\
\text { Abusos físicos o sexuales } \\
\text { previos, problemas mentales o } \\
\text { huidas previas del domicilio } \\
\text { familiar fueron factores de } \\
\text { riesgo adicionales. Buena } \\
\text { relación familiar o con el grupo } \\
\text { de iguales fueron protectores. }\end{array}$ & $\begin{array}{l}\text { Bajo rendimiento escolar, } \\
\text { consumo de tóxicos, mala } \\
\text { percepción del ambiente } \\
\text { escolar, pero también mayor } \\
\text { facilidad para hacer nuevos } \\
\text { amigos. }\end{array}$ & \\
\hline $\begin{array}{l}\text { Bullying and Suicide: A Public } \\
\text { Health Approach en J } \\
\text { Adolesc Health. } \\
\text { Feldman \&Donato (2013) }\end{array}$ & & $\begin{array}{l}\text { Mayor riesgo de ser } \\
\text { diagnosticados de } \\
\text { personalidad antisocial, de } \\
\text { tener dificultades para la } \\
\text { inserción laboral o de usar } \\
\text { drogas, años después. }\end{array}$ & $\begin{array}{l}\text { Sentimientos } \\
\text { de inferioridad, } \\
\text { impotencia, } \\
\text { dolor. }\end{array}$ \\
\hline
\end{tabular}


Tabla 7. Estudios en relación a las consecuencias del ciberbullying (Continuación)

\begin{tabular}{|c|c|c|c|}
\hline Estudio & Víctima & Agresor & Testigos \\
\hline $\begin{array}{l}\text { Conductas de ciberacoso en } \\
\text { niños y adolescentes. Hay } \\
\text { una salida con la educación y } \\
\text { la conciencia social. } \\
\text { Bartrina (2014) }\end{array}$ & $\begin{array}{l}\text { Ansiedad y conductas } \\
\text { depresivas; } 16,6 \% \text { hizo una } \\
\text { demanda de atención en el } \\
\text { ámbito de la salud mental; } \\
7,5 \% \text { solicitó medidas de } \\
\text { protección al denunciar los } \\
\text { hechos; menor edad, } \\
\text { discapacidad e inmigración se } \\
\text { asocian a mayor victimización; } \\
\text { mayor sufrimiento en casos de } \\
\text { violencia en la relación de } \\
\text { pareja, incluso si el acoso es de } \\
\text { corta duración. }\end{array}$ & & \\
\hline $\begin{array}{l}\text { SaveTheChildren, Acoso } \\
\text { escolar y ciberacoso: } \\
\text { Propuestas para la acción. } \\
\text { Orjuela et al. (2014) }\end{array}$ & $\begin{array}{l}\text { Existen factores de riesgo } \\
\text { individuales, familiares y } \\
\text { sociales que aumentan su } \\
\text { vulnerabilidad. Impacto } \\
\text { negativo en el desarrollo } \\
\text { emocional a corto y largo plazo. }\end{array}$ & $\begin{array}{l}\text { Impacto negativo en el } \\
\text { desarrollo emocional a corto } \\
\text { y largo plazo. }\end{array}$ & $\begin{array}{l}\text { Se sienten mal: } \\
\text { pena, tristeza, } \\
\text { rabia. }\end{array}$ \\
\hline $\begin{array}{l}\text { Protocol de prevenció, } \\
\text { detecció i intervencióenfront } \\
\text { el ciberassetjament entre } \\
\text { iguals. } \\
\text { Generalitat de Catalunya } \\
\text { (2014) }\end{array}$ & $\begin{array}{l}\text { Problemas conductuales: en } \\
\text { casa (cambios con respecto al } \\
\text { uso de TIC's, evitar hablar del } \\
\text { tema); en la escuela (bajo } \\
\text { rendimiento, absentismo, } \\
\text { evitar contacto con iguales); } \\
\text { con sus pertenencias. } \\
\text { Somatización, ansiedad, } \\
\text { depresión. }\end{array}$ & & \\
\hline
\end{tabular}

En relación a los síntomas físicos, tanto en víctimas como en agresores y testigos, encontramos algunos más comunes como el dolor abdominal, trastornos del sueño, cefalea, fatiga, enuresis secundaria, pérdida de apetito, pérdida de peso, tics, mareos y vértigo (Garaigordobil, 2011).

Respecto a los síntomas psicológicos más recurrentes, normalmente en las víctimas, encontramos aspectos como ansiedad, depresión y baja autoestima. A estos síntomas, Orjuela et al. (2014) añade otros como la irritabilidad, nerviosismo, sentimientos de soledad e impotencia, baja autoestima e ideaciones suicidas son también referidos con frecuencia.

En cuanto a los cambios de carácter conductual, el no conectarse a internet o hacerlo con más frecuencia, mostrar cierta frustración, tristeza o enojo después del uso de dispositivos tecnológicos son rasgos que determinan más si cabe el enfoque del diagnóstico (Generalitat de Catalunya, 2014).

Así, cualquier sanitario que atienda a menores debería conocer bien los síntomas que pueden ser producidos por este fenómeno que, junto con la información que les pueda proporcionar sobre el uso de los dispositivos tecnológicos, puede permitir una detección 
temprana de casos como el ciberbullying y con ello una rápida y eficaz intervención con el menor.

\subsubsection{Contexto educativo}

Las nuevas generaciones acceden desde edades muy tempranas al mundo digital, las redes sociales, los teléfonos móviles, aplicaciones en smartphones, etc. Por ello, se hace necesario que la educación que reciban se centre en aspectos relacionados con la seguridad, privacidad y protección de los derechos de las personas. Esto implica que las familias y los educadores deben enseñar desde pequeños a los niños cuales son los riesgos que implica el uso de la tecnología y cómo prevenirlos. Sin embargo, muchas veces el problema empieza ahí puesto que son los propios adultos los que no conocen o no son conscientes de los riesgos reales a los que se enfrenta un menor cuando hace uso de la tecnología, y más si cabe, enseñarles y educarles en la prevención (Inteco, 2012).

Por ello, desde el sistema educativo se debe favorecer este proceso que se empieza a desarrollar desde el entorno más cercano como son la familia, amigos, medios como la televisión, Internet, etc. Así, se hace necesario que hoy en día la escuela integre esta nueva cultura a través de la alfabetización digital, y convertirlo en instrumento cotidiano de uso educativo (Soler, 2008).

La actividad tutorial en todos los ámbitos educativos pasa necesariamente no sólo por integrar el uso de las TIC en todos los procesos orientadores, sino también por ayudar a los jóvenes y adultos a adaptarlas a sus estilos de vida, y no al revés, como está ya sucediendo de manera alarmante en muchos de ellos, sobre todo en lo que concierne al uso de internet (Álvarez \& Bisquerra, 2009).

Todo ello conlleva la necesidad de poner en marcha programas de información y formación adecuada para adolescentes, familias y docentes, en el ámbito de las tecnologías. Esta formación debe apoyarse en dos perspectivas; una tecnológica y otra humanística. Es decir, que atienda a los medios, pero también a los fines de la educación (Naval, Sábada \& Bringué, 2003).

La escuela ha pasado de ser observada únicamente como escenario de prácticas rutinarias y cerradas para la adquisición de saberes instrumentales y conocimientos académicos, a ser contemplada en su amplia dimensión de escenario de desarrollo y aprendizaje para la vida y el bienestar de individuos y sociedades (Ortega, Del Rey \& Sánchez, 2012).

Considerando lo anteriormente citado, los centros educativos de todos los niveles tienen en la actualidad el deber de incluir dentro de la formación integral aspectos como el sensibilizar y prevenir que entre el mismo alumnado surjan situaciones de maltrato e intimidación, aunque se sabe que el ciberbullying no sucede precisamente dentro de la escuela, es ahí donde debe abordarse como parte de la educación integral (Ortega, 2010). 
Con dicha finalidad, Avilés (2013) afirma que la comunidad educativa para conseguir ir más allá de la prevención e intervención de situaciones de ciberbullying, no debe centrarse únicamente en informar y formar a los alumnos sobre situaciones de riesgo, hábitos de uso y buenas prácticas saludables en el uso de las tecnologías, sino que la finalidad es la toma de consciencia, la gestión de sentimientos y el aprendizaje de pautas de actuación. Para ello el mismo autor propone acciones como hacer protagonista al propio alumno; trabajar con el grupo la convivencia como grupo y no sólo individualmente; disponer de instrumentos institucionales para combatir el ciberbullying; educar en ámbitos saludables de autoprotección y de buenas prácticas en los espacios virtuales; aprender a valorar en positivo los contenidos virtuales; insertar en el currículo el trabajo en valores de convivencia respecto al ciberbullying; organizar el centro para abordar el ciberbullying; haber consensuado un protocolo de respuesta y seguir ciertos modelos disciplinarios.

En la misma línea, Hinduja \& Patchin (2015a) afirman que son muchas las investigaciones han demostrado que un clima escolar positivo contribuye a la mejora de una gran variedad de aspectos conductuales, emocionales y académicos. Así, añaden que como resultado de sus investigaciones pueden afirmar que los estudiantes que presentan un clima positivo en la escuela también experimentan menos comportamientos problemáticos online. De este modo, no sólo se consigue mejorar el clima y los resultados académicos, sino también enseñar a los jóvenes a ser seguros, inteligentes, honestos y responsables al usar las TIC. Para ello, estos autores proponen diez aspectos que el docente debe tener en cuenta:

- Promover la conciencia. Los docentes deben dedicar tiempo en el aula a enseñar a los alumnos todas las formas de intimidación que existen con la finalidad de crear conciencia sobre los riesgos, las posibles sanciones legales y escolares y los daños emocionales, psicológicos, reputacionales e incluso físicos puede resultar. Los estudiantes deben darse cuenta de que incluso si no están intimidando a otros, tienen la responsabilidad de garantizar la seguridad de sus compañeros, y por tanto si ven que alguien está siendo intimidado, deben hacer algo al respecto. Las escuelas también deben estructurar, modelar y recompensar los comportamientos apropiados y provechosos, en vez de hablar solamente en contra y sancionar las acciones que no se consideren apropiadas.

- Favorecer la comunicación. La interacción entre el personal del centro y los estudiantes debe existir. El personal debe trabajar intencionalmente con la finalidad de crear una atmósfera de confianza y un diálogo continuo respecto a los problemas que enfrentan los jóvenes. Los estudiantes deben conocer y sentirse completamente cómodos con al menos un adulto en la escuela a quien puedan acercarse para cualquier aspecto que les preocupe.

- Aprender los nombres de los alumnos. Los docentes deben dedicar tiempo a aprender los nombres de todos sus alumnos con el fin de construir relaciones, combatir sentimientos de poca importancia, promover la conexión y pertenencia, y reforzar sentimientos críticos de confianza, respeto mutuo y seguridad. Esta es 
una manera simple pero muy poderosa con la que los docentes pueden demostrar que realmente se preocupan por cada uno de sus alumnos.

- Desarrollar relaciones con el resto de la comunidad escolar. Los docentes deben trabajar junto con los padres y otros miembros de la comunidad. Todo el mundo puede ayudar a combatir colectivamente estos problemas. Enseñar a los adolescentes a usar la tecnología con sabiduría, discreción y previsión es responsabilidad de todos en la comunidad.

- Configurar informes anónimos. Las escuelas deben crear formas seguras y privadas para que los estudiantes reporten asuntos que les preocupen y que de otra manera podrían sentirse incómodos, asustados o avergonzados de compartir abiertamente. Los alumnos no quieren ser vistos como unos chivatos. Así, por ejemplo, los sistemas de información podrían incluir un formulario en una página web de la escuela, un número de teléfono para recibir llamadas o textos confidenciales. A pesar de ello, lo más importante son los mecanismos de respuesta a esos informes, ya que lo más esencial es que las escuelas investiguen y respondan rápida y apropiadamente a todos los informes que lleguen. De lo contrario, los estudiantes aprenderán rápidamente que no ocurre nada cuando se informa de alguna incidencia y dejarán de hacerlo.

- Generar esperanza. Desde la escuela se debe trabajar para cultivar un fuerte sentido de esperanza y positividad en todo el estudiantado para contrarrestar los mensajes negativos de quienes intimidan y para ayudar a amortiguar los estresores típicos de los adolescentes. Los mejores docentes demuestran preocuparse por algo más que el éxito académico de los jóvenes.

- Construir campañas sociales de normalización positivas. La norma social consiste en cambiar las mentalidades predominantes sobre ciertos comportamientos. Por ejemplo, si la mayoría de los jóvenes piensan que la intimidación es una parte común y natural de la cultura adolescente, o que cualquiera que habla con un adulto acerca de sus problemas es débil, entonces estas creencias dominarán y se extenderán. La realidad es que la gran mayoría de los niños desprecian el acoso, no quieren herir a otros y desean tener grandes relaciones con sus compañeros.

Por eso es necesario promover todas aquellas acciones positivas que los alumnos están haciendo, celebrar los éxitos, destacar y recomendar actos de bondad, y dejar claro que el cuidado y la compasión son la norma en su escuela, y no la excepción.

- Obtener la ayuda de los estudiantes. Muchos jóvenes quieren participar activamente en la lucha contra el acoso y promover la positividad en su centro escolar. El grupo de iguales ejerce una poderosa influencia en las actitudes, creencias y comportamientos de los adolescentes en esta etapa de su desarrollo. 
Los líderes podrían hablar con sus compañeros sobre estos asuntos informalmente o en sesiones informativas previamente organizadas.

- Recoger datos. Los docentes deben considerar la posibilidad de llevar a cabo una evaluación formal regular de los estudiantes para averiguar el alcance real del acoso en el centro y otros problemas relacionados, y así conocer sus factores contribuyentes y los resultados negativos que resultan. Esto ayudará a formar y dirigir esfuerzos para que los recursos se gasten de la mejor manera posible.

- Nunca hay que dejar de aprender. Los propios docentes deben continuar aprendiendo acerca de los nuevos desarrollos tecnológicos, dispositivos y formas de acoso online. También deben establecer relaciones con el personal de otras escuelas, para así saber dónde pueden obtener ayuda cuando se les presente un problema en su centro. Además, hay muchos recursos disponibles para ayudar a los educadores a identificar, prevenir y responder al bullying y ciberbullying.

En definitiva, los centros precisan de una guía clara y práctica de actuación para hacer frente a situaciones de acoso. También se requiere formación y orientación a los docentes sobre cómo actuar en el aula ante casos de acoso. En el caso del ciberbullying, los medios de comunicación social, teléfonos, tabletas, Internet, etc., no son el problema, son sólo herramientas que pueden ser manejadas de manera útil o perjudicial y por tanto hay que formar a los alumnos en cómo hacer un buen uso de ellos. Con tal finalidad, Hinduja (2016) propone como enfoques más prometedores para reducir el ciberbullying la puesta en marcha en 2017 en los centros escolares programas de: resiliencia; normalización social; habilidades sociales y relacionales; solución de problemas y técnicas de toma de decisiones; inteligencia emocional, autoconciencia y autogestión; y entrenamiento en empatía.

\subsubsection{Contexto familiar}

El problema de la violencia a través de las nuevas tecnologías debe ser abordado de forma transituacional, obteniendo información tanto del contexto familiar, escolar o de ocio (Félix, 2010).

De ello se deriva la importancia de ser consciente de lo que implica este tipo de problemática en los más jóvenes, y no dejar que toda la responsabilidad del uso adecuado de la tecnología recaiga únicamente sobre las instituciones educativas, ya que la familia es un pilar fundamental sobre el que deben apoyarse las estrategias de prevención e intervención contra el ciberbullying. Todo el trabajo que se haga en las aulas debe tener su réplica en el hogar de los alumnos (Ortega, 2010).

Los cambios que se han producido en estos últimos años con el acceso a las nuevas tecnologías han conllevado consigo un cambio también en el ámbito familiar, puesto que se ha producido una brecha digital entre padres e hijos y ello genera en los padres un aumento de su inseguridad en el desempeño de su tarea como educadores. Esta sensación 
genera en los padres una tendencia a pensar que, obviando los cambios, se consiguen distanciar a los hijos de los riesgos que implica el uso de la red, así como también, que facilitando el uso intensivo, y normalmente incontrolado de las tecnologías, se obtendrá una integración completa de los hijos en la sociedad de la información. Ambas posiciones suelen ser el camino fácil y seguro que los padres deciden escoger debido a las conscientes limitaciones de destrezas informáticas que presentan en relación a la de sus hijos.

Todos estos datos nos hacen reflexionar sobre cuál es el principal problema que encuentran a la hora de incorporar en sus hogares las nuevas tecnologías y educar a sus hijos en el uso de ésta, y no es otra que la creciente necesidad que encuentran estas generaciones de reflexionar concienzudamente sobre el uso correcto de estos dispositivos en el día a día en sus hogares, tanto en el ámbito educativo como en el de ocio.

Y, ¿cómo podemos conseguirlo? El modo más eficaz y conveniente de conseguirlo sería mediante la formación en el uso de las tecnologías y por supuesto de todo aquello que implica su uso, como pueden ser los peligros asociados. Con ellos conseguiríamos que los padres eduquen a sus hijos fomentando el uso responsable y crítico de las tecnologías. Para ello, la acción principal es formar a las familias correctamente para que adquiera la aptitud necesaria que le permita orientar, guiar y así favorecer la educación de sus hijos en el uso adecuado de las tecnologías.

Según los autores Kowalsky, Limber \& Agstston (2010), las familias tendrían que tener en cuenta una serie de aspectos como son: explicar los riesgos de comunicarse por la red; enseñarles que no somos invisibles por la red; que los menores aprendan a proteger las contraseñas; filtrar/supervisar el uso que hacen de los dispositivos tecnológicos; y vigilar la reputación de nuestro hijo por la red.

A estas orientaciones, Aftab (2010) añade otros consejos que los padres pueden proporcionar a sus hijos, entre las que se encuentran: no hablar o aceptar a personas desconocidas en chats o foros; no hacer comentarios negativos de otras personas; y ser respetuosos con los demás.

Otras normas de buen uso (Caballer, 2005), dirigidas a los padres con la finalidad de potenciar un mayor control parental son: crear una lista de normas relativas a la utilización de Internet consensuadas entre padres e hijos; establecer horarios y límites de tiempo; situar el ordenador en una zona pública de la casa; incorporar elementos de filtrado de contenidos; y propiciar la necesidad de comunicación padres-hijos.

Con todo ello debemos ser conscientes de la importancia que toma la familia en la prevención del ciberbullying, y para ello es necesario, inicialmente, que sean conscientes de los pros y contra del uso de las tecnologías y que sepan gestionar el uso que sus hijos hagan de los dispositivos tecnológicos de modo que inculquen a sus hijos tanto valores sociales como conocimientos relacionados con el correcto uso de los dispositivos tecnológicos. 
Por otra parte, si el problema de ciberbullying ya ha sucedido y nuestros hijos están implicados en él, también es necesario conocer una serie de pautas sobre cómo actuar. Para ello, Hinduja \& Patchin nos presentan una serie de acciones a seguir tanto en el caso que vuestro hijo sea el acosado como el acosador.

Si vuestro hijo es el que está siendo acosado las familias deben seguir las siguientes pautas (Hinduja \& Patchin, 2015b):

- Asegúrate de que tu hijo está (y se siente) seguro. La seguridad y el bienestar de su hijo siempre debe ser la principal prioridad. Por eso hay que transmitirle un apoyo incondicional. Los padres deben demostrar a sus hijos a través de palabras y acciones que ambos desean el mismo resultado final: detener el ciberbullying.

- Habla y escucha a tu hijo. Involucra a tu hijo en una conversación sobre lo que está sucediendo. Tómate el tiempo que sea necesario para entender exactamente qué sucedió, y el contexto concreto en el que ocurrió. Además, no minimice la situación ni excuseal agresor.

- Recoger pruebas. Imprime o haz capturas de pantalla de conversaciones, mensajes, fotografías y cualquier otro elemento que pueda servir como prueba clara de que tu hijo está siendo víctima de ciberbullying. Mantén un registro de todos y cada uno de los incidentes para poderlos presentar en el proceso de investigación. Además, mantén notas sobre detalles relevantes como ubicación, frecuencia, gravedad del daño, participación de terceros o testigos, y la historia de fondo.

- Trabajar con la escuela. Busca la ayuda del centro educativo, si el agresor va a la misma escuela. Tu hijo tiene el derecho de sentirse seguro en la escuela, y los docentes son responsables de asegurar esto a través de una investigación y una respuesta apropiada.

- Abstente de contactar con los padres del agresor. Algunos padres de niños agresores se pueden mostrar a la defensiva y por lo tanto no estará receptivo a tus pensamientos. Sea cuidadoso en su enfoque para evitar drama adicional y posibles represalias.

- Póngase en contacto con el proveedor de las aplicaciones que han sido utilizadas para ejercer el ciberbullying. Ellos pueden proporcionar datos adicionales.

- Póngase en contacto con la policía. Existen leyes relacionadas con las amenazas online, y la aplicación de la ley puede ayudar en estos casos, ya sea informalmente o formalmente.

- Si el acoso se basa en la raza, sexo o discapacidad, tome medidas especiales y comunícalo a los órganos pertinentes.

- Si es necesario, busca ayuda de profesionales. Tu hijo puede sentirse mejor al hablar con un profesional de salud mental. Los niños pueden preferir dialogar con un tercero que puede ser percibido como más objetivo. 
- Implementar medidas para evitar que vuelva a ocurrir. Si tu hijo está siendo intimidado a través de las redes sociales (Facebook, Instagram, Snapchat, Twitter, etc.), establezca controles de privacidad dentro de cada plataforma para impedir que el matón se ponga en contacto con ellos y archive un informe. También animarlos a que hablen contigo antes de que problemas que inicialmente son pequeños se conviertan en situaciones importantes.

Por el contrario, si vuestro hijo es el agresor, también hay que tomar medidas, y para ellos las familias pueden seguir las siguientes pautas (Hinduja\& Patchin, 2015b):

- Reconocer el problema. Como padre, acepta la realidad de que tu hijo podría estar participando en conductas de agresión online que están perjudicando a otros.

- Mantén la calma. Al abordar el ciberbullying, trata de discutir el tema de una manera nivelada sin demonizar, no respetar o juzgar a tu hijo. Recuerda que tu hijo o hija no es el problema; el problema es su comportamiento. Trata con ella, pero hay que tratarlos con dignidad. De lo contrario, pueden atacar y tomar represalias si se sienten atacados o victimizados por sí mismos, y no se hará ningún progreso.

- Mantén una línea abierta de comunicación. Muchos jóvenes se involucran en el ciberbullying para vengarse de algo que alguien hizo primero. Asegúrate de que sus hijos sepan que pueden acudir a ti para hablar sobre los problemas que están teniendo con sus compañeros. Ofrecerle la oportunidad y habilidades para resolver problemas interpersonales de manera apropiada, en lugar de recurrir a la venganza.

- Detener el acoso. El objetivo principal es conseguir que el acoso termine y nunca vuelva a suceder. Asegúrate de que todos los casos de intimidación se detienen inmediatamente, independientemente de quién lo inició. Nadie merece ser maltratado, por ninguna razón, nunca.

- Comprender la raíz del problema. Es difícil identificar la razón por la cual tu hijo ha actuado, pero trate de llegar al fondo del problema.

- Investigar. Toma medidas para conocer a fondo el grado de intimidación de tu hijo. Podría abarcar múltiples entornos, sitios web, aplicaciones y dispositivos. Podría ser muy directa y observable, o indirecta y extremadamente sutil. Trabajar para llegar al fondo de lo que sucedió exactamente.

- Haz que los niños entiendan cómo se sienten los niños a los que está agrediendo. Explica la gravedad del ciberbullying y cómo se sentiría él si fuese el agredido. Trate de cultivar empatía y compasión en los niños de maneras creativas y convincentes, para que realmente entiendan que todos tenemos nuestros puntos doloridos, calurosos y vulnerabilidades.

- Configurar controles parentales. Monitorea las actividades online de tu hijo, tanto formal como informalmente. Esto se puede hacer mediante la instalación de 
software o aplicaciones en su computadora portátil, tableta o teléfono. También debes rutinariamente y aleatoriamente revisar sus dispositivos para ver lo que están haciendo, al menos hasta que se sienta seguro de que se puede confiar en ellos.

- Comparte sus preocupaciones. No eres el único padre que se enfrenta a estos problemas. Ponte en contacto con otros padres que estén en tu misma situación para que toda la comunidad pueda reunirse alrededor del tema y tomar una posición. Este frente unido puede ayudar a crear y promover una cultura en la que todos los miembros de un grupo de iguales reconocen que el acoso es siempre negativo.

- Mantente educado. Aunque sabemos que vuestras vidas están muy ocupadas, es importante que dediques tiempo para aprender continuamente sobre el uso de las nuevas tecnologías y sitios que tus hijos están usando. También debes saber dónde puedes solicitar ayuda e interactuar con otras personas que tengan experiencias y estrategias relevantes para compartir.

Toda esta información comentada nos deja ver claramente el importante papel que toman las familias ante situaciones de ciberbullying, tanto en la prevención como en la intervención. Sin su ayuda y dedicación, conjuntamente con los centros escolares, la detección y erradicación del ciberbullying no sería posible.

\subsection{EVALUACIÓN}

La evaluación en el ciberbullying es un aspecto muy relevante puesto que, como cualquier otro fenómeno, una evaluación eficaz facilita la detección precoz y la correcta intervención.

A pesar de su importancia y necesidad, autores como Lucas et al. (2016) destacan que debido a la inestabilidad de la conceptualización se han utilizado diferentes metodologías en la evaluación y obtención de distintos grados de prevalencia. Diversos estudios realizados fuera de nuestro país han encontrado tasas de prevalencia que van desde un 9\% (Ybarra et al., 2006) a un 72\% (Juvonen \& Gross, 2008). En cambio, en España, Díaz, Martínez \& Martín (2013) desarrollaron un estudio a nivel nacional por el Observatorio Estatal de la Convivencia Escolar sobre 23.100 alumnos de secundaria, en los cuales se observó que un 2,5\%-7\% del alumnado había reconocido ser víctima y un 2,5-3,5\% agresor en los últimos dos meses. En cambio, Buelga et al. (2010) en su estudio realizado en la Comunidad Valenciana con una muestra de 2.101 alumnos de entre 11 a 17 puso de manifiesto que un $24,6 \%$ había sido acosado por el móvil y un $29 \%$ por Internet en el último año. Estos resultados coinciden con la revisión llevada a cabo por Tokunaga (2010), en la cual entre un $20 \%$ y un $40 \%$ de los adolescentes experimentaría cibervictimización. 
Diversos estudios han indicado el rápido incremento de esta nueva forma de acoso entre la población adolescente. Wolak, Mitchell \& Finkelhor (2006) descubrieron que cinco años después de la publicación de su primer estudio sobre ciberbullying la tasa de prevalencia se había duplicado. Además, Nansel et al. (2001) señalan que los índices de prevalencia encontrados en el bullying tradicional son inferiores a los de ciberbullying. Del mismo modo, las dos variables analizadas a la hora de detectar al alumno implicado en el ciberbullying han sido la edad y el nivel educativo y género, como en el caso del bullying tradicional. Según Buelga et al. (2010) y Williams y Guerra (2007), acotan que la primera variable parece tener la misma muestra que la detectada en bullying presencial. Sin embargo, en relación con la variable género, Garaigordobil y Aliri (2013) realizaron un estudio con una muestra de 3.026 adolescentes de entre 12 y 18 años el País Vasco y encontraron un porcentaje mayor de chicas víctimas $17,6 \%$, que chicos $12,5 \%$. Por el contrario, según Tokunaga (2010) existen diferencias en cuanto al género, puesto que en los resultados obtenidos en su estudio observó un mayor porcentaje de chicos con el papel tanto de víctimas como de agresores (Lucas et al., 2016).

Así, para abordar mejor esta temática de la evaluación del ciberbullying seguiremos a Lucas et al. (2016), que exponen los instrumentos más destacados en España y en el contexto europeo y estadounidense para evaluar el ciberbullying. Al respecto, presentamos la siguiente Tabla 8 en base a la que los citados autores realizaron en relación a España.

Tabla 8.Instrumentos nacionales para evaluar el Ciberbullying: Características conceptuales y psicométricas (Lucas et al., 2016).

\begin{tabular}{|c|c|c|c|}
\hline Autor/año región & Instrumento & $\begin{array}{l}\text { Edad/ Nivel } \\
\text { educativo }\end{array}$ & Formas/dispositivo \\
\hline $\begin{array}{l}\text { Álvarez - García et } \\
\text { al. (2011)/ Asturias }\end{array}$ & $\begin{array}{l}\text { Cuestionario de } \\
\text { Violencia Escolar- } \\
\text { Revisado (CUVE-R) } \\
\end{array}$ & 1ㅇ-4으 ESO & $\begin{array}{l}\text { Hostigamiento, Violación } \\
\text { de la intimidad Móvil/ } \\
\text { Redes sociales }\end{array}$ \\
\hline $\begin{array}{l}\text { Buelga et al. (2010)/ } \\
\text { Comunidad } \\
\text { Valenciana }\end{array}$ & $\begin{array}{l}\text { Escalas de victimización } \\
\text { (EV) a través del } \\
\text { teléfono móvil y a } \\
\text { través de Internet } \\
\text { Incluye dos preguntas } \\
\text { que evalúan la } \\
\text { intensidad y la duración } \\
\text { del acoso }\end{array}$ & 10-4으 ESO & $\begin{array}{l}\text { Hostigamiento, } \\
\text { Persecución, Denigración, } \\
\text { Violación de la intimidad, } \\
\text { Exclusión social, } \\
\text { Suplantación de identidad } \\
\text { Móvil/Internet }\end{array}$ \\
\hline $\begin{array}{l}\text { Calvete, Orue, } \\
\text { Estévez, Villardón \& } \\
\text { Padilla(2010)/ } \\
\text { Vizcaya }\end{array}$ & $\begin{array}{l}\text { Cuestionario } \\
\text { Cyberbullying (CBQ) }\end{array}$ & 12-17 años & $\begin{array}{l}\text { Hostigamiento, } \\
\text { Persecución, Denigración, } \\
\text { Violación de la intimidad, } \\
\text { Exclusión social, } \\
\text { Suplantación de identidad, } \\
\text { Happyslapping } \\
\text { Móvil/Internet }\end{array}$ \\
\hline
\end{tabular}


Tabla 8.Instrumentos nacionales para evaluar el Ciberbullying: Características conceptuales y psicométricas (Lucas et al., 2016). (Continuación)

\begin{tabular}{|c|c|c|c|}
\hline Autor/año región & Instrumento & $\begin{array}{l}\text { Edad/ Nivel } \\
\text { educativo }\end{array}$ & Formas/dispositivo \\
\hline $\begin{array}{l}\text { Díaz et al. (2013)/ } \\
\text { España }\end{array}$ & $\begin{array}{l}\text { Acoso con nuevas } \\
\text { tecnologías } \\
\text { (El instrumento } \\
\text { también evalúa acoso } \\
\text { tradicional) }\end{array}$ & $\begin{array}{l}\text { 10-4을ㅇ } \\
\text { (12-18 años) }\end{array}$ & $\begin{array}{l}\text { Hostigamiento, } \\
\text { Persecución, Violación de la } \\
\text { intimidad } \\
\text { Móvil/Internet }\end{array}$ \\
\hline $\begin{array}{l}\text { Gairagordobil \& } \\
\text { Aliri (2013)/ } \\
\text { País Vasco }\end{array}$ & $\begin{array}{l}\text { Cyberbullying:Screening } \\
\text { de acoso entre iguales } \\
\text { (Editado por TEA) }\end{array}$ & 12-18 años & $\begin{array}{l}\text { Hostigamiento, } \\
\text { Persecución, denigración, } \\
\text { Violación de la intimidad, } \\
\text { Exclusión social, } \\
\text { Suplantación de la } \\
\text { identidad, Happyslapping } \\
\text { Móvil/Internet }\end{array}$ \\
\hline $\begin{array}{l}\text { Ortega et al. } \\
\text { (2008)/ Córdoba }\end{array}$ & $\begin{array}{l}\text { Cuestionario } \\
\text { Cyberbullying } \\
\text { (adaptación } \\
\text { instrumento Smith et } \\
\text { al., 2006) } \\
\text { Pregunta también por } \\
\text { sentimientos, } \\
\text { estrategias } \\
\text { afrontamiento, etc. }\end{array}$ & 10-4을 ESO & $\begin{array}{l}\text { Hostigamiento, } \\
\text { Persecución, Denigración, } \\
\text { Violación de la intimidad, } \\
\text { Exclusión social, } \\
\text { Suplantación de identidad } \\
\text { Móvil/ Internet }\end{array}$ \\
\hline
\end{tabular}

Los datos presentados en la tabla anterior recogen seis instrumentos nacionales, todos ellos publicados entre los años 2008 y 2013, siendo el más reciente el de Gairagordobil \& Aliri (2013).

Respecto a los datos relacionados con la edad o nivel educativo a la que va dirigido la aplicación de la prueba, también coinciden bastante en ello puesto que, en todas, el inicio es a los 12 años, cinco de ellos extendiéndose hasta los 18 años (Álvarez-García et al., 2011; Buelga et al., 2010; Día et al., 2013; Gairagordobil \& Aliri, 2013; Ortega et al., 2008) y uno hasta los 17 años (Calvete et al., 2010).

En cuanto al último aspecto analizado, formas/dispositivos, se contempla que todos los instrumentos analizados incluyen la dimensión electrónica e intencional del comportamiento evaluado.

Respecto al carácter repetitivo solo dos lo incorporan (Buelga et al., 2010; Ortega et al., 2008).

El desequilibrio de poder, por ejemplo, no se contempla en ninguno de los cuestionarios, así como tampoco otros aspectos característicos del ciberbullying.

En cambio, todos ellos incluyen ítems relacionados con las acciones que se realizan a través del móvil e internet y miden también la frecuencia en la que se da la conducta de agresión. 
Si analizamos las clasificaciones de comportamiento de ciberbullying que son estudiadas, estas varían según el instrumento puesto que cada una se basa en un criterio, aunque sí coinciden en el término hostigamiento.

En cuanto a los instrumentos internacionales, presentamos la siguiente Tabla 9 en base al estudio realizado por Lucas et. al (2016).

Tabla 9. Instrumentos internacionales para evaluar el cyberbullying: Características conceptuales y psicométricas (Lucas et al., 2016)

\begin{tabular}{|c|c|c|c|}
\hline $\begin{array}{c}\text { Autores y año/ } \\
\text { Región }\end{array}$ & Instrumento & $\begin{array}{c}\text { Edad/ Nivel } \\
\text { educativo }\end{array}$ & Formas/ Dispositivo \\
\hline $\begin{array}{l}\text { Beran \& Li } \\
\text { (2007)/Canada }\end{array}$ & $\begin{array}{l}\text { Cyber-harassment student } \\
\text { survey }\end{array}$ & $\begin{array}{l}\text { 70-9o grado } \\
\text { (12-15 años) }\end{array}$ & $\begin{array}{l}\text { E, I, R, DP } \\
\text { Incluye definición 'harassment' }\end{array}$ \\
\hline $\begin{array}{l}\text { Hinduja \& } \\
\text { Patchin } \\
\text { (2008)/EUA }\end{array}$ & $\begin{array}{l}\text { General } \\
\text { cyberbullying } \\
\text { measure }\end{array}$ & 10-17 años & $\begin{array}{l}\text { Exclusión social, Hostigamiento, } \\
\text { Persecución } \\
\text { Móvil/Internet }\end{array}$ \\
\hline $\begin{array}{l}\text { Menesini et al. } \\
(2011) / \text { Italia }\end{array}$ & $\begin{array}{l}\text { Cyberbullying } \\
\text { Scale }\end{array}$ & 11-18 años & $\begin{array}{l}\text { Hostigamiento, Violación de la } \\
\text { intimidad, Denigración, Persecución, } \\
\text { Happyslapping } \\
\text { Móvil/Internet }\end{array}$ \\
\hline $\begin{array}{l}\text { Ortega et al. } \\
\text { (2009)/ Córdoba2 }\end{array}$ & $\begin{array}{l}\text { DAPNHE Questionnaire3 } \\
\text { European } \\
\text { Cyberbullying } \\
\text { Research Project (ECRP) } \\
\text { (También evalúa } \\
\text { bullying } \\
\text { tradicional) }\end{array}$ & $\begin{array}{l}\text { 10-3응ㅇ } \\
\text { 1Bach. }\end{array}$ & $\begin{array}{l}\text { Hostigamiento, Persecución, } \\
\text { Denigración, Violación de la intimidad. } \\
\text { Móvil/Internet }\end{array}$ \\
\hline $\begin{array}{l}\text { Smith et al. } \\
(2008) / \text { Inglaterra }\end{array}$ & $\begin{array}{l}\text { Cyberbullying } \\
\text { questionnarie } \\
\text { (También evalúa bullying } \\
\text { tradicional con } \\
\text { Olweusbullying/Victimque } \\
\text { stionnaire) }\end{array}$ & & $\begin{array}{l}\text { Medios: Mensajes de texto, fotos o } \\
\text { vídeos, Ilamadas de teléfono, correo } \\
\text { electrónico, chats, mensajería } \\
\text { instantánea y páginas web. } \\
\text { Móvil/Internet. }\end{array}$ \\
\hline $\begin{array}{l}\text { Stewart et al. } \\
\text { (2014)/EUA }\end{array}$ & $\begin{array}{l}\text { Cyberbullying } \\
\text { Scale }\end{array}$ & $\begin{array}{l}\text { 60-12ㅇ grado } \\
\text { (11-18 años) }\end{array}$ & $\begin{array}{l}\text { Medios: Correo electrónico, mensajes } \\
\text { de texto/Twitter, imágenes, } \\
\text { mensajería instantánea, videos online, } \\
\text { redes sociales, chats, mundo virtual } \\
\text { (TheSims). } \\
\text { Hostigamiento, Persecución, } \\
\text { Denigración, Exclusión Social, } \\
\text { Suplantación de la identidad, } \\
\text { Violación de la intimidad. } \\
\text { Móvil/Internet }\end{array}$ \\
\hline $\begin{array}{l}\text { Ybarra et al. } \\
(2006) / E U A\end{array}$ & $\begin{array}{l}\text { Internet } \\
\text { Harassment/Youth } \\
\text { Internet Safety Survey }\end{array}$ & 10-17 años & Hostigamiento, Denigración Internet \\
\hline $\begin{array}{l}\text { Ybarra \& Mitchell } \\
\text { (2008)/EUA }\end{array}$ & $\begin{array}{l}\text { Growing up with media } \\
\text { (GuwM): youth- reported } \\
\text { internet harassment }\end{array}$ & $10-15$ años & $\begin{array}{l}\text { Hostigamiento, Denigración, } \\
\text { Persecución } \\
\text { Internet }\end{array}$ \\
\hline $\begin{array}{l}\text { Williams \& } \\
\text { Guerra } \\
(2007) / \text { USA }\end{array}$ & & $\begin{array}{l}\text { 5o-8o (10-14 } \\
\text { años) }\end{array}$ & Denigración Móvil/Internet \\
\hline
\end{tabular}


En la Tabla 9, en la que se recogen instrumentos internacionales, se pueden detectar algunas semejanzas respecto a los instrumentos nacionales.

El primer instrumento fue publicado en 2007, es decir anterior a los publicados en nuestro país. En cuanto a las edades a las que van dirigidas las pruebas, podemos contemplar que disminuye puesto que en cuatro de los estudios la edad inicial es a los 10 años (Hinduja \& Patchin, 2008; Mitchell, Wolak \& Finkelhor, 2006; Williams \& Guerra, 2007; Ybarra \& Mitchell, 2008; Ybarra).

Respecto a las formas estudiadas de ciberbullying la reflexión es similar a los nacionales, puesto que coinciden en aspectos como la medición de formas como el hostigamiento y al medio en el que se producen los hechos, móvil o internet, pero también muestran diferencias entre ellos en cuanto a la tipología utilizada en su estudio.

Todos estos datos nos dejan ver la gran variabilidad que existe en cuanto a los formatos que se utilizan para evaluar el ciberbullying. Muchos de los investigadores del fenómeno del ciberbullying lo achacan a las dificultades existentes en la conceptualización y operativización de este fenómeno (Lucas et al., 2016). Por tanto, uno de los primeros retos sería este, llegar a un consenso común en cuanto a la conceptualización y operativización.

A partir de aquí, Lucas et al. (2016) plantean otra serie de retos en cuanto a la evaluación del ciberbullying entre las que se destacan aspectos como la elaboración de nuevos instrumentos de evaluación basándose en la mejora de los ya existentes para lograr que todos los investigadores utilicen los mismos instrumentos de evaluación, cuestión que hasta el momento no sucede puesto que cada instrumento elaborado suele ser únicamente utilizado en los estudios del mismo autor que los construye (Berne et al., 2013; Tokunaga, 2010).

Respecto a estos instrumentos, cabe destacar los aspectos psicométricos. Siguiendo a Lucas et al. (2016), después del análisis de estos instrumentos concluyen que en tres de los instrumentos (Álvarez-García et al., 2011; Díaz-Aguado et a., 2013; Gairagordobil \& Aliri, 2013) se han realizado análisis factoriales exploratorios (EFA). Otros de los trabajos han realizado confirmatorios (Álvarez-García et al., 2011; Calvete et al., 2010), cuya finalidad era validar el constructo que evaluaban. En cuanto a medidas de fiabilidad, todos los estudios presentados exceptuando el de Ortega et al. (2008) aportan datos de consistencia interna como indicador de la fiabilidad, aspecto que consideran los investigadores (Lucas et al., 2016; Berne et al, 2013) sería recomendable complementar con otras medidas de fiabilidad, así como la necesidad de contemplar otras evidencias de validez. A pesar de ello, gran parte de los investigadores de la temática del ciberbullying vuelven a coincidir en que todo ello debe partir del consenso de una definición común sobre el constructo.

Otro de los aspectos importantes es la necesidad de incluir ítems específicos que hagan referencia a las características propias del ciberbullying y no únicamente a las del acoso 
tradicional. Teniendo en cuenta a los participantes, como mejora se debería contemplar la obtención de datos de su red social para que aporten más información puesto que los menores tienden a ocultar información, y con esto conseguiríamos complementar los datos obtenidos más allá del autoinforme (Benítez, Padilla \& Ongena, 2012).

\subsection{LEGISLACIÓN}

En el presente capítulo consideramos importante presentar información sobre la legislación vigente que regula el ciberbullying en nuestro país. El ciberbullying es una problemática que está tomando mucha importancia en España por el aumento de casos en estos últimos años, y siendo conscientes de su trascendencia hay una serie de artículos del Código Penal que penan las acciones de ciberbullying, dándole así relevancia a la problemática y sensibilizando con ello a la población.

Con ello España, según datos que publica la agencia Efe, se convierte en el único país de la Unión Europea que cuenta con una regulación a nivel penal, según detalla un estudio que fue presentado en noviembre de 2016 en el Parlamento Europeo. Esto se debe a que la no existencia de una definición de ciberbullying aceptada por todos a nivel europeo dificulta el cálculo de la prevalencia.

Así en España, está cubierta por el Código Penal desde la reforma de 2015, ya que desde ese momento se incluye el acoso en medios telemáticos.

A pesar de ello, algunos jueces solicitan cambios en la legislación española pues consideran necesario que las compañías que operan en Internet y en redes sociales sean también responsables legalmente de los delitos que sean cometidos por los menores de edad por ese medio. Esta exención hace que los magistrados encuentren dificultades a la hora de hacer una atribución civil.

Presentaremos a continuación los artículos que hacen referencia al ciberbullying, siguiendo los datos legislativos indicados por Llaneza (2015), indicando cuales son las acciones sancionables. Para ello, debemos tener en cuenta que los menores de edad solo pueden tener responsabilidad penal a partir de los 14 años, antes de esa edad no son imputables. En relación a este dato se hace referencia en el Artículo 5 de la Ley Orgánica $5 / 2000$.

$>$ Artículo 5 de la Ley Orgánica 5/2000, de 12 de enero, reguladora de la responsabilidad penal de los menores:

1. Los menores serán responsables con arreglo a esta Ley cuando hayan cometido los hechos a los que se refiere el artículo 1 y no concurra en ellos ninguna de las causas de exención o extinción de la responsabilidad criminal previstas en el vigente Código Penal.

2. No obstante lo anterior, a los menores en quienes concurran las circunstancias previstas en los números 1, 2 y 3 del artículo 20 del vigente Código Penal les serán aplicables, en 
caso necesario, las medidas terapéuticas a las que se refiere el artículo 7.1, letras d) y e), de la presente Ley.

3. Las edades indicadas en el articulado de esta Ley se han de entender siempre referidas al momento de la comisión de los hechos, sin que el haberse rebasado las mismas antes del comienzo del procedimiento o durante la tramitación del mismo tenga incidencia alguna sobre la competencia atribuida por esta misma Ley a los Jueces y Fiscales de Menores.

Entre los artículos que penan las conductas relacionadas con el uso y difusión de la información contenida en soportes informáticos, electrónicos o digitales y por medios tecnológicos, así como la publicación de vídeos y fotografías por los mismos medios, encontramos el artículo 197 del Código Penal.

\section{Artículo 197 del Código Penal}

1. El que, para descubrir los secretos o vulnerar la intimidad de otro, sin su consentimiento, se apodere de sus papeles, cartas, mensajes de correo electrónico o cualesquiera otros documentos o efectos personales o intercepte sus telecomunicaciones o utilice artificios técnicos de escucha, transmisión, grabación o reproducción del sonido o de la imagen, o de cualquier otra señal de comunicación, será castigado con las penas de prisión de uno a cuatro años y multa de doce a veinticuatro meses.

2. Las mismas penas se impondrán al que, sin estar autorizado, se apodere, utilice o modifique, en perjuicio de tercero, datos reservados de carácter personal o familiar de otro que se hallen registrados en ficheros o soportes informáticos, electrónicos o telemáticos, o en cualquier otro tipo de archivo o registro público o privado. Iguales penas se impondrán a quien, sin estar autorizado, acceda por cualquier medio a los mismos y a quien los altere o utilice en perjuicio del titular de los datos o de un tercero.

3. El que por cualquier medio o procedimiento y vulnerando las medidas de seguridad establecidas para impedirlo, acceda sin autorización a datos o programas informáticos contenidos en un sistema informático o en parte del mismo o se mantenga dentro del mismo en contra de la voluntad de quien tenga el legítimo derecho a excluirlo, será castigado con pena de prisión de seis meses a dos años.

Cuando de acuerdo con lo establecido en el artículo 31 bis una persona jurídica sea responsable de los delitos comprendidos en este artículo, se le impondrá la pena de multa de seis meses a dos años. Atendidas las reglas establecidas en el artículo 66 bis, los jueces y tribunales podrán asimismo imponer las penas recogidas en las letras b) a g) del apartado 7 del artículo 33.

4. Se impondrá la pena de prisión de dos a cinco años si se difunden, revelan o ceden a terceros los datos o hechos descubiertos o las imágenes captadas a que se refieren los números anteriores. 
Será castigado con las penas de prisión de uno a tres años y multa de doce a veinticuatro meses, el que, con conocimiento de su origen ilícito y sin haber tomado parte en su descubrimiento, realizare la conducta descrita en el párrafo anterior.

5. Si los hechos descritos en los apartados 1 y 2 de este artículo se realizan por las personas encargadas o responsables de los ficheros, soportes informáticos, electrónicos o telemáticos, archivos o registros, se impondrá la pena de prisión de tres a cinco años, y si se difunden, ceden o revelan los datos reservados, se impondrá la pena en su mitad superior.

6. Igualmente, cuando los hechos descritos en los apartados anteriores afecten a datos de carácter personal que revelen la ideología, religión, creencias, salud, origen racial o vida sexual, o la víctima fuere un menor de edad o un incapaz, se impondrán las penas previstas en su mitad superior.

7. Si los hechos se realizan con fines lucrativos, se impondrán las penas respectivamente previstas en los apartados 1 al 4 de este artículo en su mitad superior. Si además afectan a datos de los mencionados en el apartado anterior, la pena a imponer será la de prisión de cuatro a siete años.

8. Si los hechos descritos en los apartados anteriores se cometiesen en el seno de una organización o grupo criminales, se aplicarán respectivamente las penas superiores en grado.

Respecto a otro tipo de delitos, más relacionados con el exhibicionismo o la provocación sexual, podemos detallar en el Código Penal los artículos 185 y 186.

Artículo 185 del Código Penal

El que ejecutare o hiciere ejecutar a otra persona actos de exhibición obscena ante menores de edad o incapaces, será castigado con la pena de prisión de seis meses a un año o multa de 12 a 24 meses.

Artículo 186 del Código Penal

El que, por cualquier medio directo, vendiere, difundiere o exhibiere material pornográfico entre menores de edad o incapaces, será castigado con la pena de prisión de seis meses a un año o multa de 12 a 24 meses.

Si además, el contenido de las publicaciones pudiese constituir delito de injurias, se atendería a los Artículos 208 y 209 del Código Penal. En último lugar, si se causan daños en los equipos informáticos o se impide o dificulta su uso, se podrían indicar daños informáticos que están penados en el Artículo 264.

Artículo 208 del Código Penal

Es injuria la acción o expresión que lesionan la dignidad de otra persona, menoscabando su fama o atentando contra su propia estimación. 
Solamente serán constitutivas de delito las injurias que, por su naturaleza, efectos y circunstancias, sean tenidas en el concepto público por graves.

Las injurias que consistan en la imputación de hechos no se considerarán graves, salvo cuando se hayan llevado a cabo con conocimiento de su falsedad o temerario desprecio hacia la verdad.

\section{Artículo 209 del Código Penal}

Las injurias graves hechas con publicidad se castigarán con la pena de multa de seis a catorce meses $y$, en otro caso, con la de tres a siete meses.

Artículo 264 del Código Penal

2. El que por cualquier medio, sin estar autorizado y de manera grave obstaculizara o interrumpiera el funcionamiento de un sistema informático ajeno, introduciendo, transmitiendo, dañando, borrando, deteriorando, alterando, suprimiendo o haciendo inaccesibles datos informáticos, cuando el resultado producido fuera grave, será castigado, con la pena de prisión de seis meses a tres años.

Toda esta información que terminamos de aportar es de especial relevancia, puesto que tanto los docentes como las familias deben conocer que las conductas como el ciberbullying están penadas por la ley, aspecto muchas veces desconocidos.

Así, los adultos deben hacer reflexionar a los menores sobre la importancia de los hechos, que no se trata de un juego sino hay leyes que lo penan pues están dañando a otras personas ya que muchas veces los menores se sienten seres anónimos cuando utilizan los dispositivos electrónicos y no son conscientes que cualquier acción realizada queda registrada.

Así, queremos destacar que son la vulneración de la intimidad, el acceder sin autorización a cierta información, la exhibición obscena, el material pornográfico y las injurias o expresiones que lesionen la dignidad, las que vienen acareadas con penas de prisión y que en muchas ocasiones son los padres los responsables de las acciones de sus hijos.

\subsection{GLOSARIO}

Una vez definido el concepto de ciberbullying, así como los tipos y las diferencias con otros términos como grooming y sexting, junto con aspectos de la evaluación, consideramos conveniente presentar una serie de términos que es muy importante conocer para poder entender mejor la problemática del ciberbullying. De este modo podremos adentrarnos en él con conocimiento, y así detectarlo, prevenirlo e intervenir con efectividad, puesto que muchos términos son conocidos por las generaciones más jóvenes, pero no tanto por el conjunto de la sociedad que no pertenece a la era digital.

Para ello hemos recurrido al glosario que presentan Hinduja \& Patchin (2014), que recoge una breve descripción de los términos comunes utilizados en la jerga tecnológica, puesto que es el más completo publicado hasta el momento. A partir de estos términos, y tras la 
posterior adaptación al español, hemos realizado una clasificación, puesto que la versión de estos autores no presentaba ninguna categorización (ver Tabla 10).

Tabla 10. Categorías y no de vocablos

\begin{tabular}{llc}
\hline & \multicolumn{1}{c}{ Categoría } & № de vocablos \\
\hline A & Red de contactos y términos vinculados & 22 \\
\hline B & Entorno de red & 13 \\
\hline C & Seguridad de red & 10 \\
\hline D & Peligros en la red & 18 \\
\hline E & Herramientas y dispositivos tecnológicos & 11 \\
\hline F & Perfil usuarios & 4 \\
\hline
\end{tabular}

A) Categoría "Red de contactos y términos vinculados".

Conceptos que hacen referencia a las redes que permiten el contacto a través de los dispositivos tecnológicos normalmente con conexión a internet. En definitiva, hablamos de las denominadas redes sociales. Además, añadimos en esta categoría términos vinculados, que se refiere a términos relacionados con el uso de dichas redes (ver Tabla 11).

Tabla 11. Red de contactos y términos vinculados

\begin{tabular}{ll}
\hline Facebook & $\begin{array}{l}\text { Los usuarios crean perfiles "personales" para representarse a sí mismos, } \\
\text { citando intereses y publicando fotos y comunicándose a través de } \\
\text { mensajes o publicaciones públicas o privadas. }\end{array}$ \\
\hline Following & $\begin{array}{l}\text { Acto de solicitar por parte de una persona la conexión con tu red social } \\
\text { online (Twitter, Instagram y sitios similares). }\end{array}$ \\
\hline Friending & $\begin{array}{l}\text { Acto de solicitar por parte de una persona la conexión con tu red social } \\
\text { online (en Facebook). }\end{array}$ \\
\hline Hashtag & $\begin{array}{l}\text { Descriptor o etiqueta precedidos por el signo de número (\#) que ayuda a } \\
\text { los demás a encontrar fácilmente el contenido relacionado con esa } \\
\text { palabra o frase. Facebook, Twitter y Instagram, por ejemplo, permiten a } \\
\\
\text { los usuarios buscar y hacer clic a través de hashtags para encontrar } \\
\text { contenido de otros usuarios que también están en la lista (tagged) con ese } \\
\text { hashtag. }\end{array}$ \\
\hline $\begin{array}{l}\text { Aplicación donde los usuarios pueden aplicar filtros a las fotos y videos } \\
\text { antes de publicarlos y que otros indiquen que les gusta y los comenten. El } \\
\text { usuario también puede compartir sus contenidos en otras redes sociales } \\
\text { como Facebook y Twitter. }\end{array}$ \\
$\begin{array}{l}\text { "Internet Relay Chat". Una red en la que las conversaciones en tiempo real } \\
\text { tienen lugar entre dos o más personas en un "canal" dedicado a un área } \\
\text { específica de interés. Véase también "chat" o "sala de chat." }\end{array}$ \\
$\begin{array}{l}\text { Aplicación que facilita a plataformas (iOS y Android), mensajería } \\
\text { instantánea en una interfaz atractiva a través de los teléfonos o tabletas. } \\
\text { Los usuarios pueden enviar enlaces, imágenes, vídeos, mensajes de } \\
\text { grupo, etc. }\end{array}$ \\
\hline Kik
\end{tabular}


Tabla 11. Red de contactos y términos vinculados. (Continuación)

\begin{tabular}{|c|c|}
\hline $\begin{array}{l}\text { Lista de } \\
\text { Amigos }\end{array}$ & $\begin{array}{l}\text { Colección de nombres que representa los amigos o contactos dentro de } \\
\text { una mensajería instantánea o de conversación. Son útiles para informar a } \\
\text { un usuario cuando los amigos de esa persona están en línea y disponibles } \\
\text { para chatear. }\end{array}$ \\
\hline Musical.ly & $\begin{array}{l}\text { Aplicación para compartir videos musicales que permite al usuario crear y } \\
\text { compartir sus propios } 15 \text { segundos de videoclips musicales fascinantes y } \\
\text { creativos (por ejemplo, playback de una canción popular y el baile). }\end{array}$ \\
\hline Perfil & $\begin{array}{l}\text { En el contexto de las redes sociales en línea, página de personalización de } \\
\text { usuario que representa a esa persona. Los antecedentes, intereses y } \\
\text { amigos se enumeran para reflejar quién es esa persona o como le gustaría } \\
\text { que fuera vista. A menudo se incluyen también imágenes, información } \\
\text { biográfica y de contacto y otros datos interesantes sobre el usuario. }\end{array}$ \\
\hline Periscope & $\begin{array}{l}\text { Una aplicación (propiedad de Twitter) que permite a un usuario transmitir } \\
\text { video en vivo, y por lo tanto permite que otras personas vean lo que el } \\
\text { transmisor está haciendo o viendo en tiempo real. }\end{array}$ \\
\hline Secret & $\begin{array}{l}\text { Aplicación que ofrece a los usuarios la posibilidad de compartir lo que } \\
\text { están pensando y sintiendo con los amigos de la lista de contactos de su } \\
\text { teléfono, sin dejar de ser anónimo. }\end{array}$ \\
\hline Snapchat & $\begin{array}{l}\text { Una aplicación que permite a los usuarios compartir fotos y videos con } \\
\text { amigos de su lista de contactos, que sólo puede ser visto por un período } \\
\text { de entre } 1 \text { a } 10 \text { segundos antes de desaparecer. }\end{array}$ \\
\hline Snaps & Imágenes o vídeos de Snapchat enviados entre usuarios. \\
\hline Tinder & $\begin{array}{l}\text { Aplicación de citas online que permite a las personas ajustarse en base a } \\
\text { aspectos de atracción física. Inicialmente se encuentran coincidencias } \\
\text { potenciales basadas en filtros como el género y la ubicación. Si a dos } \\
\text { usuarios les gusta recíprocamente su imagen, la aplicación les permite } \\
\text { chartear. }\end{array}$ \\
\hline Tweet & Un mensaje corto (140 caracteres [o menos]) publicado en Twitter. \\
\hline Twitter & $\begin{array}{l}\text { Red social que permite a los usuarios informar a sus amigos o seguidores, } \\
\text { lo que están haciendo usando } 140 \text { caracteres. }\end{array}$ \\
\hline Viber & $\begin{array}{l}\text { Mensajería instantánea y aplicación VolP. Los usuarios también pueden } \\
\text { intercambiar imágenes, vídeo y mensajes de audio. }\end{array}$ \\
\hline Vine & $\begin{array}{l}\text { Aplicación de video propiedad de Twitter que permite a los usuarios } \\
\text { capturar momentos en seis segundos y compartirlos con otros. }\end{array}$ \\
\hline $\begin{array}{l}\text { Webs de } \\
\text { redes } \\
\text { sociales }\end{array}$ & $\begin{array}{l}\text { Servicios en línea que unen a personas en torno a un interés común y } \\
\text { proporcionando un entorno interactivo de fotos, blogs, perfiles de usuario } \\
\text { y sistemas de mensajería. Algunos ejemplos son Facebook e Instagram. }\end{array}$ \\
\hline WhatsApp & $\begin{array}{l}\text { Aplicación de mensajería multiplataforma que permite al usuario enviar } \\
\text { SMS a través de Internet, independientemente del dispositivo o la } \\
\text { compatibilidad. }\end{array}$ \\
\hline Whisper & $\begin{array}{l}\text { Aplicación que permite a los usuarios compartir sus secretos de forma } \\
\text { anónima con otros usuarios mediante texto e imágenes. Los individuos } \\
\text { comparten su secreto (u otro mensaje de autorevelación) en la aplicación, } \\
\text { seleccionan una imagen relevante como fondo, y luego lo publican para } \\
\text { que otros indiquen me gusta, comenten y compartan con los demás. }\end{array}$ \\
\hline
\end{tabular}


B) Categoría "Entorno de red".

Términos relacionados con Internet, es decir contenidos y acciones que solamente se pueden utilizar con conexión a la red (ver Tabla 12).

Tabla 12. Entorno de red

\begin{tabular}{|c|c|}
\hline Ask.fm & $\begin{array}{l}\text { Sitio web donde los usuarios pueden hacer y responder a preguntas de los } \\
\text { demás con la opción de hacerlo de forma anónima. }\end{array}$ \\
\hline BashBoard & $\begin{array}{l}\text { Tablón de anuncios en línea en el que los individuos pueden publicar lo que } \\
\text { quieran. A menudo, los mensajes son declaraciones maliciosas y de odio } \\
\text { dirigidos contra otra persona. }\end{array}$ \\
\hline Blog & $\begin{array}{l}\text { Web interactiva o diario digital, cuyos contenidos se publican en línea y pueden } \\
\text { ser vistos por algunos o todos los internautas. El acto de la actualización de un } \\
\text { blog se llama "blogging". Una persona que mantiene un blog se conoce como } \\
\text { un "blogger". El término fue creado mediante la combinación de "web" y "log". }\end{array}$ \\
\hline Chat & $\begin{array}{l}\text { Una conversación en tiempo real en línea, llevada a cabo normalmente por las } \\
\text { personas que usan sus nombres de contacto en lugar de su nombre real. Una } \\
\text { persona puede leer continuamente los mensajes de otros en la "sala de chat" } \\
\text { y luego escribir y enviar un mensaje de respuesta. }\end{array}$ \\
\hline E-mail & $\begin{array}{l}\text { El correo electrónico. Permite a los usuarios de Internet enviar y recibir } \\
\text { mensajes electrónicos desde y hacia otros usuarios de Internet. }\end{array}$ \\
\hline Internet & $\begin{array}{l}\text { Red mundial de ordenadores que se comunican entre sí a través de líneas } \\
\text { telefónicas, enlaces por satélite, redes inalámbricas, y sistemas de cable. }\end{array}$ \\
\hline $\begin{array}{l}\text { Mensajería } \\
\text { instantánea }\end{array}$ & $\begin{array}{l}\text { El acto de enviar y recibir mensajes en tiempo real entre dos o más personas } \\
\text { en una red como Internet. Esto puede ocurrir a través de un software como } \\
\text { WeChat, WhatsApp, Snapchat, Viber, y Facebook Messenger. }\end{array}$ \\
\hline Red & Dos o más equipos conectados de modo que puedan comunicarse entre sí. \\
\hline Sala de Chat & $\begin{array}{l}\text { Una sala virtual en línea, donde grupos de personas pueden enviar y recibir } \\
\text { mensajes en una pantalla. Las salas de chat populares pueden tener cientos de } \\
\text { personas comunicándose al mismo tiempo. Los mensajes escritos aparecen al } \\
\text { instante como una conversación en tiempo real. Todas las personas que } \\
\text { participan se enumeran en el lado de la pantalla con los nombres que toman } \\
\text { en el chat. }\end{array}$ \\
\hline Spam & $\begin{array}{l}\text { Correo electrónico no solicitado, por lo general de naturaleza comercial, } \\
\text { enviado desde un desconocido para el receptor. }\end{array}$ \\
\hline VolP & $\begin{array}{l}\text { Acrónimo en inglés de "Voiceover Internet Protocol". Transmisión de voz a } \\
\text { través de una conexión a Internet. Permite a los usuarios hacer llamadas } \\
\text { telefónicas a través de Internet en lugar de una línea telefónica. }\end{array}$ \\
\hline Web & $\begin{array}{l}\text { Abreviatura en inglés de "World Wide Web" y representa los sitios y páginas } \\
\text { vinculadas entre sí a través de Internet. }\end{array}$ \\
\hline Webcast & $\begin{array}{l}\text { Audio en directo o en diferido y/o sesión de vídeo que utiliza Internet para } \\
\text { transmitir. }\end{array}$ \\
\hline
\end{tabular}

C) Categoría "Seguridad de red".

Términos relacionados con todas aquellas posibilidades que ofrece la red y que permite hacer un uso seguro en cuanto a la conexión y también respecto a la información que proporcionamos al conectarnos a dicha red (ver Tabla 13). 
Tabla 13. Seguridad de red

\begin{tabular}{|c|c|}
\hline Anonymizer & $\begin{array}{l}\text { Sitio web intermediario que oculta o enmascara la dirección IP asociada con } \\
\text { el usuario de Internet. Por lo general, estos sitios permiten a una persona } \\
\text { participar en diversas actividades en Internet sin dejar una huella digital. }\end{array}$ \\
\hline Bloqueo & $\begin{array}{l}\text { La negación del acceso a determinadas partes de Internet. Por lo general se } \\
\text { muestra en la pantalla un mensaje que dice que el acceso ha sido denegado. } \\
\text { Por ejemplo, los usuarios de Facebook pueden bloquear a otros usuarios } \\
\text { para que éstos no les envíen mensajes o puedan ver sus mensajes. }\end{array}$ \\
\hline Cookie & $\begin{array}{l}\text { Un archivo en un ordenador u otro dispositivo electrónico que registra la } \\
\text { información del usuario cuando visita una página web. Las cookies se } \\
\text { utilizan a menudo para identificar las páginas web que el dispositivo ha } \\
\text { visitado, guardar la información de acceso y personalización de } \\
\text { preferencias, y permitir la presentación de la información o contenido más } \\
\text { personalizado. }\end{array}$ \\
\hline Evidencia Digital & $\begin{array}{l}\text { Signos tangibles, pruebas, información o datos que demuestran algún } \\
\text { comportamiento. Esto podría ser una captura de pantalla, un registro de la } \\
\text { actividad de Internet, salvado de contenido, etc. }\end{array}$ \\
\hline Filtrado & $\begin{array}{l}\text { El acto de restringir el acceso a ciertos sitios web o plataformas de medios } \\
\text { sociales. Por ejemplo, un filtro podría comparar el texto en una página web } \\
\text { con una lista de palabras prohibidas. Si se encuentra una coincidencia, esa } \\
\text { página web puede ser bloqueada o reportada a través de un proceso de } \\
\text { monitorización. En términos generales, un filtro permite o deniega el acceso } \\
\text { basado en reglas especificadas anteriormente. }\end{array}$ \\
\hline Firewall & $\begin{array}{l}\text { El hardware o software que restringe y regula los datos de entrada y salida } \\
\text { hacia o desde los sistemas informáticos. Los cortafuegos permiten el acceso } \\
\text { a ciertos sitios web o plataformas de medios sociales. }\end{array}$ \\
\hline Huella Digital & $\begin{array}{l}\text { La evidencia del uso de una persona de Internet, por lo general se centran } \\
\text { en determinadas fechas y horas de los sitios web visitados. Esto incluye } \\
\text { cualquier cosa que se puede vincular a la existencia, presencia o identidad } \\
\text { de un usuario. }\end{array}$ \\
\hline Monitorización & $\begin{array}{l}\text { El registro y la notificación de la actividad en línea, por lo general a través } \\
\text { de software, que puede registrar un historial de todo uso de Internet, o } \\
\text { simplemente de uso inadecuado. }\end{array}$ \\
\hline $\begin{array}{l}\text { Política de Uso } \\
\text { Aceptable (AUP) }\end{array}$ & $\begin{array}{l}\text { Una política que crean las escuelas y otras organizaciones para definir las } \\
\text { responsabilidades y los comportamientos apropiados de los usuarios de } \\
\text { ordenadores y de la red. }\end{array}$ \\
\hline Proxy & $\begin{array}{l}\text { Software o sitio web que permite una conexión a Internet para ser enrutado } \\
\text { a través de una conexión diferente. Si el ordenador de un usuario tiene } \\
\text { bloqueado el acceso a determinados sitios web o programas, el usuario } \\
\text { podría emplear un proxy para redirigir la conexión a ese sitio o programa. } \\
\text { Por ejemplo, si un filtro de software prohíbe que un usuario visite } \\
\text { directamente Facebook, un proxy podría se podría utilizar para eludir el } \\
\text { filtro y proporcionar acceso. }\end{array}$ \\
\hline
\end{tabular}

D) Categoría "Peligros en la red".

Términos relacionados con los riesgos directamente vinculados con el uso inadecuado de la red (ver Tabla 14). 
Tabla 14. Peligros en la red

\begin{tabular}{|c|c|}
\hline Acoso & $\begin{array}{l}\text { Las palabras o acciones destinadas a molestar, alarmar o abusar de otro } \\
\text { individuo. A menudo, en base a determinada condición (por ejemplo, } \\
\text { sexo, raza, discapacidad u orientación sexual). }\end{array}$ \\
\hline Amenaza & $\begin{array}{l}\text { Presentación de una declaración de medidas que implique o sugiera hacer } \\
\text { daño a otra persona. }\end{array}$ \\
\hline $\begin{array}{l}\text { Bombardeo de } \\
\text { texto }\end{array}$ & $\begin{array}{l}\text { Cuando alguien envía un gran número de textos a otro, no permitiendo } \\
\text { que esta persona use su teléfono debido a la molestia, o porque el } \\
\text { teléfono se sobrecarga de constantes mensajes entrantes. }\end{array}$ \\
\hline Bullicide & $\begin{array}{l}\text { El suicidio que resulta directamente o indirectamente de intimidaciones } \\
\text { violentas. La relación entre el acoso y el suicidio es compleja y por esa y } \\
\text { otras razones, muchos investigadores tienen preocupaciones con la } \\
\text { utilización de este término. }\end{array}$ \\
\hline Bullying & $\begin{array}{l}\text { Acoso repetido y deliberado hacia uno por otro que está en una posición } \\
\text { de poder. Puede implicar amenazas o comportamientos físicos, } \\
\text { incluyendo asalto, o formas indirectas y sutiles de agresión, incluyendo el } \\
\text { chisme y rumor de propagación. El término es generalmente reservado } \\
\text { para los jóvenes y la intimidación se refiere a estos comportamientos a } \\
\text { medida que ocurren con mayor frecuencia en o cerca de la escuela. }\end{array}$ \\
\hline Catfishing & $\begin{array}{l}\text { En el mundo virtual, el catfishing se refiere a la práctica de la creación de } \\
\text { un perfil en línea ficticia, con mayor frecuencia con el fin de atraer a una } \\
\text { relación romántica fraudulenta en otro. }\end{array}$ \\
\hline Ciberamenazas & $\begin{array}{l}\text { Material electrónico que eleva, ya sea en general o específicamente, las } \\
\text { consideraciones que el creador pueda tener a modo de intención de } \\
\text { infligir daño o violencia a los demás, o para sí mismo. }\end{array}$ \\
\hline Ciberbullying & $\begin{array}{l}\text { El daño intencional y repetido infligido a través del uso de los } \\
\text { ordenadores, teléfonos móviles y otros dispositivos electrónicos. }\end{array}$ \\
\hline Cyberbullicide & $\begin{array}{l}\text { El suicidio proveniente directa o indirectamente de las víctimas de } \\
\text { ciberacoso. La relación entre el acoso cibernético y el suicidio es compleja } \\
\text { y por esa y otras razones, muchos investigadores tienen preocupaciones } \\
\text { con la utilización de este término. }\end{array}$ \\
\hline Cyberstalking & $\begin{array}{l}\text { Acoso repetido utilizando dispositivos electrónicos y tecnología en red que } \\
\text { incluye amenazas de daño, o que es muy intimidante e intrusiva a la } \\
\text { privacidad personal de cada uno. }\end{array}$ \\
\hline Daño & Lesión física, psicológica o emocional hacia una persona. \\
\hline Flaming & $\begin{array}{l}\text { Envío de mensajes groseros, de enojo u obscenos dirigidos privadamente } \\
\text { a una persona o personas en un grupo en línea o en privado. Un } \\
\text { "flamewar" estalla cuando "llamas" se envían de ida y vuelta varias veces } \\
\text { entre los individuos. }\end{array}$ \\
\hline Happyslapping & $\begin{array}{l}\text { Forma extrema de bullying, donde las agresiones físicas se registran en } \\
\text { dispositivos electrónicos como los teléfonos, y luego se envían a otros o } \\
\text { se publican en Internet. Este término se utiliza con mayor frecuencia en el } \\
\text { Reino Unido. }\end{array}$ \\
\hline Piratería & $\begin{array}{l}\text { Acto de eludir la seguridad e irrumpir un lugar no autorizado (una red, } \\
\text { ordenador, archivo, etc.), por lo general con intenciones maliciosas. }\end{array}$ \\
\hline Sexting & $\begin{array}{l}\text { El envío o recepción de imágenes o vídeos de carácter sexual explícitos o } \\
\text { sugerentes a través del teléfono o Internet. }\end{array}$ \\
\hline Sextorsión & $\begin{array}{l}\text { Amenazas de exponer o publicar una imagen sexual con el fin de que una } \\
\text { persona haga algo o por otras razones, tales como la venganza o la } \\
\text { humillación. }\end{array}$ \\
\hline
\end{tabular}


Tabla 14. Peligros en la red. (Continuación)

\begin{tabular}{ll}
\hline Trolling & $\begin{array}{l}\text { Publicar deliberada y falsamente información para persuadir a la gente a } \\
\text { responder. A menudo hecho para provocar a los demás. }\end{array}$ \\
\hline $\begin{array}{l}\text { Venganza } \\
\text { pornográfica }\end{array}$ & $\begin{array}{l}\text { Acto de distribución de fotografías íntimas o vídeos a través de diferentes } \\
\text { medios de distribución sin el consentimiento de la otra persona. }\end{array}$ \\
\hline
\end{tabular}

E) Categoría "Herramientas y dispositivos tecnológicos".

Integra a todos aquellos términos que como su propio nombre indica hacen referencia a mecanismos tecnológicos (ver Tabla 15).

Tabla 15. Herramientas y dispositivos tecnológicos

\begin{tabular}{|c|c|}
\hline Android & $\begin{array}{l}\text { El sistema operativo creado por Google. Android está disponible en } \\
\text { teléfonos inteligentes y tabletas. }\end{array}$ \\
\hline App & $\begin{array}{l}\text { Abreviatura de "aplicación", se trata de una pieza de software, } \\
\text { refiriéndose principalmente a los utilizados en los teléfonos inteligentes, } \\
\text { tabletas y otros dispositivos táctiles. }\end{array}$ \\
\hline $\begin{array}{l}\text { Captura de } \\
\text { pantalla }\end{array}$ & $\begin{array}{l}\text { Imagen que se captura de lo que se muestra en un teléfono, tableta o } \\
\text { pantalla de ordenador. }\end{array}$ \\
\hline Dirección IP & $\begin{array}{l}\text { Dirección de "Protocolo de Internet". Una única dirección asignada a un } \\
\text { dispositivo informático que le permite enviar y recibir datos con otros } \\
\text { dispositivos informáticos que tienen sus propias direcciones únicas. }\end{array}$ \\
\hline $\begin{array}{l}\text { Dispositivo } \\
\text { inalámbrico }\end{array}$ & $\begin{array}{l}\text { Los dispositivos electrónicos que pueden acceder a Internet sin estar } \\
\text { conectada mediante un cable o línea de datos físicamente. }\end{array}$ \\
\hline Geolocalización & $\begin{array}{l}\text { Proceso o técnica de identificar la ubicación geográfica de una persona o } \\
\text { dispositivo por medio de la información digital procesadas a través de } \\
\text { Internet. }\end{array}$ \\
\hline iOS & $\begin{array}{l}\text { Sistema operativo creado por Apple Inc. iOS poderes iPods, iPhones, iPads, } \\
\text { y Apple TV. }\end{array}$ \\
\hline ISP & $\begin{array}{l}\text { "Proveedor de Servicios de Internet." Compañía que ofrece una conexión } \\
\text { a Internet a personas o empresas. La ISP puede ayudar en la identificación } \\
\text { de un individuo que publica o envía mensajes de acoso o palabras } \\
\text { amenazantes. }\end{array}$ \\
\hline SMS & $\begin{array}{l}\text { Acrónimo de los términos en inglés "Short MessageService". Protocolo de } \\
\text { comunicaciones que permite mensajes de texto cortos ( } 160 \text { caracteres o } \\
\text { menos) de teléfono móvil. }\end{array}$ \\
\hline Tablet & $\begin{array}{l}\text { Dispositivo portátil en creciente popularidad y uso. Son más pequeños que } \\
\text { un ordenador portátil y más grande que un teléfono inteligente, y } \\
\text { proporcionan gran parte de la misma funcionalidad que ambos. }\end{array}$ \\
\hline Wireless & $\begin{array}{l}\text { Comunicaciones en el que las ondas electromagnéticas transportan una } \\
\text { señal a través del espacio en lugar de a lo largo de un alambre. Se refiere } \\
\text { principalmente a la conexión inalámbrica a Internet (Wi-Fi) disponible en } \\
\text { un número creciente de lugares. }\end{array}$ \\
\hline
\end{tabular}

F) Categoría "Perfil usuarios".

Recogemos conceptos referidos a los diferentes tipos de usuarios de individuos que hacen uso de las tecnologías y también según el uso que hagan de estos dispositivos (ver Tabla 16). 
Tabla 16. Perfil usuarios

\begin{tabular}{ll}
\hline Agresor & El que instiga a la crueldad social en línea. \\
\hline Inmigrantes & $\begin{array}{l}\text { Una persona que no ha crecido con la tecnología digital, como los teléfonos } \\
\text { inteligentes, las redes sociales e Internet, pero más tarde se ha adaptado. A } \\
\text { muchos adultos se les conoce como los inmigrantes digitales, porque han } \\
\\
\text { conocido una época en que no existían estas tecnologías. }\end{array}$ \\
\hline Nativo & $\begin{array}{l}\text { Una persona que ha crecido con la tecnología digital, como los teléfonos } \\
\text { inteligentes, redes sociales e Internet. Muchos adolescentes o adultos jóvenes } \\
\text { Digital } \\
\text { serían clasificados como nativos digitales, porque no han conocido un tiempo sin } \\
\text { estas tecnologías. }\end{array}$ \\
\hline Novato & Alguien que es nuevo o inexperto en una actividad de Internet o tecnología. \\
\hline Víctima & $\begin{array}{l}\text { Persona que está en el extremo receptor de la crueldad social online. También } \\
\text { conocido como el "objetivo". }\end{array}$ \\
\hline
\end{tabular}

Teniendo en cuenta las categorías que hemos elaborado, debemos preguntarnos qué utilidad tiene el glosario y su categorización. Al respecto, este glosario nos permite además de su ordenación alfabética, su clasificación por categorías, lo que facilita el conocimiento de los términos por parte del profesorado a favor de la inserción curricular en los centros escolares. Términos como los de la categoría A y $\mathrm{F}$ están relacionados con asignaturas de lengua; las categorías $B, C$ y $E$ con contenidos tecnológicos y la $D$ con aspectos de ciencias sociales.

\subsection{SIINTESIS}

Este capítulo recoge toda aquella información necesaria para conocer el fenómeno del ciberbullying en profundidad.

Como observamos en los datos sobre riesgos en las redes en los menores de edad, uno de los principales riesgos a los que se exponen es el ciberbullying. Así, la conceptualización del término se hace esencial para el estudio de un fenómeno tan relevante y actual como es el ciberbullying. Desde el primer estudio realizado sobre ciberbullying por Finkelhor et al., (2000) en Estados Unidos, han sido abundantes las investigaciones que se han llevado a cabo sobre el ciberbullying, a pesar de ello, y como hemos visto, no existe un consenso en cuanto a su definición tanto en lo que respecta a las definiciones institucionales que hacen diferentes países europeos (Dalla et al., 2016) ni a las definiciones que han estado presentando los académicos (Aftab, 2010; Ferro, 2013; Smith, 2000; Willard, 2005, entre otros). Muchas de las definiciones presentadas a lo largo del capítulo comparten la certeza de entender el ciberbullying como un modo de bullying que se ejerce mediante el uso de las TIC, sin embargo, al profundizar más allá de este aspecto, es cuando surgen las discrepancias.

Sin embargo, y pese a estar de acuerdo con los diferentes autores que el ciberbullying es una forma de bullying, hay ciertos aspectos que lo diferencian y que no se tienen en cuenta 
a la hora de elaborar la definición de este fenómeno. Por tanto, tomando en cuenta las características específicas del ciberbullying, nosotros lo definiríamos como: una nueva forma de bullying, y que se ejerce entre menores o adolescentes, mediante el uso de la tecnología con la finalidad de acosar, amenazar o intimidar a otra persona intencionalmente, pudiéndose dar en cualquier lugar con independencia del lugar físico en el que se encuentre la víctima. Para que sea considerado ciberbullying se debe mantener en el tiempo y debe existir un desequilibrio de poder entre el agredido y el agresor. Esta acción se puede ver maximizada por el anonimato del agresor, así como también por la rápida y amplia difusión junto con la permanencia en el tiempo de la acción debido al uso de la tecnología.

Respecto a los perfiles implicados sí parece existir un consenso, siendo tres los roles característicos: agresor, víctima y agresor pasivo o espectador.

De nuevo con la clasificación y tipologías de ciberbullying vuelven a surgir las discrepancias, puesto que hay autores como Smith et al. (2006) que hacen una clasificación en función de la vía por la que se ejerce el acoso, mientras que Willard (2006) se basa en la acción que realiza puesto que considera que considera que la categorización por la vía por la que se ejerce no es muy precisa.

Por supuesto, para conocer bien el ciberbullying es importante conocer las causas por las que se origina y los factores que favorecen su aparición, así como sus consecuencias. Entre las principales causas encontramos; mayor disponibilidad y acceso a internet, minimización del daño causado, adopción de roles ficticios y el bajo porcentaje de víctimas que denuncian. Respecto a las consecuencias, encontramos cambios de diferentes índoles como; en los hábitos, estado de ánimo, red social, físicos o en sus pertenencias o cambios somáticos.

Como hemos visto desde el inicio con las definiciones, es complicado hablar del ciberbullying sin vincularlo al bullying tradicional, por ello se hace necesario un análisis de las diferencias y similitudes entre ambos. Respecto a las similitudes entre ambos, vemos que comparten características como la agresividad de la conducta, su intencionalidad, repetición en el tiempo y la existencia de un desequilibrio de poder entre los implicados. Sin embargo, son muchos los aspectos que los diferencian, entre ellos la mostrabilidad, el escenario, el medio de ejecución, el riesgo físico, la detección, los perfiles escolares de los implicados, la vigencia del maltrato, quienes contemplan la agresión, la procedencia de las agresiones y la prestación de ayuda.

Pero no sólo relacionamos el ciberbullying con el bullying, sino que también hay otros fenómenos vinculados al ciberbullying, cuya característica en común con el fenómeno que estudiamos es que los tres son peligros y riesgos actuales y muy presentes en nuestra sociedad derivados de un mal uso de las TIC. A pesar de ello, se trata de tres riesgos claramente diferenciados, puesto que los roles implicados son distintos, así como también la finalidad de las acciones ejercidas. 
El ciberbullying, como hemos visto, se trata de un problema social actual, y ello nos deja ver una clara necesidad de implicación por parte de toda la sociedad, y al tratar de un fenómeno que se produce entre menores es esencial la colaboración y el trabajo coordinado del contexto clínico, educativo y familiar. Sólo la unión de los tres conseguirá el éxito en las acciones de prevención e intervención en el ciberbullying.

Así, para una correcta prevención e intervención por parte de los contextos citados anteriormente, se hace necesaria la evaluación con la finalidad de facilitar la detección precoz y la correcta intervención. A pesar de ello, debido a la inestabilidad de la conceptualización, se han utilizado a lo largo de estos últimos años multitud de metodologías diferentes. Debido a ello, se remarca la necesidad de la creación de instrumentos generalizados para determinar su prevalencia y dirigidos a la etapa de Educación Primaria.

Respecto a los instrumentos españoles analizados, nos indican que el nivel educativo a la que va dirigido la aplicación de la prueba en todas, el inicio es a los 12 años extendiéndose hasta los 18 años (Álvarez-García et al., 2011; Buelga et al., 2010; Día et al., 2013; Gairagordobil \& Aliri, 2013; Ortega et al., 2008) y uno hasta los 17 años (Calvete et al., 2010). En cambio en los internacionales, podemos contemplar que disminuye puesto que en cuatro de los estudios la edad inicial es a los 10 años (Hinduja \& Patchin, 2008; Mitchell, Wolak \& Finkelhor, 2006; Williams \& Guerra, 2007; Ybarra \& Mitchell, 2008; Ybarra).

Como hemos comentado, al tratarse de un fenómeno social con graves consecuencias, desde el año 2015 empieza a estar presente en nuestra legislación donde se contempla el acoso en medios telemáticos como un delito. Esto da lugar a la necesidad de concienciar a la sociedad en su conjunto, y a los menores en particular de la gravedad de estas acciones.

Toda esta información sobre el fenómeno ciberbullying nos va a permitir adentrarnos en uno de los fenómenos con más prevalencia en nuestra sociedad, pero puede que se nos escapen muchos términos relacionados con este fenómeno. Para ello, podemos recurrir al glosario presentado en este capítulo con el que nos adentraremos en una categorización de los términos; Red de contactos y términos vinculados, Entorno de red, Seguridad de red, Peligros en la red, Herramientas y dispositivos tecnológicos y Perfil usuarios. Categorización que facilita el conocimiento de los términos y la posibilidad de adentrarnos más si cabe en este importante fenómeno social con tanta prevalencia en nuestra sociedad actual. 



\section{CAPÍTULO 3. CIBERBULLYING ESTADO DE LA CUESTIÓN}

\subsection{FUENTES DOCUMENTALES PRIMARIAS}

\subsubsection{Estadísticas}

3.1.1.1. Estadísticas españolas

3.1.1.2. Estadísticas estadounidenses

3.1.2. Teseo

3.1.3. Bases de datos de revistas

3.1.3.1. Eric

3.1.3.2. Psycnet

3.1.3.3. Dialnet

3.2. FUENTES DOCUMENTALES SECUNDARIAS

3.2.1. Libros ISBN

3.2.2. Recursos

3.2.2.1. Programas

3.2.2.2. Guías

3.2.2.3. Páginas web

3.2.2.4. Vídeos

3.3. SÍNTESIS 



\section{CAPÍTULO 3. CIBERBULLYING ESTADO DE LA CUESTIÓN}

La revisión de la documentación existente sobre el tema de estudio es fundamental, puesto que es evidente que, si no partimos de una base sólidamente establecida, todo el conocimiento que construyamos a partir de él podrá fácilmente tambalearse (Orellana, 2002).

Por ello, será la literatura la que nos dará pistas sobre cómo abordar la investigación. Así, como señala Buendía (1999), la revisión será fundamental al menos por dos aspectos:

- Nivel conceptual: permite profundizar más en el conocimiento relativo al problema.

- Nivel funcional: nos proporciona información sobre el estado de la cuestión, los métodos utilizados y las pruebas e instrumentos.

Hoy en día, en referencia a cómo buscar la información, se ha facilitado mucho con la informática e Internet, puesto que se puede acceder a la mayoría de bases de datos online (aunque algunas son previo pago, otras no se actualizan o simplemente han dejado de existir).

Es por ello, que como señala Aliaga (2000), ésta es la fase del proceso general de investigación que se ha visto más afectada en los últimos años, por la generalización de las tecnologías de la información y comunicación (excluyendo la fase de análisis de datos). La digitalización de la información y de Internet han permitido, respectivamente, el desarrollo de bases de datos y la disponibilidad de una gran cantidad de información que hasta ahora era inaccesible para la mayoría. En este sentido, la globalización ha resultado de gran utilidad.

El primer contacto con la información puede establecerse a partir de diversos canales, que pueden clasificarse en informales y formales (Orellana, 2002).

Respecto a los tipos de fuentes, son muchas y variadas las clasificaciones que pueden hacerse de las fuentes documentales existentes (ver por ejemplo Aliaga, 2000; Orellana, 2002; Ortega \& Fernández-Dols, 1980; entre otros) y dependiendo de los criterios tendremos distintas categorías.

Así, dependiendo del lugar de donde proceda la información, podrá hablarse de fuentes personales, institucionales o documentales. En concreto nos vamos a centrar en la clasificación de fuentes documentales puesto que son estas las que hemos utilizado para conocer el estado de la cuestión de la temática de esta investigación.

Las fuentes documentales son las que proporcionan información sobre o a partir de un documento y, a su vez, van a poder clasificarse según el nivel de complejidad y según el contenido, siendo este último en el que nos vamos a centrar. 
De este modo, atendiendo al contenido, podemos distinguir entre (UNESCO, 1971, 1976, 1982):

- Fuentes primarias: se refiere a documentos originales y completos como son los artículos de investigación (no de revisión), enciclopedias, tesis doctorales, informes de investigación, etc.

- Fuentes secundarias: resúmenes, referencias o recopilaciones de las fuentes primarias. Son de gran utilidad para poder manejar la inmensa cantidad de información disponible. Son las bases de datos, los índices de publicación, las revisiones, etc.

A continuación, vamos a realizar un análisis de diferentes fuentes documentales, primarias y secundarias, para así conocer cuál es la situación actual de la temática del ciberbullying tanto a nivel estatal como en otros países.

\subsection{FUENTES DOCUMENTALES PRIMARIAS}

Respecto a las fuentes documentales primarias, nos vamos a centrar en primer lugar en datos estadísticos, de estudios realizados tanto en España como en otros países. A continuación, presentaremos datos obtenidos del análisis de artículos de ciberbullying extraídos de diferentes bases de datos de reconocido prestigio en el campo de la educación y la psicología.

\subsubsection{Estadísticas}

Para obtener datos de primera mano hemos recurrido a las estadísticas, tanto nacionales como internacionales. A partir de ellas conoceremos cuál es la situación actual del ciberbullying, y obtendremos datos sobre aspectos como la prevalencia, el tipo de ciberbullying más frecuente, las edades en las que se desarrolla, entre otros.

\subsubsection{Estadísticas españolas}

Iniciamos así con datos nacionales recientes publicados en febrero de 2016 por Calmaestra et al. (2016).

Este proyecto ha sido financiado por Save the Children, ONG que trabaja para la infancia, decidió asumir el reto, con la colaboración de un equipo de investigación experto en la materia, de realizar el primer estudio con muestra representativa de ámbito estatal español y autonómico.

De esta forma, a través de una encuesta realizada a 21.487 estudiantes entre 12 y 16 años de Educación Secundaria Obligatoria (1을 ESO a 4 ESO) que asisten a centros educativos públicos en el territorio español, se han explorado las vivencias de las y los encuestados sobre el acoso y el ciberbullying y otros fenómenos asociados a ellos. Así, 
han obtenido información que, además de acercarnos a dimensionar el problema, nos permite trazar un perfil tanto de la víctima como del agresor de acoso y ciberbullying.

Este perfil se ha hecho atendiendo al sexo de los estudiantes, así como al ciclo educativo en el que se encuentran. Al mismo tiempo, veremos qué diferencias presentan estos perfiles al comparar los resultados obtenidos en las distintas comunidades autónomas. También han indagado sobre variables de personalidad que pueden estar relacionadas con estos fenómenos para poder entender mejor su naturaleza y de esta forma prevenirlo de una forma más efectiva.

A continuación, presentaremos sintetizados los datos obtenidos en dicho estudio, centrándonos especialmente en aquellos que hacen referencia al ciberbullying, como son aspectos relacionados con las víctimas, su prevalencia de victimización, y las experiencias de violencia en las redes. También datos sobre los niños y niñas que reconocen acosar o ciberacosar a otros, indicando la prevalencia de estos casos, así como los tipos de ciberagresiones existentes. Otro de los aspectos analizados son los motivos por los que según las víctimas se agrede, así como también las estrategias de afrontamiento de las víctimas. Y se presentan por último datos sobre las características de personalidad tanto de la víctima como del agresor.

A) Víctimas de bullying y ciberbullying.

$>$ Prevalencia de la victimización

En primer lugar, se presentan los datos de prevalencia a partir de los datos obtenidos de las encuestas realizadas a 21.487 estudiantes de ESO, que muestran que un $9,3 \%$ ha sufrido acoso y un 6,9\% ciberbullying. Extrapolado al conjunto de la población, el número de víctimas se eleva a 111.000 y 82.000 menores de edad respectivamente.

Por otro lado, un 3,7\% de las y los estudiantes habría sido víctima de ambas modalidades de acoso, como reconocen más de 44.000 encuestados.

Analizando el género, tal y como se puede observar en la Figura 4, en este estudio los datos muestran que las chicas salen peor paradas ya que un $10,6 \%$ han sufrido acoso (frente a un $8 \%$ de chicos), y un $8,5 \%$ ciberacoso (un $5,3 \%$ de chicos). Además, entre ellos es mayor el porcentaje de los que se reconocen como agresores, un 6,3\% de los niños ha acosado a otro menor de edad frente a un 3,5\% de las niñas. Esta diferencia persiste respecto al ciberacoso, un $4,5 \%$ de los niños ha sido ciberagresor frente a un $3 \%$ de ellas. 


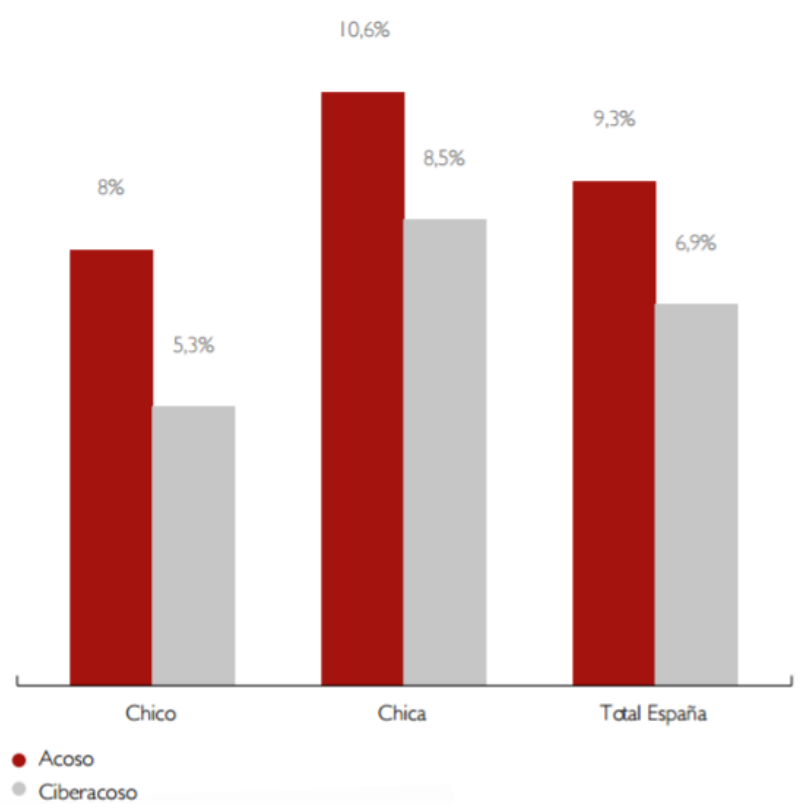

Figura 4. Porcentaje de niños y niñas víctimas de acoso y ciberacoso según género. Promedio España (Calmaestra et al., 2016).

En cuanto a los datos de prevalencia de menores que han sido víctimas de ciberbullying por comunidades autónomas (ver Figura 5), se muestran algunas diferencias. La cifra promedio española de quienes afirman haber sido víctimas frecuentemente es de un 5’8 $\%$ y $1^{\prime} 1 \%$ ocasionalmente. Las mayores proporciones en cuanto a menores que aseguran haber sido víctimas de ciberbullying ocasionalmente, se han encontrado principalmente en las comunidades autónomas de Andalucía (9’5\%), Melilla (7\%), Región de Murcia (6'1\%) e Islas Baleares (6\%). En el polo opuesto encontramos a Ceuta (3’3\%), Cantabria $\left(3^{\prime} 2 \%\right)$ y Asturias (3\%).

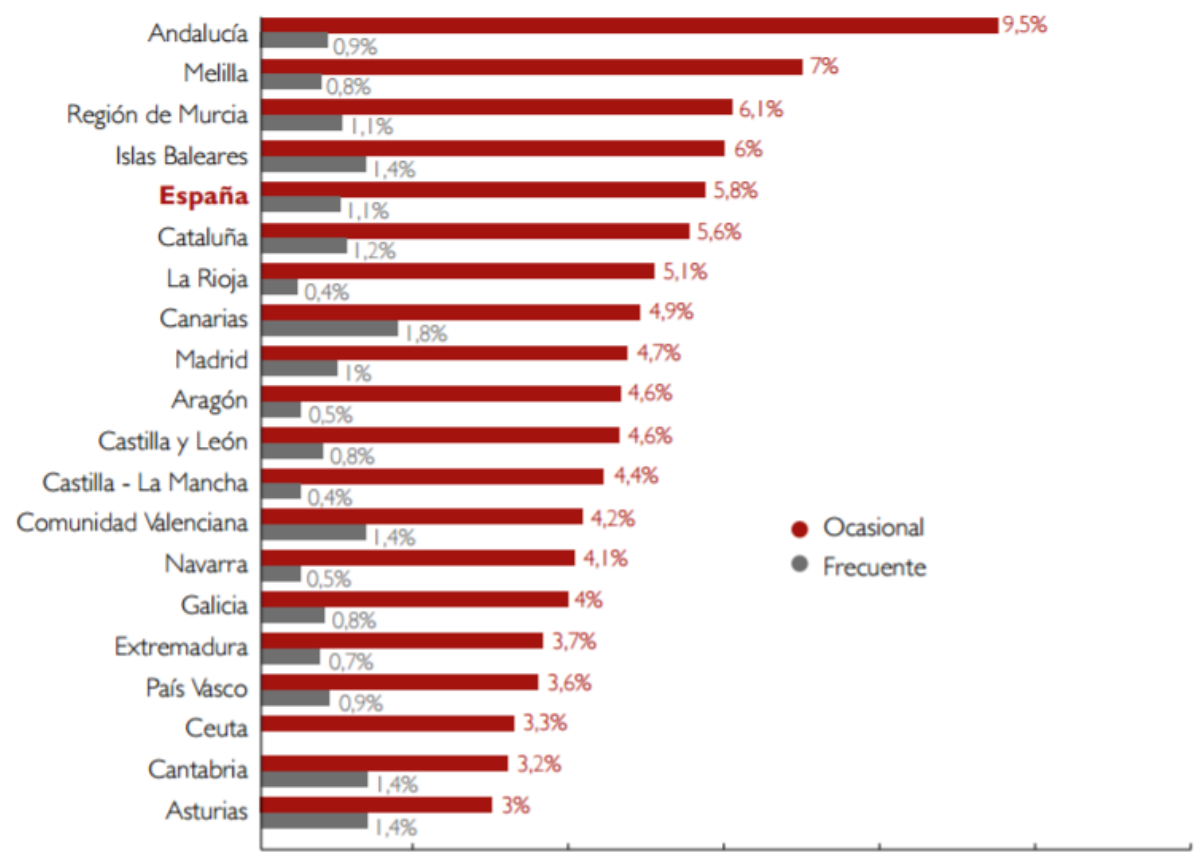

Figura 5. Porcentaje de niños y niñas que han sido víctimas de ciberacoso por CCAA. Promedio España (Calmaestra et al., 2016). 
Por su parte, tal y como podemos observar en la Figura 6, los porcentajes de niños y niñas que han sido víctimas de bullying y ciberbullying por Comunidad Autónoma, el promedio es de 3'7\% en España. Esta cifra la superan en primer lugar Andalucía con un $6 \%$, seguida por Melilla con un $4^{\prime} 3 \%$ y de Islas Baleares con un 4'1\%. Las Comunidades con porcentajes más bajos en cuanto a víctimas de ambos tipos de acoso son Ceuta (2'2\%), Navarra (1'99\%) y Asturias (1'4\%).

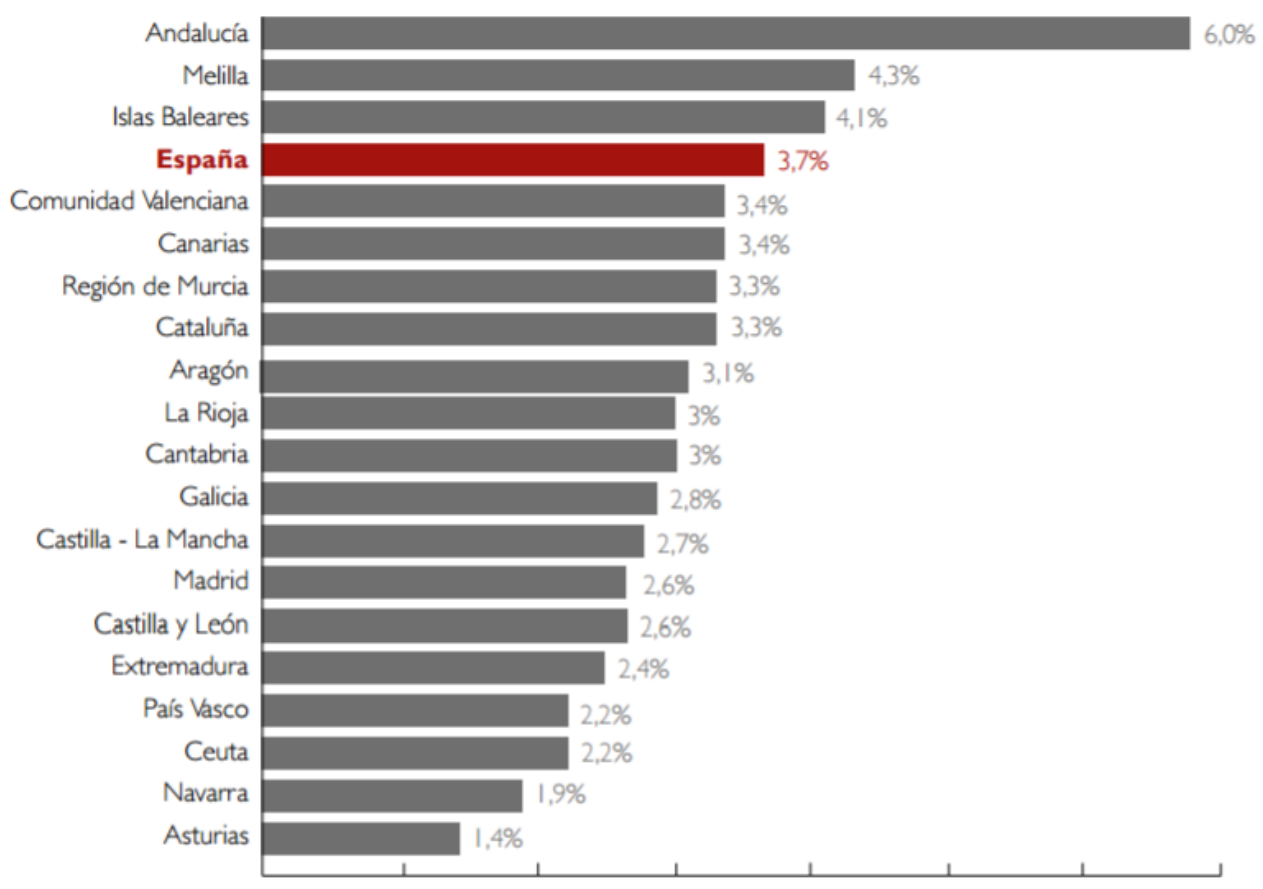

Figura 6. Porcentaje de niños y niñas víctimas de acoso y ciberacoso según género. Promedio España (Calmaestra et al., 2016).

Respecto a la edad, hay más acoso entre los más jóvenes, con más víctimas de bullying y ciberbullying entre los estudiantes de primer ciclo de la ESO que entre los de segundo ciclo. También son más los niños y niñas de primer ciclo que se reconocen como agresores (ver Figura 7).

Al igual que en el acoso tradicional, aunque de manera menos pronunciada, los estudiantes de primer ciclo de la ESO $(7,2 \%)$ consideran haber sufrido ciberacoso en mayor medida que los de segundo ciclo $(6,7 \%)$. 


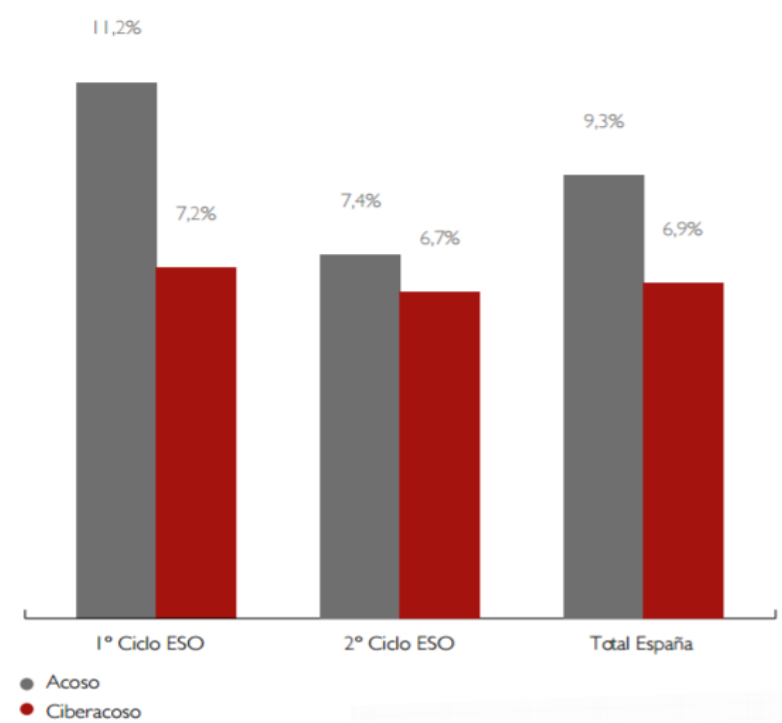

Figura 7. Porcentaje de niños y niñas víctimas de acoso y ciberacoso según ciclo educativo. Promedio España (Calmaestra et al., 2016).

Experiencias de violencia a través de las TIC.

Los porcentajes de menores que han vivido de forma ocasional o frecuente situaciones de violencia en internet o con el teléfono móvil recientemente (ver Figura 8) nos indican que el modo más frecuente son los insultos (26'4\%), seguidos de insultos indirectos $\left(22^{\prime} 4 \%\right)$ y rumores (12'99\%). Las experiencias menos frecuentes son el retoque de fotos (5'2\%) y la suplantación de identidad (4'4\%).

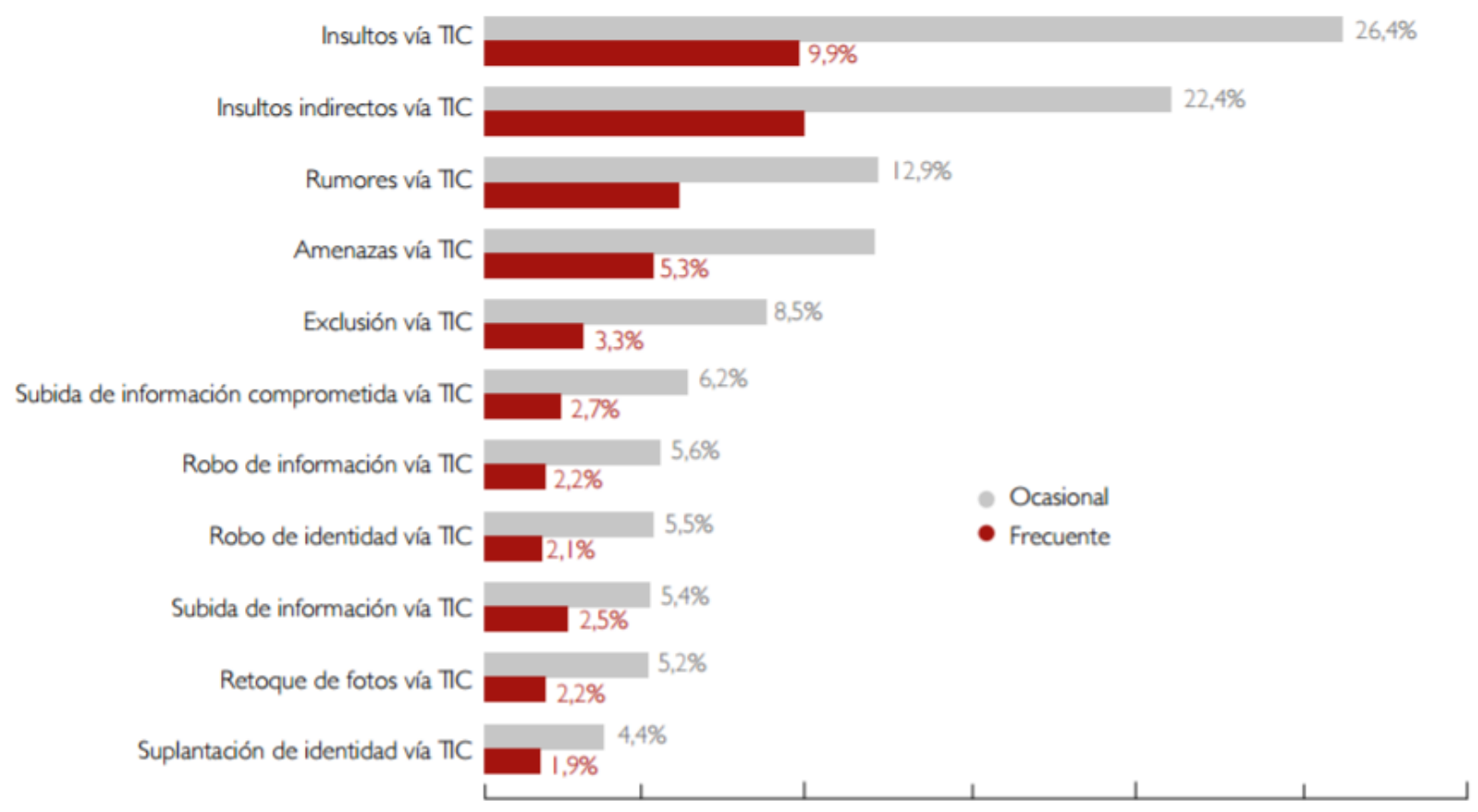

Figura 8. Porcentaje de niños y niñas que han vivido de forma ocasional o frecuente situaciones de violencia en internet o con el teléfono móvil en los últimos dos meses. Promedio España (Calmaestra et al., 2016). 
B) Niños y niñas que reconocen acosar o ciberacosar.

Prevalencia de la agresión.

Como podemos apreciar en la Figura 9, un 5,4\% del total de los encuestados afirman haber sido agresores de bullying y un 3'3\% de ciberbullying. Si nos detenemos por ciclos educativos, podemos ver que en el primer ciclo de Eso el porcentaje de acosadores es de un $6 \%$ mientras que de ciberacosadores es de un 2'9\%. En el segundo ciclo de Eso, los datos son inferiores en cuanto a la cifra de acosadores (4'9\%) sin embargo aumenta el porcentaje de ciberacosadores ( $3{ }^{\prime} 7 \%$ ) respecto a la etapa educativa anterior.

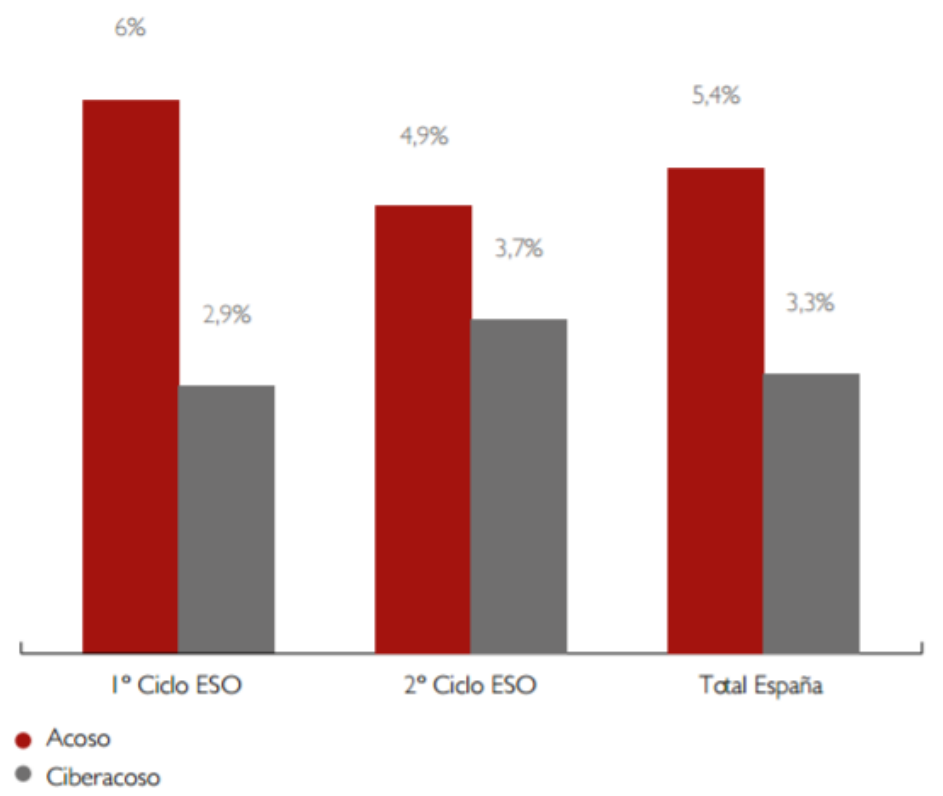

Figura 9.Porcentaje de niños y niñas agresores de acoso y ciberacoso según ciclo educativo. Promedio España (Calmaestra et al., 2016).

Melilla (3’5\%), Cataluña (3’5\%) y la Región de Murcia, Islas Baleares y Andalucía (3’3\%) están entre las CCAA donde más estudiantes reconocen haber ciberacosado a alguien, superando el promedio de España situado en un 2'6\%. Por su parte las Comunidades con cifras inferiores en cuanto a menores agresores de ciberbullying, encontramos la Comunidad Valenciana, Asturias y Galicia ambas tres con un porcentaje del 1'4\% (ver Figura 10). 


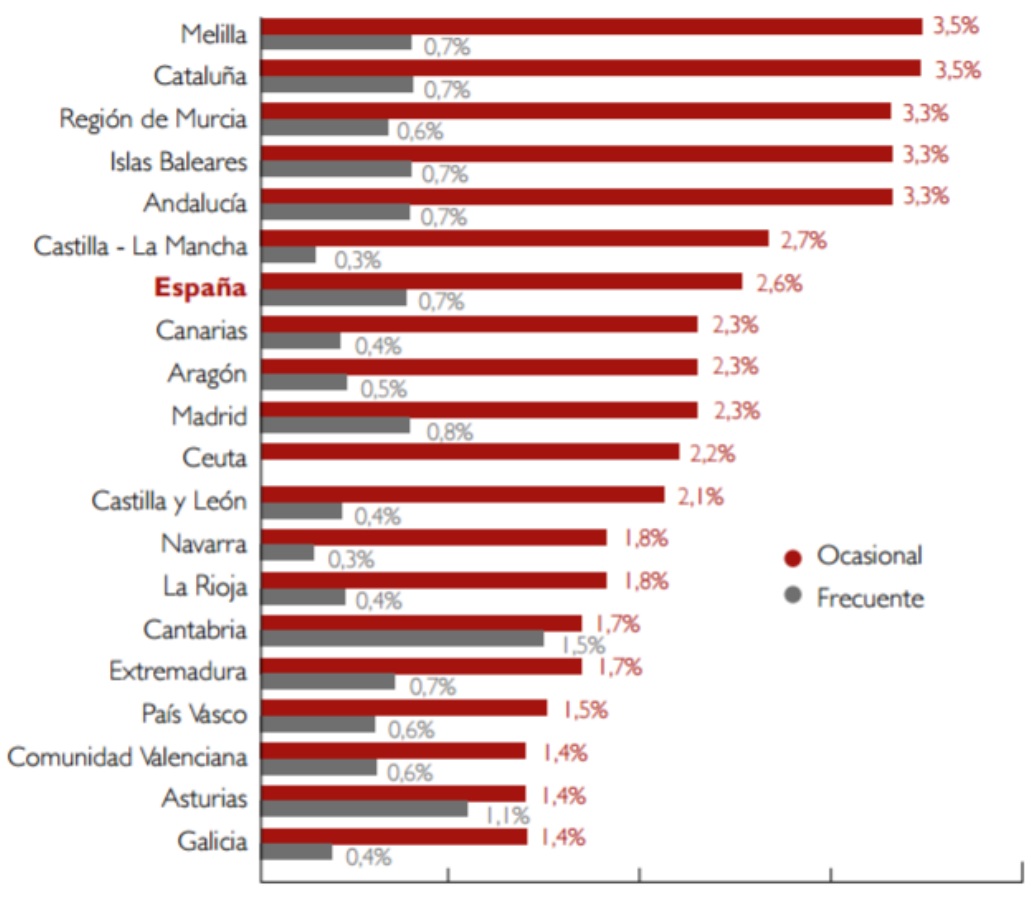

Figura 10. Porcentaje de niños y niñas agresores de acoso y ciberacoso según ciclo educativo. Promedio España (Calmaestra et al., 2016).

Los porcentajes de menores agresores de bullying y ciberbullying según género, como podemos observar en la Figura 11, indican que los chicos presentan un mayor porcentaje que las chicas, con un $6,3 \%$ y $3,5 \%$ de chicos acosadores y ciberacosadores, frente a un $4,5 \%$ y un $3 \%$ en las chicas respectivamente.

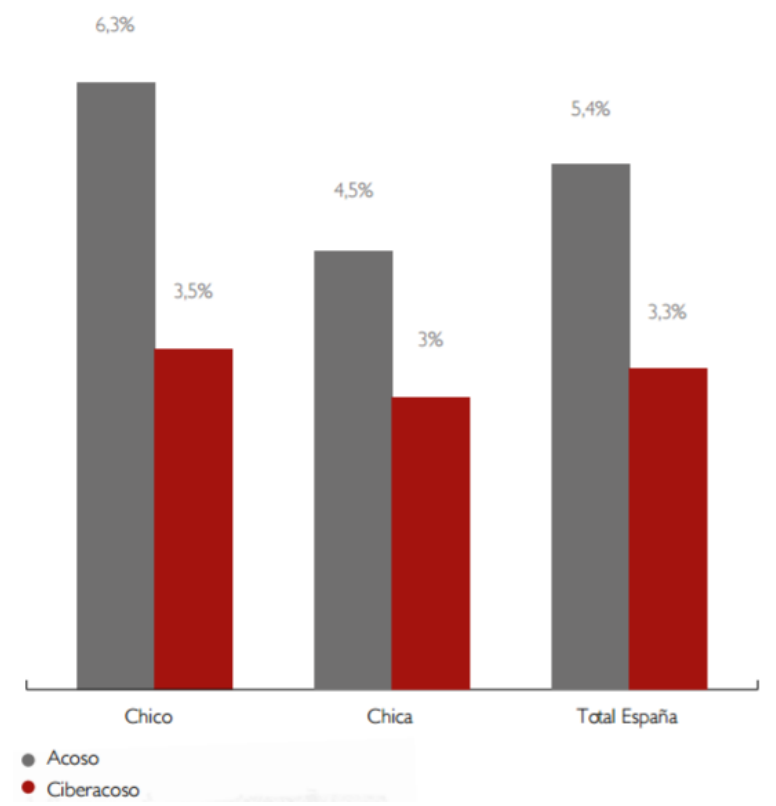

Figura 11. Porcentaje de niños y niñas agresores de acoso y ciberacoso según género. Promedio España (Calmaestra et al., 2016). 
Tipo de ciberagresiones.

Los porcentajes que hacen referencia a los menores que han provocado situaciones de agresión a través del uso de las TIC (ver Figura 12), nos indican que el tipo de agresión más frecuente son los insultos (19'1\%), los insultos indirectos (17'2\%) y las amenazas (6'7\%). Los tipos de ciberagresiones que se han dado con menor frecuencias son el robo de identidad (2\%) y subida de información personal (1'6\%).

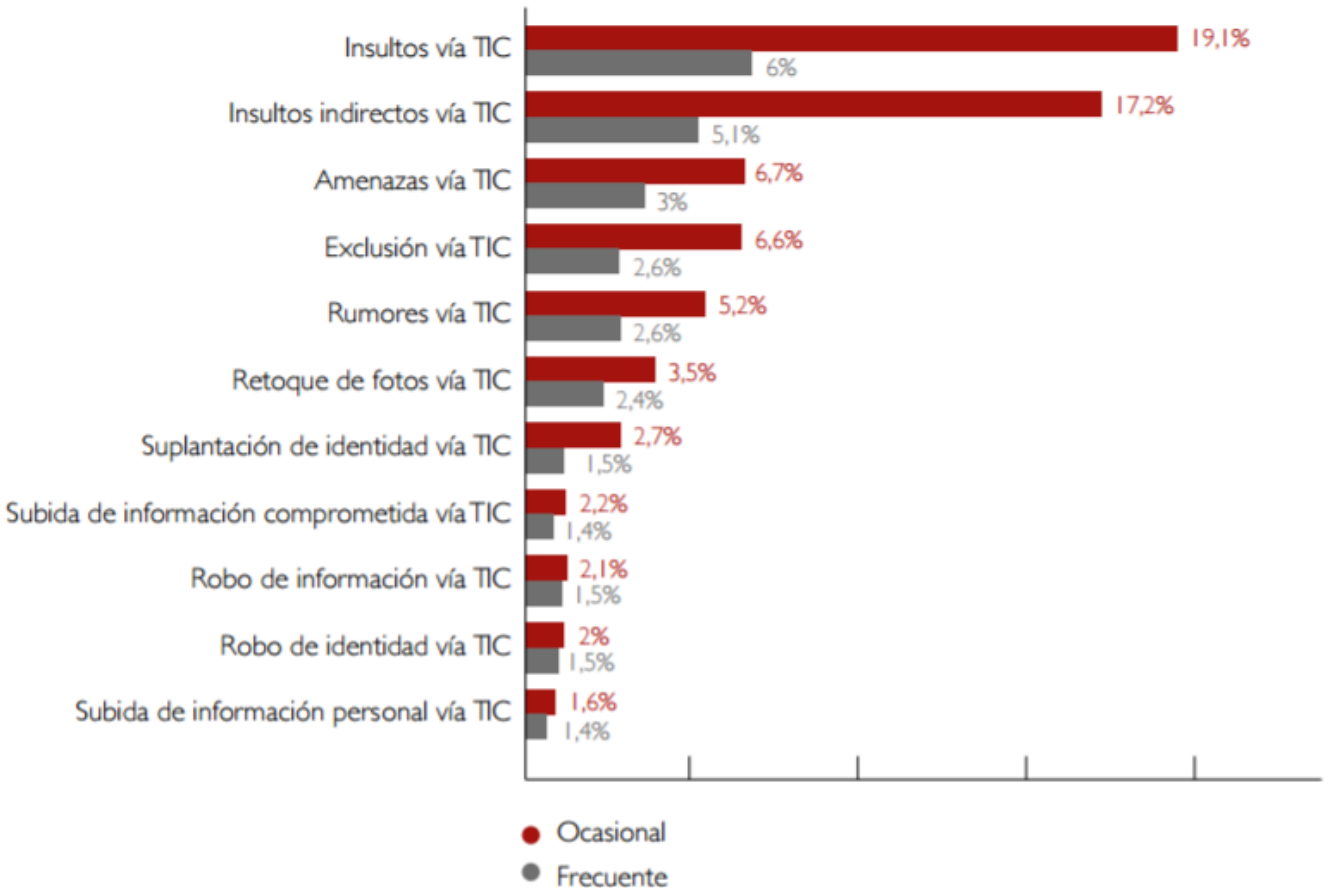

Figura 12.Porcentaje de estudiantes que han provocado de forma ocasional o frecuente situaciones de agresión en internet o con el teléfono móvil en los últimos dos meses. Promedio España (Calmaestra et al., 2016).

C) Los motivos.

Los motivos según las víctimas.

Las razones que están detrás del maltrato no están claramente definidas. Como podemos observar en la Tabla 17, las víctimas repiten principalmente tres razones por las que son acosadas tanto en el acoso como en el ciberbullying: para ser molestadas, por su aspecto físico o porque les tienen "manía". Especialmente destacable es que los niños y niñas que han agredido respondieron mayoritariamente no saber por qué ejercían este tipo de violencia sobre sus compañeros.

Aunque con cifras mucho menores, es de destacar que un 3,2\% de las víctimas de acoso y un $4,2 \%$ de las que han sufrido ciberbullying consideran que han sido víctimas debido a su orientación sexual. Un 5,1\% y un $5 \%$ respectivamente declaran que el motivo fue su color de piel, cultura o religión. 
Tabla 17. Porcentaje de niños y niñas víctimas según motivos y según tipo de victimización. Promedio España (\%) (Calmaestra et al., 2016).

\begin{tabular}{lccc} 
& $\begin{array}{c}\text { Víctima } \\
\text { acoso }\end{array}$ & $\begin{array}{c}\text { Victima } \\
\text { ciberacoso }\end{array}$ & $\begin{array}{c}\text { Víctima } \\
\text { ambos }\end{array}$ \\
\hline Por molestarme & 22.0 & 20.1 & 19.6 \\
\hline Por mis características físicas & 16.7 & 16.2 & 17.5 \\
\hline Porque me tiene manía & 15.2 & 15.0 & 15.5 \\
\hline $\begin{array}{l}\text { Por las cosas que me gustan (cine, música, libros, } \\
\text { juegos) }\end{array}$ & 11.1 & 10.9 & 11.9 \\
\hline No lo sé & 10.1 & 10.2 & 7.7 \\
\hline Para gastarme una broma & 8.7 & 8.2 & 7.8 \\
\hline Para vengarse de mi & 5.3 & 7.0 & 6.9 \\
\hline Por mi color de piel, cultura o religión & 5.1 & 5.0 & 5.3 \\
\hline Por mi orientación sexual & 3.2 & 4.2 & 4.7 \\
\hline Porque le provoqué & 2.9 & 3.0 & 3.1 \\
\hline Total & 100.0 & 100.0 & 100.0 \\
\hline
\end{tabular}

Motivos por los que se ha cometido una agresión.

Los datos que reflejan la Tabla 18 nos muestra como la mayoría de los acosadores reconoce no saber qué motiva su comportamiento, sin embargo, la primera causa más declarada para el ciberbullying es "gastarle una broma".

Los motivos que declaran los ciberagresores como razón de las conductas de ciberbullying se mueven más o menos en el mismo abanico entre chicos y chicas. Entre los chicos gastar una broma, no saberlo bien o molestarle, fueron los más señalados. Entre las chicas, desconocer por qué lo hacían, molestarle o vengarse figuraban entre aquellos más destacados.

Por último, por ciclos educativos de la ESO hay que señalar que la proporción de estudiantes de primer ciclo que desconoce los motivos de su conducta agresiva es sensiblemente más alta que la de los del segundo ciclo.

Tabla 18. Motivos de ciberagresión por género, ciclo educativo y origen y promedio España (\%) (Calmaestra et al., 2016).

\begin{tabular}{lcccc}
\hline & Chico & Chica & 1r Ciclo ESO & 20Ciclo ESO \\
\hline Para gastarle una broma & 13.8 & 9.6 & 12.8 & 11.8 \\
\hline No lo sé & 13.5 & 16.3 & 16.7 & 12.7 \\
\hline Por molestarle & 11.9 & 14.9 & 10.8 & 14.7 \\
\hline Porque me provocó & 10.5 & 8.7 & 8.6 & 10.9 \\
\hline Por sus características físicas & 9.7 & 9.8 & 10.8 & 8.9 \\
\hline Porque le tengo manía & 9.5 & 9.6 & 11.0 & 8.3 \\
\hline Para vengarme de él/ella & 9.4 & 12.1 & 10.1 & 10.5 \\
\hline Por su color de piel, cultura o religión & 7.8 & 7.6 & 7.9 & 7.6 \\
\hline Por las cosas que le gustan (cine, música, libros, juegos) & 7.2 & 5.1 & 5.4 & 7.3 \\
\hline Por su orientación sexual & 6.7 & 6.5 & 5.9 & 7.3 \\
\hline Total & 100.0 & 100.0 & 100.0 & 100.0 \\
\hline
\end{tabular}


D) Las estrategias de afrontamiento de las víctimas.

Principales estrategias de afrontamiento.

A los niños y niñas encuestados también se les preguntó cómo se enfrentaban a estas situaciones y se han identificado cinco estrategias diferentes: pedir ayuda, gestión interna (controlar la situación internamente pensando en otra cosa), reevaluación (ver el abuso desde el humor o de forma positiva), enfrentarlo negativamente (haciendo lo mismo a otros o consumiendo algún tipo de sustancia psicoactiva), y, por último, evitación (apagar el móvil o irse).

En ellas son más las que buscan ayuda o controlan internamente la situación (pensando en otra cosa, en que se va a arreglar...); en ellos priman los que se enfrentan o reevalúan el acoso (viéndolo desde el humor, como una broma...).

Frente al ciberbullying los estudiantes de primer ciclo de ESO usaron como estrategia en mayor medida la gestión interna, mientras que losde segundo ciclo usaron más el enfrentamiento. No fue significativa en ningún grupo de víctimas la estrategia de evitación.

En la Tabla 19, se muestran las estrategias de afrontamiento según el grado de acuerdo de las víctimas de acoso o ciberacoso:

Tabla 19. Las estrategias de afrontamiento según grado de acuerdo de las víctimas de acoso o ciberacoso. (Calmaestra et al. ,2016).

\begin{tabular}{ll} 
& Acuerdo medio \\
\hline 5. Solucionar activamente el problema & 3.16 \\
\hline 23. Parar la situación & 3.14 \\
\hline 8. Pensar diversas soluciones & 3.10 \\
\hline 29. No parar hasta resolver el problema & 3.09 \\
\hline 13. Buscar ayuda de un familiar & 2.94 \\
\hline 25. Compartir con alguien su estado de ánimo & 2.92 \\
\hline 7. Pedir ayuda a un amigo/a & 2.78 \\
\hline 14. Analizar qué ha provocado la situación & 2.78 \\
\hline 15. No pensar en el problema & 2.78 \\
\hline 11. Cambiar el comportamiento de la persona responsable & 2.75 \\
\hline 28. Convencerse que todo mejorará & 2.75 \\
\hline 26. Pensar en alternativas & 2.60 \\
\hline 24. Dar vueltas repetidamente a su estado de ánimo & 2.54 \\
\hline 4. Tratar de ver lo positivo de la situación & 2.54 \\
\hline 21. Concentrarse en sí mismo para no pensar & 2.52 \\
\hline 10. Tener en cuenta otros puntos de vista & 2.52 \\
\hline 27. Olvidar lo ocurrido & 2.38 \\
\hline 22. Entender y perdonar & 2.36 \\
\hline 3. Irse o apagar el móvil, el ordenador & 2.32 \\
\hline 1. Buscar una ayuda profesional & 2.29 \\
\hline 20. Pensar en soluciones pasadas para volverlo a hacer & 2.25 \\
\hline
\end{tabular}


Tabla 19. Las estrategias de afrontamiento según grado de acuerdo de las víctimas de acoso o ciberacoso. (Calmaestra et al. ,2016). (Continuación)

\begin{tabular}{lc}
\hline & Acuerdo medio \\
\hline 19. Guardar sus sentimientos para sí mismo/a & 2.25 \\
\hline 2. Elaborar un plan & 2.20 \\
\hline 9. Dejar de utilizar el teléfono móvil, red social... & 2.16 \\
\hline 16. Tomárselo con humor & 2.15 \\
\hline 30. Acostumbrarse a la situación & 1.87 \\
\hline 18. Dormir más & 1.81 \\
\hline 6. Resignarse & 1.62 \\
\hline 17. Vengarse & 1.55 \\
\hline 12. Consumir sustancias & 1.37 \\
\hline
\end{tabular}

E) Las características de personalidad (autoestima, habilidades sociales y empatía) tanto de la víctima como del agresor.

Las víctimas de acoso mostraron menor autoestima y habilidades comunicativas. Los niños y niñas con conductas de agresión de acoso destacaron en más baja autoestima, menor empatía cognitiva y afectiva, menos asertividad y una más baja capacidad para resolver conflictos (ver Tabla 20).

Tabla 20. Características de la personalidad (autoestima, empatía y habilidades sociales) tanto de la víctima como del agresor (Calmaestra et al., 2016).

\begin{tabular}{lcccc}
\hline & $\begin{array}{c}\text { Víctima } \\
\text { tradicional }\end{array}$ & Cibervíctima & $\begin{array}{c}\text { Agresor } \\
\text { tradicional }\end{array}$ & Ciberagresor \\
\hline Autoestima & $\downarrow$ & $\downarrow$ & $\downarrow$ & $\downarrow$ \\
\hline Empatía cognitiva & $\uparrow$ & $\uparrow$ & $\downarrow$ & $\downarrow$ \\
\hline Empatía afectiva & $\uparrow$ & $\uparrow$ & $\downarrow$ & $\downarrow$ \\
\hline HHSS Comunicativas & $\downarrow$ & $\downarrow$ & $\downarrow$ & $\downarrow$ \\
\hline HHSS Asertividad & $=$ & $\uparrow$ & $\downarrow$ & $\downarrow$ \\
\hline HHSS Resolución de & $=$ & $\uparrow$ & $\downarrow$ & $\downarrow$ \\
Conflictos & & & & \\
\hline
\end{tabular}

Leyenda

$=\quad \uparrow$

Estable, poca influencia

Más alta

Más baja

Para evitar este tipo de conductas resulta determinante reforzar la educación emocional y la adquisición de habilidades sociales y valores de convivencia. Los resultados del estudio nos dicen que el predominio de algunos rasgos de personalidad y la escasez 0 
ausencia de otros son importantes para detectar, prevenir y actuar contra los problemas de violencia a los que nos enfrentamos.

Tanto las víctimas como los que agreden muestran escasa autoestima. Entre los niños y niñas que declaran haber acosado a otro menor de edad, se detecta, además, menor empatía cognitiva y afectiva, menos asertividad y una más baja capacidad para resolver conflictos. No hay diferencias significativas ni por edades ni por sexos.

Los datos obtenidos en este estudio los consideramos de especial relevancia puesto que son datos actuales de 2016 del estado español, y también con datos a nivel autonómico que evidencian la importancia de la problemática que envuelve el ciberbullying, puesto que se trata de un problema real y actual sobre el que hay que actuar.

Así datos como la prevalencia del ciberbullying según ciclo educativo, tipo de ciberagresiones predominantes, motivos de la ciberagresión, como también las principales estrategias de afrontamiento o cómo se ven afectadas las características de personalidad, tanto en la víctima como en el agresor, nos ofrecen datos que nos permiten abordar de un modo más realista la prevención y la intervención en casos de ciberbullying.

\subsubsection{Estadísticas estadounidenses}

Con la finalidad de conocer la situación actual del ciberbullying hemos recurrido también a estudios de otros países, en este caso a un estudio estadounidense puesto que es uno de los países donde más se está estudiando la temática.

En concreto este estudio, realizado por Hinduja \& Patchin (2016b) encuestó una muestra representativa a nivel nacional de 5.700 estudiantes de escuelas intermedias y secundarias entre los 12 y 17 años en los Estados Unidos. Los datos fueron recogidos entre julio y octubre de 2016.

Del estudio analizamos los siguientes aspectos: uso de la tecnología, victimización del ciberbullying, datos por género y la evolución de la cifra de adolescentes que han sido víctimas de ciberbullying en estos últimos años.

A) El uso de tecnología por los adolescentes.

Se desprenden los siguientes resultados (ver Figura 13); los teléfonos móviles y otros dispositivos continúan siendo la tecnología más popular utilizada por los adolescentes, puesto que las cuatro actividades principales que realizan a lo largo de la semana están relacionadas con el uso de las TIC.

De las 21 variables analizadas respecto a las tecnologías más utilizadas semanalmente por los menores de edades comprendidas entre los 12 y los 17 años, los dispositivos más utilizados son los teléfonos móviles, seguidos de las apps y del envío de mensajes.

Facebook sigue siendo una de las redes sociales que utilizan más frecuentemente. Por su parte, Instagram y Snapchat están aumentando en popularidad. 
En el lado opuesto; las salas de chat, Tumblr y Ask.fm siguen siendo poco populares en este grupo de edad.

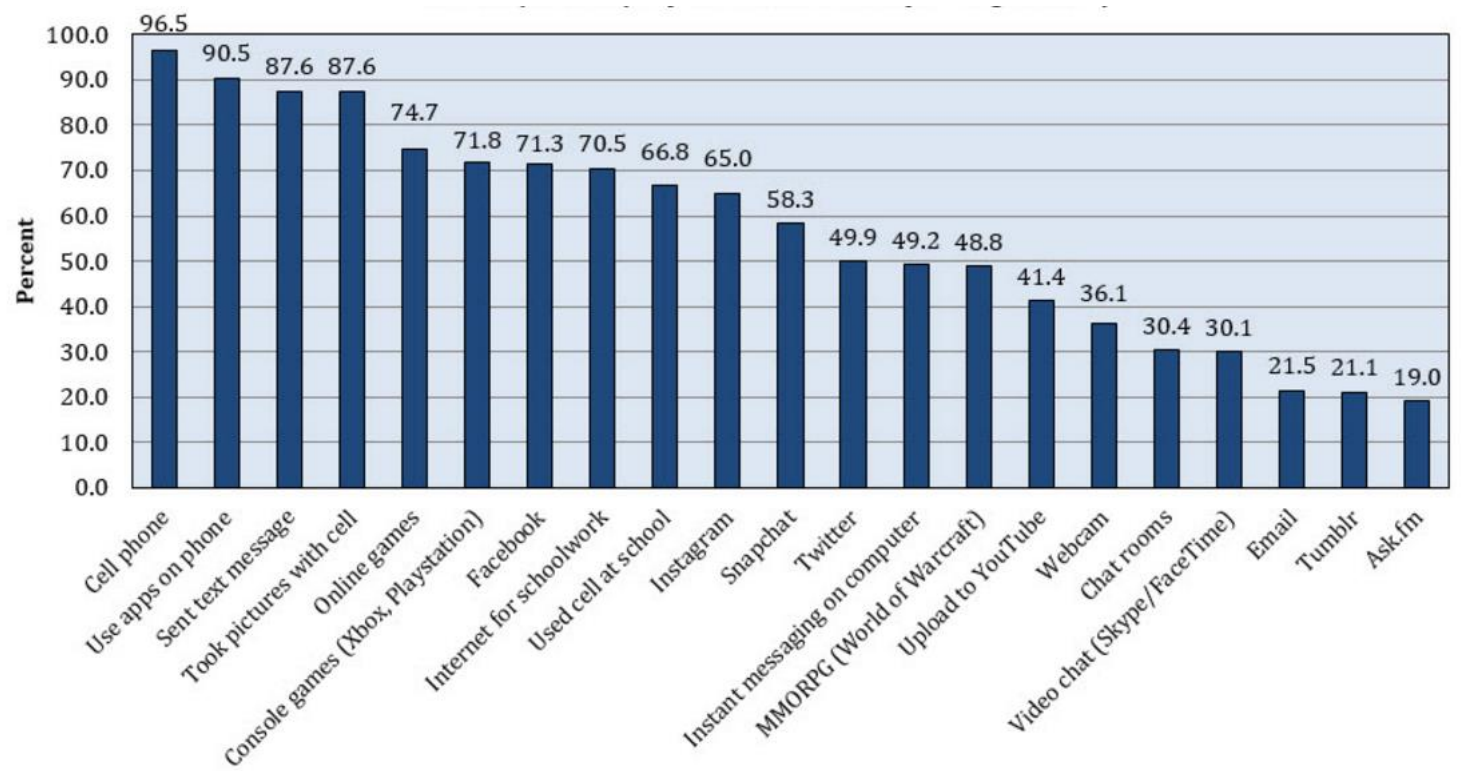

Figura 13.Uso de las tecnologías por parte de los adolescentes (12-17 años). Actividades semanales (Hinduja \& Patchin, 2016b)

B) La victimización del Ciberbullying.

En relación a la victimización los datos (ver Figura 14) indican que aproximadamente el $34 \%$ de los estudiantes de la muestra afirman haber sido víctimas de ciberbullying a lo largo de sus vidas.

Cuando se les preguntó acerca de los tipos específicos de ciberbullying experimentados recientemente se les indicaron once variables.

Entre ellos destacan los datos obtenidos en cuanto al porcentaje de menores que reconocen haber recibido comentarios malos o negativos $(22,5 \%)$ o haber sido víctima de la difusión de rumores online $(20,1 \%)$.

Casi un 26\% de la muestra afirmó haber sido víctima de más de una modalidad de acoso online, con una frecuencia de dos o más veces en los últimos 30 días previos al pase de la encuesta. 


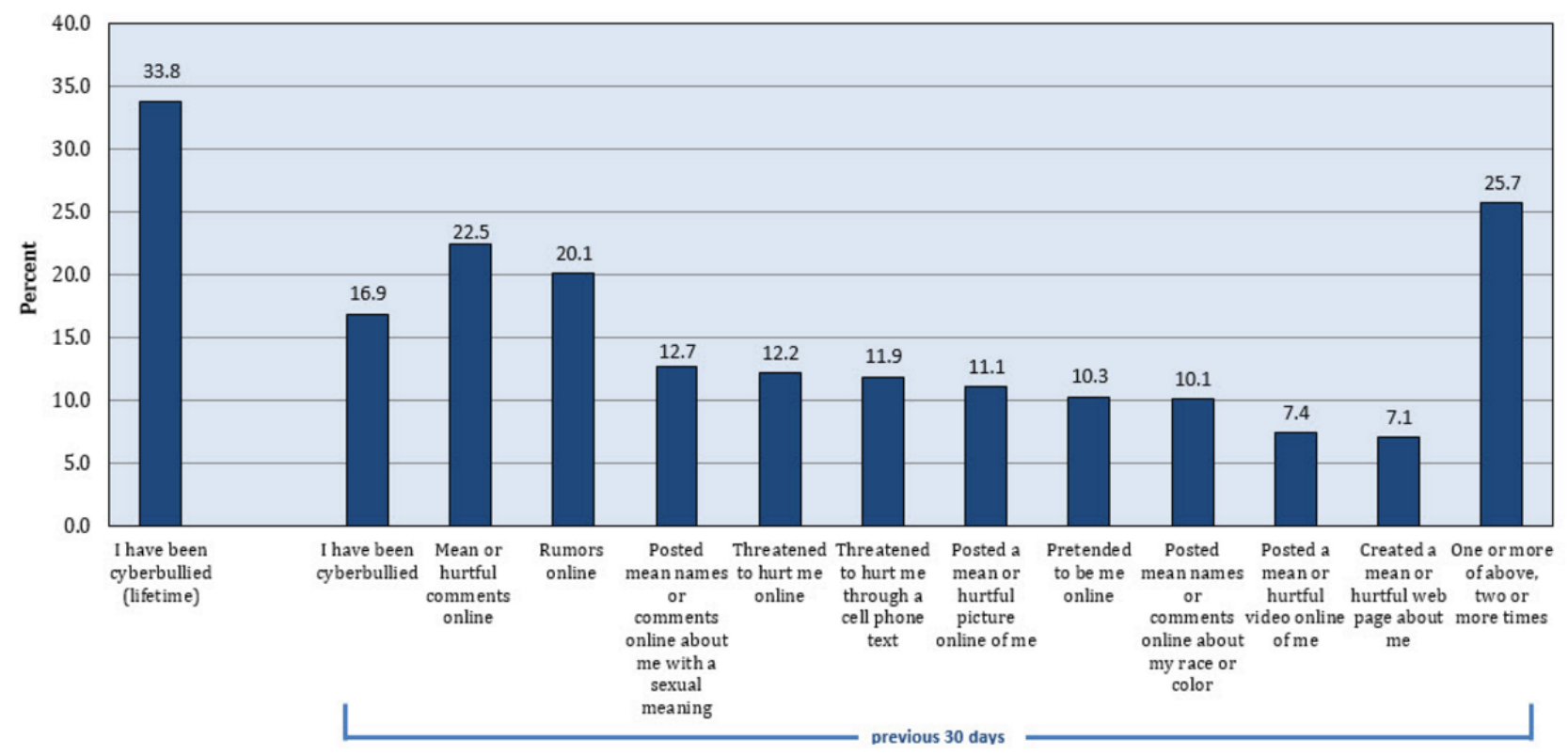

Figura 14.Victimización ciberbullying (Hinduja \& Patchin, 2016a)

\section{C) Ciberbullying por género.}

Los resultados en cuanto a la prevalencia en relación al género (ver Figura 15) indican que las adolescentes son significativamente más propensas a haber experimentado ciberbullying a lo largo de su vida, en concreto un $36^{\prime} 7 \%$ de las chicas frente a un $30^{\prime} 5 \%$ de los chicos.

En el caso de los menores que indican haber sido agresores de ciberbullying a lo largo de su vida, los chicos presentan cifran mayores con un $12^{\prime} 7 \%$ frente a un $10^{\prime} 2 \%$ de las chicas.

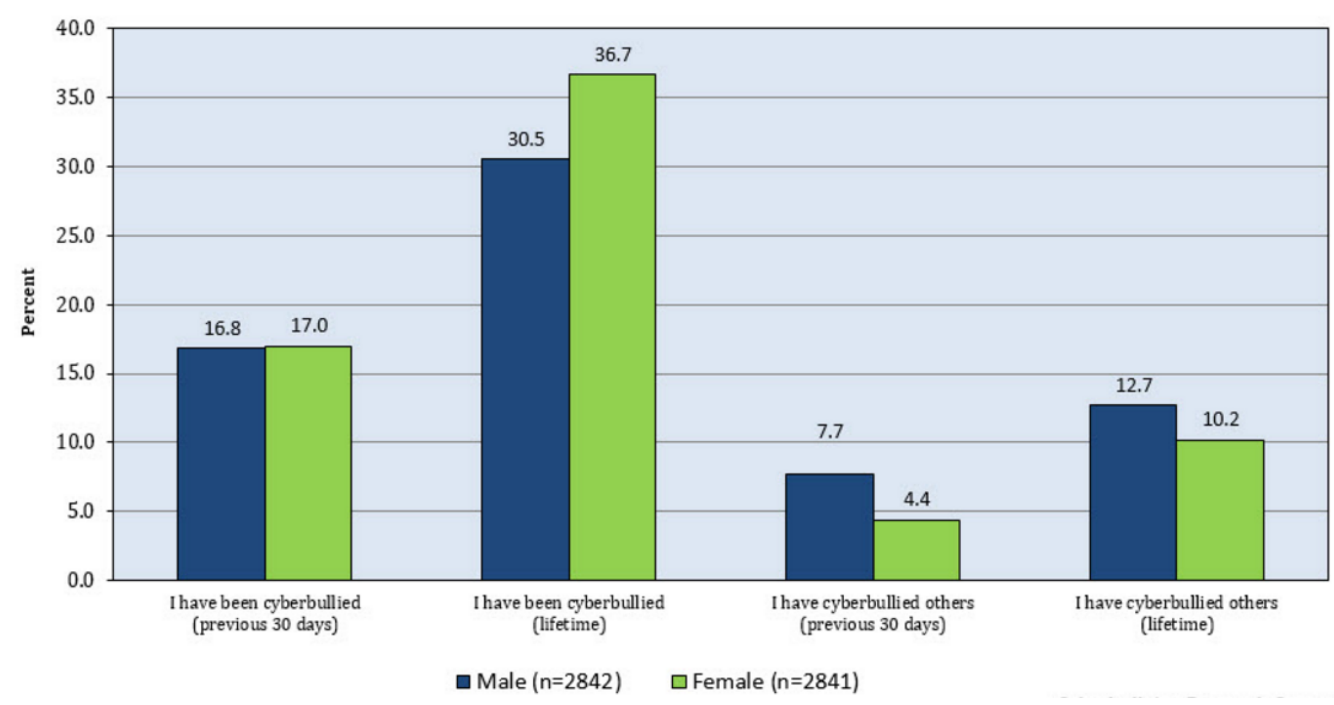

Figura 15.Prevalencia en relación al género (Hinduja \& Patchin, 2016b) 
D) Datos sobre la prevalencia del ciberbullying en los últimos años.

Complementando a este estudio, los mismos autores Hinduja \& Patchin han presentado también en 2016 otro estudio; Summary of Our Cyberbullying Research (Hinduja \& Patchin, 2016c) publicado por Cyberbullying Research Center a partir de los datos de estudiantes de escuelas de educación primaria y secundaria. Sin embargo, los datos que presentan hacen referencia a la evolución de estos diez últimos años.

Así, los primeros resultados presentados muestran el porcentaje de encuestados que han experimentado ciberbullying en algún momento de su vida en los diez estudios más recientes.

Como se ilustra en la Figura 16, las tasas de victimización por ciberbullying han variado a lo largo de estos últimos años que han estudiado el fenómeno. Como dato promedio el estudio revela que un $27^{\prime} 9 \%$ de los estudiantes que han participado en estos 10 últimos estudios han afirmado haber sido víctimas de ciberbullying en algún momento de su vida. Esta cifra ha ido oscilando con los años, no pudiéndose definir con una tendencia que vaya en crecimiento o disminución continua, siendo el 2014 el año que presenta mayor prevalencia con 34'6\%, seguido por el año 2015 con un 34\%.

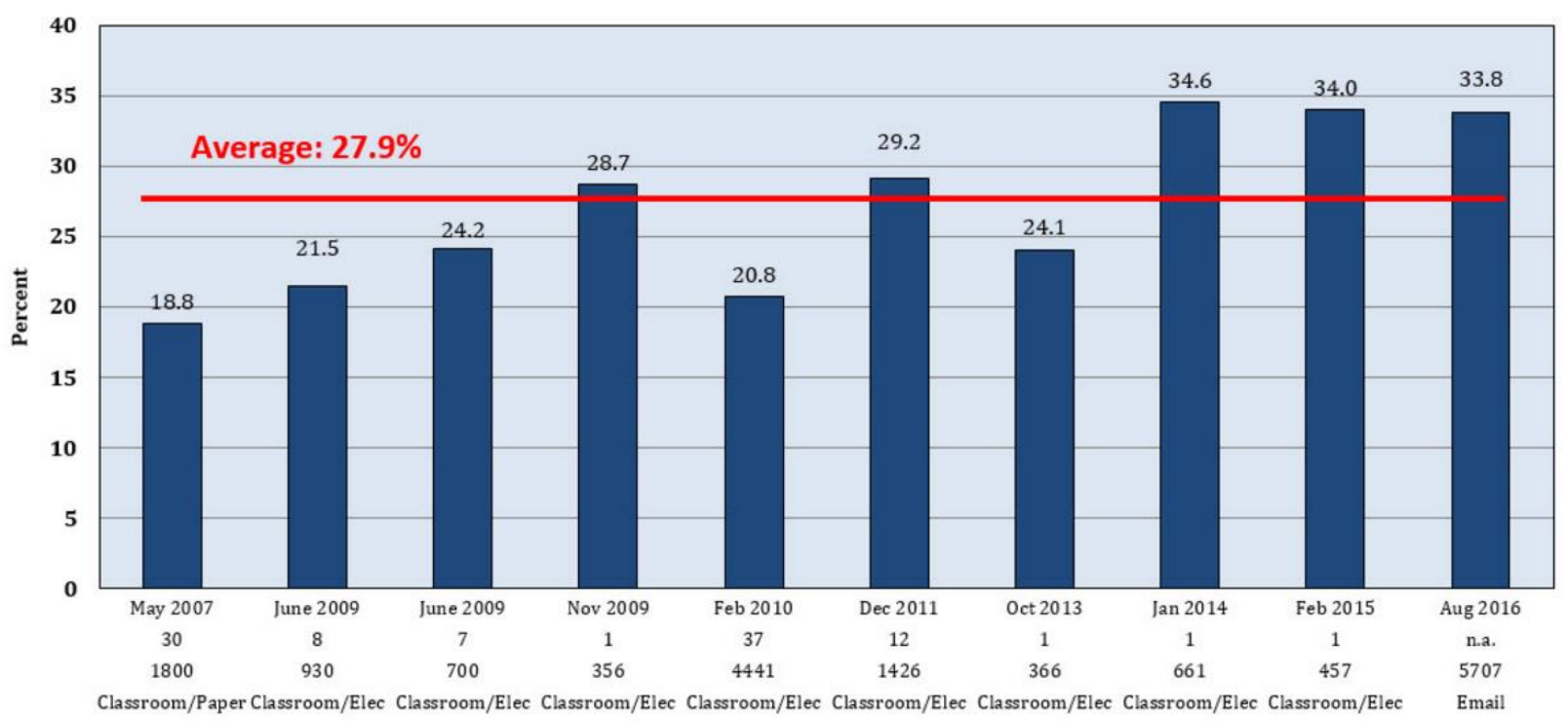

Figura 16.Tasas de victimización por ciberbullying a lo largo de estos últimos años (Hinduja \& Patchin, 2016c)

Respecto a los datos que hacen referencia a los menores que reconocen haber sido agresores de ciberbullying (ver Figura 17), éstos también varían en los últimos años. De promedio, un $15^{\prime} 8 \%$ de los menores que han formado parte de los últimos diez estudios han admitido que haber realizado ciberbullying a otros en algún momento de su vida. Al igual que con la prevalencia de victimización no se aprecia una tendencia clara, sino que varía en función de los años. Así es en 2010 cuando se detecta una mayor prevalencia 
de ciberagresores, en concreto un 19'4\% siendo este último año 2016 uno con los porcentajes más bajos con un $11^{\prime} 5 \%$.

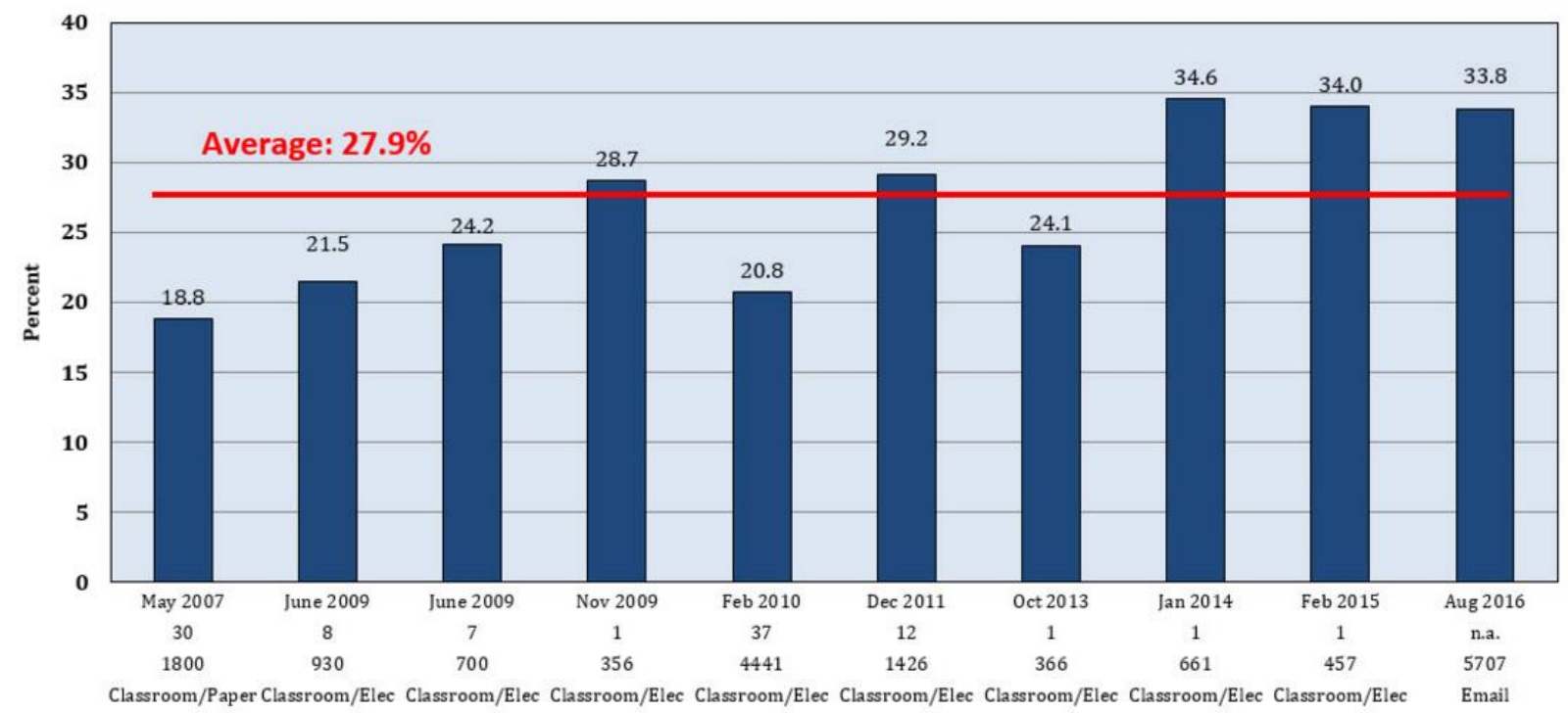

Figura 17. Tasas de victimización por ciberbullying a lo largo de estos últimos años (Hinduja \& Patchin, 2016c)

Ambos estudios nos presentan datos muy interesantes a partir de los cuales podemos obtener mucha información en cuanto a la situación actual del ciberbullying en un país tan importante como Estados Unidos. En concreto este segundo estudio nos ofrece datos muy relevantes puesto que evidencian el aumento de victimización respecto a otros años superando bastante la tasa media. Respecto a los alumnos que admiten haber ofendido a compañeros, los últimos datos muestran un descenso respecto a estudios de años anteriores.

Todo ello nos hace ver que también otros países, en este caso Estados Unidos, muestran un interés en relación a esta problemática, realizando estudios como los que hemos presentado anteriormente. Como sus datos indican, se hace cada vez más necesaria la actuación ante dicho problema puesto que está ascendiendo el número de alumnos que reconocen haber sido víctimas de ciberbullying en algún momento de sus vidas siendo el móvil el dispositivo más utilizado para este tipo de prácticas, dispositivos que cada vez se adquieren a edades más tempranas.

\subsubsection{Teseo}

Otra de las fuentes documentales que consideramos necesario revisar, son las tesis doctorales relacionadas con el ciberbullying que han sido realizadas en España. Para ello hemos recurrido a Teseo, base de datos del Ministerio de Educación donde se recogen las Tesis Doctorales realizadas en universidades españolas desde 1976. 
Hemos realizado una búsqueda en dicha base de datos. Para ello hemos utilizado diferentes términos como son ciberacoso, cyberbullying y ciberbullying. En total son diez las tesis encontradas relacionadas con esta temática, publicadas todas ellas entre el año 2011 y el 2016, es decir, en los últimos seis años (ver Tabla 21).

Las dos primeras tesis constan del año 2011. En 2012 y 2103 sólo encontramos una publicación. En cambio, en los siguientes años; 2014, 2015 y 2016, son dos las tesis publicadas. Estos datos nos dejan ver que la cifra de tesis de esta temática es baja, debido a la actualidad de la temática, y no ha variado mucho el número de publicaciones a lo largo de los años.

Las tesis están escritas mayoritariamente desde el ámbito educativo o psicológico, centrándose en diferentes etapas educativas, destacando la adolescencia. Predominan los estudios centrados en la investigación de la prevalencia en diferentes contextos.

En cuanto a las universidades que han llevado a cabo estas tesis doctorales; cinco de ellas son de Andalucía (dos de Córdoba), dos de Murcia, dos del País Vasco y la otra de la Universidad Nacional de Educación a Distancia. Por tanto, vemos que predominan las Universidades andaluzas en cuanto a publicaciones de tesis sobre ciberbullying.

En la dirección de estas tesis, destacan dos investigadoras. Maite Garaigordóbil, ha dirigido dos tesis; una en 2014 y otra en 2016, ambos trabajos se centran en la etapa de la adolescencia y han sido dirigidos sólo por dicha investigadora. Actualmente Garaigordóbil dirige el grupo de investigación Evaluación Psicológica: Diseño de instrumentos, evaluación de programas de intervención y aplicaciones epidemiológicas, financiado por el Gobierno Vasco y ha recibido el primer Premio Nacional de Investigación Educativa en 1994 y 2003, concedido por el Ministerio de Educación.

La otra investigadora que destaca en este campo es Rosario Ortega, que ha dirigido también dos tesis en 2011 y 2013, en este caso junto con otros directores; Joaquín Antonio Mora y Eva María Romera. Ortega es investigadora principal del Laboratorio de Estudios sobre Convivencia y Prevención de la Violencia (LAECOVI) cuya sede es la Universidad de Córdoba.

En cuanto al número de directores que han dirigido cada una de las tesis, vemos que predominan las que han sido dirigidas por más de un investigador. En concreto, de las diez publicadas sobre la temática del ciberbullying; dos tesis han sido dirigidas por tres directores, otras cinco han sido dirigidas por dos directores, y tres de ellas por un solo director.

El análisis de las tesis publicadas hasta el momento nos indica que el fenómeno del ciberbullying se está investigando en las universidades españolas prácticamente desde sus inicios, y aunque no son muchas las tesis publicadas al respecto, sí existen grupos investigadores relevantes sobre la temática. 
Tabla 21. Tesis Doctorales relacionadas con el Ciberbullying publicadas en España

\begin{tabular}{|c|c|c|c|c|}
\hline Título & Año & Autor & Universidad & Directores \\
\hline $\begin{array}{l}\text { Ciberbullying, una nueva } \\
\text { forma de acoso escolar. }\end{array}$ & 2016 & $\begin{array}{l}\text { Gema Álvarez } \\
\text { Idarraga }\end{array}$ & $\begin{array}{l}\text { Universidad } \\
\text { Nacional de } \\
\text { Educación a } \\
\text { Distancia }\end{array}$ & $\begin{array}{l}\text { Consuelo Del Val } \\
\text { Cid } \\
\text { Carmen Alemán } \\
\text { Bracho }\end{array}$ \\
\hline $\begin{array}{l}\text { Bullying y cyberbullying: } \\
\text { prevalencia en adolescentes y } \\
\text { jóvenes de Cantabria. }\end{array}$ & 2016 & $\begin{array}{l}\text { Mạ Aida } \\
\text { Fernández Tomé }\end{array}$ & $\begin{array}{l}\text { Universidad del } \\
\text { País Vasco }\end{array}$ & $\begin{array}{l}\text { Maite Garaigordóbil } \\
\text { Landazábal }\end{array}$ \\
\hline $\begin{array}{l}\text { Análisis del ciberacoso en las } \\
\text { relaciones entre adolescentes } \\
\text { y su reflejo en los medios. }\end{array}$ & 2015 & $\begin{array}{l}\text { María del Carmen } \\
\text { Rodríguez } \\
\text { Domínguez }\end{array}$ & $\begin{array}{l}\text { Universidad de } \\
\text { Sevilla }\end{array}$ & $\begin{array}{l}\text { María Mercedes } \\
\text { Durán Segura } \\
\text { Roberto Martínez } \\
\text { Pecino } \\
\end{array}$ \\
\hline $\begin{array}{l}\text { Cyberbullying. Análisis de su } \\
\text { incidencia entre estudiantes y } \\
\text { percepciones del profesorado. }\end{array}$ & 2015 & $\begin{array}{l}\text { Ana María } \\
\text { Giménez Gualdo }\end{array}$ & $\begin{array}{l}\text { Universidad de } \\
\text { Murcia }\end{array}$ & $\begin{array}{l}\text { Javier J. Maquilón } \\
\text { Sánchez } \\
\text { Pilar Arnaiz Sánchez }\end{array}$ \\
\hline $\begin{array}{l}\text { Intervención en ciberbullying: } \\
\text { diseño y evaluación de un } \\
\text { programa para adolescentes. }\end{array}$ & 2014 & $\begin{array}{l}\text { Vanesa Martínez } \\
\text { Valderrey }\end{array}$ & $\begin{array}{l}\text { Universidad del } \\
\text { País Vasco }\end{array}$ & $\begin{array}{l}\text { Maite Garaigordóbil } \\
\text { Landazábal }\end{array}$ \\
\hline $\begin{array}{l}\text { Victimización de menores por } \\
\text { actos de ciberacoso } \\
\text { continuado y actividades } \\
\text { cotidianas en el ciberespacio. }\end{array}$ & 2014 & $\begin{array}{l}\text { Natalia García } \\
\text { Guilabert }\end{array}$ & $\begin{array}{l}\text { Universidad de } \\
\text { Murcia }\end{array}$ & $\begin{array}{l}\text { Fernando Miro } \\
\text { LLinares }\end{array}$ \\
\hline $\begin{array}{l}\text { Acoso y ciberacoso en } \\
\text { escolares de primaria: factores } \\
\text { de personalidad y de contexto } \\
\text { entre iguales. }\end{array}$ & 2013 & $\begin{array}{l}\text { Cristina María } \\
\text { García Fernández }\end{array}$ & $\begin{array}{l}\text { Universidad de } \\
\text { Córdoba }\end{array}$ & $\begin{array}{l}\text { Eva María Romera } \\
\text { Félix } \\
\text { Rosario Ortega Ruiz }\end{array}$ \\
\hline $\begin{array}{l}\text { Violencia, victimización y } \\
\text { cyberbullying en adolescentes } \\
\text { escolarizados/as: una } \\
\text { perspectiva desde el trabajo } \\
\text { social. }\end{array}$ & 2012 & $\begin{array}{l}\text { Rosa María } \\
\text { Varela Garay }\end{array}$ & $\begin{array}{c}\text { Universidad } \\
\text { Pablo de Olavide }\end{array}$ & $\begin{array}{l}\text { Gonzalo Musitu } \\
\text { Ochoa } \\
\text { Francisco Palmero } \\
\text { Cantero } \\
\text { Nuria Cordero } \\
\text { Ramos }\end{array}$ \\
\hline $\begin{array}{l}\text { Cyberbullying: prevalencia y } \\
\text { características de un nuevo } \\
\text { tipo de bullying indirecto. }\end{array}$ & 2011 & $\begin{array}{l}\text { Juan Calmaestra } \\
\text { Villen }\end{array}$ & $\begin{array}{l}\text { Universidad de } \\
\text { Córdoba }\end{array}$ & $\begin{array}{l}\text { Joaquín Antonio } \\
\text { Mora Merchán } \\
\text { Rosario Ortega Ruiz }\end{array}$ \\
\hline $\begin{array}{l}\text { Incidencia e impacto do } \\
\text { cyberbullying nos alumnos do } \\
\text { terceiro ciclo do ensino } \\
\text { publico portugués. }\end{array}$ & 2011 & $\begin{array}{l}\text { Pedro Miguel } \\
\text { Barros Ventura }\end{array}$ & $\begin{array}{l}\text { Universidad de } \\
\text { Granada }\end{array}$ & $\begin{array}{l}\text { Tomás Sola } \\
\text { Martínez } \\
\text { Joao Amado } \\
\text { Antonio Jesús } \\
\text { Moreno Ortiz } \\
\end{array}$ \\
\hline
\end{tabular}

\subsubsection{Bases de datos de revistas}

Otra de las fuentes documentales primarias que se han revisado han sido las revistas científicas. Un reflejo real de las investigaciones que se realizan sobre la temática del ciberbullying en los diferentes países nos la muestran las bases de datos que nos dan acceso a las revistas que realizan publicaciones sobre estas investigaciones que se llevan a cabo. 
Para ello hemos recurrido a tres prestigiosas bases de datos como son ERIC, PSYCNET y DIALNET.

ERIC y PSYCNET son bases de datos a nivel internacional especializadas en Educación, la primera y en Psicología la segunda. DIALNET, es una base de datos de producción hispana especializada en ciencias humanas y sociales.

En la Tabla 22 vemos reflejado los datos recogidos en cada una de las bases de datos. En total se han analizado 481 artículos de revista, que han sido publicados desde 2006 y 2016. Se escoge este rango de años con la finalidad de regoger los estudios más recientes sobre la temática, y se observa que además es en 2006 cuando empiezan a publicarse los primeros estudios sobre ciberbullying

Tabla 22. Datos recogidos en cada una de las bases de datos

\begin{tabular}{ccc}
\hline Base de datos & Número de publicaciones analizadas & Año de publicación \\
\hline ERIC & 142 & $2006-2016$ \\
\hline PSYCNET & 199 & $2006-2016$ \\
\hline DIALNET & 70 & $2006-2016$ \\
\hline
\end{tabular}

Los campos de estudio analizados en estas publicaciones han sido; el año de publicación, el autor o autores del artículo, la revista que lo publica, el país de procedencia de la institución en la que se lleva a cabo el estudio, la clasificación de estos según su naturaleza en empíricos o teóricos, y por último las palabras claves que se detallan en cada uno de ellos.

\subsubsection{Eric}

Para la realización del análisis de artículos relacionados con el ciberbullying de ámbito internacional hemos utilizado la base de datos ERIC (Educational Resources Information Center), es patrocinada por el Departamento de Educación de Estados Unidos y es la principal fuente de información bibliográfica referencial en ciencias de la educación. Está conformada por dos fuentes: CurrentIndex to Journals in Education (CIJE) y Resources in Education (RIE), ambos cubren más de 14.000 documentos e indexan sobre 20.000 artículos de revistas por año.

En la realización de la búsqueda de artículos sobre ciberbullying en la base de datos ERIC, se ha utilizado como palabra clave el término "cyberbullying", en inglés, puesto que se trata de una base de datos cuyo idioma utilizado es el inglés.

En la búsqueda a partir de este término, acotando las fechas de publicación entre 2006 y 2016, se filtraron un total de 342 artículos. Según los datos que se ofrecen en su página web, la mayoría de estos artículos han sido publicados en los últimos 5 años, contando con un total de 220 publicaciones desde 2012. Este dato nos indica el aumento de 
publicaciones de esta temática en estos últimos años, ya que además 65 de estos artículos son del 2015 y 21 de ellos del 2016.

Del total de 342 artículos encontrados, no todos ellos han sido analizados en el presente análisis puesto que no todos tenían un acceso abierto, algunos tampoco a su abstract y otros aportaban información insuficiente o que no se adaptaba a los campos de estudio requeridos para el presente análisis. Por todo ello, finalmente han sido analizados un total de 142 artículos que sí presentaban y tenían acceso abierto a la información que se requería.

A) Número de publicaciones por año

Los resultados obtenidos nos indican que se ha producido un aumento progresivo de publicaciones del 2006 al 2012, siendo el 2012 el año en el que más artículos sobre ciberbullying se publicaron, un total de 35. En el 2013 y 2014 vuelve a descender el número de publicaciones progresivamente, ascendiendo en 2015 a 25 y volviendo a descender en 2016 a 13 (ver Figura 18).

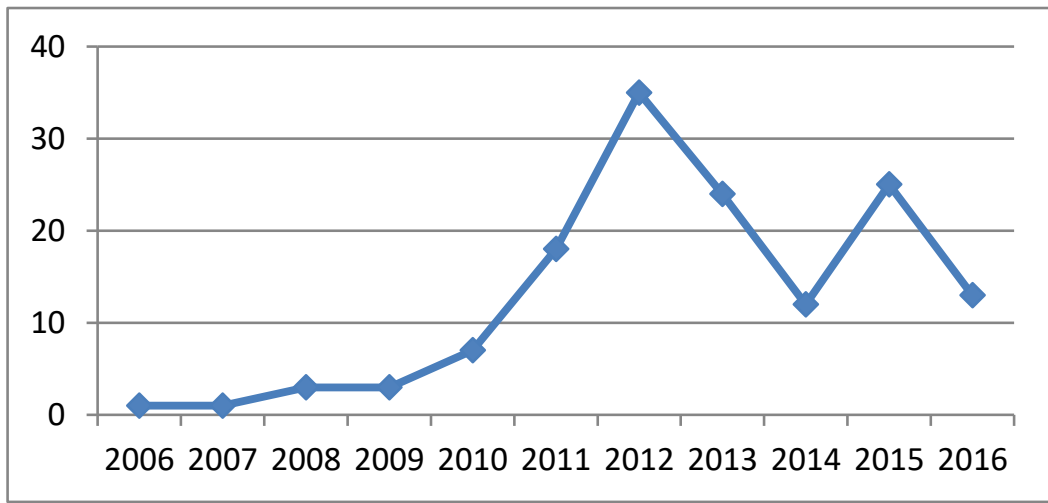

Figura 18. Número de artículos por año (Base de datos ERIC)

B) Número de artículos por años y por país de procedencia de la institución que realiza el estudio.

Cabe destacar que se han publicado artículos relacionados con el ciberbullying en un total de 28 países (ver Tabla 23), algunos de los artículos han sido realizados por instituciones de varios países. El país en el que más artículos se han publicado en estos últimos años, partiendo de los artículos utilizados para este estudio, ha sido EE.UU. con un total de 47 artículos, seguido de Canadá, Australia, Turquía y Reino Unido, en ese orden.

En cuanto a los datos por años, se puede indicar que el dato más destacado es la diferencia de procedencia de los países de publicación, siendo en el 2011 y 2014 un 50\% de los artículos de EE.UU. El resto de los años se caracterizan por una distribución poco uniforme en cuanto a los países de publicación siendo entre ellos muy variados. En 2008 
destacan las publicaciones provenientes de Canadá; en 2009, 2010, 2012, 2013, 2014 y 2015 las provenientes de EE. UU y en 2016 de Bélgica.

Si nos centramos en los datos obtenidos en España, podemos añadir que sólo se han analizado tres publicaciones, dos de ellas de 2015 y otra de 2013.

Analizando los datos por continentes vemos que Europa es el que cuenta con más publicaciones, 62 concretamente, seguido de América con 59 publicaciones. En el resto de continentes el dato de publicaciones es muy bajo o de cero.

Por tanto, respecto a estos datos podemos concluir que el ciberbullying es un tema estudiando en puntos muy diferentes de nuestro planeta, es decir, que preocupa a las diferentes sociedades, aunque destaca en cuanto a publicaciones EE.UU.

Tabla 23. № de artículos por años y país de procedencia de la institución que realiza el estudio(Base de datos $E R I C)$

\begin{tabular}{|c|c|c|c|c|c|c|c|c|c|c|c|c|c|c|c|c|c|c|c|c|c|c|c|c|c|c|c|c|}
\hline \multirow[b]{2}{*}{ Año } & \multicolumn{28}{|c|}{ Países } \\
\hline & 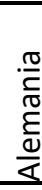 & $\begin{array}{l}\frac{.0}{\bar{T}} \\
\frac{0}{2} \\
\frac{n}{2} \\
\frac{1}{4}\end{array}$ & 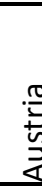 & 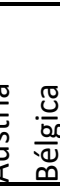 & 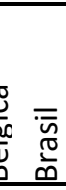 & $\begin{array}{r}\frac{\pi}{0} \\
\frac{\pi}{0} \\
\frac{1}{\pi} \\
\end{array}$ & 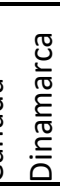 & $\underset{\mathrm{U}}{\supset}$ & 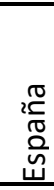 & 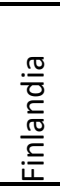 & $\begin{array}{l}\frac{\pi}{00} \\
\overline{0} \\
\mathbb{8} \\
0\end{array}$ & $\begin{array}{l}\frac{\pi}{U} \\
\frac{U}{0} \\
\end{array}$ & $\stackrel{\widetilde{0}}{\underline{0}}$ & 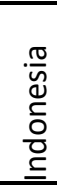 & $\begin{array}{l}\frac{\pi}{0} \\
\frac{1}{0} \\
\underline{\underline{T}} \\
\end{array}$ & $\begin{array}{l}\bar{\Phi} \\
\underline{\tilde{\omega}} \\
\underline{\underline{\omega}}\end{array}$ & $\stackrel{.00}{ \pm}$ & $\frac{\frac{\pi}{N}}{\frac{\pi}{\pi}}$ & 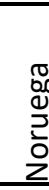 & 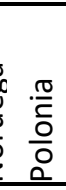 & 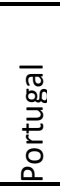 & 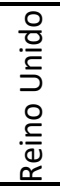 & 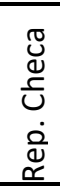 & $\frac{\pi}{0 .}$ & 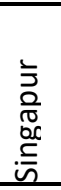 & 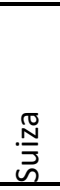 & $\stackrel{\frac{c}{\pi}}{\frac{\sqrt{\pi}}{\pi}}$ & $\begin{array}{l}\frac{\pi}{J} \\
\frac{0}{J} \\
\frac{1}{5}\end{array}$ \\
\hline 2016 & & 2 & & 3 & 1 & & & 1 & & & & & & 1 & & 1 & & & & & 1 & 1 & & & & & & 2 \\
\hline 2015 & 1 & 3 & 1 & & & 2 & & 6 & 2 & & & & 1 & & 1 & 3 & 1 & & 1 & 1 & & 2 & 1 & & & & & 2 \\
\hline 2014 & & 3 & & & & 1 & & 6 & & & & & & & 1 & & & & & & & 2 & & & & & & \\
\hline 2013 & 2 & 2 & & & & 4 & & $\begin{array}{l}1 \\
0\end{array}$ & 1 & 2 & & 1 & & & & 1 & & & & & & 1 & & & & 1 & 2 & \\
\hline 2012 & 3 & 4 & & & & 4 & 1 & 8 & & & 1 & & & & 1 & 1 & 1 & & & 1 & & 5 & 1 & & & 1 & & 5 \\
\hline 2011 & & 1 & & 1 & & 2 & & 9 & & & & & & & 1 & & & 1 & & & & & & 1 & 1 & & & 3 \\
\hline 2010 & & & & & & & & 3 & & & & & & & & & & & & & & 1 & & & 1 & & & 2 \\
\hline 2009 & & & & & & 1 & & 2 & & & & & & & & & & & & & & & & & & & & \\
\hline 2008 & & & & & & 2 & & 1 & & & & & & & & & & & & & & & & & & & & \\
\hline 2007 & & & & & & & & 1 & & & & & & & & & & & & & & & & & & & & \\
\hline 2006 & & & & & & 1 & & & & & & & & & & & & & & & & & & & & & & \\
\hline Total & 6 & $\begin{array}{l}1 \\
5 \\
\end{array}$ & 1 & 4 & 1 & $\begin{array}{l}1 \\
7 \\
\end{array}$ & 1 & $\begin{array}{l}4 \\
7 \\
\end{array}$ & 3 & 2 & 1 & 1 & 1 & 1 & 4 & 6 & 2 & 1 & 1 & 2 & 1 & $\begin{array}{l}1 \\
2 \\
\end{array}$ & 2 & 1 & 2 & 2 & 2 & $\begin{array}{l}1 \\
4 \\
\end{array}$ \\
\hline
\end{tabular}

\section{C) Autores}

Hemos realizado un análisis para comprobar si hay una continuidad en cuanto a la publicación de artículos relacionados con el ciberbullying (ver Tabla 24). En relación a esto, se ha podido detectar que hay algunos autores que han publicado más de una vez en estos años, no siendo más de 6 las publicaciones que han hecho con temática ciberbullying. 
En concreto Marilyn Campbell ha sido la autora que más artículos ha escrito, un total de seis artículos, todos ellos escritos junto a otros autores.

También autores como Wanda Cassidy, Barbara Spears o Margaret Jackson cuentan con un total de cuatro artículos escritos, también junto a otros autores.

A continuación, en cuanto a número de artículos escritos, encontramos a autores como Peter Smith, quien publica entre 2012 y 2015 cuatro artículos tanto individualmente como con otros autores, o Des Butter también con cuatro artículos publicados.

Otro de los autores que destaca es Li Qing, puesto que publica en solitario un total de tres publicaciones entre 2006 y 2008.

Por último, nombrar a los autores Hinduja y Patchin que ambos dos han publicado también entre 2007 y 2013 un total de cuatro artículos.

Toda esta información deja ver que hay una continuidad en cuanto a la publicación de artículos de ciberbullying en muy pocos autores, y que son muchos los que escriben sobre la temática una sola vez.

Tabla 24. № de autores que publican sobre Ciberbullying (Base de datos ERIC)

\begin{tabular}{cccccccccccc}
\hline Año & 2006 & 2007 & 2008 & 2009 & 2010 & 2011 & 2012 & 2013 & 2014 & 2015 & 2016 \\
\hline Autores & 1 & 2 & 2 & 8 & 14 & 45 & 95 & 70 & 31 & 82 & 36 \\
\hline
\end{tabular}

Otro aspecto a estudiar en cuanto a los autores de las publicaciones es el número de autores que participan en una misma publicación (ver Tabla 25), y en el caso de la temática del ciberbullying la prevalencia es clara, puesto que más del $80 \%$ las publicaciones han sido realizadas por un equipo de dos o más autores que investigan juntos, llegando hasta un máximo de 13 autores en un mismo artículo.

Tabla 25. № de autores que participan en una misma publicación (Base de datos ERIC)

\begin{tabular}{cc}
\hline No autores & No artículos \\
\hline 1 & 25 \\
\hline 2 & 47 \\
\hline 3 & 40 \\
\hline 4 & 9 \\
\hline 5 & 13 \\
\hline 6 & 5 \\
\hline 7 & 2 \\
\hline 13 & 1 \\
\hline
\end{tabular}


Entre ellos podemos destacar equipos de dos como los formados por; Hinduja y Patchin, y Pabian y Vandebosch. En los grupos formados por tres autores podemos destacar a Cassidy, Brown y Jackson; Eden, Heiman y Olenik-Shemesh; y Paul, Smith y Blumberg.

D) Procedencia de las publicaciones

En este apartado analizaremos las revistas en las que se han publicado dichos artículos (ver Tabla 26). La revista que más publicaciones a nivel internacional recoge, con diferencia a las demás, es School Psychology International con un total de 16 publicaciones. Le siguen otras como Journal of School Violence (9), Emotional \& Behavioural Difficulties (9) y Pastoral Care in Education (8). Además, 18 revistas más cuentan con más de una publicación en este rango de años, y otras 45 con sólo una publicación.

School Psychology International destaca por sus publicaciones relacionadas con aquellos aspectos que proveen servicios de calidad en salud mental, educativa, terapéuticos y de apoyo a las escuelas y sus comunidades en todo el mundo. Ofrece artículos que reflejan la investigación académica de alta calidad en el campo, así como ejemplos de mejores prácticas probadas.

Por su parte, Emotional \& Behavioural Difficulties (EBDs) tiene como objetivo principal contribuir a la comprensión de los lectores de las dificultades sociales, emocionales y de comportamiento, así como su conocimiento de las formas apropiadas de prevenir y responder a los EBDs en términos de intervención y política.

Otra de las revistas, Journal of School Violence se define como internacional y multidisciplinaria y se centra en la publicación de estudios empíricos relacionados con la violencia escolar y la victimización. Explora una amplia gama de temas contemporáneos centrados en la violencia en el entorno escolar, cuestiones a menudo incluyen; la naturaleza, extensión, prevención y consecuencias de la violencia escolar para estudiantes, maestros y personal de todo tipo de sistemas educativos.

Por último, destacamos Pastoral Care in Education, revista internacional de desarrollo personal, social y emocional dirigida a todos los profesores, profesionales, investigadores y académicos. La revista aborda importantes temas contemporáneos como; aspectos actuales de desarrollo curricular (ciudadanía, salud, educación social y moral); manejo del comportamiento; enfoques escolares; estructuras escolares; así como también temas como la exclusión escolar, intimidación y desarrollo emocional. 
Tabla 26. Revistas en las que se han publicado artículos relacionados con Ciberbullying (Base de datos ERIC)

\begin{tabular}{lc}
\hline \multicolumn{1}{c}{ Publicación } & $\begin{array}{c}\text { No } \\
\text { artículos }\end{array}$ \\
\hline SchoolPsychology International & 16 \\
\hline Emotional\&BehaviouralDifficulties & 9 \\
\hline Journal of SchoolViolence & 9 \\
\hline Pastoral Care in Education & 8 \\
\hline Journal of Youth and Adolescence & 5 \\
\hline PreventingSchoolFailure & 5 \\
\hline Psychology in theSchools & 5 \\
\hline Australian Journal of Educational \& Developmental & 4 \\
Psychology & \\
\hline EducationalResearch & 4 \\
\hline Universal Journal of Educational Research & 4 \\
\hline Alberta Journal of Educational Research & 3 \\
\hline Journal of EarlyAdolescence & 3 \\
\hline Journal of Information Systems Education & 3 \\
\hline Journal of SchoolHealth & 3 \\
\hline Alabama CounselingAssociationJournal & 2 \\
\hline Education and Information Technologies & 2 \\
\hline Educational Sciences: Theory and Practice & 2 \\
\hline Interactive Technology and Smart Education & 2 \\
\hline NASSP Bulletin & 2 \\
\hline Turkish Online Journal of Qualitative Inquiry & 2 \\
\hline Social Psychology of Education: An International Journal & 2 \\
\hline Turkish Online Journal of Educational Technology & 2 \\
\hline
\end{tabular}

El siguiente análisis que realizamos es el número de artículos que se han publicado por año y el número de revistas que los publican (ver Tabla 27). Con estos datos se puede añadir que hay una tendencia en cuanto a publicar en el mismo año diferentes artículos de ciberbullying en una misma revista. Así por ejemplo en 2012 muchas de las publicaciones pertenecen al Emotional \& Behavioural Difficulties y a School Psychology International, o en 2013 a Journal of Youth and Adolescence. Esto se debe a que algunas revistas publican en un mismo volumen diferentes artículos de una misma temática. $A$ pesar de ello, siguen siendo muchas las publicaciones que recogen artículos de la temática que se está analizando, el ciberbullying. 
Tabla 27. № de artículos que se han publicado por año y el número de revistas que los publican (Base de datos ERIC)

\begin{tabular}{cccccccccccc}
\cline { 2 - 12 } & \multicolumn{10}{c}{ Año } \\
\cline { 2 - 13 } & 2006 & 2007 & 2008 & 2009 & 2010 & 2011 & 2012 & 2013 & 2014 & 2015 & 2016 \\
\hline № revistas & 1 & 1 & 3 & 3 & 7 & 12 & 17 & 16 & 10 & 20 & 11 \\
\hline $\begin{array}{c}\text { № } \\
\text { artículos }\end{array}$ & 1 & 1 & 3 & 3 & 7 & 18 & 35 & 24 & 12 & 25 & 13 \\
\hline
\end{tabular}

E) Tipo de estudio

Podemos determinar que predominan los estudios empíricos sobre los teóricos, puesto que sólo 18 artículos de los 142 analizados son revisiones teóricas.

\section{F) Palabras clave}

Destacan significativamente términos "bullying" término directamente vinculado con el ciberbullying, así como otros términos que hacen referencia a la adolescencia como "adolescents", "highereducation" o "secondaryschools". Otros de los términos muy utilizados en las palabras clave han sido "victims" o "victimizations", "social networking" o "harassment", términos estrechamente vinculados al ciberbullying. Se ha analizado también en muchos estudios la diferencia entre sexos, "genderdifference", o las consecuencias del acoso con términos como "depression", "mental health" o "loneliness". Por supuesto, muchos estudios se centran en aspectos como la prevención y la intervención, utilizando las palabras clave "prevention" e "intervention".

De esto podemos deducir que son muchos los aspectos estudiados en los artículos analizados, siendo como hemos comentado la mayoría estudios empíricos cuya finalidad es extraer datos concretos de prevalencia de algún aspecto concreto relacionado con el ciberbullying en una población determinada.

\subsubsection{Psycnet}

Otra de las bases de datos de revistas utilizada ha sido APA PSYCNET, puesto que es la única plataforma de búsqueda diseñada específicamente para ofrecer contenido de American Psychological Association (APA), cuyo objetivo es la expansión del papel de la psicología en el avance de la salud y el reconocimiento creciente de la psicología como ciencia.

Hemos escogido esta base de datos pues es una de las más reconocidas en el ámbito de la psicología, de modo que con ella complementábamos la búsqueda hecha en la base de datos ERIC, más específica en el ámbito educativo.

Para realizar el estudio hemos hecho una búsqueda utilizando el término ciberbullying, delimitando que este término aparezca en el título. Otra de las acotaciones que hemos realizado es el año de publicación, de 2006 a 2016, así como también que se tratase de 
un artículo de revista. A partir de esta búsqueda, delimitando estos campos, el resultado es de 199 artículos.

A) Número de publicaciones por año.

Respecto a estos datos, como podemos observar en la Figura 19, ha habido una tendencia generalmente ascendente, exceptuando el año 2007 en el que no aparecen publicaciones y el año 2011 en el que se observa un descenso en el número de publicaciones pasando de quince publicaciones en el 2010 a seis en el 2011. El año con más número de publicaciones lo encontramos en 2015 con un total de 40, ascendiendo sorprendentemente en 2016 a 18 artículos publicados sobre ciberbullying.

Con esto podemos ver el claro aumento en cuanto a publicaciones, exceptuando este último año, lo que nos deja ver la importancia que va tomando la temática del ciberbullying para los investigadores con el paso de los años.

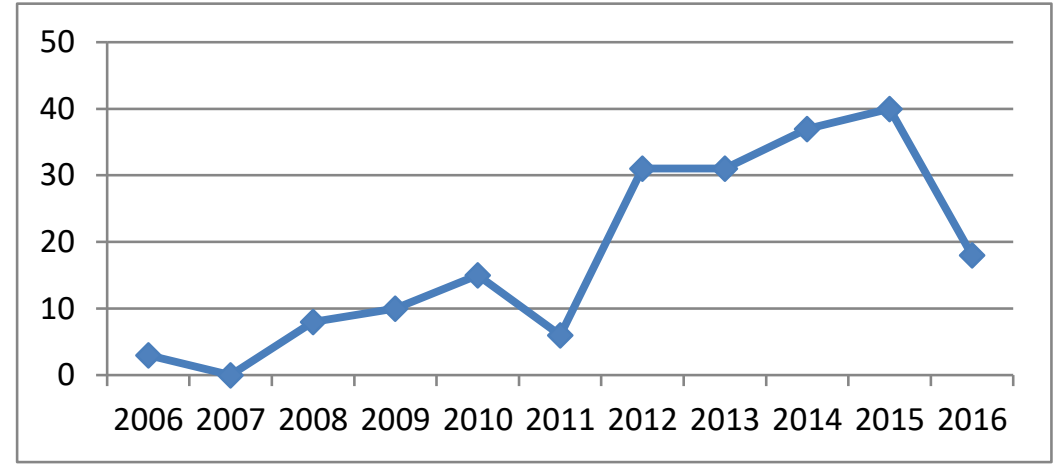

Figura 19. Número de artículos por año (Base de datos PSYCNET)

B) Número de publicaciones de artículos por años y por país de procedencia de la institución que realiza el estudio

Respecto a este dato (ver Tabla 28) podemos ver que son muchos los países que investigan sobre el tema, siendo Estados Unidos el que más publicaciones ha realizado en estos últimos años con un total de 35, seguidos por España con 27 y de Reino Unido y Alemania con 20.

Si analizamos los datos por años, destaca en cuanto al número de publicaciones en 2006, 2010, 2013 y 2014 EE.UU. En cambio, en 2012 es Reino Unido es que reúne mayor número de publicaciones y en 2015 España, con cifras bastante superiores al resto de países.

Por continentes, destacan claramente las publicaciones de origen europeo con un total de 149, seguido de las 59 publicaciones americanas. En el resto de continentes la cifra es muy baja. 
Estos datos reflejan que son muchos los países interesados en la investigación sobre el ciberbullying, entre ellos destaca nuestro país en los últimos años, siendo junto con Estados Unidos uno de los países que más ha investigado sobre la temática.

Tabla 28. № de artículos por años y país de procedencia de la institución que realiza el estudio (Base de datos PSYCNET)

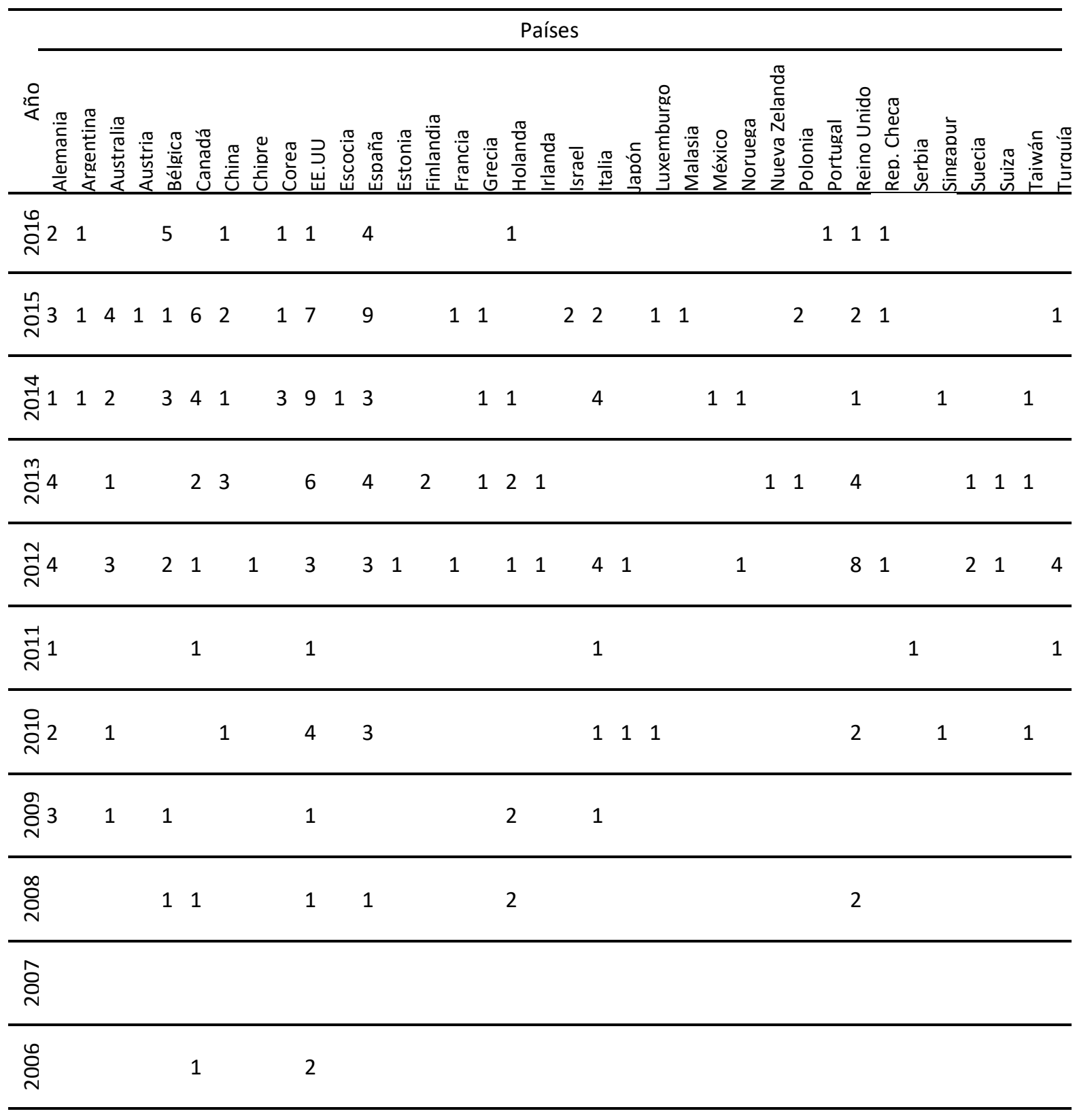

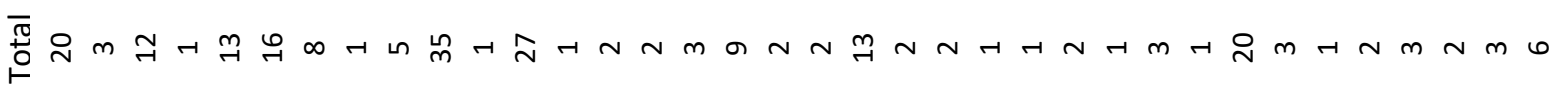


C) Autores

Se puede observar que el número de autores es superior al número de artículos publicados (ver Tabla 29), y esto se debe a que la mayoría de los artículos están escritos por más de un autor.

Tabla 29. № de autores que publican sobre Ciberbullying (Base de datos PSYCNET)

\begin{tabular}{cccccccccccc}
\hline Año & 2006 & 2007 & 2008 & 2009 & 2010 & 2011 & 2012 & 2013 & 2014 & 2015 & 2016 \\
\hline Autores & 4 & 0 & 20 & 35 & 37 & 13 & 109 & 89 & 119 & 146 & 51 \\
\hline
\end{tabular}

Destacan en cuanto al número de publicaciones autores como Heidi Vandebosch con 12 publicaciones, todas ellas junto a otros investigadores. Le siguen Rosario Ortega y Peter Smith con un total de 11 artículos, también como resultado de investigaciones grupales. Por último, con 6 publicaciones, destacamos a Sara Pabian.

Otro aspecto a estudiar en cuanto a los autores de las publicaciones es el número de autores que participan en una misma publicación (ver Tabla 30). Como podemos apreciar en la siguiente tabla, poco más de un $10 \%$ de los artículos han sido publicados por un solo autor. Por el contrario, observamos que un $30 \%$ ha sido escrito por dos autores y un $27 \%$ por tres autores. Esto define una clara tendencia a publicar e investigar sobre el ciberbullying en equipo, siendo pocos los autores los que publican en solitario.

Tabla 30. № de autores que participan en una misma publicación (Base de datos PSYCNET)

\begin{tabular}{cc}
\hline $\begin{array}{c}\text { № } \\
\text { autores }\end{array}$ & $\begin{array}{c}\text { № } \\
\text { artículos }\end{array}$ \\
\hline 1 & 21 \\
\hline 2 & 61 \\
\hline 3 & 53 \\
\hline 4 & 31 \\
\hline 5 & 12 \\
\hline 6 & 11 \\
\hline 7 & 3 \\
\hline 8 & 2 \\
\hline 9 & 2 \\
\hline 11 & 1 \\
\hline 13 & 2 \\
\hline
\end{tabular}

Qing Li es el único autor que ha publicado en solitario más de un artículo, en este caso han sido 2 las publicaciones en solitario. 
En las publicaciones que cuentan con dos autores, Hinduja y Patchin destacan con un total de 3 artículos. Le siguen otros con 2 publicaciones; Vandebosch y Van Cleemput, Sampasa y Hamilton, Pabian y Vandebosch, y Cuadrado y Fernández.

En las publicaciones con tres autores destaca el equipo formado por Paul, Smith y Blumberg con 3 publicaciones. Con 2 publicaciones encontramos a Barlińska, Szuster y Winiewski; García, Romera y Ortega; Katzer, Fetchenhauer y Belschak; Slonje, y Smith y Frisén.

Respecto a las publicaciones con más de tres autores, los grupos no se consolidan y ninguno de ellos cuenta con más de un artículo.

D) Procedencia de las publicaciones

Como se puede observar en la Tabla 31, son dos las que destacan con un total de 15 artículos publicados sobre ciberbullying; "Cyberpsychology, Behavior, and Social Networking" y "Computers in Human Behavior".

Cyberpsychology, Behavior, and Social Networking, es una revista dirigida a comprender el impacto social y psicológico de las prácticas de redes sociales actuales. Altamente considerado como fuente relevante en este campo, ha estado a la vanguardia de las redes sociales y la realidad virtual durante casi 20 años. Es conocida por sus estudios que profundizan en los efectos que las tecnologías interactivas provocan en el comportamiento y en la sociedad en su conjunto, tanto positivos como negativos.

Computers in Human Behavior es una revista académica dedicada a examinar el uso de los ordenadores desde una perspectiva psicológica. Aborda tanto el uso de los ordenadores en psicología, psiquiatría y disciplinas afines, como el impacto psicológico del uso de éstos en individuos, grupos y sociedad.

Como podemos observar en la siguiente tabla, hay otras 8 revistas que cuentan con cinco o más artículos publicados. Queremos destacar aquí, por su origen, la revista Psicothema puesto que fue fundada en Asturias en 1989 y está editada conjuntamente por la Facultad de Psicología de la Universidad de Oviedo y el Colegio Oficial de Psicólogos del Principado de Asturias. Esta revista publica trabajos tanto de investigación básica como aplicada, pertenecientes a cualquier ámbito de la Psicología.

Por el contrario, son la gran mayoría, en total 65 , las que cuentan con una sola publicación lo que nos deja ver que son muchas las revistas que publican sobre la temática puntualmente y no tantas las que llevan un seguimiento en la investigación del ciberbullying. 
Tabla 31. Revistas en las que se han publicado artículos relacionados con Ciberbullying (Base de datos PSYCNET)

\begin{tabular}{l|c}
\hline \multicolumn{1}{c|}{ Publicación } & No artículos \\
\hline Cyberpsychology, Behavior, and Social Networking & 15 \\
\hline Computers in Human Behavior & 15 \\
\hline SchoolPsychology International & 8 \\
\hline Journal of SchoolViolence & 7 \\
\hline European Journal of Developmental Psychology & 7 \\
\hline Psicothema & 6 \\
\hline Australian Journal of Guidance and Counselling & 6 \\
\hline Journal of Youth and Adolescence & 5 \\
\hline Journal of AdolescentHealth & 5 \\
\hline Emotional\&BehaviouralDifficulties & 5 \\
\hline Journal of Interpersonal Violence & 4 \\
\hline Children and Youth Services Review & 4 \\
\hline Psychology in theSchools & 3 \\
\hline Personality and Individual Differences & 3 \\
\hline Pensamiento Psicológico & 3 \\
\hline Journal of Adolescence & 3 \\
\hline CyberPsychology\&Behavior & 3 \\
\hline Computers\&Education & 3 \\
\hline Annual Review of CyberTherapy and Telemedicine & 3 \\
\hline AggressiveBehavior & 3 \\
\hline Aggression and ViolentBehavior & 2 \\
\hline Youth Violence and Juvenile Justice & 2 \\
\hline The Journal of Early Adolescence & 2 \\
\hline ScandinavianJournal of Psychology & 2 \\
\hline Praxis der Kinderpsychologie und Kinderpsychiatrie & 2 \\
\hline Journal of YouthStudies & 2 \\
\hline Journal of Psychology & 2 \\
\hline Journal of Community \& Applied Social Psychology & 2 \\
\hline Child Psychiatry and Human Development & 2 \\
\hline Apuntes de Psicología & 2 \\
\hline Alberta Journal of Educational Research & 2 \\
\hline
\end{tabular}

También en relación a las revistas, otro dato relevante que podemos observar en la Tabla 32 es que una misma revista tiende a publicar en un mismo año varios artículos sobre la temática. Así, destacamos entre otras, en 2016 cinco de sus publicaciones pertenecen a Computers in Human Behavior. En 2015 destaca Journal of School Violence con cinco publicaciones. Y con seis publicaciones en 2012 European Journal of Developmental Psychology. 
Tabla 32. № de artículos que se han publicado por año y el número de revistas que los publican (Base de datos PSYCNET)

\begin{tabular}{cccccccccccc}
\hline & \multicolumn{10}{c}{ Año } \\
\cline { 2 - 15 } & 2006 & 2007 & 2008 & 2009 & 2010 & 2011 & 2012 & 2013 & 2014 & 2015 & 2016 \\
\hline № revistas & 3 & 0 & 7 & 9 & 9 & 5 & 16 & 23 & 30 & 26 & 12 \\
\hline № artículos & 3 & 0 & 8 & 10 & 15 & 6 & 31 & 31 & 37 & 40 & 18 \\
\hline
\end{tabular}

E) Tipo de estudio

Tras su análisis, podemos determinar que sólo un 3\%, es decir 6 publicaciones, son revisiones teóricas, predominando sustancialmente el número de investigaciones empíricas. Dato que nos muestra que los investigadores se centran más en obtener resultados con la puesta en marcha de materiales de evaluación, prevención o intervención sobre una determinada población que en la investigación teórica del fenómeno.

F) Palabras clave

Destacan sobre los demás términos como "bullying" y "adolescents" puesto que la mayoría de las investigaciones se centran en este rango de edad y este fenómeno está muy vinculado al bullying. Otro término relevante es "bystander", que lo definiríamos como espectador, puesto que es uno de los papeles relacionados con el ciberbullying más investigados. En cuanto a la prevalencia destacan investigaciones centradas en conocer la diferencia entre sexos y edades, utilizando así los términos "age difference" y "gender differences". Respecto a la problemática en sí, la mayoría estudian el comportamiento agresivo de los agresores, "aggressive behavior", así como también la intervención adecuada en dichas situaciones "intervention".

\subsubsection{Dialnet}

La tercera fuente documental elegida para el análisis de artículos ha sido Dialnet, por ser uno de los mayores portales bibliográficos del mundo, cuyo principal cometido es dar mayor visibilidad a la literatura científica hispana.

Dialnet se centra fundamentalmente en los ámbitos de las Ciencias Humanas y Sociales, constituyendo así una herramienta fundamental para la búsqueda de información de calidad.

Por estos dos motivos, tanto por su relevancia en el ámbito educativo y psicológico como por la visibilidad que ofrece a la investigación hispana, es por lo que hemos escogido esta tercera base de datos. Con los datos de esta base de datos queremos obtener resultados de índole más nacional. 
Para realizar dicha búsqueda de artículos hemos utilizado el término "cyberbullying". Hemos acotado la búsqueda a artículos de revista publicados entre 2006 y 2016, y también el país a España. Con ello se han obtenido un total de 70 artículos.

A) Número de publicaciones por año

En los años 2006 y 2007 no consta ninguna publicación de artículos de ciberbullying en esta búsqueda. A partir de 2008 hasta el año 2012, se produce un aumento progresivo de publicaciones, llegando en 2012 al número máximo de publicaciones con un total de 14 . De 2012 a 2016 se producen altibajos, siendo 2015, con 13 publicaciones, el segundo en cuanto a número de publicaciones. En este último año la cifra de publicaciones ha descendido.

Estos datos nos muestran que hubo una tendencia ascendente en los primeros años, concretamente del 2008 con la publicación de los primeros artículos hasta 2012, sin embargo el resto de años hasta la actualidad han sido poco constantes ya que han ido tanto en aumento como en disminución, por lo que no hay una tendencia clara en esta temática en las publicaciones españolas.

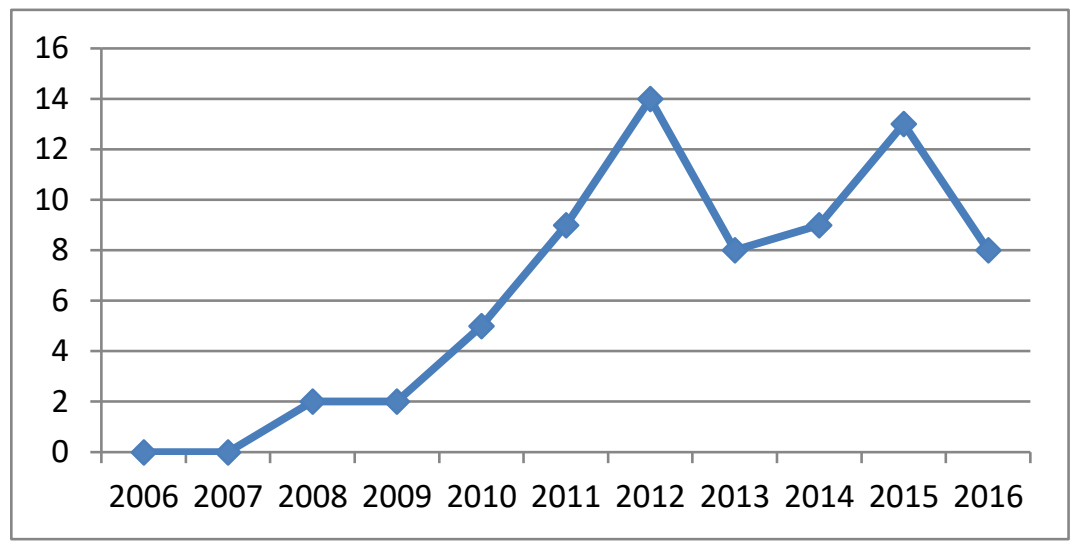

Figura 20. Número de artículos por año (Base de datos DIALNET)

B) Número de publicaciones de artículos por años y por procedencia de la institución que realiza el estudio

En este sentido, al igual que con las revistas de publicación, también hay una gran variedad en cuanto a instituciones que estudian e investigan la temática del ciberbullying. En concreto son dos las instituciones que destacan en cuanto al número de publicaciones realizadas desde 2008; el Colegio Oficial de Psicólogos del Principado de Asturias y Ediuno Ediciones de la Universidad de Oviedo, con un total de 10 publicaciones cada una. 
Como podemos observar en la siguiente Tabla 33, hay un total de 15 instituciones que han publicado entre dos y cinco artículos. El resto de las publicaciones, en concreto 11, pertenecen a instituciones que sólo han hecho una publicación.

Este dato nos muestra que no hay una continuidad en cuanto a la investigación del ciberbullying, y que son muchas las instituciones interesadas en la temática siendo pocas las que han publicado más de tres veces en estos últimos años.

Tabla 33. № de artículos por institución que realiza el estudio (Base de datos DIALNET)

\begin{tabular}{lc}
\hline \multicolumn{1}{c}{ Institución } & $\begin{array}{c}\text { No } \\
\text { artículos }\end{array}$ \\
\hline Colegio Oficial de Psicólogos del Principado de Asturias & 10 \\
\hline Ediuno. Ediciones de la Universidad de Oviedo & 10 \\
\hline Grupo Comunicar & 5 \\
\hline Universidad de Extremadura & 4 \\
\hline Asociación Nacional de Psicología Evolutiva y Educativa de la Infancia, Adolescencia & 3 \\
y Mayores & 3 \\
\hline Education \& Psychology I+D+i & 3 \\
\hline Universidad de Almería & 3 \\
\hline Universidad de Murcia & 2 \\
\hline Asociación de Análisis del Comportamiento & 2 \\
\hline Asociación para el Avance de la Psicología y la Educación (AAPE) & 2 \\
\hline Colegio Oficial de psicólogos de Andalucía Occidental & 2 \\
\hline Consejo General de la Psicología de España & 2 \\
\hline Fundación VECA para el Avance de la Psicología Clínica Conductual & 2 \\
\hline Universidad de La Laguna & 2 \\
\hline Universidad de Sevilla & 2 \\
\hline Universitat Autònoma de Barcelona & 2 \\
\hline WoltersKluwer
\end{tabular}

\section{C) Autores}

El número de autores es superior al número de artículos publicados (ver Tabla 34), y esto se debe a que la mayor parte de los artículos están escritos por más de un autor.

Tabla 34. № de autores que publican sobre Ciberbullying (Base de datos DIALNET)

\begin{tabular}{cccccccccccc}
\hline Año & 2006 & 2007 & 2008 & 2009 & 2010 & 2011 & 2012 & 2013 & 2014 & 2015 & 2016 \\
\hline Autores & 0 & 0 & 4 & 4 & 16 & 26 & 38 & 14 & 21 & 27 & 30 \\
\hline
\end{tabular}

Destacan en cuanto al número de publicaciones autores como Rosario Ortega con 10 publicaciones, todas ellas como resultado de investigaciones grupales. Le sigue Maite Garaigordobil con 8 publicaciones, la mayoría de ellas publicadas en solitario. 
Otro aspecto a estudiar en cuanto a los autores de las publicaciones es el número de autores que participan en solitario, puesto que contamos con un total de 20 publicaciones en solitario. A pesar de ello, siguen siendo más las realizadas en grupo, predominando los grupos de tres miembros con una cifra de 21 publicaciones, seguida de los grupos de dos con 16 publicaciones. Se observa también que el máximo de participantes en un mismo estudio es de seis miembros (ver Tabla 35).

Tabla 35. № de autores que participan en una misma publicación (Base de datos DIALNET)

\begin{tabular}{cc}
\hline & № \\
№ Autores & Artículos \\
\hline 1 & 20 \\
\hline 2 & 16 \\
\hline 3 & 21 \\
\hline 4 & 9 \\
\hline 5 & 3 \\
\hline 6 & 1 \\
\hline
\end{tabular}

Como autora en solitario cabe destacar la labor investigadora de Maite Garaigordobil. En el resto de publicaciones grupales no destaca ningún grupo en concreto, aunque si hay muchas investigaciones grupales realizados por miembros del grupo de investigación del Laboratorio de Estudios sobre Convivencia y Prevención de la Violencia (LAECOVI) cuya investigadora principal es Rosario Ortega.

D) Procedencia de las publicaciones

Son muchas las revistas que han publicado artículos sobre ciberbullying, pero la mayoría de ellas únicamente han publicado un artículo, siendo las que se muestran en la tabla que se presenta a continuación las únicas que han publicado más de un artículo. Destacan en concreto dos, en primer lugar "Psicothema" con un total de diez artículos publicados, seguida de "Comunicar. Revista científica iberoamericana de comunicación y educación." con cinco artículos.

Psicothema fue fundada en Asturias en 1989 y está editada conjuntamente por la Facultad de Psicología de la Universidad de Oviedo y el Colegio Oficial de Psicólogos del Principado de Asturias. Esta revista publica trabajos tanto de investigación básica como aplicada, pertenecientes a cualquier ámbito de la Psicología.

Comunicar: Revista científica iberoamericana de comunicación y educación, también de origen español, y se centra en la publicación de trabajos de investigación en comunicación y educación, especialmente la intersección de ambos: educación en medios de comunicación (media education), medios y recursos educativos, tecnología educativa, recursos informáticos y telemáticos, tecnologías audiovisuales. 
Si observamos los datos presentados en la Tabla 36, podemos afirmar que son pocas las revistas que publican asiduamente artículos sobre la temática del ciberbullying. Encontramos un total de 9 revistas que han publicado entre dos y tres artículos, mientras que un total de 34 revistas sólo han hecho una publicación.

Tabla 36. Revistas en las que se han publicado artículos relacionados con Ciberbullying (Base de datos DIALNET)

\begin{tabular}{lc}
\hline \multicolumn{1}{c}{ Publicación } & No artículos \\
\hline Psicothema & 10 \\
\hline Comunicar: Revista científica iberoamericana de comunicación y educación & 5 \\
\hline Anales de psicología & 3 \\
\hline Electronic journal of research in educational psychology & 3 \\
\hline International Journal of Developmental and Educational Psychology INFAD & 3 \\
\hline Apuntes de Psicología & 2 \\
\hline Diario La Ley & 2 \\
\hline International journal of psychology and psychological therapy & 2 \\
\hline Papeles del psicólogo & 2 \\
\hline Psicología conductual. Revista internacional de psicología clínica y de la salud & 2 \\
\hline Psychology, Society\&Education & 2 \\
\hline
\end{tabular}

Si realizamos el análisis en cuanto al número de artículos publicados cada año y el número de revistas que publican (ver Tabla 37), vemos que en algunas ocasiones el número de revistas es inferior al de publicaciones. En concreto cabe destacar en 2011 que tres de sus nueve artículos se publicaron en la revista International Journal of Developmental and Educational Psychology: INFAD. Revista de Psicología. Así, en el año 2012 también destaca la revista $P$ sicothema, con un total de siete artículos publicados en un mismo volumen. En 2015 vuelve a destacar Psicothema con dos artículos, y en 2016 Comunicar: Revista científica iberoamericana de comunicación y educación con dos publicaciones. 2016, 2 artículos del mismo volumen Comunicar: Revista científica iberoamericana de comunicación y educación.

El resto de los años, vemos que son muchas las revistas que realizan publicaciones sobre el ciberbullying. Por lo que exceptuando las nombradas, no existe una continuidad en cuanto a la publicación sobre el fenómeno del ciberbullying.

Tabla 37. № de artículos que se han publicado por año y el número de revistas que los publican (Base de datos DIALNET)

\begin{tabular}{|c|c|c|c|c|c|c|c|c|c|c|c|}
\hline & \multicolumn{11}{|c|}{ Año } \\
\hline & 2006 & 2007 & 2008 & 2009 & 2010 & 2011 & 2012 & 2013 & 2014 & 2015 & 2016 \\
\hline № Revistas & 0 & 0 & 2 & 2 & 5 & 7 & 7 & 8 & 9 & 12 & 7 \\
\hline № Artículos & 0 & 0 & 2 & 2 & 5 & 9 & 14 & 8 & 9 & 13 & 8 \\
\hline
\end{tabular}


E) Tipo de estudio

El análisis de los datos en cuanto al tipo de estudio, nos indica que un 3 de ellos son revisiones teóricas, y por lo tanto el número de investigaciones empíricas es marcadamente superior. Con ello podemos determinar que los autores que estudian la temática del ciberbullying centran sus investigaciones en obtener datos sobre una muestra concreta, más que en la investigación teórica del fenómeno.

F) Palabras clave

En cuanto a términos clave utilizados por los investigadores, términos más utilizados son principalmente aquellos que hacen referencia al acoso entre iguales, con términos como "bullying" o "acoso escolar", esto nos indica la relación constante que se establece entre el término bullying y ciberbullying. Otro término que destaca sobre los demás son los relacionados con la adolescencia ("adolescencia" o "adolescentes"), puesto que muchos estudios se centran en esta etapa educativa en sus estudios. Palabras clave como "internet", "redes sociales" o "victimización" también son reiterativas, aunque en menor grado.

\subsection{FUENTES DOCUMENTALES SECUNDARIAS}

Respecto a las fuentes documentales secundarias, nos centramos tanto en libros como en distintos tipos de recursos.

\subsubsection{Libros ISBN}

Para el análisis de las fuentes de documentación secundarias, en primer lugar hemos hecho una búsqueda de los libros escritos sobre la temática mediante la base de datos de libros editados en España. Esta base de datos contiene referencias bibliográficas de los libros editados en España desde 1972, año en que nuestro país se unió al sistema ISBN. Está gestionada por la Agencia Española del ISBN.

Para ello se ha realizado una búsqueda sencilla utilizando los términos ciberacoso, ciberbullying y cyberbullying. A partir de esta búsqueda hemos encontrado un total de 22 libros publicados en España (ver Tabla 38), en los años comprendidos entre 2006 y 2016, siendo el 2014 el año que más libros se publicaron sobre la temática, un total de seis. Además, de 2014 a 2016 se concentra el periodo de más publicaciones, con un total de doce de las veintidós encontradas.

El autor que más libros ha publicado es Jorge Flores Fernández, que ha publicado tres libros entre 2006 y 2010, seguido por Maite Garaigordobil Landazabal con dos publicaciones en 2014. El resto de autores cuenta solamente con una publicación sobre la temática. 
En cuanto al número de autores, 12 de las publicaciones han sido publicadas por un solo autor, y 10 por dos o más autores.

Respecto al contenido de estas publicaciones, la mayoría son del ámbito educativo, aunque también encontramos algunas del ámbito jurídico. En cuanto a las publicaciones que hacen referencia a educación, éstas se centran en la actuación frente a la prevención e intervención en casos de ciberbullying.

Tabla 38. Libros publicados en España sobre ciberacoso, ciberbullying y cyberbullying.

\begin{tabular}{|c|c|c|}
\hline TÍTULO & AÑO & AUTOR \\
\hline Los adolescentes y el ciberacoso. & 2016 & Sánchez Pardo, Lorenzo \\
\hline $\begin{array}{l}\text { Bullying, ciberbullying y acoso con } \\
\text { elementos sexuales: desde la prevención } \\
\text { a la reparación del daño. }\end{array}$ & 2016 & $\begin{array}{l}\text { Pérez Ferrer, Fátima } \\
\text { Pérez Vallejo, Ana María }\end{array}$ \\
\hline $\begin{array}{l}\text { Ciberacoso y violencia de género en } \\
\text { redes sociales: análisis y herramientas de } \\
\text { prevención. }\end{array}$ & 2015 & $\begin{array}{l}\text { Verdejo Espinosa, María } \\
\text { Ángeles }\end{array}$ \\
\hline $\begin{array}{l}\text { Acoso y ciberacoso escolar: la doble } \\
\text { responsabilidad civil y penal. }\end{array}$ & 2015 & Colás Escandón, Ana María \\
\hline Bullying, ciberbullying y sexting. & 2015 & $\begin{array}{l}\text { Molina del Peral, José Antonio } \\
\text { Vecina Navarro, Pilar }\end{array}$ \\
\hline $\begin{array}{l}\text { Trunky. Un elefante muy especial: } \\
\text { bullying y cyberbullying desde los ojos de } \\
\text { un elefante. }\end{array}$ & 2015 & Guillén Brando, Sergio \\
\hline $\begin{array}{l}\text { El ciberacoso como forma de ejercer la } \\
\text { violencia de género en la juventud: un } \\
\text { riesgo en la sociedad de la información y } \\
\text { del conocimiento. }\end{array}$ & 2014 & $\begin{array}{l}\text { Ministerio de Sanidad, Servicios } \\
\text { Sociales e Igualdad }\end{array}$ \\
\hline $\begin{array}{l}\text { Educar en las nuevas tecnologías: } \\
\text { prevención del ciberacoso. }\end{array}$ & 2014 & $\begin{array}{l}\text { Tébar Martínez, Manuel } \\
\text { García Fernández, Valle }\end{array}$ \\
\hline $\begin{array}{l}\text { Cyberprogram 2.0: programa de } \\
\text { intervención para prevenir y reducir el } \\
\text { ciberbullying. }\end{array}$ & 2014 & $\begin{array}{l}\text { Martínez Valderrey, Vanesa } \\
\text { Garaigordobil Landazabal, } \\
\text { Maite }\end{array}$ \\
\hline Ciberbullying: prevenir y actuar. & 2014 & Luengo Latorre, José Antonio \\
\hline $\begin{array}{l}\text { El derecho penal frente a las formas de } \\
\text { acoso a menores: bullying, ciberbullying, } \\
\text { grooming y sexting. }\end{array}$ & 2014 & Mendoza Calderón, Silvia \\
\hline $\begin{array}{l}\text { Cyberbullying, screening de acoso entre } \\
\text { iguales: screening del acoso escolar } \\
\text { presencial "bullying" y tecnológico } \\
\text { "cyberbuylling". }\end{array}$ & 2014 & $\begin{array}{l}\text { Garaigordobil Landazabal, } \\
\text { Maite }\end{array}$ \\
\hline $\begin{array}{l}\text { Ciberseguridad familiar cyberbullying, } \\
\text { hacking y otros peligros en Internet. }\end{array}$ & 2013 & Orenes, Eduardo \\
\hline
\end{tabular}


Tabla 38. Libros publicados en España sobre ciberacoso, ciberbullying y cyberbullying.

(Continuación)

\begin{tabular}{|c|c|c|}
\hline TíTULO & AÑO & AUTOR \\
\hline $\begin{array}{l}\text { Prevención del ciberacoso escolar: la } \\
\text { mediación y el aprendizaje cooperativo } \\
\text { apoyado en las tecnologías de la } \\
\text { información y comunicación. }\end{array}$ & 2011 & González Calle, Eva María \\
\hline $\begin{array}{l}\text { Acoso escolar y ciberbullying en centros } \\
\text { de educación secundaria y primaria en } \\
\text { Extremadura. }\end{array}$ & 2011 & $\begin{array}{l}\text { León del Barco, Benito } \\
\text { Felipe Castaño, María Elena } \\
\text { Gómez Carroza, Teresa }\end{array}$ \\
\hline $\begin{array}{l}\text { Protocolo de actuación escolar ante el } \\
\text { ciberbullying. }\end{array}$ & 2011 & Rey Alamillo, Rosario del \\
\hline $\begin{array}{l}\text { Ciberacoso: la tutela penal de la } \\
\text { intimidad, la integridad y la libertad } \\
\text { sexual en Internet. }\end{array}$ & 2010 & García González, Javier \\
\hline $\begin{array}{l}\text { Ciberbullying: material didáctico para la } \\
\text { prevención del acoso por medio de las } \\
\text { nuevas tecnologías. }\end{array}$ & 2010 & Flores Fernández, Jorge \\
\hline $\begin{array}{l}\text { CiberBullying: guía rápida para la } \\
\text { prevención del acoso por medio de las } \\
\text { nuevas tecnologías. }\end{array}$ & 2010 & $\begin{array}{l}\text { Flores Fernández, Jorge } \\
\text { Casal Lodeiro, Manuel }\end{array}$ \\
\hline $\begin{array}{l}\text { Ciberbullying: guía práctica para madres, } \\
\text { padres y personal docente. }\end{array}$ & 2009 & $\begin{array}{l}\text { Aftab, Parry } \\
\text { Casal Lodeiro, Manuel }\end{array}$ \\
\hline $\begin{array}{l}\text { La escuela sin ley: intimidación de } \\
\text { profesores, acoso de compañeros, el } \\
\text { maltrato físico y verbal, los padres: } \\
\text { abogados de sus hijos, los héroes del } \\
\text { ciberbullying. }\end{array}$ & 2009 & Gómez Gómez, Amalia \\
\hline $\begin{array}{l}\text { Ciberbullying: guía práctica para madres, } \\
\text { padre y personal docente. }\end{array}$ & 2006 & $\begin{array}{l}\text { Aftab, Parry } \\
\text { Flores Fernández, Jorge } \\
\text { Casal Lodeiro, Manuel }\end{array}$ \\
\hline
\end{tabular}

\subsubsection{Recursos}

Presentamos a continuación una serie de recursos relacionados con el ciberbullying. Hemos recopilado los más relevantes en lo que se refiere a programas, guías, páginas web y videos. Esta recopilación nos proporcionará información acerca del ciberbullying, y con ello nos permitirá revisar los recursos relacionados con el ciberbullying publicados hasta el momento.

\subsubsection{Programas}

Los programas presentados a continuación son una recopilación de trabajos presentados por diferentes autores cuya finalidad es la erradicación del ciberbullying y el acoso. Para 
ello han elaborado estos proyectos que proporcionan herramientas para prevenir e intervenir principalmente en el ámbito escolar.

- Avilés, J.M. (2015). Proyecto Antibullying: Prevención del bullying y cyberbullying en la comunidad educativa.

Este programa tiene como objetivo reunir las herramientas necesarias para evitar con garantías de éxito los problemas de acoso o ciberbullying. Para ello, proporciona pautas e instrumentos que permiten a los agentes educativos dar una respuesta ante dichas situaciones.

- Garaigordobil, M., y Martínez-Valdeney, V. (2014). Cyberprogram 2.0. Un programa de intervención para prevenir y reducir el ciberbullying. Madrid: Pirámide.

Este programa pretende aumentar las estrategias cooperativas de resolución de conflictos, las conductas sociales positivas, la autoestima y la empatía, así como disminuir conductas de bullying y ciberbullying en distintos tipos de violencia escolar y del uso de estrategias agresivas como técnica de resolución de conflictos interpersonales.

- San José, C.R (2014) Prevención del acoso escolar Bullying y Ciberbullying.

Tiene el propósito de contribuir a las discusiones teórico-conceptuales que lleven a promover las prácticas y cambios necesarios para construir colegios más seguros, en donde se manejen los conflictos de manera no violenta, se respeten los derechos humanos y se construya una cultura de paz, con el propósito de prevenir que este tipo de problemas se desarrollen y enquisten en las comunidades educativas.

- Del Rey, R., Casas, J.A. y Ortega, R. (2012). El programa ConRed, una práctica basada en la evidencia

Este programa pretende mejorar y reducir problemas como el ciberbullying, la dependencia a Internet y la desajustada percepción del control de la información en las redes sociales, para así potenciar el uso beneficioso de ésta.

- Garaigordobil, M. (2010). El papel de la escuela en la prevención de la violencia y en el desarrollo de una cultura de paz.

No consiste solamente en eliminar de la escuela cualquier tipo de violencia infantil y juvenil, sino que llegue a ser un centro activo y mediador de una cultura de paz.

- Garaigordobil, M. (2006). Un programa de intervención para fomentar el desarrollo socio-emocional y prevenir la conducta violenta durante la adolescencia.

Promover el desarrollo del grupo, identificar y analizar creencias-percepcionesprejuicios, disminuir el etnocentrismo, y reflexionar sobre los derechos humanos. 
- Garaigordobil, M. (2005). Programa de educación emocional para la prevención de la violencia. Caruana (Ed.)

Enseñar y aprender a convivir y a ser.

Además de estos programas presentados por investigadores prestigiosos en la temática, també cabe destacar la importancia de las iniciativas llevadas a cabo en diferentes centros escolares españoles, entre los que destacamos los siguientes:

- les Parque Goya (Zaragoza). Ciberayudantes.

Este programa permite a los alumnos participar de forma organizada formando parte del grupo de alumnos ayudantes, cuya finalidad es; cooperar en la identificación y denuncia de situaciones injustas en las que viven sus compañeros, buscar soluciones a los problemas que se derivan del uso de internet y colaborar activamente en la mejora de buenas prácticas en el uso de las redes sociales y del Whatsapp.

- Colegio Santa María (Vizcaia). Cibermanagers.

El objetivo de este programa es capacitar al alumnado de últimos cursos de Educación Secundaria en el uso seguro y saludable de internet, para que a su vez se conviertan en "managers" del alumnado más pequeño del centro, de las familias y de los propios docentes, tutorizando y acompañando sus incursiones en la red.

- les Padre Moret- Irubide (Pamplona). Actividades de prevención sobre el cyberbullying.

Este proyecto tiene como objetivo concienciar al alumnado sobre las consecuencias y reacciones ante el cyberbullying a través de la lectura y reflexión del dilema moral. Además, pretenden conseguir en el alumnado su compromiso personal como "agentes de la paz", de no aceptar el acoso y en el caso que se produzca tratar de pararlo y ayudar a las víctimas.

- Comunidad de Madrid. Proyecto de alumnos ayudantes TIC.

Proyecto puesto en marcha en un gran número de centros educativos de la Comunidad de Madrid, cuyo objetivo es la formación de alumnos ayudantes mediante una propuesta de trabajo que combina procesos de aprendizaje y de servicio a la comunidad determinada, siendo en estos casos alumnos de menor edad de otro centro o de otra etapa.

Todos estos programas y proyectos nos muestran que cada vez más se están investigando y desarrollando en nuestro estado prácticas dirigidas a los centros escolares cuya finalidad es abordar el ciberbullying desde la prevención y la intervención, aspecto que remarca un aumento de conciencia social en cuanto a la importancia de una problemática social tan grave como el ciberbullying. 


\subsubsection{Guías}

Otro de los recursos que consideramos relevante analizar es la recopilación de las guías sobre ciberbullying, con tal propósito presentamos aquellas que hemos considerado más relevantes en cuanto al contenido que ofrecen.

Éstas han sido publicadas por diferentes instituciones y van principalmente destinadas a familiares y a educadores, así como también a menores de diferentes edades.

La finalidad de estas guías es proporcionar a los contextos más cercanos a los menores materiales que les faciliten la prevención o la intervención ante casos de ciberbullying, ofreciéndoles pautas y recomendaciones al respecto.

- Save the Children (2016). Yo a eso no juego-Bullying y Ciberbullying en la infancia.

Busca promover una educación positiva y eliminar todo tipo de violencia contra la infancia, fomentando la formación interdisciplinar de los profesionales que intervienen con los jóvenes en todos los ámbitos.

- Grupo de trabajo de la Guía Clínica de ciberacoso para profesionales de la salud (2015). Guía clínica de ciberacoso para profesionales de la salud.

Esta guía tiene como finalidad facilitar el diagnóstico, tratamiento y prevención en el entorno sanitario del ciberbullying, así como mejorar la coordinación entre los ámbitos familiar, escolar, policial y judicial.

- Roca, G. (2015). Les noves tecnologies en nens i adolescents. Guía per a educar saludablement en una societat digital.

Esta guía permite el análisis exhaustivo de las diferentes tecnologías que existen en la actualidad y además ofrece pautas a los padres y educadores de la correcta incorporación de éstas, desde una dimensión que favorece el desarrollo integral y saludable.

- Luengo, J. A. (2014). Ciberbullying. Prevenir y actuar. Guía de recursos didácticos para Centros Educativos.

Recuperado dehttp://www.copmadrid.org/webcopm/recursos/CiberbullyingB.pdf

Situación del uso de las TIC en los últimos años, conceptos teóricos sobre el ciberbullying e información sobre diferentes técnicas de trabajo del ciberbullying. En esta guía nos proporcionan también pautas y materiales por la prevención a partir de la alfabetización digital desde la educación primaria. Además, la guía nos proporciona muchas actividades didácticas para llevar a cabo en las aulas y un protocolo de intervención muy desarrollado con materiales y pautas tan para padres como para profesores y alumnos. Finaliza con una serie de referencias normativas para la reflexión y acción en el centro escolar. 
- INTECO (2013). Guía de actuación contra el ciberacoso. Padres y educadores. Recuperado dehttp://www.injuve.es/sites/default/files/2013/46/publicaciones/Gu\%C3\%ADa\%20 de\%20actuaci\%C3\%B3n\%20contra\%20el\%20ciberacoso.pdf

Concepto de ciberbullying, pautas de detección, prevención y actuación, i comportar a capel proceso de denuncia y el delito que comporta. También encontraremos una serie de experiencias de casos de ciberbullying y otros riesgos del uso de las TIC, así como consejos básicos sobre el uso de las nuevas tecnologías.

- Fundación Dédalo (2012). Por un uso seguro de internet. Primaria. Recuperado de http://www.disfrutalared.com/images/yootheme/fichas didacticas/FichasDidacticas Primaria es.pdf

Conjunto de actividades relacionadas con el uso seguro de Internet donde se trabajan aspectos como los valores, el ciberbullying, la privacidad, etc.

- Junta de Castilla y León (2011). Manual de uso inteligente de las nuevas tecnologías para los alumn@s. De 8 a 10 años. Recuperado dehttp://www.cyldigital.es/sites/default/files/library/manual8-

10anosprogramaaprende.pdf

Junta de Castilla y León (2011). Manual de uso inteligente de las nuevas tecnologías para los alumn@s. De 10 a 12 años. Recuperado de https://www.cyldigital.es/sites/default/files/library/manual10-

12anosprogramaaprende.pdf

Concepto de nuevas tecnologías, información sobre los videojuegos, televisión, ordenador e Internet. También nos ofrecen información sobre los riesgos que podemos encontrar en la red. Además, nos proporcionan información sobre los @ederechos de los niños y niñas y una serie de reglas que se necesario que los menores conozcan a la hora de utilizar las nuevas tecnologías.

- Centro se Seguridad en Internet Protégeles (s.f.). Ciberbullying y privacidad. Guía para profesores.

Recuperado dehttp://www.yocontrolo.es/descargas/PROYECTO DAPHNE ES.pdf

Contenidos teóricos relacionados con el ciberbullying: concepto, quien interviene, prevención, etc., y también otras sobre la privacidad: derechos y deberes, protección de datos y delitos. También encontraremos en estos documentos una serie de actividades para trabajar el ciberbullying y la privacidad en Internet.

- Collell, J. y Escudé, C. (2008). No te enredes en la red. Guía para conocer el ciberbullying $y$ algunos peligros de internet $y$ las nuevas tecnologías. Recuperado dehttp://www.xtec.cat/ jicollell/ZGuia\%20Ciber.pdf 
Información teórica como el concepto de ciberbullying y conductas relacionadas con el ciberbullying. Presenta un conjunto de actividades dónde a partir de una serie de historias se presentan cuestiones para debatir en grupo sobre las conductas que se presentan a las historias.

\subsubsection{Páginas web}

Otro de los recursos que consideramos importante y necesario, teniendo en cuenta el uso social que hacemos de las TIC, son las páginas web cuyo contenido trata el fenómeno del ciberbullying. En estas páginas, al igual que en las guías encontramos materiales destinados a familiares, docentes y menores. En este caso el material tiende a ser más interactivo, lo que permite navegar por la red y consultar la información que se adapte a las necesidades del usuario.

Analizar este dato nos va a permitir ver los recursos más relevantes creados sobre esta temática en España en estos últimos años, y con ello poder analizar la adecuación y actualización de estos.

- PANTALLAS AMIGAS (http://www.pantallasamigas.net). Es la web más completa, y la pionera en la temática, que existe a nivel español donde encontraremos recursos relacionados con el uso seguro y saludable de las nuevas tecnologías de todo tipo: artículos, vídeos, definiciones de conceptos, materiales y recursos didácticos, etc.

- CIBERBULLYING (http://www.ciberbullying.com). En la web encontraremos información sobre el ciberbullying, recursos de prevención, consejos contra el ciberbullying, noticias, artículos, entrevistas, etc. todo relacionado con esta temática.

- PROTEGELES.COM (http://www.protegeles.com). Organización de protección al menor en Internet que proporciona información en su web como puede ser como actuar frente en un problema, recursos, guías, estudios, vídeos, etc. E información concreta dirigida a padres y madres, alumnas o profesores con una serie de normas, responsabilidades, actividades, etc.

- YO CONTROLO (http://www.yocontrolo.es/). Encontraremos información sobre casos de pérdida de privacidad o ciberbullying, recursos como guías, webs, vídeos, estudios, etc.

- CYBERBULLYING RESEARCH CENTER (http://cyberbullying.org/). Esta web es un centro de intercambio de información sobre las formas en que los adolescentes hacen un uso correcto e incorrecto de la tecnología. Se pretende proporcionar recursos para padres, educadores, orientadores y otros profesionales que trabajan con jóvenes.

- SAVE THE CHILDREN (https://www.savethechildren.es/donde/espana/violenciacontra-la-infancia/acoso-escolar-bullying). Save the Chidren trabaja en la prevención de situaciones de acoso escolar, entre ellos el ciberbullying, en los centros educativos 
teniendo en cuenta toda la comunidad. En su web ofrecen talleres dirigidos a adultos y niños, materiales, videos, etc.

- STOP BULLYING (https://espanol.stopbullying.gov/). Está página web dedica un apartado en el que se ofrece información acerca del acoso por internet, donde proporcionan información, ofrecen pautas de prevención e indican qué medidas se pueden tomar ante un caso de ciberbullying.

- RED DE BUENAS PRÁCTICAS 2.0 (http://educalab.es/recursos). Red colaborativa del profesorado de la Escuela del s. XXI, gestionada desde el Instituto Nacional de Tecnologías Educativas y de Formación del Profesorado del Ministerio de Educación cuyo objetivo es crear un medio didáctico, promoviendo entre el profesorado el acceso a los recursos digitales, la difusión de sus experiencias y proyectos innovadores, así como la comunicación a través de las redes sociales.

- PREVENCIÓN DEL CIBERBULLYING (http://www.prevencionciberbullying.com/). Web que proporciona información y recursos de sensibilización, prevención, intervención, así como también recursos didácticos.

- RED.ES - CHAVAL.ES (http://www.chaval.es/chavales/). El objetivo de esta web es fomentar el uso adecuado de la tecnología y proveer contenidos e información de confianza a los usuarios mediante consejos, guías y resolución de dudas. También ofrece un listado de referencias útiles y de calidad.

\subsubsection{Vídeos}

El último de los recursos presentados son los videos. Éstos nos ayudarán a ser conscientes de la importancia del fenómeno del ciberbullying. Encontramos diferentes materiales publicados al respecto, tanto casos reales de ciberbullying como materiales elaborados para su prevención e intervención. Entre todos los publicados hasta el momento destacamos los siguientes.

- Ciberacoso (Childnet International - Cyber Bullying). Caso de ciberbullying subtitulado español.https://www.youtube.com/watch?v=9bgdOuBn4Q4

- Ciberbullying: ciberacoso en redes sociales, videogames, smartphones... y su prevención.https://www.youtube.com/watch?v=SEC dOWFN5M\&index=1\&list=PL C186BF9FE0418ED2

- ¿Cómo actuar ante el ciberacoso? Ignora, bloquea, pide ayuda y denuncia.https://www.youtube.com/watch?v=tVAjiyNzYq0\&list=PLC186BF9FE0418 ED2\&index=7 
- Recomendaciones para el Uso Seguro de Internet y las Redes Sociales. https://www.youtube.com/watch?v=t$\underline{x 73 w 1 N 10 s \& l i s t=P L C 186 B F 9 F E 0418 E D 2 \& i n d e x=12}$

- ¿Cómo evitar ser víctima de ciberbullying por suplantación de identidad?https://www.youtube.com/watch?v=XQeFYgedVZg\&list=PLC186BF9FE0 418ED2\&index $=15$

- Decálogo por la ciberconvivencia positiva y contra la violencia digital.https://www.youtube.com/watch?v=gXvG53ccyJY\&index=17\&list=PLC186BF 9FE0418ED2

- De ayudantes a ciberayudantes, IES Parque Goya.https://www.youtube.com/watch?v=udzf7Dd2V9A

- El caso de Amanda Todd https://www.youtube.com/watch?v=hbTEOGLOvQ0

- The cyberbully 2015 https://www.youtube.com/watch?v=DUzkkLaLgHo

- Cyberbullying: create no hate.https://www.youtube.com/watch?v=MV5v0m6pEMs

Todos estos recursos van a permitir analizar los recursos existentes hasta la actualidad cuya finalidad es principalmente la prevención e intervención del ciberbullying. Encontramos materiales actuales creados en 2016, así como algunos de los primeros materiales creados para abordar dicho fenómeno que datan de 2008 en adelante.

\subsection{SÍNTESIS}

A lo largo del capítulo hemos podido observar como el fenómeno del ciberbullying ha ido creciendo con los años y con el aumento del uso de las TIC. Esto ha llevado a un aumento directo de las investigaciones y publicaciones sobre dicha temática, debido a que la ciudadanía cada día es más consciente de su relevancia y de la necesidad de abordar el problema.

Con la finalidad de conocer el estado actual del ciberbullying en nuestra sociedad, hemos consultado diferentes fuentes documentales como recursos para acceder a la información que nos interesa estudiar. De este modo, atendiendo al contenido hemos consultado diferentes fuentes documentales primarias y secundarias (UNESCO, 1971, 1976, 1982).

Así, como fuentes documentales primarias nos hemos centrado en primer lugar en los estudios estadísticos realizados en España, por ser parte de nuestra realidad más directa, y en América debido a la gran cifra de estudios que realizan sobre el ciberbullying. A continuación, hemos analizado las Tesis Doctorales y las revistas científicas.

Respecto a los estudios estadísticos podemos destacar, según los datos que se desprenden de los españoles, que en 2016 un 6'9\% de los jóvenes afirmaron haber sido víctimas de 
ciberbullying, dato que varía por Comunidad Autónoma entre un 9'5\% en Andalucía y la cifra más baja en Asturias con un 3\%. Además, un 3'7\% sufrieron bullying y ciberbullying. En cuanto al rango de edad la prevalencia es mayor entre los jóvenes de la etapa de 10 de Eso que en los que cursa $2 \circ$ Eso. La modalidad más usual para realizar ciberbullying es el envío de insultos mediante el uso de diferentes dispositivos, y los motivos por los que las víctimas creen ser ciberacosados son por ser molestados, por su aspecto físico o por tenerles manía. En cuanto al modo de afrontamiento, el más común es solucionar activamente el problema o parar la situación. Las víctimas de mostraron menor autoestima y habilidades comunicativas, mientras que los agresores presentan más baja autoestima, menor empatía cognitiva y afectiva, menos asertividad y una más baja capacidad para resolver conflictos.

Por su parte, los datos estadounidenses nos señalan que también en 2016 la prevalencia de ciberbullying es de un $34 \%$ de víctimas, y se encuentran diferencias entre sexo, siendo las chicas las que presentan un mayor índice. Para ello, los dispositivos más utilizados son los teléfonos móviles. Como dato que nos aporta información de su evolución en estos diez últimos años, se contempla que, como dato promedio, un 27'9\% de los estudiantes que han participado en estos 10 últimos estudios han afirmado haber sido víctimas de ciberbullying en algún momento de su vida. Esta cifra ha ido oscilando con los años, no pudiéndose definir con una tendencia que vaya en crecimiento o disminución continua, siendo el 2014 el año que presenta mayor prevalencia con 34'6\%, seguido por el año 2015 con un $34 \%$.

De estos datos se puede extraer que hay una cifra elevada de víctimas del ciberbullying en el año 2016, siendo más elevada en América que en España. Respecto a la evolución, sólo disponemos de datos americanos, y estos nos dejan ver que no existe un claro aumento de prevalencia, sino que el dato varía en función de los años sin seguir una tendencia clara.

En cuanto a las Tesis Doctorales, que es la segunda fuente documental primaria analizada, hemos encontrado un total de 10 tesis sobre ciberbullying todas ellas publicadas entre los años 2011 y 2016, lo que nos indica que es una temática bastante reciente. Para su análisis, nos hemos centrado en los siguientes parámetros:

a) La temática. Teniendo en cuenta el título, éste nos aporta información sobre los temas que aparecen, entre los que destacan los estudios centrados en la etapa evolutiva de la adolescencia y en estudios de prevalencia en diferentes contextos.

b) Los directores. Destacan las investigadoras Maite Garaigordóbil con dos tesis dirigidas en solitario, y Rosario Ortega también con dos tesis dirigidas conjuntamente con otros directores pertenecientes a su grupo de investigación LAECOVI.

c) Las universidades. De las tesis analizadas, vemos que predominan las Universidades andaluzas con un total de cinco tesis publicadas, dos de ellas de la Universidad de Córdoba. 
e) La producción por año. Las dos primeras tesis fueron publicadas en 2011. En 2012 y 2103 sólo encontramos una publicación. En cambio, en los siguientes años; 2014, 2015 y 2016 son dos las tesis publicadas. Estos datos nos dejan ver que la cifra de tesis de esta temática es baja, debido a la actualidad de la temática, y no ha variado mucho el número de publicaciones a lo largo de los años.

Otra de las fuentes documentales primarias que se han revisado han sido las revistas científicas a través de las bases de datos ERIC, PSYCNET y DIALNET.

ERIC y PSYCNET son bases de datos a nivel internacional especializadas en Educación, la primera y en Psicología la segunda.

DIALNET, es una base de datos de producción hispana especializada en ciencias humanas y sociales.

En total, teniendo en cuenta las tres bases de datos, se han analizado 481 artículos.

Los artículos revisados corresponden al periodo comprendido entre los años 2006 y 2016, hemos revisado este periodo, puesto que las primeras publicaciones de la temática constan del 2006 y también por acogerse a las publicaciones más recientes.

Los resultados del análisis de las bases de datos se han llevado a cabo de forma individual, ya que cada base presenta unas características que hemos considerado importante mantener y no realizar un análisis conjunto.

Para analizar los datos, hemos basado en los siguientes parámetros a revisar: número de artículos, años de mayor publicación, palabras clave, publicación (revista), autores, país o institución y tipo de artículo.

En la base de datos en la que se ha encontrado menos artículos ha sido DIALNET (70) y la que más PSYCNET (199). Entendemos que esto se debe a que el ciberbullying es un fenómeno investigado mundialmente, siendo Europa y América los continentes predominantes.

Del análisis de dichos parámetros, se ha extraído la siguiente información presentada en la Tabla 39:

Tabla 39. Síntesis análisis Revistas Científicas

\begin{tabular}{cccc}
\hline PARÁMETRO & ERIC & PSYCNET & DIALNET \\
\hline $\begin{array}{c}\text { No artículos } \\
\text { publicación }\end{array}$ & 142 & 199 & 70 \\
\hline $\begin{array}{c}\text { Países o } \\
\text { instituciones que } \\
\text { destacan }\end{array}$ & 2012 & 2015 & 2012 \\
\hline
\end{tabular}


Tabla 39. Síntesis análisis Revistas Científicas. (Continuación)

\begin{tabular}{|c|c|c|c|}
\hline PARÁMETRO & ERIC & PSYCNET & DIALNET \\
\hline $\begin{array}{l}\text { Revistas con más } \\
\text { publicaciones }\end{array}$ & $\begin{array}{c}\text { - School Psycology } \\
\text { International }\end{array}$ & $\begin{array}{c}\text { - Cyberpsychology, } \\
\text { Behavior, and } \\
\text { Social } \\
\text { Networking } \\
\text { - Computers in } \\
\text { Human Behavior }\end{array}$ & - Psicothema \\
\hline & - & - & - \\
\hline $\begin{array}{l}\text { Autores que más } \\
\text { han publicado }\end{array}$ & $\begin{array}{l}\text { - Marilyn Campbell } \\
\text { - Wanda Cassidy } \\
\text { - Barbara Spears } \\
\text { - Margaret Jackson }\end{array}$ & $\begin{array}{c}\text { - Heidi } \\
\text { Vandebosch } \\
\text { - Rosario Ortega } \\
\text { - Peter Smith }\end{array}$ & $\begin{array}{l}\text { - Maite Garaigordobil } \\
\text { - Rosario Ortega }\end{array}$ \\
\hline $\begin{array}{l}\text { Palabras clave } \\
\text { más usuales }\end{array}$ & $\begin{array}{c}\text { - Bullying } \\
\text { - Adolescents } \\
\text { - Higher education } \\
\text { - Secondary schools }\end{array}$ & $\begin{array}{l}\text { - Bullying } \\
\text { - Adolescents }\end{array}$ & $\begin{array}{c}\text { - Bullying } \\
\text { - Adolescencia }\end{array}$ \\
\hline $\begin{array}{l}\text { Tipo artículo: } \\
\text { Empírico }\end{array}$ & 124 & 193 & 67 \\
\hline $\begin{array}{l}\text { Tipo artículo: } \\
\text { Teórico }\end{array}$ & 18 & 6 & 3 \\
\hline
\end{tabular}

A modo de conclusión de este apartado dedicado a los artículos publicados en las Revistas Científicas, podemos añadir que el análisis de estas bases de datos tiene como propósito que la Comunidad Científica pueda encontrar más referencias a cerca del fenómeno del ciberbullying, en las mismas bases de datos o en otras distintas.

En cuanto a las fuentes documentales secundarias hemos encontrado diferentes libros publicados sobre ciberbullying en España, así como una serie de recursos sobre la temática.

Referente a los libros consultados en la base de datos del ISBN, hemos encontrado un total de 22 libros entre los años 2006 y 2016. Estas son todas las publicaciones españolas sobre la temática del ciberbullying.

El 2014 fue el año que más libros se publicaron sobre la temática, un total de 6. Además, de 2014 a 2016 se concentra el periodo de más publicaciones, con un total de 12 de las 22 encontradas.

El autor que más libros ha publicado es Jorge Flores Fernández, que ha publicado tres libros entre 2006 y 2010, seguido por Maite Garaigordobil Landazabal con dos publicaciones en 2014. El resto de autores cuenta solamente con una publicación sobre la temática.

Un dato a destacar, es que la investigadora Maite Garaigordobil es una de las autoras españolas que cuenta con más artículos publicados, así como libros, y además ha sido una de las directoras que más tesis ha dirigido. 
Finalmente, otra fuente documental secundaria que hemos encontrado son los recursos de ciberbullying, entre los que podemos encontrar programas, guías, páginas web y videos. Se trata de una recopilación de aquellos materiales publicados en los últimos años y que considerados más relevantes, principalmente de origen español. Al respecto queremos decir que hay bastantes recursos disponibles en nuestro país, pero no se encuentran bien especificados, los contenidos no son actuales puesto que se repiten a lo largo de los años, y las recomendaciones o retos que se plantean se hacen de modo teórico, sin llegar a concretar medidas o a establecerlas. 


\section{CAPÍTULO 4. ROL DEL PSICÓLOGO EDUCATIVO EN SITUACIONES DE CIBERBULLYING}

4.1. PSICÓLOGO EDUCATIVO. ¿QUÉ DEBE SABER?

4.2. PSICÓLOGO EDUCATIVO Y COMUNIDAD EDUCATIVA. ¿QUÉ HACER?

4.2.1. Alumnos

4.2.2. Centros Educativos

4.2.3. Familia

4.3. PLAN DE ACTUACIÓN EN UN CENTRO DE EDUCACIÓN INFANTIL Y PRIMARIA

4.4. PLAN DE PREVENCIÓN DE LA VIOLENCIA Y PROMOCIÓN DE LA CONVIVENCIA (PREVI)

4.4.1. Orientados

4.4.2. El ciberbullying en el PREVI

4.4.2.1. Medidas de prevención dirigidas al sistema educativo

4.4.2.2. Medidas de prevención dirigidas a la población de riesgo

4.4.2.3. Medidas de prevención dirigidas a toda la sociedad valenciana

4.5. SÍNTESIS 



\section{CAPITULO 4. ROL DEL PSICÓLOGO EDUCATIVO EN SITUACIONES DE CIBERBULLYING}

La Conselleria de Educación considera la orientación educativa como un proceso de ayuda que favorece la calidad y la mejora de la educación en los centros docentes, puesto que debe facilitar el conocimiento sistemático de las diferencias individuales y la respuesta organizada más adecuada. Además, la orientación educativa, constituye un elemento importante y decisivo de atención a la diversidad y, por ello, tiene como finalidad lograr una formación personalizada que propicie el desarrollo integral en conocimientos, destrezas y valores del alumnado en todos los ámbitos de la vida: personal, familiar, social y profesional. La orientación del alumnado forma parte de la función docente y corresponde ejercerla a todo el profesorado. El tutor o la tutora de cada grupo realizará su actividad orientadora o tutoría prestando una atención individualizada al alumnado en sus procesos de enseñanza y aprendizaje.

En concreto, la reconocida National Association of Schools Psychologists (NASP, 2005) define al psicólogo educativo como miembro del equipo escolar que apoya la habilidad de los estudiantes para aprender y la habilidad de los maestros para enseñar. Así su función es la de aplicar conocimientos especializados en aprendizaje y comportamiento para ayudar a los niños y jóvenes a tener éxito académico, social, conductual y emocional. Los psicólogos escolares se asocian con familias, maestros, la comunidad escolar en su conjunto y otros profesionales para crear entornos de aprendizaje seguros, saludables y de apoyo, que fortalecen las conexiones entre el hogar, la escuela y la comunidad.

La existencia de estos servicios o profesionales especializados en la orientación educativa, psicopedagógica y profesional están establecidos en el Estado Español como recurso fundamental para la mejora de los aprendizajes y apoyo al profesorado en la Ley Orgánica de Educación 2/2006 del 3 de mayo.

En concreto, el Decreto 131/1994, de 5 de julio, regula los servicios especializados de orientación educativa, psicopedagógica y profesional, y en el artículo cuarto, incluye en la estructura de los servicios especializados aludidos, los servicios psicopedagógicos escolares. Este decreto especifica que las funciones generales de los servicios especializados de orientación educativa, psicopedagógica y profesional son las siguientes:

a) Participar en el apoyo y asesoramiento a los centros educativos.

b) Elaborar y difundir materiales e instrumentos de orientación educativa y de intervención sociopsicopedagógica y logopédica en las dos lenguas oficiales de la Comunidad Valenciana.

c) Coordinar las actividades de orientación educativa y sociofamiliar que se realicen en los centros docentes de su ámbito de actuación.

d) Asesorar al profesorado en el tratamiento de la diversidad del alumnado. 
e) Asesorar al profesorado en el diseño de procedimientos e instrumentos de evaluación, tanto de los aprendizajes del alumnado, como del mismo proceso de enseñanza.

f) Detectar aquellas condiciones personales y sociales que faciliten o dificulten el proceso de enseñanza y aprendizaje del alumnado y su adaptación al ámbito escolar.

g) Realizar la evaluación y la valoración sociopsicopedagógicas y logopédicas del alumnado, para la determinación de su escolarización más adecuada y, si procede, elaborar la propuesta de diversificación curricular o de adaptación curricular significativa y, en su caso, realizar el tratamiento logopédico y rehabilitador.

h) Colaborar en la orientación académica, para favorecer en el alumnado la toma de decisiones.

i) Colaborar en la orientación del alumnado en los procesos de transición a otras etapas e itinerarios educativos, y al mundo del trabajo.

j) Llevar a cabo la orientación psicopedagógica sobre el proceso de enseñanza y aprendizaje y sobre la adaptación personal y social en el ámbito educativo.

k) Asesorar a las familias o a los representantes legales del alumnado, participando, en su caso, en el desarrollo de programas formativos de padres y madres de alumnos.

Además de las funciones generales, en este mismo decreto se concreta cuál es la estructura y la composición de dichos servicios. En cuanto a la estructura de los servicios de orientación educativa, psicopedagógica y profesional se indica lo siguiente:

a) Servicios psicopedagógicos escolares de sector. Su ámbito de intervención comprende los centros docentes sostenidos con fondos públicos de Educación Especial, Infantil, Primaria y Secundaria.

b) Departamentos de orientación en institutos de Educación Secundaria.

c) La Conselleria de Educación y Ciencia podrá crear otros servicios especializados sectorizados que, en su caso, podrán funcionar como centros de recursos para optimar la dedicación de los servicios de orientación y para atender al alumnado que requiera de una cualificación específica y otras demandas del sistema educativo que redunden en la calidad global de la enseñanza.

Respecto a la composición se añade:

1. La composición de los servicios psicopedagógicos escolares se adecuará a las necesidades de la población escolar que le corresponda atender, la tipología y el número de centros, la especificidad de la intervención, el ámbito geográfico de su actuación y los recursos educativos existentes.

2. Los profesionales que compondrán los servicios psicopedagógicos escolares podrán ser:

a) Funcionarios del cuerpo de profesores de Enseñanza Secundaria de la especialidad de Psicología y Pedagogía. 
b) Funcionarios del cuerpo de maestros de la especialidad de Educación Especial (Audición y Lenguaje).

c) Trabajadores sociales.

d) Otros profesionales, en su caso.

Así pues, estas serían las funciones, estructura y composición general de los servicios de orientación. Si se especifica un poco más en la temática estudiada, el ciberbullying, se puede observar que el papel del psicólogo educativo en relación a este fenómeno estaría especificado en algunas de sus funciones, siendo la principal la detección de aquellas condiciones personales y sociales que faciliten o dificulten el proceso de enseñanza y aprendizaje del alumnado y su adaptación al ámbito escolar. Además de esta función, de ella derivarían otras como la participación en el apoyo y asesoramiento a los centros educativos; la elaboración y difusión de materiales e instrumentos de orientación educativa y de intervención y la coordinación de las actividades de orientación educativa y sociofamiliar.

\subsection{PSICÓLOGO EDUCATIVO. ¿QUÉ DEBE SABER?}

El psicólogo educativo, como hemos nombrado, realiza muchas funciones. Una de ellas es la detección y evaluación. Para ello, ante situaciones de ciberbullying es muy importante que conozca los síntomas y cambios que provocan en las víctimas el ciberbullying, así como también debe tener información sobre todo aquello que hay que identificar relacionado con los ejecutores y participantes de la agresión.

En primer lugar, vamos a presentar, respecto al perfil de la víctima, cuáles son los cambios más frecuentes que suelen experimentar (Inteco, 2012; Garaigordobil, 2011a; Kowalski \& Limber, 2013; Hinduja \& Patchin, 2010; Generalitat de Catalunya, 2014). Para el psicólogo educativo es fundamental conocerlos puesto que son determinantes para la detección y posterior intervención.

\section{- Cambios en sus hábitos:}

- En el uso de dispositivos móviles o de Internet.

- De asistencia a clase.

- Ausencias tanto en forma de fugas como comportamiento de evitación.

- En altibajos en los tiempos de estudio y en el rendimiento académico.

- De variaciones en sus actividades que hasta el momento realizaba con asiduidad.

- En relación con los adultos, en cuanto a la frecuencia y dependencia de ellos.

- En cuanto a su capacidad de concentración y de mantenimiento de su atención.

- Por variabilidad de grupos de referencia. 
- Cambios en el estado de ánimo:

- Fundamentalmente en el humor, como mayor irritabilidad, cólera y rechazo a situaciones habituales.

- En actitudes de relajación y tensión, incluso de reacción agresiva inusual.

- Considera que quitarle el ordenador u otro dispositivo es el peor de los castigos.

- Ansiedad provocada por el nerviosismo e inquietud relacionada con la actitud de espera del acontecimiento temido.

- Miedo a ir al colegio o quedarse solo.

- Crisis de angustia agudas ante una amenaza o una situación de peligro inminente.

- Síntomas depresivos como tristeza, apatía, anhedonia, abulia, astenia o fatiga.

- Baja autoestima.

- Conductas autolesivas a través del daño corporal.

\section{- Cambios en su red social:}

- Intercambios extraños de red social y/o por repentina pobreza, ausencia de amistades y de relaciones sociales.

- Falta de defensa ante supuestas bromas públicas u observaciones públicas, inocuas aparentemente a ojos de los adultos.

- Miedo u oposición a salir de casa.

- No suele hablar de lo que hace o dice en internet.

- Se molesta cuando se le interrumpe cuando hace uso del ordenador o de otro dispositivo.

\section{- Cambios físicos o en sus pertenencias:}

- En su lenguaje corporal ante determinadas presencias: hombros encorvados, cabeza gacha, falta de contacto en ojos, rechazo de la presencia pública, etc.

- En la ocupación de espacios escolares: cercanía a adultos, miedo a recreos, ocupación de rincones, paredes y espacios protegidos y controlables visualmente, etc.

- De ocultamiento especial cuando se comunica por Internet o móvil.

- Explosiones agresivas momentáneas.

- Manifestaciones de enfermedad o dolencias frecuentes.

- Pérdida y/o deterioro de pertenencias físicas, lesiones físicas frecuentes sin explicación razonable. 


\section{- Cambios psicosomáticos:}

- Aumento o pérdida de peso rápido derivados de cambios en el comportamiento ante la comida: falta de apetito o comidas compulsivas.

- Mareos frecuentes con síntomas no comunes.

- Dolor de cabeza o estómago que no ocasionan despertares nocturnos pero que impiden realizar actividades normales como el ir al colegio.

- Diarreas frecuentes sin ir acompañadas de vómitos o fiebres.

- Trastornos de sueño como parasomnias, terrores nocturnos, pesadillas o insomnio.

En lo relacionado con los ejecutores y participantes de la agresión, siguiendo las pautas que aporta Pedreira (2015) sobre ciberbullying para profesionales de la salud, hay que identificar diferentes aspectos, que al igual que con las víctimas, van a permitir al psicólogo detectar si un determinado alumno está siendo agresor de ciberbullying.

- Aspectos comportamentales:

- Utilización de diversas cuentas online.

- Haber intimidado o acosado a algunos de sus compañeros en la escuela.

- Justificar situaciones de ciberbullying protagonizadas por otros.

- Faltar al respeto a la autoridad, los docentes o los padres y madres.

- Mostrar actitudes de prepotencia, de abuso de poder y de falta de respeto de sus iguales.

- Factores de personalidad (Garaigordobil, 2011b):

- Actitudes agresivas.

- Escasa empatía.

- No reconocimiento de las consecuencias de sus actos.

- Círculo de amigos agresivos.

- Escasa tolerancia a la frustración.

- Hiperconsumo de TIC en relación al funcionamiento personal (Echeburúa \& De Corral, 2010):

- Irritabilidad creciente.

- Cierto ensimismamiento.

- Fracaso escolar creciente.

- Absentismo escolar.

- Alteración del sueño.

- Alteración del ritmo, secuencia y cantidad de la conducta alimentaria.

- «No se apaga el teléfono móvil» nunca, ni por la noche.

- La potencia del «amigo virtual» para tomar determinadas decisiones. 
Teniendo en cuenta los indicadores anteriores, así como lo que la literatura científica pone de manifiesto respecto a aquellos aspectos del agresor y la victima en cuanto al ciberbullying, hemos elaborado una rejilla para padres y profesores, que tienen los mismos ítems, lo cual nos permitirá contrastar las observaciones de unos y otros, con el fin de que el psicólogo educativo pueda tener un primer punto de información para poder diseñar mejor su proceso de actuación. La rejilla (anexo 1) consta de los datos de identificación; si es padre, madre, profesorado y alumnado, así como la fecha de cumplimentación de la misma. Los ítems deben de contestarse poniendo una cruz en Sí, A VECES y NO.

\subsection{PSICÓLOGO EDUCATIVO Y COMUNIDAD EDUCATIVA. ¿QUÉ HACER?}

De este modo, tal y como se ha citado anteriormente, las funciones del orientador educativo son muchas. Respecto al tratamiento de la violencia escolar, entendida como una condición personal y social que dificulta el proceso de enseñanza y aprendizaje del alumnado y su adaptación al ámbito escolar, los centros escolares y en concreto los orientadores educativos, deben tratar la violencia escolar promocionando escuelas seguras. Así, la National Association of Schools Psychologists (NASP, 2006) reconoce que el acoso y la agresión entre iguales son formas de violencia escolar que pueden poner en peligro el bienestar psicológico y emocional de los niños y adolescentes, por lo que anima a los orientadores escolares a asumir un papel relevante en cuanto al desarrollo de estrategias para reducir la violencia escolar. Es por ello que entendiendo el ciberbullying como un modo de acoso entre iguales, los orientadores de los centros deben responder a esta problemática y asumirlo en su práctica profesional.

El papel de los orientadores respecto al ciberbullying debe ser el de agente de cambio dirigido a abordar esta temática en los centros educativos y proporcionar directrices para la promoción de la sensibilización, evaluación, prevención e intervención (Diamanduros, Downs \& Jenkins, 2008), al que se añadiría una quinta función contemplada en los Protocolos de Apoyo Inmediato y coordinado a Víctimas Escolares (Región de Murcia, 2015), que se trataría del seguimiento del proceso.

Con todo ello, en el rol del orientador en cuanto al ciberbullying, visualizamos dos ejes de actuación. Por una parte, el orientador debe trabajar estos cinco aspectos fundamentales que forman la parte esencial de su trabajo. En este eje determinaríamos qué es lo que se trabaja desde el departamento de orientación, y aquí se estaría hablando de la sensibilización, detección, prevención, intervención y seguimiento. Pero para tratar este tipo de temáticas el qué es muy importante, pero lo es más si cabe el quién, y este sería el segundo eje de actuación del orientador. Este segundo eje relacionado con el quién lo formarían los centros docentes, las familias y los alumnos, pues éstos serán los tres agentes sobre los que trabajará el orientador al tratar el fenómeno del ciberbullying, dado que son figuras esenciales en dicho proceso si lo que se persigue es el éxito de las acciones emprendidas (Hinduja \& Patchin, 2014). 
De este modo, las acciones que un orientador debe ejercer en relación al ciberbullying deben ser desarrolladas tanto por los orientadores de los SPE como de los Departamentos de Orientación, puesto que la labor debe ser de sensibilización, prevención, detección, intervención y seguimiento. Esto hace imprescindible que el especialista en orientación empiece a trabajar todos aquellos aspectos relacionados con el ciberbullying desde edades muy tempranas, puesto que como muestran muchos estudios recientes como los presentados en el capítulo de la Sociedad del Siglo XXI, los menores empiezan a utilizar las nuevas tecnologías desde edades muy tempranas, disponen de dispositivos propios y han creado perfiles en redes sociales, lo que hace necesario empezar a abordar la temática tan pronto como sea posible.

Respecto a la estructura del servicio, se especifica que estos profesionales atenderán tanto a Educación Infantil y Primaria como a Educación Secundaria. Los primeros serán atendidos a través de los Servicios Psicopedagógicos Escolares (SPE) y los segundos por los Departamentos de Orientación. En ambos casos, como se puede observar en la composición del servicio de orientación anteriormente nombrado, formará parte de él un funcionario del cuerpo de profesores de Enseñanza Secundaria de la especialidad de Psicología y Pedagogía. Así, en el caso del ciberbullying, las acciones que se emprendan en este ámbito dentro del servicio de orientación serán puestas en marcha por este profesional.

En concreto en el presente trabajo se remarca especialmente el papel que toma el orientador de los SPEs, ya que el trabajo se inicia en el caso del ciberbullying en la Educación Primaria con la sensibilización y prevención, puesto que como bien sabemos y se ha indicado anteriormente, las tecnologías de la información y comunicación empiezan a ser utilizadas por los menores desde edades muy tempranas por lo que la atención en estos aspectos deben ser atendida desde el inicio de su escolarización mediante medidas de sensibilización y prevención a la problemática.

Así, el orientador cuando emprende acciones contra el ciberbullying debe actuar teniendo en cuenta dos ejes que son el qué y el quién, aunque finalmente todas ellas deben confluir e ir en el mismo camino y dirección. De este modo, el orientador debe atender a los tres grandes grupos que están relacionados con las situaciones de ciberbullying: familia, centro y alumno, y trabajará con ellos aspectos como son la sensibilización, prevención, detección, intervención y seguimiento.

\subsubsection{Alumnos}

Los alumnos se consideran el eje de la problemática, es por ello que el orientador debe tomar diferentes roles según el momento en el que se encuentre.

\section{Sensibilización}

Inicialmente, el orientador debe tomar el papel de asesor e informador, en el que se presente a los alumnos con la finalidad de informarles y sensibilizarles sobre la 
problemática del ciberbullying para que éstos la conozcan y tomen conciencia real de su importancia, puesto que la sensibilización es el primer paso de la prevención.

Para poner en marcha estas acciones se pueden organizar desde el Servicio de Orientación la elaboración de dípticos con información sobre el fenómeno del ciberbullying para que los estudiantes lo conozcan, así como datos sobre las consecuencias y la importancia de este tipo de problemática. Con dicha finalidad se han elaborado diferentes recursos:

- "Pack Multimedia Educativo Ciberbullying” (Flores \&Casal, 2008), se trata de juegos multimedia virtual dirigidos a menores entre 6 y 11 años, que contiene:

- Una historia animada titulada "El cibervampiro abusón". Se relata la historia de un del acosador que es un ente que ataca al menor descuido. Van Tekling, que es el cazavampiros, introduce el tema citando casos en los que los niños y niñas fueron víctimas del "cibervampiro abusón". A continuación, se muestra cuatro historias reales donde los protagonistas cometieron una imprudencia, que el jugador habrá de detectar.

- Dos juegos interactivos:

- "La respuesta adecuada": El juego simula el envío de mensajes por el móvil. Se reciben sucesivamente SMS a los que es preciso dar respuesta eligiendo una entre las posibles. En función de si lo respondido es o no adecuado para evitar situaciones de acoso, cambia el aspecto del abusón y del personaje acosado que representa al jugador.

- "Aventura en el ciberespacio": Los "ciberaliens" aparecerán en los diversos entornos en los que se manifiesta el ciberbullying: internet, teléfono móvil o juegos online. En esos escenarios habrán de ser localizados y neutralizados en duelo, que se resolverá a nuestro favor en el caso de que encontremos respuestas adecuadas a las preguntas.

- Página web de Pantallasamigas se pueden encontrar diferentes videos de sensibilización del ciberbullying, tales como:

- Decálogo por la ciberconvivencia positiva y contra la violencia digital.

- Las 10 claves para usar Internet con seguridad.

- Recomendaciones para el Uso Seguro de Internet y las Redes Sociales.

- ¿Estás segura que puede confiar en quien está al otro lado de la Red? ¡Piénsalo!

- Privacidad y ciberacoso en redes sociales: limita tus contactos.

- "Guía para conocer el ciberbullying y algunos peligros de internet y las nuevas tecnologías: No te enredes en la red". (Collell \& Escudé, 2008b). Este material 
proporciona información sobre el ciberbullying y una serie de actividades para conocer bien y ser conscientes de algunos peligros que podemos encontrar cuando se utilizan internet y las nuevas tecnologías. Así, entre otras, encontramos actividades como:

- "La historia de Samantha" y "La historia de Miky": se expone un caso de ciberacoso y hay que analizarlo en pequeños grupos.

- "Los chats": aspectos positivos y negativos del uso de los chats.

- "El teléfono móvil": analizar las ventajas y los inconvenientes del uso de este dispositivo.

\section{Prevención}

Ésta se considera esencial en la temática del ciberbullying, pues es bien sabido que la sensibilización y prevención inicial hacia la temática es el eje fundamental del funcionamiento de cualquier acción que se emprenda. De este modo formar a los alumnos en habilidades sociales como la empatía, asertividad, prevención y resolución de conflictos, autoestima, emociones y autocontrol, junto con formación relacionada con el buen uso de las tecnologías de la información y la comunicación, es fundamental para un buen trabajo de prevención.

Teniendo en cuenta lo anterior, consideramos relevantes estas habilidades sociales puesto que forman parte esencial en el desarrollo de una persona, y el desarrollo de éstas puede facilitar en el alumno la sensibilización hacia la problemática del ciberbullying y también la adquisición de destrezas que le permitan prevenirlo o incluso afrontarlo en el caso que sea necesario. Además de estas habilidades, el alumno debe disponer de unos conocimientos básicos en cuanto al ciberbullying, es decir debe conocer de qué se trata y la importancia de ésta, así como tener ciertas competencias que le permitan hacer un buen uso de las tecnologías de la información y la comunicación.

Por tanto, la formación de los alumnos en estas habilidades puede ser gestionada por el orientador, y al mismo tiempo debería contar con la colaboración del profesorado de forma que estos contenidos, necesarios para la prevención del ciberbullying, se incluyan en el horario de tutorías o insertado a modo de actividades en el currículum escolar.

Al respecto, podemos utilizar una serie de recursos entre los que se encuentran:

- "Guía de los alumnos" perteneciente al Plan de Prevención del ciberacoso y promoción de la navegación segura en centros escolares (Sánchez-Pascuala, s.f.,a) en la que se ofrecen pautas a los alumnos para hacer un uso correcto de Internet respondiendo a dos preguntas:

- ¿Qué debes hacer cuando navegas por Internet?

- Siempre utilizar un nombre secreto. Tus datos personales son siempre tuyos. 
- Habla con tus padres.

- Cuida de tu ordenador.

- Ignora el spam.

- Demuestra que sabes utilizar Internet

- ¿Qué no debes hacer cuando navegas por Internet?

- Nunca te fíes de los extraños. Un desconocido no es tu amigo o tu amiga.

- No acuerdes nunca citas con desconocidos a través de Internet.

- Recuerda que Internet no es un medio para insultar o molestar a la gente.

- No te creas los regalos y los chollos.

- Recuerda que los virus acechan constantemente.

- Decálogo "ilnternet es muy positivo, pero tengo que respetar las normas!" (Protégeles, 2013) en el que se describen doce recomendaciones para hacer un buen uso de Internet:

- No des información personal a aquellos que no sean de tu confianza.

- No incluyas datos personales en tu dirección de e-mail.

- Usa contraseñas seguras, complicadas y secretas.

- No subas fotografías o vídeos de otros sin su consentimiento.

- No abras correos ni archivos adjuntos de desconocidos nunca.

- No creas todo lo que se dice en Internet: muchas cosas son falsas o erróneas.

- Utiliza la webcam solo con personas que conoces cara a cara.

- No tengas citas a ciegas con desconocidos.

- Ten presente que Internet no es anónimo.

- Acepta como amigos tan solo a aquellos que conoces tal solo en persona.

- Insultar, amenazar, robar contraseñas y hacerte pasar por otras personas son delitos.

- Cuidado con la información que subes, ya que puede ser vista por cualquiera y puede permanecer en la red toda la vida.

\section{Detección}

El orientador debe asesorar a los alumnos, así como informarles de la importancia de la detección entre los propios alumnos de modo que aprendan a romper la ley del silencio, puesto que es esencial una detección temprana y para ello los alumnos deben conocer bien qué indicios hay que tener en cuenta y qué acciones implican el ciberbullying.

- "El acoso escolar es violencia ino lo permitas!", publicado por Protección online (s.f.), incluye el concepto de ciberbullying y una serie de pautas a seguir ante la detección de situaciones de ciberbullying, entre ellas: 
- Si observas que un compañero o compañera acosa a otro niño o niña:

- Puede que sientas miedo o rechazo ante esa situación, pero actúa.

- Si ves que tú solo no puedes ponerle freno y que no es lo más conveniente; pide ayuda a un adulto. Esto no es chivarse, es ser solidario con quien lo necesita.

- Apoya al compañero o compañera que está siendo acosado. Nadie merece que le traten mal.

- Si agredes a algún compañero o compañera:

- Pregúntate: “¿Qué es lo que me sucede?, ¿por qué me hace gracia o me siento más fuerte cuando molesto a otras personas?"

- Piensa cómo se debe sentir la persona a la que le estás haciendo daño.

- Habla de lo que te sucede con algún adulto. Alguien que te escuche y te ayude.

- Controla tus emociones para que éstas no te controlen a ti. La violencia no es una buena manera de responder.

- Si un compañero o compañera te hace daño con frecuencia y durante un cierto tiempo:

- Es posible que te sientas triste, temeroso, avergonzado y culpable, porque sufres una situación injusta.

- No guardes el secreto. Si hay algo que te hace daño, no te lo calles. Hablarlo no es chivarse, es exigir el respeto que todos merecemos.

- Cuéntalo a tus padres o algún adulto de confianza. Es importante que lo cuentes en el colegio.

- Procura no estar solo y evita situaciones o lugares que puedan ser arriesgados.

- No respondas de la misma manera, es decir, agrediendo.

- En el momento en el que te hacen daño crea un escudo imaginario a tu alrededor que te proteja. Todo lo que te están diciendo rebota como una pelota. Respira, piensa que eres fuerte.

- Todos tenemos derecho a ser protegidos contra cualquier forma de violencia y a ser tratados con respeto.

En este apartado también debemos nombrar la formación, puesto que es recomendable formar a los alumnos en la detección, que sepan diferenciar claramente cuáles son las acciones que implican ciberbullying, así como también que sepan cómo actuar en el 
momento que observan una determinada situación que podría tratarse de ciberbullying. Por supuesto, se les debe presentar a algún adulto de referencia a quién acudir cuando se detecta algún caso, y que sean conscientes de la importancia de esta detección temprana. Para esta detección, y debido a que muchas veces les resulta complicado verbalizar situaciones de esta índole, bien por miedo o vergüenza, sería conveniente establecer en el centro medios y procedimientos que faciliten la detección o comunicación de las situaciones de ciberbullying como podría ser un buzón de quejas, una dirección de correo, etc. donde transmitir de forma anónima a modo de mensaje qué es lo que ha observado para que desde el centro se tomen las medidas oportunas. Estas medidas serían adecuadas para la recogida de datos cualitativos a partir de observaciones de los estudiantes. Por otra parte, el mismo orientador puede poner en marcha acciones de detección con medidas de recogida directa de datos para determinar la prevalencia de ciberbullying en el centro y datos sobre la ciberconducta, lo que permitiría al orientador saber si se podría estar en riesgo de futuras experiencias de ciberbullying. Para dicha finalidad hay diferentes instrumentos de evaluación (Lucas, Pérez \& Giménez, 2016) a partir de los cuales se puede evaluar el ciberbullying.

\section{$>$ Intervención}

Aquí, igual que en el resto de fases, es fundamental la función y el acompañamiento del orientador puesto que es aquí donde se debe intervenir directamente sobre el alumnado, tanto en los implicados en los hechos como en el resto de la audiencia cercana a los implicados, que sería generalmente el grupo clase. El orientador debe asesorar e informar directamente a los implicados individualmente para tratar de abarcar el fenómeno lo más pronto posible para así minimizar sus efectos y actuar de la forma más contundente y efectiva posible. En este punto, el rol del orientador se centraría en dotar al alumnado de habilidades que le ayuden a afrontar positivamente la situación que están viviendo de modo que pueda salir de ella, y salir reforzado para que no vuelva a suceder.

Así, en la intervención sería esencial la realización de un plan de actuación y tratamiento. Para ello lo principal es conocer previamente la realidad del alumno para posteriormente actuar tanto a nivel del alumno como a nivel familiar, con los profesores, con el acosador en el caso que sea alguien que pertenezca al centro y también con el grupo clase. Esta actuación debe llevar una evaluación y un seguimiento continuo.

Entre las pautas que se le pueden proporcionar al alumno que está sufriendo este tipo de acoso para saber qué hacer ante el ciberbullying, en "El acoso escolar es violencia ino lo permitas!", publicado por Protección online (s.f.) se especifican las siguientes acciones:

- Si sufres algún ataque o agresión, no respondas.

- Guarda los mensajes como prueba. No tienes que abrirlos.

- Bloquea al remitente. 
- Cuéntaselo a tus padres, tutores, profesores o algún adulto en quien confíes.

- A través de una página web o servicio de internet puedes poner una denuncia. En todas las redes sociales puedes hacer clic en el botón denuncia.

- También puedes escribir a cualquiera de las siguientes páginas para pedir información o denunciar: www.gdt.guardiacivil.es y www.policia.es

En cuanto a la intervención con los acosadores (Giménez \& Rubio, 2007), esta debe ir encaminada a:

- No justificar en ningún momento los hechos agresivos.

- Ajustar y recordar de forma clara las normas de funcionamiento de la clase y las reglas del grupo.

- Ejercitar la tolerancia y el respeto.

- Trabajar la igualdad de sexos, razas y culturas.

- Trabajar en clase la resolución de conflictos desde estrategias no violentas

- Ejercitar el papel de ponerse en el lugar de la víctima.

- Enseñar disciplina y exigir al agresor actitudes de arrepentimiento y de reparación por el daño causado.

- Si es necesario sancionar la conducta no deseada para educar en la responsabilidad.

Seguimiento

Una vez realizada la intervención, y tomadas las medidas oportunas, tanto con el alumno agresor como con el agredido, es necesario llevar un seguimiento del caso para valorar la efectividad de las medidas tomadas así también como la posibilidad de retomar las acciones que sean pertinentes en el caso que se requieran nuevas medidas.

Con dicha finalidad se podrían realizar entrevistas semiestructuradas a los alumnos, tanto a los implicados como a los compañeros de clase, para que den su visión sobre la situación en el aula y cómo ven a sus compañeros. También sería adecuado elaborar guías de seguimiento donde se detallen las acciones a llevar a cabo por los alumnos en esta fase del proceso, así como la realización de juegos de simulación, etc.

Podemos pensar que el trabajo del orientador finaliza tras la acción que emprende con los alumnos, pero esta actuación no se reduce a esto, puesto que para que la función de este profesional sea eficaz se debe centrar también en los dos focos restantes de la problemática, pues el papel de la familia y del centro es esencial para abarcar una situación 
de ciberbullying. Fenómenos como estos no se pueden abordar centrándose sólo en los alumnos puesto que puede suceder tanto dentro como fuera del centro y, por ello, es esencial que familiares y profesores sepan responder y actuar eficazmente.

\subsubsection{Centros Educativos}

El orientador, debe asesorar, informar, formar y apoyar a los centros educativos para dotarlos de las herramientas necesarias para la sensibilización, prevención, detección, intervención y seguimiento. Es imprescindible que toda la comunidad educativa se involucre en el ciberbullying, que sean conscientes de su existencia, que se les dé información sobre su importancia y sobre la relevancia que toman ellos en dicho proceso, puesto que el orientador necesita de la colaboración de todo el centro para que las acciones que emprendan tomen sentido y sean eficaces.

\section{Sensibilización}

Hay que formar a los docentes en el fenómeno del ciberbullying para sensibilizarles sobre la temática mediante la realización de talleres, formación online o folletos informativos con la finalidad de promover su conocimiento. Así, la sensibilización a los docentes podría contemplar contenidos como:

- Situación actual del uso de las nuevas tecnologías por parte de los menores.

- Definición del concepto ciberbullying.

- Roles existentes.

- Consecuencias de estos actos.

- Hacer conscientes a los docentes del importantísimo papel que juegan y de la necesidad de contar con ellos para la realización de programas de prevención y de intervención del ciberbullying.

Para ello, podíamos utilizar una serie de recursos como:

- Recortes de prensa donde se pone de manifiesto la realidad actual.

- Casos reales de ciberbullying como los que se recogen en la página ciberbullying.com:http://www.ciberbullying.com/cyberbullying/casos-deciberbullying/

- Videos:

- El caso de Amanda Todd.

- Ciberbully (película 2011): es una película dramática estadounidense que sigue a Taylor Hillridge, una adolescente que cae víctima del acoso cibernético.

- Ciberbully (película 2015): es una película televisiva británica protagonizada por una típica chica adolescente que vive una parte 
importante de su vida on-line y es acusada por un desconocido de ser una ciberacosadora.

- Si no lo haces en tu vida normal... ¿̇por qué lo haces en Internet?

\section{Prevención}

Existen una serie de actividades dirigidas a los alumnos sobre ciberbullying mediante las cuales los docentes puedan sensibilizar y prevenir la aparición del ciberbullying en sus aulas. En este sentido, el material "Ciberbullying: guía de recursos para centros educativos en casos de ciberacoso" (Luengo, 2011), proporciona una serie de recursos en forma de unidades didácticas dirigidas a los centros escolares con la finalidad de intervenir en la prevención de la aparición del ciberbullying. Entre estas unidades encontramos:

- La intimidad en la red.

- Relaciones entre acoso y ciberacoso.

- ¿ ¿Conoces cómo te protege la Ley en Internet? Derechos y responsabilidades en el uso cotidiano.

- Investigaciones sobre usos y abusos de las TIC por adolescentes y jóvenes ¿Conoces realmente lo que pasa y por qué pasa?

- Cómo hacer las cosas bien en la red.

- Un día cualquiera en Internet.

- Cuéntanos cómo ves Internet

\section{Detección}

Es imprescindible que los docentes tengan información y formación al respecto, puesto que son ellos los que interactúan todos los días con los alumnos y por tanto los que pueden hacer una detección más precoz. Para ello deben conocer perfectamente los indicadores de detección del ciberbullying, que se pueden consultar en la "Guía S.O.S contra el ciberbullying: educadores" (Inteco, 2014a), donde se recogen entre otros contenidos; la forma en que este problema se pone de manifiesto, destacando aspectos como los cambios en los hábitos en relación a diferentes ámbitos, cambios en el estado de ánimo, cambios en sus relaciones, y cambios y síntomas físicos y psicosomáticos. Conocer las formas de manifiesto permitirá a los docentes mediante la observación detectar en el aula cualquier alumno que pueda presentar indicios de estar sufriendo ciberbullying.

\section{Intervención}

El orientador siempre va a contar con el apoyo y respaldo del docente en el aula, así podrán actuar conjuntamente y tomar las medidas de intervención que consideren oportunas en el aula, que podrán ser entre otras: 
- La adopción de medidas de protección, seguridad y apoyo a la víctima, así como acciones para ampliar su círculo de relaciones.

- En cuanto al posible agresor, observar atentamente sus acciones y actitudes.

En cuanto a recursos de intervención, contamos entre otros con la "Guía SOS contra el ciberbullying: Educadores" (Inteco, 2014a) en la cual se detallan acciones sobre cómo actuar en el centro educativo al detectar un caso de ciberbullying, entre ellas:

- Hay que conseguir romper la barrera del miedo, haciendo comprender a los alumnos que el que lo está pasando mal requiere apoyo y no desprecio.

- Abrir un periodo de evaluación y reflexión que hay que utilizar para conocer lo que realmente está sucediendo y quiénes son los implicados en cualquier grado.

- Determinar las medidas que van a ser necesarias de manera inmediata para detener los efectos perjudiciales y minimizar los ya producidos.

- Contemplarse la retirada, sin destrucción de las pruebas, de los comentarios y materiales utilizados para hostigar al menor a fin de intentar restablecer cuanto antes su honor.

- Apoyar las medidas restauradoras de las relaciones personales más allá de las medidas disciplinarias y de castigo que tendrán siempre un carácter secundario.

- Proponer al acosador, con apoyo del acosado, el compromiso del cese del acoso, la restitución del daño y la petición de perdón al acosado.

\section{Seguimiento}

Dada la cercanía del docente al alumnado, el orientador solicitará al docente el seguimiento tanto de la víctima como del agresor, en el caso que se encuentren en la misma aula, para valorar; el grado de integración del alumno, su estado emocional, la adaptación social, etc. Como recursos podemos utilizar las reuniones de la Comisión de Coordinación Pedagógica, el desarrollo de guías de observación, desarrollo de entrevistas semiestructuradas con el profesorado, etc.

\subsubsection{Familia}

Puesto que este fenómeno se produce muchas veces fuera del centro escolar, y porque también estamos hablando generalmente de menores de edad, y la función de los familiares es más que esencial. De este modo, el orientador debe actuar con las familias al igual que con el resto de colectivos ofreciendo acciones de asesoramiento, información, formación y apoyo. 


\section{Sensibilización}

Conocer de la mejor manera posible la existencia de esta problemática, es uno de los puntos clave en la erradicación futura de esta problemática. Por tanto, hay que dotarles de aquellas herramientas que sean necesarias, y formarles en el ciberbullying para que ellos desde casa aprendan a actuar eficazmente y así trabajen conjuntamente con el centro educativo.

Esta fase de sensibilización es de vital importancia para que los padres sean conscientes de todo lo que implica el ciberbullying.

Los recursos que podemos facilitarles son entre otros:

- Recortes de prensa donde se pone de manifiesto la realidad actual.

- Casos reales de ciberbullying como los que se recogen en la página ciberbullying.com: http://www.ciberbullying.com/cyberbullying/casos-deciberbullying/

- Videos:

- El caso de Amanda Todd.

- Ciberbully (película 2011): es una película dramática estadounidense que sigue a Taylor Hillridge, una adolescente que cae víctima del acoso cibernético.

- Ciberbully (película 2015): es una película televisiva británica protagonizada por una típica chica adolescente que vive una parte importante de su vida on-line y es acusada por un desconocido de ser una ciberacosadora.

- Si no lo haces en tu vida normal... ¿¿por qué lo haces en Internet?

\section{$>$ Prevención}

En este apartado podríamos proporcionar a los padres una serie de consejos sobre la importancia de que sus hijos hagan un buen uso de internet, y que aprendan ciertas normas de utilización de Internet que deben llevarse a cabo en casa para la prevención del ciberbullying.

Así sería recomendable, tal y como se indica en la "Guía de la familia"(Sánchez-Pascuala, s.f.a), que las familias conozcan una serie de recomendaciones generales como:

- Aprender a conocer Internet.

- El fomento del diálogo y la comunicación.

- La importancia de los datos personales.

- La seguridad de tu equipo informático.

- La importancia de las normas de utilización.

Además de los aspectos tecnológicos, los padres también deben formar a sus hijos en habilidades sociales, entre otras: 
- Asertividad

- Autoestima

- Empatía

\section{Detección}

Sería conveniente que en las sesiones de formación que se realicen que se les ofrezcan pautas de detección para que ellos conozcan cuáles son las formas en las que se presenta el ciberbullying en sus hijos, de modo que puedan prestar atención a estos aspectos. En la "Guía S.O.S. contra el ciberbullying: padres" (Inteco, 2014b), se presentan las formas en las que el ciberbullying puede ponerse en manifiesto:

- Cambios en los hábitos en relación a diferentes ámbitos:

- En el uso de dispositivos o de Internet.

- En la asistencia a clase, por ejemplo, ausencias pobremente justificadas.

- Abandono o ausencia en actividades hasta ese momento preferidas.

- Altibajos en los tiempos de estudio y en el rendimiento del trabajo escolar.

- Variaciones en las actividades de ocio habituales.

- Modificación de los hábitos alimenticios.

- Disminución de la capacidad de concentración y de su mantenimiento.

- Ocultamiento especial cuando se comunica por Internet o teléfono móvil.

- Cambios en el estado de ánimo:

- Cambios de humor.

- Momentos de tristeza, apatía o indiferencia.

- Inusuales actitudes de relajación y tensión, incluso de reacción agresiva.

- Explosiones momentáneas de agresividad.

- Cambios en sus relaciones:

- Cambios extraños en el grupo de personas con las que se relaciona y/o repentina pobreza, ausencia de amistades y de relaciones sociales.

- Falta de defensa o exagerada reacción ante supuestas bromas u observaciones públicas. Estos comentarios pueden parecer inocuos a ojos de los adultos, pero contar con otros significados para el menor.

- Miedo u oposición a salir de casa.

- Excesivas reservas en la comunicación. 
- Cambios en sus grupos de amigos, en ocasiones cambios radicales.

- Variaciones en la relación con los adultos, en cuanto a su frecuencia y la dependencia de ellos.

- Variabilidad de los grupos y personas que tiene como referentes o modelos a seguir e imitar.

- Cambios y síntomas físicos y psicosomáticos:

- Modificaciones en su lenguaje corporal ante la presencia de determinadas personas: hombros encorvados, cabeza gacha, falta de contacto en los ojos, rechazo de la presencia pública, etc.

- En la ocupación de espacios escolares: cercanía a adultos, miedo a los recreos, ocupación de rincones, paredes y espacios protegidos y controlables visualmente, etc.

- Manifestaciones de enfermedad o dolencias frecuentes.

- Lesiones físicas frecuentes sin explicación razonable. También debe considerarse la pérdida y/o deterioro de pertenencias físicas.

- Mareos frecuentes con síntomas no comunes.

- Dolores de cabeza o de estómago que no ocasionan despertares nocturnos pero que impiden realizar actividades normales como el ir al colegio.

- Diarreas frecuentes sin ir acompañadas de vómitos o fiebres.

No debemos olvidar que en la mayoría de las ocasiones el ciberbullying se produce fuera de las aulas, por tanto, la detección en casa es esencial, pues allí donde el niño pasa más tiempo y son por tanto los familiares las personas que comparten más tiempo de ocio con ellos.

Si bien es importante el núcleo familiar, no podemos olvidar que hoy en día juega un papel importante en el ciberbullying el grupo de amigos. De ahí la importancia que tienen los padres de los amigos de nuestros hijos en esta fase de detección. Al respecto, sería adecuado "conocer" a dichos padres y poder tener una comunicación fluida con ellos.

\section{Intervención}

Es necesaria la acción conjunta de alumnos con el centro y por supuesto con la familia, ya que el ciberbullying como ya se ha detallado se da más fuera del centro, por lo tanto la tarea de intervención por parte de la familia es más que necesaria. Así el tutor en colaboración con el orientador colaborará con los familiares para la instauración de pautas de afrontamiento adecuadas mediante reuniones individuales del orientador con la familia 
en las que se les informará de la situación de su hijo y de las medidas puestas en marcha desde el centro.

No debemos olvidar que puede que sean los familiares los que detecten la situación de ciberbullying, y por tanto habrá que ofrecerles información sobre las pautas de actuación a seguir ante la detección de ciberbullying, y unos de los materiales que ofrece esta información y pautas es el "Decálogo de actuación Ciberacoso: padres."(Ministerio de Industria, energía y turismo, 2015):

- Escuchar y dialogar con su hijo.

- Reforzar su autoestima.

- No culpabilizarle.

- Trazar un plan.

- Comunicar la situación al colegio.

- Aconsejar a su hijo sobre cómo actuar ante el ciberacoso.

- Buscar la ayuda de expertos y denunciar el caso a las autoridades, en el caso que sea necesario.

Además de ello, es importante ofrecerles a las familias la posibilidad de expresar sus sentimientos, de modo que valoren la situación objetivamente, ofreciéndoles pautas para un afrontamiento adecuado de la situación en casa, y requiriendo en el caso que sea necesaria la atención de servicios externos.

\section{Seguimiento}

En esta última fase, el seguimiento, contar con el apoyo y la colaboración de la familia es imprescindible. Ésta debe hacer un seguimiento al hijo, observar la conducta de éste, ver el uso que hace de las tecnologías, tener una conversación fluida con él que les exprese cómo se siente, etc. Desde el centro es importante que mantengan una comunicación continuada con la familia para valorar conjuntamente la adecuación de las medidas emprendidas o la necesidad de la puesta en marcha de otras acciones.

\subsection{PLAN DE ACTUACIÓN EN UN CENTRO DE EDUCACIÓN INFANTIL Y PRIMARIA}

En cualquier centro educativo se hace necesaria la existencia de un plan de actuación en el que se determinen qué acciones hay que emprender cuando se detecta un caso de ciberbullying. Se trata de una serie de acciones que se deben seguir por parte de todos los implicados en el caso de ciberbullying para tratar de resolver con la máxima rapidez y eficacia posible toda aquella situación de ciberbullying que se detecte en el centro o en el ámbito familiar. 
Así, se diferenciarán dos tipos de acciones diferentes según si la detección del caso de ciberbullying se ha efectuado en casa por medio de los familiares o, por el contrario, se ha detectado en el centro escolar por parte de la comunidad educativa.

Actualmente encontramos vigente la ORDEN 62/2014, de 28 de julio, de la Consellería de Educación, Cultura y Deporte, por la que se actualiza la normativa que regula la elaboración de los planes de convivencia en los centros educativos de la Comunitat Valenciana y se establecen los protocolos de actuación e intervención ante supuestos de violencia escolar. En ella se presenta un Protocolo de actuación ante el acoso y/o ciberacoso.

A pesar de ello consideramos pertinente establecer un protocolo con pautas más determinadas; especificando las fases, los participantes, los recursos y las tomas de decisiones. Además de esto, diferenciamos dos tipos de planes de actuación, según si la detección se produce en el centro escolar o en la familia.

A. Centro Educativo. Es necesario que exista un plan de actuación en el que se deben seguir también una serie de fases de actuación que se detallarán a continuación.

- Fase I: El miembro de la comunidad educativa que detecta la situación se pone en comunicación con el director del centro educativo.

Los casos de ciberbullying al igual que los de bullying suelen ser detectados dentro de los centros educativos generalmente por parte de los profesores tutores, pues son ellos los que están en un contacto más directo y diario con los alumnos, aunque también cualquier persona de la comunidad educativa lo puede hacer (profesores especialistas, monitores del comedor, monitores de actividades extraordinarias, etc.). En este caso, cuando el miembro de la comunidad educativa detecte que se esté dando supuestamente un caso de ciberbullying, el primer paso a seguir sería ponerse en contacto con el director del centro para informarle al respecto.

- Fase II: Reunión del director del centro con el profesorado y el orientador del centro.

Tras la comunicación del miembro de la comunidad educativa al director del centro, es conveniente que éste se reúna con el resto del profesorado del centro, concretamente con el profesor tutor del alumno que está siendo víctima, así como también con el orientador del centro. En esta reunión se les informa del problema detectado y se solicita al profesorado su colaboración para la correcta detección (información acerca de la modalidad del acoso, dispositivo utilizado, frecuencia, pruebas de mensajes, etc.),y al orientador su ayuda para abordar el caso de la mejor forma posible.

- Fase III: Aportación por parte del orientador de pautas de actuación y materiales y puesta en marcha de las acciones.

En esta fase, una vez el orientador ya dispone de la información suficiente sobre el caso, es el momento en el que puede ofrecer al centro pautas de actuación adecuadas, así como 
la aportación de materiales de detección e intervención que sean necesarios en dicho caso. Entre ellas podemos determinar acciones como: aumento de la supervisión de los alumnos implicados por parte de la comunidad educativa, reuniones con los alumnos implicados en el acoso y/o con los compañeros, actividades grupales con el grupo clase, etc.

- Fase IV: Puesta en común y toma de decisiones.

Una vez reunido todo el equipo docente con el orientador, y con las pautas proporcionadas por éste último, es momento de poner de nuevo en común toda la información conseguida en las últimas acciones emprendidas para tomar una decisión al respecto y determinar si se trata o no de un caso de ciberbullying.

- Fase V: Seguimiento a la toma de decisión.

Ya tomada la decisión sobre el caso, en el supuesto que sea negativa la decisión, es decir, que se concluya que no se trata de un caso de ciberbullying, habría que cerrar el proceso, pero llevar un seguimiento de éste para que se siga haciendo observación y así asegurarse ciertamente que la decisión ha sido la correcta.

En el caso de determinar que sí se está produciendo una situación de ciberbullying, el centro educativo debe tomar medidas urgentes de actuación; reunirse con los alumnos implicados para informarles de las medidas que se van a llevar a cabo, de la importancia de los hechos, así como también se les van a proporcionar pautas de actuación de seguridad para la víctima tanto en el centro escolar como con el uso de las TIC, y la importancia de comunicar a un adulto cualquier tipo se situación de acoso. Además, debe ponerse en contacto con la familia para informarle al respecto, así como también con la institución educativa y con los responsables del Plan de Prevención de la Violencia y Promoción de la Convivencia (PREVI).

En la Tabla 40 se especifica el protocolo de actuación para el Centro Educativo en casos de ciberbullying, y para ello se especifican; las fases que se deben seguir, los implicados que participan en cada una de las fases, los recursos necesarios para el correcto desarrollo de las acciones pertenecientes a cada fase y las decisiones que habría que tomar en cada fase. 
Tabla 40. Protocolo de actuación para el Centro Educativo en casos de ciberbullying

\begin{tabular}{|c|c|c|c|c|}
\hline Fase & Participantes & Recursos & $\begin{array}{c}\text { Toma de } \\
\text { decisiones }\end{array}$ & Observaciones \\
\hline $\begin{array}{l}\text { I: El miembro de la } \\
\text { comunidad } \\
\text { educativa que } \\
\text { detecta la situación } \\
\text { se pone en } \\
\text { comunicación con el } \\
\text { director del centro } \\
\text { educativo. }\end{array}$ & $\begin{array}{l}\text { - Miembro de } \\
\text { la comunidad } \\
\text { educativa } \\
\text { - Director }\end{array}$ & $\begin{array}{l}\text { Informe escrito } \\
\text { sobre las } \\
\text { observaciones del } \\
\text { aula por parte del } \\
\text { profesor tutor. }\end{array}$ & $\begin{array}{l}\text { Si el proceso } \\
\text { debe seguir en } \\
\text { marcha o no. } \\
\text { Si: hay indicios. } \\
\text { No: no hay } \\
\text { indicios o falta } \\
\text { información al } \\
\text { respecto. }\end{array}$ & \\
\hline $\begin{array}{l}\text { II: Reunión del } \\
\text { director del centro } \\
\text { con el profesorado y } \\
\text { orientador del } \\
\text { centro. }\end{array}$ & $\begin{array}{l}\text { - Profesorado } \\
\text { - Director } \\
\text { - Orientador }\end{array}$ & $\begin{array}{l}\text { - Convocatoria de } \\
\text { reunión. } \\
\text { - Orden del día de } \\
\text { la reunión con los } \\
\text { puntos clave a } \\
\text { tratar. }\end{array}$ & $\begin{array}{l}\text { El papel que } \\
\text { cada agente va a } \\
\text { tomar en las } \\
\text { acciones a } \\
\text { emprender. }\end{array}$ & \\
\hline $\begin{array}{l}\text { III: Aportación por } \\
\text { parte del orientador } \\
\text { de pautas de } \\
\text { actuación y } \\
\text { materiales y puesta } \\
\text { en marcha de las } \\
\text { acciones. }\end{array}$ & $\begin{array}{l}\text { - Orientador } \\
\text { - Profesorado }\end{array}$ & $\begin{array}{l}\text { - Informe con } \\
\text { pautas de } \\
\text { actuación. } \\
\text { - Materiales de } \\
\text { detección e } \\
\text { intervención. }\end{array}$ & $\begin{array}{l}\text { Qué pautas de } \\
\text { actuación y } \\
\text { material es } \\
\text { necesario para } \\
\text { abordar la } \\
\text { situación. }\end{array}$ & \\
\hline $\begin{array}{l}\text { IV: Puesta en común } \\
\text { y toma de } \\
\text { decisiones. }\end{array}$ & $\begin{array}{l}\text { - Profesorado } \\
\text { - Director } \\
\text { - Orientador }\end{array}$ & $\begin{array}{l}\text { Informes sobre } \\
\text { todas las acciones } \\
\text { emprendidas y sus } \\
\text { resultados, así } \\
\text { como el estado de } \\
\text { la cuestión. }\end{array}$ & $\begin{array}{l}\text { Valoración de las } \\
\text { acciones } \\
\text { emprendidas } \\
\text { que valoren la } \\
\text { toma de } \\
\text { decisión final. }\end{array}$ & \\
\hline $\begin{array}{l}\text { V: Seguimiento a la } \\
\text { toma de decisión. }\end{array}$ & $\begin{array}{l}\text { - Profesorado } \\
\text { - Director } \\
\text { - Orientador } \\
\text { - Familia }\end{array}$ & $\begin{array}{l}\text { - No: plan de } \\
\text { seguimiento. } \\
\text { - Sí: entrevista con } \\
\text { la familia e } \\
\text { informar a la } \\
\text { institución } \\
\text { educativa. }\end{array}$ & $\begin{array}{l}\text { En función de la } \\
\text { decisión } \\
\text { tomada: } \\
\text { No: realizar un } \\
\text { plan de } \\
\text { seguimiento. } \\
\text { Si: informar a de } \\
\text { la situación a la } \\
\text { familia e } \\
\text { institución } \\
\text { educativa. }\end{array}$ & \\
\hline
\end{tabular}


B. Familia. En la línea de actuación de ciberbullying por parte de la familia, se deberían seguir las siguientes fases que se especifican a continuación.

- Fase I: Contactar con el director del centro educativo y con el orientador del mismo centro.

La primera acción a emprender cuando se detecte un caso de ciberbullying desde el ámbito familiar es ponerse en contacto con el centro educativo donde asiste el menor, en concreto con la dirección del centro y con el orientador. A éstos se les debe facilitar toda la información que tengamos (mensajes capturados, dispositivos utilizados en el acoso, frecuencia de los hechos, información de los agresores, etc.), así como indicarles los indicios y las observaciones que nos han hecho ver que el menor pueda estar sufriendo ciberbullying.

- Fase II: Seguimiento del caso por parte del centro para aportar indicadores.

En esta segunda fase del protocolo de actuación es necesario que el centro educativo continúe con las acciones, de modo que desde el centro se sigan aportando datos al caso que indiquen si se está produciendo una situación de ciberbullying. Para ello habría que informar al profesorado en una reunión, con la finalidad de aumentar la supervisión y vigilancia de la comunidad educativa y así obtener toda la información posible al respecto.

- Fase III: Toma de decisiones por parte del centro y de la familia.

La tercera fase de actuación sería la toma de decisión en la que tanto la familia como el centro decidan, en base a los indicadores detectados, si ciertamente se está produciendo ciberbullying, o si no es así y los indicios iniciales no indican que se trate de esta problemática.

- Fase IV: Seguimiento del caso en función de la decisión tomada.

En la fase anterior, toma de decisión, pueden ser dos las decisiones tomadas. Por una parte, se puede determinar que el alumno no presenta indicios de estar sufriendo ciberbullying. En este caso habría que seguir en alerta tanto por parte de la familia como del centro para descartar definitivamente que se esté dando ciberbullying o por el contrario que se sigan recabando datos que aporten más información al caso.

Por otra parte, en el caso que se determine que sí se está produciendo ciberbullying, el centro debe seguir el protocolo de actuación que tiene determinado en caso de acoso escolar, reuniendo de nuevo a la familia para informarles al respecto, y por supuesto, informar a la institución educativa (ver Tabla 41). 
Tabla 41. Protocolo de actuación para la familia en casos de ciberbullying

\begin{tabular}{|c|c|c|c|c|}
\hline Fase & Participantes & Recursos & $\begin{array}{c}\text { Toma de } \\
\text { decisiones }\end{array}$ & Observaciones \\
\hline $\begin{array}{l}\text { I: Contactar } \\
\text { con el director } \\
\text { del centro } \\
\text { educativo y } \\
\text { con el } \\
\text { orientador del } \\
\text { mismo centro. }\end{array}$ & $\begin{array}{l}\text { - Director } \\
\text { - Orientador } \\
\text { - Familia }\end{array}$ & $\begin{array}{l}\text { Informe que } \\
\text { recoja toda la } \\
\text { información } \\
\text { que la familia } \\
\text { ha recogido } \\
\text { hasta el } \\
\text { momento y } \\
\text { que le ha } \\
\text { hecho } \\
\text { sospechar. }\end{array}$ & $\begin{array}{l}\text { Valorar si la } \\
\text { información } \\
\text { proporcionada } \\
\text { es suficiente y } \\
\text { aporta indicios } \\
\text { de } \\
\text { ciberbullying. }\end{array}$ & \\
\hline $\begin{array}{l}\text { II: Seguimiento } \\
\text { del caso por } \\
\text { parte del } \\
\text { centro para } \\
\text { aportar } \\
\text { indicadores. }\end{array}$ & $\begin{array}{l}\text { - Director } \\
\text { - Orientador } \\
\text { - Profesorado }\end{array}$ & $\begin{array}{l}\text { Informe del } \\
\text { centro } \\
\text { educativo en el } \\
\text { que se recoja } \\
\text { toda la } \\
\text { información } \\
\text { detectada en el } \\
\text { centro. }\end{array}$ & $\begin{array}{l}\text { Ampliar la } \\
\text { información } \\
\text { desde el centro } \\
\text { educativo que } \\
\text { complemente } \\
\text { la aportada por } \\
\text { la familia. }\end{array}$ & \\
\hline $\begin{array}{l}\text { III: Toma de } \\
\text { decisiones por } \\
\text { parte del } \\
\text { centro y de la } \\
\text { familia. }\end{array}$ & $\begin{array}{l}\text { - Director } \\
\text { - Orientador } \\
\text { - Familia }\end{array}$ & $\begin{array}{l}\text { Informes sobre } \\
\text { todas las } \\
\text { acciones } \\
\text { emprendidas y } \\
\text { sus resultados, } \\
\text { así como el } \\
\text { estado de la } \\
\text { cuestión. }\end{array}$ & $\begin{array}{l}\text { Valorar si se } \\
\text { está } \\
\text { produciendo o } \\
\text { no una } \\
\text { situación de } \\
\text { ciberbullying. }\end{array}$ & \\
\hline $\begin{array}{l}\text { IV: } \\
\text { Seguimiento } \\
\text { del caso en } \\
\text { función de la } \\
\text { decisión } \\
\text { tomada. }\end{array}$ & $\begin{array}{l}\text { - Director } \\
\text { - Orientador }\end{array}$ & $\begin{array}{l}\text { - No: plan de } \\
\text { seguimiento. } \\
\text { - Sí: entrevista } \\
\text { con la familia e } \\
\text { informar a la } \\
\text { institución } \\
\text { educativa. }\end{array}$ & $\begin{array}{l}\text { En función de } \\
\text { la decisión } \\
\text { tomada: } \\
\text { No: realizar un } \\
\text { plan de } \\
\text { seguimiento. } \\
\text { Si: informar a } \\
\text { de la situación } \\
\text { a la institución } \\
\text { educativa. }\end{array}$ & \\
\hline
\end{tabular}

La importancia de tener un protocolo que facilite la comunicación entre todos los implicados sirve para conocer aquellos recursos que son más importantes en cada fase del proceso, quienes deben estar implicados y la decisión que hay que tomar al respecto en función de la información de la que dispongamos. 


\subsection{PLAN DE PREVENCIÓN DE LA VIOLENCIA Y PROMOCIÓN DE LA CONVIVENCIA (PREVI)}

EI PREVI (Plan de Prevención de la Violencia y Promoción de la Convivencia) es un plan impulsado por la Conselleria de Educación de la Comunidad Valenciana que ha sido concebido para dar respuesta a las necesidades detectadas por la propia comunidad educativa, y por tanto cada una de sus iniciativas están diseñadas para atender problemas concretos y reales. EI PREVI forma parte de un conjunto de medidas que fueron puestas en marcha a partir de la creación del Observatorio para la Convivencia Escolar en los Centros de la Comunitat Valenciana, por el Decreto 233/2004, de 22 de octubre, del Consell, dirigidas al fomento de la convivencia y la prevención de la violencia en los centros docentes. Este decreto, a su vez daba respuesta al Decreto 39/2008, de 4 de abril, del Consell, sobre la convivencia en los centros docentes no universitarios sostenidos con fondos públicos y sobre los derechos y deberes del alumnado, padres, madres, tutores o tutoras, profesorado y personal de administración y servicios.

Este plan contempla diferentes tipos de medidas:

- Medidas de prevención dirigidas al sistema educativo. Éstas han sido programadas para que a partir de los conocimientos y la información obtenida se intervenga con aquellos instrumentos que sean sencillos y operativos, de modo que se logre que toda la comunidad educativa se sienta segura, protegida y participante en un clima donde la violencia no sea una respuesta tolerable.

- Protocolos de actuación: protocolos para detectar e intervenir desde cualquier posición dentro del sistema. De esa forma un profesor, director, inspector, padre/madre, alumno o alumna puede saber en qué situación se encuentra, qué puede hacer, con quién puede contactar y qué puede esperar de la Administración Educativa.

- Registro Central: tiene por objeto registrar y analizar todos los casos de problemas de convivencia que se den en los centros.

- Recomendaciones: ayudar y orientar a padres y madres a reconocer si sus hijos o hijas son víctima de violencia escolar, o si se comportan de forma violenta en el centro escolar. A partir de ahí incluye orientaciones sobre qué hacer en cualquiera de los dos casos.

- Materiales y talleres: talleres de formación para la convivencia dirigidos a profesorado, alumnado y familias de la Comunitat Valenciana.

- Formación del profesorado: tiene por objeto mejorar la gestión del aula para la promoción de la convivencia, el aprendizaje constructivo, y la adquisición de habilidades para los procesos de negociación y mediación. 
- Fomento de las tutorías: la tutoría es un momento muy adecuado para educar en la convivencia. Pretendemos impulsar la figura del tutor como educador de la convivencia y mediador de conflictos.

- Planes de convivencia: cada centro elaborará y pondrá en marcha su Plan de Convivencia, como modelo de actuación, para abordar la prevención de situaciones conflictivas, la resolución pacífica de las mismas y la atención tanto al alumnado cuyo comportamiento no se ajuste a las normas de convivencia del centro, como al que necesite ayuda o protección.

- Buenas Prácticas, convocatoria de premios: promover la educación en la convivencia, potenciar al centro docente como un sistema de tolerancia, aceptación mutua y solidaridad y también incentivar a la comunidad educativa.

- Medidas de prevención concretas dirigidas a la población en riesgo con las que se pretende que todo el alumnado que sufra o pueda sufrir algún tipo de situación se sienta atendido inmediatamente.

- Unidades de Atención e Intervención: actuarán como observadores de la situación de violencia en los centros de las tres provincias, e informarán y redirigirán, como si de una oficina de atención se tratase y cuando sea el caso, a víctimas y a agresores a instituciones de psicoterapia.

- Protocolo de asistencia jurídica a docentes: protocolo es de aplicación al personal docente dependiente de la Conselleria de Cultura, Educación y Deporte que preste sus servicios en los centros docentes de titularidad de la Generalitat Valenciana.

- Protocolo conjunto: Educación - Oficinas de Atención a Víctimas del Delito: la Generalitat, consciente del problema existente establece medidas y protocolos de actuación que ayuden a prevenir y gestionar situaciones de conflicto en el ámbito educativo.

- Medidas de prevención y sensibilización dirigidas a toda la sociedad, ya que es necesario que el conjunto de la sociedad se implique si lo que se persigue es que las acciones emprendidas sean exitosas.

- Campañas de publicidad y sensibilización: cartelería y trípticos en todos los centros educativos y cuñas radiofónicas en cadenas musicales y una canción, y un spot de televisión.

- Charlas informativas: Charlas psicoeducativas sobre violencia escolar (qué es, cómo prevenirla y cómo intervenir cuando se produce) impartidas en todas las comarcas de la Comunidad Valenciana.

- Taller de formación - sensibilización para profesionales de los medios de comunicación: para clarificar conceptos, los factores de riesgo, la influencia de los medios a corto y largo plazo, y recomendaciones sobre "qué y cómo" informar. 
- Congreso Familia y Escuela: un espacio para la convivencia: para que se reflexione, se debata y trabaje en las líneas de cooperación entre la escuela y la familia.

\subsubsection{Orientados}

En la página web de Conselleria de Educació, Investigació, Cultura i Esport se pueden visitar diferentes apartados con información. En concreto, haciendo referencia a la convivencia e igualdad se presenta en la página de inicio un enlace con la página web Orientados. Esta página web va dirigida a alumnos, profesorado y familia, y en ella se ofrece información relacionada con el conflicto, bullying, entre otros.

A. El apartado dedicado a los alumnos con dos líneas de información. Por una parte, se puede obtener información relacionada con el concepto de maltrato entre compañeros o bullying, así como recomendaciones sobre cómo actuar en caso de estar siendo molestado por un compañero o de estar viendo como un compañero es molestado por otro. Entre estas se citan:

- ¿Qué cosas podrías hacer si un compañero te molesta?

- No llores, ni te enfades.

- Pasa de él, ellos. Ni le mires, ni le escuches.

- Haz como que no le has oído.

- Habla con tus compañeros o amigos, Cuéntales que te pasa.

- También puedes hablar con un adulto. No eres un chivato. ¡Estás pidiendo ayuda!

- Si te ridiculiza, cuestiónalo.

- Eres testigo de cómo un compañero molesta a otro.

- Estas harto de presenciar este tipo de agresiones.

- Sabes que perjudican a un compañero, y te sientes mal. Están perjudicando a toda la clase, creando un mal clima.

- Ya no tienes la misma relación con un antiguo amigo al que "maltratan", por miedo a que te suceda lo mismo. Lo echas de menos, pero no sabes que hacer.

- ¿Qué puedes hacer?

- Hay que hacer que el compañero que maltrata no se sienta apoyado por el grupo: ¿Cómo? Busca apoyo en compañeros que vean este problema como tú. No os riáis de sus insultos o burlas a compañeros. 
- No estáis solos: busca la ayuda de algún profesor o adulto. Cuéntale lo que estáis viendo.

En otro de los apartados de la web dirigida a los alumnos se presenta información respecto a los personajes involucrados en una agresión, y datos de estos como la forma en la que actúa, qué le ocurre, las consecuencias de actuar o de sufrir de ese modo, cómo se puede sentir esa persona en diferentes ámbitos y con quién puede contar esa persona.

B. Respecto al profesorado, la página web ofrece información relacionada con aspectos como la tipología de los conflictos, donde se especifican aspectos como la conducta del alumno en el aula con pautas para aprender a manejar las conductas disruptivas en el aula mediante la aplicación de diferentes dinámicas de grupo, así como también información sobre los conflictos interpersonales entre los alumnos de las que se ofrece información sobre técnicas como el arbitraje, negociación, conciliación, mediación y juicio.

Otro de los apartados que se presentan dirigidos al profesorado son una serie de recomendaciones y consejos para mejorar la salud emocional del profesor y evitar problemas como el burnout, como ejemplos de casos, el concepto, las causas sobre las que se produce este problema y las consecuencias de padecerlo. También se exponen pautas para la prevención e intervención (solución de problemas, técnicas de relajación y respiración, apoyo social en el trabajo, trabajo en equipo y asertividad).

Se ofrecen además otras pautas dirigidas a los profesores dirigidas a cómo afrontar mejor las entrevistas que van a realizar a lo largo del curso tanto con alumnos, familiares, otros docentes, etc. Para ello se especifica la figura del tutor, así como sus funciones y cualidades. También, en referencia a las entrevistas se aporta información sobre los aspectos generales de la entrevista que es importante tener en cuenta como pueden ser los aspectos que hay que potenciar y los que habría que evitar. Además, se informa sobre los diferentes tipos de entrevista y reuniones existentes, y concretamente hay un apartado dirigido a las entrevistas de acoso donde se proporciona información específica dirigida a los diferentes tipos de entrevistas que se pueden dar en esos casos como puede ser la entrevista con el alumno-víctima, alumno-acosador, alumno-espectador, profesorado, padres de la víctima o padres del acosador.

Además de esta información también en la página ofrecen a los docentes recursos de material audiovisual donde se presentan diferentes materiales con los que trabajar diferentes temáticas con materiales y dosieres para trabajar en el aula. Por último, se presenta información sobre técnicas de estudio que se van a poder utilizar y poner en marcha en las clases de tutoría. 
En relación al apartado dedicado a la familia, en la web se ofrece información en la que se dan pautas sobre la importancia de la relación entre la familia y la escuela, en la que se especifica que se trata de un deber del profesor y un derecho de las familias. En el siguiente apartado se aportan pautas en el caso que se necesite ayuda para mejorar la relación con los hijos, mediante información como las fases de la adolescencia y los diferentes estilos educativos.

C. Otra de la información que se proporciona a las familias es toda aquella relacionada con la comunicación entre los padres y los hijos, donde se especifican pautas para mejorar la comunicación (escuchar, aceptar sus sentimientos, utilizar un lenguaje respetuoso con ellos, elogiar a los hijos y corregirles tantas veces como sea necesario).

Por último, también en el apartado dedicado a las familias se puede encontrar información sobre cómo actuar ante los problemas específicos de los hijos, y es en este apartado donde se ofrecen pautas para afrontar problemas relacionados con la escuela entre los que se encuentra información sobre el acoso escolar con pautas sobre cómo reconocer si el hijo está siendo víctima de acoso escolar o si está siendo agresor. El apartado siguiente está relacionado con otros problemas como el uso de las nuevas tecnologías y con recomendaciones al respecto.

\subsubsection{El ciberbullying en el PREVI}

Teniendo en cuenta la estructura del PREVI, en este punto vamos a aportar una serie de aspectos que complementarían este plan para que se atendiera también el acoso por medio de las tecnologías, como es el caso del ciberbullying ya que se entiende que un plan de prevención de la violencia actual debe abordar este fenómeno, y por tanto es más que necesario tomar medidas, tal y como se toman en el PREVI con el acoso tradicional. Para ello se va a tomar como referencia el programa PREVI actual y se van a proponer algunas modificaciones y mejoras para que el ciberbullying esté contemplado en este plan.

\subsubsection{Medidas de prevención dirigidas al sistema educativo}

En primer lugar, se detallan las medidas de prevención dirigidas al sistema educativo, que se trata de un conjunto de protocolos de actuación diseñados para detectar e intervenir de modo que cualquier persona conozca en qué situación se encuentra ante un caso de violencia, qué se puede hacer, con quién puede contactar y qué puede esperar de la Administración Educativa.

Una de las primeras medidas que se presentan son los protocolos de detección precoz que son una serie de plantillas a cumplimentar por parte del profesorado, director/jefe de estudios $u$ orientador del centro educativo cuando se conozca alguna situación. En concreto se recogen tres modelos: 
- Información por parte del profesor/tutor/orientador: recoge información sobre el tipo de maltrato, el autor de la agresión, la localización y la frecuencia.

- Modelo de entrevista para el profesor/tutor/orientador con la víctima del maltrato: con la finalidad de conocer el perfil del caso víctima de la incidencia.

- Recogida de datos del profesor/tutor/orientador a la familia: cuya finalidad es obtener información sobre la familia, así como también sobre las acciones emprendidas hasta el momento, el resultado de éstas y el estado e información del hijo.

Estos modelos tienen como finalidad ofrecer una orientación que facilite la intervención ante posibles casos de acoso y al mismo tiempo que permita al profesorado, equipo directivo y departamento de orientación distinguir sobre qué es y qué no es acoso entre iguales, hacer un registro de las acciones emprendidas desde el centro e informar a la Inspección Educativa en el caso que sea necesario.

Respecto a estos documentos se propone en concreto en el modelo de recogida de datos del tutor/profesor/orientador añadir un apartado que haga referencia al tipo de maltrato, y contemplar uno que haga referencia al que se produce mediante el uso de las TIC en el que se podrían señalar acciones como:

- Envío de mensajes ofensivos.

- Exclusión de una conversación.

- Suplantación de identidad.

- Envío de fotos o videos ofensivos.

- Otros.

De este modo se incluirá en la detección el ciberbullying en este modelo de recogida de datos.

El siguiente paso a llevar a cabo después de las medidas de detección es la presentación de un modelo de actuación ante situaciones de emergencia y/o especial gravedad puesto en marcha por el Servicio Central de Inspección Educativa. Se trata de un protocolo mediante el cual todas las personas y servicios que sean pertinentes se pondrán en marcha en el caso de detectarse una situación de violencia en el centro siendo coordinado por un coordinador del programa PREVI.

Respecto al procedimiento ante situaciones que afectan a la convivencia escolar, podríamos seguir el mismo que se propone (Félix, Soriano, Godoy y Martínez, 2008), también para acciones relacionadas con el ciberbullying. 


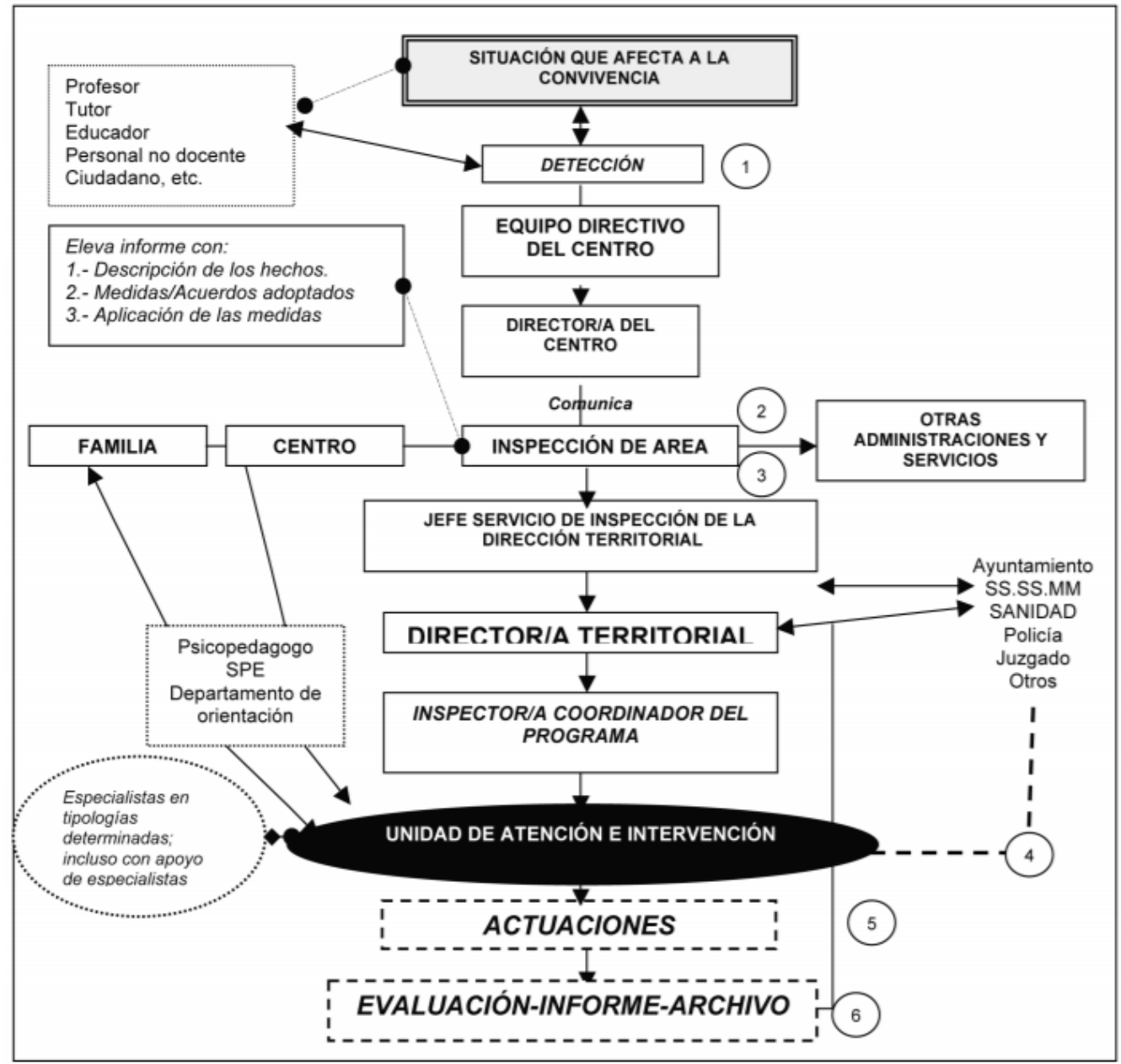

Figura 21. Protocolo de Intervención en situaciones que afectan la convivencia (Félix, Soriano, Godoy \& Martínez, 2008).

También incluidos en los protocolos de actuación se encuentra el protocolo de notificación de incidencias en el entorno del centro educativo. Estos protocolos se componen de un conjunto de plantillas con las que se puede notificar acerca de las incidencias que se observen o detecten en el centro educativo y que puedan alterar la convivencia. Respecto a estas plantillas proponemos una modificación, puesto que no está contemplado en ellas el ciberbullying. Por tanto, en el apartado dirigido a indicar si se ha detectado alguna situación en las inmediaciones del centro sería necesario añadir un apartado en el que se puede indicar si se ha detectado una situación de ciberbullying en el entorno educativo.

El segundo aspecto que se trabaja como medida de prevención en el sistema educativo es la utilización del registro central que tiene por finalidad registrar y analizar todos los casos de problemas de convivencia que se den en los centros. Esta información será introducida por el director o el jefe de estudios del centro de forma online.

En concreto en este apartado, al igual que con los modelos anteriormente citados, consideramos que sería necesario añadir el ciberbullying, puesto que no está contemplado. Así se añadiría al tipo de maltrato uno nuevo que hiciera referencia al maltrato mediante el uso de las tecnologías especificándose acciones como envío de 
mensajes ofensivos, exclusión de una conversación, suplantación de identidad, envío de fotos o videos ofensivos, etc.

También como medida preventiva el PREVI presenta una serie de recomendaciones dirigidas a padres y madres sobre indicadores de violencia escolar y cómo intervenir en cada caso. Al igual que se ha concretado en otros apartados, se detecta de nuevo la ausencia del ciberbullying.

En primer lugar, respecto a las recomendaciones dirigidas a los familiares para reconocer si sus hijos están sufriendo violencia a partir de una serie de indicadores que le permitirán reconocer si su hijo sufre ciberbullying. Por tanto, sería recomendable añadir un apartado para reconocer si su hijo es víctima en este caso de ciberbullying a partir de una serie de conductas observadas.

En cuanto a las indicaciones necesarias para las familias sobre qué hacer en el caso de detectar un caso de violencia, añadiríamos a estas indicaciones otras que hagan referencia al uso de las tecnologías, puesto que habría que hacerles conscientes de la existencia e importancia del ciberbullying a los niños, así como tomar medidas con el uso de las TIC en el caso de una potencial situación de ciberbullying. Del mismo modo, en el caso que se confirmara que se sufre ciberbullying trataríamos de contemplar medidas relacionadas con el uso de los dispositivos además de estas ya contempladas para el acoso tradicional.

Otra de las medidas tomadas es la elaboración de materiales, recursos y talleres dirigidos al sistema educativo. En cuanto a los talleres que realizan dirigidos al profesorado, alumnado y familias, habría que realizar talleres específicos para tratar el ciberbullying puesto que es un tema muy actual y sobre el que están surgiendo muchos casos por lo que se hace necesaria la formación en todos estos colectivos del sistema educativo. Se les debe formar para que conozcan esta problemática y su realidad de modo que aprendan a prevenirla y detectarla y que sepan cómo intervenir si se les presenta un caso. Se trataría se sesiones de formación prácticas y teóricas en formato seminario dirigidas a profesorado y familias, y también al alumnado.

De igual modo, en cuanto a los materiales, remarcamos la necesidad de la elaboración de guías específicas de ciberbullying dirigidas tanto a familias como a profesorado en las que se trate la temática del ciberbullying, se les proporcione toda la información necesaria y se especifique el papel de estos colectivos en la prevención, detección e intervención. Para los alumnos habría que poner en marcha programas de prevención en los que se trabajen diferentes aspectos relacionados con el ciberbullying y desde edades muy tempranas para así evitar la aparición de casos con esta problemática lo antes posible.

Respecto a los recursos, el plan PREVI dispone de una página web llamada Orientados cuyo objetivo es informar, orientar y asesorar al profesorado, alumnado y a las familias sobre las líneas de actuación y prevención ante situaciones conflictivas. De igual modo que hay un apartado dedicado al acoso, podríamos ampliar éste con información relacionada con el ciberbulying tal como hemos expuesto en el punto uno y dos de este capítulo. 
La formación al profesorado, como ya se había indicado en el apartado de los talleres, es otro de los aspectos imprescindibles puesto que para que los docentes sepan prevenir, detectar e intervenir es necesario formarles mediante cursos organizados dentro del Plan PREVI.

Para poder trabajar adecuadamente el fenómeno del ciberbullying igual que con otros tipos de violencia, y tal y como proponen en el plan, proponemos la realización de acciones como jornadas de sensibilización puesto que es un tema nuevo y actual y hay que darle la importancia necesaria y sensibilizar en este caso a los docentes de la complejidad e importancia de este tipo de problemas en los menores. Por supuesto la realización de cursos de formación, seminarios y grupos de trabajo para formarles en la parte teórica y práctica, así como para involucrarlos en la investigación y creación de nuevos materiales sobre la temática.

También en el PREVI se le da importancia al fomento de las tutorías como tiempo adecuado para educar en la convivencia. En el caso del ciberbullying también habría que aprovechar estos espacios de tiempo, sobretodo en la educación secundaria que es cuando tienen hora de tutoría para trabajar con los alumnos estos aspectos mediante materiales previamente elaborados por los docentes y más concretamente con materiales que proporcionen los orientadores de los centros o el mismo plan PREVI disponga de materiales con los que los docentes puedan impartir este contenido en clases. Como se ha especificado anteriormente, las tutorías están contempladas en Educación Secundaria por lo que para Educación Primaria sería interesante contar con materiales en los que se trabaje esta temática insertado dentro del currículo escolar.

Por último, como medida de prevención se presenta el Plan de Convivencia, que es un modelo de actuación para abordar la prevención de situaciones conflictivas, la resolución pacífica de las mismas y la atención del alumnado. Este plan es elaborado por cada uno de los centros de modo que se adapta a la realidad de estos, por este motivo se considera necesario que se adapte a la realidad de la sociedad actual y por ello el ciberbullying y las medidas de actuación para éste deberían estar contempladas en todos los planes de convivencia de los centros. Así, se podrían contemplar actividades en las que se trabaje el ciberbullying, y determinar los protocolos de prevención y de intervención.

\subsubsection{Medidas de prevención dirigidas a la población de riesgo}

La segunda de las medidas que contempla el plan PREVI son las que se toman en situaciones que son consideradas de riesgo. Para ello se cuenta con una Unidades de Atención e Intervención cuyas funciones son las de recibir consultas y/o incidencias con relación a la convivencia escolar, así como asesorar a los centros que lo soliciten, y actuar también en casos de incidencias grave. Estas medidas serían igualmente necesarias en situaciones de ciberbullying, y por tanto sería necesaria la incorporación a esta unidad de personal especializado en la temática del ciberbullying. Concretamente en la ORDEN 3/2017, de 6 de febrero, de la Conselleria de Educación, Investigación, Cultura y Deporte, 
por la cual se constituyen las unidades de atención e intervención del Plan de prevención de la violencia y promoción de la convivencia (PREVI) y se establece el procedimiento para su funcionamiento, se hace referencia al ciberbullying como una de las líneas principales de intervención de estas unidades. Así, entre sus objetivos se encuentra; incentivar actuaciones preventivas ante los episodios de conflictividad en el ámbito escolar, en especial, los relacionados con el ciberbullying y, en general, el relacionado con el uso de las tecnologías para acosar a cualquier miembro de la comunidad educativa. En cuanto a su procedimiento de intervención, se añade que las actuaciones de asesoramiento, coordinación interdepartamental e interinstitucional, sensibilización y formación llevadas a cabo por las UAI seguirán el procedimiento regulado en los protocolos recogidos en la Orden 62/2014, de 28 de julio, ante casos de acoso y ciberbullying. Aún así, se proponen como funciones a llevar a cabo después de la constitución de estas unidades, la necesidad de colaborar en la implementación, evaluación y propuestas de modificación de los diferentes protocolos recogidos en la Orden 62/2014, de 28 de julio, ante casos de acoso y ciberbullying, peleas y amenazas muy graves, maltrato infantil, violencia de género, agresiones a profesorado/personal de administración y servicios. Protocolo que se podría complementar con la propuesta de los planes de actuación que hemos presentado anteriormente en este capítulo.

Otra de las medidas tomadas, dirigidas a la población en riesgo, es el Protocolo de Actuaciones a seguir en caso de que el Personal Docente dependiente de la Conselleria de Cultura, Educación y Deporte sea objeto de una acción ilícita con ocasión del desempeño de su cargo o función. Esta medida se debería contemplar también para los casos de ciberbullying.

Por último, la tercera medida para este tipo de situaciones es un Acuerdo de Colaboración entre la Conselleria de Justicia, Interior y Administraciones Públicas y la Conselleria de Cultura, Educación y Deporte, para la atención de la comunidad educativa en casos de violencia escolar. En este caso concreto debe contemplarse el ciberbullying como un modo más de ejercer la violencia entre iguales de modo que al surgir un caso se pueda solicitar también la colaboración entre estas dos consellerias para realizar una actuación eficaz en dicho caso.

\subsubsection{Medidas de prevención dirigidas a toda la sociedad valenciana}

Estas medidas tienen como finalidad sensibilizar a toda la sociedad sobre los problemas de convivencia escolar, ya que se entiende que es una problemática de la sociedad en su conjunto.

En este tipo de medidas consideramos necesario que se impulsen también acciones de información y sensibilización del ciberbullying. Para ello, campañas de publicidad y sensibilización televisivos, radiofónicos o a modo de carteles para colocar en sitios públicos sería muy beneficioso, puesto que este tipo de acoso es poco conocido en la sociedad y muchas veces está infravalorado, pues no se es consciente de la importancia y del riesgo 
real de sufrir ciberbullying. Por este motivo, la puesta en marcha de charlar informativas dirigidas a la sociedad en su conjunto serían positivas, así como la realización de talleres.

A nivel más específico sería importante implicar y contar con la colaboración de instituciones educativas como las universidades para que realicen estudios sobre la situación actual del ciberbullying, la organización de congresos sobre la temática, etc. es decir, que se involucren en las acciones dirigidas a la sociedad y que con sus conocimientos ayuden y colaboren con el plan PREVI para que este contemple todas las medidas posibles dirigidas a la prevención, detección e intervención del ciberbullying.

En definitiva, consideramos de gran importancia el completar la página web de Conselleria de la Generalitat con aquellas aportaciones que en esta investigación se llevan a cabo, de manera que tanto el acoso tradicional como el ciberbullying pudiesen ser contemplados en esta página oficial.

\subsection{SÍNTESIS}

El psicólogo educativo es una figura fundamental en la detección de aquellas condiciones personales y sociales que faciliten o dificulten el proceso de enseñanza y aprendizaje del alumnado y su adaptación al ámbito escolar. Por tanto, el rol que ejerce este profesional es esencial para abordar las situaciones ciberbullying.

Debido a ello es importante que este profesional conozca todos aquellos aspectos que son esenciales para la identificación de las situaciones de ciberbullying, como son los perfiles de las víctimas y de los agresores. Respecto a las víctimas, exponemos una serie de indicadores centrado en aquellas áreas que la literatura científica enumera como fundamentales para la identificación del ciberbullying, así entre otras tenemos los cambios que se producen en los hábitos de comportamiento, en el estado de ánimo, en el rol social. En cuanto a los agresores, analizamos aquellos factores de personalidad, comportamentales y el uso excesivo de las TIC. Partiendo de lo anterior, hemos confeccionado unas rejillas para que el psicólogo pueda obtener información que le permita tomar decisiones para poder encauzar su intervención de una manera más eficaz.

Pero su función no es solamente identificar los perfiles de los implicados, sino que debe saber cómo actuar frente a una situación de ciberbullying, dado que su función se desarrolla en centros de educación primaria y secundaria. Así, debe realizar su función en el centro teniendo en cuenta dos ejes, que son el qué y el quién, aunque finalmente todas ellas deben confluir e ir en el mismo camino y dirección.

De este modo, el orientador debe atender a los tres grandes grupos que están relacionados con las situaciones de ciberbullying: familia, centro y alumno, y trabajará con ellos aspectos como son la sensibilización, prevención, detección, intervención y seguimiento.

A estas funciones del orientador frente al ciberbullying, añadimos la necesidad de disponer en los centros educativos de un protocolo de actuación específico de ciberbullying, en 
concreto una destinado al mismo centro y otro a las familias. En ambos, el rol del orientador es de nuevo el eje central. Estos protocolos constan de una serie de fases cada uno. Así, respecto al CENTRO EDUCATIVO tenemos:

- Fase I: El miembro de la comunidad educativa que detecta la situación se pone en comunicación con el director del centro educativo.

- Fase II: Reunión del director del centro con el profesorado y el orientador del centro.

- Fase III: Aportación por parte del orientador de pautas de actuación y materiales y puesta en marcha de las acciones.

- Fase IV: Puesta en común y toma de decisiones.

- Fase V: Seguimiento a la toma de decisión.

En cuanto a la FAMILIA, presentamos las siguientes fases:

Fase I: Contactar con el director del centro educativo y con el orientador del mismo centro.

- Fase II: Seguimiento del caso por parte del centro para aportar indicadores.

- Fase III: Toma de decisiones por parte del centro y de la familia.

- Fase IV: Seguimiento del caso en función de la decisión tomada.

Asimismo, en el caso que se determine que SI se está produciendo ciberbullying, el centro debe seguir el protocolo de actuación que tiene determinado en caso de acoso escolar, reuniendo de nuevo a la familia para informarles al respecto, y por supuesto, informar a la institución educativa.

La importancia de tener un protocolo que facilite la comunicación entre todos los implicados sirve para conocer aquellos recursos que son más importantes en cada fase del proceso, quienes deben estar implicados y la decisión que hay que tomar al respecto en función de la información de la que dispongamos.

Todas estas acciones realizadas desde los centros, en la Comunidad Valenciana, se ven complementadas por las medidas llevadas a cabo en el Plan de Prevención de la Violencia y Promoción de la Convivencia (PREVI), cuya finalidad es dar respuesta a las necesidades detectadas por la comunidad educativa. Estas medidas actualmente están destinadas principalmente a los casos de acoso tradicional, y por ello, destacamos en este capítulo la necesidad de contemplar el ciberbullying en el PREVI, puesto que consideramos que es un fenómeno muy presente en nuestros centros educativos y que requiere de una atención especializada. De este modo, llevamos a cabo diversas aportaciones relativas a la "Medidas de prevención dirigidas al sistema educativo", "Medidas de prevención dirigidas a la población de riesgo" y "Medidas de prevención dirigidas a la sociedad valenciana". 



\section{CAPÍTULO 5. EVALUACIÓN DE NECESIDADES}

\subsection{OBJETIVOS}

5.2. PARTICIPANTES

5.2.1. Participantes: profesorado

5.2.2. Participantes: familias

5.3. INSTRUMENTOS: CUESTIONARIOS

5.3.1. Cuestionario profesorado

5.3.2. Cuestionario familias

5.3.3. Procedimiento

5.4. RESULTADOS Y VALORACIÓN DE LAS NECESIDADES

5.4.1. Resultados del profesorado

5.4.2. Resultados de las familias

5.4.3. Análisis de los resultados y valoración de necesidades 5.5. SÍNTESIS 



\section{CAPÍTULO 5. EVALUACIÓN DE NECESIDADES}

Como hemos descrito en el capítulo IV, respecto al rol del psicólogo educativo, sus funciones son muchas, pero entre ellas destacamos las relacionadas con el fenómeno del ciberbullying, entre estas tareas se encuentran; la detección de aquellas condiciones personales y sociales que faciliten o dificulten el proceso de enseñanza y aprendizaje del alumnado y su adaptación al ámbito escolar. Además de esta función, se derivan otras como la participación en el apoyo y asesoramiento a los centros educativos; la elaboración y difusión de materiales e instrumentos de orientación educativa y de intervención y la coordinación de las actividades de orientación educativa y sociofamiliar.

En relación a esta tarea, y como hemos visto en anteriores capítulos, se aprecia según los datos analizados en las diferentes estadísticas presentadas, que la edad de comienzo del uso de las TIC ha disminuido en estos últimos años, y con ello disminuye también la edad en la que los niños son víctimas del ciberbullying. Además de ello, respecto a las investigaciones y trabajos realizados hasta el momento, se comprueba que la mayoría de los que se centran en la prevención del ciberbullying van dirigidos fundamentalmente al alumnado de Educación Secundaria. Con ello, los niños menores que cursan Educación Primaria no llegan a tener esta información y formación.

Así, partiendo de estos datos analizados, consideramos necesario abordar la prevención de este fenómeno en edades anteriores a la Educación Secundaria, puesto que, si su finalidad es prevenir las situaciones de ciberbullying, su abordaje se debería emprender en relación a la edad de comienzo en el uso de las TIC, así como también teniendo en cuenta la edad en la que los menores empiezan a ser víctimas de ciberbullying.

Por todo ello, decidimos elaborar y desarrollar de un programa de prevención dirigido al alumnado del segundo y tercer ciclo de Educación Primaria, mediante actividades insertadas en el currículo escolar que permitan al alumnado adquirir una serie de habilidades relacionadas con la prevención del ciberbullying, ya que el desarrollo de las competencias digitales se expone claramente en las ocho competencias del currículo de Primaria (Real Decreto 1513/2006). Así, la competencia digital se considera transversal respecto a cada una de las áreas curriculares que conforman la etapa educativa.

Con dicha finalidad, emprendemos una investigación una evaluación de necesidades tanto de los centros escolares como de las familias. A partir de esta detección de necesidades, manifestadas a partir de la percepción de docentes y de padres y madres de varios centros de Educación Primaria, estaremos en condiciones de diseñar e implementar un programa de prevención del ciberbullying que dé respuesta a estas necesidades detectadas, con la finalidad de realizar acciones de prevención del ciberbullying. 


\subsection{OBJETIVOS}

En nuestra investigación nos centramos en un objetivo general y en una serie de objetivos específicos, respecto a los dos grupos evaluados.

Objetivo general:

- Evaluar a los docentes y padres/madres para conocer cómo abordan el ciberbullying desde el contexto educativo y familiar, y qué necesidades tienen al respecto.

Objetivos específicos respecto a los docentes:

- Conocer la percepción de los docentes respecto al uso de las TIC en las aulas y otros espacios del centro y las situaciones que se detectan en las instalaciones del centro a consecuencia del uso de éstas.

- Conocer la percepción de los docentes en cuanto a la información de la que disponen los menores respecto al uso de las TIC así como sus riesgos y su modo de afrontamiento.

- Determinar la información de la que disponen los docentes respecto a los riesgos derivados del uso de las TIC en los menores.

- Establecer los recursos de los que disponen los docentes en la prevención de los riesgos derivados del uso de las TIC en los menores.

- Evaluar las necesidades e intereses de los docentes respecto al ciberbullying.

Objetivos específicos respecto a los padres/madres:

- Conocer las pautas la supervisión y pautas familiares que siguen los padres y madres respecto al uso de los menores de las TIC en el hogar.

- Establecer en qué medida los progenitores conciencian a sus hijos sobre la importancia de hacer un buen uso de las TIC y de sus riesgos.

- Determinar la información y formación de los padres y madres respecto al uso seguro de las TIC.

- Evaluar las necesidades e intereses de los familiares en cuanto a la prevención en riesgos del uso de las TIC dirigidas a los menores en los centros escolares. 


\subsection{PARTICIPANTES}

\subsubsection{Participantes: profesorado}

La muestra estaba compuesta por un total de 55 profesores que imparten docencia en los cinco centros públicos de Educación Infantil y Primaria de la localidad de Nules (Castellón): Lope de Vega, Nou Pedro Alcázar, Cervantes, Pio XII y Jaume I.

En cuanto a la distribución de la muestra (ver Tabla 42) encontramos profesores tutores que imparten docencia en Educación Primaria. El otro grupo de la muestra que hemos nombrado como especialistas, que representan el 49,10\%, hace referencia a aquellos docentes con especialidad que imparten docencia tanto en Educación Infantil como Primaria, entre los que encontramos principalmente docentes de Educación Infantil, Lengua Extranjera, Educación Musical, Educación Física y Educación Especial

Tabla 42. Muestra de los docentes participantes por nivel en el que imparten docencia.

\begin{tabular}{lcc}
\hline \multicolumn{1}{c}{ Nivel educativo } & N & Porcentaje \\
\hline 1을d. Primaria & 3 & $5,50 \%$ \\
\hline 2ㅇ Ed. Primaria & 4 & $7,30 \%$ \\
\hline 3o Ed. Primaria & 6 & $10,90 \%$ \\
\hline 4을d. Primaria & 5 & $9,10 \%$ \\
\hline 5 d. Primaria & 6 & $10,90 \%$ \\
\hline 6을d. Primaria & 4 & $7,30 \%$ \\
\hline Especialistas & 27 & $49,10 \%$ \\
\hline Total & $\mathbf{5 5}$ & $100 \%$ \\
\hline
\end{tabular}

Otra característica que cabe destacar de los participantes es el género de los docentes (ver Tabla 43), predominando el femenino con un $74,5 \%$ frente a un $25,5 \%$ de hombres.

Tabla 43. Descripción de la muestra de los docentes participantes.

\begin{tabular}{|c|c|c|c|}
\hline \multicolumn{2}{|c|}{ Características } & \multirow{2}{*}{$\begin{array}{l}\mathrm{N} \\
14\end{array}$} & \multirow{2}{*}{$\begin{array}{c}\% \\
25,5\end{array}$} \\
\hline & Masculino & & \\
\hline 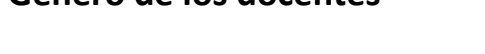 & Femenino & 41 & 74,5 \\
\hline Total & & 55 & 100 \\
\hline \multirow{3}{*}{ Años de experiencia docente } & Menos de 10 años & 15 & 27,3 \\
\hline & $10-20$ años & 25 & 45,4 \\
\hline & Más de 20 años & 15 & 27,3 \\
\hline Total & & 55 & 100 \\
\hline
\end{tabular}


Los años de experiencia (ver Tabla 43) nos indican que casi la mitad de los participantes tiene entre 10 y 20 años de experiencia, siendo el mismo porcentaje los que tienen experiencia de menos de 10 años $(27,3 \%)$ y los que tienen más de 10 años de experiencia $(27,3 \%)$.

\subsubsection{Participantes: familias}

Las familias fueron el segundo grupo de participantes en nuestra evaluación inicial de necesidades.

La muestra de las familias, está compuesta por un total de 156 padres y madres, de alumnos del segundo y tercer ciclo de Educación Primara del C.E.I.P Pio XII y C.E.I.P Lope de Vega, ambos de Nules (Castellón).

Los porcentajes por curso (ver Tabla 44) nos indican que el grupo que más muestra tiene es el que representa a los padres y madres de alumnos de 5o de Educación Primaria con un $31,4 \%$. Por el contrario 60 de Educación Primaria representa un 19,9\%, datos que corresponden con el número de alumnos por curso.

Tabla 44. Muestra de los padres y madres participan
\begin{tabular}{lcc}
\hline Nivel educativo & N & Porcentaje \\
\hline 3o Ed. Primaria & 41 & $26,30 \%$ \\
\hline 4o Ed. Primaria & 35 & $22,40 \%$ \\
\hline 5 Ed. Primaria & 49 & $31,40 \%$ \\
\hline 6o Ed. Primaria & 31 & $19,90 \%$ \\
\hline Total & $\mathbf{1 5 6}$ & $100 \%$ \\
\hline
\end{tabular}

En cuanto al género (ver tabla 45), predomina el femenino con un $66,7 \%$ sobre el masculino con un $33,3 \%$.

El número de hijos nos indica que el $61,5 \%$ de los encuestados tiene dos hijos, seguido de un 16,7\% con un hijo (ver Tabla 45). Esta cifra disminuye a mayor número de hijos, siendo un $16 \%$ los que tienen tres hijos y sólo un $5,8 \%$ los que afirman tener cuatro hijos. 
Tabla 45. Descripción de la muestra de los padres y madres participantes.

\begin{tabular}{|c|c|c|c|}
\hline Característ & icas & $\mathbf{N}$ & $\%$ \\
\hline \multirow{2}{*}{ Género } & Masculino & 52 & $33,30 \%$ \\
\hline & Femenino & 104 & $66,70 \%$ \\
\hline \multicolumn{2}{|l|}{ Total } & 156 & $100 \%$ \\
\hline \multirow{5}{*}{ Número de hijos } & 1 & 26 & $16,70 \%$ \\
\hline & 2 & 96 & $61,50 \%$ \\
\hline & & & \\
\hline & 3 & 25 & $16 \%$ \\
\hline & 4 & 9 & $5,80 \%$ \\
\hline \multicolumn{2}{|l|}{ Total } & 156 & $100 \%$ \\
\hline
\end{tabular}

\subsection{INSTRUMENTOS: CUESTIONARIOS}

Bausela (2003) señala que el cuestionario es uno de los métodos más utilizados en el análisis de necesidades.

La técnica del cuestionario permite saber qué piensan y opinan los encuestados mediante preguntas realizadas por escrito y que pueden contestar sin que el encuestador esté presente.

Con ello, se pregunta a los encuestados sobre una cuestión que queremos investigar, no siendo necesario conocer la opinión de una muestra elevada de participantes.

Los cuestionarios diseñados para esta investigación tienen por objeto conocer las necesidades relacionadas con el uso de las TIC en los menores, por parte del profesorado y familiares de alumnos de Educación Primaria.

Así, para cualquier programa de prevención es necesario partir de una evaluación inicial de la situación de la que parten tanto familias como profesores, y a pesar de la gran importancia que está tomando este fenómeno y de la conciencia que tenemos de la importancia que toman en estas situaciones la familia y los profesores, no hay ningún cuestionario que evalúe la conducta de estos dos grupos respecto al uso de las nuevas tecnologías en lo que se refiere al uso que hacen los menores así como a la concienciación y conocimientos de estos adultos.

Por ello, y partiendo de los numerosos recursos y guías que existen sobre el ciberbullying como: la Guía de actuación contra el ciberbullying para padres y educadores de Inteco; documentos de prevención de Protegeles.com como la Guía Parental, los folletos informativos o el cuadernillo familiar; la Guía Buen Uso de Internet de la Generalitat 
Valenciana; Plan de Prevención del ciberacoso y prevención de la navegación segura en centros escolares de la Junta de Castilla y León, etc. Construimos para ello dos cuestionarios; uno para el profesorado y otro para los familiares del alumnado que cursa el segundo y tercer ciclo de Educación Primaria con la finalidad de alcanzar los objetivos citados anteriormente.

\subsubsection{Cuestionario profesorado}

Para la evaluación de necesidades del profesorado, el equipo de investigación elaboró un cuestionario formado por 22 preguntas (ver anexo 2). Del total, 21 de las cuestiones en escala Likert de cinco anclajes siendo 1: nunca, 2: casi nunca, 3: a menudo, 4: casi siempre y 5: siempre. La cuestión número 22 es de respuesta abierta.

Respecto al contenido de este cuestionario, teniendo en cuenta su finalidad y los objetivos propuestos inicialmente, contemplan diferentes bloques en los que se incluyen una serie de ítems que evalúan ciertos aspectos relacionados con la finalidad de esta evaluación de necesidades.

- Bloque I: Percepción respecto al uso de las TIC en las aulas y otros espacios del centro y las situaciones que se detectan en las instalaciones del centro a consecuencia del uso de éstas.

1. En mi clase, suelo controlar y atajar los conflictos y agresiones, no llegando a ser un problema.

2. En el patio del colegio se producen actos violentos motivados por discusiones iniciadas en redes sociales o aplicaciones tecnológicas.

5. En el aula se dan situaciones de violencia entre los alumnos que posteriormente se trasladan a las redes sociales o whatsapp.

8. Se producen en el aula situaciones de violencia debido a situaciones iniciadas en las redes sociales, chats, whatsapp, etc.

9. Los alumnos utilizan los dispositivos móviles en la hora de recreo.

12. En el aula los alumnos utilizan los dispositivos móviles (móviles, tablets, etc).

17. En las salidas organizadas por el centro los alumnos utilizan los dispositivos móviles.

21. Los alumnos en el aula comentan situaciones negativas o problemáticas que han ocurrido por medio de las nuevas tecnologías o Internet.

- Bloque II: Percepción en cuanto a la información de la que disponen los menores respecto al uso de las TIC así como sus riesgos y su modo de afrontamiento.

3. Los alumnos hacen uso de las nuevas tecnologías con fines agresivos y violentos. 
6. Los alumnos conocen los riesgos que supone el uso no responsable de las nuevas tecnologías.

10. Los alumnos suelen pedir ayuda a los profesores para tratar de resolver conflictos que se han iniciado por medio de las nuevas tecnologías.

- Bloque III: Información que disponen respecto a los riesgos derivados del uso de las TIC en los menores.

13. Dispongo de información sobre el ciberbullying.

14. Dispongo de información sobre el sexting.

15. Dispongo de información sobre el groming.

19. Las familias, en general, están muy implicadas en el buen uso de las nuevas tecnologías por parte de los menores.

- Bloque IV: Recursos de los que disponen en la prevención de los riesgos derivados del uso de las TIC en los menores.

4. Como profesor/a, sin ayuda de otro profesional, no estoy preparado para resolver los problemas de malas relaciones y violencia, tanto en el centro como por medio de las nuevas tecnologías.

7. Las relaciones interpersonales son uno de los objetivos más importantes del desarrollo de mi actividad docente.

11. Como profesor conozco las pautas a seguir ante un caso de ciberbullying en el centro.

16. Como profesor tengo información y formación suficiente sobre los riesgos en el uso de las nuevas tecnologías.

- Bloque IV: Necesidades e intereses respecto al ciberbullying.

18. Considero que implantar un proyecto de prevención e intervención sobre las agresiones y violencia en la escuela es una buena idea.

20. Para eliminar los problemas de violencia es necesario que el equipo completo de profesores tome conciencia y se decida a actuar.

\subsubsection{Cuestionario familias}

Respecto al cuestionario de evaluación de necesidades dirigido a los familiares (ver anexo $3)$, principalmente padres y madres, el equipo de investigación elaboró un cuestionario formado por 25 preguntas formuladas en escala dicotómica, si/no. 
Respecto a las cuestiones planteadas, teniendo en cuenta su finalidad y los objetivos propuestos inicialmente, encontramos diferentes bloques en los que se contemplan una serie de ítems que los evalúan.

- Bloque I: Pautas de supervisión y pautas familiares que siguen respecto al uso de los menores de las TIC en el hogar.

4. He enseñado a mi hijo/a a utilizar Internet y las herramientas, programas y servicios de forma segura.

7. Superviso la actividad de mi hijo/a en Internet y le traslado nuevos puntos de vista compartiendo actividades.

10. El ordenador está colocado en una habitación familiar de la casa.

15. Mi hijo tiene al menos un dispositivo móvil (tablet, móvil, portátil, etc.)

18. Sé las contraseñas de mi hijo/a.

20. Hay establecidas en casa reglas con mis hijos acerca de cuándo y por cuánto tiempo pueden estar utilizando internet.

22. Hay establecidos en casa criterios de edades para empezar a utilizar los dispositivos (ordenador, tableta, móvil) y para acceder a diferentes contenidos y servicios.

23. Sé qué funcionalidades tiene el teléfono móvil de mi hijo/a (en caso de que tenga).

24. Mi hijo/a sabe usar los controles de privacidad en Internet para bloquear usuarios.

25. Mi hijo/a me enseña sus perfiles, páginas y comunicaciones cuando se lo pido.

- Bloque II: En qué medida conciencian a sus hijos sobre la importancia de hacer un buen uso de las TIC y de sus riesgos.

5. He hablado con mi hijo/a acerca de los peligros de relacionarse con gente de Internet.

8. Le he trasladado a mi hijo/a la importancia de no comunicarle a nadie (ni siquiera amigos) el nombre de usuario y contraseña personales explicando las posibles repercusiones.

11. He informado a mi hijo/a sobre la importancia de no proporcionar información personal y/o familiar a través de la red, incluidas fotografías o cualquier tipo de documento por correo electrónico con información privada.

16. Le he inculcado a mi hijo valores como el respeto en la relación con los demás, y el conocimiento de qué es aceptable y qué no, tanto en la vida real como en la Red.

19. Fomento la confianza mutua transmitiendo a mis hijos que pueden hablarme sobre sus problemas de modo que podamos buscar soluciones juntos. 
21. Hablo con mis hijos acerca de las normas de comportamiento en Internet poniendo especial incidencia en la necesidad de actuar con responsabilidad.

- Bloque III: Información y formación respecto al uso seguro de las TIC.

1. Sé cómo usar los controles de privacidad en Internet para bloquear usuarios.

2. Conozco bien los riesgos a los que se exponen los menores con el uso de las nuevas tecnologías.

3. He recibido formación sobre el uso seguro y responsable de las nuevas tecnologías por parte de menores.

9. Conozco cómo utilizar y actualizar la protección de los equipos con la instalación de las herramientas de seguridad adecuadas (antivirus, firewall, etc.).

12. Sé lo que es el ciberbullying.

13. Sé lo que es el grooming.

14. Sé lo que es el sexting.

- Bloque IV: Necesidades e intereses en cuanto a la prevención en riesgos del uso de las TIC dirigidas a los menores en los centros escolares.

6. Considero necesaria la prevención en los centros educativos sobre los riesgos en el uso de las nuevas tecnologías por parte de los menores.

17. Es importante concienciar a la sociedad sobre los riesgos del uso de las nuevas tecnologías.

\subsubsection{Procedimiento}

El procedimiento que se ha llevado a cabo para la recogida de la información de las muestras fue la que se detalla a continuación.

En el caso del profesorado, el procedimiento fue el siguiente:

1. La autora junto con los directores de la investigación diseñaron el cuestionario.

2. La investigadora se reunió con los equipos directivos de los centros participantes (Lope de Vega, Nou Pedro Alcázar, Cervantes, Pio XII y Jaume I) con la finalidad de explicar el objeto de la investigación y entregó en papel los cuestionarios a los equipos directivos.

3. Los equipos directivos reunieron a los docentes para explicarles el objeto de la investigación y distribuyeron los cuestionarios entre los docentes del centro.

4. Los docentes de manera voluntaria hicieron llegar al equipo directivo los cuestionarios en papel.

5. La investigadora acudió a los centros a recoger los cuestionarios. 
Respecto a los cuestionarios de las familias:

1. La autora junto con los directores de la investigación diseñaron el cuestionario.

2. La investigadora se reunió con los equipos directivos de los centros participantes (Lope de Vega y Pio XII) y con los profesores tutores del segundo y tercer ciclo de educación Primaria, con la finalidad de explicar el objeto de la investigación; y entregó en papel y dentro de un sobre cada uno de los cuestionarios a los profesores.

3. Los profesores tutores del segundo y tercer ciclo de Educación Primaria entregaron a cada uno de los alumnos un sobre con el cuestionario, y les indicaron el modo de proceder.

4. Los alumnos voluntariamente devolvieron a los profesores los sobres cerrados con los cuestionarios cumplimentados por sus familiares.

5. La investigadora recogió los cuestionarios de los centros educativos.

\subsection{RESULTADOS Y VALORACIÓN DE LAS NECESIDADES}

Una vez recibidos los cuestionarios, se procedió al análisis de las mismas.

Así, la pertinencia del programa alude a si "realmente es necesaria la implementación, si es cierto que existen necesidades que se han de cubrir", Anguera, Chacón \& Sánchez (2008), Fernández Ballesteros (1995) y la OMS (1981). Comprobar si el programa era pertinente fue el primer paso.

Las respuestas ofrecidas por los docentes y las familias son las que presentaremos a continuación siguiendo los bloques determinados y explicados en el apartado de instrumentos de evaluación del presente capítulo.

\subsubsection{Resultados del profesorado}

Los datos extraídos de los resultados de las respuestas del profesorado que ha participado en la evaluación de necesidades podemos verlos en las diferentes tablas que se presentan en el presente apartado. Para ver a qué contenido hace referencia cada ítem podemos consultar el apartado anterior de instrumentos de evaluación donde están clasificados por bloques o el anexo 2 en el que encontramos el cuestionario al completo.

- Bloque I: Percepción respecto al uso de las TIC en las aulas y otros espacios del centro y las situaciones que se detectan en las instalaciones del centro a consecuencia del uso de éstas.

Las medias obtenidas en este bloque (ver Tabla 46) nos indican que los profesores afirman con un $56,4 \%$ saber controlar siempre los conflictos en las aulas (ítem 1 ). 
Además de ello, afirman que nunca se usan dispositivos móviles en las aulas $(83,6 \%)$ ni en las instalaciones escolares $(98,2 \%)$ o en las salidas organizadas por el centro (80\%) (ítems $9,12$ y 17$)$.

También consideran que en las aulas $(76,4 \%$ ) y en los espacios del centro $(74,5 \%)$ nunca se producen situaciones violentas derivadas del uso de las TIC ni tampoco que las situaciones violentas que se producen en las aulas se trasladen al uso de las TIC $(78,2 \%)$ (ítems 2,5 y 8).

A pesar de ello un $56,4 \%$ de los docentes son conscientes de que les alumnos nunca comentan en el aula las situaciones negativas que les ocurren derivadas del uso de las TIC (ítem 21).

Tabla 46. Datos de las medias y desviaciones típicas de los resultados de los ítems del bloque I

\begin{tabular}{ccc}
\hline Ítem & $\mathbf{M}$ & $\mathbf{D T}$ \\
\hline 1 & 4,47 & 0,690 \\
\hline 2 & 1,25 & 0,440 \\
\hline 5 & 1,29 & 0,599 \\
\hline 8 & 1,29 & 0,567 \\
\hline 9 & 1,07 & 0,539 \\
\hline 12 & 1,35 & 0,821 \\
\hline 17 & 1,29 & 0,712 \\
\hline 21 & 1,73 & 1,062 \\
\hline
\end{tabular}

- Bloque II: Percepción en cuanto a la información de la que disponen los menores respecto al uso de las TIC así como sus riesgos y su modo de afrontamiento.

Siguiendo los datos recogidos en la Tabla 47 , un $74,5 \%$ de los docentes consideran que los menores nunca hacen uso de las TIC con fines agresivos o violentos (ítem 3).

Respecto a los datos sobre si los menores no conocen los riesgos del uso no responsable de las TIC, los docentes indican en un 34,5\% a menudo, seguido muy de cerca por casi nunca con un 30,9\% (ítem 6).

También añaden de nuevo que consideran en un $47,3 \%$ que los alumnos nunca suelen pedir ayuda a los profesores para resolver conflictos iniciados con las TIC (ítem 10). 
Tabla 47. Datos de las medias y desviaciones típicas de los resultados de los ítems del bloque II

\begin{tabular}{ccc}
\hline Ítem & $\mathbf{M}$ & $\mathbf{D T}$ \\
\hline 3 & 1,25 & 0,440 \\
\hline 6 & 2,53 & 1,052 \\
\hline 10 & 2,09 & 1,281 \\
\hline
\end{tabular}

- Bloque III: Información que disponen respecto a los riesgos derivados del uso de las TIC en los menores.

Los datos obtenidos en los ítems correspondientes a este bloque (ver Tabla 48), nos indican que los docentes afirman que un 30,9\% de ellos disponen a menudo información respecto al ciberbullying (ítem 13). La cifra varía en cuanto a otros fenómenos de riesgo derivados del uso de las TIC como el sexting del que afirman un 49'1\% no tener nada de información (ítem 14 ) o el grooming con un $54,5 \%$ de docentes que afirman no disponer de información sobre él (ítem 15).

También afirman en un 41,8\% que las familias se implican a menudo en cuanto al buen uso de las TIC por parte de los menores es medio (ítem 19).

Tabla 48. Datos de las medias y desviaciones típicas de los resultados de los ítems del bloque III

\begin{tabular}{ccc}
\hline Ítem & $\mathbf{M}$ & $\mathbf{D T}$ \\
\hline 13 & 2,96 & 1,261 \\
\hline 14 & 2,09 & 1,295 \\
\hline 15 & 1,76 & 1,088 \\
\hline 19 & 2,82 & 1,002 \\
\hline
\end{tabular}

- Bloque IV: Recursos de los que disponen en la prevención de los riesgos derivados del uso de las TIC en los menores.

Respecto a este bloque los resultados (ver Tabla 49) nos indican que un 38,2\% de los docentes afirman que sin ayuda casi nunca podrían resolver las situaciones conflictivas tanto dentro del centro escolar como por medio de las TIC (ítem 4).

Un $50,9 \%$ afirman que las relaciones interpersonales es uno de los objetivos principales de su actividad docente (ítem 7).

Los docentes afirman en un $23,6 \%$ que no conocen las pautas a seguir ante un caso de ciberbulying, situándose las cifras más altas entre el nunca y a menudo, siendo así pocos los que afirman que sí conocen las pautas que se deben seguir (ítem 11). 
Además, un $41,8 \%$ de los docentes considera que a menudo dispone de información y formación suficiente sobre el riesgo del uso de las TIC (ítem 16).

Tabla 49.Datos de las medias y desviaciones típicas de los resultados de los ítems del bloque IV

\begin{tabular}{ccc}
\hline Ítem & $\mathbf{M}$ & $\mathbf{D T}$ \\
\hline 4 & 2,22 & 1,049 \\
\hline 7 & 4,27 & 0,912 \\
\hline 11 & 2,18 & 1,301 \\
\hline 16 & 2,16 & 1,135 \\
\hline
\end{tabular}

\section{- Bloque V: Necesidades e intereses respecto al ciberbullying.}

Los datos analizados a partir de los resultados de las respuestas de los ítems de este bloque (ver Tabla 50), nos confirman que un $81,8 \%$ de los docentes considera que es necesario la implantación de un proyecto de prevención e intervención en la escuela (ítem 18).

Dato que coincide en cuanto a la necesidad de actuar el equipo completo y la necesidad de la toma de conciencia de todos para eliminar los problemas de violencia en un $78,2 \%$ de los docentes (ítem 20).

Tabla 50. Datos de las medias y desviaciones típicas de los resultados de los ítems del bloque $V$

\begin{tabular}{ccc}
\hline Ítem & $\mathbf{M}$ & $\mathbf{D T}$ \\
\hline 18 & 4,67 & 0,818 \\
\hline 20 & 4,69 & 0,717 \\
\hline
\end{tabular}

La cuestión número 22 , con respuesta abierta en la que se indica que pueden añadir aspectos importantes que no se hayan preguntado, los docentes remarcan que sobretodo los alumnos de Educación Infantil no hacen uso de las redes sociales y algunos docentes indican además que el uso de dispositivos móviles en el centro está prohibidos.

En los cursos de primaria, sobre todo en el segundo y tercer ciclo, los docentes indican que sí han escuchado en el aula a algunos alumnos decir que se les ha excluido de un grupo de whatsapp o que se han difundido imágenes suyas con fines despectivos. En concreto en sexto de primaria una de las tutoras participantes añade que los conflictos en el uso principalmente del whatsapp son recurrentes entre sus alumnos.

Añaden la necesidad de disponer de protocolos de prevención e intervención ante casos de acoso por medio de las TIC, de recursos para trabajar la prevención con los menores y de formación a los docentes para poder actuar adecuadamente en el caso que se les presente algún tipo de situación violenta o agresiva derivada del uso de las TIC. 


\subsubsection{Resultados de las familias}

Los datos extraídos de los resultados de las respuestas de las familias que han participado en la evaluación de necesidades podemos verlos en las diferentes tablas que se presentan en el presente apartado. Para ver a qué contenido hace referencia cada ítem podemos consultar el apartado anterior de instrumentos de evaluación donde están clasificados por bloques o el anexo 3 en el que encontramos el cuestionario al completo.

- Bloque I: Pautas de supervisión y pautas familiares que siguen respecto al uso de los menores de las TIC en el hogar.

En la Tabla 51 podemos observar todos estos datos, entre los que nos indican que el $57,1 \%$ de los padres y madres afirman que han enseñado a sus hijos a utilizar las TIC de forma segura, aún así un 42,9\% afirman no haberlo hecho (ítem 4).

Un 73,7\% supervisan el uso de las TIC que hacen sus hijos (ítem 7) y un 75,6\% tienen colocado el ordenador en una zona común de la casa (ítem 10).

El $76,9 \%$ de los padres sabe las contraseñas de sus hijos (ítem 18), el 85,3\% conoce las funcionalidades de los dispositivos de los hijos (ítem 23) y el $81,4 \%$ afirma que sus hijos les muestran sus perfiles y páginas web que consultan cuando ellos lo solicitan (ítem 25).

Tienen determinadas pautas de uso, puesto que un $75 \%$ tienen determinado cuándo y cuánto tiempo pueden hacer uso (ítem 20) y un 76,3\% limitan el uso dependiendo de la edad del menor (ítem 22).

Dato significativo es que el $88,5 \%$ de los familiares afirman que sus hijos tienen al menos un dispositivo móvil (ítem 15), y a pesar de ello un $81,4 \%$ afirman que sus hijos no saben usar los controles de privacidad en internet para bloquear usuarios.

Tabla 51. Datos de los porcentajes de los resultados de los ítems del bloque I

\begin{tabular}{ccc}
\cline { 2 - 3 } & \multicolumn{2}{c}{$\%$} \\
\hline Ítem & sí & NO \\
\hline 4 & 57,1 & 42,9 \\
\hline 7 & 73,7 & 26,3 \\
\hline 10 & 75,6 & 24,4 \\
\hline 15 & 88,5 & 11,5 \\
\hline 18 & 76,9 & 23,1 \\
\hline 20 & 75,0 & 25,0 \\
\hline 22 & 76,3 & 23,7 \\
\hline 23 & 85,3 & 14,7 \\
\hline 24 & 40,4 & 59,6 \\
\hline 25 & 81,4 & 18,6 \\
\hline
\end{tabular}


- Bloque II: En qué medida conciencian a sus hijos sobre la importancia de hacer un buen uso de las TIC y de sus riesgos.

De las respuestas de los familiares a las cuestiones planteadas relacionadas con este bloque se desprende (ver Tabla 52) que un $85,9 \%$ de los padres conciencian a sus hijos sobre los peligros que existen en la red (ítem 5), y un $87,2 \%$ habla con los hijos acerca de las normas de comportamiento en internet y la necesidad de actuar con responsabilidad (ítem 21).

Además, un $84,6 \%$ les remarcan la importancia de no comunicar a nadie las contraseñas y el nombre de usuario y las repercusiones que ello puede conllevar (ítem 8), y también un $87,2 \%$ les informan de la importancia de no proporcionar información (ítem 11).

Un $96,8 \%$ de los familiares afirma inculcar valores de respeto hacia los demás en las redes (ítem 16), y la transmisión de confianza para que les cuenten los problemas para poder buscar soluciones en un $97,4 \%$ de los casos (ítem 19).

Tabla 52. Datos de los porcentajes de los resultados de los ítems del bloque II

$\%$

\begin{tabular}{ccc}
\hline Ítem & Sí & NO \\
\hline 5 & 85,9 & 14,1 \\
\hline 8 & 84,6 & 15,4 \\
\hline 11 & 87,2 & 12,8 \\
\hline 16 & 96,8 & 3,2 \\
\hline 19 & 97,4 & 2,6 \\
\hline 21 & 87,2 & 12,8 \\
\hline
\end{tabular}

- $\quad$ Bloque III: Información y formación respecto al uso seguro de las TIC.

En cuanto a la información y formación propia de los familiares los datos (ver Tabla 53) nos indican que un 62,2\% afirman saber utilizar los controles de privacidad (ítem 1) y un 62,9\% saben utilizar los controles de protección de los equipos (ítem 9).

El 89,7\% consideran que conocen los riesgos a los que se exponen los menores (ítem 2), a pesar de ello sólo el 59,1\% conoce qué es el ciberbullying (ítem 12), el 79,5\% no conoce a qué hace referencia el término grooming (ítem 13) y un $71,2 \%$ no conoce lo que es el sexting (ítem14).

En cuanto a la formación, un 79,5\% afirman no haber recibido formación sobre el uso seguro y responsable de las tecnologías por parte de los menores (ítem 3). 
Tabla 53. Datos de los porcentajes de los resultados de los ítems del bloque III

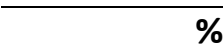

\begin{tabular}{ccc}
\hline Ítem & sí & NO \\
\hline 1 & 62,2 & 37,8 \\
\hline 2 & 89,7 & 10,3 \\
\hline 3 & 20,5 & 79,5 \\
\hline 9 & 69,2 & 30,8 \\
\hline 12 & 59,0 & 41,0 \\
\hline 13 & 20,5 & 79,5 \\
\hline 14 & 28,8 & 71,2 \\
\hline
\end{tabular}

- Bloque IV: Necesidades e intereses en cuanto a la prevención en riesgos del uso de las TIC dirigidas a los menores en los centros escolares.

Las respuestas relacionadas con las necesidades detectadas (ver Tabla 54), nos indican que un $96,2 \%$ de los padres y madres considera necesaria la prevención sobre los riesgos en el uso de las nuevas tecnologías en los centros escolares (ítem 6), y además un 99,4\% de estos familiares afirman que es importante concienciar a la sociedad sobre estos riesgos (ítem 17).

Tabla 54. Datos de los porcentajes de los resultados de los ítems del bloque IV

$\%$

\begin{tabular}{ccc}
\hline Ítem & sí & NO \\
\hline 6 & 96,2 & 3,8 \\
\hline 17 & 99,4 & 0,6
\end{tabular}

\subsubsection{Análisis de los resultados y valoración de necesidades}

En primer lugar, de los resultados de las respuestas de los padres y madres extraemos que las pautas y la supervisión familiar según afirman los familiares en un porcentaje elevado son las adecuadas. Sin embargo, destacan que la gran mayoría, nueve de cada diez, de los menores disponen de dispositivos móviles propios y al mismo tiempo más de cuatro de cada diez afirma que no les han enseñado a sus hijos a hacer un uso seguro de ellos y casi el $60 \%$ reconoce que sus hijos no saben usar los controles de privacidad. 
En cuanto a concienciación familiar, los datos indican que las familias parecen estar bastante concienciadas y hablan con sus hijos sobre la importancia de hacer un uso seguro, transmitiéndoles confianza y valores de respecto hacía los demás también cuando usan las TIC.

Respecto a la información y formación de los padres y madres, estos reconocen no haber recibido ninguna formación en el uso seguro de las TIC en los menores, y también cabe destacar que aunque afirman conocer los riesgos de las TIC desconocen fenómenos tan peligrosos como el ciberbullying, grooming o sexting. Los datos también indican que cuatro de cada diez padres no saben usar controles da privacidad y protección en los equipos.

Dato a resaltar sin duda son las necesidades e intereses que transmiten, puesto que prácticamente la totalidad de los participantes considera necesaria la prevención en los centros educativos sobre los riesgos en el uso de las TIC por parte de los menores así como la importancia de concienciar a la sociedad sobre los riesgos en el uso de las TIC.

Por su parte, los docentes afirman que no detectan en las aulas o en las instalaciones de los centros situaciones de violencia derivadas del uso de las TIC, ello debido en parte a que no se pueden utilizar estos dispositivos en los centros, ni tampoco que las situaciones violentas o agresivas iniciadas en las aulas se trasladen a la comunicación por medio de las TIC. A pesar de ello son muy pocos los docentes que reconocen que los alumnos les han transmitido alguna vez situaciones ocurridas mediante el uso de las TIC.

En la percepción de los docentes en cuanto a la información que disponen los menores del uso, riesgos y afrontamiento a situaciones derivadas de las TIC; casi un $70 \%$ reconoce que a menudo o casi nunca los alumnos conocen los riesgos del uso no responsable, y además son conscientes como afirmábamos anteriormente que los alumnos no suelen acudir a los profesores para tratar de resolver conflictos iniciados en las redes.

La información de la que disponen los docentes nos deja ver que al igual que los familiares, muchos de ellos desconocen fenómenos como el ciberbullying, sexting o grooming, y también reconocen que menos de un $25 \%$ de los familiares se implican en el buen uso de las TIC por parte de los menores.

Respecto a los recursos de los que disponen hay una gran parte de los docentes que reconoce no disponer de pautas a seguir para hacer frente a situaciones de ciberbullying, ni tampoco disponen de la suficiente información y formación sobre los riesgos. Más de la mitad indican que sin ayuda de otros profesionales no se sienten capacitados para resolver los conflictos derivados de las TIC, y reconocen la importancia de trabajar las relaciones interpersonales siendo este un objetivo principal en su labor como docentes.

En cuanto a la necesidad de implantar un proyecto de prevención e intervención contra la violencia lo consideran positivamente, al igual que la necesidad de actuar en equipo para eliminar la violencia. 
Explícitamente nos remarcan su interés en la elaboración de protocolos y materiales para trabajar en el aula, así como cursos de formación para los docentes, pues aunque son conscientes que en edades más tempranas el uso de las TIC, y sobretodo de las redes sociales y mensajería instantánea, no son frecuentes sí que en los últimos cursos de Educación Primaria se han detectado algunas situaciones que pueden derivar en ciberbullying.

\subsection{SÍNTESIS}

Cualquier investigación, y más concretamente la nuestra, debe iniciarse con una evaluación de necesidades tanto de los centros escolares como de las familias con el objetivo de evaluar a los docentes y padres/madres para conocer cómo abordan el ciberbullying desde estos dos contextos y qué necesidades tienen al respecto.

A partir de esta detección de necesidades, manifestadas a partir de la percepción de docentes y de padres y madres de varios centros de Educación Primaria, estaremos en condición de diseñar e implementar un programa de prevención del ciberbullying que dé respuesta a estas necesidades detectadas, con la finalidad de realizar acciones de prevención del ciberbullying.

La muestra de docentes estaba compuesta por un total de 55 profesores que imparten docencia en los cinco centros públicos de Educación Infantil y Primaria de la localidad de Nules (Castellón): Lope de Vega, Nou Pedro Alcázar, Cervantes, Pio XII y Jaume I.

Para la evaluación de necesidades del profesorado el equipo de investigación elaboró un cuestionario formado por 22 preguntas (ver anexo 2). 21 de las cuestiones en escala Likert de cinco anclajes siendo 1: nunca, 2: casi nunca, 3: a menudo, 4: casi siempre y 5: siempre. La cuestión número 22 es de respuesta abierta.

Por su parte, la muestra de las familias, está compuesta por un total de 156 padres y madres, de alumnos del segundo y tercer ciclo de Educación Primara del C.E.I.P Pio XII y C.E.I.P Lope de Vega, ambos de Nules (Castellón).

Respecto al cuestionario de evaluación de necesidades dirigido a los familiares (ver anexo $3)$, principalmente padres y madres, el equipo de investigación elaboró un cuestionario formado por 25 preguntas formuladas en escala dicotómica, sí/no.

Como datos significativos extraídos de las evaluaciones de necesidades a estos dos colectivos, podemos destacar entre que prácticamente la totalidad de los familiares considera necesaria la prevención en los centros educativos sobre los riesgos en el uso de las TIC por parte de los menores así como la importancia de concienciar a la sociedad sobre los riesgos en el uso de las TIC.

Por su parte los docentes, una gran parte de ellos reconoce no disponer de pautas a seguir para hacer frente a situaciones de ciberbullying, ni tampoco disponen de la suficiente 
información y formación sobre los riesgos. Más de la mitad indican que sin ayuda de otros profesionales no se sienten capacitados para resolver los conflictos derivados de las TIC, y reconocen la importancia de trabajar las relaciones interpersonales siendo este un objetivo principal en su labor como docentes.

Consideran necesario la implantación de un proyecto de prevención e intervención contra la violencia, de la elaboración de protocolos y materiales para trabajar en el aula, así como cursos de formación para los docentes. 

CAPÍTULO 6. DISEÑO DEL PROGRAMA

6.1. OBJETIVOS

6.2. METODOLOGÍA

6.3. CONTENIDOS

6.4. ACTIVIDADES

6.5. SÍNTESIS 



\section{CAPÍTULO 6. DISEÑO DEL PROGRAMA}

El fenómeno del Ciberbullying adquiere en estos momentos una gran relevancia en nuestra sociedad, no solamente entre los adultos, jóvenes y niños, sino también entre otros colectivos como pueden ser las personas con diversidad funcional. Esto, pone de manifiesto la necesidad de abordar este fenómeno no solo desde la intervención sino, fundamentalmente desde la prevención.

En el estudio que presentamos en esta Tesis, nos centraremos en la etapa educativa de la Educación Primaria, concretamente en el segundo y tercer ciclo de la misma, ya que tal como hemos podido deducir de los resultados que se desprenden de los capítulos anteriores, la edad en que se presenta el Ciberbullying desciende de manera alarmante, así, prácticamente la gran mayoría de estudios hacen referencia a la adolescencia y etapas evolutivas posteriores, y muy pocos a etapas inferiores. Hay que destacar, sin embargo, que la mayor parte de los estudios apuntan a una tendencia cada vez mayor del descenso de la edad en la aparición del ciberbullying

Este punto de partida, también es compartido por muchos expertos en el tema, así, la Dra. Garaigordobil en una entrevista concedida recientemente (Infocopline 21/12/2016) al Colegio Oficialde Psicólogos, ponía de manifiesto la necesidad de establecer programas de prevención en el contexto educativo.

Considerando lo anteriormente citado, los centros educativos de todos los niveles tienen en la actualidad el deber de incluir dentro de la formación integral aspectos como sensibilizar y prevenir que entre el mismo alumnado surjan situaciones de maltrato e intimidación, aunque se sabe que el ciberbullying no sucede precisamente dentro de la escuela, es ahí donde debe abordarse como parte de la educación integral (Ortega, 2010). La nueva educación que hay que realizar en el ámbito de las TIC también debe procurar capacitar en determinadas destrezas y habilidades, que suscitará unas actitudes y disposiciones. Entre estas últimas es imprescindible la necesidad de formar en una actitud sanamente crítica ante las TIC.

\subsection{OBJETIVOS}

Diseñar un programa preventivo/formativo ante posibles situaciones de ciberbullying cuyo objetivo principal es realizar acciones de prevención del ciberbullying en los centros escolares en el segundo y tercer ciclo de la Educación Primaria mediante actividades insertas en el currículo escolar, de forma que el alumno tenga la posibilidad de adquirir estos conocimientos y habilidades relacionadas con la prevención del ciberbullying progresivamente durante los cuatro últimos cursos de la Educación Primaria. 


\subsection{METODOLOGÍA}

Está claro que nos estamos moviendo en una sociedad en la que las competencias digitales adquieren especial relevancia. Si nos centramos en Primaria, aparte de lo expuesto anteriormente, es porque esta etapa constituye un punto de inflexión en el uso de las TIC, ya que representa el paso de una utilización lúdica a un uso de aplicación escolar, puesto que las actividades escolares con los ordenadores se encuentran en el día a día de la resolución de actividades escolares. De ahí, que los alumnos no solo deben conocer y saber utilizarlos aspectos técnicos del ordenador, sino que fundamentalmente deben saber hacer un uso responsable de las herramientas que le ofrece Internet.

De este modo, la competencia digital, en nuestro sistema educativo, se entiende como "aquella competencia que implica el uso creativo, crítico y seguro de las TIC para alcanzar los objetivos relacionados con el trabajo, empleabilidad, el aprendizaje, el uso del tiempo libre, la inclusión y participación en la sociedad. Esta competencia supone, además de la adecuación a los cambios que introducen las nuevas tecnologías en la alfabetización, la lectura y la escritura, un conjunto nuevo de habilidades y actitudes necesarias hoy en día para ser competente en un mundo digital" (BOE, 25 enero 2015)

Así mismo, el desarrollo de las competencias digitales se expone claramente en las ocho competencias del currículo de Primaria (Real Decreto 1513/2006). Así, la competencia digital se considera transversal respecto a cada una de las áreas curriculares que conforman la etapa educativa.

Dicha competencia comprende cinco dimensiones:

1. Dimensión de aprendizaje. Su objetivo es la transformación de la información en conocimiento, permitiendo la adquisición del mismo.

2. Dimensión informacional. Su objetivo es la obtención, la evaluación y el tratamiento de la información en entornos digitales.

3. Dimensión comunicativa. Su objetivo es la comunicación interpersonal y social.

4. Dimensión de ciudadanía digital. Su objetivo es facilitar las prácticas sociales y culturales de la sociedad.

5. Dimensión tecnológica. Su objetivo la alfabetización tecnológica y el conocimiento y dominio de los entornos digitales

Teniendo en cuenta lo anterior, nuestro trabajo se centra en desarrollar la dimensión cuatro, ya que constituyen, a nuestro entender, la base para llevar a cabo un buen programa de prevención del ciberbullying.

La cuestión que nos planteamos ahora, es cómo lo podemos realizar. Para ello, y destacando la transversalidad curricular de Primaria, optamos por la Inserción Curricular. Esta nos permite introducir el fenómeno del ciberbullying en el currículo de manera armónica y funcional, haciéndolo parte de manera activa del proceso de 
Enseñanza/Aprendizaje. Así, Sánchez (2002) establece una serie de formas para llevar a cabo la inserción de manera efectiva. De entre ellas, nosotros escogemos la forma Integrada, ya que nos permite implicar varias asignaturas de las diferentes áreas para trabajar el fenómeno del ciberbulliyng en estos cursos de Primaria.

Así, para llevar a cabo dicha inserción tendremos en cuenta los modelos pedagógicos de inserción que actualmente suelen utilizarse de acuerdo con la temática que se desee introducir en el currículo. Estos modelos son, entre otros: Modelos tutoriales, Modelos de Sistemas modulares, Modelos de Aprendizaje Basado en Proyectos, Modelos basados en competencias profesionales. etc. Nosotros nos basaremos en los Modelos Educativos Centrados en el Aprendizaje; ya que en dicho modelo adquiere especial relevancia la relación con los entornos abiertos, constituyendo de este modo nuevas formas de propuestas curriculares flexibles.

Teniendo en cuenta el objetivo de nuestra investigación utilizamos el Modelo de Inserción curricular de Hilda Taba como soporte teórico de nuestro programa de prevención del Ciberbullying en la etapa de Primaria (Addine et al., 2000).

El modelo curricular de Taba pone el énfasis en la necesidad de que en los programas escolares se incluyan aquellos aspectos que den respuestas efectivas a las necesidades y problemáticas que la sociedad nos plantea en cada momento. Ello implica, a diferencia de otros modelos, la conveniencia de introducir el diagnóstico de las necesidades sociales. El modelo se configura en torno a siete elementos:

a) Diagnóstico de las necesidades sociales

b) Formulación de los objetivos

c) Selección de los contenidos

d) Organización de los contenidos

e) Selección de las actividades de aprendizaje

f) Organización de las actividades de aprendizaje

g) Determinar lo que se va a evaluar.

En definitiva, y tal como se presenta en el siguiente punto, nuestro programa se adecua a las características de dicho modelo. 


\subsection{CONTENIDOS}

El programa de prevención del ciberbullying "Conviure en un món real i digital", ha sido diseñado a partir de un conjunto de actividades insertas al currículo escolar, concretamente en las siguientes asignaturas:

- Ciencias sociales

- Ciencias de la naturaleza

- Lengua castellana y literatura

La elección de estas asignaturas está realizada tras la consulta del DECRETO 108/2014, de 4 de julio, del Consell, por el que establece el currículo y desarrolla la ordenación general de la educación primaria en la Comunitat Valenciana, donde se detallan los contenidos en cada una de las áreas y cursos de Educación Primaria. Además, consultamos también el Real Decreto 126/2014, de 28 de febrero, por el que se establece el currículo básico de la Educación Primaria.

Tras su análisis, consideramos que las asignaturas anteriormente citadas son las que más se adecúan en cuanto a contenidos y objetivos curriculares. También se consideran por tratarse de asignaturas troncales, cuyo su contenido se adapta muy bien a la finalidad que perseguimos, y además son impartidas por los tutores de curso, ya que consideramos importante que se relacione el aspecto educativo con la labor cotidiana que realiza el grupo en el aula.

En cuanto a los contenidos propios a desarrollar en el programa debemos saber que esta inserción curricular no solamente va a cubrir la prevención en cuanto a aspectos tecnológicos, sino también en aspectos humanísticos. Es decir, para conseguir los objetivos propuestos es necesario trabajar aspectos tecnológicos sin embargo, trabajar únicamente estos aspectos no sería suficiente, pues para poder asumir esta información y aplicarla correctamente es necesario que ciertas habilidades personales y sociales estén muy desarrolladas, para así prevenir la aparición de problemas como el ciberbullying.

En concreto las habilidades centradas en el buen uso de las TIC y las relacionadas con la resolución de conflictos serán aspectos centrales en nuestro proyecto pues trabajándolos desde edades tempranas creemos que son aspectos clave en la prevención del ciberbullying. Cabe remarcar que las temáticas van siendo trabajadas progresivamente, algunas a lo largo del mismo ciclo educativo y otras como las dos habilidades que acabamos de nombrar se trabajarán progresivamente a lo largo de los últimos cuatro años de Educación Primaria, pues se trata de un programa que se debe aplicar de modo longitudinal.

Por tanto, las temáticas que se trabajarán en este programa se clasifican del siguiente modo. En los cursos de tercero y cuarto de primaria se trabajarán un conjunto de actividades relacionadas con habilidades tecnológicas y personales cómo son: 
- Buen uso de las TIC

- Prevención y resolución de conflictos

- Autoestima

- Emociones

- Autocontrol

A continuación, en quinto y sexto curso de primaria se seguirán trabajando aspectos tecnológicos e introduciremos habilidades sociales, dado que estos últimos se tienen que desarrollar con posterioridad a las habilidades más personales. Así los contenidos a trabajar los dos últimos cursos de la educación primaria son:

- Buen uso de las TIC

- Resolución de conflictos

- Empatía

- Asertividad

- Ciberbullying

Estos elementos son considerados como clave en la prevención de situaciones de violencia, y han sido citados por numerosos investigadores en publicaciones sobre ciberbullying: Calmaestra et al., 2016; Avilés, 2013; Cáceres, 2010; Luengo, 2014; Orjuela, 2013, entre otros.

Partiendo de todos estos elementos iniciales que van a determinar el programa, se elabora un dossier para los alumnos de cada curso escolar (anexos 4, 5, 6 y 7). El dossier de cada curso escolar está formado por cinco bloques temáticos con tres actividades por cada bloque (dos relacionadas con el contenido curricular y una de síntesis) siendo un total de quince actividades por curso escolar.

Además de los cuadernos para los alumnos en los que se incluyen las fichas con las actividades, se ha elaborado un dossier para cada uno de los docentes en los que además de las actividades de los alumnos se incluye otra información que consideramos relevante para la aplicación del programa. Quisiéramos indicar que el cuaderno de los docentes y algunas de las actividades están redactadas en valenciano, pues es la lengua vehicular del centro educativo en la que se imparten las asignaturas de ciencias sociales y ciencias de la naturaleza en el centro experimental.

Así, en el cuaderno de los docentes (anexos 8, 9, 10 y 11) se incluye una introducción en la que se especifican los objetivos generales del programa; las características y configuración del programa, y el procedimiento para la aplicación del programa.

A continuación, en este cuaderno se presenta una tabla que recoge todas las actividades que incluye el programa clasificadas por curso y por temática, así como el nombre de las actividades para que todos los docentes conozcan todas las actividades incluidas en todos los cursos. 
En cada uno de los cuadernos se presenta también una tabla específica de dicho curso en la que se determinan las asignaturas, la temática curricular, la temática transversal del programa y un registro de las actividades.

A partir de aquí, el cuarderno del docente se distribuye por bloques, uno para cada una de las temáticas trabajadas en cada curso. Al inicio de cada bloque temático se presenta una serie de información; donde se especifica la definición del concepto de la temática a trabajar, los objetivos que se persiguen y una tabla resumen con las actividades que incluye el bloque clasificadas por las asignaturas curriculares para facilitar así su inserción.

A continuación, el docente dispone de una ficha de trabajo correspondiente a cada una de las fichas de los alumnos donde se especifican los siguientes campos informativos:

- Asignatura: indica la asignatura en la cual hay que insertar la actividad.

- Contenido curricular: materia de la asignatura con la que está relacionada la actividad.

- Objetivos curriculares y objetivos de la temática: remarca los objetivos tanto curriculares como de la temática que se trabajan a la actividad.

- Metodología y procedimiento: determina cómo y de qué forma se debe llevar a cabo la actividad.

- Temporalización: tiempo aproximado de la realización de la actividad.

- Orientaciones: datos relacionados con la actividad que facilitan al profesorado la aplicación de la actividad, tanto a nivel teórico como práctico.

- Recursos: materiales necesarios para desarrollar adecuadamente la actividad.

Toda esta información permite al docente llevar un seguimiento de las actividades realizadas, así como organizarse y planificarse. Por supuesto toda esta información facilita la aplicación del programa puesto que se le indica explícitamente en qué asignatura y contenido específico está insertada dicha actividad.

Al finalizar cada bloque, se le presenta al docente una ficha de evaluación de las actividades trabajadas en cada uno de los bloques de contenidos. También al final del cuaderno del profesor, hay una ficha de evaluación final del programa para este curso educativo, que se debe pasar a los alumnos una vez finalizado el programa para valorar la asimilación de los contenidos.

El cuaderno finaliza con un pequeño documento que recoge algunos recursos extra como guías, enlaces de páginas web y vídeos con los que se pueden ampliar los conocimientos relacionados con la temática principal del programa; el ciberbullying.

Con la finalidad de implicar a todos los docentes del centro, especialmente a los especialistas que imparten docencia con los alumnos de segundo y tercer ciclo de Educación Primaria, pues es a estos a los que va dirigido el programa, también se ha elaborado un dossier con actividades complementarias. 
Este cuaderno complementario (anexo 12) se inicia con una introducción en la que se especifica su finalidad, se describe el programa y las temáticas que se están trabajando insertadas en el currículo de cada curso mediante nuestro programa. A continuación, se presenta una tabla a modo de registro de anotación donde indicar qué actividades se han realizado y en qué curso. Ya posteriormente se recogen las actividades clasificadas en las ocho temáticas que se trabajan en el programa, incluyendo al inicio una definición del concepto a trabajar. Cada bloque consta de cinco actividades en las que se detalla el objetivo de la actividad, la descripción y los recursos necesarios para su aplicación.

\subsection{ACTIVIDADES}

Con la finalidad de visualizar mejor el programa "Conviure en un món real i digital", presentamos a continuación las Tablas 55, 56, 57 y 58, en las que se recogen por cursos las asignaturas en las que se realiza la inserción curricular del programa en dicho curso, las temáticas curriculares en las que se incluyen las actividades y la temática transversal del programa que se trabaja en ellas.

\section{Tercer curso de primaria}

Tabla 55. Resumen cuaderno contenidos tercero curso de Educación Primaria

\begin{tabular}{|c|c|c|}
\hline ASIGNATURA & $\begin{array}{l}\text { TEMÁTICA } \\
\text { CURRICULAR }\end{array}$ & TEMÁTICA TRANSVERSAL \\
\hline \multirow{6}{*}{ CIÈNCIES DE LA NATURALESA } & Alimentació & \\
\hline & Cura del nostre cos & Autoestima \\
\hline & Anem a reflexionar & \\
\hline & Animals & \\
\hline & Energia & Autocontrol \\
\hline & Anem a reflexionar & \\
\hline \multirow{6}{*}{ CIÈNCIES SOCIALS } & L'aigua & \\
\hline & Vivim en comunitat & Emociones \\
\hline & Anem a reflexionar & \\
\hline & Convivim en societat & \\
\hline & $\begin{array}{c}\text { El nostre passat } \\
\text { personal }\end{array}$ & $\begin{array}{l}\text { Prevención } \mathrm{Y} \text { resolución de } \\
\text { conflictos }\end{array}$ \\
\hline & Anem a reflexionar & \\
\hline \multirow{3}{*}{$\begin{array}{l}\text { LENGUA CASTELLANA Y } \\
\text { LITERATURA }\end{array}$} & Signos de puntuación & \\
\hline & La noticia & Buen uso de las TIC \\
\hline & Vamos a reflexionar & \\
\hline
\end{tabular}




\section{Cuarto curso de primaria}

Tabla 56. Resumen cuaderno contenidos cuarto curso de Educación Primaria

\begin{tabular}{|c|c|c|}
\hline ASIGNATURA & TEMÁTICA CURRICULAR & TEMÁTICA TRANSVERSAL \\
\hline \multirow{6}{*}{ CIÈNCIES DE LA NATURALESA } & Els sentits & \multirow{3}{*}{ Emociones } \\
\hline & Agricultura & \\
\hline & Anem a reflexionar & \\
\hline & Classificació dels ésser svius & \multirow{3}{*}{ Buen uso de las TIC } \\
\hline & El reciclatgedelsmaterials & \\
\hline & Anem a reflexionar & \\
\hline \multirow{3}{*}{ CIÈNCIES SOCIALS } & El medi natural & \multirow{3}{*}{ Autocontrol } \\
\hline & L'organització territorial & \\
\hline & Anem a reflexionar & \\
\hline \multirow{6}{*}{$\begin{array}{l}\text { LENGUA CASTELLANA Y } \\
\text { LITERATURA }\end{array}$} & Sinónimos y antónimos & \multirow{3}{*}{ Autoestima } \\
\hline & Determinantes posesivos & \\
\hline & Vamos a reflexionar & \\
\hline & Expresión oral & \multirow{3}{*}{$\begin{array}{l}\text { Prevención y resolución de } \\
\text { conflictos }\end{array}$} \\
\hline & Comunicación oral & \\
\hline & Vamos a reflexionar & \\
\hline
\end{tabular}

\section{Quinto curso de primaria}

Tabla 57. Resumen cuaderno contenidos quinto curso de Educación Primaria

\begin{tabular}{|c|c|c|}
\hline ASIGNATURA & TEMÁTICA CURRICULAR & TEMÁTICA TRANSVERSAL \\
\hline \multirow{3}{*}{ CIÈNCIES DE LA NATURALESA } & La funció de relació & \multirow{3}{*}{ Buen uso de las TIC } \\
\hline & La salut & \\
\hline & Anem a reflexionar & \\
\hline \multirow{6}{*}{ CIÈNCIES SOCIALS } & Població d'Espanya i d'Europa & \multirow{3}{*}{ Asertividad } \\
\hline & Espanya & \\
\hline & Anem a reflexionar & \\
\hline & Edat mitja & \multirow{3}{*}{$\begin{array}{l}\text { Prevención y resolución de } \\
\text { conflictos }\end{array}$} \\
\hline & La reconquista dels cristians & \\
\hline & Anem a reflexionar & \\
\hline \multirow{6}{*}{$\begin{array}{l}\text { LENGUA CASTELLANA Y } \\
\text { LITERATURA }\end{array}$} & Adjetivos & \multirow{3}{*}{ Empatía } \\
\hline & Signos de puntuación & \\
\hline & Vamos a reflexionar & \\
\hline & El resumen & \multirow{3}{*}{ Ciberbullying } \\
\hline & La entrevista & \\
\hline & Vamos a reflexionar & \\
\hline
\end{tabular}




\section{Sexto curso de primaria}

Tabla 58. Resumen cuaderno contenidos sexto curso de Educación Primaria

\begin{tabular}{|c|c|c|}
\hline ASIGNATURA & TEMÁTICA CURRICULAR & TEMÁTICA TRANSVERSAL \\
\hline \multirow{3}{*}{ CIÈNCIES DE LA NATURALESA } & L'aparell digestiu & \multirow{3}{*}{ Buen uso de las TIC } \\
\hline & La respiració & \\
\hline & Anem a reflexionar & \\
\hline \multirow{6}{*}{ CIÈNCIES SOCIALS } & $\begin{array}{c}\text { Intervenció de l'ésser humà en } \\
\text { el medi }\end{array}$ & \multirow{3}{*}{ Asertividad } \\
\hline & Sectors econòmics & \\
\hline & Anem a reflexionar & \\
\hline & Industrialització & \multirow{3}{*}{$\begin{array}{l}\text { Prevención y resolución de } \\
\text { conflictos }\end{array}$} \\
\hline & Espanya al segle $X X$ & \\
\hline & Anem a reflexionar & \\
\hline \multirow{6}{*}{$\begin{array}{l}\text { LENGUA CASTELLANA Y } \\
\text { LITERATURA }\end{array}$} & Texto argumentativo & \multirow{3}{*}{ Empatía } \\
\hline & El diálogo & \\
\hline & Vamos a reflexionar & \\
\hline & El eslogan & \multirow{3}{*}{ Ciberbullying } \\
\hline & Dramatización & \\
\hline & Vamos a reflexionar & \\
\hline
\end{tabular}

Una vez presentadas las tablas anteriores con información relevante en nuestro programa relacionada con los contenidos, pasamos a presentar la Tabla 59 que recoge todas las actividades clasificadas inicialmente por curso escolar y también por la temática que se trabaja. Recordamos que algunas actividades han sido elaboradas en valenciano por las características del centro educativo en el que se aplica en programa

Tabla 59.Actividades incluidas en cada curso y clasificadas por temáticas

\begin{tabular}{|c|c|c|}
\hline CURSO & TEMÁTICA & ACTIVIDAD \\
\hline \multirow{15}{*}{$3 r$} & & 1. Així sóc jo. \\
\hline & Autoestima & 2. Em quede amb tot allò bo. \\
\hline & & 3. Anem a reflexionar. \\
\hline & \multirow{3}{*}{ Emociones } & 4. El que sentim. \\
\hline & & 5. Dime com et sents. \\
\hline & & 6. Anem a reflexionar. \\
\hline & \multirow{3}{*}{ Autocontrol } & 7. Què passarà? \\
\hline & & 8. Pren-te el teu temps. \\
\hline & & 9. Anem a reflexionar. \\
\hline & \multirow{3}{*}{$\begin{array}{l}\text { Prevención y resolución de } \\
\text { conflictos }\end{array}$} & 10. Ens relacionem. \\
\hline & & 11. Fa un temps. \\
\hline & & 12. Anem a reflexionar. \\
\hline & \multirow{3}{*}{ Buen uso de las TIC } & 13. Un día cualquiera \\
\hline & & 14. ¿Tú qué opinas? \\
\hline & & 15. Vamos a reflexionar. \\
\hline
\end{tabular}


Tabla 59.Actividades incluidas en cada curso y clasificadas por temáticas. (Continuación)

\begin{tabular}{|c|c|c|}
\hline CURSO & TEMÁTICA & ACTIVIDAD \\
\hline \multirow{5}{*}{$4 t$} & Autoestima & $\begin{array}{l}\text { 1. Autorretrato. } \\
\text { 2. Así es mi compañero. } \\
\text { 3. Vamos a reflexionar. }\end{array}$ \\
\hline & Emociones & $\begin{array}{l}\text { 4. Els altres també senten. } \\
\text { 5. Sentim diferent. } \\
\text { 6. Anem a reflexionar. }\end{array}$ \\
\hline & Autocontrol & $\begin{array}{l}\text { 7. Anem a imaginar. } \\
\text { 8. ¿Què ocorre? } \\
\text { 9. Anem a reflexionar. }\end{array}$ \\
\hline & $\begin{array}{l}\text { Prevención y resolución de } \\
\text { conflictos }\end{array}$ & $\begin{array}{l}\text { 10. ¿'Hablamos? } \\
\text { 11. ¿Què ocorre? } \\
\text { 12. Anem a reflexionar. }\end{array}$ \\
\hline & Buen uso de las TIC & $\begin{array}{l}\text { 13. A internet ho trobarem. } \\
\text { 14. Siguem responsables. } \\
\text { 15. Anem a reflexionar. }\end{array}$ \\
\hline \multirow{5}{*}{$5 \grave{e ̀ ~}$} & Empatía & $\begin{array}{l}\text { 1. Ponte en mi lugar. } \\
\text { 2. Si tú estás feliz yo estoy feliz. } \\
\text { 3. Vamos a reflexionar. }\end{array}$ \\
\hline & Asertivitdad & $\begin{array}{l}\text { 4. Els meus drets. } \\
\text { 5. Conta'm què t'agrada. } \\
\text { 6. Anem a reflexionar. }\end{array}$ \\
\hline & Ciberbullying & $\begin{array}{l}\text { 7. Carlos y el ciberbullying. } \\
\text { 8. ¿Qué necesitas saber? } \\
\text { 9. Vamos a reflexionar. }\end{array}$ \\
\hline & $\begin{array}{l}\text { Prevención y resolución de } \\
\text { conflictos }\end{array}$ & $\begin{array}{l}\text { 10. Els conflictes. } \\
\text { 11. Solucionem els conflictes. } \\
\text { 12. Anem a reflexionar. }\end{array}$ \\
\hline & Buen uso de las TIC & $\begin{array}{l}\text { 13. Ens relacionem per internet. } \\
\text { 14. Fem un ús saludable. } \\
\text { 15. Anem a reflexionar. }\end{array}$ \\
\hline \multirow{5}{*}{ 6è } & Empatía & $\begin{array}{l}\text { 1. Buscando la reacción adecuada. } \\
\text { 2. ¿Tú cómo lo ves? } \\
\text { 3. Vamos a reflexionar. }\end{array}$ \\
\hline & Asertividad & $\begin{array}{l}\text { 4. Algunes voltes cal dir que no. } \\
\text { 5. Queixar-se com cal. } \\
\text { 6. Anem a reflexionar. }\end{array}$ \\
\hline & Ciberbullying & $\begin{array}{ll}\text { 7. } & \text { Así sí. } \\
\text { 8. ¿Y ahora qué hago? } \\
\text { 9. Vamos a reflexionar. }\end{array}$ \\
\hline & $\begin{array}{l}\text { Prevención y resolución de } \\
\text { conflictos }\end{array}$ & $\begin{array}{l}\text { 10. Prenem la decisió. } \\
\text { 11. Jo decideixo per mi. } \\
\text { 12. Anem a reflexionar }\end{array}$ \\
\hline & Buen uso de las TIC & $\begin{array}{l}\text { 13. Compartim informació. } \\
\text { 14. Utilitzem el temps com cal. } \\
\text { 15. Anem a reflexionar. }\end{array}$ \\
\hline
\end{tabular}




\subsection{SÍNTESIS}

Nuestra investigación se ha centrado en el diseño del programa "Conviure a un món real i digital", programa preventivo/formativo ante posibles situaciones de ciberbullying cuyo objetivo principal es realizar acciones de prevención del ciberbullying en los centros escolares en el segundo y tercer ciclo de la Educación Primaria mediante actividades insertas en el currículo escolar, de forma que el alumno tenga la posibilidad de adquirir estos conocimientos y habilidades relacionadas con la prevención del ciberbullying progresivamente durante los cuatro últimos cursos de la Educación Primaria.

Teniendo en cuenta el objetivo de nuestra investigación seguimos el Modelo de Inserción curricular de Hilda Taba como soporte teórico de nuestro programa de prevención del Ciberbullying en la etapa de Primaria (Addine et al., 2000), puesto que este modelo pone el énfasis en la necesidad de que en los programas escolares se incluyan aquellos aspectos que den respuestas efectivas a las necesidades y problemáticas que la sociedad nos plantea en cada momento.

Así, el programa ha sido diseñado a partir de un conjunto de actividades insertas al currículum escolar, concretamente en las siguientes asignaturas; ciencias sociales, ciencias de la naturaleza y lengua castellana y literatura, por la adecuación de sus contenidos al objetivo de nuestro programa.

En cuanto a las temáticas que se trabajarán en nuestro programa se clasifican del siguiente modo. En los cursos de tercero y cuarto de primaria se trabajarán un conjunto de actividades relacionadas con habilidades tecnológicas y personales cómo: buen uso de las TIC, prevención y resolución de conflictos, autoestima, emocione y autocontrol.

A continuación, en quinto y sexto curso de primaria se seguirán trabajando aspectos tecnológicos e introduciremos habilidades sociales, dado que estos últimos se tienen que desarrollar con posterioridad a las habilidades más personales. Así, los contenidos a trabajar los dos últimos cursos de la educación primaria siguen siendo el buen uso de las TIC y resolución de conflictos, pues los consideramos elementos clave en nuestro programa, y en este ciclo le añadimos actividades en las que se trabaja la empatía, la asertividad y el ciberbullying.

Cabe remarcar que las temáticas van siendo trabajadas progresivamente, algunas a lo largo del mismo ciclo educativo y otras como las dos habilidades que acabamos de nombrar se trabajarán progresivamente a lo largo de los últimos cuatro años de Educación Primaria, pues se trata de un programa longitudinal.

Partiendo de todos estos elementos iniciales elaboramos diferentes materiales. Entre ellos, un dossier para los alumnos de cada curso escolar (anexos 4, 5, 6 y 7), formado por cinco bloques temáticos con tres actividades por cada bloque (dos relacionadas con el contenido curricular y una de síntesis) siendo un total de quince actividades por curso escolar. 
Además de los cuadernos para los alumnos en los que se incluyen las fichas con las actividades, se ha elaborado un dossier para cada uno de los docentes en los que además de las actividades de los alumnos se incluye otra información que consideramos relevante para la aplicación del programa.

Con la finalidad de implicar a todos los docentes del centro, especialmente a los especialistas que imparten docencia con los alumnos de segundo y tercer ciclo de Educación Primaria, pues es a estos a los que va dirigido el programa, también se ha elaborado un dossier con actividades complementarias. 


\section{CAPÍTULO 7. APLICACIÓN Y EVALUACIÓN DEL PROGRAMA}

\subsection{FASE DE APLICACIÓN}

7.1.1. Objetivos

7.1.2. Metodología

7.1.2.1. Participantes

7.1.2.2. Procedimiento

7.1.3. Programa de aplicación

7.1.4. Temporalización

7.2 FASE DE EVALUACIÓN

7.2.1. Objetivos

7.2.2. Hipótesis

7.2.3. Contextos de los centros

7.2.4. Instrumentos de evaluación

7.2.5. Diseño y procedimiento

7.2.6. Evaluación

7.2.6.1. Evaluación en el segundo ciclo (3ㅇ y 4으) de Educación Primaria 7.2.6.1.1. Evaluación CEE en el segundo ciclo Educación Primaria 7.2.6.1.2. Evaluación Escaciber en el segundo ciclo Educación Primaria

7.2.6.2. Evaluación en el tercer ciclo (5ㅇ y 6으) de Educación Primaria 7.2.6.2.1. Evaluación CEE en el tercer ciclo Educación Primaria

7.2.6.2.2. Evaluación Escaciber en el tercer ciclo Educación Primaria 7.2.6.3. Análisis de los resultados

7.2.7. Evaluación pedagógica

7.2.7.1. Resultados de la evaluación de los alumnos

7.2.7.2. Resultados de la evaluación de los profesores

7.2.7.3. Análisis de los resultados 



\section{CAPÍTULO 7. APLICACIÓN Y EVALUACIÓN DEL PROGRAMA}

Toda investigación como la nuestra requiere de la aplicación del programa diseñado así como de su posterior evaluación para valorar así su eficacia.

Por ello, en este capítulo vamos a presentar en primer lugar la fase de aplicación del programa en el centro experimental Pio XII en los dos últimos ciclos de Educación Primaria.

Posteriormente detallaremos la evaluación derivada de la aplicación de dicho programa, recogiendo los resultados de los instrumentos de evaluación utilizados para ello, así como el análisis de los datos.

\subsection{FASE DE APLICACIÓN}

\subsubsection{Objetivos}

Implementar el programa "Conviure en un món real i digital" en un Centro Educativo de Infantil y Primaria (C.E.I.P.) con la finalidad de realizar acciones de prevención del ciberbullying en el segundo y tercer ciclo de la Educación Primaria.

\subsubsection{Metodología}

\subsubsection{Participantes}

El proyecto se ha llevado a cabo con alumnos de tercero, cuarto, quinto y sexto de primaria del C.E.I.P. Pio XII de Nules (Castellón), siendo un total de 86 los alumnos participantes; 18 de tercero, 20 de cuarto, 23 de quinto y 25 de sexto curso.

Así mismo, también han participado los cuatro docentes del C.E.I.P. Pio XII tutores de los cursos de tercero, cuarto, quinto y sexto de Educación Primaria, puesto que son éstos los docentes responsables de la impartición de las asignaturas en las cuales se inserta el contenido del programa, tal y como se indica en el apartado de Metodología del diseño del programa.

\subsubsection{Procedimiento}

Este programa está diseñado para ser aplicado a los cuatro cursos que corresponden al segundo y tercer ciclo de la Educación Primaria de forma progresiva a lo largo de estos cursos, de forma que al finalizar el tercer ciclo los alumnos hayan logrado alcanzar todos los objetivos del programa de prevención.

La aplicación del programa corresponde a los profesores tutores, puesto que se considera importante que se relacione el aspecto educativo de este programa con la tarea cotidiana que realizan los alumnos en las diferentes asignaturas curriculares. Así, para que la 
aplicación sea adecuada y satisfactoria es necesaria la constancia del profesorado a lo largo del curso.

Debido a ello, el procedimiento que se sigue para la aplicación del programa se inicia a finales del curso escolar 2014/2015. La investigadora junto con su equipo se reúne con la dirección del C.E.I.P. Pio XII para presentarles el proyecto que están llevando a cabo. La dirección del centro se muestra muy interesada en la investigación.

La dirección del centro informa al claustro docente del proyecto, así como también al consejo escolar del centro y a la Asociación de Madres y Padres de Alumnos (AMPA). Todos los órganos consideran relevante la puesta en marcha de este proyecto y por tanto están de acuerdo en su aplicación. Con ello, llegamos al consenso de la aplicación del programa de prevención del ciberbullying que forma parte de dicha investigación para el curso 2015/2016.

Se solicita a Conselleria de Educación de la Generalitat Valenciana la aplicación del programa así como el pase de los cuestionarios a los alumnos del centro, mediante el envío del correspondiente proyecto a dicha institución. Conselleria aprueba nuestra solicitud, enviándonos una carta en la que se informa de su aprobación, tanto a nuestro equipo de investigación como al centro educativo.

Tras la aprobación del proyecto por parte de Conselleria, y a inicios del curso 2015/2016 la doctoranda junto con su equipo de investigación se reúnen con los docentes implicados en la aplicación del programa (maestros tutores del segundo y tercer ciclo de Educación Primaria) para explicarles en primera persona el proyecto y facilitarles indicaciones para su aplicación. Se les facilitan todos los materiales, tanto los dosieres de los docentes como los de los alumnos, y se les explica su formato, la información de la que disponen en el dossier, cómo aplicarlo puesto que debe estar insertado en el currículo escolar de tres asignaturas, etc.

En esta reunión también se les entrega a los docentes un documento de autorización para cada alumno con un sobre, que los docentes deben entregar al alumnado y estos a sus respectivos progenitores para que autoricen la aplicación del programa a dicho alumnado. Esta autorización como indica el documento se debe entregar al docente dentro del sobre cerrado, por medio de los alumnos.

Posteriormente a esta reunión, y antes de dar inicio al programa, la doctoranda realiza un curso de formación sobre ciberbullying a todos los docentes del centro escolar, pues consideramos necesario que toda la comunidad educativa conozca el proyecto que se va a llevar a cabo. Así, se realizan dos sesiones de formación donde se les informa de aspectos como qué es el ciberbullying, quienes están implicados, cómo detectarlo, etc. (se puede consultar el índice en el anexo 13) con la finalidad que todo el centro se implique y conozca el fenómeno del ciberbullying. Además, a todos los docentes se les proporciona un material complementario al programa elaborado más específicamente para los 
especialistas para que puedan realizar actividades complementarias al programa que ayuden también a la prevención del ciberbullying (anexo 12).

Con todas estas acciones realizadas, son ya los docentes quienes deben aplicar el programa siguiendo las pautas inicialmente pautadas e indicadas, insertando las actividades del programa en el currículo escolar de las asignaturas indicadas.

La investigadora acude mensualmente al centro para hablar con los docentes que están aplicando el programa, para resolver cualquier duda que pueda surgir y ver la correcta aplicación del programa.

\subsubsection{Programa de aplicación}

Respecto a los materiales, todos los materiales necesarios para la puesta en marcha del proyecto son proporcionados a los profesores y al centro en la entrevista realizada al inicio del curso, tal y como se indica en el apartado de procedimiento.

Así entregamos un dossier personalizado para cada uno de los alumnos de cada curso donde se recogen las fichas de las actividades a desarrollar durante el curso académico. Estas fichas estarán ordenadas cronológicamente y bien identificadas para que el profesor lleve el seguimiento correcto.

Además, proporcionamos un dossier a los docentes tutores encargados de llevar a cabo las actividades donde podrán encontrar al inicio las pautas generales para la puesta en marcha del proceso, junto con un cronograma que detalla cuando debe realizar cada actividad. Disponen también en el dossier de todas las actividades que contiene el alumno clasificadas por materias pero no sólo la ficha, sino que además tiene material adicional de cada una de las actividades en la que se detallar la asignatura en la que hay que insertar la actividad, el contenido curricular con el que está relacionado, la descripción de la misma, los objetivos curriculares que persigue así como los objetivos propios del proyecto, la metodología a seguir, la temporalización de la actividad, los indicadores finales de evaluación y los recursos necesarios que también se proporcionaran en el mismo dossier.

\subsubsection{Temporalización}

Este proyecto se lleva a cabo en los cursos de tercero, cuarto, quinto y sexto de Educación Primaria del C.E.I.P. Pio XII. Éste se implanta durante el curso escolar 2015/2016, iniciándose en el mes de septiembre de 2015 y finalizando en junio de 2016.

La distribución de los contenidos por materia y curso son las que están especificadas en el dossier de los docentes, y consta de 15 actividades por curso.

La finalidad es que los alumnos puedan iniciar el programa en tercer curso de Educación Primaria, y seguir el proyecto progresivamente de modo que al finalizar la etapa de la 
Educación Primaria (sexto curso de Educación Primaria) hayan adquirido todas las habilidades propuestas.

\subsection{FASE DE EVALUACIÓN}

\subsubsection{Objetivos}

Evaluar los efectos que el Programa "Conviure en un món real i digital" dirigido a los últimos ciclos de Educación Primaria ha tenido en conocimientos y competencias relacionadas con este fenómeno, y con ello evaluar la eficacia del programa.

Evaluar la adecuación de las actividades mediante la evaluación de asimilación de contenidos por parte de los alumnos respecto a los contenidos trabajados en las actividades y la evaluación de los docentes.

\subsubsection{Hipótesis}

La aplicación del Programa "Conviure en un món real i digital” aumentará las competencias en el uso y conocimiento de las TIC así como en una serie de habilidades personales y sociales como son; autoestima, emociones, autocontrol, empatía, asertividad, prevención y resolución de conflictos, ciberbullying y buen uso, todas ellas vinculadas a la prevención y afrontamiento de situaciones de acoso por medio del uso de las TIC, en base a toda la formación e información recibida progresivamente a lo largo de los cuatro cursos de Educación Primaria.

\subsubsection{Contextos de los centros}

Para la realización de esta tesis hemos trabajado con dos centros educativos de Educación Infantil y Primaria. El primero de ellos, el C.E.I.P. Pio XII como centro experimental, y el C.E.I.P. Lope de Vega como centro control, ambos con características muy similares como veremos a continuación. Pasamos pues a describir los contextos de dichos centros.

\section{C.E.I.P. Pio XII - Centro Experimental}

El programa se elaboró para ser implementado en el C.E.I.P. Pio XII situado en la localidad de Nules (Castellón), más concretamente en el Barrio de San Joaquín, al sud de la localidad. Es un centro público creado en 1991, aunque antiguamente ese mismo solar fue ocupado por otro colegio con el mismo nombre.

Es un centro de una línea ( 3 unidades de infantil y 6 de primaria), con un total de 187alumnos. La línea lingüística es avanzado 1 (lengua vehicular valenciano), donde los alumnos se inician en el castellano e inglés de forma oral desde infantil. Por su parte en 
primaria se imparte toda la docencia en valenciano, exceptuando lengua castellana y religión y valores en castellano, y la asignatura de inglés y plática en inglés.

Respecto a la plantilla de personal del centro cuenta con un total de 17 docentes; 4 de Educación Infantil, 6 de Educación Primaria y 7 especialistas.

El nivel socio-cultural del centro es medio-bajo, y cuenta con un total de 38 inmigrantes.

\section{$>$ C.E.I.P. Lope de Vega - Centro Control}

El centro control fue el C.E.I.P. Lope de Vega data de 1942, y está situado también en la localidad de Nules (Castellón), en el barrio de San Juan, al norte de la localidad.

Es un centro de una línea ( 3 unidades de infantil y 6 de primaria), con un total de 225 alumnos. La línea lingüística que sigue el centro es el Programa plurilingüe de enseñanza en castellano (PEC).

Respecto a la plantilla de personal del centro cuenta con un total de 17 docentes; 4 de Educación Infantil, 6 de Educación Primaria y 7 especialistas.

El nivel socio-cultural del centro es medio-bajo, y cuenta con un total de 35 inmigrantes.

En la siguiente Tabla 60 podemos observar una síntesis de estas características.

Tabla 60. Características contextuales de ambos centros.

\begin{tabular}{cccccc}
\hline Centro & Ubicación & Alumnos & Docentes & $\begin{array}{c}\text { Nivel socio- } \\
\text { cultural }\end{array}$ & $\begin{array}{c}\text { Oferta } \\
\text { educativa }\end{array}$ \\
\hline $\begin{array}{c}\text { C.E.I.P. } \\
\text { Pio XII }\end{array}$ & $\begin{array}{c}\text { Nules } \\
\text { Barrio San } \\
\text { Joaquín }\end{array}$ & $\mathrm{n}=187$ & $\mathrm{n}=17$ & Medio-bajo & $\begin{array}{c}\text { Educación } \\
\text { Infantil y } \\
\text { Primaria }\end{array}$ \\
\hline $\begin{array}{c}\text { C.E.I.P. } \\
\text { Lope de } \\
\text { Vega }\end{array}$ & $\begin{array}{c}\text { Nules } \\
\text { Barrio San } \\
\text { Juan }\end{array}$ & $\mathrm{n}=225$ & $\mathrm{n}=17$ & Medio-bajo & $\begin{array}{c}\text { Educación } \\
\text { Infantil y } \\
\text { Primaria }\end{array}$ \\
\hline
\end{tabular}

Como podemos observar son centros educativos con características muy similares, ambos situados en la misma localidad. En cuanto al número de docentes y alumnos, así como al nivel socio-cultural son similares también.

La única diferencia entre ambos es la lengua vehicular, puesto que en el experimental es el valenciano y en el control el castellano.

\subsubsection{Instrumentos de evaluación}

En la fase de evaluación del programa se han utilizado dos tipos de instrumentos. Dos cuestionarios para la realización del análisis de datos pretest-postest y otro pedagógico 
que hace referencia a un instrumento que evalúa la asimilación de los contenidos del programa por parte de los alumnos participantes en el programa.

Respecto a los primeros, se han utilizado dos cuestionarios diferentes, que han sido elegidos por sus adecuadas propiedades psicométricas, tanto de fiabilidad como de validez, en estudios previos.

Así para los cuatro cursos se ha utilizado el cuestionario Escaciber (Evaluación de Calidad de la Ciberconducta) y el CEE (Cuestionario de Educación Emocional), aunque este último varía según el ciclo educativo como detallaremos en los apartados correspondientes a los resultados de evaluación donde se detallan los instrumentos utilizados.

A continuación, presentamos los instrumentos.

El cuestionario de Educación Emocional (CEE) (Álvarez, 2011), ha sido elaborado con la finalidad de servir de instrumento de evaluación de programas de educación emocional, tanto en el análisis de necesidades como en la evaluación de la eficacia de los programas de intervención.

Este instrumento está configurado por cinco factores o dimensiones, que el autor define de este modo:

- Emociones (11 ítems): estado complejo del organismo caracterizado por un sentimiento fuerte de excitación o perturbación. La emoción es un concepto multidimensional que se refiere a una variedad de estados. Por eso se habla de emociones. Estas son reacciones a las informaciones que recibimos en nuestras relaciones con el entorno. El cuestionario recoge tres tipos de emociones: la ansiedad/preocupación, la depresión y la estabilidad emocional.

- Autoestima (17 ítems): nos explica cómo nos sentimos con nosotros mismos; es una información contenida en nuestro autoconcepto y se basa en la combinación de informaciones objetivas sobre sí mismo y la evaluación subjetiva de estas informaciones.

- Habilidades sociales (22 ítems): la persona que ha aprendido las habilidades sociales para relacionarse de forma satisfactoria con otras personas.

- Resolución de problemas (14 ítems): el individuo en todo su ciclo vital está afrontando constantemente diferentes situaciones problemáticas y de conflicto, tanto personales como interpersonales.

- Habilidades de vida (4 ítems): permiten mostrar comportamientos apropiados para la resolución de problemas, relacionados con asuntos personales, familiares, de tiempo libre, de la comunidad y del trabajo.

Los resultados del análisis de validación del modelo informan que los niveles de ajuste y consistencia interna son adecuados (Álvarez, 2011), lo que demuestra la idoneidad del modelo testado y de los ítems utilizados para evaluar la educación emocional. 
En cada ciclo educativo se han evaluado dimensiones diferentes, relacionadas con los contenidos trabajados en el programa. En los siguientes apartados se detallarán las dimensiones que contempla el cuestionario para cada uno de los ciclos educativos así como los ítems (ver anexos 14 y 15).

En relación al cuestionario Escaciber (Ortega, Del Rey y Sánchez, 2012), éste tiene como finalidad analizar la ciberconducta entre los y las jóvenes (anexo 16). Para ello los autores desarrollaron un instrumento ad-hoc que, por un lado, recoge las particularidades y características de la conducta cibernética $y$, por otro, nos permite agruparlas en dimensiones paralelas a las obtenidas para la convivencia escolar.

De los procesos de depuración del modelo inicial y análisis del comportamiento de cada uno de los ítems, los AFE y AFC realizados resultó un modelo de siete dimensiones, repartidas en 30 ítems:

- Relaciones en redes sociales (5 ítems): analiza la actividad social del alumnado en Internet y las redes sociales mediante indicadores como la actualización, las visitas a los perfiles de los amigos, los contactos, las relaciones con los amigos, etc.

- Uso Responsable (4 ítems): valoración del respeto y cumplimiento de las normas y convenciones sociales propias de la vida en Red como solicitar permiso para usar información personal de otros, saber cómo denunciar una agresión en Red, responder a las agresiones de forma clamada, etc.

- Uso seguro de Internet (5 ítems): análisis del uso de recursos de protección y seguridad que ofrecen los ordenadores y las redes sociales como los antivirus y de conductas de protección sobre la información personal y privada.

- Dependencia (4 ítems): reconocimiento de malestar por la limitación del uso de Internet, interés por estar permanentemente conectado, etc.

- Ciberdating (4 ítems): indicadores de la actividad de la pareja mediante las TICs y reacciones ante las discusiones como la desconexión, etc. En esta dimensión, debido a las características de la muestra se ha substituido el término pareja por amigo de modo que los indicadores harán referencia a la amistad.

- Tutorización digital docente (4 ítems): reconocimiento de la actividad docente en las redes sociales, control docente del uso del alumnado, ayuda para el uso y ayuda para la resolución de problemas.

- Supervisión familiar (4 ítems): indagación en el control y ayuda familiar en las actividades en redes sociales que la familia realiza con sus hijos e hijas.

Los resultados del análisis de validación del modelo informan que los niveles de ajuste y consistencia interna son adecuados (Ortega et al., 2012) lo que demuestra la idoneidad del modelo testado y de los ítems utilizados para evaluar la ciberconducta. 
Para la realización del segundo tipo de evaluación pedagógica, hemos elaborado unos instrumentos de evaluación; uno específicos dirigido al alumnado de cada uno de los cuatro cursos educativos a los que va dirigido el programa, y otros específicos para cada uno de los docentes que imparte el programa.

El primero hace referencia a los instrumentos que se incluían en nuestro programa en el que se evalúa al alumnado, al finalizar el programa, los contenidos trabajados durante todo el curso en este programa para ver la asimilación de estos contenidos por parte de los alumnos.

Éste ha sido elaborado por el equipo de investigación en base a las actividades planteadas en el programa para cada nivel educativo. En él se plantean un total de 10 preguntas, una relacionada con cada una de las actividades del programa. Esta evaluación es propia de cada curso, puesto que como hemos visto en cada curso se trabajan unos contenidos diferentes, y por tanto las actividades planteadas también son diferentes (ver anexos 17, $18,19$ y 20$)$.

En cuanto a los instrumentos utilizados para la evaluación pedagógica de los docentes, también ha sido elaborado por el grupo de investigación. Este se presenta al final de cada bloque de contenidos, en el dossier del profesor.

En dicho instrumento se les plantean un total de siete cuestiones relacionadas con: la dificultad de llevar a cabo las actividades; el cumplimiento del objetivo propuesto; la correspondencia del contenido del programa con el contenido curricular indicado; la utilización otros recursos a parte de los presentados en el programa; la conveniencia de modificar algún aspecto del programa; su opinión acerca de la actitud de los alumnos durante la realización del programa y la consideración de realizar alguna mejora en el programa (ver como ejemplo el anexo 21).

\subsubsection{Diseño y procedimiento}

Según Chacón, Sanduvete, Portell \& Anguera (2013), "existen distintos tipos de diseño que pueden emplearse en la aplicación de distintos programas de intervención en función de la perspectiva metodológica adoptada". Estos autores distinguen estos diseños según sea la intervención utilizada.

En esta investigación, y por sus características decidimos aplicar un diseño cuasiexperimental, según la descripción de Chacón, Shadish \& Cook (2008), un diseño cuasiexperimental se obtiene,

[...] añadiendo al diseño de un solo grupo con prueba posterior tanto un grupo control como una medida tomada en cada grupo antes de la intervención. El diseño con grupo control no equivalente y prueba previa y posterior. Aunque resuelve numerosas amenazas de validez, puede estar afectado por otras como la maduración. 
Como señalan Buendía, Colás \& Hernández (1998), este diseño es de los más utilizados en investigación educativa, "por las facilidades que supone el no depender de la elección de sujetos al azar para obtener la muestra".

Estos diseños, según Hernández-Pina (1998) "no garantizan un nivel de validez interna y externa como en los experimentales, pero ofrecen un grado de validez suficiente" para investigaciones psicopedagógicas como la nuestra.

Dentro de los distintos métodos cuasi-experimentales, nosotros utilizamos el diseño de control no equivalente y pretest.

Este diseño incluye dos grupos, uno de control y otro experimental, a los que se les ha aplicado prestest y postest al mismo tiempo. El grupo experimental es el que recibe la variable independiente o tratamiento. El grupo de control puede recibir o no un tratamiento alternativo.

En nuestra investigación contamos con dos centros de Educación Primaria de la localidad de Nules (Castellón).

El primero de ellos fue el C.E.I.P Pio XII, como centro experimental, y el segundo el C.E.I.P Lope de Vega como centro control para nuestro diseño cuasi-experimental.

Elegimos estos centros por sus características similares y porque están ubicados en la localidad de la investigadora.

El hecho de haber escogido el C.E.I.P Pio XII como centro experimental se debe a que la investigadora hizo sus prácticas universitarias en este centro.

El grupo experimental recibió el programa de prevención del ciberbullying diseñado en este trabajo y el grupo control no. El grupo control recibió la formación correspondiente a su nivel educativo.

A los dos grupos se les administró el pretest a principio del curso escolar 2015/2016, durante las primeras semanas del mes de septiembre de 2015 y el postest la penúltima semana del curso escolar de junio de 2016 (ver esquema en la Figura 22).

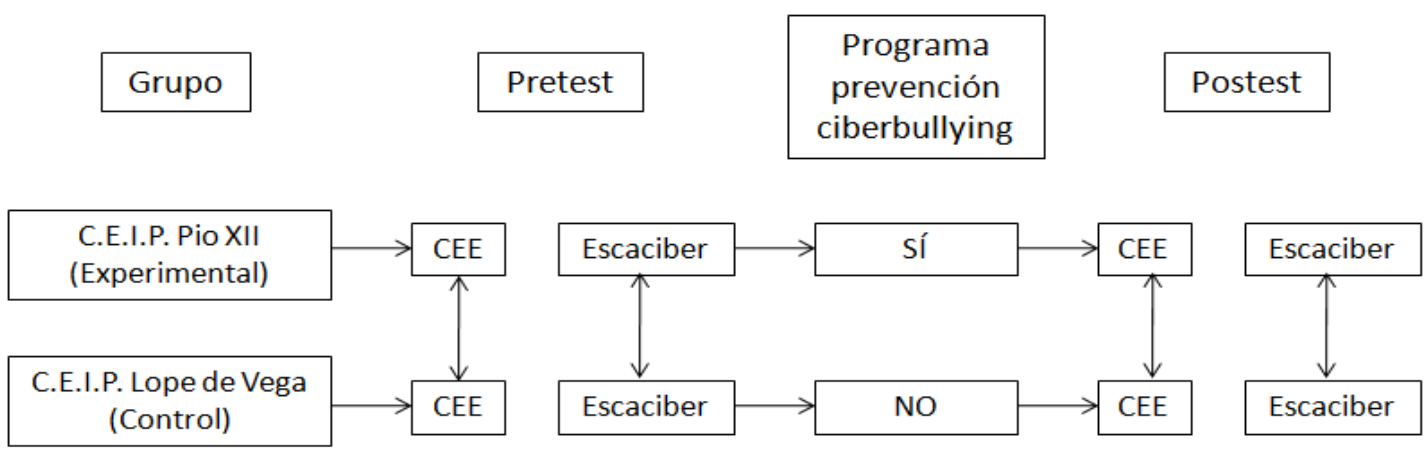

Figura 22. Diseño cuasi experimental con un grupo de control no equivalente pretest y postest, adaptado a nuestro estudio. 
El proceso que llevamos a cabo para aplicar el cuestionario fue el siguiente, tanto en el centro experimental como en el control.

- La doctoranda junto con el equipo de investigación mantuvieron una reunión con la dirección del centro a finales del curso escolar 2014/2015 en la cual se les presentó la investigación y los cuestionarios que sería necesario pasar al alumnado. Éstos a su vez informaron al claustro de profesores y al consejo escolar del centro, quienes aprobaron la implantación de la investigación en el centro.

- Tras su aprobación se solicitó a Conselleria de Educación el permiso para su puesta en marcha para el curso escolar 2015/2016. Esta solicitud fue aceptada por el inspector correspondiente y por Conselleria.

- A principios del curso 2015/2016 la investigadora se reunió con el equipo docente para explicar personalmente la investigación e informar sobre los instrumentos de evaluación que se iban a utilizar. Además, se les entregó a los docentes tutores del segundo y tercer ciclo de Educación Primaria un documento de autorización que deberían entregar a cada uno de los alumnos dentro de un sobre en el que los padres y madres debían mostrar su consentimiento para el pase de dichos cuestionarios así como la implantación del proyecto a sus hijos y cuyos alumnos sobre deberían entregar de nuevo al docente cerrado.

- La investigadora acude al centro y recoge todas las autorizaciones de consentimiento de los padres y madres, y comprueba que todos dan su consentimiento para el pase de las pruebas así como la aplicación del programa.

- La doctoranda acude al centro en septiembre de 2015, tras consensuar una fecha con todos los docentes implicados, para la aplicación de los cuestionarios. Estos instrumentos son entregados por los docentes a los alumnos, para aportarles tranquilidad y normalidad al pase de dichos instrumentos, puesto que los docentes ya disponen de la información necesaria para su pase. Aún así, la investigadora está presente en el centro y va pasando por las aulas para resolver cualquier duda que pueda surgir.

- Tras la finalización del pase de los instrumentos en los cuatro cursos, la doctoranda recoge los cuestionarios.

\subsubsection{Evaluación}

En la evaluación del programa con pretest-postest se han realizado los análisis de los datos por ciclo educativo, puesto que como se señala en apartados anteriores las temáticas abordadas en el programa son los mismos en cada uno de los ciclos.

Por tanto, presentaremos en primer lugar los resultados del segundo ciclo de Educación Primaria ( 3 ㅇ y 4을 ) en el cuestionario CEE y Escaciber, y a continuación los resultados del tercer ciclo de Educación Primaria (5ㅇ y 60) en el cuestionario CEE y Escaciber. 


\subsubsection{Evaluación en el segundo ciclo (3ํy y 4ํ) de Educación Primaria}

En el segundo ciclo de Educación Primaria se ha hecho la evaluación mediante el pase de dos cuestionarios, el Escaciber (evaluación de calidad de la Ciberconducta) y el CEE (cuestionario de educación emocional).

\subsection{Evaluación CEE en el segundo ciclo Educación Primaria}

La descripción del cuestionario de evaluación CEE la encontramos en el apartado de instrumentos de evaluación del presente capítulo.

Tal y como apreciamos en la descripción del instrumento de evaluación, éste consta de 68 ítems, sin embargo para nuestro estudio hemos elaborado un cuestionario en el que no se han seleccionado todos los ítems, sino sólo aquellos que hacían referencia a los aspectos trabajados en nuestro programa en el segundo ciclo de Educación Primaria; autoestima, emociones, autocontrol, prevención y resolución de conflictos y buen uso de las TIC.

En concreto, el cuestionario dirigido al alumnado de segundo ciclo de Educación Primaria cuenta con un total de 37 ítems (ver anexo 14), pertenecientes a las dimensiones; autoestima, resolución de problemas y toma de decisiones y autoconciencia emocional.

\section{Participantes}

Los participantes en cada uno de los instrumentos de evaluación se detallaran en cada uno de los apartados puesto que debido a las características de los instrumentos en algunos casos se ha perdido muestra como detallaremos en cada uno de ellos.

En el segundo ciclo de Educación Primaria, respecto al instrumento CEE, hemos contado con un total de 72 participantes; 36 del centro experimental y 36 del centro control.

Respecto al género de los participantes total, predomina el femenino con un $55,6 \%$ sobre el masculino (ver Tabla 61).

Tabla 61. Número de participantes según género en CEE en el segundo ciclo de primaria.

\begin{tabular}{ccccc}
\hline & Centro experimental & Centro control & & Total \\
\hline Género & $\mathrm{N}$ & $\mathrm{N}$ & $\mathrm{N}$ & $\%$ \\
\hline Masculino & 16 & 16 & 32 & 44,4 \\
\hline Femenino & 20 & 20 & 40 & 55,6 \\
\hline Total & 36 & 36 & $\mathbf{7 2}$ & 100 \\
\hline
\end{tabular}

Los datos de participantes total por curso nos indican que la diferencia entre ambos cursos es mínima, siendo un $51 \%$ los participantes de tercero y un $48,6 \%$ los de cuarto (ver Tabla $62)$. 
Tabla 62. Número de participantes según curso escolar en CEE en el segundo ciclo de primaria.

\begin{tabular}{ccccc}
\hline & Centro experimental & Centro control & Total \\
\hline Curso & $\mathrm{N}$ & $\mathrm{N}$ & $\mathrm{N}$ & $\%$ \\
\hline Tercero Ed. Primaria & 15 & 22 & 37 & 51,4 \\
\hline Cuarto Ed. Primaria & 21 & 14 & 35 & 48,6 \\
\hline Total & 36 & 36 & 72 & 100 \\
\hline
\end{tabular}

Respecto a la edad de los participantes, predominan los alumnos con 9 años con un $50 \%$ de la muestra, seguido de los 8 años con un 38,9\% (ver Tabla 63).

Tabla 63. Número de participantes según edad en CEE en el segundo ciclo de primaria.

\begin{tabular}{ccccc}
\hline & Centro experimental & Centro control & \multicolumn{2}{c}{ Total } \\
\hline Edad & $\mathrm{N}$ & $\mathrm{N}$ & $\mathrm{N}$ & $\%$ \\
\hline 8 & 13 & 15 & 28 & 38,9 \\
\hline 9 & 18 & 18 & 36 & 50 \\
\hline 10 & 5 & 3 & 8 & 11,1 \\
\hline Total & 36 & 36 & 72 & 100 \\
\hline
\end{tabular}

\section{Resultados}

El primer análisis que hemos realizado ha sido comprobar la normalidad para las muestras de los dos centros, y para ello se realizó la prueba de normalidad de Kolmogorov-Smirnov. Mostramos los resultados en la Tabla 64 en la cual se indican los valores Z de KolmogorovSmirnov, y su nivel de significación.

Se han comprobado los requisitos de normalidad de las puntuaciones en el pretest y postest de los dos grupos mediante la prueba Kolmogorov-Smirnov.

Así, se optó por el estudio paramétrico y los análisis que se realizan para comparar las dos muestras son la prueba $t$, anova y ancova.

No existen diferencias en edad entre el grupo experimental y el grupo control, analizado mediante la prueba $\mathrm{t}(\mathrm{t}(70)=0,717, \mathrm{p}=0,475)$.

Además, podemos afirmar que no existe diferencia de género entre el grupo experimental y el grupo control, analizado mediante la prueba chi-cuadrado $\left(x^{2}(1)=0, p=1,0\right)$. 
Tabla 64.CEE segundo ciclo. Prueba de normalidad de Kolmogorov-Smirnov, significación de la prueba.

\begin{tabular}{|c|c|c|c|c|c|c|c|c|c|c|c|}
\hline \multicolumn{6}{|c|}{ Centro experimental } & \multicolumn{6}{|c|}{ Centro control } \\
\hline \multicolumn{3}{|c|}{ Pretest } & \multicolumn{3}{|c|}{ Postest } & \multicolumn{3}{|c|}{ Pretest } & \multicolumn{3}{|c|}{ Postest } \\
\hline $\mathrm{Ae}$ & Rp y td & Ac & $\mathrm{Ae}$ & Rp y td & Ac & $\mathrm{Ae}$ & Rp y td & Ac & $\mathrm{Ae}$ & Rp y td & Ac \\
\hline 0,93 & $0,176^{* *}$ & $0,155^{*}$ & 0,14 & $0,154^{*}$ & 0,146 & $0,155^{*}$ & 0,107 & 0,137 & 0,107 & 0,118 & $0,169^{\prime}$ \\
\hline
\end{tabular}

${ }^{* p} \leq 0,05 ; * * p \leq 0,01 ; * * * p \leq 0.001$

$\mathrm{Ae}=$ autoestima, $\mathrm{Rp}$ y $\mathrm{td}=$ =resolución de problemas y toma de decisiones, $\mathrm{Ac}=$ autoconciencia

\section{Comparaciones del pretest del grupo experimental y pretest del grupo control}

Se realizó la prueba Anova entre los resultados del prestest del grupo experimental y el pretest del grupo control (ver Tabla 65).

Así en autoestima los resultados son significativos, es decir, existen diferencias iniciales entre ambos grupos.

En resolución de problemas y toma de decisiones, los datos indican que los resultados no son significativos y por tanto no hay diferencias iniciales entre los dos grupos.

Tampoco en autoconciencia emocional los resultados son significativos, por lo que no se aprecia diferencia.

Por lo tanto, de los tres aspectos analizados y según los resultados obtenidos podemos afirmar que solamente existen diferencias de puntuación en autoestima, y no existe diferencia en resolución de problemas y toma de decisiones y en autoconciencia emocional entre el pretest del grupo experimental y el pretest del grupo control.

Tabla 65. Resultados CEE segundo ciclo pretest grupo experimental y prestest grupo control

\begin{tabular}{|c|c|c|c|c|c|}
\hline & \multicolumn{2}{|c|}{$\begin{array}{c}\text { Grupo } \\
\text { Experimental }\end{array}$} & \multicolumn{2}{|c|}{ Grupo Control } & $\begin{array}{c}\text { Grupo } \\
\text { Experimental- } \\
\text { Control }\end{array}$ \\
\hline & \multicolumn{2}{|c|}{ Pretest } & \multicolumn{2}{|c|}{ Pretest } & Anova \\
\hline & $M$ & DT & $M$ & DT & $F(1,70)$ \\
\hline Autoestima & 35,75 & 3,255 & 33,94 & 4,188 & $4,172 *$ \\
\hline $\begin{array}{l}\text { Resolución de problemas y toma de } \\
\text { decisiones }\end{array}$ & 29,97 & 5,223 & 29,67 & 5,555 & 0,058 \\
\hline Autoconciencia emocional & 48,53 & 4,52 & 47,17 & 5,321 & 1,368 \\
\hline
\end{tabular}

\section{Comparaciones del pretest-postest del grupo experimental}

Se realizó la prueba t de muestras emparejadas entre los resultados del pretest y postest en el grupo experimental. 
Los resultados no son significativos en ninguno de los factores analizados; autoestima, resolución de problemas y toma de decisiones y autoconciencia emocional.

A pesar de ello, si nos centramos en las medias obtenidas en el pretest y postest (ver Tabla 66) podemos observar que la media del postest es superior en los tres aspectos analizados por lo que sí podemos hablar de una tendencia positiva.

Tabla 66. Resultados CEE segundo ciclo pretest y postest del grupo experimental

\begin{tabular}{|c|c|c|c|c|c|}
\hline & \multicolumn{5}{|c|}{ Grupo Experimental } \\
\hline & \multicolumn{2}{|c|}{ Pretest } & \multicolumn{2}{|c|}{ Postest } & \multirow{2}{*}{$\begin{array}{c}\text { Pretest-Postest } \\
\text { Prueba t (35) }\end{array}$} \\
\hline & $M$ & DT & $M$ & DT & \\
\hline Autoestima & 35,75 & 3,255 & 35,97 & 3,621 & $-0,262$ \\
\hline $\begin{array}{l}\text { Resolución de problemas y toma de } \\
\text { decisiones }\end{array}$ & 29,97 & 5,223 & 30,92 & 5,374 & $-0,075$ \\
\hline Autoconciencia emocional & 48,53 & 4,52 & 49,39 & 3,572 & $-0,928$ \\
\hline
\end{tabular}

\section{Comparaciones del pretest-postest del grupo control}

Se realizó la prueba t de muestras emparejadas entre los resultados del pretest y postest en el grupo experimental (ver Tabla 67).

Los resultados no son significativos en ninguno de los factores analizados; autoestima, resolución de problemas y toma de decisiones y autoconciencia emocional. Por ello no podemos afirmar que exista diferencia en las puntuaciones entre el pretest y el postest en el grupo control.

Tabla 67.Resultados CEE segundo ciclo pretest y postest del grupo control

\begin{tabular}{|c|c|c|c|c|c|}
\hline & \multicolumn{5}{|c|}{ Grupo Control } \\
\hline & \multicolumn{2}{|c|}{ Pretest } & \multicolumn{2}{|c|}{ Postest } & \multirow{2}{*}{$\begin{array}{c}\text { Pretest- } \\
\text { Postest }\end{array}$} \\
\hline & $M$ & DT & $M$ & DT & \\
\hline Autoestima & 33,94 & 4,188 & 32,94 & 3,957 & 1,100 \\
\hline $\begin{array}{l}\text { Resolución de problemas y toma de } \\
\text { decisiones }\end{array}$ & 29,67 & 5,555 & 27,82 & 6,037 & 1,176 \\
\hline Autoconciencia emocional & 47,17 & 5,321 & 47,11 & 6,103 & 0,042 \\
\hline
\end{tabular}




\section{Comparaciones del postest del grupo experimental y postest del grupo control}

Se realizó la prueba Anova entre los resultados del prestest del grupo experimental y el pretest del grupo control en resolución de problemas y toma de decisiones, y autoconciencia emocional. Para analizar los datos de autoestima se realizó la prueba Ancova para controlar lo efectos iniciales que nos indicaban que existía una diferencia en el pretest de ambos grupos (ver Tabla 68).

Las puntuaciones de ambas pruebas, tanto anova como ancova, nos indican que existen diferencias significativas entre el grupo experimental y el grupo control en autoestima, resolución de problemas y toma de decisiones y autoconciencia emocional.

Tabla 68. Resultados CEE segundo ciclo postest del grupo control y experimental

\begin{tabular}{|c|c|c|c|c|c|c|}
\hline & \multirow{2}{*}{\multicolumn{2}{|c|}{$\begin{array}{c}\text { Grupo } \\
\text { Experimental } \\
\text { Postest }\end{array}$}} & \multicolumn{2}{|c|}{ Grupo Control } & \multicolumn{2}{|c|}{$\begin{array}{l}\text { Grupo } \\
\text { imental-Control }\end{array}$} \\
\hline & & & Po & est & Anova & Ancova \\
\hline & $M$ & DT & $M$ & DT & $F(1,70)$ & $F(1,71)$ \\
\hline Autoestima & & & & & & $10,399 * *$ \\
\hline $\begin{array}{l}\text { Resolución de problemas y toma } \\
\text { de decisiones }\end{array}$ & 30,92 & 5,374 & 27,89 & 6,037 & $5,052^{*}$ & \\
\hline Autoconciencia emocional & 49,39 & 3,572 & 47,11 & 6,103 & $3,735^{*}$ & \\
\hline
\end{tabular}

\subsection{Evaluación Escaciber en el segundo ciclo Educación Primaria}

El instrumento utilizado para este análisis de los siguientes datos ha sido el Escaciber, descrito en el apartado de instrumentos de evaluación del presente capítulo.

Participantes

En la evaluación mediante el Escaciber del segundo ciclo Educación Primaria han participado un total de 71 alumnos; 36 del centro experimental y 35 del centro control.

Respecto al curso (ver Tabla 69), un 56,3\% del total de los participantes son del tercer curso de Educación Primaria mientras que un $43,7 \%$ son de cuarto curso. 
Tabla 69. Número de participantes según curso escolar en Escaciber en el segundo ciclo de primaria.

\begin{tabular}{ccccc}
\hline & Centro experimental & Centro control & \multicolumn{2}{c}{ Total } \\
\hline Curso & $\mathrm{N}$ & $\mathrm{N}$ & $\mathrm{N}$ & $\%$ \\
\hline Tercero Ed. Primaria & 22 & 18 & 40 & 56,3 \\
\hline Cuarto Ed. Primaria & 14 & 17 & 31 & 43,7 \\
\hline Total & 36 & 35 & 71 & 100 \\
\hline
\end{tabular}

El género de la muestra nos indica que un $53,5 \%$ de los participantes son mujeres mientras que un $46,5 \%$ son hombres (ver Tabla 70 ).

No existen diferencias de género entre el grupo experimental y el grupo control, tal y como nos muestran los resultados obtenidos del análisis de datos mediante la prueba chicuadrado $\left(x^{2}(1)=0,122, p=0,727\right)$.

Tabla 70. Número de participantes según género en Escaciber en el segundo ciclo de primaria.

\begin{tabular}{ccc}
\hline & \multicolumn{2}{c}{ Centro experimental y control } \\
\hline Género & $\mathrm{N}$ & $\%$ \\
\hline Masculino & 33 & 46,5 \\
\hline Femenino & 38 & 53,5 \\
\hline Total & 71 & 100 \\
\hline
\end{tabular}

\section{Resultados}

Presentamos a continuación los resultados obtenidos del cuestionario Escaciber administrado a los alumnos de segundo ciclo de Educación Primaria.

En primer lugar, recogemos los datos que hacen referencia a una de las cuestiones iniciales que les planteamos para conocer el uso de las redes sociales, que se puede observar en la Tabla 71.

De estos datos se extrae que son pocos los menores del segundo ciclo de Educación Primaria que hacen uso de las redes sociales, siendo la más utilizada Instagram con un $14,1 \%$. Respecto a la mensajería instantánea sí que encontramos un dato significativo, y es que un $59,2 \%$ de los alumnos afirma hacer uso de ella, aunque la mayoría reconoce que la utilizan desde los dispositivos móviles de sus padres o madres. 
Tabla 71.Uso de las redes sociales y mensajería instantánea en el segundo ciclo de primaria.

\begin{tabular}{lcc}
\hline & Sí & NO \\
\hline Facebook & 12,7 & 87,3 \\
\hline Tuenti & 1,4 & 98,6 \\
\hline Twitter & 4,2 & 95,8 \\
\hline Instagram & 14,1 & 85,9 \\
\hline Whatsapp & 59,2 & 40,8 \\
\hline Snapchat & 4,2 & 95,8 \\
\hline Hangouts & 1,4 & 98,6 \\
\hline
\end{tabular}

Estos resultados nos justifican en parte los datos que vamos a ofrecer a continuación del cuestionario Escaciber, puesto que como hemos detallado al inicio del apartado en la descripción del cuestionario, éste consta de siete dimensiones. Sin embargo, en este grupo de alumnos únicamente hemos podido analizar las dimensiones que hacen referencia a supervisión familiar y tutorización digital docente puesto que las demás dimensiones hacen referencia al uso de las redes sociales y, como se acaba de especificar con datos, estos menores todavía no hacen uso de ellas.

\section{Comparaciones del pretest del grupo experimental y pretest del grupo control}

Se realizó la prueba t para comparar los resultados del prestest del grupo experimental con el pretest del grupo control (ver Tabla 72).

Los resultados obtenidos son significativos en ambos aspectos analizados, lo que indica que existe diferencia tanto en supervisión familiar como en tutorización digital docente entre los resultados pretest de ambos grupos.

Tabla 72. Resultados Escaciber segundo ciclo pretest grupo experimental y prestest grupo control

\begin{tabular}{|c|c|c|c|c|c|}
\hline & \multicolumn{2}{|c|}{$\begin{array}{c}\text { Grupo } \\
\text { Experimental }\end{array}$} & \multicolumn{2}{|c|}{ Grupo Control } & $\begin{array}{c}\text { Grupo Experimental- } \\
\text { Control }\end{array}$ \\
\hline & \multicolumn{2}{|c|}{ Pretest } & \multicolumn{2}{|c|}{ Pretest } & \\
\hline & $M$ & DT & $M$ & DT & \\
\hline Supervisión familiar & 8,1765 & 1,66006 & 6,5926 & 2,45356 & $t(59)=3,000^{*}$ \\
\hline $\begin{array}{l}\text { Tutorización digital } \\
\text { docente }\end{array}$ & 8,2286 & 1,45695 & 6,6129 & 1,6264 & $\mathrm{t}(64)=4,257^{* * *}$ \\
\hline
\end{tabular}




\section{Comparaciones del pretest-postest del grupo experimental}

Se realizó la prueba t de muestras emparejadas entre los resultados del pretest y postest en el grupo experimental.

Los resultados son significativos en supervisión familiar, por tanto podemos determinar que hay diferencia en el grupo experimental entre el pretest y el postest.

En tutorización digital docente los resultados son no significativos, a pesar de ello, si nos observamos las medias obtenidas en el pretest y postest (ver Tabla 73) podemos ver que la media del postest es superior por lo que sí podemos hablar de una tendencia positiva.

Tabla 73.Resultados Escaciber segundo ciclo pretest y postest del grupo experimental

\begin{tabular}{|c|c|c|c|c|c|}
\hline & \multicolumn{5}{|c|}{ Grupo Experimental } \\
\hline & \multicolumn{2}{|c|}{ Pretest } & \multicolumn{2}{|c|}{ Postest } & \multirow{2}{*}{$\begin{array}{c}\text { Pretest-Postest } \\
\text { Prueba t }\end{array}$} \\
\hline & $\mathrm{M}$ & DT & $\mathrm{M}$ & DT & \\
\hline Supervisión familiar & 8,1765 & 1,66006 & 8,8824 & 1,40916 & $t(33)=-0,050^{*}$ \\
\hline Tutorización digital docente & 8,2286 & 1,45695 & 8,7143 & 1,69031 & $t(34)=-1,246$ \\
\hline
\end{tabular}

\section{Comparaciones del pretest-postest del grupo control}

Se realizó la prueba t de muestras emparejadas entre los resultados del pretest y postest en el grupo control.

Los resultados obtenidos son no significativos (ver Tabla 74) tanto en supervisión familiar como en tutorización digital docente, y por lo tanto, a partir de estos resultados no podemos afirmar que exista diferencia en las puntuaciones del pretest y postest del grupo control.

Tabla 74. Resultados Escaciber segundo ciclo pretest y postest del grupo control

\begin{tabular}{|c|c|c|c|c|c|}
\hline & \multicolumn{5}{|c|}{ Grupo Control } \\
\hline & \multicolumn{2}{|c|}{ Pretest } & \multicolumn{2}{|c|}{ Postest } & \multirow{2}{*}{$\begin{array}{c}\text { Pretest-Postest } \\
\text { Prueba t }\end{array}$} \\
\hline & $M$ & DT & $M$ & DT & \\
\hline Supervisión familiar & 6,5926 & 2,45356 & 7,3704 & 1,54791 & $t(26)=-1,5$ \\
\hline Tutorización digital docente & 6,6129 & 1,6264 & 6,3226 & 2,02299 & $t(30)=0,016$ \\
\hline
\end{tabular}




\section{* Comparaciones del postest del grupo experimental y postest del grupo control}

Se realizó la prueba ancova entre los resultados del postest del grupo experimental y el postest del grupo control, controlando la diferencia inicial que había en los aspectos analizados en ambos grupos en el pretest (ver Tabla 75).

Los resultados son significativos tanto para supervisión familiar como para tutorización digital, y por tanto podemos afirmar que existen diferencias en las puntuaciones del postest entre el grupo experimental y el grupo control.

Tabla 75.Resultados Escaciber segundo ciclo postest del grupo control y experimental

\begin{tabular}{|c|c|c|c|c|c|}
\hline & \multicolumn{2}{|c|}{$\begin{array}{c}\text { Grupo } \\
\text { Experimental }\end{array}$} & \multicolumn{2}{|c|}{ Grupo Control } & $\begin{array}{c}\text { Grupo Experimental- } \\
\text { Control }\end{array}$ \\
\hline & \multicolumn{2}{|c|}{ Postest } & \multicolumn{2}{|c|}{ Postest } & Ancova \\
\hline & $M$ & DT & $M$ & DT & $F$ \\
\hline Supervisión familiar & 8,806 & 0,260 & 7,466 & 0,296 & $F(1,60)=10,894 * *$ \\
\hline Tutorización digital docente & 8,754 & 0,336 & 6,278 & 0,360 & $\mathrm{~F}(1,65)=22,529 * * *$ \\
\hline
\end{tabular}

\subsubsection{Evaluación en el tercer ciclo (5 y 6으) de Educación Primaria}

\subsection{Evaluación CEE en el tercer ciclo Educación Primaria}

La información descriptiva sobre este instrumento de evaluación la podemos consultar en el apartado instrumentos de evaluación del presente capítulo.

Como apreciamos en la descripción del instrumento de evaluación, éste consta de 68 ítems, sin embargo para nuestro estudio hemos elaborado un cuestionario en el que no se han seleccionado todas las dimensiones, sino sólo aquellos que hacían referencia a los aspectos trabajados en nuestro programa en el tercer ciclo de Educación Primaria; empatía, asertividad, ciberbullying, prevención y resolución de conflictos y buen uso de las TIC.

En concreto el cuestionario dirigido al alumnado del tercer ciclo de Educación Primaria cuenta con un total de 46 ítems (ver anexo 15), pertenecientes a las dimensiones; habilidades de relación social, resolución de problemas y toma de decisiones y autoconciencia emocional.

Participantes

En el tercer ciclo de Educación Primaria, respecto al instrumento $C E E$, hemos contado con un total de 90 participantes; 45 del centro experimental y 45 del centro control. 
Respecto al género de los participantes, predomina el masculino con un $54,4 \%$ sobre el femenino con un 45,6\% (ver Tabla 76).

Tabla 76.Número de participantes según género en CEE en el tercer ciclo de primaria.

\begin{tabular}{cccrc}
\hline & Centro experimental & Centro control & \multicolumn{2}{c}{ Total } \\
\hline Género & $\mathrm{N}$ & $\mathrm{N}$ & $\mathrm{N}$ & $\%$ \\
\hline Masculino & 24 & 25 & 49 & 54,4 \\
\hline Femenino & 21 & 20 & 41 & 45,6 \\
\hline Total & 45 & 45 & 90 & 100 \\
\hline
\end{tabular}

Los datos de participantes total por curso nos indican que la diferencia entre ambos cursos es mínima, siendo un $52,2 \%$ los participantes de quinto curso y un $47,8 \%$ los de sexto curso (ver Tabla 77).

Tabla 77.Número de participantes según curso escolar en CEE en el tercer ciclo de primaria.

\begin{tabular}{cccrc}
\hline & Centro experimental & Centro control & \multicolumn{2}{c}{ Total } \\
\hline Curso & $\mathrm{N}$ & $\mathrm{N}$ & $\mathrm{N}$ & $\%$ \\
\hline Quinto Ed. Primaria & 23 & 24 & 47 & 52,2 \\
\hline Sexto Ed. Primaria & 22 & 21 & 43 & 47,8 \\
\hline Total & 45 & 45 & 90 & 100 \\
\hline
\end{tabular}

Respecto a la edad de los participantes, predominan los alumnos de 11 años con un 53,3\% de la muestra, seguido de los alumnos con 10 años con un 33,4\% (ver Tabla 78).

Tabla 78.Número de participantes según edad en CEE en el tercer ciclo de primaria.

\begin{tabular}{ccccc}
\hline & Centro experimental & Centro control & \multicolumn{2}{c}{ Total } \\
\hline Edad & $\mathrm{N}$ & $\mathrm{N}$ & $\mathrm{N}$ & $\%$ \\
\hline 10 & 19 & 11 & 30 & 33,4 \\
\hline 11 & 22 & 26 & 48 & 53,3 \\
\hline 12 & 2 & 8 & 10 & 11,1 \\
\hline 13 & 2 & 0 & 2 & 2,2 \\
\hline Total & 45 & 45 & 90 & 100
\end{tabular}




\section{Resultados}

El primer análisis que hemos realizado ha sido comprobar la normalidad para las muestras de los dos centros, y para ello se realizó la prueba de normalidad de Kolmogorov-Smirnov. Mostramos los resultados en la Tabla 79 en la cual se indican los valores Z de KolmogorovSmirnov, y su nivel de significación.

Se han comprobado los requisitos de normalidad de las puntuaciones en el pretest y postest de los dos grupos mediante la prueba Kolmogorov-Smirnov.

Así, se optó por el estudio paramétrico y los análisis que se realizan para comparar las dos muestras son la prueba $t$, anova y ancova.

No existe diferencia de género entre los grupos experimental y control antes del cuasiexperimento $\left(x^{2}(1)=0,407, p=0,523\right)$.

En cuanto a la edad, no existe diferencia de edad entre el grupo experimental y control analizando los datos mediante la prueba $\mathrm{t}(\mathrm{t}(88)=1,490, \mathrm{p}=0,140)$.

Tabla 79. CEE tercer ciclo. Prueba de normalidad de Kolmogorov-Smirnov, significación de la prueba.

\begin{tabular}{|c|c|c|c|c|c|c|c|c|c|c|c|c|}
\hline & \multicolumn{6}{|c|}{ Centro experimental } & \multicolumn{6}{|c|}{ Centro control } \\
\hline & \multicolumn{3}{|c|}{ Pretest } & \multicolumn{3}{|c|}{ Postest } & \multicolumn{3}{|c|}{ Pretest } & \multicolumn{3}{|c|}{ Postest } \\
\hline & HRs & Rp y td & Ac & HRs & Rp y td & Ac & HRs & Rp y td & Ac & HRs & $\mathrm{Rp}$ y $\mathrm{td}$ & Ac \\
\hline $\mathrm{Z}$ & $0,152^{*}$ & 0,129 & 0,121 & $0,137^{*}$ & 0,105 & $0,152^{*}$ & 0,125 & 0,120 & $0,132^{*}$ & $0,164 * *$ & 0,104 & $0,150 *$ \\
\hline
\end{tabular}

${ }^{*} \mathrm{p} \leq 0,05 ;{ }^{* *} \mathrm{p} \leq 0,01 ;{ }^{* * *} \mathrm{p} \leq 0.001$

HRs=habilidades de relación social, $\mathrm{Rp}$ y $\mathrm{td}=$ =resolución de problemas y toma de decisiones, $\mathrm{Ac}=$ autoconciencia

\section{Comparaciones del pretest del grupo experimental y pretest del grupo control}

Se realizó la prueba Anova entre las puntuaciones del prestest del grupo experimental y el pretest del grupo control (ver Tabla 80).

Los resultados no son significativos en resolución de problemas y toma de decisiones por lo que podemos afirmar que no existen diferencias en el prestest entre ambos grupos.

Por su parte, los resultados son significativos en habilidades de relación social y autoconciencia emocional, y por lo tanto, con estos resultados podemos afirmar que existen diferencias en las puntuaciones del pretest entre el grupo experimental y el grupo control. 
Tabla 80. Resultados CEE tercer ciclo, pretest grupo experimental y prestest grupo control

\begin{tabular}{|c|c|c|c|c|c|}
\hline & \multicolumn{2}{|c|}{$\begin{array}{l}\text { Grupo } \\
\text { Experimental }\end{array}$} & \multicolumn{2}{|c|}{ Grupo Control } & $\begin{array}{c}\text { Grupo } \\
\text { Experimental- } \\
\text { Control }\end{array}$ \\
\hline & \multicolumn{2}{|c|}{ Pretest } & \multicolumn{2}{|c|}{ Pretest } & Anova \\
\hline & M & DT & $M$ & DT & $F(1,88)$ \\
\hline Habilidades de relación social & 61,47 & 7,238 & 58,22 & 6,554 & $4,968^{*}$ \\
\hline $\begin{array}{l}\text { Resolución de problemas y toma de } \\
\text { decisiones }\end{array}$ & 29,40 & 5,437 & 27,24 & 5,403 & 3,559 \\
\hline Autoconciencia emocional & 49,67 & 4,178 & 47,33 & 4,695 & $6,203^{*}$ \\
\hline
\end{tabular}

\section{Comparaciones del pretest-postest del grupo experimental}

Se realizó la prueba t entre las puntuaciones pretest y postest del grupo experimental (ver Tabla 81).

Los resultados son no significativos en los tres aspectos analizados; habilidades de relación social, resolución de problemas y toma de decisiones, y autoconciencia emocional. Por tanto, no podemos afirmar que haya una diferencia entre las puntuaciones pretest y postest del grupo experimental pero si se observa en las medias una tendencia positiva.

Tabla 81.Resultados CEE tercer ciclo, pretest y postest del grupo experimental

\begin{tabular}{|c|c|c|c|c|c|}
\hline & \multicolumn{5}{|c|}{ Grupo Experimental } \\
\hline & \multicolumn{2}{|c|}{ Pretest } & \multicolumn{2}{|c|}{ Postest } & \multirow{2}{*}{$\begin{array}{c}\text { Pretest-Postest } \\
\text { Prueba t(44) }\end{array}$} \\
\hline & $M$ & DT & $M$ & DT & \\
\hline Habilidades de relación social & 61,47 & 7,238 & 62,36 & 6,439 & $t=-0,670$ \\
\hline $\begin{array}{l}\text { Resolución de problemas y toma de } \\
\text { decisiones }\end{array}$ & 29,40 & 5,437 & 30,07 & 4,929 & $t=-0,627$ \\
\hline Autoconciencia emocional & 49,67 & 4,178 & 49,20 & 4,989 & $t=-0,514$ \\
\hline
\end{tabular}




\section{* Comparaciones del pretest-postest del grupo control}

Se realizó la prueba t entre las puntuaciones del prestest y postest del grupo control (ver Tabla 82).

Los resultados obtenidos son no significativos, y por tanto no podemos afirmar que exista una diferencia entre las puntuaciones del pretest y postest del grupo control.

Tabla 82. Resultados CEE tercer ciclo, pretest y postest del grupo control

\begin{tabular}{|c|c|c|c|c|c|}
\hline & \multicolumn{5}{|c|}{ Grupo Control } \\
\hline & \multicolumn{2}{|c|}{ Pretest } & \multicolumn{2}{|c|}{ Postest } & \multirow{2}{*}{$\begin{array}{c}\text { Pretest-Postest } \\
\text { Prueba t (44) }\end{array}$} \\
\hline & $\mathrm{M}$ & DT & M & DT & \\
\hline Habilidades de relación social & 58,22 & 6,554 & 58,4 & 9,151 & $-0,100$ \\
\hline Resolución de problemas y toma de decisiones & 27,24 & 5,403 & 27,58 & 5,949 & $-0,244$ \\
\hline Autoconciencia emocional & 47,33 & 4,695 & 47,29 & 5,926 & 0,042 \\
\hline
\end{tabular}

\section{* Comparaciones del postest del grupo experimental y postest del grupo control}

Se realizó el análisis anova en el postest del grupo experimental y el postest del grupo control en resolución de problemas y toma de decisiones.

Para comparar los resultados del postest del grupo experimental y el postest del grupo control en habilidades de relación social y autoconciencia emocional se realizó la del análisis ancova para controlar los efectos inciales de estos aspectos pues mostraban diferencias en el pretest entre ambos grupos.

Como podemos observar en la Tabla 83, los resultados son no significativos en autoconciencia emocional, y por ello no podemos afirmar que exista una diferencia en las puntuaciones postest entre los grupos experimental y control.

Por su parte, los resultados son significativos en habilidades de relación social y resolución de problemas y toma de decisiones, por lo tanto, a partir de estos resultados podemos afirmar que existe diferencia en las puntuaciones del postest entre el grupo experimental y el grupo control. 
Tabla 83.Resultados CEE tercer ciclo, postest grupo experimental y postest grupo control

\begin{tabular}{|c|c|c|c|c|c|c|}
\hline & \multirow{2}{*}{\multicolumn{2}{|c|}{$\begin{array}{c}\text { Grupo } \\
\text { Experimental } \\
\text { Postest }\end{array}$}} & \multicolumn{2}{|c|}{ Grupo Control } & \multicolumn{2}{|c|}{$\begin{array}{l}\text { Grupo Experimental- } \\
\text { Control }\end{array}$} \\
\hline & & & Po & test & Anova & Ancova \\
\hline & $\mathrm{M}$ & DT & $\mathrm{M}$ & DT & $F(1,88)$ & $F(1,89)$ \\
\hline Habilidades de relación social & 62,36 & 6,439 & 58,40 & 9,151 & & $5,257^{*}$ \\
\hline $\begin{array}{l}\text { Resolución de problemas y toma de } \\
\text { decisiones }\end{array}$ & 30,07 & 4,929 & 27,58 & 5,949 & $4,671^{*}$ & \\
\hline Autoconciencia emocional & 49,20 & 4,989 & 47,29 & 5,926 & & 1,672 \\
\hline
\end{tabular}

\subsection{Evaluación Escaciber en el tercer ciclo Educación Primaria}

Dado que este cuestionario ha sido ya descrito en otro apartado; instrumentos de evaluación, y que lo podemos encontrar en este capítulo, os remitimos a él para obtener más información al respecto.

Participantes

En la evaluación mediante el cuestionario Escaciber del tercer ciclo Educación Primaria han participado un total de 88 alumnos; 41 del centro experimental y 47 del centro control.

Respecto al curso (ver Tabla 84), un 53,4\% del total de los participantes son de quinto curso de Educación Primaria mientras que un $46,6 \%$ son de sexto curso.

Tabla 84.Número de participantes según curso escolar en Escaciber en el tercer ciclo de primaria.

\begin{tabular}{ccccc}
\hline & Centro experimental & Centro control & \multicolumn{2}{c}{ Total } \\
\hline Curso & $\mathrm{N}$ & $\mathrm{N}$ & $\mathrm{N}$ & $\%$ \\
\hline Quinto Ed. Primaria & 21 & 26 & 47 & 53,4 \\
\hline Sexto Ed. Primaria & 20 & 21 & 41 & 46,6 \\
\hline Total & 41 & 47 & 88 & 100 \\
\hline
\end{tabular}

El género de la muestra nos indica que un $52,3 \%$ de los participantes son hombres mientras que un 47,7\% son mujeres (ver Tabla 85). 
No existen diferencias de género entre los grupos experimental y control teniendo en cuenta los resultados de los análisis realizados con la prueba chi-cuadrado $\left(x^{2}(1)=1,082\right.$; $p=0,298)$.

Tabla 85.Número de participantes según género en Escaciber en el tercer ciclo de primaria.

\begin{tabular}{lcc}
\hline & \multicolumn{2}{c}{ Centro experimental y control } \\
\hline Género & $\mathrm{N}$ & $\%$ \\
\hline Masculino & 46 & 52,3 \\
\hline Femenino & 42 & 47,7 \\
\hline Total & 88 & 100 \\
\hline
\end{tabular}

\section{Resultados}

Presentamos a continuación los resultados obtenidos del cuestionario Escaciber administrado a los alumnos del tercer ciclo de Educación Primaria.

En primer lugar, recogemos los datos que hacen referencia a una de las cuestiones iniciales que les planteamos para conocer el uso de las redes sociales, que se puede observar en la Tabla 86.

De estos datos se extrae que los menores del tercer ciclo de Educación Primaria ya empiezan a hacer uso de las redes sociales, siendo la más utilizada Instagram con un 46,6\%, Facebook con un 30,7\% y Snapchat con un $23,9 \%$. Respecto a la mensajería instantánea sí encontramos un dato muy significativo, y es que un $94,3 \%$ de los alumnos afirma hacer uso de ella.

Tabla 86.Uso de las redes sociales y mensajería instantánea en el tercer ciclo de primaria.

\begin{tabular}{lcc}
\hline & Sí & NO \\
\hline Facebook & 30,7 & 69,3 \\
\hline Tuenti & 4,5 & 95,5 \\
\hline Twitter & 10,2 & 89,8 \\
\hline Instagram & 46,6 & 53,4 \\
\hline Whatsapp & 94,3 & 4,5 \\
\hline Snapchat & 23,9 & 76,1 \\
\hline Hangouts & 3,4 & 96,6 \\
\hline
\end{tabular}




\section{Comparaciones del pretest del grupo experimental y pretest del grupo control}

Se realizó la prueba t entre los resultados del pretest del grupo experimental y pretest del grupo control (ver Tabla 87).

Los resultados no son significativos en ninguna de las dimensiones analizadas, exceptuando uso seguro cuyos resultados si son significativos. Por tanto, en uso seguro podemos afirmar que existe una diferencia entre las puntuaciones de pretest de ambos grupos, sin embargo en el resto no podemos afirmar que exista esta diferencia.

Tabla 87.Resultados Escaciber tercer ciclo, pretest grupo experimental y pretest grupo control

\begin{tabular}{|c|c|c|c|c|c|}
\hline & \multicolumn{2}{|c|}{$\begin{array}{c}\text { Grupo } \\
\text { Experimental }\end{array}$} & \multicolumn{2}{|c|}{ Grupo Control } & $\begin{array}{c}\text { Grupo Experimental- } \\
\text { Control }\end{array}$ \\
\hline & \multicolumn{2}{|c|}{ Pretest } & \multicolumn{2}{|c|}{ Pretest } & \\
\hline & $M$ & DT & $M$ & DT & \\
\hline Uso responsable & 7,1026 & 2,18602 & 6,8444 & 1,95350 & 0,567 \\
\hline $\begin{array}{c}\text { Relaciones en redes } \\
\text { sociales }\end{array}$ & 9,6250 & 1,54733 & 9,5217 & 1,85878 & 0,281 \\
\hline $\begin{array}{c}\text { Tutorización digital } \\
\text { docente }\end{array}$ & 7,5610 & 2,08625 & 8,0000 & 1,61515 & 1,092 \\
\hline Supervisión familiar & 6,0488 & 1,49919 & 6,2766 & 1,69015 & $-0,670$ \\
\hline Dependencia & 8,3415 & 1,27691 & 8,0000 & 1,45960 & 1,171 \\
\hline Ciberdating & 7,0000 & 1,44914 & 7,6383 & 1,86996 & 1,801 \\
\hline Uso seguro & 7,3902 & 2,14334 & 8,3478 & 2,19309 & $2,058^{*}$ \\
\hline
\end{tabular}

\section{Comparaciones del pretest-postest del grupo experimental}

Se realizó la prueba t entre los resultados del pretest y postest del grupo experimental (ver Tabla 88).

En tutorización digital docente y dependencia los resultados son no significativos por lo que no podemos afirmar que haya una diferencia entre las puntuaciones de pretest $y$ postest aunque si podemos observar en la Tabla 88 las medias de ambos que nos indican que existe una tendencia positiva.

Los resultados son significativos en: uso responsable, relaciones en redes sociales, supervisión familiar, ciberdating y uso seguro. Por lo tanto, podemos afirmar que existe una diferencia entre las puntuaciones del pretest y postest del grupo experimental. 
Tabla 88. Resultados Escaciber tercer ciclo, pretest-postest grupo experimental

\begin{tabular}{|c|c|c|c|c|c|}
\hline & \multicolumn{5}{|c|}{ Grupo Experimental } \\
\hline & \multicolumn{2}{|c|}{ Pretest } & \multicolumn{2}{|c|}{ Postest } & \multirow{2}{*}{$\begin{array}{c}\text { Pretest-Postest } \\
\text { Prueba t }\end{array}$} \\
\hline & $M$ & DT & $M$ & DT & \\
\hline Uso responsable & 7,1026 & 2,18602 & 8,1026 & 2,04932 & $-2,132 *$ \\
\hline Relaciones en redes sociales & 9,6250 & 1,54733 & 10,6750 & 1,49164 & $-3,201 * *$ \\
\hline Tutorización digital docente & 7,5610 & 2,08625 & 7,8049 & 1,73522 & $-0,547$ \\
\hline Supervisión familiar & 6,0488 & 1,49919 & 8,5366 & 1,76207 & $-6,473 * * *$ \\
\hline Dependencia & 8,3415 & 1,27691 & 8,6829 & 1,33115 & $-1,117$ \\
\hline Ciberdating & 7,0000 & 1,44914 & 8,4634 & 1,85873 & $-4,049 * * *$ \\
\hline Uso seguro & 7,3902 & 2,14334 & 10,6098 & 2,03566 & $-7,123 * * *$ \\
\hline
\end{tabular}

\section{Comparaciones del pretest-postest del grupo control}

Se realizó la prueba t entre los resultados del pretest y postest del grupo control (ver Tabla 89).

En tutorización digital docente y dependencia los resultados son no significativos por lo que no podemos afirmar que haya una diferencia entre las puntuaciones de pretest y postest.

Los resultados son significativos en: uso responsable, relaciones en redes sociales, supervisión familiar, ciberdating y uso seguro. Por lo tanto, podemos afirmar que existe una diferencia entre las puntuaciones del pretest y postest del grupo control.

Tabla 89.Resultados Escaciber tercer ciclo, pretest-postest grupo control

\begin{tabular}{|c|c|c|c|c|c|}
\hline & \multicolumn{5}{|c|}{ Grupo Control } \\
\hline & \multicolumn{2}{|c|}{ Pretest } & \multicolumn{2}{|c|}{ Postest } & \multirow{2}{*}{$\begin{array}{c}\text { Pretest-Postest } \\
\text { Prueba t }\end{array}$} \\
\hline & $M$ & DT & $\mathrm{M}$ & DT & \\
\hline Uso responsable & 6,8444 & 1,95350 & 8,2889 & 1,50185 & $-3,576 * *$ \\
\hline Relaciones en redes sociales & 9,5217 & 1,85878 & 10,9348 & 1,98217 & $-3,267^{*}$ \\
\hline Tutorización digital docente & 8,0000 & 1,61515 & 8,5106 & 1,75539 & $-1,410$ \\
\hline Supervisión familiar & 6,2766 & 1,69015 & 8,1702 & 1,74853 & $-4,730 * * *$ \\
\hline Dependencia & 8,0000 & 1,45960 & 8,3404 & 1,61886 & $-1,153$ \\
\hline Ciberdating & 7,6383 & 1,86996 & 8,4894 & 1,08091 & $-2,555^{*}$ \\
\hline Uso seguro & 8,3478 & 2,19309 & 10,6739 & 1,47655 & $-5,656 * * *$ \\
\hline
\end{tabular}




\section{Comparaciones del postest del grupo experimental y postest del grupo control}

Se realizó la prueba t entre los resultados del postest del grupo experimental y postest del grupo control (ver Tabla 90). En uso seguro, para controlar la diferencia inicial entre las puntuaciones del pretest entre ambos grupos se realizó un análisis ancova.

Los resultados no son significativos en ninguna de las dimensiones analizadas, y por tanto no podemos afirmar que exista una diferencia en las puntuaciones del postest entre el grupo experimental y el grupo control.

Tabla 90. Resultados Escaciber tercer ciclo, postest grupo experimental y postest grupo control

\begin{tabular}{|c|c|c|c|c|c|c|}
\hline & \multirow{2}{*}{\multicolumn{2}{|c|}{$\begin{array}{c}\begin{array}{c}\text { Grupo } \\
\text { Experimental }\end{array} \\
\text { Postest }\end{array}$}} & \multirow{2}{*}{\multicolumn{2}{|c|}{$\begin{array}{c}\text { Grupo Control } \\
\text { Postest }\end{array}$}} & \multicolumn{2}{|c|}{$\begin{array}{c}\text { Grupo Experimental- } \\
\text { Control }\end{array}$} \\
\hline & & & & & \multirow{2}{*}{$\begin{array}{c}\text { Ancova } \\
\mathrm{F}\end{array}$} & \multirow{2}{*}{ Prueba $\mathrm{t}$} \\
\hline & $M$ & DT & $M$ & DT & & \\
\hline Uso responsable & 8,0000 & 2,0494 & 8,2776 & 1,48474 & & $-0,716$ \\
\hline $\begin{array}{l}\text { Relaciones en redes } \\
\text { sociales }\end{array}$ & 10,6341 & 1,49593 & 10,9362 & 1,96053 & & $-0,818$ \\
\hline $\begin{array}{l}\text { Tutorización digital } \\
\text { docente }\end{array}$ & 7,8049 & 1,73522 & 8,5106 & 1,75539 & & $-1,893$ \\
\hline Supervisión familiar & 8,5366 & 1,76207 & 8,1705 & 1,74853 & & 0,976 \\
\hline Dependencia & 8,6829 & 1,33115 & 8,3404 & 1,61886 & & 1,089 \\
\hline Ciberdating & 8,4634 & 1,85873 & 8,4894 & 1,08091 & & $-0,079$ \\
\hline Uso seguro & 10,6098 & 2,03566 & 10,6739 & 1,47655 & 0,053 & \\
\hline
\end{tabular}

${ }^{*} p \leq 0,05 ;{ }^{* *} p \leq 0,01 ;{ }^{* * *} \mathrm{p} \leq 0.001$

\subsubsection{Análisis de los resultados}

Tal y como hemos indicado al inicio de este apartado de evaluación, la primera evaluación que hemos realizado ha sido mediante el análisis de los resultados de los instrumentos de evaluación CEE y Escaciber.

Para ello hemos presentado los datos por ciclos educativos puesto que los bloques de contenido de nuestro programa es común aunque las actividades y los objetivos específicos de cada una son diferentes.

Así, en el segundo ciclo de Educación Primaria para comprobar la eficacia de nuestro programa hemos analizados los resultados del Cuestionario de Educación Emocional, cuyos análisis comparativos postest entre los grupos experimental y control nos indican que existen diferencias significativas en las puntuaciones entre ambos grupos de todas las 
dimensiones analizadas; autoestima, resolución de problemas y tomas de decisiones y autoconciencia emocional.

Los resultados del segundo instrumento de evaluación utilizado en el segundo ciclo para evaluar la eficacia del programa es el Escaciber. Al analizar sus resultados nos indican que existen diferencias significativas entre los resultados del postest del grupo experimental y control en sus dos dimensiones analizadas; supervisión familiar y tutorización digital docente. Considerando que las mejoras significativas en la dimensión supervisión familiar se debe a la toma de conciencia por partes de los padres y madres al estar informados, mediante la solicitud de autorización de la participación de sus hijos en el programa, de las acciones que se iban a desarrollar en el centro educativo y por tanto de su especial relevancia.

En el tercer ciclo de Educación Primaria también se han utilizado los mismos instrumentos para evaluar la eficacia del programa en estos cursos Escaciber.

Respecto al instrumento CEE, los resultados extraídos del análisis de las puntuaciones postest entre el centro experimental $y$ el centro control nos indican que son no significativos en autoconciencia emocional, y por ello no podemos afirmar que exista una diferencia en las puntuaciones postest entre los grupos experimental y control. Por su parte, los resultados son significativos en habilidades de relación social y resolución de problemas y toma de decisiones, por lo tanto, a partir de estos resultados podemos afirmar que existe diferencia en las puntuaciones del postest entre el grupo experimental y el grupo control.

Por su parte, los análisis comparativos de las puntaciones postest del instrumento Escaciber entre el grupo experimental y el grupo control, nos indica que no son significativos en ninguna de las dimensiones analizadas, y por tanto no podemos afirmar que exista una diferencia en las puntuaciones del postest entre el grupo experimental y el grupo control. Sin embargo, los datos obtenidos en el pretest-postest del centro experimental sí nos indican que hay diferencias significativas en este grupo.

Con todo ello podemos afirmar que el programa ha sido efectivo en su totalidad en el segundo ciclo de Educación Primaria puesto que todas las dimensiones analizadas en los dos cuestionarios, CEE y Escaciber, han obtenidos resultados significativos. Por lo tanto, las actividades contempladas en el programa dirigidas a este ciclo educativo relacionadas con la autoestima, emociones, autocontrol, prevención y resolución de conflictos y buen uso de las TIC, han mejorado estas habilidades directamente vinculadas a la prevención del ciberbullying.

Por su parte, los resultados del tercer ciclo nos indican que sí que los resultados obtenidos en habilidades como la resolución de conflictos y habilidades de comunicación son significativas, y por tanto las actividades contempladas en el programa dirigió a este ciclo educativo relacionadas con la asertividad y la prevención y resolución de problemas han 
aumentado sus habilidades en estos ámbitos, sin embargo no han sido significativos los resultados obtenidos en las actividades de empatía.

Por lo que respecta al componente de conducta cibernética, teniendo en cuenta el análisis postest entre los grupos, los resultados no son significativos, sin embargo los resultados son significativos en el análisis pretest-postest del grupo experimental en las siguientes dimensiones: uso responsable, relaciones en redes sociales, supervisión familiar, ciberdating y uso seguro. En tutorización digital docente y dependencia los resultados son no significativos, pero sí podemos observar que existe una tendencia positiva. Por lo tanto, podemos afirmar que existe una diferencia entre las puntuaciones del pretest y postest del grupo experimental, y con ello un aumento de las habilidades en estos aspectos trabajados con las actividades de ciberbullying y buen uso de las TIC.

A partir de dichos datos, consideramos que nuestro programa es eficaz puesto que se han obtenido resultados significativos en la gran mayoría de las dimensiones evaluadas, teniendo en cuenta que nuestro objetivo era comprobar la eficacia del programa a lo largo de los cuatro cursos de Educación Primaria, que es al alumnado que va dirigido este programa, puesto que se trata de un estudio longitudinal y los datos que ahora mostramos solamente hacen referencia a la aplicación del programa durante un único curso escolar.

\subsubsection{Evaluación pedagógica}

La evaluación que nombramos pedagógica, y la cual vamos a abordar en este apartado, hace referencia a los resultados obtenidos a partir del material que incluye nuestro programa; un instrumento de evaluación dirigido a los alumnos en el que se evalúa la asimilación de sus conocimientos respecto a los contenidos trabajados en el programa y por otra parte una evaluación que realiza el profesor al finalizar cada bloque de contenido del programa.

Este instrumento está descrito en el apartado de instrumentos de evaluación de este capítulo, y por tanto para más información podemos consultarlo en él.

\subsubsection{Resultados de la evaluación de los alumnos}

En este apartado vamos a presentar los datos que se aportan como resultado de las respuestas de los alumnos a nuestros instrumentos que se incluían en nuestro programa en el que se evalúan, al finalizar el programa, los contenidos trabajados durante todo el curso en este programa para ver la asimilación de estos contenidos por parte de los alumnos.

La descripción de dichos instrumentos se describe en el apartado de instrumentos de evaluación del presente capítulo. También presentamos información detallada en los siguientes apartados que hacen referencia a cada nivel educativo. 
* Tercero de Educación Primaria

En tercer curso el programa se ha aplicado a todo el grupo con un total de 18 alumnos.

El instrumento de evaluación elaborado para tal finalidad lo podemos ver en el anexo 17. En él encontramos cuestiones que hacen referencia a diferentes contenidos trabajados en el programa de tercero de Educación Primaria, como son: autoestima (cuestiones 1 y 2), emociones (cuestiones 3 y 4), autocontrol (cuestiones 5 y 6), prevención y resolución de problemas (cuestiones 7 y 8 ), y buen uso de las TIC (cuestiones 9 y 10).

Los datos indican que los alumnos de este curso han obtenido una nota media de 8,89 sobre 10 puntos (ver la tabla del anexo 22), oscilando todas las calificaciones individuales entre 7 y 10.

Respecto al porcentaje de respuestas contestadas correctamente por el grupo-clase en cada una de las cuestiones planeadas (ver Figura 23), nos indica que los contenidos mejor asimilados por bloque son aquellos que hacen referencia a los contenidos relacionados con la autoestima con un $100 \%$ y $94 \%$ de respuestas correctas, seguida por el bloque de contenidos del buen uso de las TIC con un $89 \%$ y $100 \%$ de respuestas correctas. Por el contrario, el bloque con puntuaciones más bajas es el relacionado con el contenido de autocontrol, y prevención y resolución de problemas.

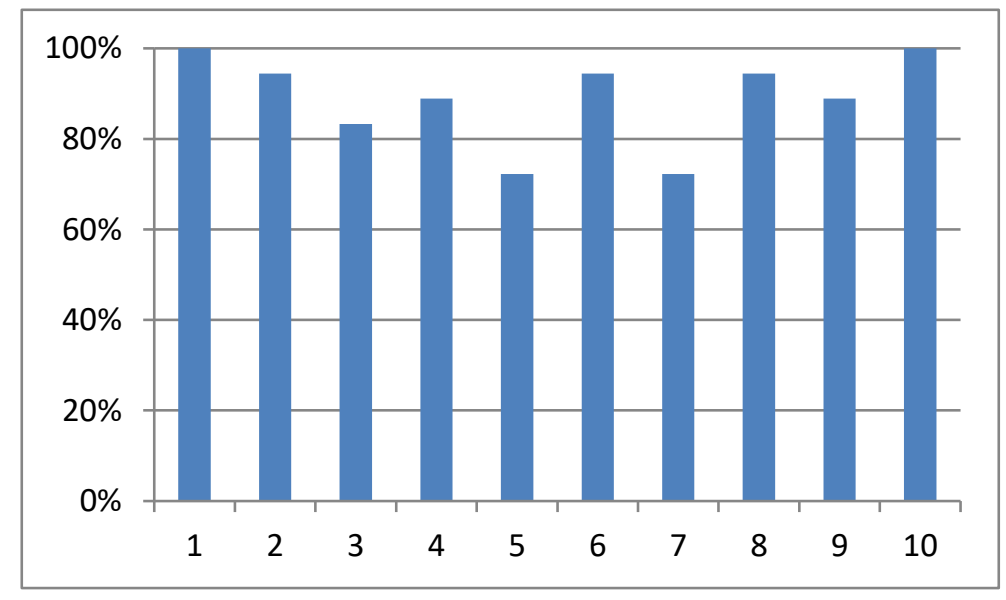

Figura 23.Porcentaje de respuestas correctas en cada pregunta en la evaluación pedagógica de 3o de Ed. Primaria.

\section{* Cuarto de Educación Primaria}

En cuarto curso el programa se ha aplicado a todo el grupo, con un total de 20 alumnos.

El instrumento de evaluación elaborado para tal finalidad lo podemos ver en el anexo 18. En él encontramos cuestiones que hacen referencia a diferentes contenidos trabajados en el programa de cuarto curso de Educación Primaria, como son: autoestima (cuestiones 1 y 
2), emociones (cuestiones 3 y 4), autocontrol (cuestiones 5 y 6), prevención y resolución de problemas (cuestiones 7 y 8 ), y buen uso de las TIC (cuestiones 9 y 10).

Los datos indican que los alumnos de este curso han obtenido una nota media de 8,5 sobre 10 puntos (ver la tabla del anexo 23), oscilando todas las calificaciones individuales entre 7 y 10.

Respecto al porcentaje de respuestas contestadas correctamente por el grupo-clase en cada una de las cuestiones planeadas (ver Figura 24) nos indica que los contenidos mejor asimilados por bloque son aquellos que hacen referencia al bloque de contenidos relacionados con el ciberbullying con un $100 \%$ y $96 \%$, seguida por el bloque de contenidos de autoestima con un $85 \%$ y $100 \%$ de respuestas correctas. Por el contrario, el bloque con puntuaciones más bajas es el relacionado con el contenido de prevención y resolución de problemas, y emociones.

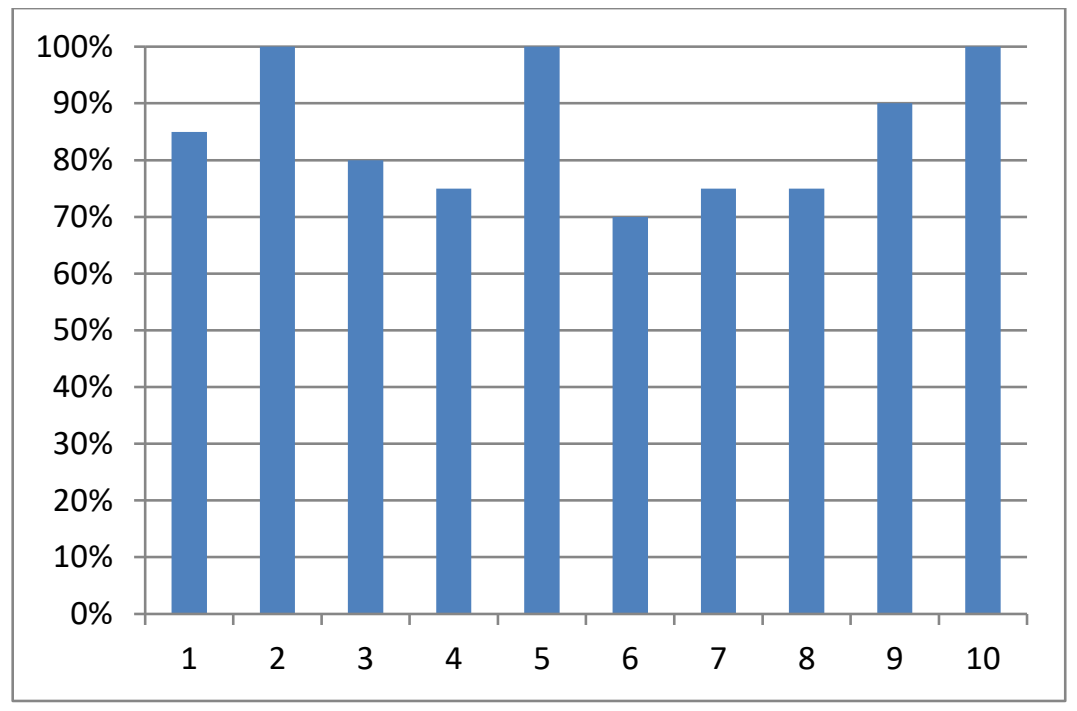

Figura 24.Porcentaje de respuestas correctas en cada pregunta de la evaluación pedagógica de 4ㅇ de Ed. Primaria.

\section{Quinto de Educación Primaria}

En quinto curso el programa se ha aplicado a todo el grupo, con un total de 23 alumnos.

El instrumento de evaluación elaborado para tal finalidad lo podemos ver en el anexo 19. En él encontramos cuestiones que hacen referencia a diferentes contenidos trabajados en el programa de quinto curso de Educación Primaria, como son: empatía (cuestiones 1 y 2 ), asertividad (cuestiones 3 y 4), ciberbullying (cuestiones 5 y 6 ), prevención y resolución de problemas (cuestiones 7 y 8 ), y buen uso de las TIC (cuestiones 9 y 10). 
Los datos indican que los alumnos de este curso han obtenido una nota media de 8,91 sobre 10 puntos (ver la tabla del anexo 24), oscilando todas las calificaciones individuales entre 7 y 10.

Respecto al porcentaje de respuestas contestadas correctamente por el grupo-clase en cada una de las cuestiones planeadas (ver Figura 25) nos indica que los contenidos mejor asimilados por bloque son aquellos que hacen referencia al bloque de contenidos relacionados con el buen uso de las TIC con un $90 \%$ y $100 \%$, seguida por el bloque de contenidos de asertividad con un $83 \%$ y $100 \%$ de respuestas correctas. Por el contrario, el bloque con puntuaciones más bajas es el relacionado con el contenido de prevención y resolución de problemas.

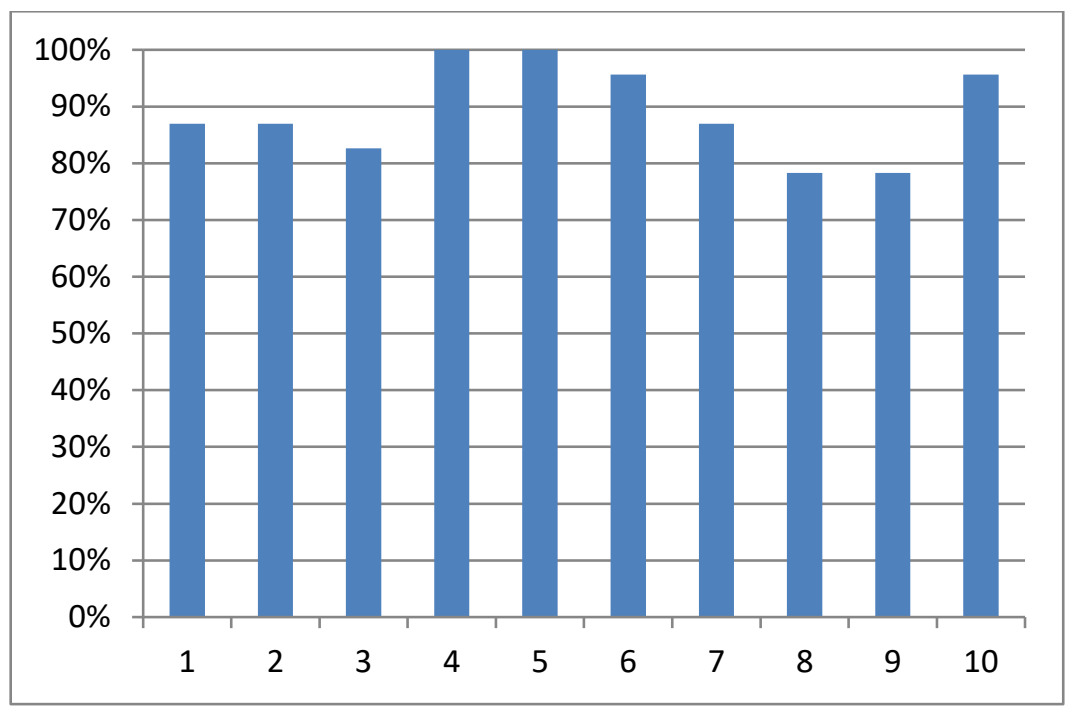

Figura 25. Porcentaje de respuestas correctas en cada pregunta de la evaluación pedagógica de 50 de Ed. Primaria.

\section{Sexto de Educación Primaria}

En sexto curso el programa se ha aplicado a todo el grupo, con un total de 25 alumnos.

El instrumento de evaluación elaborado para tal finalidad lo podemos ver en el anexo 20. En él encontramos cuestiones que hacen referencia a diferentes contenidos trabajados en el programa de quinto curso de Educación Primaria, como son: empatía (cuestiones 1 y 2 ), asertividad (cuestiones 3 y 4), ciberbullying (cuestiones 5 y 6 ), prevención y resolución de problemas (cuestiones 7 y 8 ), y buen uso de las TIC (cuestiones 9 y 10).

Los datos indican que los alumnos de este curso han obtenido una nota media de 8,96 sobre 10 puntos (ver la tabla del anexo 25), oscilando todas las calificaciones individuales entre 7 y 10. 
Respecto al porcentaje de respuestas contestadas correctamente por el grupo-clase en cada una de las cuestiones planeadas (ver Figura 26) nos indica que los contenidos mejor asimilados por bloque son aquellos que hacen referencia al bloque de contenidos relacionados con el buen uso de las TIC con un $90 \%$ y $100 \%$, seguida por el bloque de contenidos del uso de las TIC con dos $100 \%$ de respuestas correctas. Por el contrario, el bloque con puntuaciones más bajas es el relacionado con el contenido de asertividad con un $72 \%$ y $84 \%$.

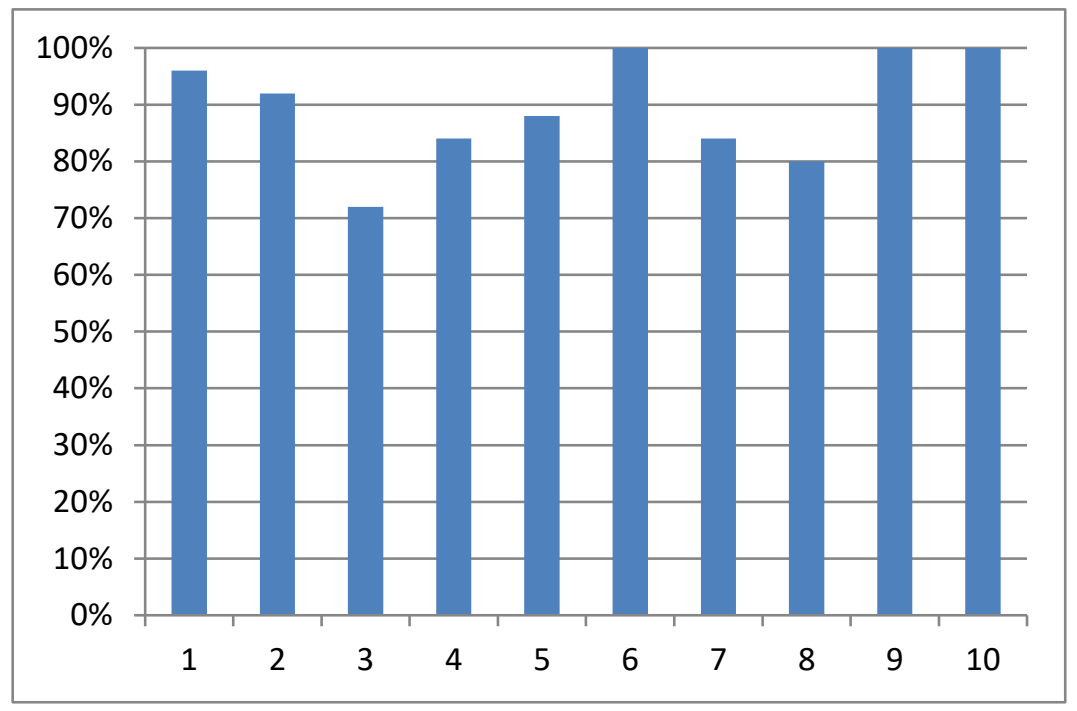

Figura 26. Porcentaje de respuestas correctas en cada pregunta en la evaluación pedagógica de 6ㅇde Ed. Primaria.

\subsubsection{Resultados de la evaluación de los profesores}

Otra de las evaluaciones que hemos realizado del programa para obtener información ha sido a los profesores encargados de aplicar el programa en las aulas. Así, hablamos de los profesores tutores del segundo y tercer ciclo de Educación Primaria, quienes al finalizar cada uno de los bloques trabajados, siendo un total de cuatro.

Al final de cada bloque de contenidos, en su dossier, disponían de un cuestionario, el cual encontramos descrito en el capítulo de instrumentos de evaluación.

Presentamos a continuación las valoraciones de los profesores por ciclo educativo, puesto que como ya hemos indicado en diferentes apartados anteriores las temáticas trabajadas son iguales en los cursos de un mismo ciclo educativo.

\section{Segundo ciclo de Educación Primaria}

Las fichas a cumplimentar por los dos docentes del segundo ciclo han sido en relación a los siguientes contenidos: autoestima, emociones, autocontrol, prevención y resolución de conflictos y buen uso de las TIC (ver Figura 27). 
En la ficha de evaluación vemos que los dos profesores indican que les ha resultado fácil o muy fácil llevar a cabo las actividades planteadas, siendo más las indicadas como muy fáciles.

El siguiente aspecto evaluado hace referencia al cumplimiento del objetivo propuesto para las actividades, donde indican que todas las actividades cumplen el objetivo propuesto en el programa para esas actividades.

La correspondencia del contenido del programa con el contenido curricular indicado es adecuada pues así lo afirman.

En cuanto a la utilización otros recursos a parte de los presentados en el programa, indican que haber utilizado otros más allá del que disponían en el material en cada una de las actividades.

Ambos consideran que no es necesario modificar ningún aspecto del programa.

Respecto a sus opiniones acerca de la actitud de los alumnos durante la realización del programa añaden que los alumnos se han mostrado muy motivados durante la realización de las actividades e interactuaban mucho entre ellos, se implicaban mucho y hacían muchas preguntas porque les interesaban los contenidos.

Consideran que el programa no necesita ninguna modificación para su mejora.

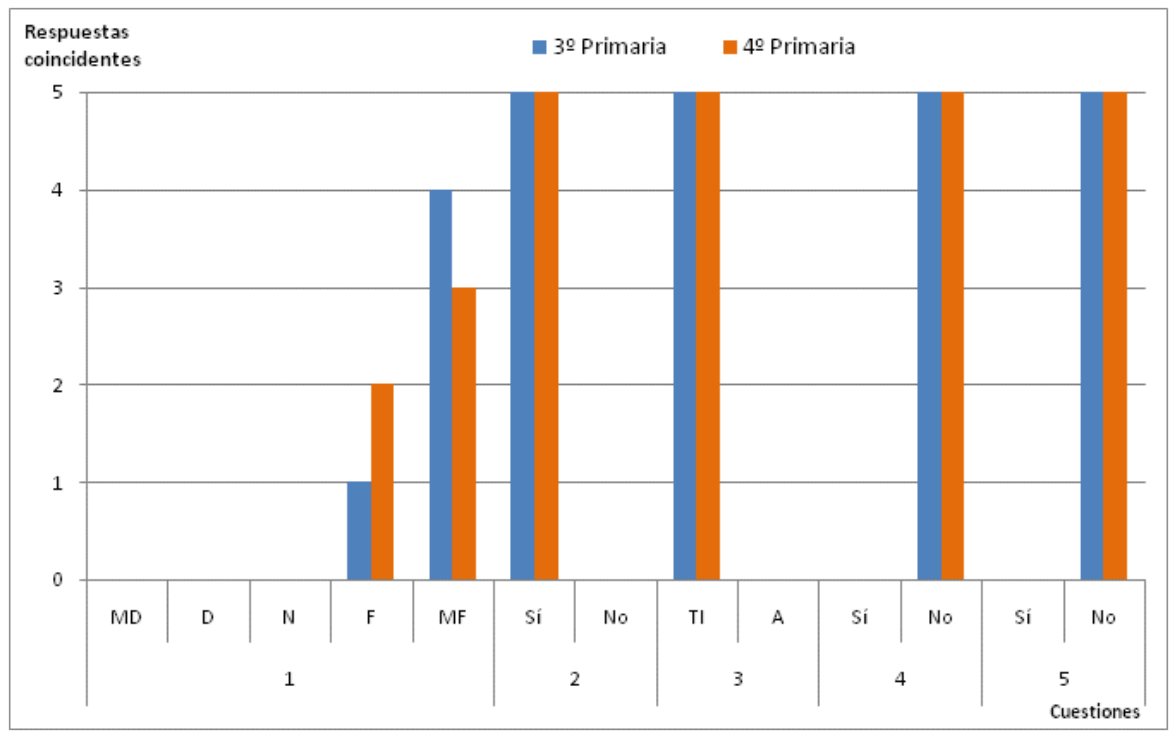

Figura 27. Resultados de la evaluación pedagógica a los docentes del segundo ciclo de Ed. Primaria.

\section{* Tercer ciclo de Educación Primaria}

Las fichas a cumplimentar por los dos docentes del tercer ciclo han sido en relación a los siguientes contenidos: empatía, asertividad, ciberbullying, prevención y resolución de conflictos y buen uso de las TIC (ver Figura 28). 
En la ficha de evaluación vemos que los dos profesores indican que les ha resultado fácil o muy fácil llevar a cabo las actividades planteadas, siendo más las indicadas como muy fáciles.

El siguiente aspecto evaluado hace referencia al cumplimiento del objetivo propuesto para las actividades, donde indican que todas las actividades cumplen el objetivo propuesto en el programa para esas actividades.

La correspondencia del contenido del programa con el contenido curricular indicado es adecuada pues así lo afirman.

En cuanto a la utilización otros recursos a parte de los presentados en el programa, indican que haber utilizado otros más allá del que disponían en el material en cada una de las actividades.

Ambos consideran que no es necesario modificar ningún aspecto del programa.

Respecto a sus opiniones acerca de la actitud de los alumnos durante la realización del programa añaden que los alumnos se han mostrado muy implicados con la realización de las actividades, durante la realización de las actividades se mostraban motivados e interactuaban mucho entre ellos, además mostraron especial interés por el bloque de contenidos del buen uso de las TIC.

Consideran que el programa no necesita ninguna modificación para su mejora.

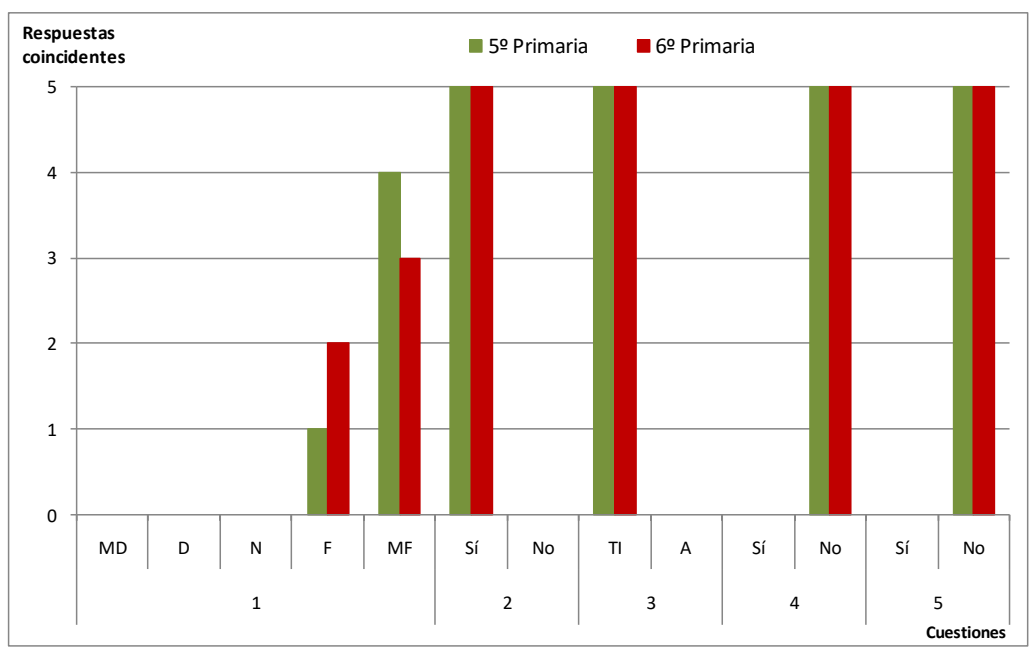

Figura 28. Resultados de la evaluación pedagógica a los docentes del tercer ciclo de Ed. Primaria.

\subsubsection{Análisis de los resultados}

Los resultados obtenidos de las evaluaciones realizadas a los alumnos con la finalidad de conocer su nivel de asimilación de los contenidos trabajados en el programa, los hemos presentado en el apartado anterior por cursos. 
De ellos extraemos que ha habido una elevada asimilación de los contenidos de todos los bloques trabajados en el programa en los cuatro cursos por parte de los alumnos, obteniéndose unas calificaciones medias entre 8,5 y 9 sobre 10 puntos, no habiendo en ningún curso ningún alumno con calificación menor a 7.

Éstas se podrían definir como excelentes ya que en el ámbito educativo se considera que las calificaciones superiores a 7 determinan que la asimilación de los contenidos ha sido adecuada.

Además de las evaluaciones de los alumnos, también contamos con datos de evaluación de los docentes quienes coinciden al consideran que las actividades propuestas les han resultado fácil o muy fácil de llevar a cabo.

También indican que el objetivo propuesto para las actividades se cumple, y que el contenido del programa corresponde con el contenido curricular indicado.

Afirman no haber utilizado otros recursos a parte de los presentados en el programa, y que por todo ello consideran que no es necesario modificar ningún aspecto del programa.

Todos estos datos nos indican que las actividades incluidas en el programa se adecuan a la finalidad, los alumnos han asimilado correctamente sus contenidos y los docentes evalúan positivamente el programa no apuntando ningún aspecto de mejora al respecto.

\subsection{SÍNTESIS}

El proyecto se ha llevado a cabo con alumnos de tercero, cuarto, quinto y sexto de primaria del C.E.I.P. Pio XII de Nules (Castellón), siendo un total de 86 los alumnos participantes; 18 de tercero, 20 de cuarto, 23 de quinto y 25 de sexto curso. También han participado los cuatro docentes del C.E.I.P. Pio XII tutores dichos cursos, puesto que son éstos los docentes responsables de la impartición de las asignaturas en las cuales se inserta el contenido del programa.

Tras los trámites correspondientes con el centro y Conselleria, se realiza un curso de formación a los docentes sobre ciberbullying así como una reunión informativa a los docentes implicados en el programa y se les facilitan los materiales del programa para su aplicación entre los que se encuentran el dosier de los alumnos, el de los profesores y el dosier con actividades complementarias.

La aplicación del programa inicia el mes de septiembre de 2015 y finaliza en junio de 2016, es decir durante el curso escolar 2015/2016.

Respecto a la evaluación del programa, ésta tiene como objetivo evaluar la eficacia del programa del programa "Conviure en un món real i digital".

También presentamos como objetivo de esta fase, evaluar la adecuación de las actividades mediante la evaluación de asimilación de contenidos por parte de los alumnos respecto a los contenidos trabajados en las actividades y la evaluación de los docentes. 
Así, la hipótesis que nos planteamos es que la aplicación del Programa "Conviure en un món real i digital" aumentará las competencias en el uso y conocimiento de las TIC así como en ciertas habilidades personales y sociales vinculadas a la prevención y afrontamiento de situaciones de acoso por medio del uso de las TIC, en base a toda la formación e información recibida progresivamente a lo largo de los cuatro cursos de Educación Primaria.

Para evaluar la eficacia del programa han sido dos los instrumentos utilizados; Cuestionario de Educación Emocional (CEE) y Escaciber. El diseño que hemos utilizado para el análisis de los datos ha sido el método cuasi-experimental, con la finalidad de ver las diferencias en el postest entre el C.E.I.P. Pio XXI (centro experimental) y el C.E.I.P. Lope de Vega (centro control), y así valorar la eficacia del programa.

A partir de dichos resultados derivados de los análisis correspondientes, consideramos que nuestro programa es eficaz puesto que se han obtenido resultados significativos en la gran mayoría de las dimensiones evaluadas, teniendo en cuenta que nuestro objetivo era comprobar la eficacia del programa a lo largo de los últimos cuatro cursos de Educación Primaria, que es al alumnado que va dirigido este programa, puesto que se trata de un programa cuyo contenido se desarrolla progresivamente a lo largo de los últimos cuatro últimos cursos de la Educación Primaria, y por tanto su análisis debería ser longitudinal, y por tanto debemos tener en cuenta que los datos que ahora mostramos solamente hacen referencia a la aplicación del programa durante un único curso escolar.

En cuanto a la evaluación de la adecuación de las actividades mediante la evaluación de asimilación de contenidos por parte de los alumnos respecto a los contenidos trabajados en las actividades y la evaluación de los docentes, podemos aportar que ha habido una elevada asimilación de los contenidos de todos los bloques trabajados en el programa en los cuatro cursos por parte de los alumnos, obteniéndose unas calificaciones medias entre 8,5 y 9 sobre 10 puntos. También la evaluación docente de los contenidos del programa es positiva ya que todos los datos aportados por los docentes nos indican que las actividades incluidas en el programa se adecuan a la finalidad del programa, y no proponen ninguna mejora en él. 
CAPÍTULO 8. SÍNTESIS Y PROPUESTAS 



\section{CAPÍTULO 8. SÍNTESIS Y PROPUESTAS}

La estructura que hemos adoptado a lo largo de esta tesis respecto a la configuración de los capítulos es la de una introducción a la temática a tratar, desarrollo del tema y síntesis del capítulo. De ahí, que ahora vayamos a realizar una reflexión global de nuestro trabajo de investigación. Así mismo, expondremos las aportaciones más importantes que hacemos a la comunidad científica, al tiempo que plantearemos las futuras líneas de trabajo e investigación que se pueden derivar de la presente tesis.

No cabe la menor duda que el tema abordado es una los que más repercusión tiene en estos momentos, en la sociedad en general y en el ámbito escolar en particular. De ahí que tomemos como punto de partida las características que definen a la sociedad del Siglo XXI, donde todas las generaciones que la forman están caracterizadas por la incorporación de las TIC en sus vidas, modificando con ello sus hábitos del día a día.

Los datos obtenidos en estos últimos años en Europa y España muestran que la cifra de hogares con acceso a internet está aumentando vertiginosamente en estos últimos años, situándose en un $83 \%$ de hogares europeos con acceso a internet y un $79 \%$ en España. En cuanto a la posesión de dispositivos tecnológicos en los hogares españoles, un 77’1\% dispone de alguno, siendo el teléfono móvil el más frecuente.

Centrándonos en la generación $Z$, formada principalmente por aquellos menores y jóvenes presentes hoy en día en nuestros centros educativos, podemos decir que tiene una serie de características que la identifican, entre la que destacamos su hiperconectividad permanente, que genera la evolución a un nuevo tipo de individuo que se diferencia de las generaciones anteriores, influyendo directamente en ciertos aspectos importantes de su proceso de socialización, desarrollo cognitivo, proceso de individualización y desarrollo moral.

Ello lo demuestran los datos presentados por Garmendia et al. (2016), que indican que a mayor edad más acceden los menores a internet diariamente y lo hacen, mayoritariamente, en todos los rangos de edad desde alguna habitación del hogar, siendo los smartphones (59\%) los dispositivos más utilizados en todos los grupos de edad. En cuanto a la edad media de inicio en el acceso a internet, esta cifra se está modificando a la baja en los últimos años, y actualmente está en los 7 años, cifra que ha disminuido respecto a menores de nacidos años antes. También disminuye la edad de pertenencia del primer teléfono móvil que es a los 10 años. Todo ello conlleva riesgos, y es que el $18 \%$ de los menores dicen que se han sentido molestos por algo que han visto en internet y el $12 \%$ de los menores han experimentado alguna forma de bullying online mayormente por Whatsapp (53\%). Además, existen otras experiencias que los menores determinan como más dañinas como son hechos como el que les traten mal (23\%), seguidos de acciones como haber visto imágenes sexuales (19\%) o recibir imágenes sexuales (13\%).

Todos estos datos nos ofrecen una información actual del uso de las TIC en los menores, pues todo ello supone un reto para la Generación Z, quienes deberán aprender a equilibrar 
su vida real con la cibernética, para así combatir con el riesgo de adicción tecnológica y otros peligros relacionados con la privacidad, el acoso y el cibercrimen.

Así, es importante que psicólogos, educadores y otros colectivos interesados en el desarrollo de los jóvenes, aborden en tema; describiéndolo y orientándolo, desde los aspectos negativos al entendimiento de internet.

Como observamos en los datos sobre riesgos en las redes en los menores de edad, uno de los principales riesgos a los que se exponen es el ciberbullying. Así, la conceptualización del término se hace esencial para el estudio de un fenómeno tan relevante y actual como es el ciberbullying.

Desde el primer estudio realizado sobre ciberbullying por Finkelhor et al., (2000) en Estados Unidos, han sido abundantes las investigaciones que se han llevado a cabo sobre el ciberbullying, a pesar de ello, y como hemos visto, no existe un consenso en cuanto a su definición tanto en lo que respecta a las definiciones institucionales que hacen diferentes países europeos (Dalla et al., 2016) ni a las definiciones que han estado presentando los académicos (Aftab, 2010; Ferro, 2013; Smith, 2000; Willard, 2005, entre otros). Muchas de las definiciones presentadas a lo largo del capítulo comparten la certeza de entender el ciberbullying como un modo de bullying que se ejerce mediante el uso de las TIC, sin embargo, al profundizar más allá de este aspecto, es cuando surgen las discrepancias.

Sin embargo, y pese a estar de acuerdo con los diferentes autores que el ciberbullying es una forma de bullying, hay ciertos aspectos que lo diferencian y que no se tienen en cuenta a la hora de elaborar la definición de este fenómeno.

Por tanto, tomando en cuenta las características específicas del ciberbullying, nosotros lo definiríamos como: una nueva forma de bullying, y que se ejerce entre menores o adolescentes, mediante el uso de la tecnología con la finalidad de acosar, amenazar o intimidar a otra persona intencionalmente, pudiéndose dar en cualquier lugar con independencia del lugar físico en el que se encuentre la víctima. Para que sea considerado ciberbullying se debe mantener en el tiempo y debe existir un desequilibrio de poder entre el agredido y el agresor. Esta acción se puede ver maximizada por el anonimato del agresor, así como también por la rápida y amplia difusión junto con la permanencia en el tiempo de la acción debido al uso de la tecnología.

Debido a esta inestabilidad en la conceptualización, se han utilizado a lo largo de estos últimos años multitud de metodologías diferentes de evaluación. El tema de evaluación adquiere especial relevancia, ya que los estudios que hemos revisado ponen de manifiesto que hacen falta más estudios psicométricos para determinar la validez y fiabilidad de dichos instrumentos. Cabe destacar que hay pocos instrumentos, y que la mayoría hacen referencia a la etapa adolescente, no habiendo encontrado ninguno para la etapa de Primaria.

Respecto a los instrumentos españoles analizados, nos indican que el nivel educativo a la que va dirigido la aplicación de la prueba en todas, el inicio es a los 12 años extendiéndose 
hasta los 18 años (Álvarez-García et al., 2011; Buelga et al., 2010; Díaz-Aguado et al., 2013; Gairagordobil \& Aliri, 2013; Ortega et al., 2008) y uno hasta los 17 años (Calvete et al., 2010). En cambio en los internacionales, podemos contemplar que disminuye puesto que en cuatro de los estudios la edad inicial es a los 10 años (Hinduja \& Patchin, 2008; Mitchell, Wolak \& Finkelhor, 2006; Williams \& Guerra, 2007; Ybarra \& Mitchell, 2008).

Así, este fenómeno se ha considerado complejo de definir, muestra de ello es el glosario de términos (Hinduja \& Patchin, 2014) que hemos consultado, poniéndose de relieve el desconocimiento de gran parte de estos términos. Al respecto, consideramos oportuno el establecer una serie de categorías que incluyesen dichos términos, así tenemos: Red de contactos y términos vinculados; Entorno de red; Seguridad de red; Peligros en la red; Herramientas y dispositivos tecnológicos; y Perfil de usuarios.

Todo ello nos facilita tanto el conocimiento de los términos como el poderlos trabajar de manera curricular en las diferentes áreas de la Educación Primaria.

De ahí la necesidad de poder abordar el fenómeno del ciberbullying partiendo de la realidad, de ahí la importancia del capítulo estado de la cuestión donde llevamos a cabo un estudio de las fuentes documentales tanto primarias como secundarias que nos aportan información sobre esta temática. Presentamos a continuación los datos más relevantes extraídos de dichas fuentes:

- Fuentes documentales primarias:

- Estadísticas españolas y estadounidenses: cifra elevada de víctimas del ciberbullying en el año 2016, siendo más elevada en América que en España.

- Tesis doctorales españolas: 10 tesis sobre ciberbullying todas ellas publicadas entre los años 2011 y 2016, lo que nos indica que es una temática bastante reciente, mayoritariamente centrados en la etapa evolutiva de la adolescencia. Destacan como directoras las investigadoras Maite Garaigordóbil y Rosario Ortega.

- Bases de datos de revistas: se han analizado un total de 481 artículos partiendo de ERIC, PSYCNET y DIALNET. Destacan en general las publicaciones estadounidenses, y autores como Marilyn Campbell, Wanda Cassidy, Heidi Vandebosch, Peter Smith, Rosario Ortega o Maite Garaigordobil.

- Fuentes documentales secundarias:

- Libros: hemos encontrado un total de 22 libros entre los años 2006 y 2016 en la base de datos del ISBN, siendo Jorge Flores el autor que más libros ha publicado sobre la temática en nuestro país. 
- Recursos: se trata de una recopilación de aquellos materiales publicados en los últimos años y que considerados más relevantes, principalmente de origen español, entre los que podemos encontrar; programas, guías, páginas web y videos.

Dato a destacar, tras el análisis de todas las fuentes documentales tanto primarias como secundarias, es que la investigadora Maite Garaigordobil es una de las autoras españolas que cuenta con más artículos publicados, así como libros, y además ha sido una de las directoras que más tesis ha dirigido.

Mención aparte merece los recursos que hemos analizado, estos representan una parte importante de las fuentes documentales secundarias. Al respecto queremos decir que hay bastantes recursos disponibles en nuestro país, pero no se encuentran bien especificados, los contenidos no son actuales puesto que se repiten a lo largo de los años, y las recomendaciones o retos que se plantean se hacen de modo teórico, sin llegar a concretar medidas o a establecerlas.

Ahora bien, en base a todos estos datos nos podemos plantear, ante un fenómeno tal actual como el ciberbullying cómo podemos actuar, dado que la práctica del ciberbullying, tanto para las escuelas como para los hogares, está siendo hoy en día una problemática grave y relevante, y por ello debe tratarse de forma integral, siendo la prevención y la identificación de éste el aspecto esencial (García, Joffre, Martínez \& Llanes, 2011).

Aun considerando todos los contextos cercanos a los menores relevantes ante situaciones como el ciberbullying, creemos que la escuela, a pesar de ser el ciberbullying un modo de acoso entre iguales que no se produce normalmente en el entorno escolar, toma una especial relevancia puesto que el ciberbullying sí se establece a partir de relaciones que suelen emerger en la vida escolar.

Y con ello es importante el preguntarnos, ¿cuál es el papel del psicólogo educativo? Desde nuestra perspectiva, éste adquiere un papel relevante en todos los aspectos, ya que como hemos puesto de manifiesto, el fenómeno del ciberbullying afecta a toda la comunidad educativa. Para ello, debemos contemplar dos aspectos básicos, ¿qué debe saber? Teniendo en cuenta que la detección y evaluación es una función esencial del psicólogo educativo, es muy importante que conozca los síntomas y cambios en las víctimas el ciberbullying, así como también debe tener información sobre todo aquello que hay que identificar relacionado con los ejecutores y participantes de la agresión. Para ello hemos elaborado y presentado unas rejillas con las que el psicólogo pueda obtener información que le permita tomar decisiones para poder encauzar su intervención de una manera más eficaz.

Y, además, ¿qué debe hacer el psicólogo educativo? El papel de los orientadores respecto al ciberbullying debe ser el de agente de cambio dirigido a abordar esta temática en los centros educativos y proporcionar directrices. Por tanto, en el rol del orientador en cuanto al ciberbullying, visualizamos dos ejes de actuación. Por una parte, el orientador debe 
trabajar cinco aspectos fundamentales que forman la parte esencial de su trabajo. En este eje determinaríamos qué es lo que se trabaja desde el departamento de orientación, y aquí se estaría hablando de la sensibilización, detección, prevención, intervención y seguimiento. Pero para tratar este tipo de temáticas el qué es muy importante, pero lo es más si cabe el quién, y este sería el segundo eje de actuación del orientador. Este segundo eje relacionado con el quién lo formarían los centros docentes, las familias y los alumnos, pues éstos serán los tres agentes sobre los que trabajará el orientador al tratar el fenómeno del ciberbullying, dado que son figuras esenciales en dicho proceso si lo que se persigue es el éxito de las acciones emprendidas (Hinduja \& Patchin, 2014).Para ello proporcionamos una serie de indicadores y recursos específicos para que el orientador pueda trabajar en cada una de las fases y con cada uno de los agentes implicados.

Además, en relación al rol del orientador, y como aportación a estos profesionales y a la sociedad en general, hemos determinado un plan de actuación en situaciones de ciberbullying, uno específico para los centros escolares y otro para las familias, para tratar de resolver con la máxima rapidez y eficacia posible toda aquella situación de ciberbullying. En él un proporcionamos pautas más determinadas a las encontradas hasta el momento en los protocolos actuales; especificando las fases, los participantes, los recursos y las tomas de decisiones.

Complementamos además todo ello añadiendo diversas aportaciones relativas al ciberbullying; así las acciones realizadas desde los centros, en la Comunidad Valenciana, llevadas a cabo en el Plan de Prevención de la Violencia y Promoción de la Convivencia (PREVI), cuya finalidad es dar respuesta a las necesidades detectadas por la comunidad educativa. Así hacemos aportaciones concretas respecto a las "Medidas de prevención dirigidas al sistema educativo", "Medidas de prevención dirigidas a la población de riesgo" y "Medidas de prevención dirigidas a la sociedad valenciana".

Todas estas cuestiones trabajadas a lo largo de los capítulos teóricos, nos aportan una visión sobre el fenómeno del ciberbullying, así como también algunas aportaciones propias a ciertos aspectos que tras analizar hemos considerado que era necesario complementar y mejorar. Pero todo ello, toma especial sentido en la segunda parte de nuestra tesis, pues es donde presentamos nuestro proyecto; un programa de prevención del ciberbullying dirigido a los alumnos del segundo y tercer ciclo de Educación Primaria "Conviure en un món real i digital".

Para ello partimos de las necesidades detectadas en nuestro entorno, en concreto de los datos extraídos de las evaluaciones realizadas a docentes y padres y madres de alumnos de Educación Primaria. A partir de esta detección de necesidades, manifestadas a partir de la percepción de docentes y de padres y madres de varios centros de Educación Primaria, estaremos en condición de diseñar e implementar un programa de prevención del ciberbullying que dé respuesta a estas necesidades detectadas, con la finalidad de realizar acciones de prevención del ciberbullying. 
Así los objetivos tanto el general como específicos respecto a los docentes y los padres y madres, podemos afirmar que se han conseguido; tal como ponen de manifiesto los resultados del cuestionario para el profesorado y del cuestionario para familias.

Esta evaluación de necesidades, nos indican que prácticamente la totalidad de los familiares considera necesaria la prevención en los centros educativos sobre los riesgos en el uso de las TIC por parte de los menores así como la importancia de concienciar a la sociedad sobre los riesgos en el uso de las TIC. Por su parte los docentes, una gran parte de ellos reconoce no disponer de pautas a seguir para hacer frente a situaciones de ciberbullying, ni tampoco disponen de la suficiente información y formación sobre los riesgos. Más de la mitad indican que sin ayuda de otros profesionales no se sienten capacitados para resolver los conflictos derivados de las TIC, y reconocen la importancia de trabajar las relaciones interpersonales siendo este un objetivo principal en su labor como docentes. Consideran necesario la implantación de un proyecto de prevención e intervención contra la violencia, de la elaboración de protocolos y materiales para trabajar en el aula, así como cursos de formación para los docentes.

A partir de los resultados obtenidos en la evaluación de necesidades, diseñamos el programa "Conviure a un món real i digital", programa preventivo/formativo ante posibles situaciones de ciberbullying cuyo objetivo principal es realizar acciones de prevención del ciberbullying en los centros escolares en el segundo y tercer ciclo de la Educación Primaria mediante actividades insertas en el currículo escolar, de forma que el alumno tenga la posibilidad de adquirir estos conocimientos y habilidades relacionadas con la prevención del ciberbullying progresivamente durante los cuatro últimos cursos de la Educación Primaria.

Teniendo en cuenta el objetivo de nuestra investigación seguimos el Modelo de Inserción curricular de Hilda Taba como soporte teórico de nuestro programa de prevención del Ciberbullying en la etapa de Primaria (Addine et al., 2000), puesto que este modelo pone el énfasis en la necesidad de que en los programas escolares se incluyan aquellos aspectos que den respuestas efectivas a las necesidades y problemáticas que la sociedad nos plantea en cada momento.

Así, el programa ha sido diseñado a partir de un conjunto de actividades insertas al currículum escolar, concretamente en las siguientes asignaturas; ciencias sociales, ciencias de la naturaleza y lengua castellana y literatura, por la adecuación de sus contenidos al objetivo de nuestro programa.

En cuanto a las temáticas que se trabajarán en nuestro programa se clasifican del siguiente modo. En los cursos de tercero y cuarto de primaria se trabajarán un conjunto de actividades relacionadas con habilidades tecnológicas y personales cómo: buen uso de las TIC, prevención y resolución de conflictos, autoestima, emocione y autocontrol. A continuación, en quinto y sexto curso de primaria se seguirán trabajando aspectos tecnológicos e introduciremos habilidades sociales, dado que estos últimos se tienen que 
desarrollar con posterioridad a las habilidades más personales. Así, los contenidos a trabajar los dos últimos cursos de la educación primaria siguen siendo el buen uso de las TIC y resolución de conflictos, pues los consideramos elementos clave en nuestro programa, y en este ciclo le añadimos actividades en las que se trabaja la empatía, la asertividad y el ciberbullying.

Cabe remarcar que las temáticas van siendo trabajadas progresivamente, algunas a lo largo del mismo ciclo educativo y otras como las dos habilidades que acabamos de nombrar se trabajarán progresivamente a lo largo de los últimos cuatro años de Educación Primaria, pues se trata de un programa longitudinal.

El proyecto se ha llevado a cabo con alumnos de tercero, cuarto, quinto y sexto de primaria del C.E.I.P. Pio XII de Nules (Castellón), siendo un total de 86 los alumnos participantes; 18 de tercero, 20 de cuarto, 23 de quinto y 25 de sexto curso. También han participado los cuatro docentes del C.E.I.P. Pio XII tutores dichos cursos, puesto que son éstos los docentes responsables de la impartición de las asignaturas en las cuales se inserta el contenido del programa.

Respecto a la evaluación del programa, ésta tiene como objetivo evaluar la eficacia del programa del programa "Conviure en un món real i digital". También presentamos como objetivo de esta fase, evaluar la adecuación de las actividades mediante la evaluación de asimilación de contenidos por parte de los alumnos respecto a los contenidos trabajados en las actividades y la evaluación de los docentes. Dichos objetivos han sido conseguidos.

En cuanto a la hipótesis que nos planteamos referente a la aplicación del programa "Conviure en un món real i digital", aumentará las competencias en el uso y conocimiento de las TIC así como en ciertas habilidades personales y sociales vinculadas a la prevención y afrontamiento de situaciones de acoso por medio del uso de las TIC, en base a toda la formación e información recibida progresivamente a lo largo de los cuatro cursos de Educación Primaria. Los resultados obtenidos confirman dicha hipótesis.

Para evaluar la eficacia del programa han sido dos los instrumentos utilizados; Cuestionario de Educación Emocional (CEE) y Escaciber. El diseño que hemos utilizado para el análisis de los datos ha sido el método cuasi-experimental, con la finalidad de ver las diferencias en el postest entre el C.E.I.P. Pio XXI (centro experimental) y el C.E.I.P. Lope de Vega (centro control), y así valorar la eficacia del programa.

La evaluación del programa, implantado en el C.E.I.P. Pio XII de Nules, han puesto de manifiesto que el programa "Conviure en un món real i digital es eficaz puesto que se han obtenido resultados significativos en la gran mayoría de las dimensiones evaluadas, teniendo en cuenta que nuestro objetivo era comprobar la eficacia del programa a lo largo de los últimos cuatro cursos de Educación Primaria, que es al alumnado que va dirigido este programa, puesto que se trata de un programa cuyo contenido se desarrolla progresivamente a lo largo de los últimos cuatro últimos cursos de la Educación Primaria, y por tanto su análisis debería ser longitudinal, y por tanto debemos tener en cuenta que 
los datos que ahora mostramos solamente hacen referencia a la aplicación del programa durante un único curso escolar.

En cuanto a la evaluación de la adecuación de las actividades mediante la evaluación de asimilación de contenidos por parte de los alumnos respecto a los contenidos trabajados en las actividades y la evaluación de los docentes, podemos aportar que ha habido una elevada asimilación de los contenidos de todos los bloques trabajados en el programa en los cuatro cursos por parte de los alumnos, obteniéndose unas calificaciones medias entre 8,5 y 9 sobre 10 puntos. También la evaluación docente de los contenidos del programa es positiva ya que todos los datos aportados por los docentes nos indican que las actividades incluidas en el programa se adecuan a la finalidad del programa, y no proponen ninguna mejora en él.

Así, la evaluación global del programa ha puesto de manifiesto que los datos obtenidos son significativos y positivos, y con ello se cumplen los objetivos e hipótesis uncialmente contemplados.

Teniendo en cuenta de manera global nuestra investigación, cabe preguntarnos ¿cuál ha sido nuestra aportación a la comunidad científica? Entre otras destacamos:

- La elaboración de una definición propia del término ciberbullying que incluye todas las características específicas del fenómeno y que va más allá de una extensión de la definición del término bullying indicando únicamente que éste se da por medio de las TIC.

- Categorización de un glosario de términos que permite la inserción curricular, ya que facilita el conocimiento de los términos por parte del profesorado a favor de la inserción curricular en los centros escolares.

- Establecimiento de un punto de partida para futuras investigaciones a través del estudio realizado de las fuentes primarias y secundarias.

- Recopilación de los recursos más importantes que el Psicólogo tiene a su disposición para proporcionarlos a los centros educativos, alumnos y familias, en las diferentes etapas en las que se puede abordar la temática; sensibilización, prevención, detección, intervención y seguimiento. Además de la confección de unas rejillas con las que el psicólogo pueda obtener información que le permita tomar decisiones para poder encauzar su intervención de una manera más eficaz.

- Diseño de un protocolo de actuación específico de ciberbullying, en concreto una destinado al mismo centro y otro a las familias.

- Aportación sobre el ciberbullying en el PREVI entre las que destacamos diversas aportaciones relativas a la "Medidas de prevención dirigidas al sistema educativo", "Medidas de prevención dirigidas a la población de riesgo" y "Medidas de prevención dirigidas a la sociedad valenciana". 
- Diseño e implantación del Programa de prevención del ciberbullying, "Conviure a un món real i digital” para los dos últimos ciclos de Educación Primaria, a partir de la inserción curricular en tres materias de contenidos directamente vinculados a las situaciones de ciberbullying, siendo éstos tanto contenidos relacionados con la TIC como contenidos de índole humanístico.

Las limitaciones encontradas en nuestro trabajo han sido:

- Muestra de participantes reducida.

- Falta de instrumentos de evaluación de la ciberconducta adaptados a la etapa de la Educación Primaria.

- Evaluación del programa en un solo curso escolar, teniendo en cuenta que sería necesaria una evaluación longitudinal del programa.

Con ello, en cuanto a las líneas futuras de trabajo, mencionamos:

- Seguir trabajando en la mejora del programa, aplicando los resultados de nuestra investigación.

- Aplicación del programa a otros centros educativos.

- Formación del profesorado.

- Formación de padres.

Como líneas futuras de investigación nos podemos centrar:

- Desarrollo del programa de manera longitudinal en los centros educativos que participen:

- Objetivo: Implementar en centro educativos de Educación Primaria el programa de modo que los alumnos adquieran progresivamente las habilidades desarrolladas en el programa. Para ello deberían iniciar el programa en tercer curso y finalizarlo en sexto curso de Educación Primaria.

- Elaboración de instrumentos de evaluación para la etapa de Educación Primaria.

- Objetivo: Diseñar un instrumento de evaluación en el que se contemplen dimensiones relacionadas con ciertas habilidades relacionadas con el uso de las TIC, concretamente la ciberconducta, y 
también donde se contemplen habilidades de índole personal y social pues están directamente relacionadas con el buen uso de las TIC.

- Validación de instrumentos.

- Objetivo: Validar los instrumentos diseñados con muestras de alumnos de Educación Primaria, con la finalidad de disponer de instrumentos con validez y fiabilidad en este campo.

- Diseño, implementación y evaluación de un curso on line de formación para padres.

- Objetivo: El ciberbullying es un fenómeno en el cual se debe implicar a toda la sociedad en su conjunto, y por tanto al tratarse de un tipo de acoso que se produce entre iguales es esencial ofrecer a los padres una formación, de modo que se complemente la formación que se les ofrece a los alumnos en los centros educativos. Para ello, y con la finalidad de llegar al mayor público familiar posible, sería adecuado un diseño de formación online en la que se les transmita todos aquellos datos que se recogen a lo largo de la tesis y que los familiares deberían conocer.

- Diseño e implementación de un curso on line de formación para el profesorado.

- Objetivo: Del mismo modo que es esencial una formación a las familias, también lo es para los docentes de los centros escolares, pues se les debe proporcionar la máxima información posible sobre este fenómeno, así como dotarles de recursos para actuar y luchar contra este tipo de violencia.

Por todo ello, la intención de nuestro equipo de investigación es seguir trabajando en esta línea, puesto que consideramos que es necesario que este programa se implante en todos los centros educativos de Educación Primaria. Los resultados obtenidos en el estudio, así como también el interés mostrado por el proyecto, la implicación y posterior petición del programa diseñado por parte de los equipos directivos y de los docentes de los centros educativos directamente implicados en esta investigación, nos han ilusionado más si cabe en el proyecto.

Para ello, invitamos a las instituciones correspondientes a seguir apoyando este tipo de proyectos tan necesarios en una sociedad como la actual, puesto que el ciberbullying es un problema de la sociedad en su conjunto, y sólo unidos conseguiremos erradicarlo, dejando que las TIC sean únicamente un instrumento de aprendizaje y de avance, y con ello permitiremos que nuestros menores sean felices viviendo en el mundo que les ha tocado vivir. 


\section{BIBLIOGRAFÍA}

Adán, J. (2017, 16 de enero). Lucía, la niña de 13 años que se suicidó tras sufrir acoso escolar: 'Mamá, no puedo más'. El Mundo. Recuperado de http://www.elmundo.es/sociedad/2017/01/16/587d08f146163f94548b466b.html

Addine, F., González, M., Batista, L. C., Pla, R., Laffita, R.\& Quintero, G. (2000). Diseño curricular. La Habana: Instituto Pedagógico Latinoamericano y Caribeño.

Aftab, P. (2010). What is Cyberbullying? Recuperado de http://aftab.com/index.php?page=cyberbullying.

Agustina, J. R. \& Gómez-Durán, E. L. (2012). Sexting: Research criteria of a globalized social phenomenon. Archives of Sexual Behavior, 41, 1325-1328.

Aliaga, F. (2000). Bases epistemológicas y proceso de investigación psicoeducativa. Valencia: CSV.

Álvarez, D., Rodríguez, C., González, P., Núñez, J.C., \& Álvarez, L. (2010). La formación de los futuros docentes. Psicodidáctica, 15 (1), 35-56.

Álvarez, G. (2015). Intervención con adolescentes víctimas de ciberbullying: un abordaje desde el trabajo social. Trabajo Social Hoy, 74, 75-92.

Álvarez, M. (2011) (coord.) Diseño y evaluación de programas de educación emocional. Madrid: WoltersKluwer España.

Álvarez, M., Álvarez, L., Avilés, J.M., Fierro, A., García, L., Gutiérrez, J.E.,... Urra, J. (2015). Guía de actuación contra el ciberacoso. Ministerio de industria, energía y turismo. Recuperado

http://www.injuve.es/sites/default/files/2013/46/publicaciones/Gu\%C3\%ADa\%20d e\%20actuaci\%C3\%B3n\%20contra\%20el\%20ciberacoso.pdf

Álvarez, M. \& Bisquerra, R. (Coord.) (2009). Manual de orientación y tutoría. Barcelona: WoltersKluwer.

Álvarez-García, D., Núñez, J.C., Álvarez-Pérez, L., Dobarro, A., Rodríguez, C. \& GonzálezCastro, P. (2011). Violencia a través de las tecnologías de la información y la comunicación en estudiantes de secundaria. Anales de psicología, 27 (1), 221-231.

Anguera, M. T., Chacón, S. \& Sánchez, M. (2008). Bases metodológicas en evaluación de programas. En M. T. Anguera, S. Chacón \& A. Blanco (Coords.), Evaluación de programas sociales y sanitarios: un abordaje metodológico (pp. 37-68). Madrid, España: Síntesis.Belsey, B. (2005). Cyberbullying: An emerging Threta to the always of generation.Recuperado de http://www.cyberbullying.ca

Avilés, J. Ma (2012). Manual contra el bullying. Guía para el profesorado. Lima: Libro Amigo. 
Avilés, J.Mạ. (2013). Análisis psicosocial del ciberbullying: claves para una educación moral. Papeles del Psicólogo, 34(1), 65-73. Recuperado de: http://www.papelesdelpsicologo.es/pdf/2172.pdf

Bartrina, M.J. (2014). Conductas de ciberacoso en niños y adolescentes. Hay una salida con la educación y la conciencia social. Educar, 50 (2), 383-400.

Bausela, E. (2003). Diseño y aplicación de un cuestionario de detección de necesidades de orientación psicológica en un grupo de alumnos de/as de la universidad de León en fase piloto. Revista psicodiáctica, 14, 115-130.

Benítez, I., Padilla, J.L. \& Ongena, Y. (2012). Evaluation of the convergence between "selfreporters" and "proxies" in a disability questionnaire by means of behaviour coding method. Quality and Quantity 46(4), 1311-1322. doi: 10.1007/s11135-011-9443-z.

Beran, T. \& Li, Q. (2007). The relationship between cyberbullying and school bullying. Journal of Student Wellbeing, 1, 15-33.

Berne, S., Frisén, A., Schultze-Krumbholz, A., Scheithauer, H., Naruskov, K. \& Luik, P. (2013). Cyberbullying assessment instruments: A systematic review. Aggression and Violent Behavior, 18(2), 320-334. doi:10.1016/j.avb.2012. 11.022

Berríos, L. \& Buxarrais, M. R. (2005). Las tecnologías de la información y la comunicación (TIC) y los adolescentes. Algunos datos. OEI, Monografías virtuales: Ciudadanía, democracia y valores en sociedades plurales, 5 .

Blanco, I. \& Römer, M. (2010). Los niños frente a las pantallas. Madrid: Editorial Universitas SA.

Borowsky, I., Taliaferro, L. \& McMorris, B. (2013). Suicidal Thinking and BehaviourAmong Youth Involved in Verbal and Social Bullying: Risk and Protective factors. Journal of Adolescent Health, 53, 4-12.

Brugess, A., Patchin, J.W. \& Hinduja, S. (2006). Cyberbullying: the victimizaction of adolescent girls. Recuperado de http://www.cyberbullying.us/cyberbullying_girls_ victimization.pdf

Buelga, S., Cava, M.J., \& Musitu, G. (2010). Cyberbullying: victimización entre adolescentes a través del teléfono móvil y de Internet. Psicothema, 4, 784- 789.

Buendía, L. (1999). El proceso de la investigación empírico-experimental. En L. Buendía, D. González, J. Gutiérrez \& M. Pegalajar. Modelos de análisis de la investigación educativa. Sevilla: Alfar.

Buendía, L., Colás, P. \& Hernández-Pina, F. (1998). Métodos de investigación en psicopedagogía. Madrid: McGraw-Hill.

Caballer, S. (2005). El buen uso de Internet. Recuperado de http://sai.edu.gva.es/sites/default/files/docs/Manual_Buen_Uso_Internet_es.pdf 
Cáceres, M. (2010). Ciberbullying, el efecto mediador de las TICS en el acoso escolar. Temas para la Educación. Revista digital para profesionales de la enseñanza, 1-8.

Calmaestra, J., Escorial, A., García, P., del Moral, C., Perazzo, C. \&Ubrich, T. (2016). Yo a eso no juego. Bullyng y Ciberbullyng en la infancia. España: Save the Children. Recuperado de https://www.savethechildren.es/sites/default/files/imce/docs/yo_a_eso_no_juego .pdf

Calmaestra, J., Ortega, R., Maldonado, A. \& Mora-Merchán, J. A. (2010). Exploring Cyberbullying in Spain. En J. A. Mora-Merchán y T. Jäger (Eds.), Cyberbullying. A crossnational comparison(pp. 146-162). Landau: Verlag Empirische Pädagogik.

Calvete, E., Orue, I., Estévez, A., Villardón, L., \& Padilla, P. (2010). Cyberbullying in adolescents: Modalities and aggressors' profi le. Computers in Human Behavior, 26(5), 1128-1135. doi:10.1016/j. chb.2010.03.017

Campbell, G. (2005). Regulation of gene expression in the distal region of the Drosophila legbythe Hox11 homolog, C15. Developmental. Biology, 278(2), 607--618.

Castells, M.(2011). Entrevista a Manuel Castells. Catedra multilingüisme UOC. Recuperado de http://catedramultilinguisme.uoc.edu/portal/castellano/sala-depremsa/actualitat/entrevistes/2011/manuel_castells.html.

Chacón, S., Sanduvete, S. Portell, M. \& Anguera, M.T. (2013). Reporting a program evaluation: Needs, program plan, intervention, and decisions. International Journal of Clinical and HealthPsychology, 13, 58-66.

Chacón, S., Shadish, W. R. \& Cook, T. D. (2008). Diseños evaluativos de intervención media. En Anguera M.T., Chacón, S. y Blanco, A. Evaluación de programas sociales y sanitarios. Un abordaje metodológico (pp. 185-218. Madrid: Síntesis.

Collell, J. \& Escudé, C. (2008a). Ciberbullying. L'assetjament a través de la xarxa. Àmbits de Psicopedagogia, 24, 20-23.

Collell, J. \& Escudé, C. (2008b). No te enredes en la red. Guía para conocer el ciberbullying $\mathrm{y}$ algunos peligros de internet $\mathrm{y}$ las nuevas tecnologías. Recuperado de www.xtec.cat/ jicollell/ZGuia\%20Ciber.pdf

Cooper, K., Quayle, E., Jonsson, L. \& Svedin, C. G. (2016). Adolescents and self-taken sexual images: A review of the literature. Computers in Human Behavior, 55, 706-716.

Curell, N. (2015). Guía clínica de ciberacoso para profesionales de la salud. Madrid: Hospital Universitario La Paz, Sociedad Española de Medicina del Adolescente, Red.es.

Dalla, V., Di Pietro, A., Morel, S. \& Psaila, E. (2016). Cyberbullying among Young People. Recuperado de http://www.europarl.europa.eu/supporting-analyses

David, C., \& Feldman, M. (2007). Electronic media, violence, and adolescents: An emerging public health problem. Journal of Adolescent Health, 41(6), 51-55. 
De Masi, P. (2000). Doesthe Pickup in Productivity Growth Mean That Thereis a 'New Economy'?, United States of America - Selectedlssues, IMF Staff Country Report No. 00/112, Washington, D.C.: International MonetaryFund.

Decreto 108/2014, de 4 de julio, del Consell, por el que establece el currículo y desarrolla la ordenación general de la educación primaria en la Comunitat Valenciana. Diari Oficial de la Generalitat Valenciana. Valencia, 7 de julio de 2014, núm. 7311, pp. 16325-16694.

Decreto 233/2004, de 22 de octubre, del Consell de la Generalitat, por el que se crea el Observatorio para la Convivencia Escolar en los Centros de la Comunidad Valenciana. Diari Oficial de la Generalitat Valenciana. Valencia, 22 de octubre de 2004, núm. 4.871, pp. 26890-26893

Decreto 39/2008, de 4 de abril, del Consell, sobre la convivencia en los centros docentes no universitarios sostenidos con fondos públicos y sobre los derechos y deberes del alumnado, padres, madres, tutores o tutoras, profesorado y personal de administración y servicios. Diari Oficial de la Generalitat Valenciana.Valencia, 4 de abril de 2008, núm. 5738, pp.-55906-55931

Del Rey, R., Elipe, P. \& Ortega-Ruiz, R. (2013). Bullying and cyberbullying: Overlapping and predictive value of the co-occurrence. Psicothema, 24(4), 608-613.

Diamanduros, T., Downs, E., \& Jenkins, S. J. (2008). The role of school psychologists in the assessment, prevention, and intervention of cyberbullying. Psychology in the Schools, 45(8), 693-704.

Díaz-Aguado, M. J., Martínez, R. \& Martín, J. (2013). El acoso entre adolescente en España. Prevalencia, papeles adoptados por todo el grupo y características a las que atribuyen la victimización. Revista de Educación, 362, 348-379. doi: 10-4438/1988592XRE- 2011-362-164.

Döring, N. (2014). Consensual sexting among adolescents: Risk prevention through abstinence education or safer sexting. Cyberpsychology, 8, 1-18.

Echeburúa, E. \& de Corral, P. (2010). Adicción a las nuevas tecnologías y a las redes sociales en jóvenes: un nuevo reto, Adicciones, 22(2), 91-95.

Echenique, E. E. G. (2013). Hablemos de estudiantes digitales y no de nativos digitales. Universitas Tarraconensis. Revista de Ciències de l'Educació, 1(1), 7-21.

Erdur, Ö. \&Tanrıkulu, í. (2010). Psychological consequences of cyber bullying experiences among Turkish secondary school children. Procedia-Social and Behavioral Sciences, 2(2), 2771-2776.

Feldman, M. \& Donato, I. (2013). Bullying and Suicide: A Public Health Approach. Journal of Adolescent Health, 53, 51-53. 
Félix, V. (2010). Implicaciones educativas, familiares y legales del ciberacoso. Quaderns digitals: Revista de Nuevas Tecnologías y Sociedad, (65), 11.

Félix, V., Soriano, M., Godoy, C. \& Martínez, I. (2008). Prevención de la violencia y promoción de la convivencia escolar en la Comunitat Valenciana: Plan PREVI. Aula abierta, 36(1), 97-110.

Félix, V., Soriano-Ferrer, M., Godoy-Mesas, C. \& Sancho-Vicente, S. (2010). El ciberacoso en la enseñanza obligatoria. Aula Abierta, 38, 47-58.

Fernández, F. J. \& Fernández, M.J. (2016). Los docentes de la Generación Z y sus competencias digitales/Generation $Z$ 's Teachers and their Digital Skills. Comunicar, 24(46), 97-105.

Fernández-Ballesteros, R. (1995). El proceso de evaluación de programas. En R. FernándezBallesteros (Ed.), Evaluación de programas. Una guía práctica en ámbitos sociales y de salud (pp.75-113). Madrid: Síntesis.

Ferro, J. (2013). Acoso escolar a través de las nuevas tecnologías. Cyberacoso y grooming. Jaén: Formación Alcalá.

Finkelhor, D., Mitchell, K. J. \& Wolak, J. (2000). Online Victimization: A Report on the Nation's Youth.Washington, DC: National Center for Missing \& Exploited Children. Recuperado de http://www.unh.edu/ccrc/pdf/Victimization_Online_Survey.pdf

Flores, J. \& Casal, M. (2008). Ciberbullying. Material didáctico para la prevención del acoso por medio de las nuevas tecnologías. Vitoria-Gasteiz: Ararteko. Recuperado de http://www.pantallasamigas.net/recursos-educativos-materiales-didacticos/packciberbullying/index.htm

Fundación Telefónica (2013). Claves Educativas para el 2020. Cómo debería ser la educación del Siglo XXI. Recuperado de http://www.fundaciontelefonica.com/arte_cultura/publicacioneslistado/paginaitem-publicaciones/itempubli/257/

Gallardo, E. E. (2013). Hablemos de estudiantes digitales y no de nativos digitales. Universitas Tarraconensis. Revista de Ciències de l'Educació, 1(1), 7-21.

Gámez-Guadix, M., Almendros, C., Borrajo, E., \&Calvete, E. (2015). Prevalence and association of sexting and online sexual victimization among spanish adults. Sexuality Research and Social Policy, 12, 145- 154.

Gámez-Guadix, M., Santisteban, P., \& Resett, S. (2017). Sexting among Spanish adolescents: Prevalence and personality profiles. Psicothema, 29(1), 29-34.

Garaigordobil, M. (2011a). Bullying y ciberbullying. Conceptualización, prevalencia y evaluación, en Formación continuada a distancia. Consejos General Colegios Oficiales de Psicólogos. Recuperado de http://www.psicologiaysexologia.org/wpcontent/uploads/2013/11/Bullying-y-cyberbullyung.pdf 
Garaigordobil, M. (2011b). Prevalencia y consecuencias del cyberbullying: una revisión. International Journal of Psychological Therapy, 11(2), 233-254. Recuperado de: http://www.ijpsy.com/volumen11/num2/295.html

Garaigordobil, M. (2014). Cyberbullying: Una nueva forma de violencia entre iguales a través de los medios electrónicos. Padres y Maestros/Journal of Parents and Teachers, (357), 34-41.

Garaigordobil, M. (2016, 21 de diciembre). La necesidad de implementar programas validados para prevenir el acoso escolar. Infocopline. Recuperado de http://www.infocop.es/view_article.asp?id=6444\&cat $=49$

Garaigordobil, M. \& Aliri, J. (2013). Ciberacoso (cyberbullying) en adolescentes y jóvenes del País Vasco: Diferencias de sexo en víctimas, agresores y observadores. Psicología Conductual, 21, 461-474.

Garaigordobil, M. \& Martinez, V. (2014). Efecto del Cyberprogram 2.0 sobre la reducción de la victimización y la mejora de la competencia social en la adolescencia. Psicodidáctica, 19 (2), 289-305.

García, F., Portillo, J., Romo, J. \& y Benito, M. (2007). Nativos digitales y modelos de aprendizaje. In SPDECE.

García, G., Joffre, V. M., Martínez, G. J. \& Llanes, A. (2011). Ciberbullying: forma virtual de intimidación escolar. Revista Colombiana de psiquiatría, 40(1), 115-130.

Garmendia, M., Garitaonandia, C., Martínez, G. \& Casado, M. A. (2011). Riesgos y seguridad en internet: Los menores españoles en el contexto europeo Resultados de la encuesta de EU Kids Online. País Vasco: EU Kids Online.

Garmendia, M., Jiménez, E., Casado, M.A. \& Mascheroni, G. (2016). Net Children Go Mobile: Riesgos y oportunidades en internet y el uso de dispositivos móviles entre menores españoles (2010-2015). Madrid: Red.es/Universidad del País Vasco/EuskalHerrikoUnibertsitatea.

Generalitat de Catalunya (2014). Protocol de prevenció, detecció i intervenció enfront el ciberassetjament entre iguals. Barcelona: Xarxa Telemática Educativa de Catalunya. Recuperado de http://www.xtec.cat/web/centres/convivencia/recursos/resconflictes/ciberassetj ament_iguals

Giménez, M. B. \& Rubio, E. M. (2007). Acoso escolar: desarrollo, prevención y herramientas de trabajo. Madrid: Narcea Ediciones.

Gini, G. \& Pozzoli, T. (2013). Bullied children and psychosomatic problems: a meta-analysis. Pediatrics, 132(4), 720-9.

Grail Research (2011). Consumers of tomorrow insights and observations about Generation Z. Recuperado de http://goo.gl/7qYuWt) (17-08-2014). 
Grigg, D. W. (2010). Cyber-aggression: Definition and concept of cyberbullying. Australian Journal of Guidance and Counselling, 20(02), 143-156.

Hernández, M. Á. \& Solano, I. M. (2007). Ciberbullying, un problema de acoso escolar. Revista Iberoamericana de Educación a distancia, 10(1), 17.

Hernández-Pina, F. (1998). Diseños de investigación experimental. En Buendía Eisman, L., P. Colás Bravo y F. Hernández Pina. Métodos de investigación en psicopedagogía. Madrid: McGraw-Hill.

Hidalgo, M.I. (2015). Guía clínica de ciberacoso para profesionales de la salud. Plan de confianza del ámbito digital del Ministerio de Industria, Energía y Turismo. Hospital Madrid: Universitario La Paz, Sociedad Española de Medicina del Adolescente, Red. es.

Hinduja, S. (2016). The Priority for Cyberbullying Prevention in 2017 and Beyond. Cyberbullying Research Center. Recuperado de http://cyberbullying.org/prioritycyberbullying-prevention-2017-beyond

Hinduja, S. \& Patchin, J. (2010). Bullying, Cyberbullying, and Suicide, Archives of Suicide Research, 14 (3), 206-221.

Hinduja, S. \& Patchin, J. (2010). Bullying, Cyberbullying, and Suicide, Archives of Suicide Research, 14 (3), 206-221.

Hinduja, S. \& Patchin, J. (2014). Cyberbullying glossary. Recuperado de http://cyberbullying.org/cyberbullying-glossary.pdf

Hinduja, S. \& Patchin, J. (2015a). Developing a positive school climate. Top ten tips to prevent bullying and cyberbullying. Cyberbullying Research Center. Recuperado de http://cyberbullying.org/developing-a-positive-school-climate-to-prevent-bullyingand-cyberbullying

Hinduja, S. \& Patchin, J. (2015b). What to Do When Your Child Cyberbullies Others: Top Ten Tips for Parents.Cyberbullying Research Center. Recuperado de http://cyberbullying.org/what-to-do-when-your-child-cyberbullies-others

Hinduja, S. \& Patchin, J. (2016a). Sexting: Advice for teens. Cyberbullying Research Center.Recuperado de http://cyberbullying.org/sexting-advice-teens

Hinduja, S. \& Patchin, J. (2016b). Cyberbullying Data. Recuperado de http://cyberbullying.org/2016-cyberbullying-data

Hinduja, S. \& Patchin, J. (2016c). Summary of Our Cyberbullying Research (2004-2016). Recuperado de http://cyberbullying.org/summary-of-our-cyberbullying-research

Instituto Nacional de Estadística (INE) (2016). Encuesta sobre equipamiento y uso de tecnologías de información y comunicación en los hogares. Recuperado de http://www.ine.es/prensa/np991.pdf 
Instituto Nacional de Tecnologías de Comunicación(INTECO) (2009a). Guía Legal sobre $\begin{array}{llll}\text { Ciberbullying } y & \text { Grooming. Recuperado de }\end{array}$ https://www.incibe.es/CERT/guias_estudios/guias/guiaManual_groming_ciberbully ing

Instituto Nacional de Tecnologías de Comunicación (INTECO) (2009b). Estudio sobre hábitos seguros en el uso de las TIC por niños y adolescentes y e-confianza de sus padres. https://www.incibe.es/CERT/guias_estudios/Estudios/Estudio_ninos

Instituto Nacional de Tecnologías de Comunicación (INTECO) (2011). Guía sobre adolescencia y sexting: qué es y cómo prevenirlo. Recuperado de https://www.incibe.es/CERT/guias_estudios/guias/Guia_sexting

Instituto Nacional de Tecnologías de Comunicación (INTECO) (2012). Estudio sobre la seguridad de la información y la e-confianza de los hogares españoles. Recuperado de https://www.incibe.es/CERT/guias_estudios/Estudios/Estudio_hogares_1C2012 (18oleada)https://www.incibe.es/CERT/guias_estudios/Estudios/Estudio_hogares _3C2011 (17ㅇo oleada)

Instituto Nacional de Tecnologías de Comunicación (INTECO) (2013). Guía SOS contra el grooming. Padres y educadores. Recuperado de http://www.adolescenciasema.org/usuario/documentos/sos_grooming.pdf

Instituto Nacional de Tecnologías de la Comunicación (INTECO) (2014a). Guía S.O.S. contra el ciberbullying: educadores. Recuperado de http://www.chaval.es/chavales/sites/default/files/Guia_SOS_Educadores_vf_pi.pdf Instituto Nacional de Tecnologías de la Comunicación (INTECO) (2014b). Guía S.O.S. contra el ciberbullying: padres. Recuperado de http://www.chaval.es/chavales/sites/default/files/SOS_ciberbullying_padres.pdf

Instituto Nacional de Tecnologías Educativas y de Formación del Profesorado (INTEF) (2016). Indicadores del uso de las TIC en España y en Europa. Recuperado de http://blog.educalab.es/intef/wp-content/uploads/sites/4/2016/11/2016_1128Indicadores_TIC_2016_INTEF.pdf

International Learning Advisory Board (2008). Learning in the 21st Century: Teaching Today's Students on Their Terms. IEAB. Recuperado de http://www.certiport.com/Portal/Common/DocumentLibrary/IEAB_Whitepaper04 0808 .pdf

Juvonen, J. \& Gross, E. (2008). Extending the school grounds? Bullying experiences in cyberspace. The Journal of School Health, 78(9), 496-505.

Kowalski R., Limber, S. \& Agatston, P. (2010). CyberBullying: El acoso escolar en la era digital. Bilbao: Desclée de Brower. 
Kowalski, R. \& Limber, S. (2007). Electronic bullying among middle school students. Journal of Adolescent Health, 41, 22-30.

Kowalsky, R. \& Limber, S. (2013). Psychological, Physical, and Academic Correlates of Cyberbullying and Traditional Bullying. Journal of Adolescent Health, 53, 513-520.

Llaneza, P. (2015). Guía clínica de ciberacoso para profesionales de la salud. Plan de confianza del ámbito digital del Ministerio de Industria, Energía y Turismo. Madrid: Hospital Universitario La Paz, Sociedad Española de Medicina del Adolescente, Red.es.

Lucas, B., Pérez, A.\& Giménez, M. (2016). La evaluación del cyberbullying: situación actual y retos futuros. Papeles del Psicólogo, 37(1), 27-35.

Luengo, J. A. (2011). Ciberbullying: Guía de recursos para centros educativos en casos de ciberacoso. Madrid: Oficina del Defensor del menor en la Comunidad de Madrid.

Luengo, J. A. (2014). Ciberbullying: Prevenir y Actuar. Guía de recursos didácticos para centros educativos. Recuperado de www.copmadrid.org/webcopm/recursos/CiberbullyingB.pdf

Marquès, P. (2000). Las TIC y sus aportaciones a la sociedad. España: CissPraxis.

Martín, A. Á. (2015). HORIZONTE 2020: ¿esperanza o advertencia? Revista de Estudios de Juventud, 108, 9-18.

McGuckin, C., Perren, S., Corcoran, L., Cowie, H., Dehue, F., Ševčíková, A. \& Völlink, T. (2013). Coping with cyberbullying. How can prevent cyberbullying and how victimscan cope with it. En P.K. Smith. \& G. Steffgen (Coords.).Cyberbullying through the new media: Findings from an international network. New York: Psychology Press.

Menesini E. \& Nocentini, A. (2009). Cyberbullying definition and measurement: Some critical considerations. Zeitschrift Fur Psychologie/ Journal of Psychology, 217, 230232. doi:10.1027/0044-3409.217.4.230

Ministerio de Industria, energía y turismo (2015). Decálogo de actuación Ciberacoso: padres. Recuperado de http://www.chaval.es/chavales/catalogoderecursos/dec\%C3\%A1logo-deactuaci\%C3\%B3n-ante-el-ciberacoso-para-padres

Ministerio del Interior (2014). Encuesta sobre hábitos de uso y seguridad de Internet de menores $y$ jóvenes en España. Recuperado de http://www.interior.gob.es/documents/10180/2563633/Encuesta+sobre+h\%C3\%A 1bitos+de+uso+y+seguridad+de+internet+de+menores+y+j\%C3\%B3venes+en+Espa \%C3\%B1a/b88a590a-514d-49a2-9162-f58b7e2cb354

Mishna, F., Saini, M. \& Solomon, S. (2009). Ongoing and online: Children and youth's perceptions of cyber bullying. Children and Youth Services Review, 31(12), 12221228. 
Mora, J.A. \& Ortega, R. (2007). Las nuevas formas de bullyingy violencia escolar. En R. Ortega, JA. Mora y Jäger, T. (Eds.). Actuando contra el bullying y la violencia escolar. El papel de los medios de comunicación, las autoridades cales y de Internet E-Book. Recuperado de mhttp://www.bullying-in-school.info/

Nansel, T. R., Overpeck, M., Pilla, R., Ruan, J., Simons-Morton, B. \& Scheidt, P. (2001). Bullying behaviors among US youth: Prevalence and association with psychological adjustment. Journal of the American Medical Association, 285, 2094-2100. doi:10.1001/jama. 285.16.2094

National Association of School Psychologists (NASP) (2005). What is a school psychologist? Recuperado de https://www.nasponline.org/about-school-psychology/who-areschool-psychologists

National Association of School Psychologists (NASP) (2006). NASP position statement on school violence. Recuperado de https://www.nasponline.org/×26815.xml

Naval, C., Sádaba, C. C., \& Bringué, X. (2003). Impacto de las Tecnologías de la Información y de la Comunicación (TIC) en las relaciones sociales de los jóvenes navarros. Navarra: Instituto Navarro de Deporte y Juventud.

Olweus, D. (1973). Hackkycklingarochoversittare: forskningornskol-mobbning. Estocolmo: Almqvist \&Wiksell.

Olweus, D. (1993). Bullying at school: What we know and what we can do.Oxford: Blackwell.

O'Moore, M., Cross, D. S., Valimaki, M., Almeida, A., Berne, S., Deboutte, G.,...Stald, G. (2013). Guidelines to preventcyber-bullying: A cross-nationalreview. En P. Smith \& G. Steffgen (Eds.). Cyberbullying through the new media: Findings from an international network (pp. 136-158). New York, NY: Psychology Press.

Orden 3/2017, de 6 de febrero, de la Conselleria de Educación, Investigación, Cultura y Deporte, por la cual se constituyen las unidades de atención e intervención del Plan de prevención de la violencia y promoción de la convivencia (PREVI) y se establece el procedimiento para su funcionamiento. Diari Oficial de la Generalitat Valenciana. Valencia, 6 de febrero de 2017, núm. 7980, pp.-5982-5990.

Orden 62/2014, de 28 de julio, de la Conselleria de Educación, Cultura y Deporte, por la que se actualiza la normativa que regula la elaboración de los planes de convivencia en los centros educativos de la Comunitat Valenciana y se establecen los protocolos de actuación e intervención ante supuestos de violencia escolar. Diari Oficial de la Generalitat Valenciana. Valencia, 28 de julio de 2014, núm. 7330, pp.-19267-19284.

Orden ECD/65/2015, de 21 de enero, por la que se describen las relaciones entre las competencias, los contenidos y los criterios de evaluación de la educación primaria, la educación secundaria obligatoria y el bachillerato.Boletín Oficial del Estado. Madrid, de 29 de enero de 2015, núm. 25, pp. 6986 a 7003. 
Orellana, M.N. (2002). Bases metodológicas de la Investigación Educativa. Proyecto Docente. Valencia: Universitat de València.

Organización Mundial de la Salud (OMS) (1981). Evaluación de los programas de salud. Normas fundamentales. Serie salud para todos, 6. Geneva: OMS.

Orjuela, L. (2013). Acoso escolar y ciberacoso: propuestas para la acción: informe. Madrid: Save the Children.

Orjuela, L., Cabrera de los Santos, B., Calmaestra, J., Mora-Merchán, J. \& Ortega-Ruiz, R. (2014). Save the Children, Acoso escolar y ciberacoso: Propuestas para la acción. Informe. Recuperado de http://www.savethechildren.es/docs/Ficheros/675/Acoso_escolar_y_ciberacoso_i nforme_vOK_-_05.14.pdf

Ortega, I., Soto, I. \& Cerdán, C. (2016). Generación Z. El último salto generacional. Recuperado de http://ethic.es/wpcontent/uploads/2016/04/ResumenEjecutivo_GeneracionZ_140315-2.pdf

Ortega, J.E. \& Fernández-Dols, J. M. (1980). Fuentes documentales en Psicología. Madrid: Debate.

Ortega, R. (2010). Agresividad injustificada, bullying y violencia escolar. Madrid: Alianza.

Ortega, R., Calmaestra, J. \& Mora, J. (2008). Ciberbulling International. Journal of Psychology and Psychological Therapy, 8 (2) 183-192.

Ortega, R., Del Rey, R. \& Casas, J.A. (2013). Redes sociales y cyberbullying: el proyecto ConRed. Revista Digital de la Asociación CONVIVES, 3, 34-44.

Ortega, R., Del Rey, R. \& Sánchez, V. (2012). Nuevas dimensiones de la convivencia escolar y juvenil. Ciberconducta y relaciones en la Red: Ciberconvivencia. Madrid: Ministerio de Cultura.

Ortega, R., Elipe, P. \&Calmaestra, J. (2009). Emociones de agresores y víctimas de cyberbullying: un estudio preliminar en estudiantes de secundaria. Ansiedad y Estrés, 15.

Ortega-Barón, J., Buelga, S. \& Cava, M.J. (2016). Influencia del clima escolar y familiar en adolescentes, víctimas de ciberacoso. Comunicar, 24(46), 57-65.

Patchin, J. \& Hinduja, S. (2006). Bullies Move beyond the Schoolyard: A Preliminary Look at Cyberbullying. Youth Violence and Juvenile Justice, 4(2), 148- 169.

Pedreira, J.L. (2015). Guía clínica de ciberacoso para profesionales de la salud. Madrid: Plan de confianza del ámbito digital del Ministerio de Industria, Energía y Turismo. Hospital Universitario La Paz, Sociedad Española de Medicina del Adolescente, Red.es. Recuperado de http://www.chaval.es/chavales/sites/default/files/Guia_Ciberacoso_Profesionales_ Salud_FBlanco.pdf 
Pérez, P., Flores, J., de la Fuente, S., Álvarez, E., García, L. \& Gutiérrez, C. (2011). Guía sobre adolescencia y sexting: qué es y cómo prevenirlo. Pantallas Amigas. Recuperado de http://www.sexting.es/wp-content/uploads/guia-adolescentes-y-sexting-que-es-ycomo-prevenirlo-INTECO-PANTALLASAMIGAS.pdf

Prensky, M (2001). Digital Natives, Digital Immigrants. On the Horizon, Vol. 9 No. 5, October. Recuperado de http://www.marcprensky.com/writing/Prensky\%20\%20Digital\%20Natives,\%20Digital\%20Immigrants\%20-\%20Part1.pdf

Protección online (s.f.). Pautas para niños y niñas ante el acoso escolar: El acoso escolar es violencia ino lo permitas! Recuperado de http://www.protecciononline.com/elacoso-escolar-es-violencia-no-lo-permitas/

Protégeles (2013). iInternet es muy positivo, pero tengo que respetar las normas! Recuperado

http://www.centrointernetsegura.es/descargas/folleto las normas de internet.p $\underline{\mathrm{df}}$

Real Decreto 126/2014, de 28 de febrero, por el que se establece el currículo básico de la Educación Primaria. Boletín Oficial del Estado. Madrid, de 1 de marzo de 2014, núm. 52, pp. 19349 a 19420.

Real Decreto 1513/2006, de 7 de diciembre, por el que se establecen las enseñanzas mínimas de la Educación primaria. Boletín Oficial del Estado. Madrid, 7 de diciembre de 2006, núm. 293, pp. 43053-43102.

Región de Murcia (2015). Protocolos AVE. Protocolos de Apoyo inmediato y coordinado a Víctimas Escolares. Recuperado de https://www.carm.es/web/pagina?IDCONTENIDO=50502\&IDTIPO=100\&RASTRO=c 792\$m4001,5316

Reig, D. \& Vilches, L. F. (2013). Los jóvenes en la era de la hiperconectividad: tendencias, claves y miradas. Madrid: Fundación Telefónica. Recuperado de file:///C:/Users/Raquel/Downloads/Los_jovenes_en_la_era_de_la_hiperconectivid ad.pdf

Reig, D. (2015). Jóvenes de un nuevo mundo: cambios cognitivos, sociales, en valores, de la Generación conectada. Revista de Estudios de Juventud, (108), 21-32.

Roca, G. (Coord.) (2015). Las nuevas tecnologías en niños y adolescentes. Guía para educar saludablemente en una sociedad digital. Barcelona: Hospital Sant Joan de Déu (ed).

Rodríguez, N. (2004). Guerra en las Aulas. Madrid: Vivir Mejor.

Salmerón, M.A, Campillo, F., y Casas, J., (2013). Acoso a través de internet. En Pediatría integral, 7, 529-533. Recuperado de http://www.pediatriaintegral.es/numerosanteriores/publicacion-2013-09/acoso-traves-de-internet/ 
Salmivalli, C. \& Poskiparta, E. (2012). Making bullying prevention a priority in Finnish schools: The KiVa antibullying program. New directions for youth development, 133, 41-53.

Sánchez, J. (2002).Integración curricular de las TIC. Conceptos e ideas. Recuperado de www. C5.cl

Sánchez-Pascuala, F. (coord.) (s.f.,a). Guía de la familia. Plan de Prevención del ciberacoso y promoción de la navegación segura en centros escolares. Junta de Castilla y León. Recuperado de http://www.educa.jcyl.es/ciberacoso/es/plan-prevencionciberacoso-navegacion-segura/guias-informativas/guia-familia

Sánchez-Pascuala, F. (coord.) (s.f.,b). Guía de los alumnos. Plan de Prevención del ciberacoso y promoción de la navegación segura en centros escolares (Junta de Castilla y León. Recuperado de http://www.educa.jcyl.es/ciberacoso/es/planprevencion-ciberacoso-navegacion-segura/guias-informativas/guia-alumnos

Shariff, S. (2005). Cyber-Dilemmas in the New Millennium: Balancing Free Expression and Student Safety in Cyber-Space. Speciallssue: Schools and Courts: CompetingRights in the New Millennium. McGillJournal of Education40(3) 467-487.

Slonje, R., Smith, P. K. \& Frisén, A. (2012). Processes of cyberbullying, and feelings of remorse by bullies: A pilot study. European Journal of Developmental Psychology, 9(2), 244-259.

Slonje, R., Smith, P. K. \& Frisén, A. (2013). The nature of cyberbullying, and strategies for prevention. Computers in Human Behavior, 29(1), 26-32.

Smith, P.K (2006). Ciberacoso: naturaleza y extensión de un nuevo tipo de acoso dentro y fuera de la escuela. Congreso Educación Palma de Mallorca.

Smith, PK. (2000). What good schools can do about bullying. Childhood, 7, 193-212.

Smith, T., Scahill, L., Dawson, G., Guthrie, D., Lord, C. \& Odom, S. (2006). Designing research studies on psychosocial interventions in autism. Journal of Autism and DevelopmentalDisorders, 37, 354-366.

Soler, V. (2008). El uso de las TIC (Tecnologías de la Información y la Comunicación) como herramienta didáctica en la escuela, en Contribuciones a las Ciencias Sociales. Recuperado de www.eumed.net/rev/cccss/02/vsp.htm

Tokunaga, R.S. (2010). Following you home from school: A critical review and synthesis of research on cyberbullying victimization. Computers in Human Behavior, 26, 277-287. doi:10.1016/j.chb.2009.11.014

Torres, F. C., \& Vivas, G. P. M. (2009). Mitos, realidades y preguntas de investigación sobre los 'nativos digitales': una revisión. Universitas Psychologica, 8(2), 323-338.

UNESCO (1971). International Guide to Educational Documentation. 1960-1965 (2a ed.). París: UNESCO. 
UNESCO (1976). Terminología de la Documentación. París: UNESCO.

UNESCO (1982). Directory of Educational Documentation and Information Services (4a ed.). París: UNESCO.

Vandebosch, H. \& Van Cleemput, K. (2009). Cyberbullying among youngsters: Profiles of bullies and victims. New Media Society, 11(8), 1349-1371.

Willard, N. (2005). Educator's guide to cyberbullying and cyberthreats. Recuperado de http://cyberbully.org/docs/cbcteducator.pdf

Willard, N. (2006). Cyberbullying and cyberthreats. Effectively managing Internet use risks in schools. Recuperado de http://new.csriu.org/cyberbully/docs/cbctpresentation.pdf

Williams, K. \& Guerra, N. (2007). Prevalence and predictors of Internet bullying. Journal of Adolescent Health, 41, S14- 21. doi:10.1016/j.jadohealth. 2007.08.018

Wolak, J., Mitchell, K.J. \& Finkelhor, D. (2006). Online victimization of youth: 5 years later. Alexandria, VA: National Center for Missing and Exploited Children.

Ybarra, M. L. \& Mitchell, K. J. (2004). Online aggressor/targets, aggressors, and targets: A comparison of associated youth characteristics. Journal of child Psychology and Psychiatry, 45(7), 1308-1316.

Ybarra, M.L., Mitchell, K.J., Wolak, J. \& Finkelhor, D. (2006). Examining characteristics and associated distress related to Internet harassment: Findings from the second youth Internet safety survey. Pediatrics, 118, 1169-1177. doi: 10.1542/peds.2006-0815 


\section{ANEXOS}

ANEXO 1. Rejilla de observación ciberbullying.

ANEXO 2. Instrumento de evaluación de necesidades docentes.

ANEXO 3. Instrumento de evaluación de necesidades de padres y madres.

ANEXO 4. Cuaderno del alumno de 3ㅇde Educación Primaria del programa "Conviure en un món real i digital".

ANEXO 5. Cuaderno del alumno de 40 de Educación Primaria del programa "Conviure en un món real i digital".

ANEXO 6. Cuaderno del alumno de 5 de Educación Primaria del programa "Conviure en un món real i digital".

ANEXO 7. Cuaderno del alumno de 60 de Educación Primaria del programa "Conviure en un món real i digital".

ANEXO 8. Cuaderno del profesor de 3 de Educación Primaria del programa "Conviure en un món real i digital".

ANEXO 9. Cuaderno del profesor de 4ํ de Educación Primaria del programa "Conviure en un món real i digital".

ANEXO 10. Cuaderno del profesor de 50 de Educación Primaria del programa "Conviure en un món real i digital”.

ANEXO 11. Cuaderno del profesor de 6ㅇ de Educación Primaria del programa "Conviure en un món real i digital".

ANEXO 12. Cuaderno de actividades complementarias para el profesorado de Educación Primaria del programa "Conviure en un món real i digital".

ANEXO 13. Índice curso de formación docente sobre ciberbullying.

ANEXO 14. Cuestionario CEE para el segundo ciclo de Educación Primaria.

ANEXO 15. Cuestionario CEE para el tercer ciclo de Educación Primaria.

ANEXO 16. Cuestionario Escaciber.

ANEXO 17. Instrumento de evaluación pedagógica para el alumnado de 3o de Educación Primaria.

ANEXO 18. Instrumento de evaluación pedagógica para el alumnado de 4을 de Educación Primaria. 
ANEXO 19. Instrumento de evaluación pedagógica para el alumnado de 5o de Educación Primaria.

ANEXO 20. Instrumento de evaluación pedagógica para el alumnado de 60 de Educación Primaria.

ANEXO 21. Instrumento de evaluación pedagógica docente.

ANEXO 22. Resultados de la evaluación pedagógica del alumnado de 30 de Educación Primaria.

ANEXO 23. Resultados de la evaluación pedagógica del alumnado de 4을 de Educación Primaria.

ANEXO 24. Resultados de la evaluación pedagógica del alumnado de 5o de Educación Primaria.

ANEXO 25. Resultados de la evaluación pedagógica del alumnado de 60 de Educación Primaria. 


\section{REJILLA CIBERBULLYING}

Complete la siguiente rejilla poniendo una $\mathrm{X}$ donde considere adecuado.

Alumno/a:

Profesor/a: Fecha cumplimentación:

Padre/Madre: Fecha cumplimentación

VÍCTIMA

\begin{tabular}{|l|l|l|l|}
\hline INDICADOR & SÍ & A VECES & NO \\
\hline Asiste regularmente a clase. & & & \\
\hline Ha observado que hace un uso abusivo del móvil, internet. & & & \\
\hline Presenta un bajón acusado en su rendimiento académico. & & & \\
\hline $\begin{array}{l}\text { Ha cambiado de manera manifiesta el modo de hacer las } \\
\text { actividades escolares (por ejemplo: de participar mucho a } \\
\text { no participar...). }\end{array}$ & & & \\
\hline $\begin{array}{l}\text { Ha cambiado de grupo de referencia sin justificación } \\
\text { aparente. }\end{array}$ & & & \\
\hline Últimamente muestra un grado elevado de irritabilidad & & & \\
\hline $\begin{array}{l}\text { No admite y se enfada mucho si se le prohíbe el uso del } \\
\text { ordenador y/o del móvil. }\end{array}$ & & & \\
\hline En su quehacer cotidiano muestra mucha ansiedad. & & & \\
\hline $\begin{array}{l}\text { Desde hace un tiempo pone muchas excusas para no ir al } \\
\text { colegio. }\end{array}$ & & & \\
\hline $\begin{array}{l}\text { Haya cambios sensibles en su manera de manera de ser: } \\
\text { apatía, tristeza, malhumor... }\end{array}$ & & & \\
\hline $\begin{array}{l}\text { Se observa una baja empatía en sus relaciones } \\
\text { interpersonales. }\end{array}$ & & & \\
\hline Muestra una conducta muy autoritaria con todos. & & \\
\hline Duerme mal. & & & \\
\hline Presenta frecuentes dolores de cabeza. & & & \\
\hline Hay cambios sensibles en sus hábitos alimentarios. & & \\
\hline
\end{tabular}

Otros aspectos a destacar: 


\section{COMENTARIO DEL PSICOLOGO/A EDUCATIVO}

Complete la siguiente rejilla poniendo una $\mathrm{X}$ donde considere adecuado.

Alumno/a:

Profesor/a: Fecha cumplimentación:

Padre/Madre: Fecha cumplimentación

AGRESOR

\begin{tabular}{|l|l|l|l|}
\hline INDICADOR & SÍ & A VECES & NO \\
\hline Habitualmente suele intimidar a sus compañeros. & & & \\
\hline Suele justificar las agresiones. & & & \\
\hline Ha participado en algún caso de acoso escolar. & & & \\
\hline $\begin{array}{l}\text { Comenta y enaltece situaciones de ciberbullying } \\
\text { protagonizadas por otros. }\end{array}$ & & & \\
\hline $\begin{array}{l}\text { Se muestra autoritario con los profesores, padres, } \\
\text { compañeros... }\end{array}$ & & & \\
\hline Manifiesta poca capacidad de empatía con las personas. & & & \\
\hline Su grupo de amigos/as suelen ser agresivos. & & & \\
\hline Hay un frecuente y prolongado fracaso escolar. & & & \\
\hline Su mundo es el móvil, internet. & & & \\
\hline Presenta alteraciones sensibles del sueño. & & & \\
\hline
\end{tabular}

Otros aspectos a destacar: 
ANEXO 2. INSTRUMENTO DE EVALUACIÓN DE NECESIDADES DOCENTES.

\section{Menores y TIC en el centro escolar \\ Cuestionario para profesores/as}

A continuación encontrará una serie de cuestiones sobre situaciones producidas en el centro, relacionadas con el uso que los alumnos realizan de las TIC e Internet, y sobre la actuación del profesorado ante dichas situaciones.

Por favor, lea las cuestiones que le planteamos a continuación y valórelas del 1 al 5 , (siendo 1: nunca, 2: casi nunca, 3: a menudo, 4: casi siempre y 5: siempre).

La información que nos proporcione es de gran valor para nosotros, por lo que le pedimos que conteste con la máxima sinceridad. El cuestionario es anónimo, sólo le pedimos algunos datos iniciales:

Fecha:

Centro:

Género:

Curso en el que imparte clase:

Años de experiencia docente:

1. En mi clase, suelo controlar y atajar los conflictos y agresiones, no llegando a ser un problema.

$\begin{array}{lllll}1 & 2 & 3 & 4 & 5\end{array}$

2. En el patio del colegio se producen actos violentos motivados por discusiones iniciadas en redes sociales 0 aplicaciones $\begin{array}{lllllll}1 & 2 & 3 & 4 & 5\end{array}$ tecnológicas.

3. Los alumnos hacen uso de las nuevas tecnologías con fines agresivos y violentos.

$\begin{array}{lllll}1 & 2 & 3 & 4 & 5\end{array}$

4. Como profesor/a, sin ayuda de otro profesional, no estoy preparado para resolver los problemas de malas relaciones y violencia, tanto en el centro como por medio de las nuevas tecnologías.

5. En el aula se dan situaciones de violencia entre los alumnos que posteriormente se trasladan a las redes sociales o whatsapp.

6. Los alumnos conocen los riesgos que supone el uso no responsable de las nuevas tecnologías.

7. Las relaciones interpersonales son uno de los objetivos más importantes del desarrollo de mi actividad docente.

$\begin{array}{llll}2 & 3 & 4 & 5\end{array}$

8. Se producen en el aula situaciones de violencia debido a situaciones iniciadas en las redes sociales, chats, whatsapp, etc.

9. Los alumnos utilizan los dispositivos móviles en la hora de recreo.

$\begin{array}{lllll}1 & 2 & 3 & 4 & 5\end{array}$

$\begin{array}{lllll}1 & 2 & 3 & 4 & 5\end{array}$

$\begin{array}{lllll}1 & 2 & 3 & 4 & 5\end{array}$

$\begin{array}{lllll}1 & 2 & 3 & 4 & 5\end{array}$

$\begin{array}{lllll}1 & 2 & 3 & 4 & 5\end{array}$


ANEXO 2. INSTRUMENTO DE EVALUACIÓN DE NECESIDADES DOCENTES.

\begin{tabular}{|c|c|c|c|c|c|}
\hline $\begin{array}{l}\text { 10. Los alumnos suelen pedir ayuda a los profesores para } \\
\text { tratar de resolver conflictos que se han iniciado por medio de las } \\
\text { nuevas tecnologías. }\end{array}$ & 1 & 2 & 3 & 4 & 5 \\
\hline $\begin{array}{l}\text { 11. Como profesor conozco las pautas a seguir ante un caso } \\
\text { de ciberbullying en el centro. }\end{array}$ & 1 & 2 & 3 & 4 & 5 \\
\hline $\begin{array}{l}\text { 12. En el aula los alumnos utilizan los dispositivos móviles } \\
\text { (móviles, tablets, etc). }\end{array}$ & 1 & 2 & 3 & 4 & 5 \\
\hline Dispongo de información sobre el ciberbullying. & 1 & 2 & 3 & 4 & 5 \\
\hline Dispongo de información sobre el sexting. & 1 & 2 & 3 & 4 & 5 \\
\hline Dispongo de información sobre el groming. & 1 & 2 & 3 & 4 & 5 \\
\hline $\begin{array}{l}\text { 16. Como profesor tengo información y formación suficiente } \\
\text { sobre los riesgos en el uso de las nuevas tecnologías. }\end{array}$ & 1 & 2 & 3 & 4 & 5 \\
\hline $\begin{array}{l}\text { 17. En las salidas organizadas por el centro los alumnos } \\
\text { utilizan los dispositivos móviles. }\end{array}$ & 1 & 2 & 3 & 4 & 5 \\
\hline $\begin{array}{l}\text { 18. Considero que implantar un proyecto de prevención e } \\
\text { intervención sobre las agresiones y violencia en la escuela es } \\
\text { una buena idea. }\end{array}$ & 1 & 2 & 3 & 4 & 5 \\
\hline $\begin{array}{l}\text { Las familias, en general, están muy implicadas en el } \\
\text { buen uso de las nuevas tecnologías por parte de los menores. }\end{array}$ & 1 & 2 & 3 & 4 & 5 \\
\hline $\begin{array}{l}\text { 20. Para eliminar los problemas de violencia es necesario que } \\
\text { el equipo completo de profesores tome conciencia y se decida a } \\
\text { actuar. }\end{array}$ & 1 & 2 & 3 & 4 & 5 \\
\hline $\begin{array}{l}\text { 21. Los alumnos en el aula comentan situaciones negativas o } \\
\text { problemáticas que han ocurrido por medio de las nuevas } \\
\text { tecnologías o Internet. }\end{array}$ & 1 & 2 & 3 & 4 & 5 \\
\hline
\end{tabular}

22. Si quiere añadir algo más que no le hayamos preguntado y que considere importante, este es el momento.

\section{Muchas gracias por su colaboración.}




\section{Conocimiento de los padres y madres del uso de las TIC en los menores}

Solicitamos su colaboración para conocer mejor el uso que realizan sus hijos/as de las tecnologías e Internet. Para ello, necesitamos que nos cumplimenten el presente cuestionario en el cual encontrará una serie de cuestiones relacionadas con el conocimiento que usted posee sobre dichas herramientas y sobre la utilización que sus hijos/as realizan de las mismas.

La información que nos proporcione es de gran valor para nosotros ya que con sus respuestas estará contribuyendo al establecimiento de estrategias y recursos para prevenir problemas derivados del mal uso de las TIC.

El cuestionario es anónimo, sólo le pedimos algunos datos iniciales para conocer las características de su entorno familiar. Por favor, lea cada cuestión y conteste de manera sincera a cada una de ellas. Una vez cumplimentado, devuélvalo al colegio, por medio de su hijo, a través del sobre (cerrado) que le hemos facilitado.

\section{Edad:}

Género:

¿Cuántos hijos/as tiene?

¿En qué curso escolar se encuentran tus hijos/as?

Centro educativo de tus hijos/as:

\begin{tabular}{|l|c|c|}
\hline $\begin{array}{l}\text { 1. Sé cómo usar los controles de privacidad en Internet para bloquear } \\
\text { usuarios. }\end{array}$ & $\mathrm{SI}$ & $\mathrm{NO}$ \\
\hline $\begin{array}{l}\text { 2. Conozco bien los riesgos a los que se exponen los menores con el uso de } \\
\text { las nuevas tecnologías. }\end{array}$ & $\mathrm{SI}$ & $\mathrm{NO}$ \\
\hline $\begin{array}{l}\text { 3. He recibido formación sobre el uso seguro y responsable de las nuevas } \\
\text { tecnologías por parte de menores. }\end{array}$ & $\mathrm{SI}$ & $\mathrm{NO}$ \\
\hline $\begin{array}{l}\text { 4. He enseñado a mi hijo/a a utilizar Internet y las herramientas, programas y } \\
\text { servicios de forma segura. }\end{array}$ & $\mathrm{SI}$ & $\mathrm{NO}$ \\
\hline $\begin{array}{l}\text { 5. He hablado con mi hijo/a acerca de los peligros de relacionarse con gente } \\
\text { de Internet. }\end{array}$ & $\mathrm{SI}$ & $\mathrm{NO}$ \\
\hline $\begin{array}{l}\text { 6. Considero necesaria la prevención en los centros educativos sobre los } \\
\text { riesgos en el uso de las nuevas tecnologías por parte de los menores. }\end{array}$ & $\mathrm{SI}$ & $\mathrm{NO}$ \\
\hline $\begin{array}{l}\text { 7. Superviso la actividad de mi hijo/a en Internet y le traslado nuevos puntos } \\
\text { de vista compartiendo actividades. }\end{array}$ & $\mathrm{SI}$ & $\mathrm{NO}$ \\
\hline $\begin{array}{l}\text { 8. Le he trasladado a mi hijo/a la importancia de no comunicarle a nadie (ni } \\
\text { siquiera amigos) el nombre de usuario y contraseña personales explicando } \\
\text { las posibles repercusiones. }\end{array}$ & $\mathrm{SI}$ & $\mathrm{NO}$ \\
\hline $\begin{array}{l}\text { 9. Conozco cómo utilizar y actualizar la protección de los equipos con la } \\
\text { instalación de las herramientas de seguridad adecuadas (antivirus, firewall, } \\
\text { etc.). }\end{array}$ & $\mathrm{SI}$ & $\mathrm{NO}$ \\
\hline
\end{tabular}




\begin{tabular}{|l|l|l|}
\hline 10. El ordenador está colocado en una habitación familiar de la casa. & $\mathrm{SI}$ & $\mathrm{NO}$ \\
\hline $\begin{array}{l}\text { 11. He informado a mi hijo/a sobre la importancia de no proporcionar } \\
\text { información personal y/o familiar a través de la red, incluidas fotografías o } \\
\text { cualquier tipo de documento por correo electrónico con información privada. }\end{array}$ & $\mathrm{SI}$ & $\mathrm{NO}$ \\
\hline $\begin{array}{l}\text { 12. Sé lo que es el ciberbullying. } \\
\text { 13. Sé lo que es el grooming. }\end{array}$ & $\mathrm{SI}$ & $\mathrm{NO}$ \\
\hline $\begin{array}{l}\text { 14. Sé lo que es el sexting. } \\
\text { 15. Mi hijo tiene al menos un dispositivo móvil (tablet, móvil, portátil, etc.) }\end{array}$ & $\mathrm{SI}$ & $\mathrm{NO}$ \\
\hline $\begin{array}{l}\text { 16. Le he inculcado a mi hijo valores como el respeto en la relación con los } \\
\text { demás, y el conocimiento de qué es aceptable y qué no, tanto en la vida real } \\
\text { como en la Red. }\end{array}$ & $\mathrm{SI}$ & $\mathrm{NO}$ \\
\hline $\begin{array}{l}\text { 17. Es importante concienciar a la sociedad sobre los riesgos del uso de las } \\
\text { nuevas tecnologías. }\end{array}$ & $\mathrm{SI}$ & $\mathrm{NO}$ \\
\hline $\begin{array}{l}\text { 18. Sé las contraseñas de mi hijo/a. } \\
\text { 19. Fomento la confianza mutua transmitiendo a mis hijos que pueden } \\
\text { hablarme sobre sus problemas de modo que podamos buscar soluciones } \\
\text { juntos. }\end{array}$ & $\mathrm{SI}$ & $\mathrm{NO}$ \\
\hline $\begin{array}{l}\text { 20. Hay establecidas en casa reglas con mis hijos acerca de cuándo y por } \\
\text { cuánto tiempo pueden estar utilizando internet. }\end{array}$ & $\mathrm{SI}$ & $\mathrm{NO}$ \\
\hline $\begin{array}{l}\text { 21. Hablo con mis hijos acerca de las normas de comportamiento en Internet } \\
\text { poniendo especial incidencia en la necesidad de actuar con responsabilidad. }\end{array}$ & $\mathrm{SI}$ & $\mathrm{NO}$ \\
\hline $\begin{array}{l}\text { 22. Hay establecidos en casa criterios de edades para empezar a utilizar los } \\
\text { dispositivos (ordenador, tableta, móvil) y para acceder a diferentes } \\
\text { contenidos y servicios. }\end{array}$ & $\mathrm{SI}$ & $\mathrm{NO}$ \\
\hline $\begin{array}{l}\text { 23. Sé qué funcionalidades tiene el teléfono móvil de mi hijo/a (en caso de } \\
\text { que tenga). }\end{array}$ & $\mathrm{SI}$ & $\mathrm{NO}$ \\
\hline $\begin{array}{l}\text { 24. Mi hijo/a sabe usar los controles de privacidad en Internet para bloquear } \\
\text { usuarios. }\end{array}$ & $\mathrm{SI}$ & $\mathrm{NO}$ \\
\hline $\begin{array}{l}\text { 25. Mi hijo/a me enseña sus perfiles, páginas y comunicaciones cuando se lo } \\
\text { pido. }\end{array}$ & $\mathrm{SI}$ & $\mathrm{NO}$ \\
\hline
\end{tabular}

Muchas gracias por su colaboración. 
ANEXO 4. CUADERNO DEL ALUMNO DE 3o DE EDUCACIÓN PRIMARIA DEL PROGRAMA “CONVIURE EN UN MÓN REAL I DIGITAL".

\title{
Conviure en un món real i digital
}

\author{
QUADERN DE L'ALUMNE \\ TERCER DE PRIMÀRIA
}

CENTRE:

ALUMNE/A:

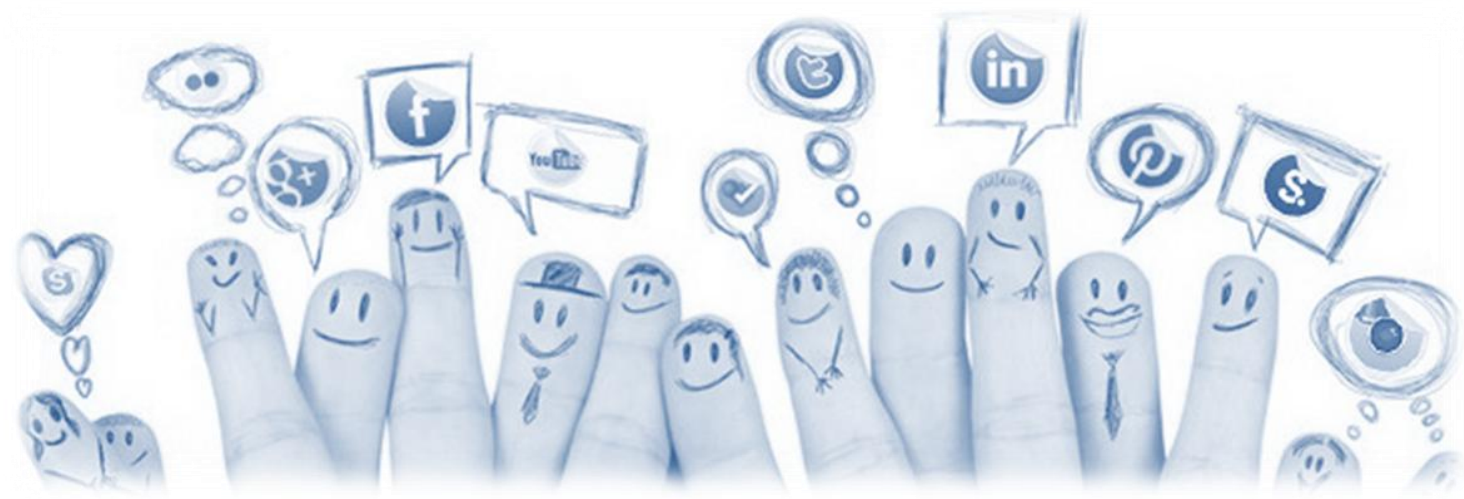




\section{ÍNDEX}

Quadre de registre.

\section{Activitats:}

Fitxa 1: Aixú sóc jo..........................................................................

Fitxa 2: Em quedo amb to allo bo b............................................5

Fitxa 3: Anem a reflexionar .............................................................6

Fitxa 4: El que sentim ........................................................................7

Fitea 5: Digues com et sents ..........................................................8

Fitxa 6: Anem a reflexionar..........................................................

Fitxa 7: Què passarà? ....................................................................10

Fitxa 8: Prente el teu temps......................................................11

Fitxa 9: Anem a reflexionar.........................................................12

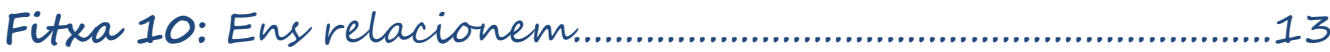

Fitea 11: Fa un temps.................................................................14

Fitxa 12: Anem a reflexionar.....................................................15

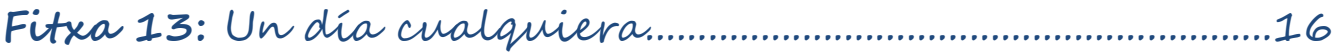

Fitxa 14: ¿Tú qué opinas? ................................................................17

Fitxa 15: Vamos a reflexionar.....................................................18 


\section{TERCER DE PRIMÀRIA}

\begin{tabular}{|l|l|l|}
\hline \multirow{2}{*}{ ASSIGNATURA } & \multicolumn{1}{|c|}{ No I NOM FITXA } & REGISTRE DE \\
FITXES FETES
\end{tabular}




\section{Alxí sóc jo}

EL MEU NOM:

LA MEUA EDAT:

SÓC UN ESTUDIANT (bo - dolent -regular):

SÓc TAMBÉ (senyala amb una creu)

- Ros

- Bru

- Rosat
- Alt

- Un poc baix

- Estudiós
- Simpàtic

- Alegre

- Un poc avorrit

- AltRES:

¿QUANTES MENJADES (desdejuni, esmorzar, menjar...) FAIG AL DIA?

EL QUE MÉS M'AGRADA MENJAR:

EL QUE MENYS M'AGRADA MENJAR :

ESPORTS QUE PRACTIQUE:

RECORDA...

Cadascun de nosaltres som molt importants, som diferents, som autèntics. 


\section{EM QUEDE AMB TOT ALLÒ BO}

\section{Fes un llistat de coses que et fan sentir bé:}

Exemple: Jugar a bàsquet, menjar fruita, eixir a passejar amb els meus pares...

-

\section{Fes un llista de coses que NO et fan sentir bé:}

Exemple: Menjar molts dolços, veure moltes hores la televisió, estar molta estona assegut...

\section{RECORDA...}

Sempre has de valorar positivament les coses bones i que et fan sentir bé, i intentar canviar aquelles coses menys bones. Així aconseguiràs sentir-te millor amb tu mateix. 


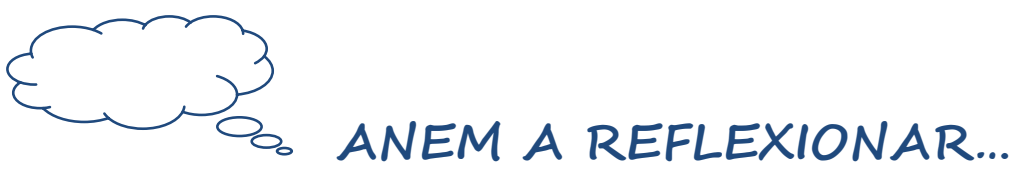

Després d'haver realitzat les activitats anteriors, reflexionarem sobre els aspectes que hem treballat. Per a això, contesta les següents qüestions:

1. És important conèixer-nos bé a nosaltres mateixos i als altres.

Vertader $\quad \square$ Fals

2. Cadascun de nosaltres som únics, autèntics i diferents.

Vertader $\quad \square$ Fals

3. Què cal fer per a sentir-se bé? 


\section{EL QUE SENTIM}

\section{Saps què són les emocions? Explica-ho.}

\section{Escriu al costat de cada oració l'emoció que li correspon.}

Enuig Tristesa Alegria Por Preocupació Sorpresa

1. Que bé que les fonts tinguin aigua potable per a tots!

2. Vaja, el riu està sec! Això no ho havia vist mai així, ha de ser perquè fa temps que no plou.

3. Va ser horrible veure com hi ha nens del desert que no poden beure aigua neta cada dia, haurien de fer alguna cosa

4. Papà, has deixat els gels al sol i s'han fos!

5. Jo no vull pujar a la muntanya, està nevant molt i és molt perillós!

6. És una llàstima que hi hagi gent que tiri escombraries en les platges i rius, així contaminen l'aigua

\section{RECORDA...}

Hi ha dies que sentim alegria perquè les coses ens surten bé, altres dies sentim tristesa perquè alguna cosa va malament, o sentim enuig per algun motiu. Sentir por, vergonya, tristesa, ira, sorpresa...,és una resposta del nostre organisme davant un succés determinat. 


\section{DIME COM ET SENTS}

\section{Completa les següents frases}

- Avui sent perquè

- Quan sortim al pati sent

- En una baralla sent perquè

2. El teu germà sempre t'agafa la teva gorra preferida de la teva habitació, sense demanar-te permís, per posar-se-la.

Què sents? Per què et sents així?

Com respondràs? Què li diràs?

RECORDA...

És bo que els expliquem adequadament als altres que és el que ens passa per a no tenir problemes amb els companys i amics, i sentir-nos millor amb nosaltres mateixos.

Si algun dia estàs enfadat, explica als altres com et sents amb claredat i fermesa, però sense violència i sense agressivitat. 


\section{ANEM A REFLEXIONAR...}

Després d'haver realitzat les activitats anteriors, reflexionarem sobre els aspectes que hem treballat. Per a això, contesta les següents qüestions:

1. Escriu dues emocions que hagis tingut $i$ una frase de cada un d'ells.

Emoció:

Frase:

Emoció:

Frase:

2. Per què és important expressar adequadament les teves emocions als altres? 


\section{QUĖ PASSARÀ?}

Entrem a la casa d'un amic. El nostre amic té un gos, i en obrir la porta comença a lladrar-nos i a mossegar-nos la sabata prohibint-nos el pas.

- 1. Per què creus que el gos ha reaccionat així i què podríem fer per evitar que torni a passar?

- 2. Com reaccionaries en aquest moment?

- 3. Què passaria si reaccionares així?

RECORDA...

És important que davant de qualsevol situació que ens passi,sapiguem reaccionar d'una manera adequada valorant prèviament les conseqüències de la nostra reacció i sabent si aquestes ens afavoreixen o no. 


\section{PREN-TE EL TEU TEMPS}

Raquel estava a la seva habitació estudiant, era un dissabte al matí i feia molt de sol. Havia deixat la llum del bany i dels passadissos enceses sense adonar-se'n. La seva mare va entrar a la seva habitació i li va dir amb un to elevat de veu que s'havia deixat els llums encesos des de feia molta estona i que això no estava bé ja que estava consumint molta energia innecessàriament. Raquel en aquest moment es va sentir molt trista i amb un atac d'ira va tancar la porta d'un cop.

- 1. Quin ha estat l'error de Raquel?

- 2. Quina conseqüència podria comportar la reacció de Raquel?

- 3. Què podria fer Raquel davant d'una situació així per controlar?

- 4. Quines accions alternatives creus que podria haver tingut?

RECORDA...

Per reaccionar correctament davant de situacions que ens provoquen enuig, ira, ràbia...,hem d'aplicar una de les tècniques de control. Així aconseguirem reaccionar d'una manera positiva, i evitarem problemes i discussions. 


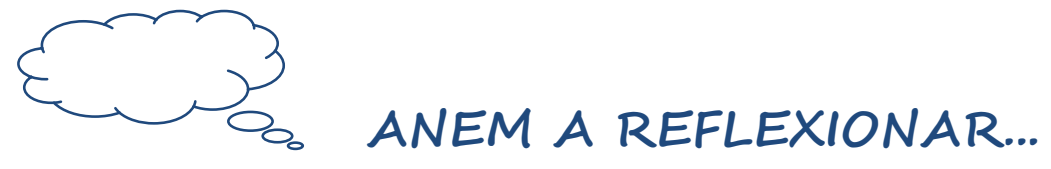

Després d'haver realitzat les activitats anteriors, reflexionarem sobre els aspectes que hem treballat. Per a això, contesta les següents qüestions:

1. Sara està parlant amb la seva amiga Laura. Volen quedar a la tarda, Sara vol anar al parc a patinar però Laura prefereix anar al cinema. Sara vol anar a patinar per sobre de tot, i comença a cridar-li a la Laura dient-li que és millor anar a patinar i que ella si van al cinema no sortirà. A la Laura no li ha agradat l'actitud de Sara i ha marxat sense voler quedar amb ella per jugar.

- Creus que la reacció de Sara és la correcta?
Sí
No

- La reacció d'enuig de Sara ha tingut com a conseqüència que la Laura se n'anés. Aquesta conseqüència és bona per a Sara?
Sí
No

- Què podria haver fet en comptes de cridar-li a la seva amiga? Quin consell li donaries a Sara?

2. En situacions que ens provoquen enuig, ràbia, ira...,què podem fer per controlar-nos?

- Comptar fins a 10 


\section{ENS RELACIONEM}

1. Què és un grup?

\section{Quins grups tens tu?}

- Equip de bàsquet

$\bullet$

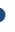

\section{Quines activitats realitzes en grup? Fes un Ilistat.}

- Jugar al pati amb companys.

4. Com consideres que són les relacions en grup? Raona la teua resposta.

RECORDA...

Quan ens ajuntem més de tres persones formem un grup i, normalment, les relacions que mantenim entre nosaltres no solen ser fàcils. 


\section{FA UN TEMPS...}

1. Pensa una situació del passat en la qual hagis estat en grup i la relació hagi estat positiva.

- Què va ocórrer?

- Com et vas sentir?

- Canviaries alguna cosa?

2. Ara pensa una situació del passat en la qual hagis estat en grup i la relació no hagi estat positiva.

- Què va ocórrer?

- Com et vas sentir?

- Canviaries alguna cosa?

RECORDA...

Si ens relacionem positivament amb la gent ens sentirem millor, farem amistats amb més facilitat, coneixerem millor a la gent, etc. 


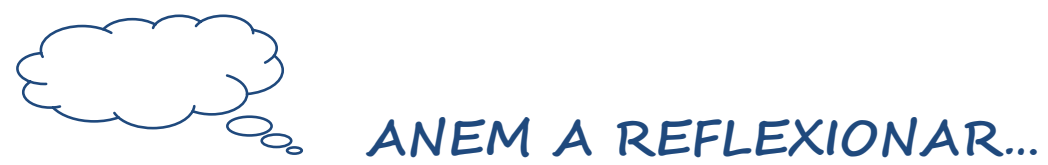

Després d'haver realitzat les activitats anteriors, reflexionarem sobre els aspectes que hem treballat. Per a això, contesta les següents qüestions:

1. Com diries que són les relacions en grup?

2. És important reconèixer les situacions bones i dolentes que hem viscut en el passat, i veure què podem canviar de les dolentes perquè no tornin a ocórrer en el futur.
Vertader
Fals

3. Què ocorre quan ens barallem, discutim, etc. amb els companys? Raona la teua resposta. 


\section{UN DÍA CUALQUIERA}

\section{Lee el siguiente texto:}

Clara, una niña de 9 años, se levanta a las siete y media de la mañana: se lava, se viste y mientras desayuna ve en la televisión o en la tableta dibujos o series.

Más tarde, a las 9 de la mañana, entra en el colegio hasta las cinco de la tarde. Mientras está en el colegio Clara se centra en su trabajo en el aula con sus profesores y compañeros. A la hora del recreo habla y juega con ellos.

Cuando sale por la tarde, mientras merienda mira en la televisión algún programa. A continuación, antes de ponerse a hacer los deberes o a estudiar se conecta al móvil y se envía mensajes de WhatsApp con amigos o compañeros de clase. Después se pone a hacer los deberes con el ordenador encendido escuchando música que se descargó el día anterior y mientras revisa su cuenta de la red social buscando alguna novedad.

Terminados ya los deberes, se ducha y cena, y antes de irse a dormir se pone en el ordenador o la tableta a ver videos en YouTube mientras se descarga nuevos juegos.

2. Escribe a continuación un texto narrativo contando como es tu día a día con el uso de las nuevas tecnologías. Recuerda utilizar correctamente los signos de puntuación.

\section{RECUERDA...}

A lo largo del día tenemos tiempo para realizar muchas actividades, por eso no debemos dejar de hacer y practicar actividades con otra gente o cosas que nos gustan por pasar tiempo con los dispositivos electrónicos. Lo importante es organizar bien el tiempo y tener ratos para realizar todo aquello que nos guste, siempre saludablemente. 


\section{¿TÚ QUÉ OPINAS?}

\section{Lee el siguiente texto.}

\section{EL USO DE LAS TIC}

\section{Los beneficios y los riesgos del uso de las nuevas tecnologías.}

Castellón, 20 de septiembre de 2015.

Todo ha ocurrido muy deprisa. Desde hace un tiempo el uso de las Tecnologías de la Información y la Comunicación (TICS) se han convertido en un elemento más de nuestras vidas sin pararnos a pensar si nos aportan beneficios o riesgos.

Expertos en psicología y educación alertan que el uso de las TICS nos ayuda mucho a quienes las utilizamos pero también tienen sus peligros, por eso importante ser precavido cuando las utilizamos y aprender a utilizarlas de forma segura.

Según aseguran los expertos, los videojuegos son divertidos y bien utilizados nos pueden ayudar a mejorar la concentración, la creatividad, la imaginación, la memoria, entre otros, sin embargo es importante controlar el tiempo que les dedicamos pues si jugamos en exceso puede afectar a nuestro rendimiento escolar y estar mucho tiempo sentados puede perjudicarnos físicamente.

Respecto a la televisión, al igual que con el ordenador, afirman que hay programas educativos para niños y dibujos animados con los que se pueden aprender muchas cosas y pasarlo muy bien, pero es necesario controlar el tiempo que se pasa frente a la televisión, porque mucho tiempo viendo la tele puede ser perjudicial.

Así, recomiendan que lo más importante sea hacer un uso responsable de estos dispositivos y seguir los consejos de los adultos, pues la seguridad es lo más importante y si los utilizamos de forma correcta aprovecharemos mucho más sus beneficios.

\section{2. ¿Qué tipo de texto es?}

- ¿Cuáles son sus partes? Señálalas con diferentes colores en el texto.

\section{RECUERDA...}

Las nuevas tecnologías nos ayudan mucho, con ellas aprendemos muchas cosas y mejoramos aspectos como la concentración o la creatividad pero si no las utilizamos adecuadamente, nos pueden causar problemas físicos y perjudicarnos en muchos otros aspectos. 


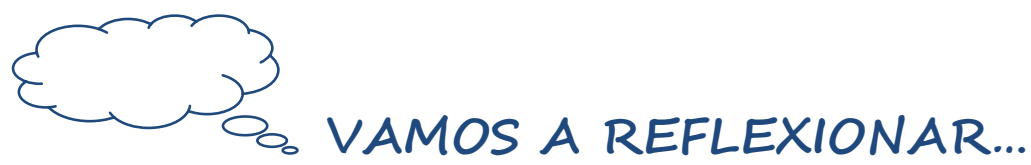

Después de haber realizado las actividades anteriores, vamos a reflexionar sobre los aspectos que hemos trabajado. Para ello, contesta las siguientes cuestiones:

1. ¿Qué debemos hacer para utilizar las nuevas tecnologías con responsabilidad? Señala las respuestas correctas.

Seleccionar los videojuegos y programas de televisión con nuestros padres.

Dar las contraseñas a otras personas que no sean nuestros padres.

Utilizar videojuegos piratas pues pueden tener virus.

Respetar los horarios y los tipos de programas que nos aconsejan los padres.

2. ¿Qué cosas buenas nos aportan los videojuegos, la televisión y el ordenador?

3. ¿Qué problemas podemos tener si no usamos adecuadamente los dispositivos tecnológicos? 
ANEXO 5. CUADERNO DEL ALUMNO DE 40 DE EDUCACIÓN PRIMARIA DEL PROGRAMA “CONVIURE EN UN MÓN REAL I DIGITAL".

\section{Conviure en un món real i digital QUADERN DE L'ALUMNE QUART DE PRIMÀRIA}

CENTRE:

ALUMNE/A:

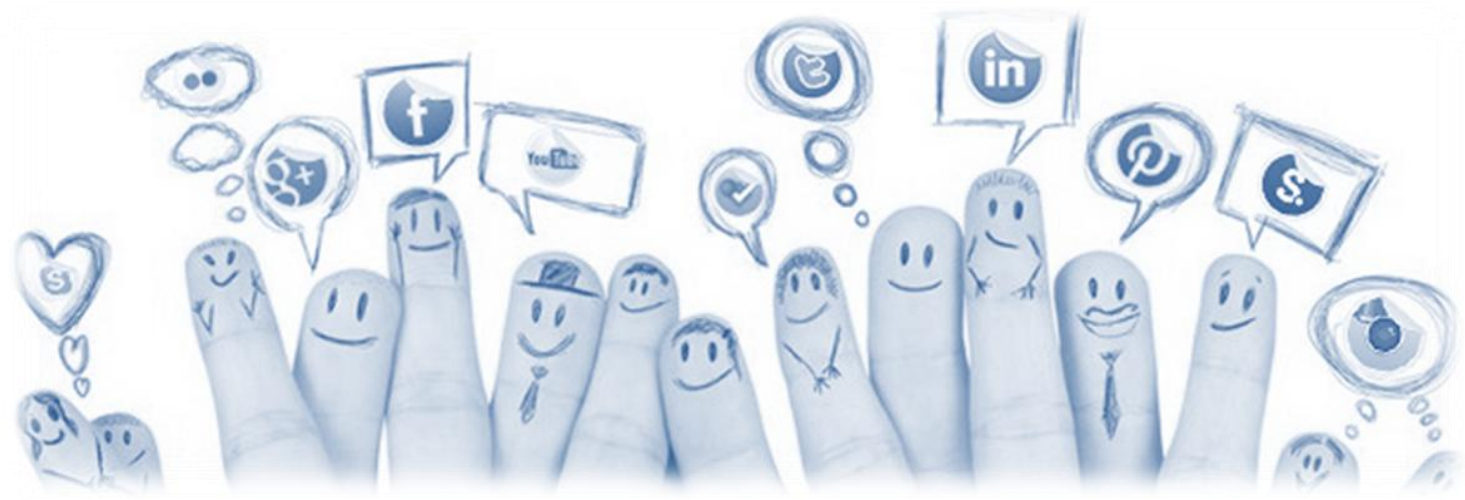




\section{ÍNDEX}

Quadre de registre

\section{Activitats.}

Fitxa 1:Autorretrato 4

Fitxa 2:Así es mi compañero ................................................................

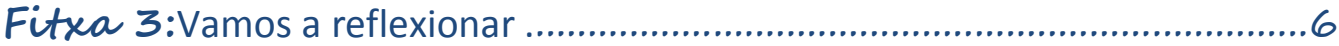

Fitxa 4:Els altres també senten ...........................................................

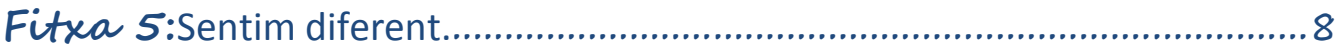

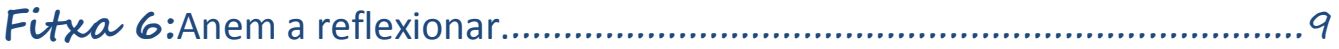

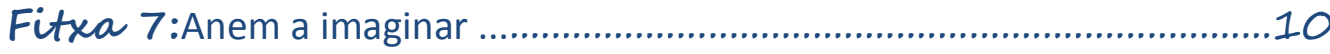

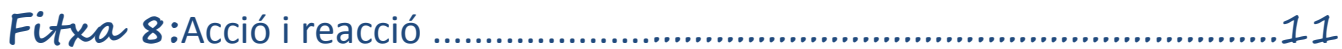

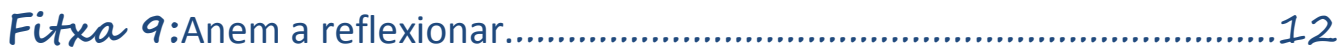

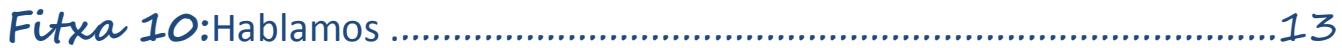

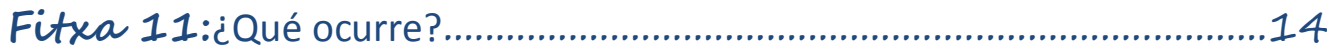

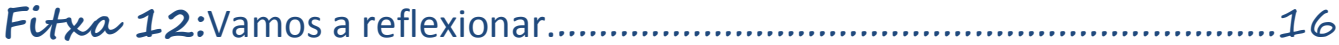

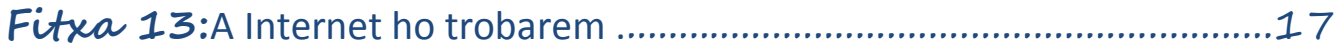

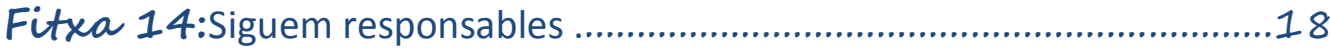

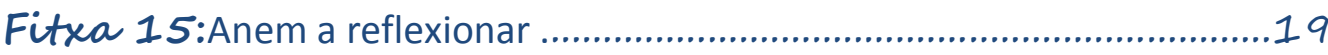




\section{QUART DE PRIMÀRIA}

\begin{tabular}{|l|l|l|}
\hline \multirow{2}{*}{ ASSIGNATURA } & \multicolumn{1}{|c|}{ No I NOM FITXA } & REGISTRE DE \\
FITXES FETES
\end{tabular}




\section{AUTORRETRATO}

1. Escribe dos cualidades que consideras que tienes Por ejemplo: simpático, alegre...

2. Escribe un defecto que consideras que tienes Por ejemplo: borde, antipático...

(1)

3. Escribe en la primera columna las dos cualidades y los dos defectos que has anotado en las actividades anteriores y busca un sinónimo y un antónimo de cada uno.

\begin{tabular}{|l|l|l|}
\hline Cualidad/Defecto & Sinónimo & Antónimo \\
\hline & & \\
\hline & & \\
\hline & & \\
\hline & & \\
\hline
\end{tabular}

RECUERDA...

El conjunto de cualidades y defectos que tenemos son los que nos hacen ser únicos, por eso debemos aceptarlos y verlos como algo nuestro que forma parte de nosotros. 


\section{ASÍ ES MI COMPAÑERO}

1. Completa las siguientes oraciones y subraya los determinantes posesivos que encuentres.

$\checkmark$ Mi compañero/a se llama

$\checkmark$ Se le da muy bien

$\checkmark$ Lo que más me gusta de su forma de ser es

$\checkmark$ En nuestros ratos juntos nos gusta

2. Escribe en la tablas los determinantes posesivos que has subrayado en el ejercicio anterior y clasifícalos :

\begin{tabular}{|l|l|l|}
\hline Determinante posesivo & Persona & Número \\
\hline & & \\
\hline & & \\
\hline & & \\
\hline
\end{tabular}

RECUERDA...

Es importante escuchar las cosas buenas que los demás dicen de nosotros porque eso nos hace sentir mejor y nos ayuda a recordar todo lo bueno que tenemos. 


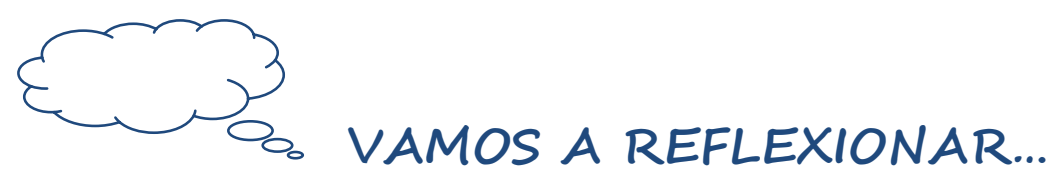

Después de haber realizado las actividades anteriores, vamos a reflexionar sobre los aspectos que hemos trabajado. Para ello, contesta las siguientes cuestiones:

1. Todos tenemos cualidades y defectos.
$\square$ Verdadero
Falso

2. Escribe tres cualidades que tengas.

3. ¿Cómo te sientes cuando tus compañeros dicen cosas buenas sobre ti? 


\section{ELS ALTRES TAMBÉ SENTEN}

1. Vista: Fixa't bé en aquestes imatges, què emoció expressen?

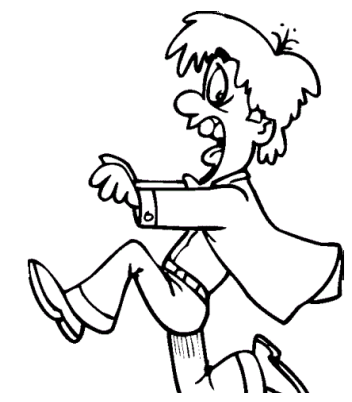

Alexandre està jugant i apareix un gos per darrere. Com se sent?

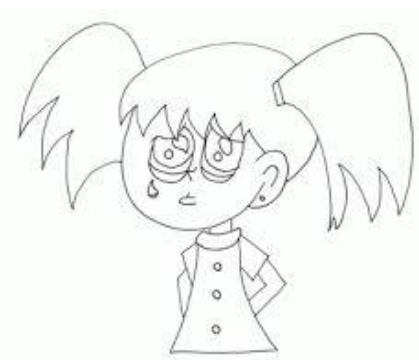

Carme s'ha barallat amb el seua mic Lluís. Com se sent?

2. Oïda: Joan et diu aquesta frase, què creus que sent?

Vaja! Doncs si aquest és

Lluís, quant de temps

sense veure'l. No esperava

trobar-lo per aquí!

$>$

3. Tacte: ¿què voldria expressar Elena amb aquest gest?

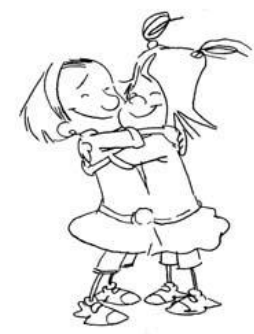

RECORDA...

Totes les persones sentim emocions i és molt important que nosaltres reconeguem les emocions dels altres, perquè això ens ajudarà a tenir millors relacions amb ells i tot funcionarà millor. 


\section{SENTIM DIFERENT}

\section{Respon.}

1.

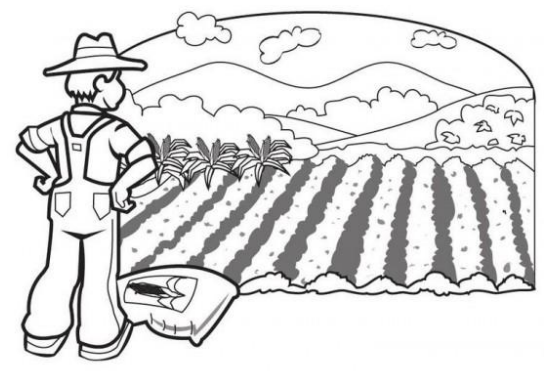

Què sents?
2.

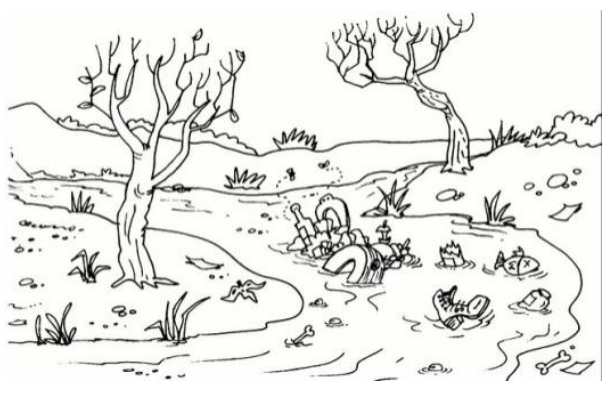

Què sents?

2. Els agricultors són els encarregats de la cura i cultiu de les terres i les plantes per a la producció d'aliments. Carles, un dels agricultors de tarongers de Castelló, està trist perquè aquest any la collita no ha estat bona a causa de les pluges.

- Què podries fer o dir perquè Carles es sent millor?

- Què no li hauries de dir o fer?

RECORDA...

Les persones tenim emocions diferents, i no està bé ni malament sentir una cosa o una altra. Hem de compartir i comprendre les emocions que sentim amb els altres, posant-nos al lloc de l'altre i escoltant bé el que ens diuen. 


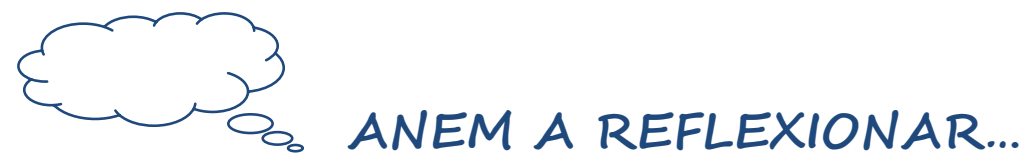

Després d'haver realitzat les activitats anteriors, reflexionarem sobre els aspectes que hem treballat. Per a això, contesta les següents qüestions:

1.Totes les persones tenim emocions i és important reconèixer com es sent en els altres perquè tot funcioni millor i evitar problemes. Escriu l'emoció que expressen aquestes expressions.
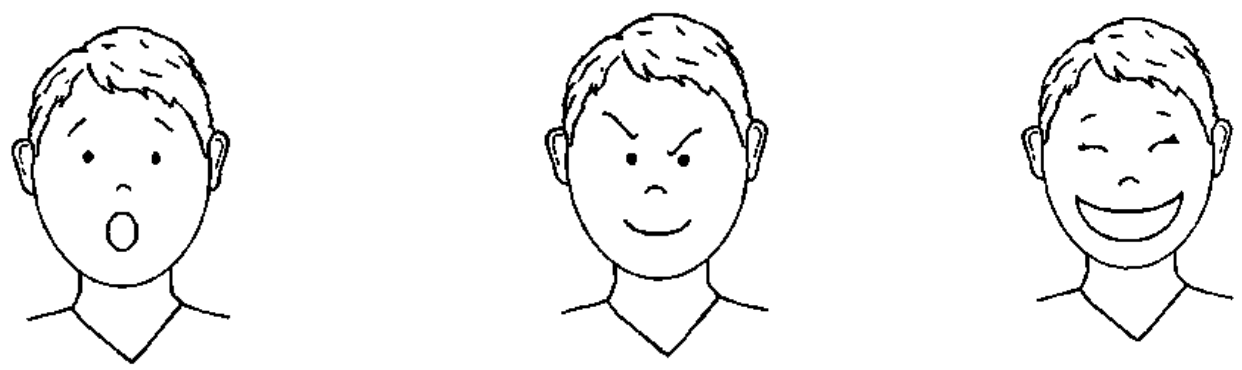

2. Totes les persones tenim les mateixes emocions, i està mal estar trist davantd'una determinada situació.

Vertader

Fals

3. Què podem fer quan una persona ens explica com se sent? 


\section{ANEM A IMAGINAR}

1. Pensa en una situació o esdeveniment que pugui fer-te sentir agressivitat o ira.

\section{SITUACIÓ}

COM REACCCIONAS DAVANT AQUESTA SITUACIÓ?

DE QUINA LA RESTA PODRIES AFRONTAR LA SITUACIÓ?

2. Imagina un paisatge còmode $\mathrm{i}$ agradable; una platja, una muntanya, etc. Tanca els ulls $\mathbf{i}$ pensa en ell. Concentra't en les sensacions del teu cos i respira profundament.

- A què fa olor?

- Què és el que veus?

- Com et sents?

RECORDA...

Hi ha accions dels altres que ens provoquen sentiments d'ira i de ràbia. Per evitar reaccionar així, és important aplicar tècniques d'autocontrol que ens ajudin a reaccionar millor. 


\section{ACCIÓ I REACCIÓ}

1. Escriu la teva opinió sobre el teu municipi.

- En quin municipi vius?

- T'agrada viure allí? Per què?

- Què és el que menys t'agrada i què canviaries?

2. Llegeix i subratlla el text que correspon al nombre d'alumne que t'ha adjudicat el professor i segueix les indicacions:

- Alumne 1:Digues la teva opinió amb un to de veu alta, mostrant cara d'enuig i donant cops mentre parles.

- Alumne 2:Digues la teva amb un to de veu baixeta i agradable, i somrientli al teu company.

Quina ha estat la reacció del teu company a la teua actuació? ¿Amb quina de les dues actuacions creus que és la més adequada?

\section{RECORDA...}

És important parar-nos a pensar com fer les coses, controlar les nostres accions, si cal aturantnos a pensar i a tranquil/litzar-nos. Si la nostra acció és bona la reacció dels altres també ho serà. 


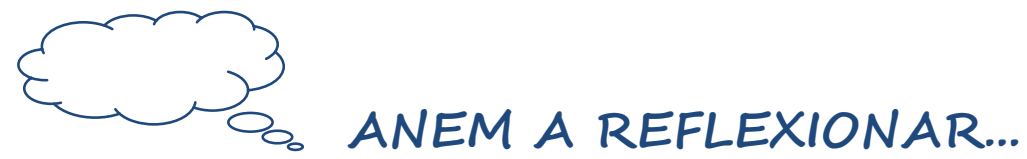

Després d'haver realitzat les activitats anteriors, reflexionarem sobre els aspectes que hem treballat. Per a això, contesta les següents qüestions:

1. Anomena dos situacions en què les accions dels altres et provoqui ira o ràbia.

- Que no m'escoltin quan parlo.

2. Igual que hi ha accions dels altres que ens provoquen ira i ràbia, també poden haver accions meves que provoquin reaccions dolentes en els altres. Per això és important controlar-me, perquè si la meva acció és bona, segurament la reacció dels altres també ho serà.

Vertader $\quad \square$ Fals

3. Quina tècnica d'autocontrol podries utilitzar en moments en què sentis ira o ràbia? Explica com ho faries. 


\section{¿HABLAMOS?}

1. La actitud que mostramos en una conversación es muy importante, por eso debemos mostrar siempre una actitud positiva. Señala las acciones correctas.

$\square$ Tener en cuenta lo que dicen los compañeros.

Estar callado durante la conversación.

No escuchar a los compañeros cuando hablan.

Expresar adecuadamente lo que se siente.

$\square$ Querer salirse con la suya.

Participar activamente en la conversación.

\section{Selecciona y escribe el tema sobre el que conversaréis en grupo.}

Tema: Importancia de tener amigos.

Ideas a desarrollar sobre el tema:

-

RECUERDA...

Cuando nos relacionamos con gente y nos comunicamos debemos tomar una actitud positiva; tomar en cuenta lo que dicen los compañeros, expresar adecuadamente lo que sentimos y participar activamente en la conversación, así la comunicación será buena y no surgirán problemas. 


\section{¿QUÉ OCURRE?}

1. David está con sus amigos José y Laura. Están en el patio del colegio conversando:

- DAVID: Chicos, esta tarde podríamos quedar e ir a jugar a mí casa. Tengo un juego nuevo que os va a gustar.

- JOSÉ: Vale, me parece buena idea. Se lo preguntaré a mis padres.

- LAURA: Uf, que calor que tengo, al final no ha llovido.

- DAVID: Entonces si os viene bien a la salida del cole lo hablamos y vamos a mi casa.

- ¿Qué habilidad le falta a Laura?

\section{María habla con sus dos amigas Nuria y Susana.}

- MARÍA: Esta mañana he ido a casa mi abuela y me ha enseñado a hacer galletas. Estaban muy ricas y son muy fáciles de hacer.

- NURIA: Oye María, pues podrías enseñarme a hacer esas galletas.

- SUSANA: Yo también se hacer galletas de chocolate, me enseñó mi madre.

- NURIA: María, pregúntale a tu abuela qué día podemos ir a su casa.

- ¿Qué norma de conversación no está respetando Nuria? 
3. Claudia, Marcos y Sofía están realizando un trabajo en clase.

- MARCOS: Yo creo que deberíamos distribuirnos el trabajo, cada uno puede hacer una parte y después nos juntamos y lo terminamos juntos.

- CLAUDIA: De acu...

- MARCOS: Tú Claudia podrías hacer la introducción, y mientras Sofía que busque información sobre los mamíferos y yo buscaré fotos.

- SOFÍA: Pero...

- MARCOS: Entonces ya tendremos claras las partes y solo será juntarlo.

- ¿Quién no está dejando hablar a los compañeros?

RECUERDA...

Es importante que conozcamos qué habilidades podemos desarrollar para que todo vaya bien cuando nos comunicamos y nos relacionamos en grupo. 


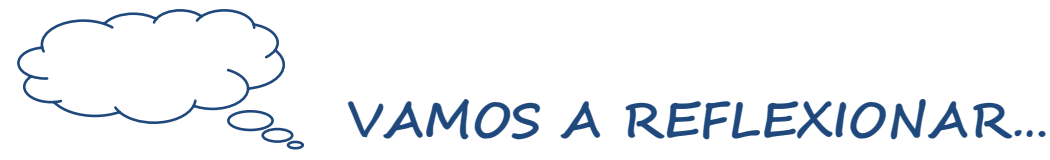

Después de haber realizado las actividades anteriores, vamos a reflexionar sobre los aspectos que hemos trabajado. Para ello, contesta las siguientes cuestiones:

1. Cuándo nos relacionamos en grupo hay que tomar una actitud positiva; tener en cuenta lo que dicen los compañeros, expresar adecuadamente lo que se siente y participar activamente en la conversación.

Verdadero

Falso

2. ¿Qué habilidades hay que desarrollar para que las relaciones sean buenas? 


\section{A INTERNET HO TROBAREM}

\section{Què és Internet? Quins usos pots fer d'Internet?}

\section{Què volem saber de les bactèries?}

3. Quina font d'informació hem utilitzat per a buscar la resposta al nostre dubte?

- Quins consells hem conèixer $\mathbf{i}$ seguir per a fer a correctament una recerca d'informació a Internet?

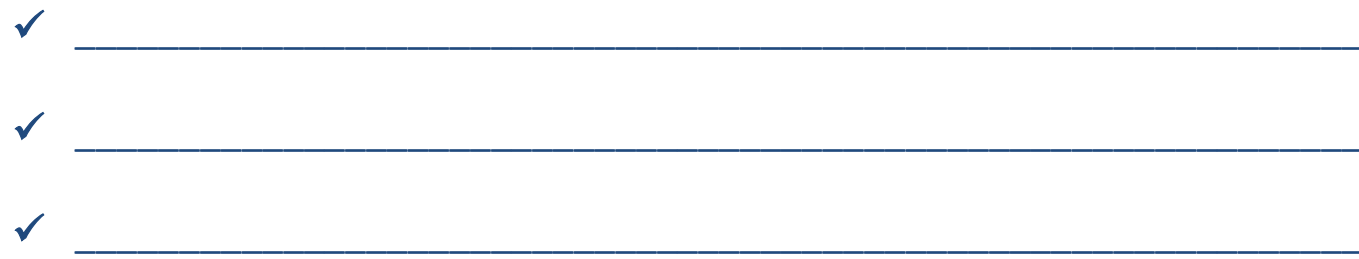

RECORDA...

Quan cerquem informació a Internet és molt important seleccionar bé la pàgina web, ser conscients que no tota la informació que hi ha a la xarxa és reial o fiable, i que els nostres pares ens ajuden a elegir quina és la millor pàgina, així com també avisar-los si veiem alguna cosa que no ens agrada. Internet és una bona eina, però cal utilitzar-la amb responsabilitat i amb l'autorització i supervisió d'un adult! 


\section{SIGUEM RESPONSABLES}

1. Creieu que és important reciclar el fem a casa?

- Si reciclem a casa, estem sent responsables amb el nostre ecosistema? Raona la teua resposta.

2. Per fer un ús responsable d'Internet mentre juguem cal tenir en compte aquests consells:

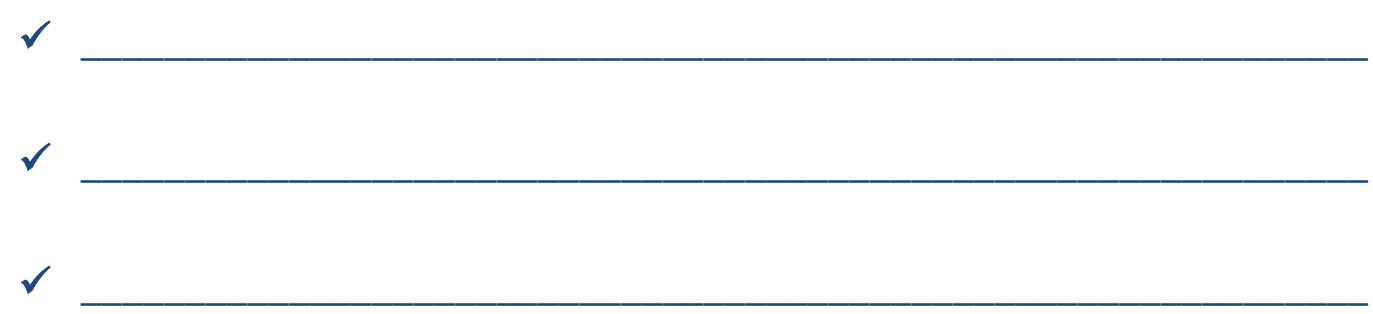

RECORDA...

Hem d'anar amb molt de compte quan juguem a Internet: cal utilitzar jocs que siguin Iliures i gratuïts, no utilitzar dades personals per a identificar-se al joc, desconfiar si ens diuen que ens ha tocat un premi i no respondre als missatges de gent desconeguda. Recordeu que sempre cal utilitzar Internet amb la supervisió d'un adult i si a més seguim aquests consells, aconseguirem passar-ho molt bé jugant per Internet sense riscos! 


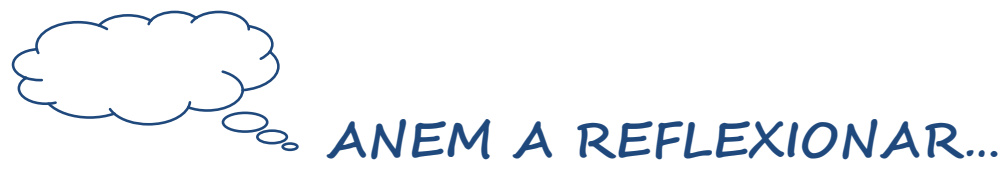

Després d'haver realitzat les activitats anteriors, reflexionarem sobre els aspectes que hem treballat. Per a això, contesta les següents qüestions:

1. Recordeu que a Internet podem buscar informació que ens interessa però cal fer-ho amb responsabilitat. Senyala els consells que cal seguir.

$\square$ Tota la informació que hi ha a la xarxa és reial o fiable.

$\square$ És important que els nostres pares ens ajuden a elegir quina és la millor pàgina.

$\square$ Selecciona sempre aquelles pàgines on el contingut sigui per a persones adultes o majors que tu.

$\square$ Si mentre busques informació a la xarxa trobes alguna cosa que no t'agrada o et fa sentir malament, avisa a un adult per a que t'ajudi.

2. A Internet també podem jugar... Escriu dos consells que cal seguir per a jugar amb seguretat a Internet. 
ANEXo 6. CUADERNO DEL ALUMNO DE 5o DE EDUCACIÓN PRIMARIA DEL PROGRAMA “CONVIURE EN UN MÓN REAL I DIGITAL".

\section{Conviure en un món real i digital QUADERN DE L'ALUMNE CINQUÈ DE PRIMÀRIA}

CENTRE:

ALUMNE/A:

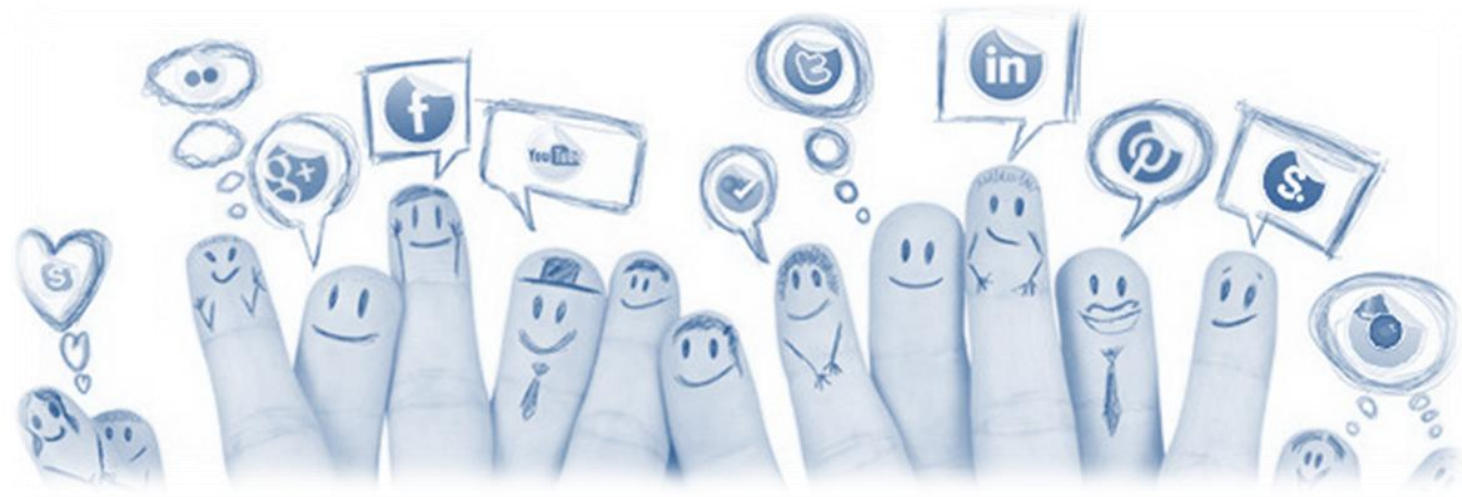




\section{ÍNDEX}

Quadre de registre.

\section{Activitats.}

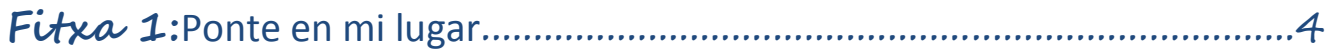

Fitxa 2:Si tú estás feliz yo estoy feliz.......................................................5

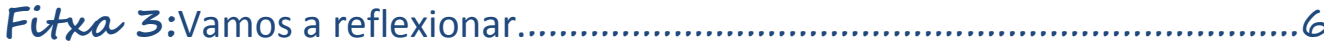

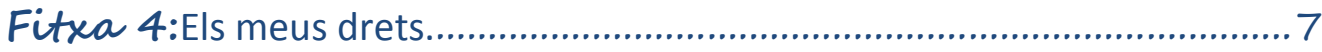

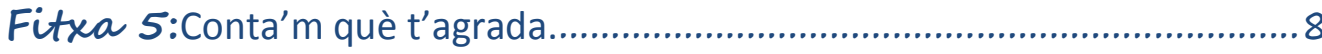

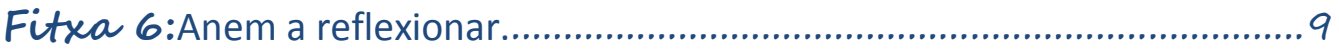

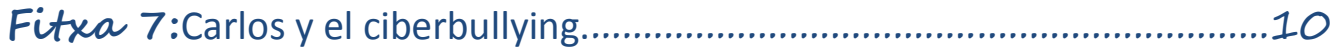

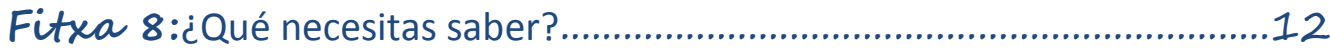

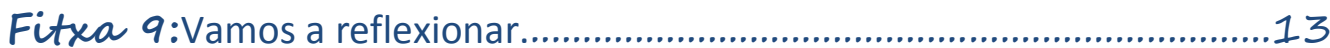

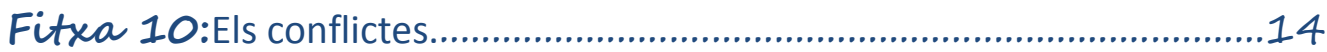

Fitxa 11:Solucionem els conflictes.....................................................

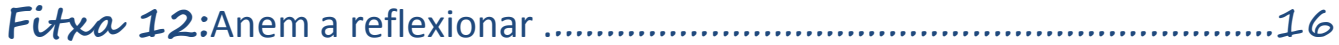

Fitxa 13:Ens relacionem per Internet ..................................................

Fitxa 14:Fem un ús saludable ....................................................... 18

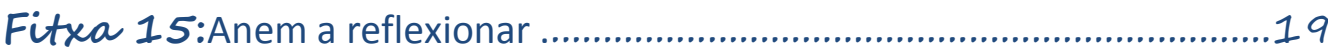




\section{CINQUÈ DE PRIMÀRIA}

\begin{tabular}{|c|c|c|}
\hline ASSIGNATURA & No I NOM FITXA & $\begin{array}{l}\text { REGISTRE DE } \\
\text { FITXES FETES }\end{array}$ \\
\hline \multirow{3}{*}{$\begin{array}{l}\text { CIĖNCIES DE LA } \\
\text { NATURALESA }\end{array}$} & $\begin{array}{l}\text { 13. Ens relacionem per } \\
\text { Internet. }\end{array}$ & \\
\hline & 14. Fem un ús saludable. & \\
\hline & 15. Anem a reflexionar. & \\
\hline \multirow{6}{*}{ CIËNCIES SOCIALS } & 4. Els meus drets. & \\
\hline & 5. Conta'm què t'agrada. & \\
\hline & 6. Anem a reflexionar. & \\
\hline & 10. Els conflictes. & \\
\hline & 11. Solucionem els conflictes. & \\
\hline & 12. Anem a reflexionar. & \\
\hline \multirow{6}{*}{$\begin{array}{c}\text { LENGUA } \\
\text { CASTELLANA Y } \\
\text { LITERATURA }\end{array}$} & 1. Ponte en mi lugar. & \\
\hline & $\begin{array}{l}\text { 2. Si tú estás feliz yo estoy } \\
\text { feliz. }\end{array}$ & \\
\hline & 3. Vamos a reflexionar. & \\
\hline & 7. Carlos y el ciberbullying. & \\
\hline & 8. ¿Qué necesitas saber? & \\
\hline & 9. Vamos a reflexionar. & \\
\hline
\end{tabular}




\section{PONTE EN MI LUGAR}

\section{Completa y subraya los adjetivos que encuentres en las frases:}

- Si mi amigo está triste yo lo que hago es

- Cuando veo a un niño solo pienso que

- Si veo que mi madre está muy feliz yo

- Cuando mi profesor está furioso entonces yo

\section{Completa el texto con las palabras que tienes a continuación:}

$$
\text { alegre sentimientos tristeza feliz compartir }
$$

Aprender a ponerse en el lugar del otro es muy importante. Si te pones en el lugar del otro haces que esa persona se sienta Si él está alegre, tú también estarás y si está triste tú también sentirás . Porque los sentimientos ayuda a comprender a los demás. Por eso me gusta que los demás compartan mis persona se sienta feliz. Compartir los sentimientos ayuda a comprender a los demás. 


\section{SI TÚ ESTÁS FELIZ YO ESTOY FELIZ}

\section{Lee el siguiente texto:}

Manuel es un chico de diez años que vive en Valencia. Sus padres están muy preocupados porque desde hace un tiempo Manuel ha cambiado mucho de carácter. Tiene muchos problemas con los compañeros del colegio. No quieren jugar con él, siempre está solo en el patio y en clase. Él se acerca a los compañeros pero ellos no le hacen caso, incluso algunas veces se meten con él, le insultan cuando están en el colegio o le mandan mensajes al móvil o por las redes sociales cuando está en casa. Sus padres le preguntan a Manuel cómo se siente pero él no les responde.

- Escríbeles un mensaje a los padres de Manuel expresándoles cómo te sentirías tú si fueses Manuel.

\section{Completa la tabla:}

\begin{tabular}{|c|c|c|}
\hline Nombre de mi amigo & Mi sentimiento & Cuando \\
\hline Pablo & Tristeza & Esturo enfermo \\
\hline & & \\
\hline & & \\
\hline
\end{tabular}

RECUERDA...

Continuamente estamos compartiendo sentimientos con amigos y compañeros, y eso es muy bueno porque nos ayuda a tener mejores relaciones con ellos. 


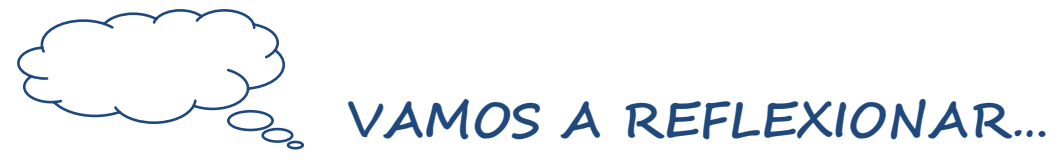

Después de haber realizado las actividades anteriores, vamos a reflexionar sobre los aspectos que hemos trabajado. Para ello, contesta las siguientes cuestiones:

1. Lee y responde a las preguntas:

- Tu amigo está muy contento porque va a tener un hermano dentro de pocos meses.

- ¿Cómo te sientes tú?

- Tú le has dado un empujón a Laura al salir de clase, y te has ido sin pedirle perdón.

- ¿Cómo se siente Laura?

2. ¿Por qué es importante ponerse en el lugar de las otras personas? ¿Cómo lo podemos hacer? 


\section{ELS MEUS DRETS}

Els ciutadans d'Espanya tenim, entre altres, els següents drets:

- Tota persona té dret a la llibertat i a la seguretat.

- Es garanteix el dret a l'honor, a la intimitat personal i familiar i a la pròpia imatge.

- Tots tenen dret a expressar i difondre lliurement els pensaments, idees i opinions per mitjà de la paraula, l'escrit o qualsevol altre mitjà de reproducció.

- Tots tenen el dret a l'educació.

\section{Completa les següents frases:}

- Jo tinc dret a...

- És important defendre els meus drets perquè...

2. El teu amic i tu esteu al pati jugant, haveu quedat que cada volta colpejarà u la pilota però el teu amic l'està colpejant tota l'estona i no et deixa fer-ho a tu. Tu tens dret a colpejar la pilota igual que ell.

- Què li diràs al teu amic?

\section{RECORDA...}

Defensa els teus drets adequadament comunicant com et sents així evitaràs que els altres s'aprofiten de tu i aconseguiràs que canvien la seua conducta i que no et perjudiqui. 


\section{CONTA'M QUÈ T'AGRADA}

1. Escriu una carta a un amic contant-li aspectes culturals i costums que més t'agraden d'Espanya per tractar de convèncer-lo perquè visiti el nostres país.

2. Per parelles, conversa amb el teu company on un farà de l'amic que rep la carta i l'altre el que l'envia. Converseu utilitzant elogis sobre el que ha escrit $\mathbf{i}$ contestant a aquests adequadament.

- Paraules i expressions que podeu utilitzar per fer elogis:

Et feliciti

Em pareix molt bé

És preciós

- Per donar les gràcies:

Adequat: moltes gràcies, molt agraït i gràcies per les teues paraules.

× No adequat: no digues tonteries, això no importa i tens raó sóc genial

RECORDA...

Expressar un elogi és dir alguna cosa positiva o mostrar agraïment a una altra persona, i ho devem fer amb sinceritat i adequadament. Quan responem a un elogi cal agrair-lo i fer veure que t'agrada el que et diuen. 


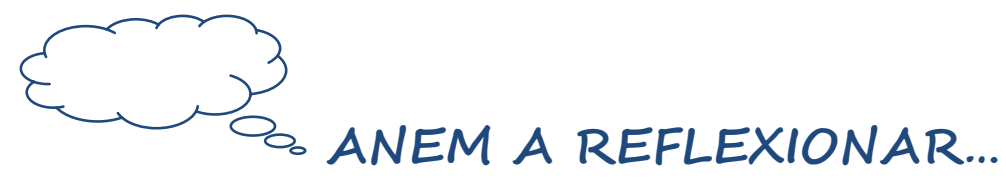

Després d'haver realitzat les activitats anteriors, reflexionarem sobre els aspectes que hem treballat. Per a això, contesta les següents qüestions:

\section{1. És important defendre els teus drets?}

Sí

\section{Com devem expressar els nostres drets?}

Adequadament, utilitzant un to de veu correcte i un vocabulari adequat.

Amb un to de veu elevat i sense deixar parlar a l'altra persona.

Altres:

\section{Escriu a continuació:}

- Dos paraules o expressions adequades per a expressar elogis.

- Dos paraules o expressions adequades per a respondre a un elogi. 


\section{CARLOS Y EL CIBERBULLYING}

\section{Lee el texto.}

Carlos, un niño de 11 años tiene problemas con compañeros de clase. Desde hace unas semanas recibe mensajes al móvil y correos electrónicos donde algunos compañeros de clase lo amenazan y lo insultan, y en los grupos de clase de WhatsApp no le dejan participar. Carlos es víctima de ciberbullying, que es cuando un niño o adolescente es amenazado, acosado, humillado, molestado de una manera u otra reiteradamente, por otro niño o adolescente mediante el uso de Internet, tecnologías interactivas y digitales o teléfono móvil.

La gente cercana a Carlos se ha dado cuenta que desde hace un tiempo Carlos ha cambiado mucho su carácter pues siempre está triste, sus notas escolares han empeorado, no quiere asistir a clase ni salir a jugar por las tardes y dice que le duele mucho el estómago y que se encuentra mareado. Todo esto son consecuencias del ciberbullying, pues debemos saber que este problema es muy frecuente y que las consecuencias que conlleva son muy importantes.

Durante mucho tiempo Carlos no ha querido contar lo que estaba sufriendo a sus padres ni a sus profesores, y sus compañeros, aunque sí lo sabían tampoco se lo han comunicado a ningún adulto. Mientras tanto, Carlos ha sufrido todas las consecuencias que comentábamos, y lo ha pasado muy mal, puesto que el ciberbullying es un problema muy grave con consecuencias legales muy importantes para las personas que envían estos mensajes que son los agresores, pues se trata de un delito.

Por eso es necesario que sepamos lo qué es y que cuando veamos que algún compañero lo está sufriendo avisemos a algún adulto, para así tratar de solucionar esta situación lo antes posible y que nuestros amigos y compañeros no lleguen a sufrir lo que está viviendo Carlos. 
2. Haz un resumen en el que se expresen las ideas principales que transmite el texto que has leído.

RECUERDA...

El ciberbullying es cuando un niño o adolescente es amenazado, acosado, humillado, molestado de una manera u otra reiteradamente, por otro niño o adolescente mediante el uso de Internet, tecnologías interactivas y digitales o teléfono móvil. Las consecuencias que conlleva son muy importantes por eso es necesario que cuando sepamos que alguien lo está sufriendo avisemos a un adulto. 


\section{¿QUÉ NECESITAS SABER?}

Escribe a continuación dos preguntas para la entrevista que realizaremos en clase sobre el ciberbullying.

1.

Respuesta:

2.

Respuesta:

\section{RECUERDA...}

Realizar acciones como enviar mensajes amenazantes, excluir a alguien de un grupo, difundir videos o imágenes de otros, suplantar la identidad, difundir secretos o rumores de otros niños o adolescentes es ciberbullying. 
Después de haber realizado las actividades anteriores, vamos a reflexionar sobre los aspectos que hemos trabajado. Para ello, contesta las siguientes cuestiones:

1. ¿Qué es el ciberbullying?

2. Las consecuencias del ciberbullying no son muy graves por eso no es importante avisar a un adulto si nos ocurre a nosotros o si vemos que alguien lo está sufriendo.

Verdadero

Falso

3. Nombra tres ejemplos de acciones que son ciberbullying.

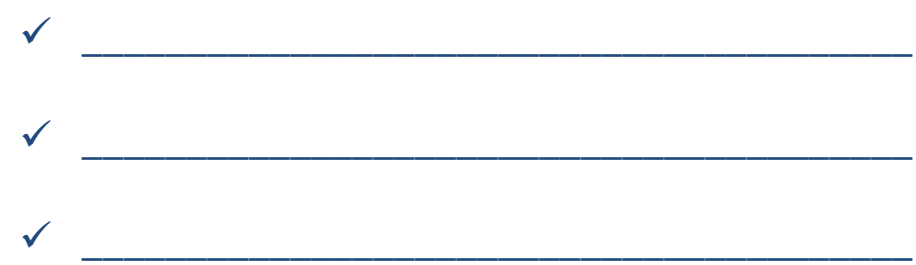




\section{ELS CONFLICTES}

Les situacions que vos plantegem a continuació són conflictes:

- La lluita dels visigots contra els vàndals, alans i sueus.

- La invasió musulmana en la batalla del Guadalete.

1. Què és un conflicte per a tu? Senyala la resposta.

Quan hi ha una lluita per una cosa.

Dos persones que es criden perquè no s'entenen.

Fer coses que molesten als altres.

2. Per què creus que es produeixen els conflictes?

3. Pensa alguna situació conflictiva que hages viscut i escriu-la.

\section{RECORDA...}

Tenir problemes es bastant freqüent però hem d'aprendre a evitar-los, doncs no ens aporten res positiu. És molt important que en eixos moments ens parem a pensar i ens adonem que fent les coses d'una altra forma, sense entrar en conflicte, solucionarem les coses millor i les relacions que tindrem amb els altres també seran més bones. 


\section{SOLUCIONEM ELS CONFLICTES}

1. Quin és el conflicte?

2. Per què s'ha produït el conflicte?

3. Pensa i escriu la solució que consideres més adient i digues que haguera passat si hagueren actuat d'eixa forma.

RECORDA...

Si solucionem els problemes aconseguirem entendre millor als altres i els altres ens entendran millor a nosaltres, es tindran en compte tant les nostres idees com les dels altres i evitarem que tornen a sorgir més problemes per tant les relacions amb els altres seran millors. 


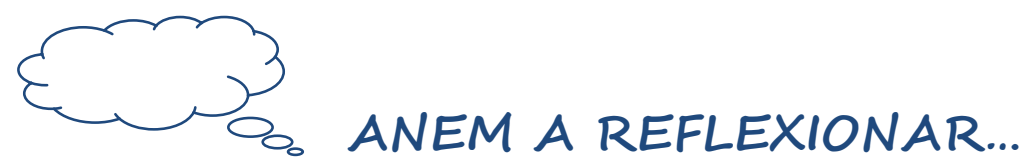

Després d'haver realitzat les activitats anteriors, reflexionarem sobre els aspectes que hem treballat. Per a això, contesta les següents qüestions:

1. Tenir problemes és una cosa freqüent; doncs a casa, amb els amics o companys tenim conflictes perquè no estem d'acord amb alguna cosa, pensem diferent, etc.

Vertader

Fals

2. Senyala la resposta correcta.

El més important quan ens trobem amb un conflicte és ...

Seguir amb el conflicte i sense pensar en les conseqüències.

Parar-nos a pensar i tractar de resoldre'I buscant la forma correcta d'actuar.

Fugir del conflicte i deixar a l'altra persona parlant.

3. Què aconseguirem si solucionem els problemes? 


\section{ENS RELACIONEM PER INTERNET}

1. Per quins canals de comunicació ens podem relacionar?

2. Escriu tres aspectes positius de relacionar-se amb les noves tecnologies.

- Escriu tres consells que cal seguir per a comunicar-nos positivament amb les noves tecnologies.

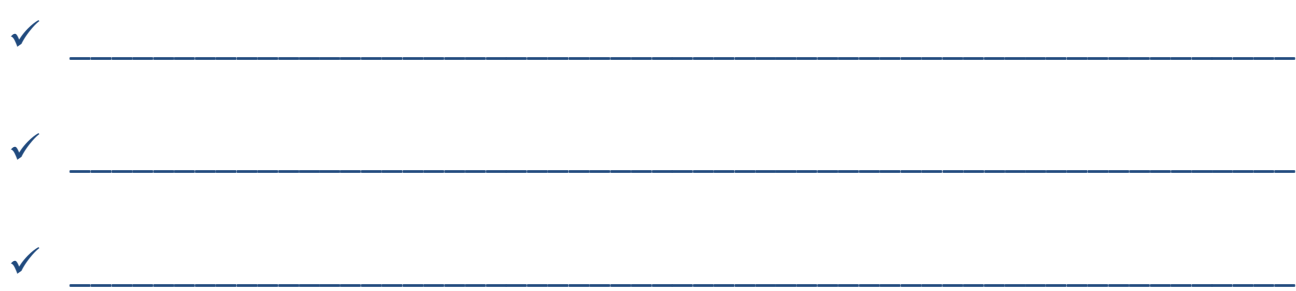

RECORDA...

Hui en dia ens comuniquem principalment per dispositius electrònics que ens faciliten molt la comunicació però també cal anar molt en compte, posar tots els nostres sentits alerta i seguir els consells que hem après com no respondre a desconeguts, no enviar missatges ofensius, no proporcionar el nostre telèfon a desconeguts, etc. 


\section{FEM UN ÚS SALUDABLE}

1. Escriu tres hàbits que cal seguir per a seguir una vida saludable.

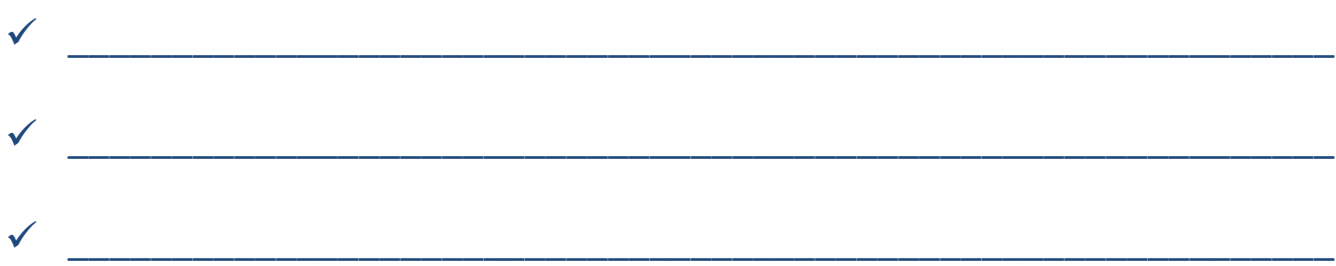

2. Anota dos accions perilloses que podem sofrir per l'ús de les noves tecnologies i que poden afectar a la nostra salut.

- I dos accions que hàbits saludables que podem seguir quan utilitzem les noves tecnologies per a prevenir aquests perills.

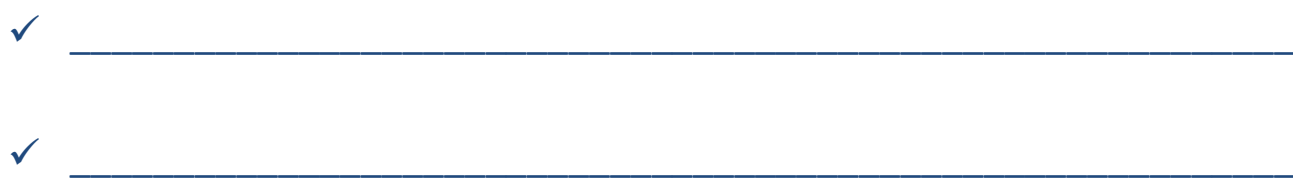

RECORDA...

L'ús inadequat i irresponsable de les noves tecnologies pot ser perillós per a la nostra salut. Per això cal que respectem els horaris que ens marquen els pares, no comunicar-nos amb desconeguts, respectar als altres, pensar bé la informació que compartim a les xarxes,entre altres. Si seguim aquests hàbits saludables amb l'ús de les noves tecnologies aconseguirem que la nostra salut sigui millor i ens sentirem millor! 


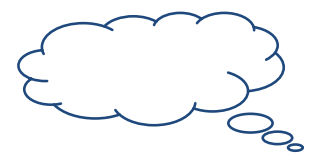

ANEM A REFLEXIONAR...

Després d'haver realitzat les activitats anteriors, reflexionarem sobre els aspectes que hem treballat. Per a això, contesta les següents qüestions:

1. Les noves tecnologies ens permeten comunicar-nos i relacionar-nos amb altra gent, però cal fer un bon ús d'elles.

Vertader

Fals

2. Senyala les opcions correctes.

Quan utilitzem les noves tecnologies per a comunicar-nos cal fer un bon ús d'elles i per tant cal...

No respondre a telefonades o missatges de números que no coneixem.

Donar el número de telèfon a tots aquells que ens el demanen.

Escriure missatges ofensius a altres persones.

No difondre imatges d'una altra persona sense el seu consentiment.

3. Quines accions poden ser perilloses per a la nostra salut? 
ANEXO 7. CUADERNO DEL ALUMNO DE 6o DE EDUCACIÓN PRIMARIA DEL PROGRAMA “CONVIURE EN UN MÓN REAL I DIGITAL".

\title{
Conviure en un món \\ real i digital
}

\author{
QUADERN DE L'ALUMNE \\ SISÈ DE PRIMÀRIA
}

CENTRE:

ALUMNE/A:

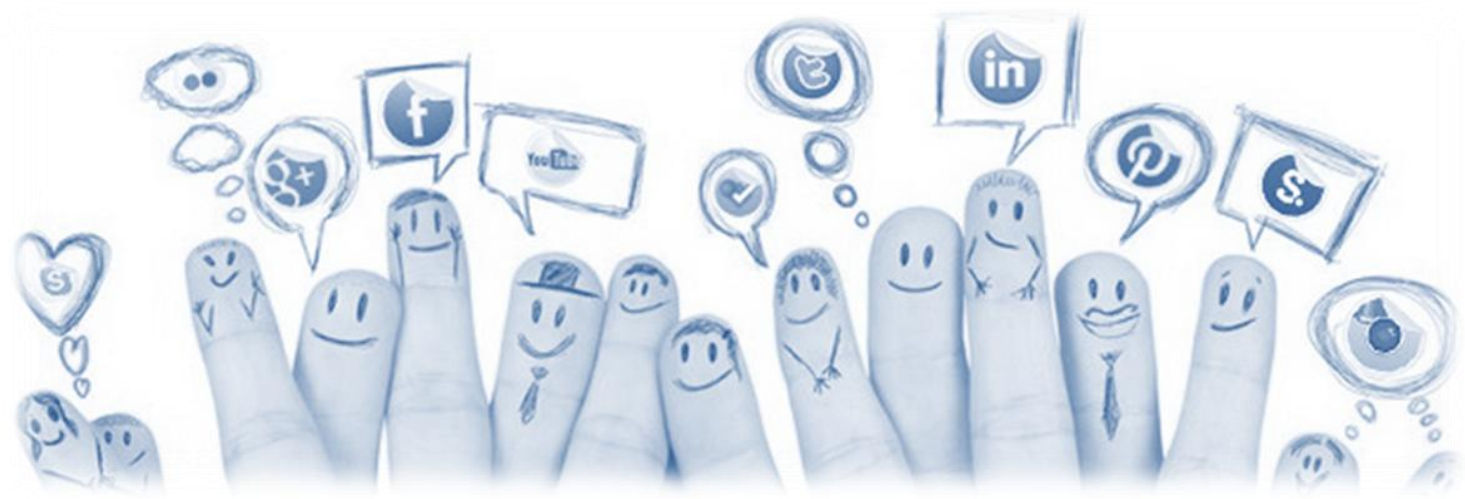




\section{ÍNDEX}

Quadre de registre.

\section{Activitats:}

Fitxa 1:Buscando la reacción adecuada.....................................................4

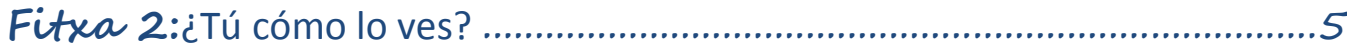

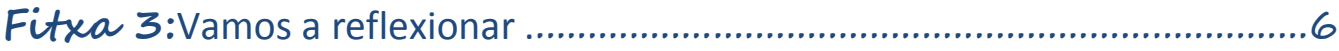

Fitxa 4:Algunes voltes cal dir no......................................................... 7

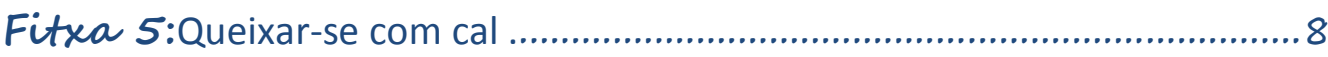

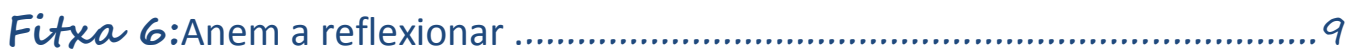

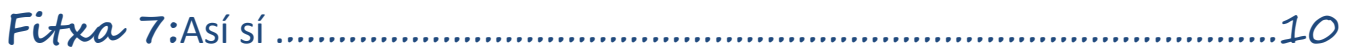

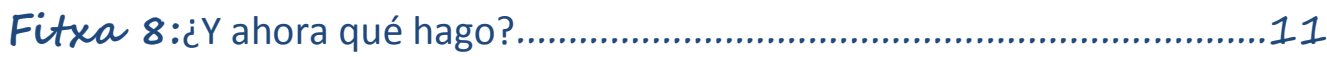

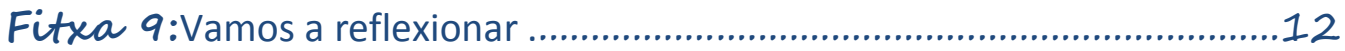

Fitxa 10:Prenem la decisió ................................................................ 13

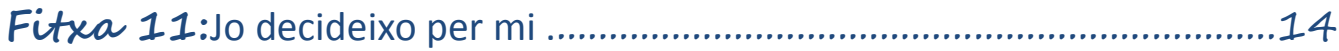

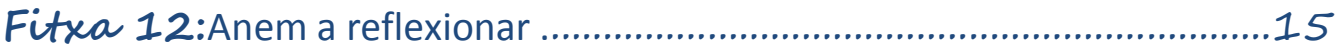

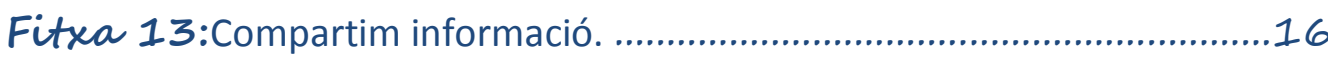

Fitxa 14:Utilitzem el temps com cal.................................................17

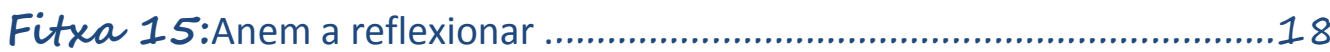




\section{SISÈ DE PRIMÀRIA}

\begin{tabular}{|c|c|c|}
\hline ASSIGNATURA & No I NOM FITXA & $\begin{array}{l}\text { REGISTRE DE } \\
\text { FITXES FETES }\end{array}$ \\
\hline \multirow{3}{*}{$\begin{array}{l}\text { CIÈNCIES DE LA } \\
\text { NATURALESA }\end{array}$} & 13. Compartim informació. & \\
\hline & $\begin{array}{l}\text { 14. Utilitzem el temps com } \\
\text { cal. }\end{array}$ & \\
\hline & 15. Anem a reflexionar. & \\
\hline \multirow{6}{*}{ CIĖNCIES SOCIALS } & 4. Algunes voltes cal dir no. & \\
\hline & 5. Queixar-se com cal. & \\
\hline & 6. Anem a reflexionar. & \\
\hline & 10. Prenem la decisió. & \\
\hline & 11. Jo decideixo per mi. & \\
\hline & 12. Anem a reflexionar. & \\
\hline \multirow{6}{*}{$\begin{array}{c}\text { LENGUA } \\
\text { CASTELLANA Y } \\
\text { LITERATURA }\end{array}$} & $\begin{array}{l}\text { 1. Buscando la reacción } \\
\text { adecuada. }\end{array}$ & \\
\hline & 2. ¿Tú cómo lo ves? & \\
\hline & 3. Vamos a reflexionar. & \\
\hline & 7. Así sí. & \\
\hline & 8. ¿Y ahora qué hago? & \\
\hline & 9. Vamos a reflexionar. & \\
\hline
\end{tabular}




\section{BUSCANDO LA REACCIÓN ADECUADA}

\section{Lee y señala en qué situación la reacción de Andrés es adecuada:}

Carmen le está contando a su amigo Andrés que hace días que no se habla con una amiga porque discutieron.

\section{Situación 1:}

Andrés: Vamos Carmen, no creo que sea para tanto. Seguro que encuentras otras amigas.

Carmen: Ya, pero ella es mi amiga y no quiero estar discutida con ella. ¡No entiendo por qué está tan enfadada!

Andrés: Yo no entiendo tu preocupación. ¿Qué ganas poniéndote así? ¡Yo de ti me olvidaría ya de ella!

\section{Situación 2:}

Andrés: No me esperaba nunca que estuvieseis tantos días sin hablaros con lo amigas que sois. Entiendo que te encuentres mal porque estas cosas duelen mucho.

Carmen: Ella es mi amiga. ¡No entiendo por qué está tan enfadada! Andrés:iCómo te comprendo! Sabes que me tienes para lo que necesites, podemos quedar esta tarde $\mathrm{o}$ ir a hablar con tu amiga para tratar de arreglar las cosas.

2. Escribe un texto argumentativo sobre la importancia de reaccionar adecuadamente ante situaciones como la anterior.

RECUERDA...

Cuando alguien comparte sus sentimientos debemos responder adecuadamente, y eso implica: reconocer lo que le pasa a la otra persona, compartir sus sentimientos y ofrecerle nuestra ayuda en la medida de lo posible. 


\section{¿TÚ CÓMO LO VES?}

1. Lee las siguientes frases e indica cómo te sentirías tú si te ocurriese esa situación. Pregúntale a tu compañero cómo se sentiría él y anótalo también.

- Tu amigo hace una fiesta de cumpleaños pero no te invita.

- ¿Cómo te sientes tú?

- ¿Cómo se siente tu compañero?

- Quedas para ir a patinar con un amigo pero no acude a la cita.

- ¿Cómo te sientes tú?

- ¿Cómo se siente tu compañero?

- Un compañero de clase te coge siempre el material.

- ¿Cómo te sientes tú?

- ¿Cómo se siente tu compañero?

2. Escoge una de las situaciones anteriores y escribe un diálogo teniendo en cuenta el sentimiento de la otra persona y lo importante que es compartir los sentimientos y ofrecer ayuda en situaciones como las que hemos planteado en la actividad anterior.

RECUERDA...

Aceptar a los demás significa entender los sentimientos ajenos, lo que nos llevará a mantener unas buenas relaciones. 


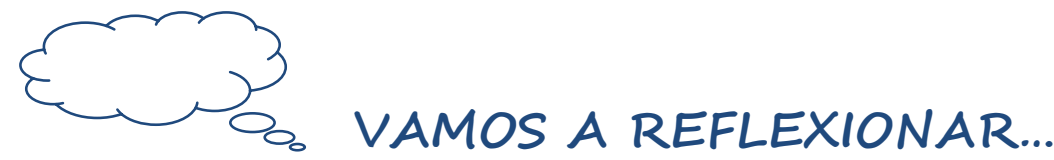

Después de haber realizado las actividades anteriores, vamos a reflexionar sobre los aspectos que hemos trabajado. Para ello, contesta las siguientes cuestiones:

\section{Lee y señala cuál sería la reacción más adecuada de Sofía:}

Marcos le cuenta a Sofía que está muy contento porque su amigo Luís le ha regalado una entrada para ir a ver un partido de fútbol.

$\square$ ¡Vaya rollo! Seguro que ese partido no vale nada y por eso te ha regalado la entrada.

$\square$ ¡Qué bien! Entiendo que estés tan contento, con lo que te gusta a ti el fútbol seguro que lo pasas genial.

2. ¿Qué debemos tener en cuenta a la hora de reaccionar cuando un amigo o compañero nos expresa sus sentimientos? Razona tu respuesta. 


\section{ALGUNES VOLTES CAL DIR NO}

\section{Respon a aquestes propostes.}

\section{Situació 1:}

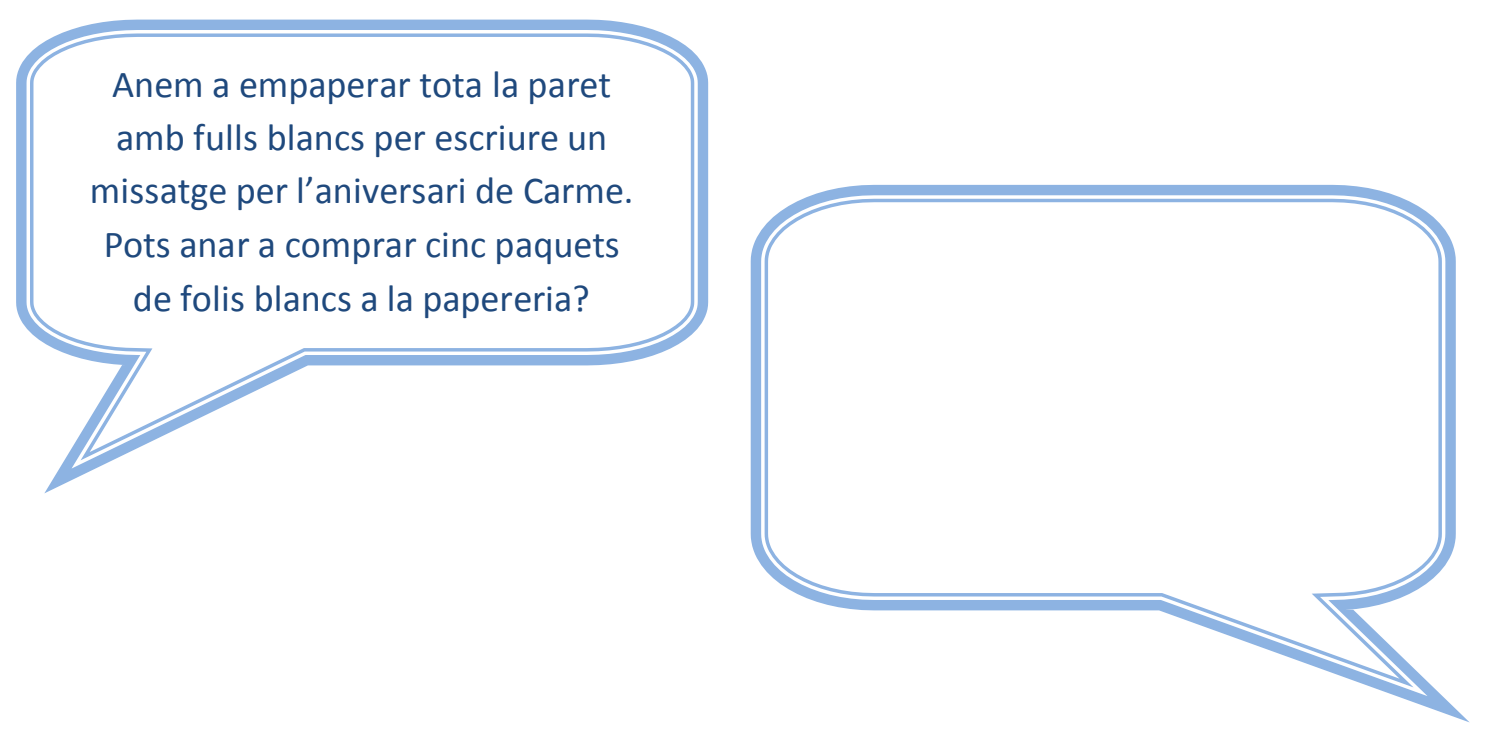

\section{Situació 2:}
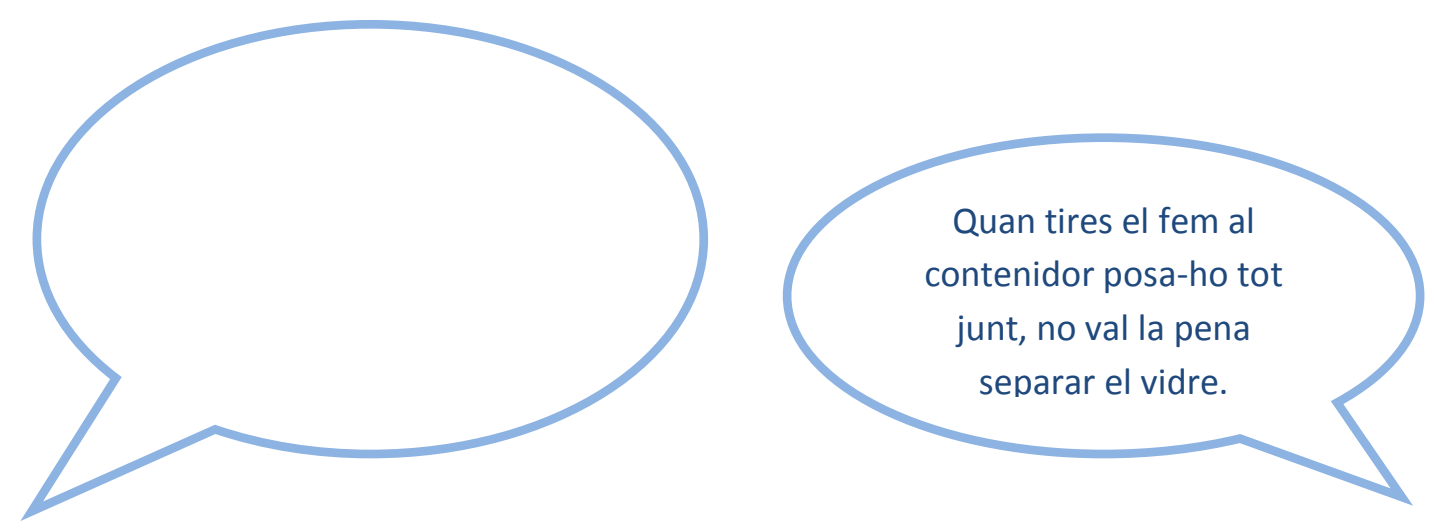

\section{RECORDA...}

Moltes voltes ens consta dir no en certes situacions, però no ens tenim que sentir malament ni avergonyits per fer-ho, devem mostrar el que pensem i actuar com volem. Si accepten fer alguna cosa que no volem, ens sentirem malament i ens podem posar en problemes per actuar inadequadament. 


\section{QUEIXAR-SE COM CAL}

1. Llegeix els següents diàlegs i senyala si la queixa és adequada o inadequada.

Carles, el cambrer del bar, serveix a una taula el menjar i a l'hora de pagar el client s'adona que li ha cobrat malament.

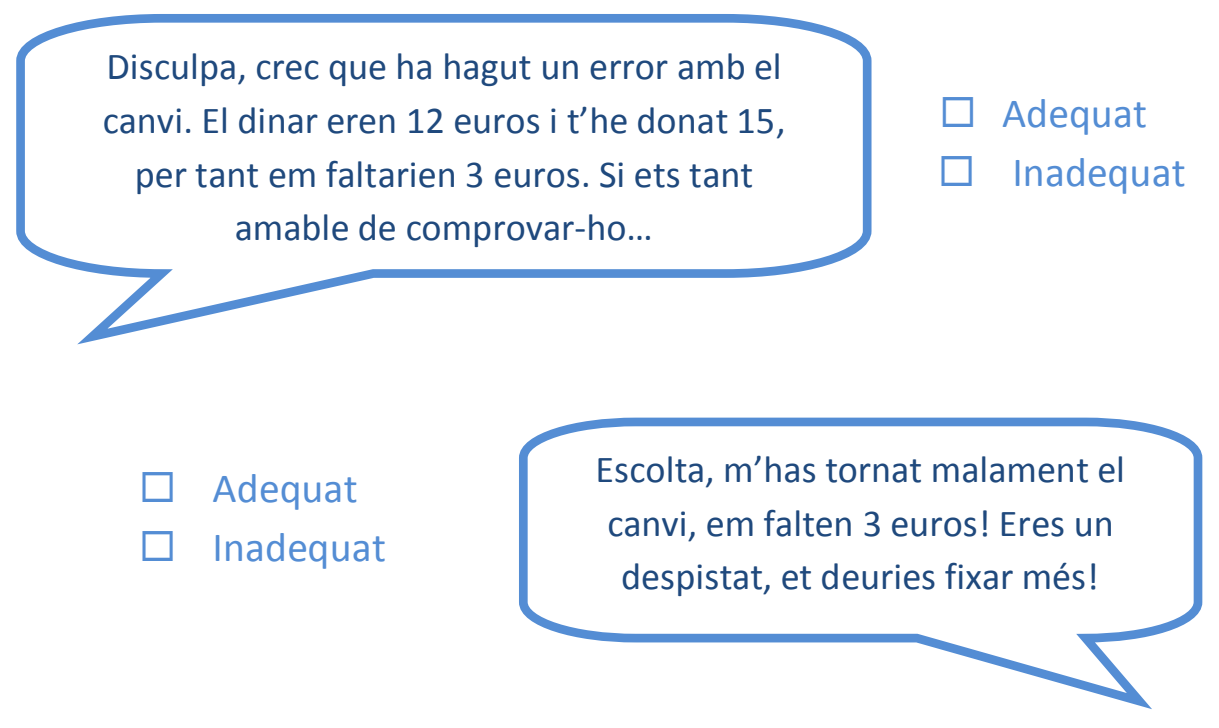

2. Digues quins avantatges $\mathrm{i}$ inconvenients té expressar una queixa.

Avantatges
Inconvenients

RECORDA...

Saber expressar adequadament les nostres queixes és molt important, es tracta

d'expressar alguna cosa que no ens agrada i que ens perjudica amb educació $i$ bones formes. Quan una queixa és justa, cal acceptar-la i utilitzar-la per tractar de millorar els nostres actes. 


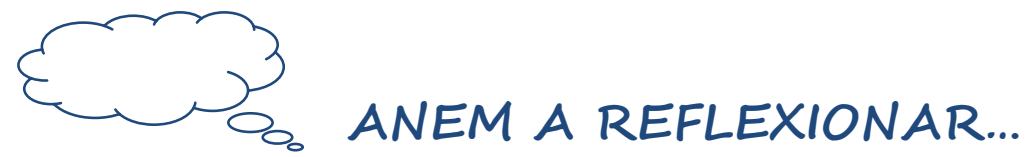

Després d'haver realitzat les activitats anteriors, reflexionarem sobre els aspectes que hem treballat. Per a això, contesta les següents qüestions:

1. Què ens pot ocórrer si no fem alguna cosa que no volem fer però no diem que NO? Senyala la resposta correcta.

Estarem contents de fer-ho.

Ens sentirem malament per fer una cosa que no volem fer.

Es bo que sempre diguem sí a tot el que ens demanen.

2. Senyala si aquesta queixa és justa o no ho és.

$\square$ sí $\quad \square$ NO

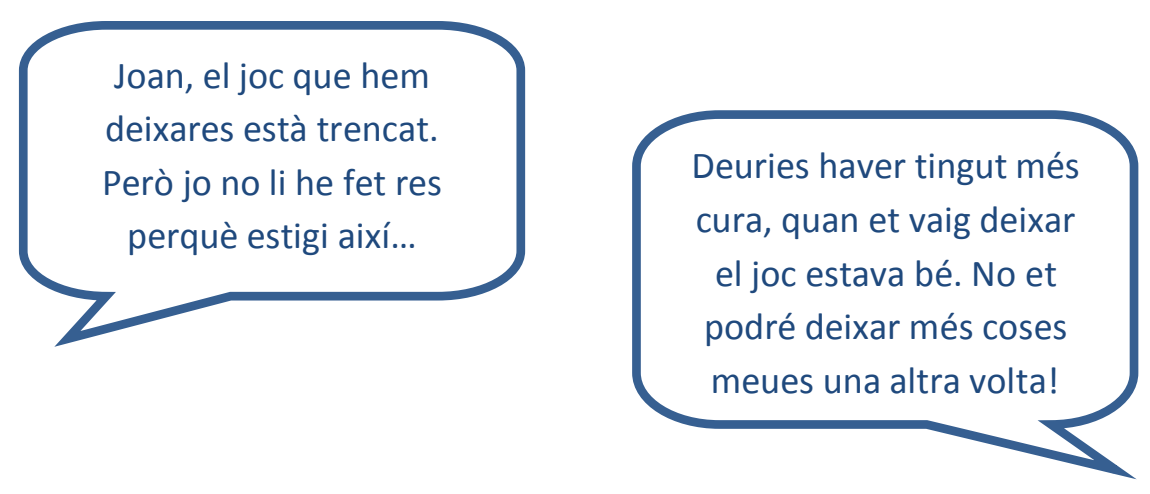

3. Quan ens queixem adequadament, com ho devem expressar? 


\section{Así sí}

1. Escribe tres acciones que es importante realizar para evitar el ciberbullying.

-

2. Escribe un eslogan para una campaña publicitaria para la prevención del ciberbullying.

RECUERDA..

Es muy importante que aprendamos a utilizar adecuadamente las nuevas tecnologías, no publicar información personal en las redes sociales, compartir fotos e imágenes solo con personas conocidas, no responder a mensajes ofensivos, etc. pues así evitaremos tener problemas tan graves como el ciberbullying. 


\section{¿Y AHORA QUÉ HAGO?}

\section{Lee el texto y responde a la siguiente pregunta.}

Juan es un chico de 11 años, tiene móvil y perfil de WhatsApp y participa en muchos grupos de WhatsApp con amigos y compañeros de clase. Un día Juan envió a un grupo de WhatsApp donde participa mucha gente una foto suya y Carlos, uno de los chicos que estaba en el grupo de WhatsApp, empezó a enviar mensajes riéndose de la foto y metiéndose con Juan. El resto de compañeros leían los mensajes pero nadie decía nada y Juan seguía respondiendo a los mensajes que le enviaba Carlos. Juan empezó a encontrarse mal, siempre le dolía la cabeza, sus notas empezaron a bajar y dejó de ir al colegio porque le decía a sus padres que estaba enfermo. Juan perdió un curso entero y tuvo que cambiarse de colegio.

- ¿Cómo podría haber afrontado Juan esta situación?

2. Representa esta historia en grupos de tres, siendo uno Juan, otro Carlos y el tercero un compañero que está en el grupo de WhatsApp. Ponte en su lugar y piensa bien cómo se siente cada uno y qué podría hacer para afrontar el problema.

RECUERDA...

Ante cualquier acto que os haga ver que estáis sufriendo acoso o que algún compañero lo está sufriendo; debéis avisar a un adulto, no contestar a las provocaciones, dejar de utilizar los dispositivos con los que os molestan, guardar bien todos los mensajes y avisar a la persona que acosa que lo que está haciendo os molesta y que está cometiendo un delito grave. 


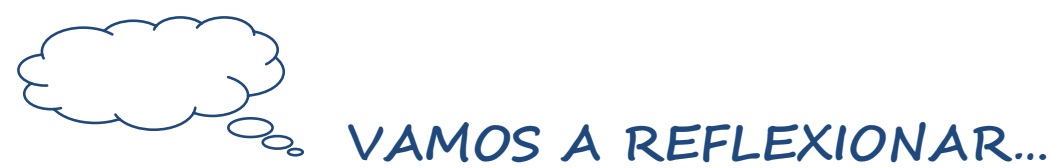

Después de haber realizado las actividades anteriores, vamos a reflexionar sobre los aspectos que hemos trabajado. Para ello, contesta las siguientes cuestiones:

1. Señala acciones que debemos realizar para evitar situaciones de ciberbullying.

Hacer un buen uso de las nuevas tecnologías.

Responder a los mensajes ofensivos que nos envían.

No publicar información personal que después puedan utilizar en tu contra.

Enviar fotos y mensajes a gente desconocida.

Guardar bien las contraseñas de nuestras cuentas de redes sociales.

2. Escribe qué harías si alguien te manda un mensaje como este.

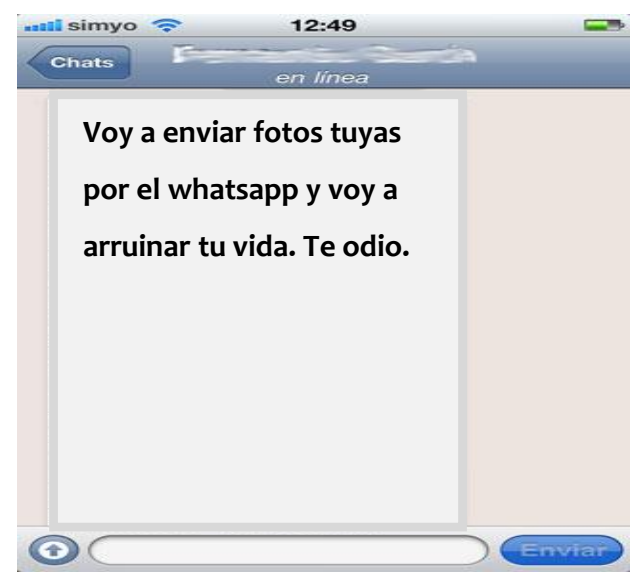




\section{PRENEM LA DECISIÓ}

Fa molts anys, amb la industrialització espanyola, la nostra societat va canviar molt sobretot laboralment. Pensa en aquesta situació que et plantegem a continuació i respon a les preguntes.

Treballes al camp i tens que prendre la decisió de seguir treballant amb ferramentes tradicionals, $\mathrm{o}$ bé comprar unes màquines noves que han sortit,perquè t'ha sorgit molta feina i necessites produir més però en aquests moments tens problemes econòmics $i$ no et pots permetre gastar-te molts diners.

1. Pensa quin és el problema.

2. Quines són les possibles solucions?

3. Quines seran les conseqüències de cada solució?

4. Elegeix una de les solucions prenent la decisió que consideres més adequada.

\section{RECORDA...}

Prendre una decisió es buscar varies solucions al problema, pensar i reflexionar bé sobre les conseqüències que comporten cada una d'elles i després elegir la que considerem millor i més adequada. 
1. Què opines del sufragi femení? Creus que tots, homes i dones, tenim els mateixos drets a votar? Raona la teua resposta.

2. Escriu una situació que hagis viscut on has pres una decisió per tu mateix.

3. Què hem de fer abans de prendre una bona decisió?

RECORDA...

Cada u té l'oportunitat i pot decidir per si mateix. Si prens bones decisions, la gent del teu voltant confiarà més amb tu perquè s'adonaran que penses bé les coses abans de fer-les i decideixes fer les coses com cal. 


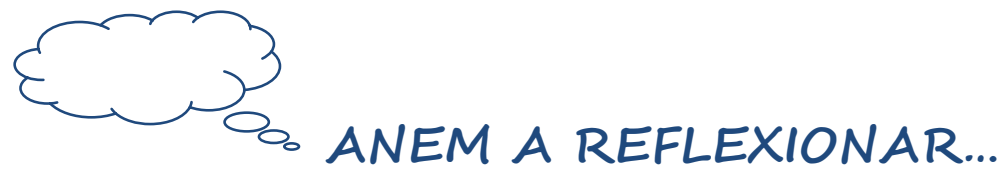

Després d'haver realitzat les activitats anteriors, reflexionarem sobre els aspectes que hem treballat. Per a això, contesta les següents qüestions:

1. Quins passos cal seguir per a prendre una bona decisió?

2. Quan hem de prendre una decisió nosaltres no podem decidir com actuar, els altres ens diran que hem de fer i com hem d'actuar.

Vertader

Fals

- Justifica la teua resposta. 
1. Anota a continuació la informació sobre l'aparell digestiu que t'ha pertocat.

2. Imagina que els teus companys es troben lluny, com podríeu compartir la informació per a fer un resum conjunt?

- Quins consells cal seguir per a compartir informació per l'ordinador, mòbil, etc.?

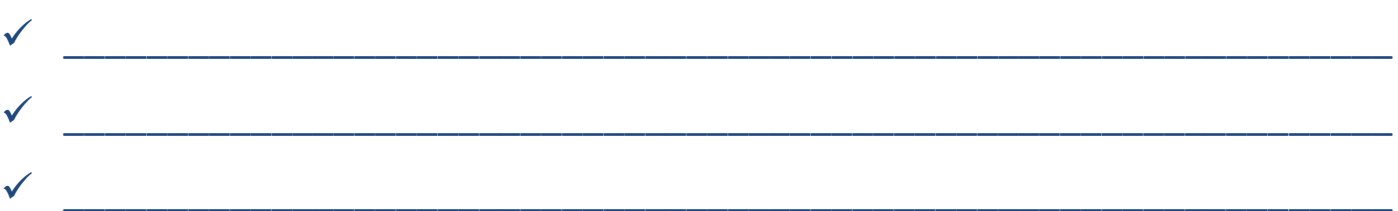

\section{RECORDA...}

Compartir informació d'uns als altres quan estem lluny és molt fàcil, però cal tenir molta cura quan utilitzem aquestes eines perquè Internet és una xarxa molt gran i tot

el que difonem ho pot veure molta gent. Per això, és important utilitzar filtres de seguretat i privacitat, i saber bé amb qui estem compartint aquesta informació entre altres. Si seguim aquests conselles que hem après, compatir serà més segur! 


\section{UTILITZEM EL TEMPS COM CAL}

1. Escriu dos hàbits saludables que cal seguir per a tenir cura del nostre sistema respiratori i prevenir malalties.

2. Imagina que estàs a casa jugant a l'ordinador, portes més de dues hores jugant, i el nostre pare ens diu que ja és hora d'anar a sopar, aleshores ens posem una mica nerviosos i li fem un crit al pare.

- Per què creus que ens t'has pogut posar nerviós i què podries fer en aquest moment?

- Creus que és convenient utilitzar dispositius electrònics com l'ordinador, la tableta, el mòbil, etc.? Raona la teua resposta.

- Quins problemes ens pot causar l'ús inadequat de les noves tecnologies?

RECORDA...

Les Tic ens aporten moltes coses bones però cal respectar els horaris que ens marquen a casa i utilitzar cada dispositiu per a la seua finalitat. Si alguna volta deixar d'utilitzar les Tic vos provoca angoixa o vos posa de mal humor, és perquè alguna cosa va malament, per tant cal mantenir la calma, relaxar-nos i adonar-nos que hi ha moltes altres coses importants a fer. 


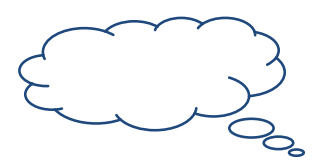

ANEM A REFLEXIONAR...

Després d'haver realitzat les activitats anteriors, reflexionarem sobre els aspectes que hem treballat. Per a això, contesta les següents qüestions:

1. Senyala les frases correctes.

Quan utilitzem les noves tecnologies com per a compartir informació cal...

Utilitzar una contrasenya segura, i mai l'hem de compartir amb amics o companys i menys amb gent desconeguda, nomes amb els nostres pares.

Obrir tots els correus, arxius, missatges, etc. que rebem, també de gent que no coneixem.

No reenviar correus o missatges en cadena que prometen tenir bona sort o aconseguir alguna cosa a canvi.

Assegurar-se bé de tancar la sessió després d'utilitzar-la.

Acceptar a contactes o gent que no coneguem.

2. Consideres que utilitzar els dispositius tecnològics moltes hores i fer un ús abusiu d'aquests, ens pot causar problemes d'addicció molt greus? Raona la teua resposta. 
ANEXO 8. CUADERNO DEL PROFESOR DE 3० DE EDUCACIÓN PRIMARIA DEL PROGRAMA CONVIURE EN UN MÓN REAL I DIGITAL.

\title{
Conviure en un món real $i$ digital
}

\author{
QUADERN DEL PROFESSOR
}

TERCER DE PRIMÀRIA

CENTRE:

PROFESSOR/A:

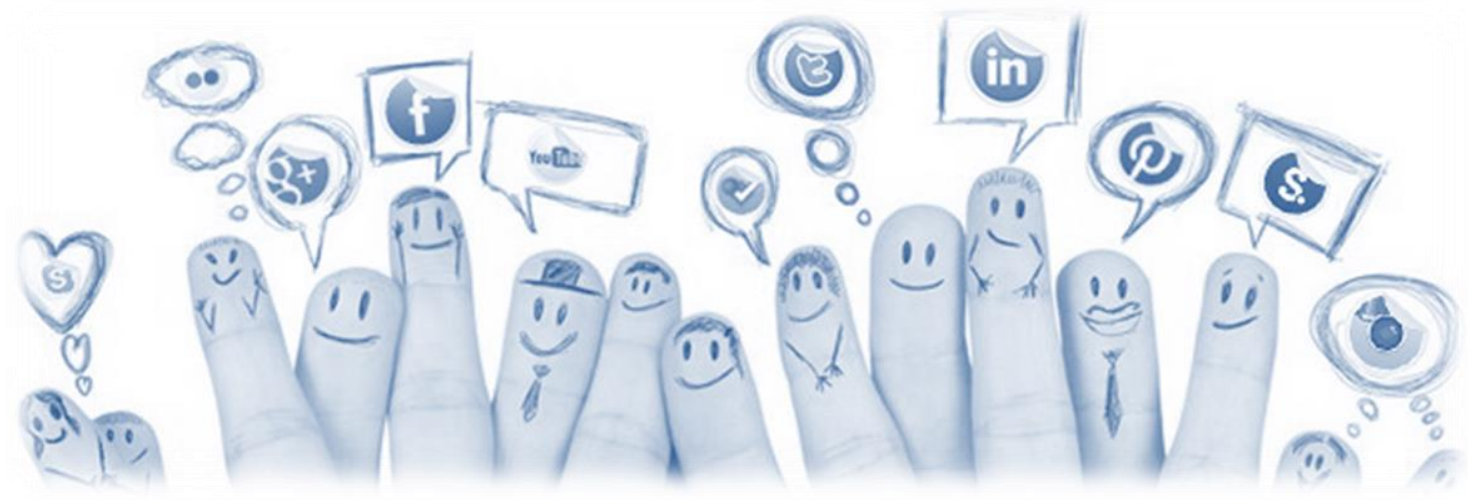




\section{ÍNDEX}

Introducció ................................................................................

Objectiu general del programa ......................................................6

Caracteristiques $i$ configuració del programa ..........................6

Procediment per a l'aplicació del programa ..............................9

Taula de distribució de les activitats ...............................11

Activitats:

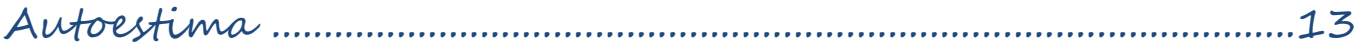

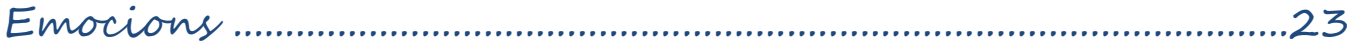

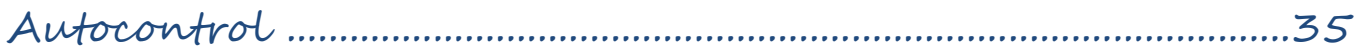

Prevenció $i$ resolució de conflictes .............................................47

Bon ús de les TIC .............................................................................5.5

Qüestionari final ............................................................69

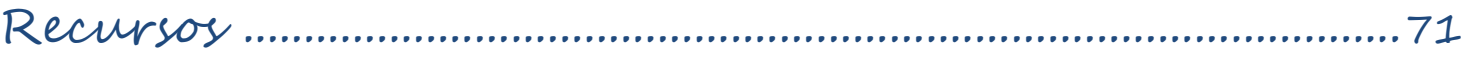




\section{INTRODUCCIÓ}

La infantesa, la pre-adolescència i l'adolescència són etapes crucials en el desenvolupament de les persones, tant a nivell personal com social i acadèmic/professional. Açò dona lloc a que els més joves siguin molt vulnerables davant l'entorn que els envolta i als continus canvis que caracteritzen la nostra societat actual. Els nostres joves han nascut en la era de les TIC, i fan ús d'elles des de edats molt primerenques.

En l'actualitat, els xiquets i les xiquetes, anomenats natius digitals, comencen a utilitzar les Tecnologies de la Informació i de la Comunicació (Tics) partir dels 3 anys d'edat, malgrat això, no saben com fer-ho de forma responsable i com protegir-se de les possibles amenaces. Així, sovint es troben amb una sèrie de dificultats com són l'accés a informació inadequada per a l'edat, sobretot continguts pornogràfics o violents, els riscos tècnics, la pèrdua de privacitat, la suplantació d'identitat, els fraus econòmics i l'addicció a pantalles, entre altres (Salmerón, Campillo i Casas, 2013). Aspectes com aquests provoquen que s'acreixi l'alarma social, doncs aquests riscos són desconeguts per als educadors, els pares i les mares, que han crescut en un context no digital (Del Riu, Sádaba i Bringué, 2010).

Un dels riscos que formen part dels anteriorment citats, és el ciberbullying. Parlem de Ciberbullying "quan un nen o adolescent és turmentat, amenaçat, assetjat, humiliat, molestat d'una manera o una altra, per un altre nen o adolescent mitjançant l'ús d'Internet, tecnologies interactives i digitals o telèfon mòbil" (Collell i Escudé, 2008).

Aquest tipus de maltractament entre iguals s'ha convertit en un problema complex entre els nostres adolescents, que sol tenir repercussions indesitjables en la convivència escolar (Avilés, 2013), i encara que la violència no és cap cosa nova, ja que a la fi dels anys 70 el noruec Olweus es va iniciar en l'estudi de la violència entre escolars mundialment conegut amb l'expressió bullying, les formes de materialització de la mateixa han anat evolucionant amb el temps, ideant noves formes de dur-la a terme (Hernández i Solano, 2007).

Considerant l'anteriorment citat, els centres educatius de tots els nivells tenen en l'actualitat el deure incloure dins de la formació integral aspectes com el sensibilitzar i prevenir que entre el mateix alumnat sorgeixin situacions de maltractament $\mathrm{i}$ intimidació, encara que es sap que el ciberbullying no succeeix precisament dins de l'escola, és aquí on ha d'abordar-se com a part de l'educació integral (Ortega, 2010).

La nova educació que cal realitzar en l'àmbit de les TIC també ha de procurar capacitar en determinades destreses i habilitats, que suscitarà unes actituds i disposicions. Entre aquestes últimes és imprescindible la necessitat de formar en una actitud sanament crítica davant les TIC. És a dir, saber distingir en què ens ajuden i en què ens limiten, 
per poder actuar en conseqüència. Aquest procés ha d'estar present i donar-se de manera integrada en la família, a l'escola i en la societat (Berríos i Buxarris, 2005).

Per tot això, és convenient destacar la necessitat de dur a terme accions de prevenció a edats primerenques, per oferir una informació i formació adequada als nens, progenitors i professorat, en l'àmbit de les TIC. Aquesta formació ha de basar-se en dues perspectives, una tecnològica i una altra humanística. És a dir, que atengui als mitjans, però també a les finalitats de l'educació (Naval, Sábada i Bringué, 2003).

* objectiu general del programa

L'objectiu principal d'aquest programa no es altre que realitzar accions de prevenció del ciberbullying als centres escolars en el segon i tercer cicle de l'educació primària mitjançant activitats inserides en el currículum escolar, de manera que l'alumne tingui la possibilitat d'adquirir aquests coneixements $\mathrm{i}$ aptituds relacionades amb la prevenció del ciberbullying progressivament durant els quatre últims cursos de l'educació primària.

\section{* característiques I configuració del programa}

El programa de prevenció del ciberbullying ha sigut dissenyat a partir d'un conjunt d'activitats inserides al currículum escolar, concretament a les següents assignatures:

- Ciències socials

- Ciències de la naturalesa

- Llengua castellana i literatura

Aquesta inserció curricular no solament va a cobrir la prevenció en quant a aspectes tecnològics, sinó també en aspectes humanístics. És a dir, per aconseguir els objectius proposats és necessari treballar aspectes tecnològics no obstant això, treballar únicament aquests aspectes no seria suficient, doncs per poder assumir aquesta informació i aplicar-la correctament és necessari que certes habilitats personals i socials estiguin ben desenvolupades, per així prevenir l'aparició de problemes com el ciberbullying. En concret les habilitats centrades en el bon ús de les TIC i les relacionades amb la resolució de conflictes seran aspectes centrals en el nostre projecte doncs treballant-los des d'edats primerenques creiem que són aspectes clau en la prevenció del ciberbullying.

Per tant les temàtiques que es treballaran en aquest programa es classifiquen del següent mode. En els cursos de tercer i quart de primària es treballaran un conjunt d'activitats relacionades amb habilitats tecnològiques i personals com són:

- Bon ús de les TIC

- Prevenció i resolució de conflictes 
- Autoestima

- Emocions

- Autocontrol

A continuació en cinquè $i$ sisè curs de primària es seguiran treballant aspectes tecnològics i introduirem habilitats socials, atès que aquests últims s'han de desenvolupar amb posterioritat a les habilitats més personals. Així els continguts a treballar els dos últims cursos de l'educació primària són:

- Bon ús de les TIC

- Resolució de conflictes

- Empatia

- Assertivitat

- Ciberbullying

El programa disposa d'un dossier que inclou totes les activitats a desenvolupar al llarg del programa. Aquestes activitats es troben classificades per cursos escolars (tercer, quart, cinquè i sisè de primària).

El dossier de cada curs escolar, al mateix temps, està format per cinc blocs temàtics amb tres activitats per cada bloc (dos relacionades amb el contingut curricular i una d'avaluació) sent un total de quinze activitats per curs escolar.

\begin{tabular}{|c|c|c|}
\hline CURS & TEMÀTICA & ACTIVITAT \\
\hline \multirow{5}{*}{$3 r$} & Autoestima & $\begin{array}{l}\text { 1. Així sóc jo. } \\
\text { 2. Em quede amb tot allò bo. } \\
\text { 3. Anem a reflexionar. }\end{array}$ \\
\hline & Emocions & $\begin{array}{l}\text { 4. El que sentim. } \\
\text { 5. Dime com et sents. } \\
\text { 6. Anem a reflexionar. }\end{array}$ \\
\hline & Autocontrol & $\begin{array}{l}\text { 7. Què passarà? } \\
\text { 8. Pren-te el teu temps. } \\
\text { 9. Anem a reflexionar. }\end{array}$ \\
\hline & $\begin{array}{l}\text { Prevenció i resolució de } \\
\text { conflictes }\end{array}$ & $\begin{array}{l}\text { 10. Ens relacionem. } \\
\text { 11. Fa un temps. } \\
\text { 12. Anem a reflexionar. }\end{array}$ \\
\hline & Bon ús de les TIC & $\begin{array}{l}\text { 13. Un día cualquiera } \\
\text { 14. ¿Tú qué opinas? } \\
\text { 15. Vamos a reflexionar. }\end{array}$ \\
\hline $4 t$ & Autoestima & $\begin{array}{l}\text { 1. Autorretrato. } \\
\text { 2. Así es mi compañero. } \\
\text { 3. Vamos a reflexionar. }\end{array}$ \\
\hline
\end{tabular}




\begin{tabular}{|c|c|c|}
\hline & Emocions & $\begin{array}{l}\text { 4. Els altres també senten. } \\
\text { 5. Sentim diferent. } \\
\text { 6. Anem a reflexionar. }\end{array}$ \\
\hline & Autocontrol & $\begin{array}{l}\text { 7. Anem a imaginar. } \\
\text { 8. ¿Què ocorre? } \\
\text { 9. Anem a reflexionar. }\end{array}$ \\
\hline & $\begin{array}{l}\text { Prevenció i resolució de } \\
\text { conflictes }\end{array}$ & $\begin{array}{l}\text { 10. ¿Hablamos? } \\
\text { 11. ¿Qué ocorre? } \\
\text { 12. Anem a reflexionar. }\end{array}$ \\
\hline & Bon ús de les TIC & $\begin{array}{l}\text { 13. A internet ho trobarem. } \\
\text { 14. Siguem responsables. } \\
\text { 15. Anem a reflexionar. }\end{array}$ \\
\hline \multirow{5}{*}{5 '̀̀ } & Empatia & $\begin{array}{l}\text { 1. Ponte en mi lugar. } \\
\text { 2. Si tú estás feliz yo estoy feliz. } \\
\text { 3. Vamos a reflexionar. }\end{array}$ \\
\hline & Assertivitat & $\begin{array}{l}\text { 4. Els meus drets. } \\
\text { 5. Conta'm què t'agrada. } \\
\text { 6. Anem a reflexionar. }\end{array}$ \\
\hline & Ciberbullying & $\begin{array}{l}\text { 7. Carlos y el ciberbullying. } \\
\text { 8. ¿Qué necesitas saber? } \\
\text { 9. Vamos a reflexionar. }\end{array}$ \\
\hline & $\begin{array}{l}\text { Prevenció i resolució de } \\
\text { conflictes }\end{array}$ & $\begin{array}{l}\text { 10. Els conflictes. } \\
\text { 11. Solucionem els conflictes. } \\
\text { 12. Anem a reflexionar. }\end{array}$ \\
\hline & Bon ús de les TIC & $\begin{array}{l}\text { 13. Ens relacionem per internet. } \\
\text { 14. Fem un ús saludable. } \\
\text { 15. Anem a reflexionar. }\end{array}$ \\
\hline \multirow{5}{*}{ 6è } & Empatia & $\begin{array}{l}\text { 1. Buscando la reacción adecuada. } \\
\text { 2. ¿Tú cómo lo ves? } \\
\text { 3. Vamos a reflexionar. }\end{array}$ \\
\hline & Assertivitat & $\begin{array}{l}\text { 4. Algunes voltes cal dir que no. } \\
\text { 5. Queixar-se com cal. } \\
\text { 6. Anem a reflexionar. }\end{array}$ \\
\hline & Ciberbullying & $\begin{array}{l}\text { 7. Así sí. } \\
\text { 8. ¿Y ahora qué hago? } \\
\text { 9. Vamos a reflexionar. }\end{array}$ \\
\hline & $\begin{array}{l}\text { Prevenció i resolució de } \\
\text { conflictes }\end{array}$ & $\begin{array}{l}\text { 10. Prenem la decisió. } \\
\text { 11. Jo decideixo per mi. } \\
\text { 12. Anem a reflexionar }\end{array}$ \\
\hline & Bon ús de les TIC & $\begin{array}{l}\text { 13. Compartim informació. } \\
\text { 14. Utilitzem el temps com cal. } \\
\text { 15. Anem a reflexionar. }\end{array}$ \\
\hline
\end{tabular}


Al inici de cada bloc temàtic es presenta una sèrie d'informació on s'especifica el concepte de la temàtica a treballar, els objectius que es persegueixen i una taula resum amb les activitats que inclou el bloc classificades per les assignatures curriculars per a facilitar així la seua inserció.

Respecte al material que es presenta a cada bloc per al professorat inclou, a més de les fitxes dels alumnes, una fitxa tècnica per a cadascuna de les activitats que conté els següents camps informatius:

- Assignatura: indica l'assignatura en la qual cal inserir l'activitat.

- Contingut curricular: matèria de l'assignatura amb la que està relacionada l'activitat.

- Objectius curriculars i objectius de la temàtica: remarca els objectius tant curriculars com de la temàtica que es treballen a l'activitat.

- Metodologia i procediment: determina com i de quina forma portar a cap l'activitat.

- Temporalització: temps aproximat de la realització de l'activitat.

- Orientacions: dades relacionades amb l'activitat que faciliten al professorat l'aplicació de l'activitat, tant a nivell teòric com a pràctic.

- Recursos: materials necessaris per a desenvolupar adequadament l'activitat.

Després de cada un dels blocs temàtics, es troba una fitxa d'avaluació per ser emplenada pel professor/a sobre les activitats corresponents a aquest bloc. Aquesta avaluació serà d'ajuda per millorar el programa.

A més del programa, al final d'aquest document hi ha un apartat amb una fitxa d'avaluació final del programa per a l'alumnat per a aquest curs educatiu, i també un petit document amb recursos extra com guies, enllaços de pàgines web i vídeos amb els que es poden ampliar els coneixements relacionats amb la temàtica principal del programa, el ciberbullying.

\section{procediment per a l'aplicació del programa}

Aquest programa està dissenyat per a ser aplicat als quatre cursos que corresponen al segon i tercer cicle de l'educació primària de forma progressiva al llarg d'aquests cursos, de forma que al finalitzar el tercer cicle els alumnes hagen assolit tots els objectius del programa de prevenció.

L'aplicació del programa correspon als professors tutors, ja que es considera important que es relacioni l'aspecte educatiu d'aquest programa amb la tasca quotidiana que realitzen els alumnes en les diferents assignatures curriculars. Així, per a que l'aplicació sigui adequada i satisfactòria és necessària la constància del professorat al llarg del curs. 


\section{TERCER DE PRIMÀRIA}

\begin{tabular}{|c|c|c|c|c|}
\hline ASSIGNATURA & $\begin{array}{l}\text { TEMÀTICA } \\
\text { CURRICULAR }\end{array}$ & $\begin{array}{c}\text { TEMÀTICA } \\
\text { TRANSVERSAL }\end{array}$ & \multicolumn{2}{|c|}{$\begin{array}{l}\text { REGISTRE } \\
\text { DE FITXES } \\
\text { FETES }\end{array}$} \\
\hline \multirow{6}{*}{$\begin{array}{c}\text { CIĖNCIES DE } \\
\text { LA } \\
\text { NATURALESA }\end{array}$} & Alimentació & \multirow{3}{*}{ Autoestima } & 1 & \\
\hline & Cura del nostre cos & & 2 & \\
\hline & Anem a reflexionar & & 3 & \\
\hline & Animals & \multirow{3}{*}{ Autocontrol } & 7 & \\
\hline & Energia & & 8 & \\
\hline & Anem a reflexionar & & 9 & \\
\hline \multirow{6}{*}{$\begin{array}{l}\text { CIENCIES } \\
\text { SOCIALS }\end{array}$} & L'aigua & \multirow{3}{*}{ Emocions } & 4 & \\
\hline & Vivim en comunitat & & 5 & \\
\hline & Anem a reflexionar & & 6 & \\
\hline & Convivim en societat & \multirow{3}{*}{$\begin{array}{c}\text { Prevenció i resolució } \\
\text { de conflictes }\end{array}$} & 10 & \\
\hline & $\begin{array}{c}\text { El nostre passat } \\
\text { personal }\end{array}$ & & 11 & \\
\hline & Anem a reflexionar & & 12 & \\
\hline \multirow{3}{*}{$\begin{array}{c}\text { LENGUA } \\
\text { CASTELLANA Y } \\
\text { LITERATURA }\end{array}$} & Signos de puntuación & \multirow{3}{*}{ Bon ús de les TIC } & 13 & \\
\hline & La noticia & & 14 & \\
\hline & Vamos a reflexionar & & 15 & \\
\hline
\end{tabular}




\section{AUTOESTIMA}

Acceptació, valoració $i$ estima cap a un mateix.

\section{Objectivs.}

$\checkmark$ Conèixer-nos a nosaltres mateixos.

$\checkmark$ Atendre i tenir cura de les necessitats psicològiques i físiques. 
CURS: $3 r$ PRIMÀRIA

FITXA: 1

ASSIGNATURA: CIÈNCIES DE LA NATURALESA

ACTIVITAT: AIXÍ SÓC JO

CONTINGUTS: ALIMENTACIÓ I AUTOESTIMA

\section{OBJECTIUSS CURRICULARS}

- Conèixer l'alimentació que segueixen.

- Reflexionar sobre els seus hàbits alimentaris.

\section{OBJETIUS SOBRE LA TEMÀTICA}

- Desenvolupar el coneixement de sí mateix i dels companys.

- Aprendre a valorar positivament les seues qualitats.

\section{METODOLOGIA / PROCEDIMIENT}

Com s'ha especificat en les dades anteriors, aquesta activitat formarà part del tema de l'alimentació i en aquesta es treballarà aquest contingut amb l'autoestima. Per a això, hem elaborat la fitxa número 1, que cada alumne té en el seu quadern de treball.

1. Introducció grupal de l'activitat als alumnes i treball individual de l'activitat:

Com bé sabeu, estem treballant el tema de l'alimentació, i com ja hem comentat al llarg del tema, és molt important seguir una alimentació saludable. Així, a continuació anem a realitzar una fitxa que hem de completar individualment. Cal respondre a les preguntes que ens formulen, $i$ a partir de les respostes que contesteu obtindrem informació de cadascun de nosaltres. Haurem d'escriure el nostre nom, edat, característiques físiques i de la nostra forma de ser, i també informació sobre la nostra alimentació.

2. Comentem les respostes de l'activitat en grup:

Digueu-me, quants menjars feu al dia? Què és el que més us agrada? I el que menys?

(Ens centrarem en les preguntes de l'alimentació i esport, les del nom i edat les obviem per complet en aquesta xerrada.)

I què em dieu de l'última pregunta? Quin ha estat vostra resposta? Per què heu respost això?

(Ja obtinguts dades sobre les respostes dels alumnes a aquestes preguntes, ens centrem en l'última pregunta "T'agrada com ets?". Preguntem també als alumnes que han contestat a aquesta pregunta.)

3. Reflexió final en grup:

En emplenar aquesta fitxa hem posat dades de cadascun de nosaltres, això ens permet conèixer-nos millor a nosaltres mateixos $i$ també conèixer aspectes dels nostres companys. És molt important que cadascun de nosaltres sapiguem com som; si som alts, baixos, simpàtics, tristos, què ens agrada menjar, quins esports practiquem, etc. I també és molt important conèixer ben com són els nostres companys, doncs cadascun de nosaltres som únics, autèntics i diferents als altres. Hem de sentir-nos bé amb nosaltres mateixos, sentir-nos especials, acceptar-nos tal com som, i estar orgullós del 
que pensem i fem. Si a més d'això, portem hàbits de vida saludables, és a dir, practiquem esport i mengem sa, ens sentirem millor amb nosaltres mateixos.

(Després de la reflexió preguntem què opinen i si algú vol afegir alguna cosa.)

\section{TEMPORALITZACIÓ}

Temps aproximat de l'activitat 20 minuts:

1. Explicació inicial i treball individual de la fitxa: 10 minuts.

2.Preguntem sobre les respostes: 5 minuts.

3. Reflexió final: 5 minuts.

\section{ORIENTACIONS}

És important parar esment a les respostes dels alumnes, que aprenguin a conèixer-se tal com som i evitar que qualsevol alumne pugui infravalorar-se. Anem a remarcar sobretot la idea que tots i cadascun de nosaltres som diferents, únics i autèntics, que hem d'acceptarnos i cuidar-nos molt seguint hàbits alimentaris saludables, doncs això ens farà sentir millor.

Respostes recomanades:

- Les primeres respostes haurien d'estar ajustades a la realitat de cada alumne, però controlant que no suposin per a l'alumne la sensació de sentir-se diferent d'una manera despectiva, sinó remarcar la importància de la diferència com alguna cosa bona, única i especial.

- Els menjars al dia recomanats són 5.

- La resposta al que més m'agrada menjar i menys serà diferent segons l'alumne, però cal remarcar la importància d'augmentar la consumició de productes saludables com a verdures, fruites, peix, carn... i disminuir el consum de xocolata, dolços...

- Respecte als esports que practico, practicar qualsevol esport és bo, per la qual cosa solament caldria animar a aquells que no practiquen cap al fet que ho facin.

- L'última pregunta és fonamental, cal treballar ben bé totes les respostes anteriors perquè arribats a aquest punt es sentin tal com hem dit: especials, únics i diferents.

\section{RECURSOS}

- Fitxa número 1 del quadern de $3 r$ de primària. 


\section{Alxí sóc jo}

EL MEU NOM:

LA MEUA EDAT:

SÓC UN ESTUDIANT (bo - dolent -regular):

SÓC TAMBÉ (senyala amb una creu)

- Ros

- Bru

- Rosat
- Alt

- Un poc baix

- Estudiós
- Simpàtic

- Alegre

- Un poc avorrit

- ALTRES:

¿QUANTES MENJADES (desdejuni, esmorzar, menjar...) FAIG AL DIA?

EL QUE MÉS M'AGRADA MENJAR:

EL QUE MENYS M'AGRADA MENJAR :

ESPORTS QUE PRACTIQUE:

RECORDA...

Cadascun de nosaltres som molt importants, som diferents, som autèntics. 
ASSIGNATURA: CIÈNCIES DE LA NATURALESA

ACTIVITAT: EM QUEDO AMB TOT ALLÒ BO

CONTINGUTS: CURA DEL NOSTRE COS I AUTOESTIMA

\section{OBJECTIUS CURRICULARS}

- Conscienciar sobre la importància de seguir hàbits saludables.

- Desenvolupar habilitats per canviar aquelles pràctiques que no són saludables.

\section{OBJECTIUS SOBRE LA TEMÀTICA}

- Diferenciar entre les coses que ens fan sentir bé i les que ens fan sentir malament.

- Aprendre a atendre i a tenir cura de les nostres necessitats psicològiques $i$ físiques.

\section{METODOLOGIA / PROCEDIMENT}

Aquesta activitat formarà part del tema de la cura del nostre cos i es treballarà aquest contingut juntament amb l'autoestima.

1. Introducció en grup de l'activitat:

Anem a realitzar una activitat del quadern, obrim per la fitxa número 2. Recordeu la importància de conèixer-nos a nosaltres mateixos i als nostres companys?, doncs cadascun de nosaltres és diferent i per això hem de sentir-nos únics i especials.

Perfecte, doncs en aquesta activitat anem a escriure cadascun que és allò que ens fa sentir bé, i allò que NO ens fa sentir bé. Recordem que al llarg d'aquest tema hem vist com d'important que és seguir uns hàbits de vida saludables i què és el que hem de fer per tenir una bona salut.

2. Els alumnes treballaran individualment completant la fitxa:

Ara agafem la fitxa i fem primer un llistat amb tres coses que ens fan sentir bé i el segon llistat amb coses que no ens fan sentir bé.

3. Comentem en grup les respostes dels alumnes:

Quines coses us fan sentir bé? I quins us fan sentir malament?

(Anirem preguntant a alguns alumnes el que han contestat, i farem en la pissarra un Ilistat amb allò que els fa sentir bé i uns altres amb allò que no els fa sentir bé.)

4. Una vegada comentades les respostes, fem la següent reflexió en grup:

Aqui hem anotat el que vosaltres heu contestat en la fitxa, i com podeu veure cadascun ha donat una resposta diferent, i a cadascun li fan sentir bé unes coses $i$ unes altres no li fer sentir tan bé. Cadascú de nosaltres és diferent, per això és molt important que cadascú tingui cura de si mateix fent tot allò que li fa sentir bé, i eliminant tot allò que ens fa sentir malament, si vols tu pots canviar-ho!. Per això és important reflexionar sobre allò que ens fa sentir bé i seguir fent-ho, i tot allò que no ens fa sentir bé cal canviar-ho per algun hàbit sa com alimentar-se bé, menjar aliments saludables, practicar esport... $i$ així aconseguirem sentir-nos millor amb 
nosaltres mateixos. No hem d'oblidar que sempre has de valorar-nos i cuidar-nos, nosaltres som el més important!

\section{TEMPORALITZACIÓ}

Temps aproximat de l'activitat 20 minuts:

1. Explicació inicial:5 minuts.

2. Treball individual de la fitxa: 5 minuts.

3. Llistat de les respostes en la pissarra: 5 minuts.

4. Reflexió final: 5 minuts.

\section{ORIENTACIONS}

- En aquesta activitat la finalitat és que els alumnes coneguin quines coses els fan sentir bé perquè les potenciïn i aquelles que els fan sentir malament perquè tractin d'obviar-les o canviar-les. El nostre propòsit és que cadascun es senti bé amb si mateix per això és important aprendre a valorar què és el que ens afavoreix i ens ajuda a millorar i quines coses no.

\section{RECURSOS}

- Fitxa número 2 del quadern de $3 r$ de primària. 


\section{EM QUEDE AMB TOT ALLÒ BO}

\section{Fes un llistat de coses que et fan sentir bé:}

Exemple: Jugar a bàsquet, menjar fruita, eixir a passejar amb els meus pares...

-

\section{Fes un llista de coses que NO et fan sentir bé:}

Exemple: Menjar molts dolços, veure moltes hores la televisió, estar molta estona assegut...

RECORDA...

Sempre has de valorar positivament les coses bones i que et fan sentir bé, i intentar canviar aquelles coses menys bones. Així aconseguiràs sentir-te millor amb tu mateix! 


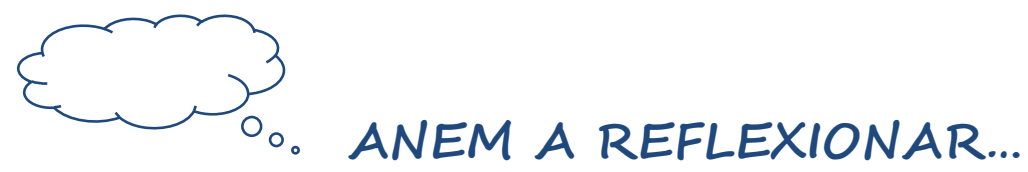

Després d'haver realitzat les activitats anteriors, reflexionarem sobre els aspectes que hem treballat. Per a això, contesta les següents qüestions:

1. És important conèixer-nos bé a nosaltres mateixos i als altres.

Vertader $\quad \square$ Fals

2. Cadascun de nosaltres som únics, autèntics i diferents.

Vertader $\quad \square$ Fals

3. Què cal fer per a sentir-se bé? 
FITXA D'AVALUACIÓ PER AL PROFESSOR/A DE LES ACTIVITATS DEL

BLOC D'AUTOESTIMA

1. Com t'ha resultat dur a terme les tasques segons les indicacions exposades en les fitxes? Molt difícil $\square \quad$ Difícil $\square \quad$ Normal $\square \quad$ Fàcil $\square \quad$ Molt fàcil $\square$

2. Creus que es compleix l'objectiu proposat? Sí $\square \quad$ No $\square$

3. Has introduït les activitats al contingut curricular assenyalat o en algun altre?

T emes indicats $\square \quad$ Altres $\square$ (indica quins:

4. Has utilitzat altres recursos a part dels que apareixen a la fitxa? Sí $\square \quad$ No $\square$

5. ¿Faries alguna modificació de millora en les fitxes per assolir els objectius de manera més òptima? Sí $\square \quad$ No $\square$

(en cas afirmatiu, indica quina:

6. Com s'han sentit els alumnes en realitzar les activitats? (motivació, implicació, interacció amb altres, ....)

7. Hi ha algun aspecte que consideres oportú comenta per a la millora del programa? 


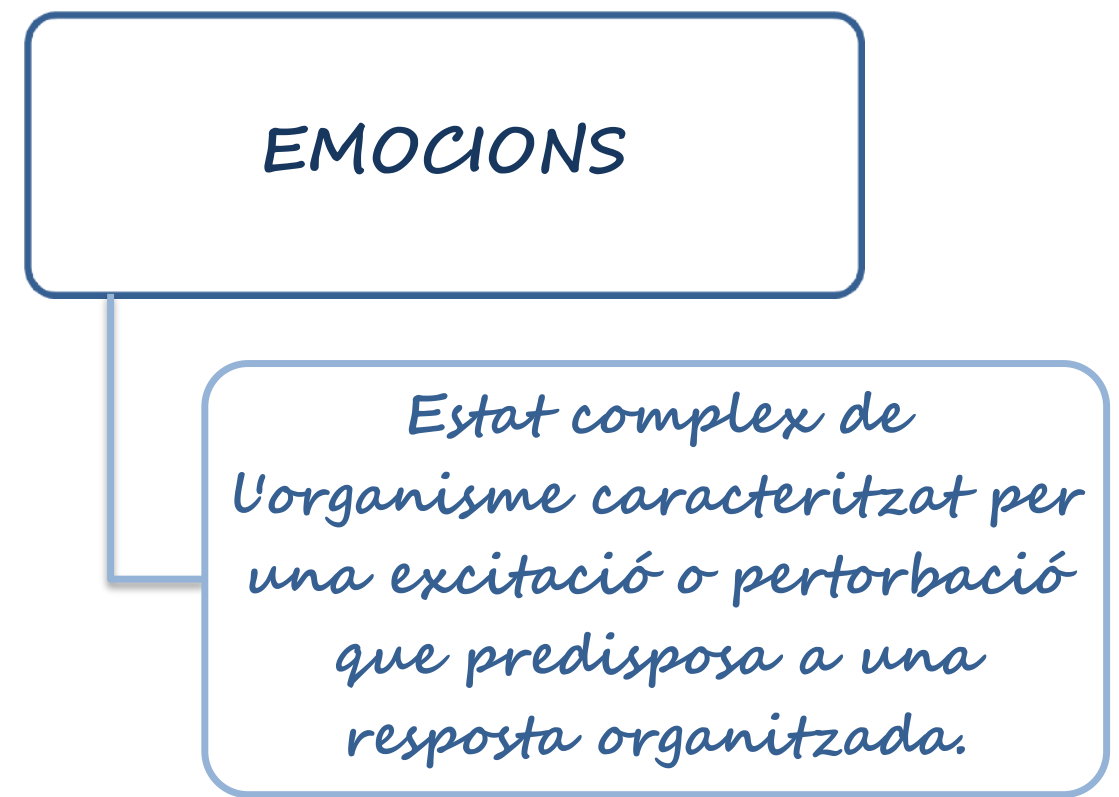

Objectius.

$\checkmark$ Tenir consciencia i discriminar les emocions.

$\checkmark$ Reconèixer les nostres emocions i expressar-les adequadament. 
ASSIGNATURA: CIÈNCIES SOCIALS

ACTIVITAT: EL QUE SENTIM

CONTINGUTS: L'AIGUA I EMOCIONS

\section{OBJECTIUS CURRICULARS}

- Reflexionar sobre la importància de l'aigua.

- Recordar els diferents estats de l'aigua.

\section{OBJECTIUS SOBRE LA TEMÀTICA}

- Desenvolupar la consciència del que són les emocions.

- Discriminar diferents tipus d'emocions.

\section{METODOLOGIA / PROCEDIMENT}

La present activitat formarà part de la unitat en qual es treballa l'aigua. Juntament amb aquest contingut curricular, en aquesta activitat treballarem també les emocions. Per això hem elaborat la fitxa número 4, que cada alumne té al seu quadern de treball.

4. En primer lloc, abans de començar la fitxa, comentarem el següent en gran grup:

En aquest tema hem parlat sobre l'aigua; els seus estats, el cicle de l'aigua, etc., i també hem comentat com d'important és que tots tinguem aigua neta. Tots nosaltres tenim molta sort perquè tenim aigua neta a casa nostra cada dia per poder dutxarnos, fer el menjar, etc., i també tenim fonts i rius on podem agafar aigua per beure. Però com creieu que se senten el nens que no tenen aigua neta per beure o per rentarse?

(Deixem que els alumnes contesten a aquesta pregunta, i donem èmfasi en què nomenen diferents emocions com l'enuig, tristesa, preocupació, ira, etc.)

Com bé heu dit, aquests nens es poden sentir tristos, preocupats, enfadats... perquè no tenen aigua neta. Tot això que senten aquests nens són emocions. Les nostres emocions canvien segons el succés que experimentem, per exemple hi ha dies que sentim alegria perquè les coses ens surten bé, altres dies sentim tristesa perquè alguna cosa va malament, o sentim enuig per algun motiu. Sentir por, vergonya, tristesa, ira, sorpresa...,és una resposta del nostre organisme davant un succés determinat.

5. Respondran individualment a la primera qüestió:

Ara que ja hem parlat de què són les emocions, anem a respondre cada un a la primera pregunta, en què ens pregunten: Saps el que són les emocions? Explica-ho.

6. Explicació de la segona qüestió en gran grup:

Ja hem definit el que són les emocions, però què emocions coneixeu i heu experimentat vosaltres? Doncs hi ha moltes; alegria, tristesa, enuig, sorpresa, etc.

(Anem anotant a la pissarra emocions que ens van dient, i fem un llistat de les que coneixen)

Llavors ara el que farem és llegir les emocions que tenim al principi de la segona activitat i relacionar-les amb les frases que tenim més a baix.

(Fem que algun alumne llegeixi en veu alta la primera frase, i entre tots donem la 
resposta, al mateix temps comentem la frase i recordem els estats de l'aigua, i anem fent el mateix amb totes les frases fins que quedi associada cada frase amb un sentiment. Tenim en l'apartat d'indicadors d'avaluació la resposta).

\section{TEMPORALITZACIÓ}

Temps aproximat de l'activitat 20 minuts:

1. Explicació inicial: 5 minuts.

2. Resposta a la primera qüestió: 5 minuts

3. Resolució de la segona qüestió: 10 minuts

\section{ORIENTACIONS}

- Definició de les emocions podria ser la següent, encara que no és l'única: "Resposta del nostre organisme davant un succés determinat".

- Facilitem a continuació les respostes al segon exercici, encara que hem de recordar que cada un sent les coses d'una manera diferent, ja que en una mateixa situació cada alumne pot experimentar una emoció diferent. Per tant, l'objectiu principal és que experimentin una emoció davant d'una situació determinada i que sàpiguen diferenciar de quin es tracta.

1. Que bé que les fonts tinguin aigua potable per a tots! - Alegria

2. Vaja, el riu està sec! Això no ho havia vist mai així, ha de ser perquè fa temps que no plou - Sorpresa

3. Va ser horrible veure com hi ha nens del desert que no poden beure aigua neta cada dia, haurien de fer alguna cosa - Preocupació

4. Papà, has deixat els gels al sol i s'han fos! - Enuig

5. Jo no vull pujar a la muntanya, està nevant molt i és molt perillós! - Por

6. És una llàstima que hi hagi gent que tiri escombraries en les platges i rius, així contaminen l'aigua- Tristesa

\section{RECURSOS}

- Fitxa número 4 del quadern de $3 r$ de primària. 


\section{EL QUE SENTIM}

\section{Saps què són les emocions? Explica-ho.}

\section{Escriu al costat de cada oració l'emoció que li correspon.}

\section{Enuig Tristesa Alegria Por Preocupació Sorpresa}

1. Que bé que les fonts tinguin aigua potable per a tots!

2. Vaja, el riu està sec! Això no ho havia vist mai així, ha de ser perquè fa temps que no plou.

3. Va ser horrible veure com hi ha nens del desert que no poden beure aigua neta cada dia, haurien de fer alguna cosa

4. Papà, has deixat els gels al sol i s'han fos!

5. Jo no vull pujar a la muntanya, està nevant molt i és molt perillós!

6. És una llàstima que hi hagi gent que tiri escombraries en les platges i rius, així contaminen l'aigua

\section{RECORDA...}

Hi ha dies que sentim alegria perquè les coses ens surten bé, altres dies sentim tristesa perquè alguna cosa va malament, o sentim enuig per algun motiu. Sentir por, vergonya, tristesa, ira, sorpresa...,és una resposta del nostre organisme davant un succés determinat. 
ASSIGNATURA: CIÈNCIES SOCIALS

\section{ACTIVITAT: DIGUES COM ET SENTS}

\section{CONTINGUTS: VIVIM EN COMUNITAT I EMOCIONS}

\section{OBJECTIUS CURRICULARS}

- Reflexionar sobre la importància d'una convivència familiar i escolar positiva.

- Desenvolupar hàbits per millorar la convivència.

\section{OBJECTIUS SOBRE LA TEMÀTICA}

- Reconèixer les nostres emocions.

- Expressar adequadament les nostres emocions als altres.

\section{METODOLOGIA/ PROCEDIMENT}

Aquesta activitat la treballarem durant el tema que avarca els continguts relacionats amb aspectes de viure en societat. Així abordarem continguts d'aquesta temàtica juntament amb les emocions. La present activitat la trobarem en la fitxa 5 del quadern d'activitats de $3 r$ de primària.

1. Iniciarem l'activitat recordant en grup que s'ha comentat en l'activitat anterior:

L'altre dia vam estar treballant les emocions, qui recorda el que vam dir que eren?

(Deixem que els alumnes vagin donant resposta, els donem feedback positiu orientant cap a la resposta correcta i també podem posar exemples: molt bé, què més coses podem dir de les emocions?, quines emocions coneixeu vosaltres ?, si avui em surt tot mal com em sento?, etc. Per finalitzar li diem a algun alumne que llegeixi la definició inicial que tenen en el requadre de la fitxa on posa Recorda: Hi ha dies que sentim alegria perquè les coses ens surten bé, altres dies sentim tristesa perquè alguna cosa va malament, o sentim enuig per algun motiu. Sentir por, vergonya, tristesa, ira, sorpresa,...,és una resposta del nostre organisme davant un succés determinat.)

2. Introducció de l'activitat en grup:

Com hem vist ara, les emocions són el que les persones sentim quan ens passa alguna cosa. Cadascú té unes emocions diferents $i$ hem d'aprendre a comunicar aquestes emocions adequadament. Nosaltres vivim amb una altra gent, venim al col-legi i aquí ens relacionem amb els companys i mestres, vam arribar a casa i estem amb els nostres pares, germans, avis,...,amb els que passem moltes hores i és molt important que convisquem a gust i sense problemes. Per això, hem de saber que per no tenir problemes amb els amics, companys, familiars,..., i també per sentir-nos millor amb nosaltres mateixos, és molt important que aprenguem a reconèixer les nostres emocions, i també aprendre a explicar adequadament als altres el que ens passa.

3. Treballem la primera activitat de la fitxa individualment:

Ara llegirem, cada un individualment, les frases que teniu escrites a la fitxa i les anem a completar. 
4. Reflexió i resolució en grup de la segona activitat:

En completar aquestes frases hem escrit les emocions que sentim i el que ens fa sentir així, doncs això és reconèixer les nostres emocions. Però a més de reconèixer-les, hem de saber també com expressar-les adequadament, per això anem a llegir la següent activitat.

(Diem a algun alumne que llegeixi la frase que es planteja en l'enunciat: El teu germà sempre t'agafa la teva gorra preferida de la teva habitació, sense demanar-te permís per posar-se-la)

A veure, penseu que us passa això a vosaltres, que un germà, germana o cosí us fa això. Què sents $i$ perquè et sents així? Cada un que anoti la resposta, i ara ho comentarem tots junts.

(Deixem un minut perquè anotin les respostes i després els diem que vagin donant les respostes en veu alta i les anotem a la pissarra, quan ja tinguem suficients respostes els diem el següent comentari).

Com podeu veure, cada un pot experimentar un sentiment diferent i no ens hem de preocupar per sentir-nos així, però el més important és aprendre a respondre bé a la situació i saber el què faríem o el que li diríem. Recordeu que hem dit que és molt important explicar per sentir-nos bé amb nosaltres mateixos i amb els altres, cal dirlos el que sentim amb claredat i fermesa, però sense violència ni agressivitat.

(Preguntem als alumnes què respondrien davant d'una situació així i com actuarien, $\mathrm{i}$ tots junts anem comentant les respostes i orientant-les cap el més adequat que podria ser el següent: Cal anar a buscar el nostre germà i dir-li que volem parlar amb ell, hem de parlar amb un to clar i ferm però sense agressivitat ni violència. Li diem que hem vist que ens ha agafat la gorra i que sentim enuig i tristesa perquè no ens agrada que ens l'agafi sense demanar permís, i que per favor la propera vegada ens ho digui abans d'agafar-la).

Després del que hem comentat, escriviu individualment a la fitxa com respondríeu i què diríeu.

\section{TEMPORALITZACIÓ}

Temps aproximat de l'activitat 20 minuts:

1. Recordatori inicial de l'activitat anterior: 4 minuts

2. Introducció a l'activitat: 4 minuts.

3. Completar la primera activitat: 5 minuts

4. Reflexió i resolució de la segona qüestió: 12 minuts

\section{ORIENTACIONS}

- Exemple de resposta a la segona pregunta plantejada (Com respondràs? Què li diràs?) Respecte al segon enunciat (El teu germà sempre t'agafa la teva gorra preferida de la teva habitació, sense demanar-te permís, per posar-se-la):

Cal anar a buscar el nostre germà i dir-li que volem parlar amb ell, hem de parlar amb 
un to clar i ferm però sense agressivitat ni violència. Li diem que hem vist que ens ha agafat la gorra i que estem enfadats, tristos ...perquè no ens agrada que ens l'agafi sense demanar permís i que per favor la propera vegada ens ho digui abans d'agafarla.

\section{RECURSOS}

- Fitxa número 5 del quadern de $3 r$ de primària. 


\section{DIME COM ET SENTS}

\section{Completa les següents frases}

- Avui sento perquè

- Quan sortim al pati sento

- En una baralla sento perquè

2. El teu germà sempre t'agafa la teva gorra preferida de la teva habitació, sense demanar-te permís, per posar-se-la.

Què sents? Per què et sents així?

Com respondràs? Què li diràs?

RECORDA...

És bo que els expliquem adequadament als altres que és el que ens passa, per així no tenir problemes amb els companys i amics, i sentir-nos millor amb nosaltres mateixos.

Si algun dia estàs enfadat, explica als altres com et sents amb claredat i fermesa, però sense violència i sense agressivitat. 


\section{$\overbrace{O}^{3}$ ANEM A REFLEXIONAR...}

Després d'haver realitzat les activitats anteriors, reflexionarem sobre els aspectes que hem treballat. Per a això, contesta les següents qüestions:

1. Escriu dues emocions que hagis tingut i una frase de cada un d'ells.

Emoció:

Frase:

Emoció:

Frase:

2. Perquè és important expressar adequadament les teves emocions als altres? 
FITXA D'AVALUACIÓ PER AL PROFESSOR/A DE LES ACTIVITATS DEL BLOC D'EMOCIONS

1. Com t'ha resultat dur a terme les tasques segons les indicacions exposades en les fitxes? Molt difícil $\square \quad$ Difícil $\square \quad$ Normal $\square \quad$ Fàcil $\square \quad$ Molt fàcil $\square$

2. Creus que es compleix l'objectiu proposat? Sí $\square \quad$ No $\square$

3. Has introduït les activitats al contingut curricular assenyalat o en algun altre?

T emes indicats $\square \quad$ Altres $\square$ (indica quins:

4. Has utilitzat altres recursos a part dels que apareixen a la fitxa? Sí $\square \quad$ No $\square$

5. ¿Faries alguna modificació de millora en les fitxes per assolir els objectius de manera més òptima? Sí $\square \quad$ No $\square$

(en cas afirmatiu, indica quina:

6. Com s'han sentit els alumnes en realitzar les activitats? (motivació, implicació, interacció amb altres, ....)

7. Hi ha algun aspecte que consideres oportú comenta per a la millora del programa? 


\section{AUTOCONTROL}

Gestionar de forma adequada les emocions $i$ els impulsos conflictius.

Objectins:

$\checkmark$ Regular les reaccions tenint en compte les conseqüències d'una determinada situació.

$\checkmark$ Aprendre a utilitzar l'estratègia de regulació més adequada a cada situació. 
ASSIGNATURA: CIÈNCIES DE LA NATURALESA

ACTIVITAT: QUÈ PASSARÀ?

CONTINGUTS: ANIMALS I AUTOCONTROL

\section{OBJECTIUS CURRICULARS}

- Reflexionar sobre les funcions vitals dels animals.

- Conscienciar sobre la importància de la cura dels animals.

\section{OBJECTIUS SOBRE LA TEMÀTICA}

- Identificar possibles reaccions i conseqüències davant d'una situació determinada.

- Desenvolupar la predisposició a regular les reaccions tenint en compte les possibles conseqüències.

\section{METODOLOGIA / PROCEDIMENT}

Aquesta activitat que desenvoluparem a continuació avarca continguts relacionats amb els animals juntament amb continguts que treballen l'autocontrol. Aquesta activitat la podem trobar a la fitxa número 7.

1. Introducció en grup a l'activitat:

Els animals tenen unes funcions vitals que són la nutrició, la relació i la reproducció. Aquestes necessitats que tenen per cobrir, en molts casos necessiten de la nostra ajuda, ja que ells no poden cuidar-se a ells mateixos, tal i com ho fem nosaltres. Per exemple, els gossos necessiten que atenguem les seves necessitats alimentàries, d'higiene i de salut: donar-los menjar, rentar-los, treure'ls a passejar, portar-los al veterinari, etc. Així, sabem que ells, igual que nosaltres, necessiten unes atencions.

A banda de les cures bàsiques, els animals també comparteixen un aspecte amb nosaltres, $i$ és que són éssers socials; es relacionen. Per això cal que coneguin i es relacionin en el seu entorn, $i$ els hem d'ensenyar unes normes de convivència bàsiques.

2. Realització de les tres primeres preguntes individualment:

Com acabem de comentar, tan els animals com els humans som éssers socials, el que significa que interaccionem uns amb altres. A causa d'això, davant d'una determinada situació reaccionem d'una manera diferent. Anem a veure això que comentem en aquesta activitat que se'ns planteja, que és la següent: Entrem a la casa d'un amic. El nostre amic té un gos, i en obrir la porta comença a lladrar-nos i a mossegar-nos la sabata prohibint-nos el pas. Penseu que aquesta situació us passa a vosaltres.

Per què creus que el gos ha reaccionat així i què podriem fer per evitar que torni a passar? Com reaccionaries en aquest moment? I què podria passar si reaccionares així? Agafeu ara la fitxa i responeu a aquestes tres preguntes.

(Cada alumne treballa individualment responent a les tres preguntes.)

3. Posada en comú i reflexió en grup de les respostes a la primera pregunta:

Ara que ja heu pensat en la situació $i$ heu respost a les preguntes, comentarem les respostes que heu donat a la pregunta: Per què creus que el gos ha reaccionat així $i$ 


\section{què podríem fer per evitar que torni a passar?}

(Preguntem als alumnes sobre les respostes $i$ les anem comentant i reflexionant sobre elles. En l'apartat d'orientacions trobarem informació al respecte.)

4. Posada en comú en grup i reflexió de les respostes a la segona i tercera pregunta:

Seguim amb les respostes a la segona i tercera pregunta. Com reaccionàries en aquesta situació? I, què passaria si reaccionares així?

(Fem un llistat a la pissarra amb les reaccions que els alumnes ens vagin dient que han anotat $\mathrm{i}$ amb les conseqüències que creuen que comportarien aquestes reaccions, i valorarem si les conseqüències de la reacció ens afavoreixen o no. Trobarem en els indicadors d'avaluació orientacions de resposta.)

Amb les respostes que heu donat hem pogut veure les diferents reaccions que poden sortir de nosaltres davant d'una mateixa situació i les conseqüències que té el reaccionar d'una manera o d'una altra. Us haureu adonat que algunes reaccions tenen conseqüències que no ens afavoreixen, per exemple si ens posem nerviosos $i$ sacsegem al gos podem rebre una mossegada seva, fer-li mal, el nostre amic es pot enfadar i nosaltres ens sentirem malament. Per tant, reaccionar d'aquesta manera no ens afavoreix. No obstant això, si reaccionem tranquils, li demanem ajuda al nostre amic o li mostrem afecte al gos, les conseqüències seran favorables ja que el nostre amic ens podrà ajudar, el gos es tranquil-litzarà i nosaltres no patirem cap contratemps.

\section{Reflexió final en grup:}

Tot això ens porta a pensar que és important que davant de qualsevol situació que ens passi sapiguem reaccionar d'una manera adequada valorant prèviament les conseqüències $i$ sabent si aquestes ens afavoreixen o no. Igual que amb aquest exemple del gos, això ens pot passar amb un amic, que sense voler ens dóna una empenta, segons com reaccionem les conseqüències seran una o unes altres, per això és important valorar les reaccions que tenim i regular-les per així evitar conseqüències no desitjables.

\section{TEMPORALITZACIÓ}

Temps aproximat de l'activitat 25 minuts:

1. Introducció en grup de l'activitat: 5 minuts.

2. Realització individual de les tres preguntes: 5 minuts.

3. Posada en comú i reflexió primera pregunta: 5 minuts.

4. Posada en comú i reflexió de la segona i tercera pregunta: 5 minuts.

5. Reflexió final: 5 minuts.

\section{ORIENTACIONS}

- La finalitat de la reflexió a les respostes de la primera pregunta és fer conscients els alumnes que els cuidats dels animals també abasten tot allò que té a veure amb el tracte i l'educació que els donem, ja que tenir un animal a casa és una responsabilitat molt gran i nosaltres som els responsables d'ells, de manera que cal 
atendre tant les seves necessitats bàsiques com altres relacionades amb la seva educació i l'ensenyament de normes de convivència.

Les respostes a les preguntes podrien ser les següents: el motiu podria ser perquè el gos no coneix a la persona que entra a casa, té por, defensa la seva casa, etc. EI que podria fer l'amo és no deixar que s'acosti a la porta, portar-lo lligat, ensenyar-li normes perquè obeeixi a certes peticions, etc.

- Amb les respostes a la segona i tercera pregunta volem fer conscients als alumnes que hi ha diferents formes de reaccionar davant d'una determinada situació i cadascuna d'elles comporta conseqüències que poden ser favorables o no. D'ací la importància d'obtenir informació sobre les possibles reaccions, valorant-les i regulant per obtenir conseqüències favorables i desitjables per a nosaltres.

Exemples de reaccions i conseqüències poden ser:

- Colpejar al gos - rebre nosaltres com a resposta un cop, un insult, un retret ...

- Cridem - creem un ambient alterat, enuig, indiferència ...

- Demanem ajuda - tranquil-litat, diàleg, no ens fem mal ...

\section{RECURSOS}

- Fitxa número 7 del quadern de $3 r$ de primària. 


\section{QUÈ PASSARÀ?}

Entrem a la casa d'un amic. El nostre amic té un gos, i en obrir la porta comença a lladrar-nos i a mossegar-nos la sabata prohibint-nos el pas.

- 1. Per què creus que el gos ha reaccionat així i què podríem fer per evitar que torni a passar?

- 2. Com reaccionaries en aquest moment?

- 3. Què passaria si reaccionares així?

RECORDA...

És important que davant de qualsevol situació que ens passi, sapiguem reaccionar d'una manera adequada valorant prèviament les conseqüències de la nostra reacció i sabent si aquestes ens afavoreixen o no. 
CURS: 3 PRIMÀRIA

FITXA: 8

ASSIGNATURA: CIÈNCIES DE LA NATURALESA

ACTIVITAT: PREN-TE EL TEU TEMPS

CONTINGUTS: ENERGIA I AUTOCONTROL

\section{OBJECTIUS CURRICULARS}

- Desenvolupar el concepte d'energia.

- Reflexionar sobre la importància de l'ús responsable de l'energia.

\section{OBJECTIUS SOBRE LA TEMÀTICA}

- Identificar diferents estratègies de regulació.

- Analitzar i valorar la reacció més adequada.

\section{METODOLOGIA / PROCEDIMENT}

La present activitat recull continguts relacionats amb l'ús de l'energia així com també continguts per a treballar l'autocontrol. La fitxa que correspon a aquesta activitat és la número 8 del quadern.

1. Introducció inicial a la activitat:

L'energia, com ja sabeu, és la capacitat de fer funcionar les coses. Hi ha diferents tipus d'energia (mecànica, elèctrica, química, tèrmica, etc.) i per exemple a la nostra llar pot ser emprada per a diferents usos com il/luminar, donar calor, etc.

Així, l'electricitat és una forma d'energia. Gràcies a l'electricitat funcionen les bombetes $i$ els electrodomèstics de casa nostra. Moltes vegades fem un ús inadequat d'aquesta energia, i no ens parem a pensar en l'important que és fer un ús responsable.

Anem a llegir l'enunciat de l'activitat i veurem el que li ha passat a Raquel.

(Un alumne llegeix en veu alta l'enunciat.)

2. Realització en grup de l'activitat donant resposta a les preguntes, i els deixem temps perquè vagin anotant les respostes:

Quin ha estat l'error que ha comès Raquel?

(Els alumnes van aportant idees i els anem conduint cap a la resposta més idònia.)

Quina conseqüència podria portar la reacció de Raquel?

(Seguim amb la pluja d'idees, en aquest cas poden ser moltes les conseqüències, les podem consultar a l'apartat d'orientacions.)

Llavors, sabent que la reacció de Raquel no ha estat la més adequada ja que les conseqüències que comporta no són les desitjables, què li recomanaríeu a Raquel que fes la propera vegada que li passi alguna cosa així? Per exemple li podríem dir que en situacions així, per controlar-se, el que podria fer és aturar-se i pensar fins a 10 abans de reaccionar d'aquesta manera. Quines altres coses podria fer?

(Els alumnes van dient exemples de coses que podria fer, anem dirigint $i$ emfatitzant aquelles respostes que s'ajustin a la nostra finalitat. Podem veure 


\section{exemples a l'apartat d'orientacions).}

Mireu, ara que ja sabem que la reacció no ha estat l'adequada, que sabem el que hem de fer si ens passa alguna cosa així, digueu-me quin creieu que hauria estat una reacció adequada? Jo per exemple crec que podria haver-li dit a la seva mare que ho sent que ha estat una distracció ...Quines altres reaccions positives hagués pogut tenir?

(Seguim amb la pluja d'idees referents a reaccions alternatives. En trobem exemples en l'apartat d'orientacions.)

3. Reflexió en grup final:

El que hem de fer per reaccionar correctament davant de situacions que ens provoquen enuig, ira, ràbia...,és aplicar una de les tècniques de control que hem comentat; ens relaxem, comptem fins a 10, tanquem els ulls i pensem en una altra cosa... Així aconseguirem reaccionar d'una manera positiva, i evitarem problemes $i$ discussions.

\section{TEMPORALITZACIÓ}

Temps aproximat de l'activitat 20 minuts:

1. Introducció en grup de l'activitat: 3 minuts

2. Realització en grup de l'activitat: 15 minuts

3. Reflexió en grup final: 2 minuts

\section{ORIENTACIONS}

- Respostes i orientacions a les preguntes:

1. Una resposta podria ser que Raquel ha deixat encesos llums que no estava fent servir i per tant estava fent un mal ús de l'electricitat i per tant un ús irresponsable d'energia.

2. Les conseqüències que poden comportar la seva reacció poden ser diverses: que la seva mare s'enfadi amb ella, que es senti malament amb si mateixa, que algú de la seva família li retret el que ha fet, etc.

Tota conseqüència que comporti aquesta reacció, si la valorem, veurem que no serà ni favorable ni desitjable per a Raquel i això és el que els hem de transmetre, que aquesta reacció sempre generarà conseqüències indesitjables.

3. El que podria fer Raquel davant situacions com aquesta per controlar és comptar fins a deu, relaxar-se, escoltar música, tancar els ulls i pensar en una altra cosa, etc.

La finalitat d'això és que siguin conscients que certes reaccions porten a situacions no desitjades, per això és important que quan ens passin situacions així ens aturem un moment i fem alguna de les coses que hem dit per així controlar reaccions que no ens beneficia en absolut.

4. En les respostes que obtinguem en aquesta pregunta anem a valorar que hi ha altres maneres de reaccionar davant d'una mateixa situació que són més adequades: dir-li a la seva mare que ho sent, que ha estat una distracció, sortir i 
apagar els llums, etc.

RECURSOS

- Fitxa número 8 del quadern de $3 r$ de primària. 


\section{PREN-TE EL TEU TEMPS}

Raquel estava a la seva habitació estudiant, era un dissabte al matí i feia molt de sol. Havia deixat la llum del bany i dels passadissos enceses sense adonar-se'n. La seva mare va entrar a la seva habitació i li va dir amb un to elevat de veu que s'havia deixat els llums encesos des de feia molta estona i que això no estava bé, ja que estava consumint molta energia innecessàriament. Raquel en aquest moment es va sentir molt trista i amb un atac d'ira va tancar la porta d'un cop.

- 1. Quin ha estat l'error de Raquel?

- 2. Quina conseqüència podria comportar la reacció de Raquel?

- 3. Què podria fer Raquel davant d'una situació així per controlar-se?

- 4. Quines accions alternatives creus que podria haver tingut?

RECORDA...

Per reaccionar correctament davant situacions que ens provoquen enuig, ira, ràbia...,hem d'aplicar una de les tècniques de control. Així aconseguirem reaccionar d'una manera positiva, i evitarem problemes i discussions. 


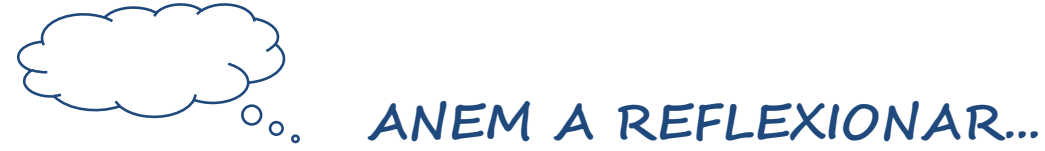

Després d'haver realitzat les activitats anteriors, reflexionarem sobre els aspectes que hem treballat. Per a això, contesta les següents qüestions:

1. Sara està parlant amb la seva amiga Laura. Volen quedar a la tarda, Sara vol anar al parc a patinar però Laura prefereix anar al cinema. Sara vol anar a patinar per sobre de tot, $\mathbf{i}$ comença a cridar-li a la Laura dient-li que és millor anar a patinar i que ella si van al cinema no sortirà. A Laura no li ha agradat l'actitud de Sara i ha marxat sense voler quedar amb ella per jugar.

- Creus que la reacció de Sara és la correcta?
Sí
No

- La reacció d'enuig de Sara ha tingut com a conseqüència que Laura se n'anés. Aquesta conseqüència és bona per a Sara?
Sí
No

- Què podria haver fet en comptes de cridar-li a la seva amiga? Quin consell li donaries a Sara?

2. En situacions que ens provoquen enuig, ràbia, ira...,què podem fer per controlar-nos?

- Comptar fins a 10 
FITXA D'AVALUACIÓ PER AL PROFESSOR/A DE LES ACTIVITATS DEL

BLOC D'AUTOCONTROL

1. Com t'ha resultat dur a terme les tasques segons les indicacions exposades en les fitxes? Molt difícil $\square \quad$ Difícil $\square \quad$ Normal $\square \quad$ Fàcil $\square \quad$ Molt fàcil $\square$

2. Creus que es compleix l'objectiu proposat? Sí $\square \quad$ No $\square$

3. Has introduït les activitats al contingut curricular assenyalat $o$ en algun altre?

T emes indicats $\square \quad$ Altres $\square$ (indica quins:

4. Has utilitzat altres recursos a part dels que apareixen a la fitxa? Sí $\square \quad$ No $\square$

5. ¿Faries alguna modificació de millora en les fitxes per assolir els objectius de manera més òptima? Sí $\square \quad$ No $\square$

(en cas afirmatiu, indica quina:

6. Com s'han sentit els alumnes en realitzar les activitats? (motivació, implicació, interacció amb altres, ....)

7. Hi ha algun aspecte que consideres oportú comenta per a la millora del programa? 


\section{PREVENCIÓ I RESOLUCIÓ DE CONFLICTES}

Evitar i solucionar discrepancies entre dos $\sigma$ més interessos simultanis que algunes voltes donen lloc a un estat de tensió emocional que comporta estats dansietat i comportaments impulsius.

\section{Objectius.}

$\checkmark$ Conèixer què són els grups i les seues característiques.

$\checkmark$ Ser conscients dels nostres actes i de les conseqüències que comporten. 
CURS: 3r PRIMÀRIA

FITXA: 10

ASSIGNATURA: CIÈNCIES SOCIALS

ACTIVITAT: ENS RELACIONEM

CONTINGUTS: CONVIVIM EN SOCIETAT I PREVENCIÓ I RESOLUCIÓ DE CONFLICTES

\section{OBJECTIUS CURRICULARS}

- Desenvolupar el concepte de convivència.

- Valorar la convivència ciutadana positiva.

\section{OBJECTIUS SOBRE LA TEMÀTICA}

- Conèixer què són les relacions en grup.

- Reflexionar sobre les característiques de les relacions en grup.

\section{METODOLOGIA / PROCEDIMENT}

Aquesta activitat que anem a desenvolupar a continuació està integrada en el tema de la convivència ciutadana, per la qual cosa treballarem aquests continguts juntament amb continguts relacionats amb la prevenció i resolució de conflictes. Per a això hem elaborat la fitxa 10 , amb la qual treballarem aquests continguts.

1. Introducció tots junts del concepte de grup i realització en grup i posteriorment individual de la primera activitat:

A veure, anem a recordar un concepte que hem treballat; qui sabria dir-me què és la convivència?

(Deixem que els alumnes responguin i els anem donant feedback respecte a la definició d'aquest concepte: conviure és viure en companyia d'uns altres.)

D'acord, llavors sabem bé que conviure és viure en companyia d'uns altres, llavors significa viure amb més gent. I Sabríeu dir-me que és un grup?

(Els alumnes van donant respostes i els orientem cap a la següent definició: un grup és quan tres o més persones es reuneixen amb una determinada finalitat com pot ser jugar, parlar... Ara els alumnes han de respondre a la primera pregunta que se'ls planteja en la fitxa.)

2. Realització en grup de la segona i tercera activitat i després anotació individual de la resposta:

Bé, ara que ja sabem el que és un grup, digueu-me exemples de grups que tingueu vosaltres, per exemple l'equip de bàsquet seria un grup perquè s'ajunten més de tres persones amb la finalitat de practicar el bàsquet. Quins més em podeu dir i quines activitats realitzeu en grup?

(Escoltem i guiem les opinions i comentaris dels alumnes tractant sempre que es respecti el torn de paraula i que tots puguin parlar, i a continuació els diem que ho anotin la resposta en la segona i tercera pregunta.)

3. Reflexió en grup sobre les característiques que tenen les relacions en grup i resposta individual a la quarta pregunta:

Llavors ja sabem que és un grup, hem vist els grups dels quals formeu part i també 
sabem les activitats que realitzeu en grup, però digueu-me... Com em diríeu que són les relacions en grup? Creeu que són fàcils i que sempre ens portem tots bé, són difícils perquè de vegades és complicat posar-se d'acord... Què opineu?

(Els alumnes responen a la pregunta aportant la seva opinió i en finalitzar els diem que responguin a la quarta pregunta que fa referència a aquest aspecte.)

4. Reflexió final en grup:

Com heu pogut veure al llarg del tema, tots convivim en societat, doncs ens relacionem amb molta gent. Quan ens ajuntem més de tres persones amb una determinada finalitat estem formant un grup, un grup que en aquest moment aquesta convivint junt. Tots formem parts de molts grups: grup de companys de classe, grup d'amics, grup d'esport... i formem cada grup amb una finalitat que pot ser jugar, passar una bona estona, practicar un esport... Moltes vegades quan estem en grup apareixen discussions, cridem... i és que formar part d'un grup no és fàcil, per això és important que aprenguem a parlar, a participar i a actuar correctament per poder així gaudir i tenir una convivència positiva.

(Podem deixar temps perquè acabin de completar les respostes a les preguntes a aquells que no els hagi donat temps durant l'activitat.)

\section{TEMPORALITZACIÓ}

Temps aproximat de l'activitat 20 minuts:

1. Recordem el concepte de convivència i introduïm el de grup: 5 minuts.

2. Grups dels que formen part i activitats de grup: 5 minuts.

3. Característiques del grup: 5 minuts.

4. Reflexió final: 5 minuts.

\section{ORIENTACIONS}

- Concepte convivència: conviure és viure en companyia d'altres

- Concepte grup: un grup és quan tres o més persones es reuneixen amb una determinada finalitat com pot ser jugar, parlar...

- Exemples de grups: grup d'amics, companys de classe, de futbol, de dansa...

- Exemples d'activitats en grup: jugar a bàsquet, sortir a patinar, parlar de música, cuinar, anar a veure una pel·lícula...

\section{RECURSOS}

- Fitxa número10 del quadern de $3 r$ de primària. 


\section{ENS RELACIONEM}

1. Què és un grup?

\section{Quins grups tens tu?}

- Equip de bàsquet

-

-

3. Quines activitats realitzes en grup? Fes un llistat.

- Jugar al pati amb companys.

4. Com consideres que són les relacions en grup? Raona la teua resposta.

RECORDA...

Quan ens ajuntem més de tres persones formem un grup i, normalment, les relacions que mantenim entre nosaltres no solen ser fàcils. 
CURSO: 3ㅇ PRIMARIA

FITXA: 11

ASSIGNATURA: CIÈNCIES SOCIALS

ACTIVITAT: FA UN TEMPS...

CONTINGUTS: EL NOSTRE PASSAT PERSONAL I PREVENCIÓ I RESOLUCIÓ DE CONFLICTES

\section{OBJECTIUS CURRICULARS}

- Valorar les situacions viscudes en el passat.

- Reflexionar sobre el futur.

\section{OBJECTIUS SOBRE LA TEMÀTICA}

- Reflexionar sobre els sentiments $\mathrm{i}$ conseqüències que produeixen els nostres actes.

- Reconèixer les conductes inadequades per modificar-les.

\section{METODOLOGIA / PROCEDIMIENT}

Aquesta activitat l'anem a desenvolupar en el tema que tracta el pas del temps. D'aquesta manera, en l'activitat, treballarem aquest contingut i a més la resolució de conflictes. Presentem l'activitat en la fitxa 11 del quadern.

1. Introducció en grup del concepte passat i el pas del temps:

Durant aquest tema hem vist el que és el passat i el pas del temps. Sabem que tot allò que ja hem viscut forma part del passat, i cadascun de nosaltres té un passat personal perquè hem viscuts coses diferents. Vosaltres sou molt joves, però així i tot des que heu nascut heu fet moltes coses que ara formen part del vostre passat.

Llavors anem a veure, digueu-me coses que us hagin ocorregut en el vostre passat quan formàveu part d'algun grup. Per exemple algun dia al pati, algun moment que considereu important amb els amics...

(Deixem temps perquè els alumnes donin respostes i expliquin coses del seu passat.)

2. Reflexió i valoració en grup:

Molt bé, doncs com heu vist cadascú ens ha explicat coses diferents del seu passat, pot ser que algunes d'elles les recordem amb més afecte $i$ altres coses que ens hagin passat no ens agradin molt... Per exemple, vam anar a un viatge amb els nostres amics i recordem coses molt boniques, no obstant això també recordem que un dia discutirem amb un company mentre jugàvem i no ens va agradar aquesta situació... Tots hem viscut coses bones $i$ coses dolentes, les bones cal recordar-les i les no tan bones cal tractar de millorar-les perquè no ens tornin a ocórrer en el present o en el futur.

A veure, penseu una situació del passat en la qual hàgiu estat en grup i hàgiu tingut una situació que no ha estat positiva $i$ una altra que hagi estat positiva i com us heu sentit en aquest moment. Per exemple us heu cridat o barallat amb un amic, o heu sortit a jugar amb un amic a un parc... Perquè recordeu el que vam dir l'altre dia; les relacions en grup no són fàcils...

(Deixem uns segons als alumnes perquè pensin històries que han viscut) 
3. Reflexió en grup sobre la importància de modificar aquestes situacions grupals seguint les normes de grup:

Segur que recordeu alguna situació així, les positives les recordareu amb afecte i us provocaran sentiments de felicitat, de diversió, de tranquil.litat... no obstant això aquelles que recordeu com que no han estat positives per a vosaltres voldreu que no tornin a ocórrer doncs us hauran fet sentir malament, perdre amistats, enfadar-vos.... Si és així, el que hem de fer és pensar com les podríem canviar, és a dir, reflexionar sobre el que vam fer malament en aquest moment i pensar quin seria la manera en la qual hauriem d'haver actuat perquè la situació no hagués acabat d'aquesta manera. I voleu saber una cosa?, si ho pensem bé i detectem quin ha estat el problema i evitem repetir-ho, això farà que ens asseiem millor, farem amistats amb més facilitat, coneixerem millor a la gent, etc.

Per exemple, un grup d'amics discuteixen $i$ es criden fort parlant els dos alhora. Podríem dir que aquesta conducta no és adequada. El que ha ocorregut és que cridarse no està bé, cal saber donar la teva opinió tranquil.lament, sense elevar la veu $i$ parlant els dos respectant els torns fins a arribar a un acord. Si sabem que això ha estat el que ha provocat la discussió, la propera vegada ens acordarem d'això i recordarem que no hem de tornar a fer això, doncs l'única cosa que ens causarà són problemes.

Ara anem a agafar la fitxa, i recordant tot el que hem comentat, anem a pensar cadascun una situació del vostre passat que ha estat positiva i una altra que no ho ha estat, $i$ individualment anem a anar contestant a les preguntes.

\section{TEMPORALITZACIÓ}

Temps aproximat de l'activitat 20 minuts:

1. El passat i el pas del temps: 5 minuts.

2. Reflexió i valoració de situacions passades: 5 minuts.

3. Modificació de las relacions en grup negatives: 10 minuts.

\section{ORIENTACIONS}

- És important que recordin els fets negatius i positius del passat com alguna cosa que els ajudi a millorar el present i el futur, és a dir, que ho utilitzin com un element de millora. Per a això han d'aprendre a definir ben bé el que va ocórrer i el que fa sentir, i saber si són conductes adequades o no. Una vegada detectades les inadequades cal ajudar-los a buscar com va ser l'acció que va derivar en aquesta situació i a buscar alternatives a aquesta actuació.

\section{RECURSOS}

- Fitxa número11 del quadern de $3 r$ de primària. 


\section{FA UN TEMPS...}

1. Pensa una situació del passat en la qual hagis estat en grup i la relació hagi estat positiva.

- Què va ocórrer?

- Com et vas sentir?

- Canviaries alguna cosa?

2. Ara pensa una situació del passat en la qual hagis estat en grup i la relació no hagi estat positiva.

- Què va ocórrer?

- Com et vas sentir?

- Canviaries alguna cosa?

RECORDA...

Si ens relacionem positivament amb la gent ens sentirem millor, farem amistats amb més facilitat, coneixerem millor a la gent, etc. 


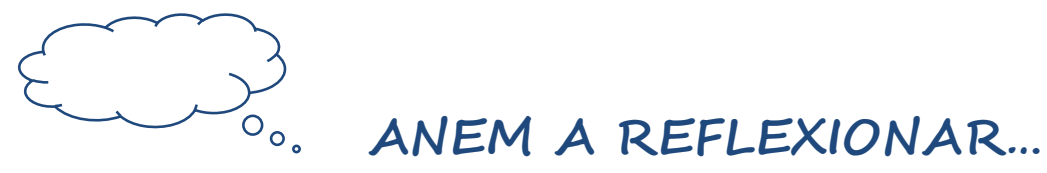

Després d'haver realitzat les activitats anteriors, reflexionarem sobre els aspectes que hem treballat. Per a això, contesta les següents qüestions:

1. Com diries que són les relacions en grup?

2. És important reconèixer les situacions bones i dolentes que hem viscut en el passat, $i$ veure què podem canviar de les dolentes perquè no tornin a ocórrer en el futur.

Vertader $\quad \square$ Fals

3. Què ocorre quan ens barallem, discutim, etc. amb els companys? Raona la teua resposta. 
FITXA D'AVALUACIÓ PER AL PROFESSOR/A DE LES ACTIVITATS DEL BLOC DE PREVENCIÓ I RESOLUCIÓ DE CONFLICTES.

1. Com t'ha resultat dur a terme les tasques segons les indicacions exposades en les fitxes? Molt difícil $\square \quad$ Difícil $\square \quad$ Normal $\square \quad$ Fàcil $\square \quad$ Molt fàcil $\square$

2. Creus que es compleix l'objectiu proposat? Sí $\square \quad$ No $\square$

3. Has introduït les activitats al contingut curricular assenyalat o en algun altre?

T emes indicats $\square \quad$ Altres $\square$ (indica quins:

4. Has utilitzat altres recursos a part dels que apareixen a la fitxa? Sí $\square \quad$ No $\square$

5. ¿Faries alguna modificació de millora en les fitxes per assolir els objectius de manera més òptima? Sí $\square \quad$ No $\square$

(en cas afirmatiu, indica quina:

6. Com s'han sentit els alumnes en realitzar les activitats? (motivació, implicació, interacció amb altres, ....)

7. Hi ha algun aspecte que consideres oportú comenta per a la millora del programa? 


\title{
BON ÚS DE LES TIC
}

\author{
Utilitzar adequadament $i$ amb \\ responsabilitat Internet $i$ les noves \\ tecnologies.
}

Objectins.

$\checkmark$ Ser conscients de l'ús que fan de les TIC.

$\checkmark$ Conèixer els beneficis i els riscos de les TIC. 
CURSO: 3 PRIMARIA

FICHA: 13

ASIGNATURA: LENGUA CASTELLANA Y LITERATURA

ACTIVIDAD: UN DÍA CUALQUIERA

CONTENIDOS: SIGNOS DE PUNTUACIÓN Y BUEN USO DE LAS TIC

\section{OBJETIVOS CURRICULARES}

- Interpretar a través de la reflexión y el diálogo de textos próximos a su experiencia.

- Planificar y escribir de forma reflexiva un texto narrativo utilizando los signos de puntuación correctos.

\section{OBJETIVOS SOBRE LA TEMÁTICA}

- Conocer que son las nuevas tecnologías.

- Reflexionar sobre el uso cotidiano de los dispositivos tecnológicos.

\section{METODOLOGÍA / PROCEDIMIENTO}

En esta actividad vamos a trabajar contenidos relacionados con el buen uso de los signos de puntuación, así como también el buen uso de las nuevas tecnologías. Para ello hemos elaborado la ficha 13.

1. Introducción en grupo de la actividad:

Vamos a realizar una actividad en la que vamos a escribir un texto narrativo sobre cómo es un día nuestro utilizando las nuevas tecnologías. Pero decidme, ¿qué son las nuevas tecnologías? ¿Quién sabría decírmelo?

(Favorecemos el debate y la participación entre los alumnos sobre el concepto de nuevas tecnologías. Encontraremos en el apartado de orientaciones una definición del concepto de nuevas tecnologías e información al respecto que consideramos que es importante transmitir a los alumnos.)

2. Realización en grupo de la primera actividad:

Ahora que ya conocemos bien que son las nuevas tecnologías, quiero que leáis el texto que tenemos en la primera actividad de la ficha.

(Vamos nombrando a varios alumnos para que lean en voz alta el texto que se presenta en la primera actividad donde se relata un día en la vida de una niña de 9 años llamada Clara.)

3. Realización individual de la segunda actividad:

Como habréis podido ver, en el texto que hemos leído se relata un día de la vida de Clara que es una niña de vuestra edad. Pues ahora lo que vamos a hacer es que cada uno de vosotros va a escribir un texto narrativo en el cual vais a contar como es un día en vuestras vidas teniendo en cuenta el uso que hacéis de las nuevas tecnologías que, como ya hemos comentado, son principalmente el teléfono móvil, la televisión, el ordenador y los videojuegos. Recordad que como ya hemos visto en estos temas, es muy importante utilizar bien los signos de puntuación, pues si no los colocamos donde toca puede cambiar el significado del texto. 
(Los alumnos trabajan individualmente redactando un texto narrativo, de máximo 10 líneas, y prestando especialmente atención al uso que hacen de los signos de puntuación.)

4. Reflexión grupal de la primera y la segunda actividad:

Llegados a este punto, tras haber leído el texto de la actividad, y como ya habéis escrito un día vuestro con el uso de las tecnologías, quiero que me contéis que similitudes tenéis con Clara, que es lo que más os ha sorprendido...

(Debatimos en clase para que los alumnos vayan reflexionando sobre el uso que hacen de las nuevas tecnologías y las similitudes con Clara. Encontraremos más información y pautas para este debate en el apartado de orientaciones.)

5. Reflexión final de la actividad:

Al leer el texto y hacer la redacción muchos os habréis dado cuenta del tiempo que pasamos todos los días utilizando dispositivos tecnológicos. Sabemos que hoy en día son necesarios para muchas cosas, y que nos aportan muchas cosas buenas, pero ojo, también hay que tener mucho cuidado con el uso que hacemos de ellas y no abusar de su utilización. A lo largo del día tenemos tiempo para realizar muchas actividades con los amigos, con la familia, con compañeros...y no debemos dejar de hacer y practicar actividades con otra gente o cosas que nos gustan, por actividades con dispositivos electrónicos. Lo importante es organizar bien el tiempo y tener ratos para realizar todo aquello que nos guste, siempre saludablemente.

\section{TEMPORALIZACIÓN}

Tiempo aproximado de la actividad 20 minutos:

1. Introducción de la actividad: 3 minutos.

2. Realización de la primera actividad: 4 minutos.

3. Realización de la segunda actividad: 6 minutos.

4. Reflexión de la primera y de la segunda actividad: 4minutos.

5. Reflexión final: 3 minutos.

\section{ORIENTACIONES}

- Las nuevas tecnologías son dispositivos electrónicos que nos ayudan en nuestra vida diaria. Estas son el teléfono móvil que nos permite comunicarnos con otra gente esté en el lugar que esté, el ordenador con el que podemos conectarnos a internet o realizar cualquier tarea, el televisor mediante las cual nos entretenemos o los videojuegos con los que podemos jugar solos o con los amigos para divertirnos.

- Aunque inicialmente hemos dicho que las nuevas tecnologías nos ayudan en nuestro día a día, dato que sería positivo, debemos remarcar a los alumnos que su uso también implica otros peligros por lo que es importante hacer un buen uso y seguir todos aquellos consejos que nos ofrecen los adultos para un uso seguro de estos dispositivos.

- En la reflexión grupal de la primera y segunda actividad, es muy importante que los 
alumnos, a partir de estos dos textos, se den cuenta del uso que hacen de las tecnologías, que están presentes todos los días y a todas horas en nuestros días. Podemos plantearles preguntas como ¿creéis que es bueno que utilicemos tanto las tecnologías? ¿los mayores utilizan tanto estos dispositivos como nosotros? ¿es necesario utilizarlas tanto? ¿nos resulta beneficioso utilizarlas? ¿puede el uso de estas tecnologías causarnos algún problema? ¿dejamos de hacer otras cosas por utilizar tantas horas los dispositivos electrónicos?...Es decir, plantearles cuestiones que les hagan reflexionar sobre el uso que hacen de las tecnologías porque muchas veces las tenemos tan integradas en nuestro día a día que no somos conscientes del abuso que hacemos de ellas.

\section{RECURSOS}

- Ficha número 13 del cuaderno de 3o de primaria. 


\section{UN DÍA CUALQUIERA}

\section{Lee el siguiente texto:}

Clara, una niña de 9 años, se levanta a las siete y media de la mañana: se lava, se viste y mientras desayuna ve en la televisión o en la tableta dibujos o series.

Más tarde, a las 9 de la mañana, entra en el colegio hasta las cinco de la tarde. Mientras está en el colegio Clara se centra en su trabajo en el aula con sus profesores y compañeros. A la hora del recreo habla y juega con ellos.

Cuando sale por la tarde, mientras merienda mira en la televisión algún programa. A continuación, antes de ponerse a hacer los deberes o a estudiar se conecta al móvil y se envía mensajes de WhatsApp con amigos o compañeros de clase. Después se pone a hacer los deberes con el ordenador encendido escuchando música que se descargó el día anterior y mientras revisa su cuenta de la red social buscando alguna novedad.

Terminados ya los deberes, se ducha y cena, y antes de irse a dormir se pone en el ordenador o la tableta a ver videos en YouTube mientras se descarga nuevos juegos.

2. Escribe a continuación un texto narrativo contando como es tu día a día con el uso de las nuevas tecnologías. Recuerda utilizar correctamente los signos de puntuación.

RECUERDA...

A lo largo del día tenemos tiempo para realizar muchas actividades, por eso no debemos dejar de hacer y practicar actividades con otra gente o cosas que nos gustan por pasar tiempo con los dispositivos electrónicos. Lo importante es organizar bien el tiempo y tener ratos para realizar todo aquello que nos guste, siempre saludablemente. 
CURSO: 3ㅇ PRIMARIA

FICHA: 14

ASIGNATURA: LENGUA CASTELLANA Y LITERATURA

ACTIVIDAD: ¿TÚ QUÉ OPINAS?

CONTENIDOS: LA NOTICIA Y EL BUEN USO DE LAS TIC

\section{OBJETIVOS CURRICULARES}

- Leer de forma guiada, adecuándose al formato y a la estructura textual, textos del ámbito social.

- Reconocer una noticia y sus partes.

\section{OBJETIVOS SOBRE LA TEMÁTICA}

- Incentivar el desarrollo de actitudes críticas sobre el uso de las nuevas tecnologías.

- Favorecer el debate entre los alumnos sobre el uso saludable de las TIC, sus beneficios y sus riesgos.

\section{METODOLOGÍA / PROCEDIMIENTO}

En esta actividad vamos a trabajar contenidos relacionados con la noticia, así como también contenidos sobre el uso de las nuevas tecnologías. Para ello hemos elaborado la ficha 14.

1. Introducción y realización grupal de la primera actividad:

Vamos a realizar una actividad, y para ello quiero que en primer lugar leamos el texto que encontraremos en la ficha.

(Leemos en voz alta la noticia que presentamos en la primera actividad.)

2. Realización grupal de la segunda actividad:

Muy bien, ahora que ya hemos leído el texto decidme, ¿qué tipo de texto es? ¿Lo conocéis?

(Los alumnos van aportando sus ideas de modo que lleguen a la conclusión de que se trata de una noticia. Para ello les vamos guiando haciendo que se fijen bien en la estructura, contenido...)

De acuerdo, como bien habéis dicho se trata de una noticia. En clase ya hemos estudiado la noticia, y ¿sabríais decirme qué partes tiene la noticia?

(De nuevo los alumnos van aportando sus ideas y conjuntamente con nuestra ayuda vamos acercándonos a la respuesta correcta. Encontraremos más información en el apartado de orientaciones.)

Ahora, que ya sabemos cuáles son las partes, vamos a colorear cada parte de un color para diferenciarlas.

(Vamos leyendo en voz alta el texto y marcando de qué punto a qué punto es cada parte de la noticia.)

3. Reflexión grupal del texto:

De acuerdo, entonces hemos quedado que el texto que hemos leido es una noticia, y la noticia es un texto que trata temas que son interesantes y actuales para un grupo de personas. ¿Sobre qué habla este texto? ¿Os resulta interesante a 


\section{vosotros?}

(Realizamos todos juntos un debate sobre el texto con la finalidad que reflexionen sobre el uso de las nuevas tecnologías, pero más que nada que aprendan a ser críticos sobre el uso de las nuevas tecnologías. Encontraremos más recomendaciones sobre cómo llevar este debate en el apartado de orientaciones.)

4. Reflexión grupal final de la actividad:

Como hemos podido ir viendo y hablando, la noticia nos aporta una información muy importante, y es que muchas veces utilizamos las nuevas tecnologías en nuestro día a día de forma normal y no somos conscientes que su uso conlleva tanto beneficios como peligros. Tanto la televisión como los videojuegos, al igual que el móvil o la Tablet, nos ayudan mucho, con ellas aprendemos muchas cosas y mejoramos aspectos como la concentración o la creatividad pero si los utilizamos más tiempo del recomendado nos pueden causar problemas físicos y perjudicarnos en muchos otros aspectos. Por eso, lo más importante es hacer un uso responsable de estos dispositivos y seguir los consejos de los adultos: seleccionar los videojuegos y programas de televisión con nuestros padres, no dar nunca las contraseñas a otras personas que no sean nuestros padres, no utilizar videojuegos piratas pues pueden tener virus, respetar los horarios y los tipos de programas que nos aconsejan los padres, y sobre todo, no pasar mucho tiempo utilizando los dispositivos tecnológicos, ihay un montón de cosas divertidas por hacer! La seguridad es lo más importante, y si los utilizamos de forma correcta siguiendo estos consejos, aprovecharemos mucho más sus beneficios.

\section{TEMPORALIZACIÓN}

Tiempo aproximado de la actividad 20 minutos:

1. Introducción y realización de la primera actividad: 4 minutos.

2. Realización de la segunda actividad: 8 minutos.

3. Reflexión del texto: 4 minutos

4. Reflexión final: 4 minutos.

\section{ORIENTACIONES}

- En esta actividad es importante que los alumnos reconozcan que el texto que se presenta en la actividad es una noticia, es decir, un texto que informa sobre un hecho novedoso actual, verdadero e interesante para un grupo de personas. Las partes de la noticia son: el titular subtitular y cuerpo o texto de la noticia.

- La finalidad más importante de esta actividad es que los alumnos entiendan el contenido del texto y sean críticos con él. Este texto les ayudará a ver que el uso de los dispositivos tecnológicos está muy extendido y que hoy en día todos lo utilizamos sin reflexionar ni conocer cuáles son sus beneficios y sus riesgos. Por tanto ellos como usuarios de este tipo de dispositivos tienen que reconocer la importancia de estos datos y con ello darse cuenta que el uso responsable es correcto, sin embargo un mal uso o un uso irresponsable conlleva riesgos para nosotros.

Para seguir con el debate les podemos plantear preguntas como: ¿qué uso hacéis 
vosotros de los dispositivos tecnológicos? ¿Sabíais que estos conllevan tanto beneficios como riesgos? ¿Hacéis vosotros un uso responsable? ¿Ahora que ya conocéis que es peligroso jugar a videojuegos o ver la televisión mucho tiempo qué cambiaríais en lo que vosotros hacéis?, etc.

\section{RECURSOS}

- Ficha número 14 del cuaderno de 3ㅇ de primaria. 


\section{¿TÚ QUÉ OPINAS?}

\section{Lee el siguiente texto.}

\section{EL USO DE LAS TIC}

\section{Los beneficios y los riesgos del uso de las nuevas tecnologías.}

Castellón, 20 de septiembre de 2015.

Todo ha ocurrido muy deprisa. Desde hace un tiempo el uso de las Tecnologías de la Información y la Comunicación (TICS) se han convertido en un elemento más de nuestras vidas sin pararnos a pensar si nos aportan beneficios o riesgos.

Expertos en psicología y educación alertan que el uso de las TICS nos ayuda mucho a quienes las utilizamos pero también tienen sus peligros, por eso importante ser precavido cuando las utilizamos y aprender a utilizarlas de forma segura.

Según aseguran los expertos, los videojuegos son divertidos y bien utilizados nos pueden ayudar a mejorar la concentración, la creatividad, la imaginación, la memoria, entre otros, sin embargo es importante controlar el tiempo que les dedicamos pues si jugamos en exceso puede afectar a nuestro rendimiento escolar y estar mucho tiempo sentados puede perjudicarnos físicamente.

Respecto a la televisión, al igual que con el ordenador, afirman que hay programas educativos para niños y dibujos animados con los que se pueden aprender muchas cosas y pasarlo muy bien, pero es necesario controlar el tiempo que se pasa frente a la televisión, porque mucho tiempo viendo la tele puede ser perjudicial.

Así, recomiendan que lo más importante es hacer un uso responsable de estos dispositivos y seguir los consejos de los adultos, pues la seguridad es lo más importante y si los utilizamos de forma rnrrorta anrnuarharamne murhn mác ciıc honofirinc

\section{2. ¿Qué tipo de texto es?}

- ¿ ¿Cuáles son sus partes? Señálalas con diferentes colores en el texto.

\section{RECUERDA...}

Las nuevas tecnologías nos ayudan mucho, con ellas aprendemos muchas cosas y mejoramos aspectos como la concentración o la creatividad pero si no las utilizamos adecuadamente, nos pueden causar problemas físicos y perjudicarnos en muchos otros aspectos. 


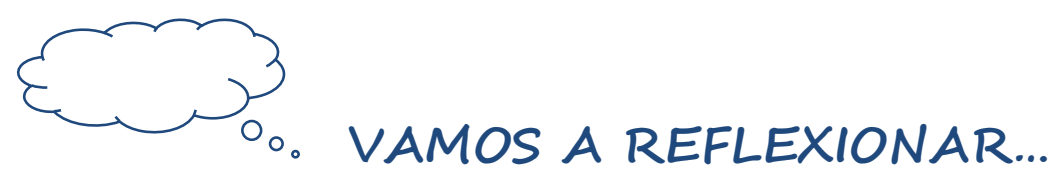

Después de haber realizado las actividades anteriores, vamos a reflexionar sobre los aspectos que hemos trabajado. Para ello, contesta las siguientes cuestiones:

1. ¿Qué debemos hacer para utilizar las nuevas tecnologías con responsabilidad? Señala las respuestas correctas.

Seleccionar los videojuegos y programas de televisión con nuestros padres.

Dar las contraseñas a otras personas que no sean nuestros padres.

Utilizar videojuegos piratas pues pueden tener virus.

Respetar los horarios y los tipos de programas que nos aconsejan los padres.

2. ¿Qué cosas buenas nos aportan los videojuegos, la televisión y el ordenador?

3. ¿Qué problemas podemos tener si no usamos adecuadamente los dispositivos tecnológicos? 
FITXA D'AVALUACIÓ PER AL PROFESSOR/A DE LES ACTIVITATS

DEL BLOC BON ÚS DE LES TICS.

1. Com t'ha resultat dur a terme les tasques segons les indicacions exposades en les fitxes?

Molt difícil $\square \quad$ Difícil $\square \quad$ Normal $\square \quad$ Fàcil $\square \quad$ Molt fàcil $\square$

2. Creus que es compleix l'objectiu proposat? Sí $\square \quad$ No $\square$

3. Has introduït les activitats al contingut curricular assenyalat o en algun altre?

T emes indicats $\square \quad$ Altres $\square$ (indica quins:

4. Has utilitzat altres recursos a part dels que apareixen a la fitxa? Sí $\square \quad$ No $\square$

5. ¿Faries alguna modificació de millora en les fitxes per assolir els objectius de manera més òptima? Sí $\square \quad$ No $\square$

(en cas afirmatiu, indica quina:

6. Com s'han sentit els alumnes en realitzar les activitats? (motivació, implicació, interacció amb altres, ....)

7. Hi ha algun aspecte que consideres oportú comenta per a la millora del programa? 


\section{QÜESTIONARI FINAL}

\section{Alumnat 3r de Primària}

Edat: $\quad$ Gènere: Xic $\square \quad$ Xica $\square$

A continuació trobaràs una sèrie de qüestions amb tres possibles respostes. Llegeix detingudament i assenyala l'opció que s'acosti més al que tu penses. No et preocupis per les respostes que marques, no hi ha respostes correctes o incorrectes, només ens interessa la teva opinió.

1. A l'hora de conèixer a algú és important ...

Tots som igual de bons i importants encara que siguem diferents.

$\square$ Si algú té una característica diferent a la resta no pot ser igual de bo i important que ells.

Alguns són millors que altres.

2. Per a sentir-te bé amb tu mateix cal...

Fixar-te només en les coses bones que t'agraden de tu.

No fer cas a les coses que no t'agraden de tu.

$\square$ Fixar-te en les coses bones que tens i intentar canviar, si vols, les que no t'agraden.

3. Quan estàs en una situació que no t'agrada res...

Estar trist o enfadat està malament, hem d'estar sempre contents.

$\square$ Estar trist o enfadat és una cosa normal i no passa res.

Tots estaran igual que jo perquè tots sentim el mateix.

4. Quan estàs molt enfadat/da...

$\square$ He d'explicar als altres com em sento i així podran entendre com estic.

$\square$ He de cridar o plorar perquè tots sàpiguen que estic enfadat.

$\square$ No he de explicar-ho a ningú, no cal parlar amb la resta de com em sento.

5. Quan estàs en una situació desagradable o et passa una cosa dolenta...

$\square$ He de fer el primer que se m'acut sense pensar, l'important és fer alguna cosa ràpid.

He de pensar en quines coses puc fer i pensar que passaria si les faig.

$\square$ En eixes situacions difícils totes les respostes són adequades. 
6. En una situació en què sents molta ràbia per alguna cosa que t'han fet..

$\square$ Cal discutir amb la persona que ens ha fet sentir ràbia perquè li quedi clar el que ha fet.

Cal expressar amb crits la ràbia perquè tots sàpiguen el que ha passat.

$\square$ He de relaxar-me i estar tranquil/tranquil·la abans de dir o fer alguna cosa.

7. Quan estic amb el meu grup de companys al pati...

A vegades hi ha situacions difícils perquè alguns pensen o volen fer alguna cosa diferent que la resta

$\square$ Tot és fàcil sempre perquè sempre estem d'acord en tot.

Sempre hi ha situacions difícils perquè cada un vol fer una cosa.

8. Quan ens barallem entre els companys...

$\square$ Ens fa sentir bé perquè diem el que volem.

$\square$ Ens posem nerviosos i ens sentim malament.

$\square$ Fem nous amics d'entre els companys que estan del nostre costat.

9. Quan estàs amb l'ordinador, la tauleta o el mòbil...

$\square$ És bo estar totes les hores lliures que tinc amb ells perquè és molt divertit.

$\square$ Utilitzar-tota l'estona no és bo perquè fa que no pugui quedar amb els meus amics.

Utilitzar-los a totes hores és bo perquè podem parlar amb els nostres amics per missatges i no cal quedar amb ells.

10. Les noves tecnologies com l'ordinador, la tauleta o el mòbil...

Són sempre positives perquè fa que ens concentrem més i que siguem més creatius.

Són molt negatives per a nosaltres, no hem d'utilitzar-les mai.

$\square$ Tenen coses bones per a nosaltres però cal anar amb compte perquè també poden ser dolentes per a la salut. 


\section{RECURSOS}

\section{GUIES}

* Junta de Castilla y León (2011). Manual de uso inteligente de las nuevas tecnologías para los alumn@s. De 8 a 10 años. Recuperado de: http://www.cyldigital.es/sites/default/files/library/manual810anosprogramaaprende.pdf

* Junta de Castilla y León (2011). Manual de uso inteligente de las nuevas tecnologías para los alumn@s. De 10 a 12 años. Recuperado de: https://www.cyldigital.es/sites/default/files/library/manual10-

12anosprogramaaprende.pdf

Concepte de noves tecnologies, informació sobre els videojocs, televisió, ordinador i Internet. També ens ofereixen informació sobre els riscs que podem trobar en la xarxa. A més, ens proporcionen informació sobre els e-drets dels xiquets i xiquetes i una sèrie de regles que es necessari que els menors coneguin a I'hora d'utilitzar les noves tecnologies.

* INTECO (2013). Guía de actuación contra el ciberacoso. Padres y educadores. Recuperado de: http://www.injuve.es/sites/default/files/2013/46/publicaciones/Gu\%C3\%ADa\%20 de\%20actuaci\%C3\%B3n\%20contra\%20el\%20ciberacoso.pdf

Concepte de ciberbullying, pautes de detecció, prevenció i actuació, i comportar a capel procés de denuncia i el delicte que comporta. També trobarem una sèrie d'experiències de casos de ciberbullying i altres riscos de l'ús de les TIC, així comconsells bàsics sobre l'ús de les noves tecnologies.

* Centro se Seguridad en Internet Protégeles (s.f.). Ciberbullying y privacidad. Guía para profesores. Recuperado de: http://www.yocontrolo.es/descargas/PROYECTO DAPHNE ES.pdf

Continguts teòrics relacionats amb el ciberbullying: concepte, qui intervé, prevenció, etc., i també altres sobre la privacitat: drets i deures, protecció de dades i delictes. També trobarem a aquests document una sèrie d'activitats per a treballar el ciberbullying i la privacitat en Internet. 
* Comisión de libertades e informática (2009). Proyecto CLI Prometeo. Manual práctico de uso de las tecnologías de la información. 9 a 11 años. Recuperado de: http://www.madrid.org/dat oeste/descargas/08 09/cli prometeo/Manual 911 castellano.pdf

Conjunt d'activitats on es treballen els diferents aspectes relacionats en l'ús de les tecnologies de la comunicació i la informació a partir d’històries relacionades amb I'ús que els menors fan d'aquestes tecnologies.

* Collell, J. y Escudé, C. (2008). No te enredes en la red. Guía para conocer el ciberbullying y algunos peligros de internet y las nuevas tecnologías. Recuperado de: http://www.xtec.cat/ jcollell/ZGuia\%20Ciber.pdf

Informació teòrica com el concepte de ciberbullying i conductes relacionades amb el ciberbullying. Presenta un conjunt d'activitats on a partir d'una sèrie d'històries es presenten qüestions per a debatre en grup sobre les conductes que es presenten a les històries.

Luengo, J. A. (2014). Ciberbullying. Prevenir y actuar. Guía de recursos didácticos para Centros Educativos. Recuperado de: http://www.copmadrid.org/webcopm/recursos/CiberbullyingB.pdf

Situació de l'ús de les TIC en els últims anys, conceptes teòrics sobre el ciberbullying i informació sobre diferents tècniques de treball del ciberbullying. En aquesta guia ens proporcionen també pautes i materials per la prevenció a partir de l'alfabetització digital des de l'educació primària. A més, la guia ens proporciona moltes activitats didàctiques per a portar a terme a les aules $\mathrm{i}$ un protocol d'intervenció ben desenvolupat amb materials i pautes tan per a pares com per a professors i alumnes. Finalitza amb una sèrie de referències normatives per a la reflexió i acció en el centre escolar.

* Fundación Dédalo (2012). Por un uso seguro de internet. Primaria. Recuperado de:http://www.disfrutalared.com/images/yootheme/fichas didacticas/FichasDida cticasPrimaria es.pdf

Conjunt d'activitats relacionades amb l'ús segur d'Internet on es treballen aspectes com els valors, el ciberbullying, la privacitat, etc. 


\section{PÀGINES WEB}

* PANTALlaS AMIgAS (http://www.pantallasamigas.net).És la web més completa, i la pionera en la temàtica, que existeix on encontrarem recursos relacionats amb l'ús segur i saludable de les noves tecnologies de tot tipus: articles, vídeos, definicions de conceptes, materials i recursos didàctics, etc.

* CIBERBULlyING (http://www.ciberbullying.com). A la web trobarem informació sobre el ciberbullying, recursos de prevenció, consells contra el ciberbullying, noticies, articles, entrevistes, etc. tot relacionat amb aquesta temàtica.

* PROTEGeleS.COM (http://www.protegeles.com). Organització de protecció al menor en Internet que proporciona informació a la seua web com pot ser com actuar front a un problema, recursos, guies, estudis, vídeos, etc. I informació concreta dirigida a pares i mares, alumnes o professors amb una sèrie de normes, responsabilitats, activitats, etc.

* YO CONTROLO (http://www.yocontrolo.es/).Trobarem informació sobre casos de pèrdua de privacitat o ciberbullying, recursos com guies, webs, vídeos, estudis, etc.

\section{VÍDEOS}

* Ciberacoso (Childnet International - Cyber Bullying). Caso de ciberbullying subtitulado español.https://www.youtube.com/watch?v=9bgdOuBn4Q4

* Ciberbullying: ciberacoso en redes sociales, videogames, smartphones... y su prevención.https://www.youtube.com/watch?v=SEC dOWFN5M\&index=1\&list= PLC186BF9FE0418ED2

* ¿Cómo actuar ante el ciberacoso? Ignora, bloquea, pide ayuda y denuncia. https://www.youtube.com/watch?v=tVAjiyNzYq0\&list=PLC186BF9FE0418ED2\&in $\underline{\operatorname{dex}=7}$

* Recomendaciones para el Uso Seguro de Internet y las Redes Sociales. https://www.youtube.com/watch?v=t$\underline{x 73 w 1 N 10 s \& l i s t=P L C 186 B F 9 F E 0418 E D 2 \& \text { index }=12}$

* ¿Cómo evitar ser víctima de ciberbullying por suplantación de identidad? https://www.youtube.com/watch?v=XQeFYgedVZg\&list=PLC186BF9FE0418ED2\& index $=15$

* Decálogo por la ciberconvivencia positiva y contra la violencia digital. https://www.youtube.com/watch?v=gXvG53ccyJY\&index=17\&list=PLC186BF9FE 0418ED2 
ANEXO 9. CUADERNO DEL PROFESOR DE 4० DE EDUCACIÓN PRIMARIA DEL PROGRAMA "CONVIURE EN UN MÓN REAL I DIGITAL".

Conviure en un món real i digital

QUADERN DEL PROFESSOR QUART DE PRIMÀRIA

CENTRE:

PROFESSOR/A:

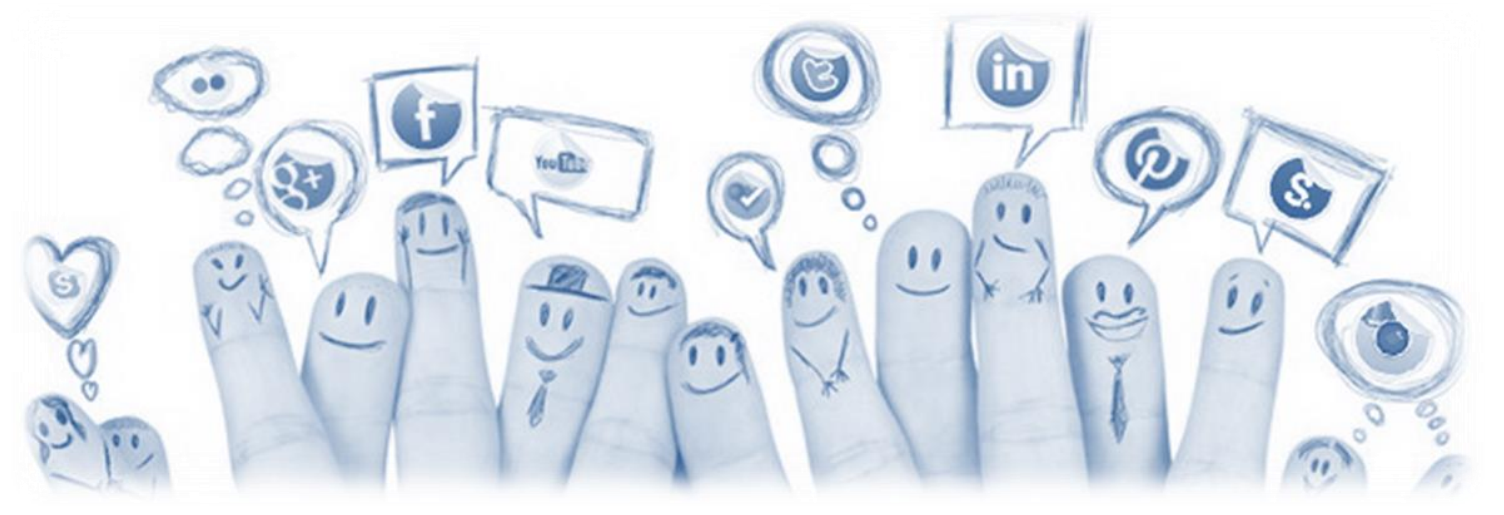




\section{ÍNDEX}

Introducció ................................................................................

Objectiu general del programa ......................................................6

Caracteristiques $i$ configuració del programa ..........................6

Procediment per a l'aplicació del programa ..............................9

Taula de distribució de les activitats ...............................1

Activitats:

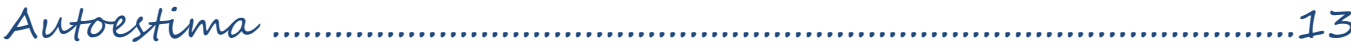

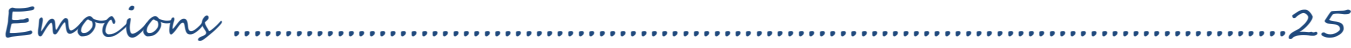

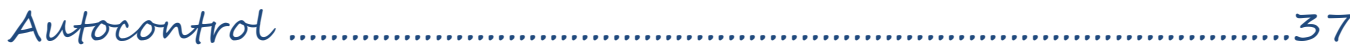

Prevenció $i$ resolució de conflictes ............................................49

Bon ús de les TIC ........................................................................61

Qüestionari final ............................................................ 73

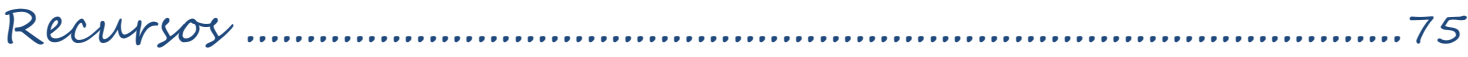




\section{INTRODUCCIÓ}

La infantesa, la pre-adolescència i l'adolescència són etapes crucials en el desenvolupament de les persones, tant a nivell personal com social i acadèmic/professional. Açò dona lloc a que els més joves siguin molt vulnerables davant l'entorn que els envolta i als continus canvis que caracteritzen la nostra societat actual. Els nostres joves han nascut en la era de les TIC, i fan ús d'elles des de edats molt primerenques.

En l'actualitat, els xiquets i les xiquetes, anomenats natius digitals, comencen a utilitzar les Tecnologies de la Informació i de la Comunicació (Tics) partir dels 3 anys d'edat, malgrat això, no saben com fer-ho de forma responsable i com protegir-se de les possibles amenaces. Així, sovint es troben amb una sèrie de dificultats com són l'accés a informació inadequada per a l'edat, sobretot continguts pornogràfics o violents, els riscos tècnics, la pèrdua de privacitat, la suplantació d'identitat, els fraus econòmics i l'addicció a pantalles, entre altres (Salmerón, Campillo i Casas, 2013). Aspectes com aquests provoquen que s'acreixi l'alarma social, doncs aquests riscos són desconeguts per als educadors, els pares i les mares, que han crescut en un context no digital (Del Riu, Sádaba i Bringué, 2010).

Un dels riscos que formen part dels anteriorment citats, és el ciberbullying. Parlem de Ciberbullying "quan un nen o adolescent és turmentat, amenaçat, assetjat, humiliat, molestat d'una manera o una altra, per un altre nen o adolescent mitjançant l'ús d'Internet, tecnologies interactives i digitals o telèfon mòbil" (Collell i Escudé, 2008).

Aquest tipus de maltractament entre iguals s'ha convertit en un problema complex entre els nostres adolescents, que sol tenir repercussions indesitjables en la convivència escolar (Avilés, 2013), i encara que la violència no és cap cosa nova, ja que a la fi dels anys 70 el noruec Olweus es va iniciar en l'estudi de la violència entre escolars mundialment conegut amb l'expressió bullying, les formes de materialització de la mateixa han anat evolucionant amb el temps, ideant noves formes de dur-la a terme (Hernández i Solano, 2007).

Considerant l'anteriorment citat, els centres educatius de tots els nivells tenen en l'actualitat el deure incloure dins de la formació integral aspectes com el sensibilitzar i prevenir que entre el mateix alumnat sorgeixin situacions de maltractament $\mathrm{i}$ intimidació, encara que es sap que el ciberbullying no succeeix precisament dins de l'escola, és aquí on ha d'abordar-se com a part de l'educació integral (Ortega, 2010).

La nova educació que cal realitzar en l'àmbit de les TIC també ha de procurar capacitar en determinades destreses i habilitats, que suscitarà unes actituds i disposicions. Entre aquestes últimes és imprescindible la necessitat de formar en una actitud sanament crítica davant les TIC. És a dir, saber distingir en què ens ajuden i en què ens limiten, 
per poder actuar en conseqüència. Aquest procés ha d'estar present i donar-se de manera integrada en la família, a l'escola i en la societat (Berríos i Buxarris, 2005).

Per tot això, és convenient destacar la necessitat de dur a terme accions de prevenció a edats primerenques, per oferir una informació i formació adequada als nens, progenitors i professorat, en l'àmbit de les TIC. Aquesta formació ha de basar-se en dues perspectives, una tecnològica i una altra humanística. És a dir, que atengui als mitjans, però també a les finalitats de l'educació (Naval, Sábada i Bringué, 2003).

* objectiu general del programa

L'objectiu principal d'aquest programa no es altre que realitzar accions de prevenció del ciberbullying als centres escolars en el segon i tercer cicle de l'educació primària mitjançant activitats inserides en el currículum escolar, de manera que l'alumne tingui la possibilitat d'adquirir aquests coneixements $\mathrm{i}$ aptituds relacionades amb la prevenció del ciberbullying progressivament durant els quatre últims cursos de l'educació primària.

\section{* característiques I configuració del programa}

El programa de prevenció del ciberbullying ha sigut dissenyat a partir d'un conjunt d'activitats inserides al currículum escolar, concretament a les següents assignatures:

- Ciències socials

- Ciències de la naturalesa

- Llengua castellana i literatura

Aquesta inserció curricular no solament va a cobrir la prevenció en quant a aspectes tecnològics, sinó també en aspectes humanístics. És a dir, per aconseguir els objectius proposats és necessari treballar aspectes tecnològics no obstant això, treballar únicament aquests aspectes no seria suficient, doncs per poder assumir aquesta informació i aplicar-la correctament és necessari que certes habilitats personals i socials estiguin ben desenvolupades, per així prevenir l'aparició de problemes com el ciberbullying. En concret les habilitats centrades en el bon ús de les TIC i les relacionades amb la resolució de conflictes seran aspectes centrals en el nostre projecte doncs treballant-los des d'edats primerenques creiem que són aspectes clau en la prevenció del ciberbullying.

Per tant les temàtiques que es treballaran en aquest programa es classifiquen del següent mode. En els cursos de tercer i quart de primària es treballaran un conjunt d'activitats relacionades amb habilitats tecnològiques i personals com són:

- Bon ús de les TIC

- Prevenció i resolució de conflictes 
- Autoestima

- Emocions

- Autocontrol

A continuació en cinquè i sisè curs de primària es seguiran treballant aspectes tecnològics i introduirem habilitats socials, atès que aquests últims s'han de desenvolupar amb posterioritat a les habilitats més personals. Així els continguts a treballar els dos últims cursos de l'educació primària són:

- Bon ús de les TIC

- Resolució de conflictes

- Empatia

- Assertivitat

- Ciberbullying

El programa disposa d'un dossier que inclou totes les activitats a desenvolupar al llarg del programa. Aquestes activitats es troben classificades per cursos escolars (tercer, quart, cinquè i sisè de primària).

El dossier de cada curs escolar, al mateix temps, està format per cinc blocs temàtics amb tres activitats per cada bloc (dos relacionades amb el contingut curricular i una d'avaluació) sent un total de quinze activitats per curs escolar.

\begin{tabular}{|c|c|c|}
\hline CURS & TEMÀTICA & ACTIVITAT \\
\hline \multirow{5}{*}{$3 r$} & Autoestima & $\begin{array}{l}\text { 1. Així sóc jo. } \\
\text { 2. Em quede amb tot allò bo. } \\
\text { 3. Anem a reflexionar. }\end{array}$ \\
\hline & Emocions & $\begin{array}{l}\text { 4. El que sentim. } \\
\text { 5. Dime com et sents. } \\
\text { 6. Anem a reflexionar. }\end{array}$ \\
\hline & Autocontrol & $\begin{array}{l}\text { 7. Què passarà? } \\
\text { 8. Pren-te el teu temps. } \\
\text { 9. Anem a reflexionar. }\end{array}$ \\
\hline & $\begin{array}{l}\text { Prevenció i resolució de } \\
\text { conflictes }\end{array}$ & $\begin{array}{l}\text { 10. Ens relacionem. } \\
\text { 11. Fa un temps. } \\
\text { 12. Anem a reflexionar. }\end{array}$ \\
\hline & Bon ús de les TIC & $\begin{array}{l}\text { 13. Un día cualquiera } \\
\text { 14. ¿Tú qué opinas? } \\
\text { 15. Vamos a reflexionar. }\end{array}$ \\
\hline $4 t$ & Autoestima & $\begin{array}{l}\text { 1. Autorretrato. } \\
\text { 2. Así es mi compañero. } \\
\text { 3. Vamos a reflexionar. }\end{array}$ \\
\hline
\end{tabular}




\begin{tabular}{|c|c|c|}
\hline & Emocions & $\begin{array}{l}\text { 4. Els altres també senten. } \\
\text { 5. Sentim diferent. } \\
\text { 6. Anem a reflexionar. }\end{array}$ \\
\hline & Autocontrol & $\begin{array}{l}\text { 7. Anem a imaginar. } \\
\text { 8. ¿Què ocorre? } \\
\text { 9. Anem a reflexionar. }\end{array}$ \\
\hline & $\begin{array}{l}\text { Prevenció i resolució de } \\
\text { conflictes }\end{array}$ & $\begin{array}{l}\text { 10. ¿Hablamos? } \\
\text { 11. ¿Qué ocorre? } \\
\text { 12. Anem a reflexionar. }\end{array}$ \\
\hline & Bon ús de les TIC & $\begin{array}{l}\text { 13. A internet ho trobarem. } \\
\text { 14. Siguem responsables. } \\
\text { 15. Anem a reflexionar. }\end{array}$ \\
\hline \multirow{5}{*}{5 è } & Empatia & $\begin{array}{l}\text { 1. Ponte en mi lugar. } \\
\text { 2. Si tú estás feliz yo estoy feliz. } \\
\text { 3. Vamos a reflexionar. }\end{array}$ \\
\hline & Assertivitat & $\begin{array}{l}\text { 4. Els meus drets. } \\
\text { 5. Conta'm què t'agrada. } \\
\text { 6. Anem a reflexionar. }\end{array}$ \\
\hline & Ciberbullying & $\begin{array}{l}\text { 7. Carlos y el ciberbullying. } \\
\text { 8. ¿Qué necesitas saber? } \\
\text { 9. Vamos a reflexionar. }\end{array}$ \\
\hline & $\begin{array}{l}\text { Prevenció i resolució de } \\
\text { conflictes }\end{array}$ & $\begin{array}{l}\text { 10. Els conflictes. } \\
\text { 11. Solucionem els conflictes. } \\
\text { 12. Anem a reflexionar. }\end{array}$ \\
\hline & Bon ús de les TIC & $\begin{array}{l}\text { 13. Ens relacionem per internet. } \\
\text { 14. Fem un ús saludable. } \\
\text { 15. Anem a reflexionar. }\end{array}$ \\
\hline \multirow{5}{*}{$6 \grave{~}$} & Empatia & $\begin{array}{l}\text { 1. Buscando la reacción adecuada. } \\
\text { 2. ¿Tú cómo lo ves? } \\
\text { 3. Vamos a reflexionar. }\end{array}$ \\
\hline & Assertivitat & $\begin{array}{l}\text { 4. Algunes voltes cal dir que no. } \\
\text { 5. Queixar-se com cal. } \\
\text { 6. Anem a reflexionar. }\end{array}$ \\
\hline & Ciberbullying & $\begin{array}{l}\text { 7. Así sí. } \\
\text { 8. ¿Y ahora qué hago? } \\
\text { 9. Vamos a reflexionar. }\end{array}$ \\
\hline & $\begin{array}{l}\text { Prevenció i resolució de } \\
\text { conflictes }\end{array}$ & $\begin{array}{l}\text { 10. Prenem la decisió. } \\
\text { 11. Jo decideixo per mi. } \\
\text { 12. Anem a reflexionar }\end{array}$ \\
\hline & Bon ús de les TIC & $\begin{array}{l}\text { 13. Compartim informació. } \\
\text { 14. Utilitzem el temps com cal. } \\
\text { 15. Anem a reflexionar. }\end{array}$ \\
\hline
\end{tabular}


Al inici de cada bloc temàtic es presenta una sèrie d'informació on s'especifica el concepte de la temàtica a treballar, els objectius que es persegueixen i una taula resum amb les activitats que inclou el bloc classificades per les assignatures curriculars per a facilitar així la seua inserció.

Respecte al material que es presenta a cada bloc per al professorat inclou, a més de les fitxes dels alumnes, una fitxa tècnica per a cadascuna de les activitats que conté els següents camps informatius:

- Assignatura: indica l'assignatura en la qual cal inserir l'activitat.

- Contingut curricular: matèria de l'assignatura amb la que està relacionada l'activitat.

- Objectius curriculars i objectius de la temàtica: remarca els objectius tant curriculars com de la temàtica que es treballen a l'activitat.

- Metodologia i procediment: determina com i de quina forma portar a cap l'activitat.

- Temporalització: temps aproximat de la realització de l'activitat.

- Orientacions: dades relacionades amb l'activitat que faciliten al professorat l'aplicació de l'activitat, tant a nivell teòric com a pràctic.

- Recursos: materials necessaris per a desenvolupar adequadament l'activitat.

Després de cada un dels blocs temàtics, es troba una fitxa d'avaluació per ser emplenada pel professor/a sobre les activitats corresponents a aquest bloc. Aquesta avaluació serà d'ajuda per millorar el programa.

A més del programa, al final d'aquest document hi ha un apartat amb una fitxa d'avaluació final del programa per a l'alumnat per a aquest curs educatiu, i també un petit document amb recursos extra com guies, enllaços de pàgines web i vídeos amb els que es poden ampliar els coneixements relacionats amb la temàtica principal del programa, el ciberbullying.

\section{procediment per a l'aplicació del programa}

Aquest programa està dissenyat per a ser aplicat als quatre cursos que corresponen al segon i tercer cicle de l'educació primària de forma progressiva al llarg d'aquests cursos, de forma que al finalitzar el tercer cicle els alumnes hagen assolit tots els objectius del programa de prevenció.

L'aplicació del programa correspon als professors tutors, ja que es considera important que es relacioni l'aspecte educatiu d'aquest programa amb la tasca quotidiana que realitzen els alumnes en les diferents assignatures curriculars. Així, per a que l'aplicació sigui adequada i satisfactòria és necessària la constància del professorat al llarg del curs. 


\section{QUART DE PRIMÀRIA}

\begin{tabular}{|c|c|c|c|c|}
\hline ASSIGNATURA & $\begin{array}{c}\text { TEMÀTICA } \\
\text { CURRICULAR }\end{array}$ & $\begin{array}{c}\text { TEMÀTICA } \\
\text { TRANSVERSAL }\end{array}$ & \multicolumn{2}{|c|}{$\begin{array}{c}\text { REGISTRE } \\
\text { DE FITXES } \\
\text { FETES }\end{array}$} \\
\hline \multirow{6}{*}{$\begin{array}{c}\text { CIÈNCIES DE } \\
\text { LA } \\
\text { NATURALESA }\end{array}$} & Els sentits & \multirow{3}{*}{ Emocions } & 4 & \\
\hline & Agricultura & & 5 & \\
\hline & Anem a reflexionar & & 6 & \\
\hline & $\begin{array}{c}\text { Classificació dels } \\
\text { éssers vius }\end{array}$ & \multirow{3}{*}{ Bon ús de les TIC } & 13 & \\
\hline & $\begin{array}{c}\text { El reciclatge dels } \\
\text { materials }\end{array}$ & & 14 & \\
\hline & Anem a reflexionar & & 15 & \\
\hline \multirow{3}{*}{$\begin{array}{l}\text { CIENCIES } \\
\text { SOCIALS }\end{array}$} & El medi natural & \multirow{3}{*}{ Autocontrol } & 7 & \\
\hline & $\begin{array}{c}\text { L'organització } \\
\text { territorial }\end{array}$ & & 8 & \\
\hline & Anem a reflexionar & & 9 & \\
\hline \multirow{6}{*}{$\begin{array}{c}\text { LENGUA } \\
\text { CASTELLANA Y } \\
\text { LITERATURA }\end{array}$} & $\begin{array}{l}\text { Sinónimos y } \\
\text { antónimos }\end{array}$ & \multirow{3}{*}{ Autoestima } & 1 & \\
\hline & $\begin{array}{c}\text { Determinantes } \\
\text { posesivos }\end{array}$ & & 2 & \\
\hline & Vamos a reflexionar & & 3 & \\
\hline & Expresión oral & \multirow{3}{*}{$\begin{array}{c}\text { Prevenció i resolució } \\
\text { de conflictes }\end{array}$} & 10 & \\
\hline & Comunicación oral & & 11 & \\
\hline & Vamos a reflexionar & & 12 & \\
\hline
\end{tabular}




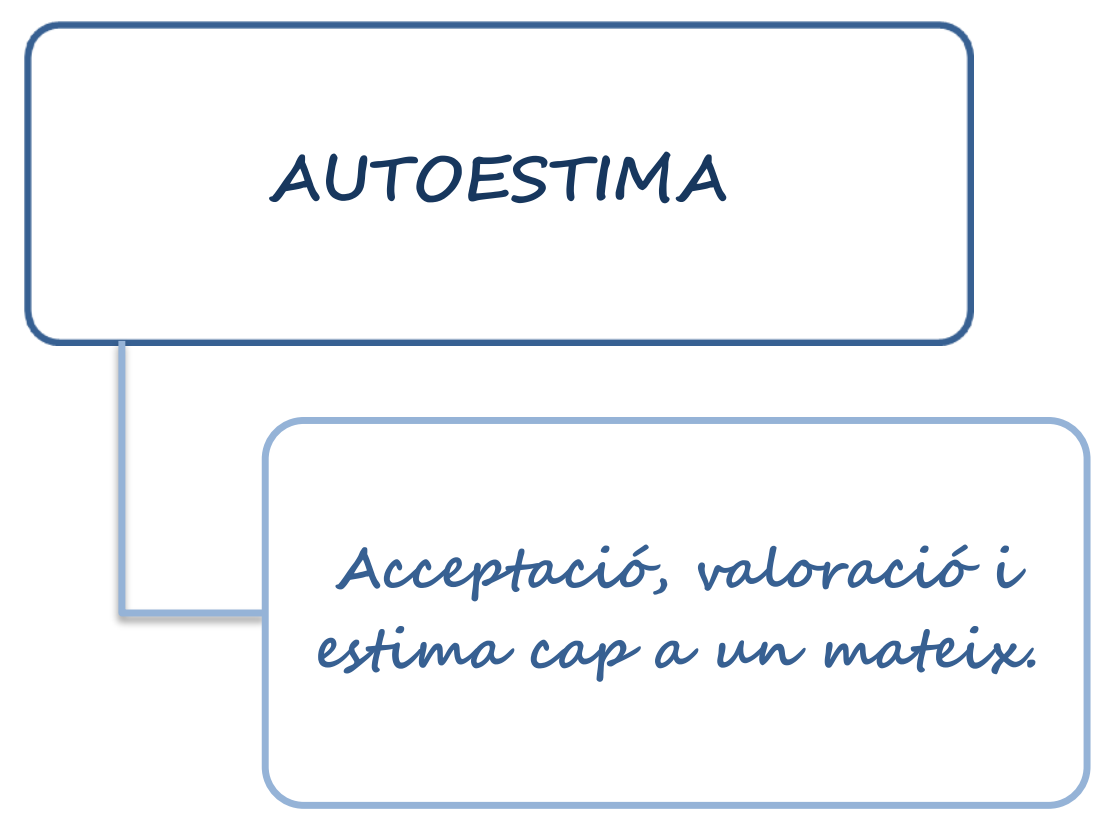

\section{Objectivs.}

$\checkmark$ Aprendre a considerar-se de forma positiva.

$\checkmark$ Autoacceptar-se incondicionalment. 
CURSO: 4ㅇ PRIMARIA

FICHA: 1

ASIGNATURA: LENGUA CASTELLANA Y LITERATURA

ACTIVIDAD: AUTORRETRATO

CONTENIDOS: SINÓNIMOS Y ANTÓNIMOS Y AUTOESTIMA

\section{OBJETIVOS CURRICULARES}

- Recordar el concepto sinónimo y antónimo.

- Trabajar la formación de sinónimos y antónimos.

\section{OBJETIVOS SOBRE LA TEMÁTICA}

- Desarrollar un conocimiento positivo de nosotros mismos.

- Aceptar nuestros defectos como parte de nosotros mismos.

\section{METODOLOGÍA / PROCEDIMIENTO}

La presente actividad abarca contenidos relacionados con los antónimos y sinónimos junto con contenidos en los que se trabaja la autoestima. Para ello hemos realizado la ficha 1.

1. Introducción grupal y realización individual de las dos primeras actividades:

Vamos a realizar la actividad en la que encontramos varios ejercicios que nos permitirán conocernos mejor a nosotros mismos. En la primera actividad tenemos que anotar dos cualidades que crees que tienes, como por ejemplo; yo pienso que una de las cualidades que tengo es que soy una persona a la que le gusta mucho hablar con la gente, o soy una persona simpática... En la segunda actividad escribiremos dos defectos que crees que tienes como sería ser una persona antipática, muy gritona... Vamos a coger la ficha y completamos las dos primeras actividades.

2. Reflexión grupal de las respuestas de estas actividades:

Bien, cada uno de vosotros habrá completado los dos primeros ejercicios, en el primero hemos anotado dos cualidades y en la segunda un defecto... A ver, ¿quién nos querría decir lo que ha puesto?

(Dejamos que los alumnos vayan aportando sus respuestas, si no hay voluntarios preguntamos al azar dando pie a que hablen y opinen aquellos que no lo suelen hacer).

3. Explicación grupal de la última actividad y realización individual de esta:

Vamos ahora a completar la tercera actividad que consiste en anotar en la primera columna las cualidades y defectos que hemos escrito antes. Una vez hayáis completado la primera columna, completaremos las siguientes escribiendo un sinónimo y un antónimo de cada uno. ¿Recordáis lo que eran los sinónimos y antónimos? Los sinónimos son palabras que tienen el mismo significado y los antónimos significados opuestos. Completamos ahora individualmente la actividad.

4. Reflexión final en grupo:

De acuerdo, como habréis visto, todos hemos puesto cualidades y defectos, pues los seres humanos somos un conjunto, con rasgos físicos peculiares, con características 
positivas y negativas que son propias y nos hacen diferentes a los demás y únicos. Muchas veces vemos las cosas negativas solo en nosotros, pensamos que hacemos las cosas mal, y tenemos algo que no nos gusta...pero no somos los únicos, todos absolutamente todos tenemos defectos, porque nadie es perfecto, todos tenemos defectos y aspectos que podemos modificar. Debemos aceptarlos y verlos como algo nuestro que forma parte de nosotros, y que es lo que nos hace ser únicos. Nos debemos querer a nosotros mismos y aceptarnos tal y como somos.

\section{TEMPORALIZACIÓN}

Tiempo aproximado de la actividad 20 minutos:

1. Realización de las dos primeras actividades: 5 minutos

2.Reflexión de las actividades: 5 minutos

3. Realización de la tercera actividad: 5 minutos

4. Reflexión final: 5 minutos

\section{ORIENTACIONES}

- En esta actividad hay que prestar mucha atención a las respuestas que dan los alumnos, para evitar que algún alumno se infravalore demasiado o que las respuestas de determinados alumnos den lugar a burlas o comentarios ofensivos por parte de los compañeros.

- También es importante insistir en que todos tenemos cualidades y defectos, que no somos los únicos, y que no hay nadie perfecto.

- Nombramos en la reflexión final el hecho de que hay que aceptarnos tal y como somos, hay que aceptarse incondicionalmente, a pesar de ello añadimos la posibilidad de modificar aquello que no nos gusta, y en esta actividad si nos preguntan cómo modificarlo podríamos orientarles mediante los antónimos, pues los antónimos de los defectos sería aquello a lo que deberíamos llegar para mejorar los defectos.

\section{RECURSOS}

- Ficha número 1 del cuaderno de 4 을 de primaria. 


\section{AUTORRETRATO}

1. Escribe dos cualidades que consideras que tienes Por ejemplo: simpático, alegre...

2. Escribe un defecto que consideras que tienes Por ejemplo: borde, antipático...

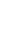

3. Escribe en la primera columna las dos cualidades y los dos defectos que has anotado en las actividades anteriores y busca un sinónimo y un antónimo de cada uno.

\begin{tabular}{|l|l|l|}
\hline Cualidad/Defecto & Sinónimo & Antónimo \\
\hline & & \\
\hline & & \\
\hline & & \\
\hline & & \\
\hline
\end{tabular}

\section{RECUERDA...}

El conjunto de cualidades y defectos que tenemos son los que nos hacen ser únicos, por eso debemos aceptarlos y verlos como algo nuestro que forma parte de nosotros. 
CURSO: 4ㅇ PRIMARIA

FICHA: 2

ASIGNATURA: LENGUA CASTELLANA Y LITERATURA

ACTIVIDAD: ASÍ ES MI COMPAÑERO/A

CONTENIDOS: DETERMINANTES POSESIVOS Y AUTOESTIMA

\section{OBJETIVOS CURRICULARES}

- Recordar cuales son los determinantes posesivos.

- Clasificar los determinantes posesivos según número y persona.

\section{OBJETIVOS SOBRE LA TEMÁTICA}

- Hacer conscientes a los alumnos de sus aspectos positivos.

- Aumentar la confianza en uno mismo.

\section{METODOLOGÍA / PROCEDIMIENTO}

Esta actividad está integrada en el tema en el que se trabajan los determinantes posesivos, en ella se trabajará dicho contenido junto con contenido relacionado con la potenciación de la autoestima. La presente actividad la podemos encontrar en la ficha 2 del cuaderno de 4 은 de primaria.

1. Recordamos en grupo lo que aprendimos en la actividad anterior:

Ahora vamos a realizar una de las actividades de cuaderno, que corresponde a la ficha 2, pero antes vamos a recordar lo que trabajamos en la actividad anterior... Recordad que completamos unos ejercicios en los que teníamos que escribir cualidades y defectos nuestros, y ¿cuál es a la conclusión a la que llegamos sobre las cualidades y defectos?

(Hacemos la pregunta a todo el grupo-clase para que vayan aportando sus respuestas $y$, al mismo tiempo reforzamos positivamente sus aportaciones. Les vamos dirigiendo hacia la reflexión a la que llegamos en la actividad anterior: "Todos, absolutamente todos, tenemos cualidades y defectos, o aspectos que podemos modificar, porque nadie es perfecto. Debemos aceptarlos y verlos como algo nuestro, que forma parte de nosotros, y que es lo que nos hace ser únicos. Nos debemos querer a nosotros mismos y aceptarnos tal y como somos.")

Bien, pues ya sabemos que todos tenemos cualidades y defectos, que no hay nadie que sea perfecto, y que todo ese conjunto de características hacen que seamos únicos, y que por tanto nos debemos de querer mucho y aceptarnos tal y como somos siempre.

2. Introducción grupal y realización individual y posteriormente por parejas de la primera actividad. Realización individual de la segundad actividad:

Ahora trabajaremos en parejas, y vamos a describir a nuestros compañeros. Tenemos que recordar bien que todos tenemos cualidades, aspectos positivos... pero muchas veces tenemos dificultades para darnos cuenta de todo lo bueno que tenemos y solo reconocemos las cosas negativas que tenemos, por eso es bueno que nuestros compañeros nos cuenten cosas sobre nosotros.

(Agrupamos a los alumnos en parejas, si son impares podemos hacer un grupo de 
tres, indicándoles bien sobre quien han de escribir, por ejemplo Pedro escribe sobre Juan, Juan sobre María y María sobre Pedro.)

Cogemos la ficha y nos fijamos en la primera actividad, tal y como estamos en parejas, tenemos que completar las frases pensando en aspectos de vuestro compañero... En la primera frase escribiremos el nombre del compañero y en las siguientes frases las leemos y las completamos pensando en nuestro compañero. La segunda por ejemplo dice; Se le da muy bien... pensamos qué se le da bien y lo escribimos. Podríamos poner se le da bien jugar a básquet, patinar, ayudar a los amigos...

Además, como estamos estudiando los determinantes posesivos, y sabemos que estos acompañan a los sustantivos e indican relación de pertenencia, y estamos hablando sobre cómo es nuestro compañero, mientras completamos las frases, nos vamos a fijar muy bien, y si hay determinantes posesivos los vamos a subrayar. Cuando los tengamos, pasamos a la segunda actividad y allí vamos a escribir los determinantes que hemos encontrado y los clasificaremos según persona y número, es decir, si es de primera, segunda o tercera persona del singular o del plural.

Vamos ahora a coger la ficha y completaremos las frases, subrayaremos los determinantes posesivos y los clasificáis, y cuando tengáis los dos los dos ejercicios completos le contáis al compañero las frases que habéis escrito sobre él en el primer ejercicio.

(Trabajo individual para completar cada uno las frases relacionadas con el compañero con el que forman pareja y para realizar la segunda actividad de clasificación de posesivos, y posteriormente con las parejas asignadas comentaran durante unos minutos que es lo que ha escrito uno sobre el otro en las primeras frases.)

3. Reflexión final de la actividad en grupo:

Al comentar la primera actividad, el compañero os habrá contado lo que ha escrito sobre vosotros, cosas que les gustan de vosotros, cosas que sabéis hacer muy bien... Y decidme, ¿cómo os habéis sentido? ¿Os ha sorprendido lo que han dicho sobre vosotros?

(Dejamos que los alumnos nos comenten sus impresiones y orientamos siempre la repuesta hacia la aceptación positiva de los aspectos que el compañero ha resaltado sobre él.)

Como ya habréis podido ver, todos tenemos muchas cualidades y cosas muy buenas, a veces nos paramos a pensar solo en las cosas malas que tenemos y que nos pasa, y se nos olvida que tenemos muchas cosas buenas. Por eso es importante escuchar las cosas buenas que los demás dicen de nosotros porque eso nos hace sentir mejor y nos ayuda a recordar todo lo bueno que tenemos.

\section{TEMPORALIZACIÓN}

Tiempo aproximado de la actividad 25 minutos:

1. Recordatorio de la actividad anterior: 5 minutos

2. Introducción y realización de la primera y segunda actividad: 15 minutos 
3. Reflexión de la actividad: 5 minutos

\section{ORIENTACIONES}

- En esta actividad vamos a trabajar la autoestima por eso es muy importante que cuando completen las frases lo hagan con cualidades y características positivas de los compañeros, pues las alabanzas de los demás en cuanto a nosotros aumenta y afianza la autoestima en uno mismo.

- Si detectamos en clase niños que tengan la autoestima baja o con relaciones negativas con los compañeros, es importante elegir para este alumno un buen compañero que sepa destacar bien sus cualidades.

- En la reflexión final, cuando hacemos las preguntas de cómo se han sentido y si les ha sorprendido, hay que prestar atención para ver la reacción de los alumnos y prestar especial atención en aquellos niños que sabemos que pueden tener una autoestima baja y potenciar con nuestras palabras esas cualidades para que empiece a reconocerlas y a ser consciente de ellas.

\section{RECURSOS}

- Ficha número 2 del cuaderno de 40 de primaria. 


\section{ASÍ ES MI COMPAÑERO}

1. Completa las siguientes oraciones y subraya los determinantes posesivos que encuentres.

$\checkmark$ Mi compañero/a se llama

$\checkmark$ Se le da muy bien

$\checkmark$ Lo que más me gusta de su forma de ser es

$\checkmark$ En nuestros ratos juntos nos gusta

2. Escribe en la tablas los determinantes posesivos que has subrayado en el ejercicio anterior y clasifícalos :

\begin{tabular}{|l|l|l|}
\hline Determinante posesivo & Persona & Número \\
\hline & & \\
\hline & & \\
\hline & & \\
\hline
\end{tabular}

RECUERDA...

Es importante escuchar las cosas buenas que los demás dicen de nosotros porque eso nos hace sentir mejor y nos ayuda a recordar todo lo bueno que tenemos. 


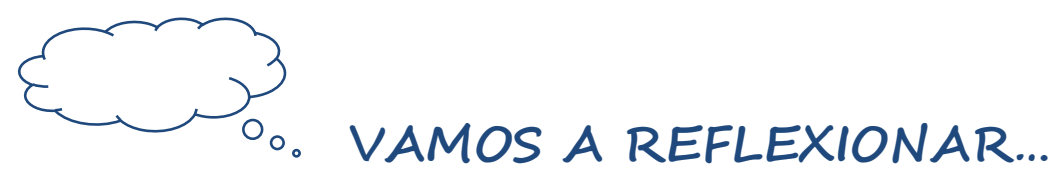

Después de haber realizado las actividades anteriores, vamos a reflexionar sobre los aspectos que hemos trabajado. Para ello, contesta las siguientes cuestiones:

1. Todos tenemos cualidades y defectos.
$\square$ Verdadero
Falso

2. Escribe tres cualidades que tengas.

3. ¿Cómo te sientes cuando tus compañeros dicen cosas buenas sobre ti? 
FITXA D'AVALUACIÓ PER AL PROFESSOR/A DE LES ACTIVITATS DEL

BLOC D'AUTOESTIMA

1. Com t'ha resultat dur a terme les tasques segons les indicacions exposades en les fitxes? Molt difícil $\square \quad$ Difícil $\square \quad$ Normal $\square \quad$ Fàcil $\square \quad$ Molt fàcil $\square$

2. Creus que es compleix l'objectiu proposat? Sí $\square \quad$ No $\square$

3. Has introduït les activitats al contingut curricular assenyalat o en algun altre?

T emes indicats $\square \quad$ Altres $\square$ (indica quins:

4. Has utilitzat altres recursos a part dels que apareixen a la fitxa? Sí $\square \quad$ No $\square$

5. ¿Faries alguna modificació de millora en les fitxes per assolir els objectius de manera més òptima? Sí $\square \quad$ No $\square$

(en cas afirmatiu, indica quina:

6. Com s'han sentit els alumnes en realitzar les activitats? (motivació, implicació, interacció amb altres, ....)

7. Hi ha algun aspecte que consideres oportú comenta per a la millora del programa? 


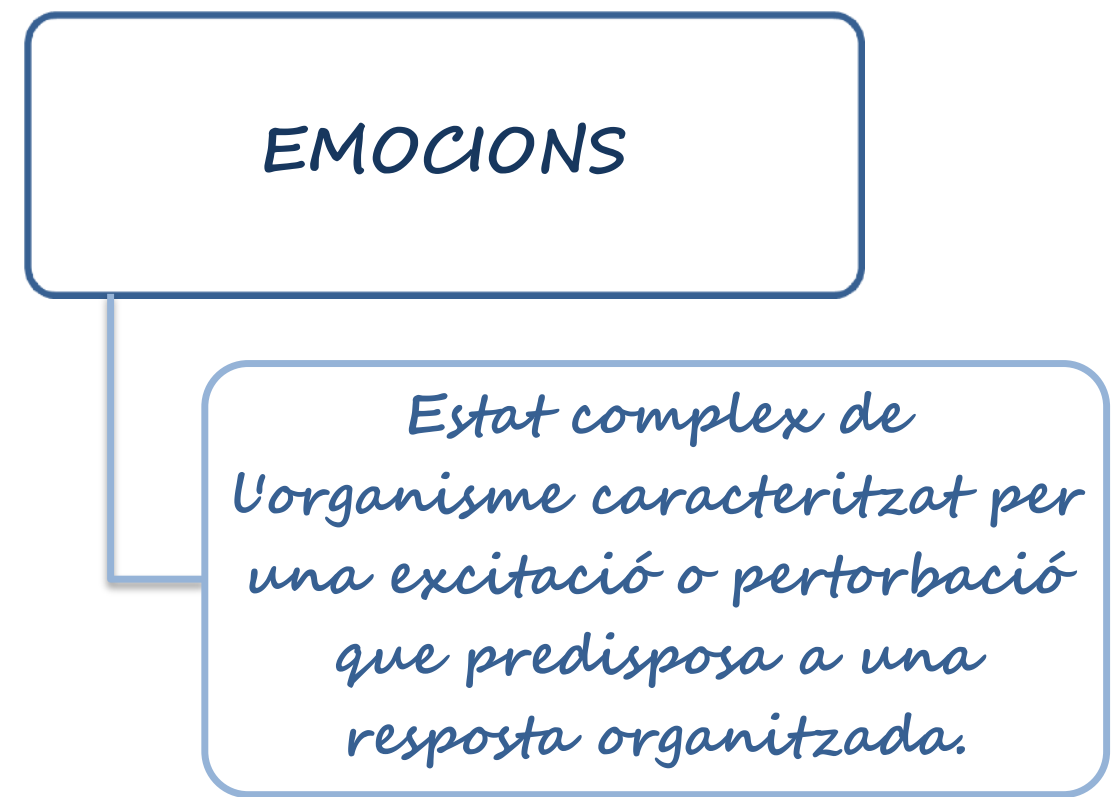

\section{Objectivs.}

$\checkmark$ Reconèixer com es senten els altres.

$\checkmark$ Saber com actuar en funció dels sentiments que expressen els altres. 
ASSIGNATURA: CIÈNCIES DE LA NATURALESA

ACTIVITAT: ELS ALTRES TAMBÉ SENTEN

CONTINGUTS: ELS SENTITS I EMOCIONS

\section{OBJECTIUS CURRICULARS}

- Conèixer els sentits i les funcions.

- Reconèixer emocions i sentiments propis i aliens.

\section{OBJECTIUS SOBRE LA TEMÀTICA}

- Prendre consciència de les emocions dels altres.

- Identificar les emocions que poden experimentar altres persones en determinades situacions.

\section{METODOLOGIA / PROCEDIMENT}

La present activitat avarca continguts pertanyents a la unitat que treballa els sentits, així com també continguts relacionats amb les emocions. Aquesta activitat la podem trobar a la fitxa 4 del quadern de treball de l'alumne.

1. Iniciarem l'activitat amb una introducció i recordatori en gran grup dels sentits:

Totes les persones tenim cinc sentits que són: la vista, l'oïda, l'olfacte, el gust i el tacte. Aquests sentits ens ajuden a percebre i entendre el que passa al nostre voltant. En el nostre entorn ocorren moltes coses, quan estem a classe els companys parlen, es mouen, juguen, etc., i tot això ho percebem amb els nostres sentits. També podem percebre amb els sentits com se sent un company o familiar, saber si sent tristesa, alegria, pena, etc., només amb mirar-lo, sentir-lo o tocar-lo podem saber què li passa. Per això és molt important que sapiguem que tota la informació que ens proporcionen els sentits ens ajudarà a conèixer millor el que passa al nostre voltant.

2. Realització dels exercicis individualment:

Com ja sabem, és molt important estar sempre atents $i$ utilitzar els sentits per saber el que passa al nostre voltant. Anem ara a realitzar uns exercicis per veure què és el que perceben els nostres sentits davant de diferents situacions que ens plantegen.

A veure, en el primer exercici trobem tres dibuixos de dues expressions de la cara diferents que representen emocions. Anem a recordar primer què són les emocions i quines coneixeu.

(Recordem el concepte d'emoció i citem algunes d'elles i les anotem a la pissarra).

Ens fixem, activant el sentit de la vista, en els dibuixos, i anotem sota l'emoció que creieu que sent aquesta persona. En el segon exercici, per mitjà del sentit de l'oïda, pensem i escrivim com se sent un amic que ens diu aquesta frase, $i$ en el tercer exercici què pot sentir un amic que ens fa el gest de la imatge. 


\section{Comentem les respostes de les activitats en grup:}

En els exercicis que hem realitzat hem vist dibuixos de situacions que ens poden ocórrer a nosaltres. Hem de saber que igual que nosaltres experimentem emocions, ja que a vegades sentim tristesa, altres vegades alegria, etc., els altres també senten emocions $i$ nosaltres podem saber com se senten si ens fixem bé en l'expressió de la seva cara, si escoltem les paraules que ens diuen o en el gest que ens fan.

Llavors, digueu-me en la primera activitat, què creieu que senten Alexandre $i$ Carme veient el gest que fan a la cara?

I que pot sentir Joan quan sentim la frase que diu?

I Elena que sent si ens fa aquest gest?

(Podem anar preguntant una per una cada situació i anotant a la pissarra les diferents emocions que consideren els alumnes que es poden adequar a la situació).

4. Reflexió final també en gran grup:

Heu vist en aquesta activitat que utilitzant els sentits podem reconèixer bé com se senten els altres, perquè ells també senten emocions, i és molt important que nosaltres les reconeguem perquè igual que a nosaltres ens agrada que els altres sàpiguen com ens sentim, als altres també els agrada que nosaltres sapiguem $i$ entenguem com se senten ja que això ens ajudarà a tenir millors relacions amb els altres, evitarem conflictes $i$ tot funcionarà millor. I això ho podem aconseguir escoltant-los, mirant-los o aproximant-nos a ells.

\section{TEMPORALITZACIÓ}

Temps aproximat de l'activitat 20 minuts:

1. Introducció i recordatori: 5 minuts

2. Realització dels exercicis individualment: 5 minuts

3. Comentaris de les activitats: 5 minuts

4. Reflexió final: 5 minuts

\section{ORIENTACIONS}

- Una definició de les emocions podria ser la següent, encara que no és l'única: "Resposta del nostre organisme davant un succés determinat".

- Exemples d'emocions: ira, tristesa, alegria, felicitat, enuig, ensurt, por, indiferència, modèstia, pena, soledat, vergonya, sorpresa, etc.

- Les respostes als exercicis poden ser les següents, si bé aquestes podrien ser les més adequades poden no ser les úniques, ja que cada persona interpreta una mateixa situació d'una manera diferent. Si seria recomanable que si un alumne expressa una emoció molt diferent de la que es planteja se li indiqui que ha de fixar-se bé i posar-se al lloc d'aquest xiquet i pensar en com se sentiria ell.

1. Alexandre sent ensurt/por. 
2. Carme sent empipament/ira.

3. Joan sent sorpresa.

4. Elena sent alegria/felicitat.

\section{RECURSOS}

- Fitxa número 4 del quadern de 4 t de primària. 


\section{ELS ALTRES TAMBÉ SENTEN}

1. Vista: Fixa't bé en aquestes imatges, quina emoció expressen?

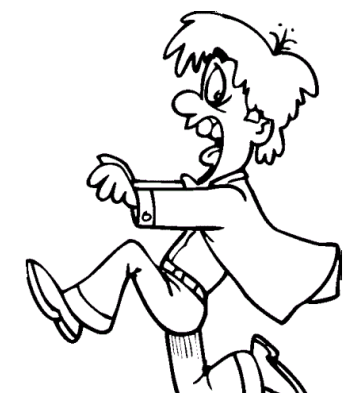

Alexandre està jugant i apareix un gos per darrere. Com se sent?

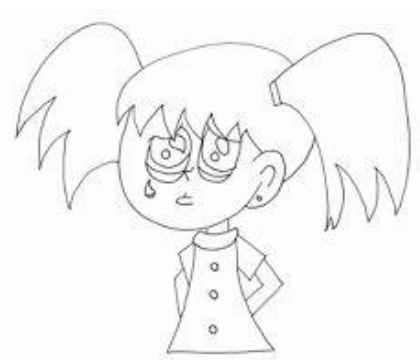

Carme s'ha barallat amb el seu amic Lluís. Com se sent?

2. Oïda: Joan et diu aquesta frase, què creus que sent?

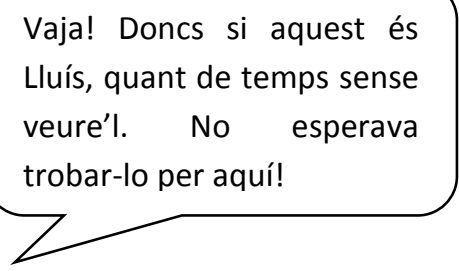

3. Tacte: ¿què voldria expressar Elena amb aquest gest?

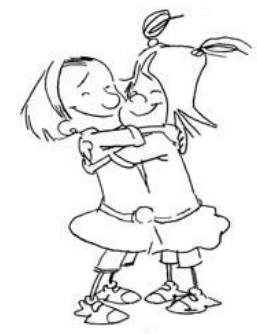

RECORDA...

Totes les persones sentim emocions i és molt important que nosaltres reconeguem les emocions dels altres perquè això ens ajudarà a tenir millors relacions amb ells i tot funcionarà millor. 
ASSIGNATURA:CIÈNCIES DE LA NATURALESA

ACTIVITAT: SENTIM DIFERENT

CONTINGUTS: AGRICULTURA I EMOCIONS

\section{OBJECTIUS CURRICULARS}

- Desenvolupar el concepte agricultura.

- Conscienciar sobre la importància de l'agricultura.

\section{OBJECTIUS SOBRE LA TEMÀTICA}

- Comparar les diferents emocions que es poden produir davant d'una mateixa situació.

- Descobrir maneres d'actuar davant les emocions dels altres.

\section{METODOLOGIA/ PROCEDIMENT}

En l'activitat que presentem treballarem continguts relacionats amb les plantes i l'agricultura juntament $a m b$ continguts relacionats amb les emocions. Els exercicis els podem trobar a la fitxa 20.

1. Iniciarem l'activitat amb una introducció en què recordarem els aspectes treballats sobre l'agricultura en grup:

Hem estat treballant en aquest tema l'agricultura, que és l'activitat encarregada de tenir cura i del cultiu de la terra i les plantes per a la producció d'aliments. Els agricultors treballen les terres $i$ les plantes per obtenir aliments, $i$ treballen dur durant tot l'any fins que arriba el moment de la recollida de la collita. El seu treball és molt important, ja que gràcies a ells obtenim aliments com les fruites, verdures, cereals, llegums,..., i també gràcies a ells els camps llueixen ben cuidats i sans.

2. Introducció i realització individual de la primera activitat:

Anem a fer ara el primer exercici, ens fixarem en les dues imatges que tenim; són dos camps amb aspecte molt diferent, ja que un ha estat ben cuidat per un agricultor, però l'altre està abandonat i ningú té cuidat d'ell. Imagineu que sortiu un dia de passeig amb la vostra família i veieu aquests dos camps. Què sentiríeu? Pot ser tristesa, alegria, sorpresa, etc. Mireu bé les imatges i anoteu què sentiu al mirar-les.

(Deixem que els alumnes observen individualment les imatges i escriguin l'emoció que experimenten en observar-les)

3. Comentem en grup les respostes dels alumnes en la primera activitat:

Digueu-me, què sentiu en veure la primera imatge? I la segona?

(Anotem a la pissarra les respostes dels alumnes a la primera imatge en una columna i en una altra columna la de la segona imatge, si coincideixen les emocions que experimenten anotem cadascuna de manera que al final puguem veure quants experimenten la mateixa emoció). 
Com podreu veure, cada un de nosaltres sent una emoció diferent davant d'una mateixa imatge, ja que totes les persones som diferents, $i$ no està ni bé ni malament que es tingui una emoció o una altra, l'important és compartir amb els altres com ens sentim i comprendre com se senten els altres escoltant-los i posantnos al seu lloc.

4. Introducció i realització en grup de la segona activitat, després individualment completaran l'exercici:

Recordeu el que us acabo de dir, i fixeu-vos que el segon exercici, ens diu: "Carles, un dels agricultors de tarongers de Castelló, està trist perquè aquest any la collita no ha estat bona a causa de les pluges". Penseu, què podríem dir o fer perquè Carles se senti millor? I què no li hauríem de dir o fer?

(Preguntem als alumnes i entre tots busquem una resposta que s'adeqüi al que hem treballat. El que sí podríem fer és posar-nos al seu lloc i dir-li que ho entens, preguntar-li si el puc ajudar en alguna cosa, que saps que ho està passant malament perquè ets conscient del molt que ha treballat. No hauríem de passar d'ell o no fer-li cas, i no cal dir-li coses com això no importa, tant se val, és normal que et passi això, no m'expliquis aquestes coses, etc. Quan acabem de comentar en grup, escriurem les respostes individualment a la fitxa.)

5. Reflexió final de l'activitat:

Llavors, no hem d'oblidar que totes les persones tenim emocions $i$ és important saber com se senten la resta. També sabem que davant d'una mateixa situació cada un pot tenir una emoció diferent, i això no està bé ni malament, simplement això ens indica que sentim diferent. Les emocions cal compartir-les, hem de comptar als altres com ens sentim, i que els altres també ens ho expliquin, posarnos al seu lloc, comprendre'ls i oferir-los la nostra ajuda.

\section{TEMPORALITZACIÓ}

\section{Temps aproximat de l'activitat $\mathbf{2 0}$ minuts:}

1. Recordatori concepte agricultura, 2. Introducció i realització primera activitat i 3. Comentem la primera activitat: 10 minuts

4. Introducció i realització de la segona activitat i 5. Reflexió final: 10 minuts

\section{ORIENTACIONS}

- Les respostes al primer exercici ens permetran veure que cada un experimenta una emoció diferent davant d'una mateixa situació, i que totes són vàlides, cap és millor que una altra simplement són diferents perquè nosaltres som diferents i sentim diferents.

- Les respostes al segon exercici poden ser les següents, amb aquestes donem pautes d'actuació davant les emocions que puguin experimentar els altres:

- El que sí podríem fer és: posar-nos al seu lloc i dir-li que ho comprens, preguntar-li si li puc ajudar en alguna cosa, que saps que ho està passant malament perquè ets conscient del molt que ha treballat, etc. 
- No hauríem de passar d'ell o no fer-li cas, i no cal dir-li coses com això no importa, tant se val, és normal que et passi això, no m'expliques aquestes coses.

\section{RECURSOS}

- Fitxa número 5 del quadern de $4 \mathrm{t}$ de primària. 


\section{SENTIM DIFERENT}

\section{Respon.}

1.

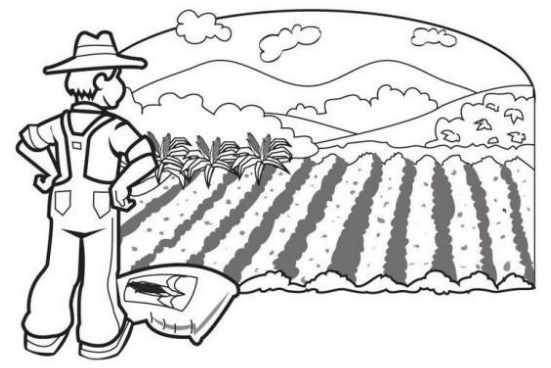

Què sents?
2.

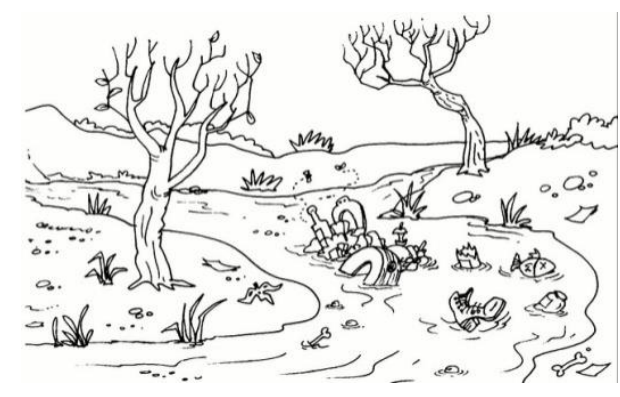

Què sents?

2. Els agricultors són els encarregats de la cura i cultiu de les terres i les plantes per a la producció d'aliments. Carles, un dels agricultors de tarongers de Castelló, està trist perquè aquest any la collita no ha estat bona a causa de les pluges.

- Què podries fer o dir perquè Carles es senti millor?

- Què no li hauries de dir o fer?

RECORDA...

Les persones tenim emocions diferents, i no està bé ni malament sentir una cosa o una altra. Hem de compartir i comprendre les emocions que sentim amb els altres, posant-nos al lloc de l'altre i escoltant bé el que ens diuen. 


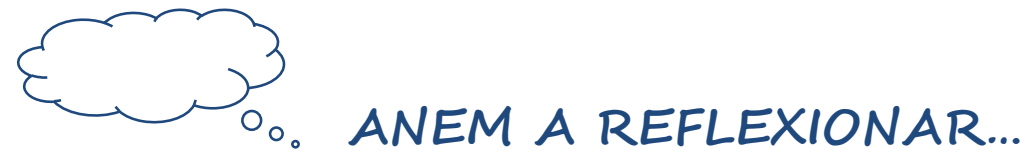

Després d'haver realitzat les activitats anteriors, reflexionarem sobre els aspectes que hem treballat. Per a això, contesta les següents qüestions:

1.Totes les persones tenim emocions i és important reconèixer com es senten els altres perquè tot funcioni millor i evitar problemes. Escriu l'emoció que expressen aquestes expressions.
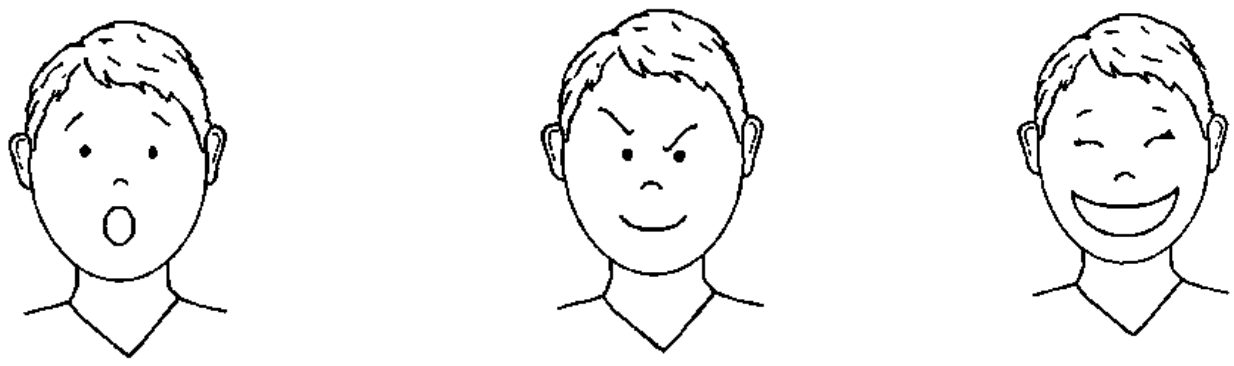

2. Totes les persones tenim les mateixes emocions, i està mal estar trist davant d'una determinada situació.

\section{Vertader}

Fals

3. Què podem fer quan una persona ens explica com se sent? 
FITXA D'AVALUACIÓ PER AL PROFESSOR/A DE LES ACTIVITATS DEL BLOC D'EMOCIONS

1. Com t'ha resultat dur a terme les tasques segons les indicacions exposades en les fitxes? Molt difícil $\square \quad$ Difícil $\square \quad$ Normal $\square \quad$ Fàcil $\square \quad$ Molt fàcil $\square$

2. Creus que es compleix l'objectiu proposat? Sí $\square \quad$ No $\square$

3. Has introduït les activitats al contingut curricular assenyalat o en algun altre?

T emes indicats $\square \quad$ Altres $\square$ (indica quins:

4. Has utilitzat altres recursos a part dels que apareixen a la fitxa? Sí $\square \quad$ No $\square$

5. ¿Faries alguna modificació de millora en les fitxes per assolir els objectius de manera més òptima? Sí $\square \quad$ No $\square$

(en cas afirmatiu, indica quina:

6. Com s'han sentit els alumnes en realitzar les activitats? (motivació, implicació, interacció amb altres, ....)

7. Hi ha algun aspecte que consideres oportú comenta per a la millora del programa? 


\section{AUTOCONTROL}

Gestionar de forma adequada les emocions $i$ els impulsos conflictius.

\section{Objectins.}

$\checkmark$ Controlar les reaccions que provoquen en nosaltres les accions d'altres.

$\checkmark$ Ser conscients de com afecten als altres les nostres accions i modificar-les. 
CURS: 4t PRIMÀRIA

FITXA: 7

ASSIGNATURA:CIÈNCIES SOCIALS

ACTIVITAT: ANEM A IMAGINAR

CONTINGUTS: EL MEDI NATURAL I AUTOCONTROL

\section{OBJECTIUS CURRICULARS}

- Reconèixer diferents tipus de paisatges.

- Reflexionar sobre el que ens transmeten els paisatges.

\section{OBJECTIUS SOBRE LA TEMÀTICA}

- Identificar les reaccions que provoquen en nosaltres les accions dels altres.

- Posar en pràctica tècniques de control per regular les nostres reaccions.

\section{METODOLOGIA / PROCEDIMENT}

En aquesta activitat treballarem continguts relacionats amb el medi natural així com continguts d'autocontrol. Aquesta activitat la podem trobar a la fitxa 22 del quadern.

1. Introducció de l'activitat en grup:

En el nostre dia a dia vivim moltes coses, estem en paisatges diferents i també ens relacionem amb molta gent. Tant l'espai del paisatge en el qual estem que pot ser urbà, industrial, etc., com la gent amb la qual estem, provoquen en nosaltres reaccions. Per exemple, si una persona ens dóna una empenta reaccionem a això per exemple amb un mal gest, o si una persona ens somriu reaccionem retornant el somriure, un paisatge urbà amb edificis molt alts $i$ amb molt de fum ens pot provocar una reacció d'aclaparament, o un paisatge natural ple de plantes $i$ animals la sensació de llibertat. És a dir, tot el que està al nostre voltant provoca en nosaltres sentiments i reaccions, i aquestes poden ser bones o dolentes.

2. Introducció en grup del primer exercici i realització individual d'aquest:

Com ja hem comentat, de vegades reaccionem al que ocorre al nostre voltant d'una manera positiva i altres tenim reaccions negatives. Anem a pensar ara cada un de nosaltres, en una situació que ens faci sentir ràbia o ira. Per exemple, a mi em produeix molta ràbia que em parlen amb un volum de veu molt elevat, o que $m^{\prime}$ agafin les meves coses sense demanar-me permís. Un cop tingueu pensada una situació així, recordeu com reaccioneu a aquesta situació. A mi una vegada una amiga va venir a casa meva a explicar-me una cosa que li havia passat i m'ho explicava cridant, en aquest moment em vaig aixecar de la cadira i li vaig dir que marxés de casa meva. La meva reacció no va ser bona, sento ràbia quan em criden i no vaig controlar la meva reacció. Com ja sé que aquesta reacció no va ser bona he de pensar de quina manera puc actuar quan em passi això per evitar reaccionar tan malament i podria ser dir-li a la meva amiga que per favor baixi el to de veu, que tracti de no parlar tan alt doncs no m'agrada que cridi.

Ara penseu una situació que us causi ràbia o ira i responeu al primer exercici.

(Deixem als alumnes que pensin una situació i que responguin individualment les tres preguntes del primer exercici). 


\section{Reflexió en grup del primer exercici:}

A veure, expliqueu-me alguna situació que us causi ràbia o ira, com reaccioneu a ella i de quines altres formes podries reaccionar millor.

(Els alumnes ens expliquen situacions que els produeixen ràbia o ira).

Com haureu pogut veure, hi ha certes accions o situacions que a tots ens produeixen ràbia o ira. La majoria de nosaltres quan ens passa això reaccionem d'una manera negativa, $i$ això hem d'aprendre a canviar-lo. Com ho podem fer? Doncs la millor manera és aprenent a generar reaccions alternatives, pensar de quina manera podem reaccionar positivament, però per a això cal que en aquell moment ens tranquil-litzem i reflexionem bé per trobar la reacció correcta. Per això és molt important que aprenguem a relaxar-nos.

4. Realització del segon exercici:

Una de les tècniques que podem aplicar quan ens passa alguna cosa que ens produeix ira o ràbia, és tancar els ulls i pensar en un paisatge que ens encanti que sigui agradable per a nosaltres. Existeixen molts tipus de paisatges; agrícoles, urbans, industrials, etc. I a cada un de nosaltres cada paisatge ens aporta una sensació diferent. En aquest moment només anem a pensar en aquest paisatge que ens produeix bones sensacions. Tanquem ara tots els ulls $i$ pensem en aquest paisatge (pausa d'uns segons), penseu a què fa olor (pausa), recordeu bé què és el que esteu veient (pausa) i com us sentiu (pausa).

Agafeu la fitxa i anoteu tot el que hem sentit, vist, olorat ...

5. Reflexió final:

Ja sabem que hi ha accions dels altres que no ens agraden $i$ ens provoquen sentiments d'ira i de ràbia, i això ens fa reaccionar d'una manera inadequada. Per evitar reaccionar així és important aprendre a identificar aquestes situacions $i$ a generar alternatives que ens ajudin a reaccionar més positivament, però abans d'això, si veiem que el nostre nerviosisme no ens permet reaccionar com hem de fer-ho, el que cal fer és relaxar-se. Tanquem els ulls, pensem en un paisatge agradable i vam començar a quedar-nos amb tot allò bo que ens aporta.

\section{TEMPORALITZACIÓ}

Temps aproximat de l'activitat 22 minuts:

1. Introducció de l'activitat: 4 minuts

2. Introducció i realització del primer exercici: 4 minuts.

3. Reflexió primer exercici: 5 minuts

4. Realització del segon exercici: 5 minuts

5. Reflexió final: 4 minuts

\section{ORIENTACIONS}

- En el primer exercici és important que reconeguin aquelles situacions en què accions produïdes per altres persones els provoquen ira o ràbia. El fet de reconèixer-los permetrà donar-se compte de la reacció que tenen davant una 
situació que els fa sentir així, de manera que podran valorar la seva reacció. Si la seva reacció davant situacions que els fan sentir ràbia o ira no és adequada, s'han de donar compte d'això i veure que hi ha altres formes millors de reaccionar a eixa situació que comporti conseqüències més positives.

- En el segon exercici hem de comprovar que estan imaginant i que es concentren bé en la situació que els plantegem. Potser alguns alumnes es relaxin en aquest moment i altres que no ho aconsegueixen, però el nostre objectiu és que capturin en les seves ments un paisatge que els faci sentir bé i que sàpiguen que tancant els ulls i pensant en això durant un instant aconseguiran relaxar-se i tranquil-litzar-se i això els portarà a una reacció més positiva, i a controlar els seus impulsos.

\section{RECURSOS}

- Fitxa número 7 del quadern de 4 t de primària. 


\section{ANEM A IMAGINAR}

1. Pensa en una situació o esdeveniment que pugui fer-te sentir agressivitat o ira.

\section{SITUACIÓ}

COM REACCCIONAS DAVANT AQUESTA SITUACIÓ?

DE QUINA LA RESTA PODRIES AFRONTAR LA SITUACIÓ?

2. Imagina un paisatge còmode i agradable; una platja, una muntanya, etc. Tanca els ulls $\mathrm{i}$ pensa en ell. Concentra't en les sensacions del teu cos i respira profundament.

- A què fa olor?

- Què és el que veus?

- Com et sents?

RECORDA...

Hi ha accions dels altres que ens provoquen sentiments d'ira i de ràbia. Per evitar reaccionar així, és important aplicar tècniques d'autocontrol que ens ajudin a reaccionar millor. 
ASSIGNATURA:CIÈNCIAS SOCIALS

ACTIVITAT: ACCIÓ I REACCIÓ

CONTINGUTS: L'ORGANITZACIÓ TERRITORIAL D'ESPANYA I AUTOCONTROL

\section{OBJECTIUS CURRICULARS}

- Conèixer el seu municipi.

- Reflexionar sobre el concepte de democràcia i drets ciutadans.

\section{OBJECTIUS SOBRE LA TEMÀTICA}

- Reconèixer les reaccions que provoquen en altres les nostres accions.

- Aprendre a controlar les reaccions inadequades per millorar la convivència amb els altres.

\section{METODOLOGIA / PROCEDIMENT}

En aquesta activitat treballarem diferents continguts relacionats amb l'organització territorial d'Espanya i continguts d'autocontrol. La present activitat la podem trobar a la fitxa 23 del quadern.

1. Introducció a l'activitat en grup:

Com ja sabeu, estem estudiant l'organització territorial d'Espanya. Hem vist que el nostre país s'organitza per comunitats, i cada comunitat en províncies. Nosaltres vivim a la Comunitat Valenciana, i en concret a la província de Castelló, però les províncies també s'organitzen per municipis. Quin és el municipi en el qual vivim nosaltres?

(Preguntem als alumnes perquè ens diguin en quin municipi viuen).

2. Realització individual del primer exercici:

D'acord, doncs ara vull conèixer la vostra opinió sobre el vostre municipi, vull saber si us agrada viure allà, per quin motiu i si hi ha alguna cosa que no us agrada i que canviaríeu. Agafeu la fitxa i responeu a les preguntes del primer exercici.

(Treballen individualment responent a les tres preguntes del primer exercici en què donaran a conèixer la seva opinió sobre el seu municipi).

3. Introducció al segon exercici:

Molt bé, ja haveu escrit la vostra opinió sobre el vostre municipi. Segurament cada un de vosaltres haurà donat una opinió diferent, i totes $i$ cadascuna d'elles és vàlida. Nosaltres vivim a Espanya, que és un país democràtic, on els ciutadans tenim uns drets. Entre ells tots tenim la llibertat d'expressar la nostra opinió, però hem de saber que perquè la convivència sigui bona, hem d'aprendre a expressar la nostra opinió adequadament, perquè igual que hem vist en l'activitat anterior que les accions dels altres provoquen una reacció en nosaltres, també les nostres accions provoquen reaccions en els altres.

I què vol dir expressar la nostra opinió adequadament? Doncs vol dir donar la nostra opinió amb un to adequat, amb vocabulari adequat, escoltant el que ens diuen els altres, $i$ acceptant l'opinió dels altres, ja que si no ho fem així el nostre 


\section{comportament pot molestar els altres.}

Sabent l'important que és el donar la nostra opinió com correspon, el posarem en pràctica. Ens organitzarem en parelles, un serà l'alumne número 1 i l'altre el 2. Cada un llegirà el text que hi ha sota el número que li hagi tocat i expressarà la seva opinió, que ha escrit en el primer exercici, seguint les indicacions que li donen. Comença l'alumne 1 i a continuació expressa la seva opinió l'alumne 2. Quan els dos hàgiu exposat la vostra opinió, comenteu què us han semblat les dues formes d'expressar l'opinió, si alguna de les dues pot fer sentir malament a la persona amb la qual parla i quina de les dues considereu millor. Seguidament responeu a la pregunta del segon exercici.

(Distribuïm el grup-classe en parelles, de manera que a cada un li assignem el nombre alumne 1 o el alumne 2.)

4. Reflexió final en grup:

Mentre heu exposat les vostres opinions us haureu adonat de la diferència que hi ha entre expressar les coses d'una manera o d'una altra. Si estem amb altres persones, les accions que nosaltres realitzem generen una reacció en ells, i si volem que la seva reacció sigui bona hem d'aprendre a controlar la nostra acció. Si parlem de males maneres, si traiem les coses als altres sense permis, si els insultem, això produirà en els altres una reacció negativa cap a nosaltres, les coses aniran malament i tindrem problemes. No obstant això, si controlem els nostres actes $i$ ens relacionem positivament, els altres reaccionaran bé $i$ tot anirà a millor. Per tant, és important parar-nos a pensar com fer les coses, controlar les nostres accions, si cal aturant-nos a pensar i a tranquil-litzar-nos. Si la nostra acció és bona la reacció dels altres també ho serà.

\section{TEMPORALITZACIÓ}

Temps aproximat de l'activitat 20 minuts:

1. Introducció general: 2 minuts

2. Realització del primer exercici: 5 minuts.

3. Introducció al segon exercici: 10 minuts

4. Reflexió final: 3 minuts.

\section{ORIENTACIONS}

- En el primer exercici tenim com a objectiu que els alumnes aprenguin a expressar la seva opinió, no existeix opinió vàlida o no vàlida, cadascú té una opinió diferent i l'important és que sàpiguen expressar-la.

- En el segon exercici cal parar atenció a les interpretacions que fan els alumnes, per això és important anar passant per la classe i veure si estan seguint les pautes que se li donen a cada alumne, i també veure què comenten sobre les dues actituds que es prenen. En aquest cas remarcarem la clara diferència que hi ha entre actuar d'una manera o altra, ja que si ho fem com l'alumne número 1 la nostra acció provocarà una reacció dolenta en l'altra persona, però si ho fem com l'alumne 2 la reacció serà millor .És a dir, que hem d'aprendre a controlar les nostres accions 
doncs elles comporten reaccions dels altres, i que encara que tots som lliures d'expressar la nostra opinió, és molt important també com ho fem.

RECURSOS

- Fitxa número 8 del quadern de 4 t de primària. 


\section{ACCIÓ I REACCIÓ}

1. Escriu la teva opinió sobre el teu municipi.

- En quin municipi vius?

- T'agrada viure allí? Per què?

- Què és el que menys t'agrada i què canviaries?

2. Llegeix i subratlla el text que correspon al nombre d'alumne que t'ha adjudicat el professor i segueix les indicacions:

- Alumne 1: Digues la teva opinió amb un to de veu alta, mostrant cara d'enuig i donant cops mentre parles.

- Alumne 2: Digues la teva amb un to de veu baixeta i agradable, i somrientli al teu company.

Quina ha estat la reacció del teu company a la teua actuació? ¿Amb quina de les dues actuacions creus que és la més adequada?

RECORDA...

És important parar-nos a pensar com fer les coses, controlar les nostres accions, si cal aturantnos a pensar i a tranquil-litzar-nos. Si la nostra acció és bona la reacció dels altres també ho serà. 


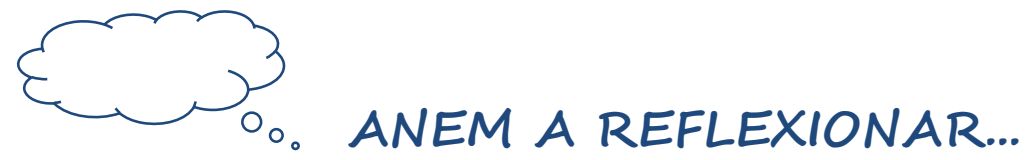

Després d'haver realitzat les activitats anteriors, reflexionarem sobre els aspectes que hem treballat. Per a això, contesta les següents qüestions:

1. Anomena dos situacions en què les accions dels altres et provoqui ira o ràbia.

- Que no m'escoltin quan parlo.

2. Igual que hi ha accions dels altres que ens provoquen ira i ràbia, també poden haver accions meves que provoquin reaccions dolentes en els altres. Per això és important controlar-me, perquè si la meva acció és bona, segurament la reacció dels altres també ho serà.

Vertader $\quad \square$ Fals

3. Quina tècnica d'autocontrol podries utilitzar en moments en què sentis ira o ràbia? Explica com ho faries. 
FITXA D'AVALUACIÓ PER AL PROFESSOR/A DE LES ACTIVITATS DEL

BLOC D'AUTOCONTROL

1. Com t'ha resultat dur a terme les tasques segons les indicacions exposades en les fitxes? Molt difícil $\square \quad$ Difícil $\square \quad$ Normal $\square \quad$ Fàcil $\square \quad$ Molt fàcil $\square$

2. Creus que es compleix l'objectiu proposat? Sí $\square \quad$ No $\square$

3. Has introduït les activitats al contingut curricular assenyalat o en algun altre?

T emes indicats $\square \quad$ Altres $\square$ (indica quins:

4. Has utilitzat altres recursos a part dels que apareixen a la fitxa? Sí $\square \quad$ No $\square$

5. ¿Faries alguna modificació de millora en les fitxes per assolir els objectius de manera més òptima? Sí $\square \quad$ No $\square$

(en cas afirmatiu, indica quina:

6. Com s'han sentit els alumnes en realitzar les activitats? (motivació, implicació, interacció amb altres, ....)

7. Hi ha algun aspecte que consideres oportú comenta per a la millora del programa? 


\section{PREVENCIÓ I RESOLUCIÓ DE CONFLICTES}

Evitar $i$ solucionar discrepancies entre dos $\sigma$ més interessos simultanis que algunes voltes donen lloc a un estat de tensió emocional que comporta estats dansietat $i$ comportaments impulsius.

\section{Objectius.}

$\checkmark$ Ser conscients de la importància de mostrar actituds adequades durant una conversa.

$\checkmark$ Aprendre habilitats que faciliten la relació en grup. 
CURSO: 4 PRIMARIA

FICHA: 10

ASIGNATURA: LENGUA CASTELLANA Y LITERATURA

ACTIVIDAD: ¿HABLAMOS?

CONTENIDOS: EXPRESIÓN ORAL Y PREVENCIÓN Y RESOLUCIÓN DE CONFLICTOS

\section{OBJETIVOS CURRICULARES}

- Participar en conversaciones.

- Reunir información y exponer la oralmente.

\section{OBJETIVOS SOBRE LA TEMÁTICA}

- Reflexionar sobre la importancia de mostrar una actitud positiva en las conversaciones.

- Discriminar entre actitudes adecuadas e inadecuadas en una conversación.

\section{METODOLOGÍA/PROCEDIMIENTO}

Esta actividad va a abarcar contenidos relacionados con la comunicación oral de cierta información recogida previamente junto con habilidades para prevenir los conflictos. Para llevar a cabo esta actividad vamos a utilizar la ficha número 10.

1. Introducción en grupo del concepto conversación y la importancia que tiene adoptar una actitud positiva durante las conversaciones:

Vamos a realizar una actividad en la que conversaremos con nuestros compañeros. Pero primer de todo, ¿sabéis lo que es una conversación? Una conversación es un diálogo entre dos o más personas en el que se habla sobre un tema, utilizando tanto lenguaje verbal como lenguaje no verbal, gestos, movimientos o expresiones faciales, postura corporal, etc. Cuando conversamos con alguien es muy importante que mostremos una actitud positiva y respetemos las normas de comunicación, así conseguiremos que la conversación sea buena y evitaremos conflictos y peleas.

2. Continuaremos con el primera actividad que lo realizaremos en gran grupo:

Entonces, sabiendo que las conversaciones pueden funcionar bien o mal en función de nuestra actitud, vamos a ver qué acciones tendríamos que tomar y cuáles no.

En el primera actividad encontramos varias acciones, y debemos señalar aquellas que consideramos que son adecuadas realizar mientras conversamos. La primera frase nos dice: Tener en cuenta lo que dicen los compañeros. ¿Creéis que cuando conversamos tenemos que tener en cuenta lo que dicen los compañeros?

(Preguntamos una a una por las frases que tenemos escritas en la actividad y les orientamos sobre qué acciones son correctas y cuáles no. Mientras lo comentamos en voz alta lo alumnos irán marcado solo aquellas que si son correctas.)

3. Introducción y realización del segunda actividad en grupos de 4 alumnos:

Ahora que ya conocemos bien la actitud que hay que adoptar en una conversación para que ésta funcione bien, vamos a hacer grupos de cuatro para hacer una conversación. 
(Distribuimos la clase en grupos de 3 ó 4 personas, atendiendo a las características de los alumnos.)

En grupos, tal y como nos hemos puesto, vamos a conversar sobre lo importante que es tener amigos. Para ello cada uno anotará en la ficha ideas que quiere contar a los compañeros. Por ejemplo si considera que es importante tener amigos, si es fácil hacer amigos, porque es bueno tener amigos...

Una vez tengáis todos las ideas anotadas podéis empezar a conversar. Ya sabéis que una conversación es un diálogo entre dos o más personas donde interviene el lenguaje oral (palabras, tono) y el no verbal (gestos, movimientos, expresiones de la cara, etc.). Por eso debemos prestar atención a todos estos aspectos y por supuesto a la actitud, que hemos dicho que debe ser positiva y que ya sabemos que acciones podemos tomar y cuáles no. Otro aspecto que debéis tener en cuenta es las frases que utilizáis en la introducción de la conversación, por ejemplo lo podemos hacer mediante una pregunta: ¿y tú qué piensas sobre los amigos?, seguimos la conversación contestando a los que los compañeros preguntan o añadiendo una opinión, y para finalizar siempre debemos transmitir que nos ha gustado conversar con ellos y que lo has pasado bien.

Si seguimos todos estos consejos conseguiremos que la conversación sea buena, que no haya peleas ni enfrentamientos, disfrutaremos hablando con los compañeros y conoceremos bien lo que piensan.

\section{TEMPORALIZACIÓN}

Tiempo aproximado de la actividad 25 minutos:

1. Información sobre los conceptos conversación y actitud positiva y 2 . Realización del primera actividad : 10 minutos

3. Introducción y realización del segunda actividad: 15 minutos

\section{ORIENTACIONES}

- Las acciones que debemos marcar en el primera actividad como correctas son:

- Tener en cuenta lo que dicen los compañeros

- Expresar adecuadamente lo que se siente

- Participar activamente en la conversación

- La finalidad de esta actividad es que los alumnos aprendan a comunicarse correctamente, que conozcan cuales son las pautas de comunicación que favorecen la comunicación positiva y que las pongan en práctica.

\section{RECURSOS}

- Ficha número 10 del cuaderno de 4으 de primaria. 


\section{¿HABLAMOS?}

1. La actitud que mostramos en una conversación es muy importante, por eso debemos mostrar siempre una actitud positiva. Señala las acciones correctas.

$\square$ Tener en cuenta lo que dicen los compañeros.

Estar callado durante la conversación.

No escuchar a los compañeros cuando hablan.

Expresar adecuadamente lo que se siente.

$\square$ Querer salirse con la suya.

Participar activamente en la conversación.

\section{Selecciona y escribe el tema sobre el que conversaréis en grupo.}

Tema: Importancia de tener amigos.

Ideas a desarrollar sobre el tema:

西

-

RECUERDA...

Cuando nos relacionamos con gente y nos comunicamos debemos tomar una actitud positiva; tomar en cuenta lo que dicen los compañeros, expresar adecuadamente lo que sentimos y participar activamente en la conversación, así la comunicación será buena y no surgirán problemas. 
CURSO: 4 PRIMARIA

FICHA: 11

ASIGNATURA: LENGUA CASTELLANA Y LITERATURA

ACTIVIDAD: ¿QUÉ OCURRE?

CONTENIDOS: COMUNICACIÓN ORAL Y PREVENCIÓN Y RESOLUCIÓN DE CONFLICTOS

\section{OBJETIVOS CURRICULARES}

- Reconocer situaciones que favorecen o impiden la comunicación.

- Desarrollar estrategias y normas de comunicación oral.

\section{OBJETIVOS SOBRE LA TEMÁTICA}

- Prevenir conflictos que puedan surgir en la comunicación oral.

- Reflexionar sobre la importancia de aprender habilidades que faciliten la relación en grupo.

\section{METODOLOGÍA/ PROCEDIMIENTO}

La actividad que vamos a desarrollar a continuación abarca contenidos relacionados con la comunicación así como también contenidos relacionados con la prevención de conflictos. Dicha actividad la podemos encontrar en la ficha número 11 del cuaderno.

1. Introducimos la actividad en grupo recordando lo aprendido en la actividad anterior, en el que remarcaremos la importancia de mostrar una actitud positiva en las conversaciones y las actitudes que son adecuadas o no en una conversación:

Como ya sabemos, la comunicación entre las personas es imprescindible. Comunicar es transmitir un mensaje a otra persona. Cuando nos relacionamos con gente y nos comunicamos, debemos tomar una actitud positiva para que la comunicación vaya bien y no surjan problemas. Dijimos que era importante tomar en cuenta lo que dicen los compañeros, expresar adecuadamente lo que sentimos y participar activamente en la conversación, pero además de la actitud, también debemos aprende habilidades para relacionarnos mejor. Así, con una buena actitud y unas buenas habilidades conseguiremos sentirnos bien, a gusto y seguros con los demás.

2. Conocemos cual es la actitud adecuada en una conversación, ahora vamos a seguir en grupo desarrollando habilidades de comunicación que favorezcan las relaciones:

Ahora que ya sabemos la actitud que debemos tomar para que todo vaya bien, ¿qué otras habilidades podríamos aprender para mejorar nuestras relaciones comunicativas? Por ejemplo, hay que escuchar lo que cuentan los demás. ¿Qué más cosas me podéis decir?

(Dejamos que los alumnos vayan diciendo habilidades que facilitan la relación con los demás, y los vamos anotando a la pizarra. Algún ejemplo más sería en los indicadores de evaluación.)

3. Realización en grupo de las actividades:

Vamos a leer pues los ejercicios que son diálogos entre compañeros, y entre todos vamos a ver cuál es la habilidad que les falta. 
(Vamos indicando a los alumnos que lean los diálogos, y después de la lectura en voz alta de cada uno planteamos en voz alta también la pregunta para que vayan aportando su opinión y, cuando ya esté consensuada, cada uno la escribe en su ficha. Tenemos las respuestas en el apartado de orientaciones.)

4. Reflexión final:

Habéis visto en estos diálogos, que la comunicación entre estos compañeros no es buena, puesto que alguno de ellos carece de alguna habilidad de comunicación y esto dificulta la conversación. Además, cuando ocurre algo así; que alguien no escuche, que hable de otra cosa, que sólo se dirija a una persona..., puede llevar a conflictos y discusiones, por eso es importante que conozcamos qué habilidades podemos desarrollar para que las relaciones y conversaciones en grupo vayan bien. Si sabemos ya cuáles son, solo nos queda ponerlas en práctica, y así veremos cómo nuestras conversaciones y relaciones son mejores.

\section{TEMPORALIZACIÓN}

Tiempo aproximado de la actividad 20 minutos:

1. Introducción de la actividad: 5 minutos.

2. Desarrollo de habilidades de comunicación: 5 minutos.

3. Realización en grupo de las actividades: 5 minutos.

4. Reflexión final: 5 minutos

\section{ORIENTACIONES}

- Ejemplos de habilidades que facilitan la relación con los demás: hablar con claridad y con un tono de voz adecuado, todos deben hablar y son igual de importantes, cuando se diga algo tiene que estar relacionado con el tema de la conversación, hablamos dirigiéndonos a todos los presentes en la conversación, respetamos los turnos de palabra, etc.

- Respuestas a las preguntas de los ejercicios:

1. Laura habla de temas que no están relacionados con la conversación.

2. Nuria al hablar sólo se dirige a María.

3. Marcos es el que no deja hablar a los compañeros.

\section{RECURSOS}

- Ficha número 11 del cuaderno de 4으 de primaria. 


\section{¿QUÉ OCURRE?}

1. David está con sus amigos José y Laura. Están en el patio del colegio conversando:

- DAVID: Chicos, esta tarde podríamos quedar e ir a jugar a mí casa. Tengo un juego nuevo que os va a gustar.

- JOSÉ: Vale, me parece buena idea. Se lo preguntaré a mis padres.

- LAURA: Uf, que calor que tengo, al final no ha llovido.

- DAVID: Entonces si os viene bien a la salida del cole lo hablamos y vamos a mi casa.

- ¿Qué habilidad le falta a Laura?

\section{María habla con sus dos amigas Nuria y Susana.}

- MARÍA: Esta mañana he ido a casa mi abuela y me ha enseñado a hacer galletas. Estaban muy ricas y son muy fáciles de hacer.

- NURIA: Oye María, pues podrías enseñarme a hacer esas galletas.

- SUSANA: Yo también se hacer galletas de chocolate, me enseñó mi madre.

- NURIA: María, pregúntale a tu abuela qué día podemos ir a su casa.

- ¿Qué norma de conversación no está respetando Nuria? 
3. Claudia, Marcos y Sofía están realizando un trabajo en clase.

- MARCOS: Yo creo que deberíamos distribuirnos el trabajo, cada uno puede hacer una parte y después nos juntamos y lo terminamos juntos.

- CLAUDIA: De acu...

- MARCOS: Tú Claudia podrías hacer la introducción, y mientras Sofía que busque información sobre los mamíferos y yo buscaré fotos.

- SOFÍA: Pero...

- MARCOS: Entonces ya tendremos claras las partes y solo será juntarlo.

- ¿Quién no está dejando hablar a los compañeros?

RECUERDA...

Es importante que conozcamos qué habilidades podemos desarrollar para que todo vaya bien cuando nos comunicamos y nos relacionamos en grupo. 


\section{VAMOS A REFLEXIONAR...}

Después de haber realizado las actividades anteriores, vamos a reflexionar sobre los aspectos que hemos trabajado. Para ello, contesta las siguientes cuestiones:

1. Cuándo nos relacionamos en grupo hay que tomar una actitud positiva; tener en cuenta lo que dicen los compañeros, expresar adecuadamente lo que se siente y participar activamente en la conversación.
Verdadero
Falso

2. ¿Qué habilidades hay que desarrollar para que las relaciones sean buenas? 
FITXA D'AVALUACIÓ PER AL PROFESSOR/A DE LES ACTIVITATS DEL BLOC DE PREVENCIÓ I RESOLUCIÓ DE CONFLICTES

1. Com t'ha resultat dur a terme les tasques segons les indicacions exposades en les fitxes? Molt difícil $\square \quad$ Difícil $\square \quad$ Normal $\square \quad$ Fàcil $\square \quad$ Molt fàcil $\square$

2. Creus que es compleix l'objectiu proposat? Sí $\square \quad$ No $\square$

3. Has introduït les activitats al contingut curricular assenyalat o en algun altre?

T emes indicats $\square \quad$ Altres $\square$ (indica quins:

4. Has utilitzat altres recursos a part dels que apareixen a la fitxa? Sí $\square \quad$ No $\square$

5. ¿Faries alguna modificació de millora en les fitxes per assolir els objectius de manera més òptima? Sí $\square \quad$ No $\square$

(en cas afirmatiu, indica quina:

6. Com s'han sentit els alumnes en realitzar les activitats? (motivació, implicació, interacció amb altres, ....)

7. Hi ha algun aspecte que consideres oportú comenta per a la millora del programa? 


\section{BON ÚS DE LES TIC}

\section{Objectins.}

$\checkmark$ Conèixer què és Internet.

$\checkmark$ Ser conscients de la importància de fer un ús responsable dels diferents usos que es poden fer d'Internet. 
ASSIGNATURA:CIÈNCIES DE LA NATURALESA

ACTIVITAT:A INTERNET HO TROBAREM

\section{CONTINGUTS:CLASSIFICACIÓ DELS ÉSSERS VIUS I BON ÚS DE LES NOVES TECNOLOGIES}

\section{OBJECTIUS CURRICULARS}

- Obtenir informació de forma responsable mitjançant eines de recerca i visualització digital amb dispositius TIC.

- Explorar informació sobre les bactèries.

\section{OBJECTIUS SOBRE LA TEMÀTICA}

- Conèixer què és Internet i els usos.

- Generar en els alumnes una visió crítica dels usos i de la informació que circula per Internet.

\section{METODOLOGIA / PROCEDIMENT}

En aquesta activitat treballarem continguts relacionats amb la classificació dels éssers vius i també continguts on treballarem el bon ús de les noves tecnologies. Per a treballar aquesta activitat hem elaborat la fitxa 13.

1. Introducció en grup de l' activitat:

En aquest tema estem estudiant les bactèries, ja hem vist alguna informació sobre aquestes però, vos agradaria saber alguna cosa més d'elles? Veure com són? Com és classifiquen? Quants tipus hi ha?

(Els alumnes responen a les nostres preguntes i exposen les seues idees sobre si els agradaria saber alguna cosa més i què és el que els voldrien conèixer sobre les bactèries.)

D'acord, són moltes les coses que ens agradaria saber però, ¿̇on podem buscar-les si al nostre llibre no ens les conten?

(Generem una pluja d'idees on els alumnes ens diguin on creuen ells que podem trobar la informació que necessitem. Són moltes les fonts d'informació (revistes, enciclopèdies, diccionaris, Internet, etc.) però la més actual i la que ens interessa que coneguin en aquesta activitat és Internet.)

2. Realització en grup de la primera activitat:

Ja havem dit moltes fonts d'informació on podríem trobar allò que volem buscar però una de les més actuals i que més s'utilitzen hui en dia per a buscar informació és Internet. Algú de vosaltres utilitza a casa Internet o els vostres pares? De segur que sí! I sabríeu dir-me que és Internet i per a que ho podem utilitzar?

(De nou els alumnes realitzen una pluja d'idees sobre què és Internet i tot allò que es pot realitzar en Internet, $\mathrm{i}$ ho anotem a la pissarra per a que després ho escriguin a la seua fitxa. Trobarem més informació a l'apartat d'orientacions sobre el concepte d'Internet i els seus usos que són importants que coneguin.)

Anotem ara cadascú a la fitxa la definició d'Internet i els usos més importants.

3. Realització en grup de la segona i tercera activitat:

Perfecte, doncs ara que ja sabem el que més ens agradaria saber sobre les 
bactèries ho anotarem a l'activitat dos, $i$ com que a Internet podem trobar informació que ens ajudarà a saber més i a realitzar la nostra feina, anem a buscar-lo!

(A partir de la informació que els alumnes ens ha dit que voldrien conèixer, seleccionem aquella que ens resulta més interessant que coneguin i utilitzant un ordinador amb pantalla o la pissarra digital, ens connectarem a Internet per a fer la recerca.)

Navegar per Internet és fàcil, nomes cal seguir aquests passos: engeguem en aquest cas l'ordinador, però ja sabeu que des de la tableta o mòbil, si tenim connexió a Internet també vos podeu connectar i obrim la finestra del navegador. Un volta ja ens hem connectat amb Internet, podem escriure directament la pàgina web si la coneixem o cercar escrivint bé el que busquem a un cercador com pot ser Google i fem un clic a cercar. D'acord? De segur que més d'una volta ho haveu fet a casa, però digueu-me, què fem ara amb tota la informació que ens ix sobre el que volem conèixer de les bactèries? Quina seleccionem?

(Els alumnes aporten les seues idees sobre quina informació seleccionar o com ho podem fer. Aquest apartat és el més important de l'activitat, doncs la majoria dels alumnes ja saben com cercar informació a Internet però han d'aprendre a tenir una visió crítica de tot allò que troben a la xarxa. Trobarem més informació a l'apartat d'orientacions sobre les pautes que els podem donar arribats a aquest punt i que anirem anotant a la pissarra per a que ells després ho escriguin a la fitxa.)

Ja haveu vist que quan busquem informació a un cercador d'Internet trobem moltes pàgines sobre el que busquem, però és necessari seguir les pautes que hem comentat per a elegir ben bé allò que busquem. Anem a respondre cadascú en la seua fitxa a l'activitat tres on hem d'escriure quina és la font que hem utilitzat per a buscar la informació i quins són els consells que cal seguir quan busquem informació per Internet.

(Elegim un dels enllaços que ens surten amb la nostra recerca, en general els més fiables són aquells que ens envien a alguna pàgina web adequada per a la seua edat i d'algun organisme reconegut, i tots junts llegim el que ens diu com a resposta al nostre dubte.)

4. Reflexió final en grup:

Com vos haureu adonat, utilitzar Internet és molt fàcil, i amb ell podem ajudar-nos per a realitzar tasques de l'escola, jugar, buscar informació que ens interessi $i$ comunicar-nos amb altra gent. Ja sabeu que quan cerquem informació és molt important seleccionar bé la pàgina web, ser conscients que no tota la informació que hi ha a la xarxa és reial o fiable, i que el millor és que els nostres pares ens ajuden a elegir quina és la millor pàgina, així com també avisar-los si veiem alguna cosa que no ens agrada. També és important que sapigueu que podeu utilitzar jocs d'Internet o xarxes socials, però cal assegurar-se bé que són adequats per a la vostra edat $i$ mai deveu facilitar informació personal a cap pàgina sense la supervisió d'un adult perquè us podeu posar en problemes, i Internet és una bona eina però cal utilitzar-la amb responsabilitat i l'autorització i supervisió d'un adult! 


\section{TEMPORALITZACIÓ}

Temps aproximat de l'activitat 20 minuts:

1. Introducció a l'activitat: 4 minuts.

2. Realització de la primera activitat: 4 minuts.

3. Realització de la segona i tercera activitat: 8 minuts.

4. Reflexió final: 4 minuts.

\section{ORIENTACIONS}

- Internet és una gran xarxa d'ordinadors que es comuniquen entre ells, units per connexions i que utilitzen un llenguatge comú que ens permet la comunicació entre millor d'usuaris de tot el món.

- Als xiquets i xiquetes Internet els permet principalment tres tipus d'accions, i és important que les coneguin. Aquestes són les que hem de remarcar:

- Ajudar-nos en les tasques escolars: ens pot ajudar a fer els deures i a practicar allò que hem après. Podem buscar informació per a fer activitats o treballs sobre algun tema, ja que Internet és la biblioteca més gran que existeix i on podem trobar informació sobre qualsevol cosa.

- Buscar informació sobre temes que ens interessen: allí trobarem informació de tot tipus.

- Jugar: podem trobar molts jocs divertits i també educatius.

- Comunicar-se: ens permet parlar amb amics, conèixer gent nova, compartir aficions, etc.

- La finalitat més important d'aquesta activitat és que els alumnes tinguin una visió crítica de la informació que hi ha a Internet i que sàpiguen elegir la informació més adequada al que busquen i també a la seua edat, per això és necessari que coneguin i posen el pràctica les següents pautes:

- Cal tenir cura quan busquem informació als cercadors d'Internet, moltes voltes el primer que ens apareix és publicitat o no té res a veure amb el que busquem.

- No hem de creure tota la informació que trobem a Internet perquè podem trobar informació que no sigui vertadera o fiable.

- Demanar ajuda als pares per a buscar informació a Internet, ells et sabran dir quines són les pàgines més segures i on et proporcionen bona informació sobre el que busques.

- Selecciona sempre aquelles pàgines on el contingut s'adequa a la teua edat.

- Si mentre busques informació a la xarxa trobes alguna cosa que no t'agrada o et fa sentir malament, avisa a un adult per a que t'ajudi, és molt important demana ajuda sempre que ho necessitem.

\section{RECURSOS}

- Fitxa número 13 del quadern de $4 \mathrm{t}$ de primària.

- Ordinador a l'aula amb connexió a Internet. 


\section{A INTERNET HO TROBAREM}

\section{Què és Internet? Quins usos pots fer d'Internet?}

\section{Què volem saber de les bactèries?}

3. Quina font d'informació hem utilitzat per a buscar la resposta al nostre dubte?

- Quins consells hem conèixer i seguir per a fer a correctament una recerca d'informació a Internet?

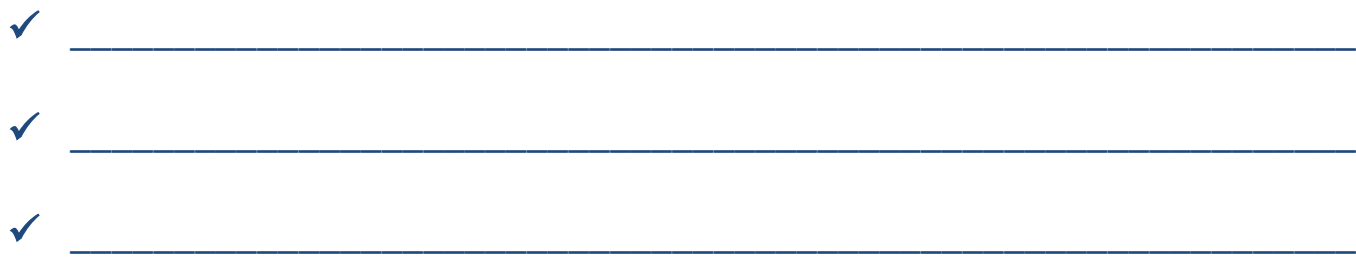

\section{RECORDA...}

Quan cerquem informació a Internet és molt important seleccionar bé la pàgina web, ser conscients que no tota la informació que hi ha a la xarxa és reial o fiable, i que els nostres pares ens ajuden a elegir quina és la millor pàgina, així com també avisar-los si veiem alguna cosa que no ens agrada. Internet és una bona eina, però cal utilitzar-la amb responsabilitat i amb l'autorització i supervisió d'un adult! 
ASSIGNATURA:CIÈNCIES DE LA NATURALESA

\section{ACTIVITAT:SIGUEM RESPONSABLES}

\section{CONTINGUTS: EL RECICLATGE DELS MATERIALS I EL BON ÚS DE LES NOVES TECNOLOGIES}

\section{OBJECTIUS CURRICULARS}

- Conèixer què són els materials i els tipus que hi ha.

- Qüestionar i debatre la importància i responsabilitat del reciclatge dels materials.

\section{OBJECTIUS SOBRE LA TEMÀTICA}

- Informar sobre l'ús d'Internet com a espai de diversió.

- Ser conscients dels riscos que comporta l'ús d'Internet com a oci.

\section{METODOLOGIA / PROCEDIMENT}

En aquesta activitat treballarem continguts relacionats amb el reciclatge dels materials i el bon ús de les noves tecnologies. Per a aquesta activitat hem elaborat la fitxa 14.

\section{Introducció en grup a l'activitat:}

Ja sabem que són els materials i les propietats que tenen, i que cada material serveix per a fabricar coses diferents. Digueu-me, quins tipus de materials coneixeu?

(Els alumnes ens van dient quins són els materials que coneixen, com per exemple: pell, fusta, plàstic, paper, cartró, vidre, porcellana, etc. )

Molt bé, doncs amb aquests materials fabriquem molts productes que utilitzem tots els dies, com botelles de plàstic o de vidre, llaunes, bosses de paper o plàstic, etc. I què hem de fer amb totes aquestes deixalles de materials que ja hem utilitzat? Les tirem a la paperera totes juntes?

(Reflexionem tots junts sobre aquesta pregunta amb la finalitat que els alumnes ens aporten respostes sobre què fer amb aquests materials una volta ja els hem utilitzat dirigint el debat cap a la importància del reciclatge.)

2. Realització individual i en grup de la primera activitat:

Nosaltres som responsables del nostre ecosistema i si volem cuidar-lo el que hem de fer és separar el fem i reciclar-lo. Però sabeu tots què és el reciclatge? Doncs és un procés que consisteix en sotmetre un material ja utilitzat a un tractament per a obtenir una matèria prima o un altre material. Creieu que és important reciclar? Som tots responsables del que realitzem amb el fem que produïm a les nostres cases? Escrigueu el que opineu a la fitxa i ara ho comentarem tots junts.

(Els alumnes valoren la importància del reciclatge i si som o no responsables del que ocorre amb el fem. En aquest punt és important que reflexionen sobre el concepte de ser responsable. Trobarem més informació de com seguir aquesta xerrada a l'apartat d'orientacions.) 


\section{Realització en grup de la segona activitat:}

D'acord, aleshores com hem pogut veure, moltes voltes nosaltres hem de ser responsables per a que no ocorrin al nostre voltant coses que no desitgem, al igual que amb el fem també tenim que ser responsables també ho devem ser amb altres coses que ens envolten. Per exemple, recordeu l'activitat de l'altre dia on parlàvem de la importància de ser saber com utilitzar adequadament la informació que trobem a Internet? Conèixer com fer bé les coses i seguir eixos consells ens ajuda a ser responsable en Internet. A més de buscar informació que ens interessa vàrem comentar que Internet també ens permet altres coses com jugar o comunicar-se. Llavors, imagineu que utilitzem Internet per a jugar, com creieu que podem ser responsables? Què hem de fer per a jugar amb responsabilitat?

(Realitzem tots junts una pluja d'idees on recollirem consells sobre com fer un ús responsable a l'hora de jugar a Internet. Podem anotar a la pissarra totes les aportacions dels alumnes per a poder-ho escriure després a la fitxa. A l'apartat d'orientacions trobarem consells, sobre com fer un bon ús d'Internet mentre juguem, que és important que els alumnes coneguin.)

Escolliu els tres consells que més vos hagin agradat sobre la utilització de jocs a Internet i escriviu-los a la fitxa.

4. Reflexió final en grup:

Coneixem tots bé què és Internet, i que amb ell podem fer moltes coses com buscar informació que ens interessa, ajudar-nos a fer els deures, jugar o comunicar-nos. Internet ens aporta moltes coses bones però cal saber que també hi ha molts riscos a Internet. És important seguir els consells que vàrem conèixer l'altre dia a l'hora de buscar informació a Internet però també hem d'anar amb molt de compte quan juguem a Internet: cal utilitzar jocs que siguin Iliures i gratuïts, no utilitzar dades personals per a identificar-te al joc, desconfiar si ens diuen que ens ha tocat un premi i no respondre als missatges de gent desconeguda. Recordeu que sempre cal utilitzar Internet amb la supervisió d'un adult i si a més seguim aquests consells, aconseguirem passar-ho molt bé jugant per Internet sense riscos!

\section{TEMPORALITZACIÓ}

Temps aproximat de l'activitat 20 minuts:

1. Introducció a l'activitat: 5 minuts.

2. Realització de la primera activitat: 5 minuts.

3. Realització de la segona activitat: 5 minuts.

4. Reflexió final: 5 minuts.

\section{ORIENTACIONS}

- Un dels conceptes importants que treballem en aquesta activitat és la responsabilitat. Mitjançant el tema del reciclatge dels materials els podem fer preguntes com: sou vosaltres responsables del que ocorre amb el fem de les vostres cases?, què és ser responsable?, per què creieu que sou responsables, etc. 
Definirem el terme responsable com la persona que respon a les conseqüències de les accions que realitza, es a dir, ser conscients que el que ocorre amb les nostres deixalles és a causa de les nostres accions i per tant ens hem de fer càrrec de les conseqüències que pot comportar l'acció de no reciclar com l'augment de la contaminació de l'aire i de les aigües, creació d'espais tòxics als abocadors, acabarem amb els recursos naturals, etc.

- A l'activitat anterior hem treballat els diferents usos que podem fer d'Internet, un era buscar informació que ens interessa i ja hem conegut els consells que cal seguir per a fer un bon ús. Un altre dels usos que hem comentat és que a Internet es pot jugar, però també cal aprendre a fer un bon ús, i això és el que anem a treballar en aquesta activitat. Per tant, els alumnes ens aniran diguin que pensen ells que poden fer per a fer un bon ús a l'hora de jugar en Internet, però a continuació vos presentem una sèrie de recomanacions que és important que surten al debat i que els alumnes coneguin:

- Utilitza jocs que siguin lliures i gratuïts, perquè aquests demanen poques dades personals per a inscriure's.

- Evitar utilitzar el teu nom i cognoms o la data de naixement per a identificar-te als jocs.

- Desconfia si et diuen que t'ha tocat un regal o t'ofereixen algun premi, perquè segurament et demanaran alguna cosa a canvi.

- Si t'apareix algun missatge que et demani dades personals o que et digui alguna cosa que et fa sentir malament, ignora el missatge i avisa als teus pares.

- No facilites informació a cap persona que no coneguis ni publiques cap informació personal teua.

\section{RECURSOS}

- Fitxa número 14 del quadern de $4 \mathrm{t}$ de primària. 


\section{SIGUEM RESPONSABLES}

1. Creieu que és important reciclar el fem a casa?

- Si reciclem a casa, estem sent responsables amb el nostre ecosistema? Raona la teua resposta.

2. Per fer un ús responsable d'Internet mentre juguem cal tenir en compte aquests consells:

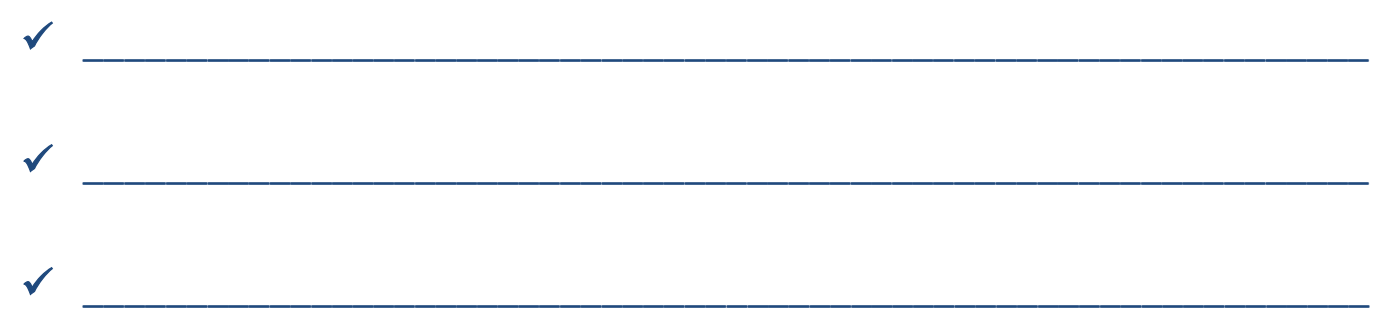

RECORDA...

Hem d'anar amb molt de compte quan juguem a Internet: cal utilitzar jocs que siguin lliures i gratuïts, no utilitzar dades personals per a identificar-se al joc, desconfiar si ens diuen que ens ha tocat un premi i no respondre als missatges de gent desconeguda. Recordeu que sempre cal utilitzar Internet amb la supervisió d'un adult i si a més seguim aquests consells, aconseguirem passar-ho molt bé jugant per Internet sense riscos! 


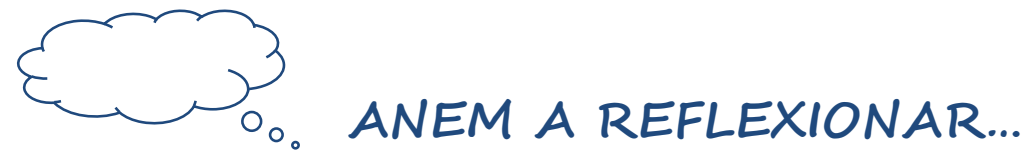

Després d'haver realitzat les activitats anteriors, reflexionarem sobre els aspectes que hem treballat. Per a això, contesta les següents qüestions:

1. Recordeu que a Internet podem buscar informació que ens interessa però cal fer-ho amb responsabilitat. Senyala els consells que cal seguir.

$\square$ Tota la informació que hi ha a la xarxa és reial o fiable.

$\square$ És important que els nostres pares ens ajuden a elegir quina és la millor pàgina.

$\square$ Selecciona sempre aquelles pàgines on el contingut sigui per a persones adultes o majors que tu.

$\square$ Si mentre busques informació a la xarxa trobes alguna cosa que no t'agrada o et fa sentir malament, avisa a un adult per a que t'ajudi.

2. A Internet també podem jugar... Escriu dos consells que cal seguir per a jugar amb seguretat a Internet. 
FITXA D'AVALUACIÓ PER AL PROFESSOR/A DE LES ACTIVITATS DEL

BLOC DEL BON ÚS DE LES TIC

1. Com t'ha resultat dur a terme les tasques segons les indicacions exposades en les fitxes? Molt difícil $\square \quad$ Difícil $\square \quad$ Normal $\square \quad$ Fàcil $\square \quad$ Molt fàcil $\square$

2. Creus que es compleix l'objectiu proposat? Sí $\square \quad$ No $\square$

3. Has introduït les activitats al contingut curricular assenyalat o en algun altre?

T emes indicats $\square \quad$ Altres $\square$ (indica quins:

4. Has utilitzat altres recursos a part dels que apareixen a la fitxa? Sí $\square \quad$ No $\square$

5. ¿Faries alguna modificació de millora en les fitxes per assolir els objectius de manera més òptima? Sí $\square \quad$ No $\square$

(en cas afirmatiu, indica quina:

6. Com s'han sentit els alumnes en realitzar les activitats? (motivació, implicació, interacció amb altres, ....)

7. Hi ha algun aspecte que consideres oportú comenta per a la millora del programa? 


\section{QÜESTIONARI FINAL}

\section{Alumnat 4rt de Primària}

Edat:

Gènere: Xic $\square \quad$ Xica $\square$

A continuació trobaràs una sèrie de qüestions amb tres possibles respostes. Llegeix detingudament i assenyala l'opció que s'acosti més al que tu penses. No et preocupis per les respostes que marques, no hi ha respostes correctes o incorrectes, només ens interessa la teva opinió.

\section{Quan ens fixem en com som ...}

$\mathrm{Hi}$ ha companys que només tenen coses bones $\mathrm{i}$ altres que només tenen coses que no m'agraden.

$\square$ Tots tenim coses bones però també coses que no ens agraden.

$\square$ Els defectes o coses que no ens agraden (com ser antipàtic) no es poden canviar mai.

2. Quan algú ens diu coses bones sobre nosaltres...

Cal escoltar-los bé perquè ens ajuden a recordar tot allò bo que tenim.

$\square$ No és important, només és important si ens diuen coses que no els agrada de nosaltres

No hem de fer cas, segur que és mentida i ho diuen perquè estiguem contents.

3. Quan estic amb un company o un amic ...

Mirant la cara i els moviments d'algú no podem saber com se sent. Ens ho ha de dir.

És important saber si està trist o content per comprendre el que fa o el que diu.

$\square$ No té res a veure com se sent un company amb el seu comportament a classe $o$ al pati.

4. Les persones tenim emocions diferents però...

Tots ens sentim sempre igual, si jo estic content els meus companys estan contents, si jo estic trist tots estan tristos també.

Quan algun amic o company se sent malament, està trist, enfadat o té por, nosaltres no podem dir-li res que pugui fer-li sentir millor.

Si penso que em passa a mi el que li ha passat a algun company podré entendre millor com se sent. 


\section{Quan sentim ràbia o estem molt enfadats...}

Responem sempre malament (cridant, insultant o plorant), i no es pot evitar.

Si em tranquil·litzo abans de dir o fer alguna cosa, podré respondre d'una millor manera.

És normal sentir-se malament i no podem fer res per a canviar-ho.

6. Quan parlo amb algú ...

És important el que li dic, és igual la cara i els gestos que faig mentre l'hi dic.

$\square$ És el mateix que jo li digui alguna cosa a algú cridant o en veu baixeta, la qüestió és dir-li-ho.

Si dic una cosa bonica però poso mala cara mentre ho dic, a l'altra persona li pot sentar malament.

\section{Quan estic parlant amb el meu grup d'amics o de companys ...}

Si no m'interessa el tema del que parlen, m'espero a que acabin i ja després parlarem d'una altra cosa.

$\square$ Quan m'ha passat alguna cosa interessant l'hi explico a tots sense deixar que ningú més parli perquè no em interrompin.

Sempre parlem els mateixos perquè no deixem que parlin els que només diuen tonteries.

8. Quan busques informació a Internet hi ha que...

Consultar les primeres pàgines web que surten perquè són les més fiables.

Ser conscients que no tota la informació que hi ha a la xarxa és real.

No cal explicar als pares tot el que busquem, no ens deixarien entrar en alguns llocs i ens perdríem informació.

9. Quan estem en Internet cal...

Contestar els missatges de gent que no coneixem és una bona manera de fer amics nous.

$\square$ Posar les nostres dades personals en els jocs perquè sigui més real $i$ ens acceptin més ràpidament

$\square$ Si ens toca un premi a l'entrar en alguna pàgina, pensar que pot ser una manera d'enganyar-nos.

10. Si mentre estàs a Internet hi ha alguna cosa que et fa sentir malament o algú et demana alguna cosa...

Cal explicar-ho a un adult.

Si no ho expliquem a ningú, ningú ho sabrà i serà com que no ha passat.

$\square$ Contar-li a un amic o company el que el que ha passat. 


\section{RECURSOS}

\section{GUIES}

* Junta de Castilla y León (2011). Manual de uso inteligente de las nuevas tecnologías para los alumn@s. De 8 a 10 años. Recuperado de: http://www.cyldigital.es/sites/default/files/library/manual810anosprogramaaprende.pdf

* Junta de Castilla y León (2011). Manual de uso inteligente de las nuevas tecnologías para los alumn@s. De 10 a 12 años. Recuperado de: https://www.cyldigital.es/sites/default/files/library/manual10-

12anosprogramaaprende.pdf

Concepte de noves tecnologies, informació sobre els videojocs, televisió, ordinador i Internet. També ens ofereixen informació sobre els riscs que podem trobar en la xarxa. A més, ens proporcionen informació sobre els e-drets dels xiquets i xiquetes i una sèrie de regles que es necessari que els menors coneguin a I'hora d'utilitzar les noves tecnologies.

* INTECO (2013). Guía de actuación contra el ciberacoso. Padres y educadores. Recuperado de: http://www.injuve.es/sites/default/files/2013/46/publicaciones/Gu\%C3\%ADa\%20 de\%20actuaci\%C3\%B3n\%20contra\%20el\%20ciberacoso.pdf

Concepte de ciberbullying, pautes de detecció, prevenció i actuació, icomportar a capel procés de denuncia iel delicte que comporta. Tambétrobarem una sèrie d'experiències de casos de ciberbullying ialtres riscos de l'ús de les TIC, així comconsells bàsics sobre l'ús de les noves tecnologies.

* Centro se Seguridad en Internet Protégeles (s.f.). Ciberbullying y privacidad. Guía para profesores. Recuperado de: http://www.yocontrolo.es/descargas/PROYECTO DAPHNE ES.pdf

Continguts teòrics relacionats amb el ciberbullying: concepte, qui intervé, prevenció, etc., i també altres sobre la privacitat: drets i deures, protecció de dades i delictes. També trobarem a aquests document una sèrie d'activitats per a treballar el ciberbullying i la privacitat en Internet. 
* Comisión de libertades e informática (2009). Proyecto CLI Prometeo. Manual práctico de uso de las tecnologías de la información. 9 a 11 años. Recuperado de:http://www.madrid.org/dat oeste/descargas/08 09/cli prometeo/Manual 9 11 castellano.pdf

Conjunt d'activitats on es treballen els diferents aspectes relacionats en l'ús de les tecnologies de la comunicació i la informació a partir d'històries relacionades amb I'ús que els menors fan d'aquestes tecnologies.

* Collell, J. y Escudé, C. (2008). No te enredes en la red. Guía para conocer el ciberbullying y algunos peligros de internet y las nuevas tecnologías. Recuperado de: http://www.xtec.cat/ jcollell/ZGuia\%20Ciber.pdf

Informació teòrica com el concepte de ciberbullying i conductes relacionades amb el ciberbullying. Presenta un conjunt d'activitats on a partir d'una sèrie d'històries es presenten qüestions per a debatre en grup sobre les conductes que es presenten a les històries.

Luengo, J. A. (2014). Ciberbullying. Prevenir y actuar. Guía de recursos didácticos para Centros Educativos. Recuperado de: http://www.copmadrid.org/webcopm/recursos/CiberbullyingB.pdf

Situació de l'ús de les TIC en els últims anys, conceptes teòrics sobre el ciberbullying i informació sobre diferents tècniques de treball del ciberbullying. En aquesta guia ens proporcionen també pautes i materials per la prevenció a partir de l'alfabetització digital des de l'educació primària. A més, la guia ens proporciona moltes activitats didàctiques per a portar a terme a les aules $\mathrm{i}$ un protocol d'intervenció ben desenvolupat amb materials i pautes tan per a pares com per a professors i alumnes. Finalitza amb una sèrie de referències normatives per a la reflexió i acció en el centre escolar.

* Fundación Dédalo (2012). Por un uso seguro de internet. Primaria. Recuperado de:http://www.disfrutalared.com/images/yootheme/fichas didacticas/FichasDida cticasPrimaria es.pdf

Conjunt d'activitats relacionades amb l'ús segur d'Internet on es treballen aspectes com els valors, el ciberbullying, la privacitat, etc. 


\section{PÀGINES WEB}

* PANTALlaS AMIgAS (http://www.pantallasamigas.net).És la web més completa, i la pionera en la temàtica, que existeix on encontrarem recursos relacionats amb l'ús segur i saludable de les noves tecnologies de tot tipus: articles, vídeos, definicions de conceptes, materials i recursos didàctics, etc.

* CIBERBULlyING (http://www.ciberbullying.com). A la web trobarem informació sobre el ciberbullying, recursos de prevenció, consells contra el ciberbullying, noticies, articles, entrevistes, etc. tot relacionat amb aquesta temàtica.

* PROTEGeleS.COM (http://www.protegeles.com). Organització de protecció al menor en Internet que proporciona informació a la seua web com pot ser com actuar front a un problema, recursos, guies, estudis, vídeos, etc. I informació concreta dirigida a pares i mares, alumnes o professors amb una sèrie de normes, responsabilitats, activitats, etc.

* YO CONTROLO (http://www.yocontrolo.es/).Trobarem informació sobre casos de pèrdua de privacitat o ciberbullying, recursos com guies, webs, vídeos, estudis, etc.

\section{VÍDEOS}

* Ciberacoso (Childnet International - Cyber Bullying). Caso de ciberbullying subtitulado español.https://www.youtube.com/watch?v=9bgdOuBn4Q4

* Ciberbullying: ciberacoso en redes sociales, videogames, smartphones... y su prevención.https://www.youtube.com/watch?v=SEC dOWFN5M\&index=1\&list= PLC186BF9FE0418ED2

* ¿Cómo actuar ante el ciberacoso? Ignora, bloquea, pide ayuda y denuncia. https://www.youtube.com/watch?v=tVAjiyNzYq0\&list=PLC186BF9FE0418ED2\&in $\underline{\operatorname{dex}=7}$

* Recomendaciones para el Uso Seguro de Internet y las Redes Sociales. https://www.youtube.com/watch?v=t$\underline{x 73 w 1 N 10 s \& l i s t=P L C 186 B F 9 F E 0418 E D 2 \& \text { index }=12}$

* ¿Cómo evitar ser víctima de ciberbullying por suplantación de identidad? https://www.youtube.com/watch?v=XQeFYgedVZg\&list=PLC186BF9FE0418ED2\& index $=15$

* Decálogo por la ciberconvivencia positiva y contra la violencia digital. https://www.youtube.com/watch?v=gXvG53ccyJY\&index=17\&list=PLC186BF9FE 0418ED2 
ANEXO 10. CUADERNO DEL PROFESOR DE 5० DE EDUCACIÓN PRIMARIA DEL PROGRAMA "CONVIURE EN UN MÓN REAL I DIGITAL"

Conviure en un món real i digital

QUADERN DEL PROFESSOR CINQUĖ DE PRIMÀRIA

CENTRE:

PROFESSOR/A:

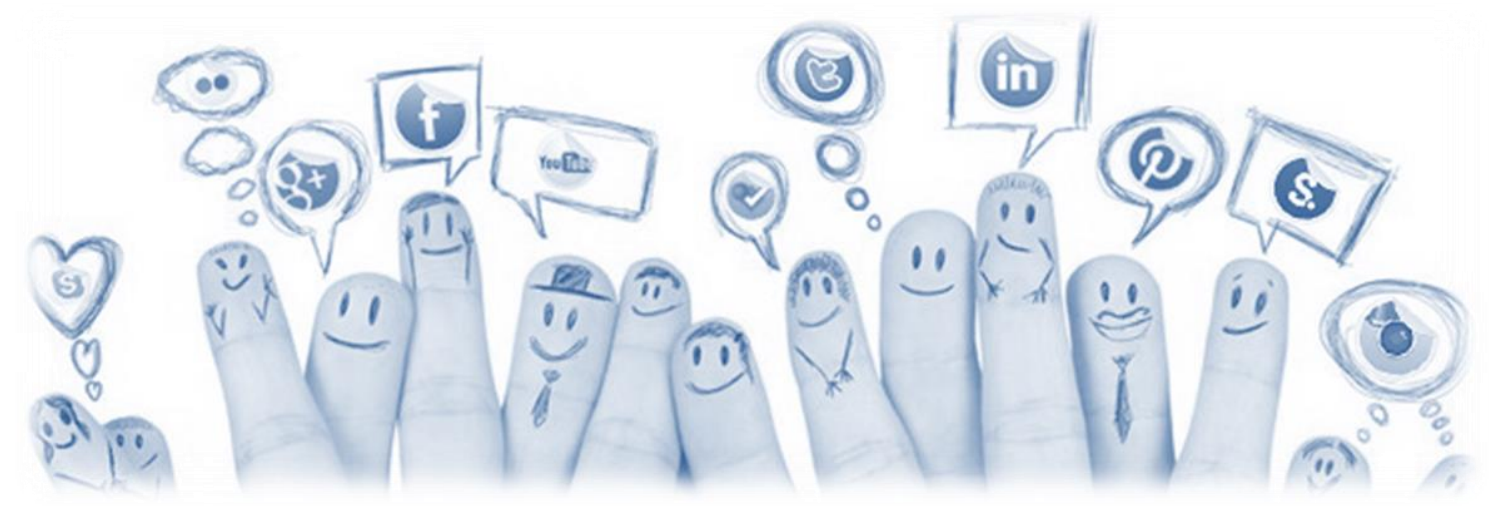




\section{ÍNDEX}

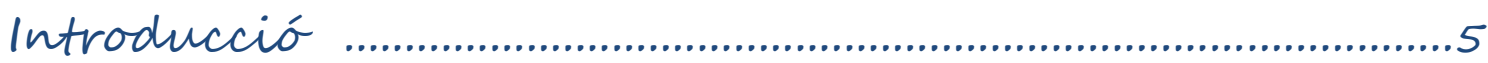

Objectiu general del programa ......................................................6

Caracteristiques $i$ configuració del programa ..........................6

Procediment per a l'aplicació del programa ..............................9

Taula de distribució de les activitats ................................11

Activitats:

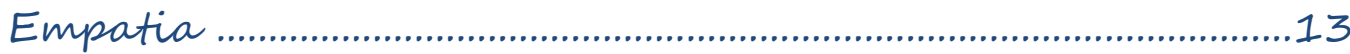

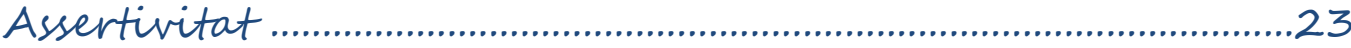

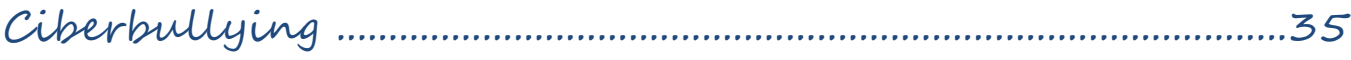

Prevenció $i$ resolució de conflictes .............................................49

Bon ús de les TIC ...........................................................................61

Qüestionari final ................................................................ 73

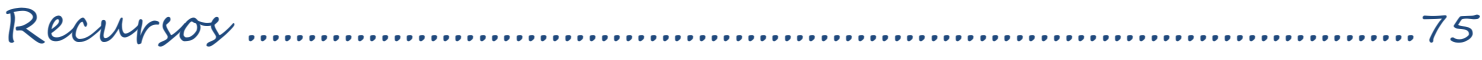




\section{INTRODUCCIÓ}

La infantesa, la pre-adolescència i l'adolescència són etapes crucials en el desenvolupament de les persones, tant a nivell personal com social i acadèmic/professional. Açò dona lloc a que els més joves siguin molt vulnerables davant l'entorn que els envolta i als continus canvis que caracteritzen la nostra societat actual. Els nostres joves han nascut en la era de les TIC, i fan ús d'elles des de edats molt primerenques.

En l'actualitat, els xiquets i les xiquetes, anomenats natius digitals, comencen a utilitzar les Tecnologies de la Informació i de la Comunicació (Tics) partir dels 3 anys d'edat, malgrat això, no saben com fer-ho de forma responsable i com protegir-se de les possibles amenaces. Així, sovint es troben amb una sèrie de dificultats com són l'accés a informació inadequada per a l'edat, sobretot continguts pornogràfics o violents, els riscos tècnics, la pèrdua de privacitat, la suplantació d'identitat, els fraus econòmics $i$ l'addicció a pantalles, entre altres (Salmerón, Campillo i Casas, 2013). Aspectes com aquests provoquen que s'acreixi l'alarma social, doncs aquests riscos són desconeguts per als educadors, els pares i les mares, que han crescut en un context no digital (Del Riu, Sádaba i Bringué, 2010).

Un dels riscos que formen part dels anteriorment citats, és el ciberbullying. Parlem de Ciberbullying "quan un nen o adolescent és turmentat, amenaçat, assetjat, humiliat, molestat d'una manera o una altra, per un altre nen o adolescent mitjançant l'ús d'Internet, tecnologies interactives i digitals o telèfon mòbil" (Collell i Escudé, 2008).

Aquest tipus de maltractament entre iguals s'ha convertit en un problema complex entre els nostres adolescents, que sol tenir repercussions indesitjables en la convivència escolar (Avilés, 2013), i encara que la violència no és cap cosa nova, ja que a la fi dels anys 70 el noruec Olweus es va iniciar en l'estudi de la violència entre escolars mundialment conegut amb l'expressió bullying, les formes de materialització de la mateixa han anat evolucionant amb el temps, ideant noves formes de dur-la a terme (Hernández i Solano, 2007).

Considerant l'anteriorment citat, els centres educatius de tots els nivells tenen en l'actualitat el deure incloure dins de la formació integral aspectes com el sensibilitzar i prevenir que entre el mateix alumnat sorgeixin situacions de maltractament $\mathrm{i}$ intimidació, encara que es sap que el ciberbullying no succeeix precisament dins de l'escola, és aquí on ha d'abordar-se com a part de l'educació integral (Ortega, 2010).

La nova educació que cal realitzar en l'àmbit de les TIC també ha de procurar capacitar en determinades destreses i habilitats, que suscitarà unes actituds i disposicions. Entre aquestes últimes és imprescindible la necessitat de formar en una actitud sanament crítica davant les TIC. És a dir, saber distingir en què ens ajuden i en què ens limiten, 
per poder actuar en conseqüència. Aquest procés ha d'estar present i donar-se de manera integrada en la família, a l'escola i en la societat (Berríos i Buxarris, 2005).

Per tot això, és convenient destacar la necessitat de dur a terme accions de prevenció a edats primerenques, per oferir una informació i formació adequada als nens, progenitors i professorat, en l'àmbit de les TIC. Aquesta formació ha de basar-se en dues perspectives, una tecnològica i una altra humanística. És a dir, que atengui als mitjans, però també a les finalitats de l'educació (Naval, Sábada i Bringué, 2003).

* objectiu general del programa

L'objectiu principal d'aquest programa no es altre que realitzar accions de prevenció del ciberbullying als centres escolars en el segon i tercer cicle de l'educació primària mitjançant activitats inserides en el currículum escolar, de manera que l'alumne tingui la possibilitat d'adquirir aquests coneixements $\mathrm{i}$ aptituds relacionades amb la prevenció del ciberbullying progressivament durant els quatre últims cursos de l'educació primària.

\section{* característiques I configuració del programa}

El programa de prevenció del ciberbullying ha sigut dissenyat a partir d'un conjunt d'activitats inserides al currículum escolar, concretament a les següents assignatures:

- Ciències socials

- Ciències de la naturalesa

- Llengua castellana i literatura

Aquesta inserció curricular no solament va a cobrir la prevenció en quant a aspectes tecnològics, sinó també en aspectes humanístics. És a dir, per aconseguir els objectius proposats és necessari treballar aspectes tecnològics no obstant això, treballar únicament aquests aspectes no seria suficient, doncs per poder assumir aquesta informació i aplicar-la correctament és necessari que certes habilitats personals i socials estiguin ben desenvolupades, per així prevenir l'aparició de problemes com el ciberbullying. En concret les habilitats centrades en el bon ús de les TIC i les relacionades amb la resolució de conflictes seran aspectes centrals en el nostre projecte doncs treballant-los des d'edats primerenques creiem que són aspectes clau en la prevenció del ciberbullying.

Per tant les temàtiques que es treballaran en aquest programa es classifiquen del següent mode. En els cursos de tercer i quart de primària es treballaran un conjunt d'activitats relacionades amb habilitats tecnològiques i personals com són:

- Bon ús de les TIC

- Prevenció i resolució de conflictes 
- Autoestima

- Emocions

- Autocontrol

A continuació en cinquè $i$ sisè curs de primària es seguiran treballant aspectes tecnològics i introduirem habilitats socials, atès que aquests últims s'han de desenvolupar amb posterioritat a les habilitats més personals. Així els continguts a treballar els dos últims cursos de l'educació primària són:

- Bon ús de les TIC

- Resolució de conflictes

- Empatia

- Assertivitat

- Ciberbullying

El programa disposa d'un dossier que inclou totes les activitats a desenvolupar al llarg del programa. Aquestes activitats es troben classificades per cursos escolars (tercer, quart, cinquè i sisè de primària).

El dossier de cada curs escolar, al mateix temps, està format per cinc blocs temàtics amb tres activitats per cada bloc (dos relacionades amb el contingut curricular i una d'avaluació) sent un total de quinze activitats per curs escolar.

\begin{tabular}{|c|c|c|}
\hline CURS & TEMÀTICA & ACTIVITAT \\
\hline \multirow{5}{*}{$3 r$} & Autoestima & $\begin{array}{l}\text { 1. Així sóc jo. } \\
\text { 2. Em quede amb tot allò bo. } \\
\text { 3. Anem a reflexionar. }\end{array}$ \\
\hline & Emocions & $\begin{array}{l}\text { 4. El que sentim. } \\
\text { 5. Dime com et sents. } \\
\text { 6. Anem a reflexionar. }\end{array}$ \\
\hline & Autocontrol & $\begin{array}{l}\text { 7. Què passarà? } \\
\text { 8. Pren-te el teu temps. } \\
\text { 9. Anem a reflexionar. }\end{array}$ \\
\hline & $\begin{array}{l}\text { Prevenció i resolució de } \\
\text { conflictes }\end{array}$ & $\begin{array}{l}\text { 10. Ens relacionem. } \\
\text { 11. Fa un temps. } \\
\text { 12. Anem a reflexionar. }\end{array}$ \\
\hline & Bon ús de les TIC & $\begin{array}{l}\text { 13. Un día cualquiera } \\
\text { 14. ¿Tú qué opinas? } \\
\text { 15. Vamos a reflexionar. }\end{array}$ \\
\hline $4 t$ & Autoestima & $\begin{array}{l}\text { 1. Autorretrato. } \\
\text { 2. Así es mi compañero. } \\
\text { 3. Vamos a reflexionar. }\end{array}$ \\
\hline
\end{tabular}




\begin{tabular}{|c|c|c|}
\hline & Emocions & $\begin{array}{l}\text { 4. Els altres també senten. } \\
\text { 5. Sentim diferent. } \\
\text { 6. Anem a reflexionar. }\end{array}$ \\
\hline & Autocontrol & $\begin{array}{l}\text { 7. Anem a imaginar. } \\
\text { 8. ¿Què ocorre? } \\
\text { 9. Anem a reflexionar. }\end{array}$ \\
\hline & $\begin{array}{l}\text { Prevenció i resolució de } \\
\text { conflictes }\end{array}$ & $\begin{array}{l}\text { 10. ¿Hablamos? } \\
\text { 11. ¿Qué ocorre? } \\
\text { 12. Anem a reflexionar. }\end{array}$ \\
\hline & Bon ús de les TIC & $\begin{array}{l}\text { 13. A internet ho trobarem. } \\
\text { 14. Siguem responsables. } \\
\text { 15. Anem a reflexionar. }\end{array}$ \\
\hline \multirow{5}{*}{5 '̀̀ } & Empatia & $\begin{array}{l}\text { 1. Ponte en mi lugar. } \\
\text { 2. Si tú estás feliz yo estoy feliz. } \\
\text { 3. Vamos a reflexionar. }\end{array}$ \\
\hline & Assertivitat & $\begin{array}{l}\text { 4. Els meus drets. } \\
\text { 5. Conta'm què t'agrada. } \\
\text { 6. Anem a reflexionar. }\end{array}$ \\
\hline & Ciberbullying & $\begin{array}{l}\text { 7. Carlos y el ciberbullying. } \\
\text { 8. ¿Qué necesitas saber? } \\
\text { 9. Vamos a reflexionar. }\end{array}$ \\
\hline & $\begin{array}{l}\text { Prevenció i resolució de } \\
\text { conflictes }\end{array}$ & $\begin{array}{l}\text { 10. Els conflictes. } \\
\text { 11. Solucionem els conflictes. } \\
\text { 12. Anem a reflexionar. }\end{array}$ \\
\hline & Bon ús de les TIC & $\begin{array}{l}\text { 13. Ens relacionem per internet. } \\
\text { 14. Fem un ús saludable. } \\
\text { 15. Anem a reflexionar. }\end{array}$ \\
\hline \multirow{5}{*}{6 è } & Empatia & $\begin{array}{l}\text { 1. Buscando la reacción adecuada. } \\
\text { 2. ¿Tú cómo lo ves? } \\
\text { 3. Vamos a reflexionar. }\end{array}$ \\
\hline & Assertivitat & $\begin{array}{l}\text { 4. Algunes voltes cal dir que no. } \\
\text { 5. Queixar-se com cal. } \\
\text { 6. Anem a reflexionar. }\end{array}$ \\
\hline & Ciberbullying & $\begin{array}{l}\text { 7. Así sí. } \\
\text { 8. ¿Y ahora qué hago? } \\
\text { 9. Vamos a reflexionar. }\end{array}$ \\
\hline & $\begin{array}{l}\text { Prevenció i resolució de } \\
\text { conflictes }\end{array}$ & $\begin{array}{l}\text { 10. Prenem la decisió. } \\
\text { 11. Jo decideixo per mi. } \\
\text { 12. Anem a reflexionar }\end{array}$ \\
\hline & Bon ús de les TIC & $\begin{array}{l}\text { 13. Compartim informació. } \\
\text { 14. Utilitzem el temps com cal. } \\
\text { 15. Anem a reflexionar. }\end{array}$ \\
\hline
\end{tabular}


Al inici de cada bloc temàtic es presenta una sèrie d'informació on s'especifica el concepte de la temàtica a treballar, els objectius que es persegueixen i una taula resum amb les activitats que inclou el bloc classificades per les assignatures curriculars per a facilitar així la seua inserció.

Respecte al material que es presenta a cada bloc per al professorat inclou, a més de les fitxes dels alumnes, una fitxa tècnica per a cadascuna de les activitats que conté els següents camps informatius:

- Assignatura: indica l'assignatura en la qual cal inserir l'activitat.

- Contingut curricular: matèria de l'assignatura amb la que està relacionada l'activitat.

- Objectius curriculars i objectius de la temàtica: remarca els objectius tant curriculars com de la temàtica que es treballen a l'activitat.

- Metodologia i procediment: determina com i de quina forma portar a cap l'activitat.

- Temporalització: temps aproximat de la realització de l'activitat.

- Orientacions: dades relacionades amb l'activitat que faciliten al professorat l'aplicació de l'activitat, tant a nivell teòric com a pràctic.

- Recursos: materials necessaris per a desenvolupar adequadament l'activitat.

Després de cada un dels blocs temàtics, es troba una fitxa d'avaluació per ser emplenada pel professor/a sobre les activitats corresponents a aquest bloc. Aquesta avaluació serà d'ajuda per millorar el programa.

A més del programa, al final d'aquest document hi ha un apartat amb una fitxa d'avaluació final del programa per a l'alumnat per a aquest curs educatiu, i també un petit document amb recursos extra com guies, enllaços de pàgines web i vídeos amb els que es poden ampliar els coneixements relacionats amb la temàtica principal del programa, el ciberbullying.

\section{procediment per a l'aplicació del programa}

Aquest programa està dissenyat per a ser aplicat als quatre cursos que corresponen al segon i tercer cicle de l'educació primària de forma progressiva al llarg d'aquests cursos, de forma que al finalitzar el tercer cicle els alumnes hagen assolit tots els objectius del programa de prevenció.

L'aplicació del programa correspon als professors tutors, ja que es considera important que es relacioni l'aspecte educatiu d'aquest programa amb la tasca quotidiana que realitzen els alumnes en les diferents assignatures curriculars. Així, per a que l'aplicació sigui adequada i satisfactòria és necessària la constància del professorat al llarg del curs. 


\section{CINQUÈ DE PRIMÀRIA}

\begin{tabular}{|c|c|c|c|c|}
\hline ASSIGNATURA & $\begin{array}{l}\text { TEMÀTICA } \\
\text { CURRICULAR }\end{array}$ & $\begin{array}{c}\text { TEMÀTICA } \\
\text { TRANSVERSAL }\end{array}$ & \multicolumn{2}{|c|}{$\begin{array}{c}\text { REGISTRE } \\
\text { DE FITXES } \\
\text { FETES }\end{array}$} \\
\hline \multirow{3}{*}{$\begin{array}{c}\text { CIĖNCIES DE } \\
\text { LA } \\
\text { NATURALESA }\end{array}$} & La funció de relació & \multirow{3}{*}{ Bon ús de les TIC } & 13 & \\
\hline & La salut & & 14 & \\
\hline & Anem a reflexionar & & 15 & \\
\hline \multirow{6}{*}{$\begin{array}{l}\text { CIENNCIES } \\
\text { SOCIALS }\end{array}$} & $\begin{array}{c}\text { Població d’Espanya i } \\
\text { d'Europa }\end{array}$ & \multirow{3}{*}{ Assertivitat } & 4 & \\
\hline & Espanya & & 5 & \\
\hline & Anem a reflexionar & & 6 & \\
\hline & Edat mitja & \multirow{3}{*}{$\begin{array}{c}\text { Prevenció i resolució } \\
\text { de conflictes }\end{array}$} & 10 & \\
\hline & $\begin{array}{l}\text { La reconquista dels } \\
\text { cristians }\end{array}$ & & 11 & \\
\hline & Anem a reflexionar & & 12 & \\
\hline \multirow{6}{*}{$\begin{array}{c}\text { LENGUA } \\
\text { CASTELLANA Y } \\
\text { LITERATURA }\end{array}$} & Adjetivos & \multirow{3}{*}{ Empatia } & 1 & \\
\hline & Signos de puntuación & & 2 & \\
\hline & Vamos a reflexionar & & 3 & \\
\hline & El resumen & \multirow{3}{*}{ Ciberbullying } & 7 & \\
\hline & La entrevista & & 8 & \\
\hline & Vamos a reflexionar & & 9 & \\
\hline
\end{tabular}




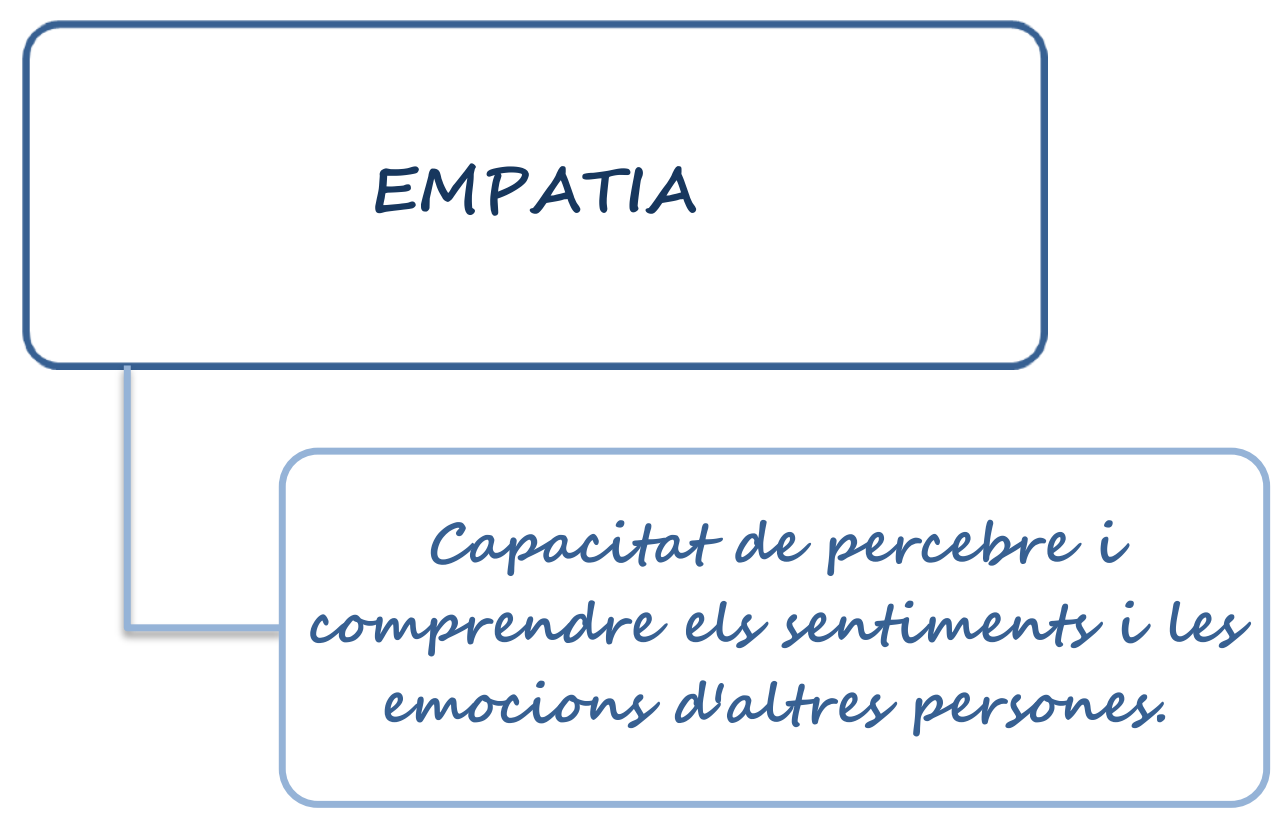

Objectivs:

$\checkmark$ Aprendre a posar-se en el lloc dels altres.

$\checkmark$ Reconèixer i compartir els sentiments i emocions d'altres. 
CURSO: 50 PRIMARIA

FICHA: 1

ASIGNATURA: LENGUA CASTELLANA Y LITERATURA

ACTIVIDAD: PONTE EN MI LUGAR

CONTENIDOS: ADJETIVOS Y EMPATÍA

\section{OBJETIVOS CURRICULARES}

- Identificar los adjetivos en los textos.

- Interpretar textos con la ayuda de los compañeros a través del diálogo y la reflexión.

\section{OBJETIVOS SOBRE LA TEMÁTICA}

- Reflexionar sobre la importancia de ponerse en el lugar del otro.

- Aprender a compartir los sentimientos de los demás.

\section{METODOLOGÍA / PROCEDIMIENTO}

En esta actividad trabajaremos contenidos de lengua como es la expresión escrita y los signos de puntuación junto con contenidos relacionados con la empatía. Dicha actividad la encontraremos en la ficha 1 del cuaderno.

1. Introducción grupal a la actividad:

¿Sabéis lo que significa ponerse en el lugar de otra persona? o si os digo, iPonte en mi lugar! ¿Qué entendéis por esto?

(Dejamos que los alumnos vayan aportando sus opiniones sobre el concepto de "ponerse en mi lugar". Orientamos la reflexión hacia la importancia que tiene el hecho de ponerse en el lugar de otra persona, que significa compartir y comprender sus sentimientos, y este es un modo de preocuparse por los demás y de que ellos se sientan más felices por ello.)

2. Realización individual del primer ejercicio:

Ahora que ya sabemos qué es ponerse en el lugar de otra persona, vamos a completar estas oraciones en las que una persona siente de un modo y vamos a escribir cómo nos sentiremos nosotros en ese momento. Porque ponerse en el lugar del otro como ya hemos dicho es compartir sus sentimientos. Fijaros bien porque una vez hayáis completado las frases tendréis que subrayar los adjetivos que encontréis, recordad bien qué son los adjetivos y subrayarlos cuando veáis uno.

(Los alumnos trabajan individualmente completando las frases y subrayando los adjetivos que encuentren.)

3. Corrección grupal del primer ejercicio:

Seguramente cada uno de vosotros habrá completado la oración de un modo, pero seguro coincidiréis muchos en el sentimiento que os provoca esa situación y el sentimiento de la otra persona. Ahora veremos por qué, pero antes quiero que me digáis qué adjetivos habéis encontrado.

(Hacemos un listado en la pizarra con los adjetivos que hayan encontrado los alumnos.) 


\section{Introducción y realización grupal del segundo ejercicio:}

Muy bien, ahora pasamos a completar entre todos el ejercicio 2 que nos ayudará a entender mejor el primer ejercicio y lo que comentábamos al principio de la actividad. Alguien que lo lea en voz alta, y entre todos levantando la mano acordamos cuál es la palabra que falta, y cada uno lo escribe en su ficha.

(Un alumno lee en voz alta el texto, y cuando hay un espacio se detiene para que el resto de alumnos vayan indicando la palabra que le corresponde de las que se facilitan al principio del ejercicio.)

\section{TEMPORALIZACIÓN}

Tiempo aproximado de la actividad 20 minutos:

1. Introducción a la actividad: 5 minutos

2. Realización del primer ejercicio: 5 minutos

3. Corrección del primer ejercicio: 5 minutos

4. Introducción y realización del segundo ejercicio: 5 minutos

\section{ORIENTACIONES}

- La finalidad del primer ejercicio es que los alumnos se den cuenta que los sentimientos de los demás provocan sentimientos en nosotros, y que ponerse en el lugar de otra persona es compartir sus sentimientos y que con ello daremos a entender a los demás que nos preocupamos por ellos. Por eso lo más común es que completen las frases expresando que experimentan el mismo sentimiento que se les indica inicialmente.

Los adjetivos que encontramos en el primer ejercicio son: triste, solo, feliz y furioso.

- El texto del ejercicio 2 se completará del siguiente modo:

Aprender a ponerse en el lugar del otro es muy importante. Si te pones en el lugar del otro haces que esa persona se sienta feliz. Si él está alegre, tú también estarás alegre, y si está triste tú también sentirás tristeza. Porque compartir los sentimientos ayuda a comprender a los demás. Por eso me gusta que los demás compartan mis sentimientos.

\section{RECURSOS}

- Ficha número 1 del cuaderno de 5o de primaria. 


\section{PONTE EN MI LUGAR}

\section{Completa y subraya los adjetivos que encuentres en las frases:}

- Si mi amigo está triste yo lo que hago es

- Cuando veo a un niño solo pienso que

- Si veo que mi madre está muy feliz yo

- Cuando mi profesor está furioso entonces yo

\section{Completa el texto con las palabras que tienes a continuación:}

alegre sentimientos tristeza feliz compartir

Aprender a ponerse en el lugar del otro es muy importante. Si te pones en el lugar del otro haces que esa persona se sienta Si él está alegre, tú también estarás y si está triste tú también sentirás . Porque los sentimientos ayuda a comprender a los demás. Por eso me gusta que los demás compartan mis persona se sienta feliz. Compartir los sentimientos ayuda a comprender a los demás. 
CURSO: 5O PRIMARIA

FICHA: 2

ASIGNATURA: LENGUA CASTELLANA Y LITERATURA

ACTIVIDAD: SI TÚ ESTÁS FELIZ YO ESTOY FELIZ

CONTENIDOS: SIGNOS DE PUNTUACIÓN Y EMPATIIA

\section{OBJETIVOS CURRICULARES}

- Interpretar de forma reflexiva y dialogada textos del ámbito social.

- Planificar y escribir un texto utilizando adecuadamente los signos de puntuación.

\section{OBJETIVOS SOBRE LA TEMÁTICA}

- Aprender a ponerse en el lugar del otro especialmente cuando hay discrepancias o conflictos.

- Reconocer y comprender los sentimientos de los compañeros y amigos.

\section{METODOLOGÍA /PROCEDIMIENTO}

En la presente actividad vamos a trabajar contenidos relacionados con el uso adecuado de los signos de puntuación así como también contenidos en los que se trabajará la empatía. Esta actividad la podemos encontrar en la ficha 2 del cuaderno.

5. Introducción de la actividad y del primer ejercicio en grupo:

El otro día vimos que es muy importante aprender a ponerse en el lugar de los demás, y ya sabemos que si lo hacemos la otra persona se sentirá más feliz, y el modo de hacerlo es compartiendo sus sentimientos, así conseguiremos comprenderlos.

Vamos a realizar el primer ejercicio de la ficha, para ello necesito que alguien lea en voz alta este texto.

(Pedimos voluntarios para leer el texto y elegimos a uno.)

Decidme, ¿qué opináis del texto? ¿Qué os trasmite? ¿Es una situación fácil la de Manuel? ¿Cómo os sentirías vosotros si os ocurriese lo mismo?

(Los alumnos aportan sus opiniones y sensaciones sobre el texto. Las opiniones serán variadas pero la finalidad es que muestren una actitud empática, es decir, que sepan ponerse en el lugar de Manuel y saber cómo se sentirían si fuesen él.)

6. Realización individual del primer ejercicio:

Como hemos comentado, la situación de Manuel no es fácil, lo está pasando mal y necesita la comprensión y la ayuda de los demás. Para ello es muy importante que aprendamos a ponernos en el lugar de los demás sobre todo cuando tenemos problemas. ¿Y cómo podemos ponernos en el lugar del otro? Pues comprendiendo cómo se sienten nuestros amigos, compañeros, etc. Para ello tenemos que pensar como nos sentiríamos nosotros si estuviésemos en esa situación y cómo nos gustaría que los demás actuaran en ese momento.

Los padres de Manuel están preocupados, y seguramente si supiesen cómo se siente Manuel le podrían ayudar. Ahora quiero que os pongáis en su lugar y penséis 
cómo os sentiríais si os ocurriere eso, y les escribáis un mensaje a sus padres para que ellos sepan cómo se puede estar sintiendo Manuel. Recordad que primero debemos tener claras las ideas que queremos trasmitir, ordenarlas y escribirlas utilizando adecuadamente los signos de puntuación.

(Los alumnos trabajan individualmente escribiendo el mensaje.)

7. Introducción y realización del segundo ejercicio individualmente:

Pues bien, para poder llegar a compartir esos sentimientos tenemos que reconocer cuáles son los sentimientos de los demás y después valorar cómo nos sentimos nosotros en ese momento. Ya sabemos que compartir los sentimientos significa reconocer y sentir lo mismo que siente la otra persona.

Para ello vamos a realizar el segundo ejercicio, en el que tenemos que pensar en dos situaciones en las que les haya ocurrido algo a dos amigos y escribir como nos hemos sentido en ese momento. Por ejemplo, yo sentí tristeza cuando mi amigo Pablo estuvo enfermo. Si recordamos momentos así nos daremos cuenta que continuamente estamos compartiendo sentimientos con amigos y compañeros y eso es muy bueno porque nos ayuda a tener mejores relaciones con ellos.

(Los alumnos completan individualmente el segundo ejercicio.)

\section{TEMPORALIZACIÓN}

Tiempo aproximado de la actividad 15 minutos:

1. Introducción de la actividad y del primer ejercicio: 5 minutos

2. Realización del primer ejercicio: 5 minutos

3. Introducción y realización del segundo ejercicio: 5 minutos

\section{ORIENTACIONES}

- La finalidad del primer ejercicio es que sean conscientes de los sentimientos que provoca una situación problemática o conflictiva en la persona que lo sufre. Para ello hay que aprender a ser empáticos, es decir, ponerse en el lugar del otro. De ese modo conseguirán comprender cómo se siente y también les ayudará a saber cómo actuar con esa persona. Escribirlo les ayudará a expresarlo más fácilmente.

- En el segundo ejercicio deben recordar situaciones en las que una acción o algún acontecimiento de un amigo les ha generado un sentimiento. Con ello se darán cuenta que ese es un modo de compartir sentimientos, y que lo hacemos muy a menudo y además es positivo que esto ocurra así.

\section{RECURSOS}

- Ficha número 2 del cuaderno de 5o de primaria. 


\section{SI TÚ ESTÁS FELIZ YO ESTOY FELIZ}

\section{Lee el siguiente texto:}

Manuel es un chico de diez años que vive en Valencia. Sus padres están muy preocupados porque desde hace un tiempo Manuel ha cambiado mucho de carácter. Tiene muchos problemas con los compañeros del colegio. No quieren jugar con él, siempre está solo en el patio y en clase. Él se acerca a los compañeros pero ellos no le hacen caso, incluso algunas veces se meten con él, le insultan cuando están en el colegio o le mandan mensajes al móvil o por las redes sociales cuando está en casa. Sus padres le preguntan a Manuel cómo se siente pero él no les responde.

- Escríbeles un mensaje a los padres de Manuel expresándoles cómo te sentirías tú si fueses Manuel.

\section{Completa la tabla:}

\begin{tabular}{|c|c|c|}
\hline Nombre de mi amigo & Mi sentimiento & Cuando \\
\hline Pablo & Tristeza & Estuvo enfermo \\
\hline & & \\
\hline & & \\
& & \\
\hline
\end{tabular}

RECUERDA...

Continuamente estamos compartiendo sentimientos con amigos y compañeros, y eso es muy bueno porque nos ayuda a tener mejores relaciones con ellos. 


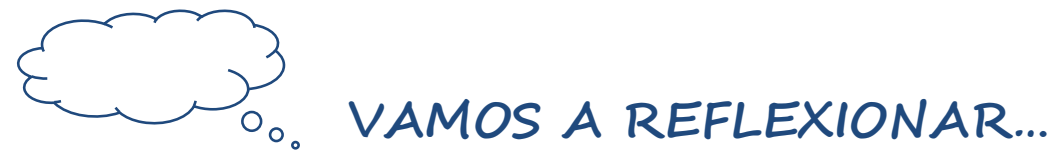

Después de haber realizado las actividades anteriores, vamos a reflexionar sobre los aspectos que hemos trabajado. Para ello, contesta las siguientes cuestiones:

1. Lee y responde a las preguntas:

- Tu amigo está muy contento porque va a tener un hermano dentro de pocos meses.

- ¿Cómo te sientes tú?

- Tú le has dado un empujón a Laura al salir de clase, y te has ido sin pedirle perdón.

- ¿Cómo se siente Laura?

2. ¿Por qué es importante ponerse en el lugar de las otras personas? ¿Cómo lo podemos hacer? 
FITXA D'AVALUACIÓ PER AL PROFESSOR/A DE LES ACTIVITATS DEL BLOC D'EMPATIA

1. Com t'ha resultat dur a terme les tasques segons les indicacions exposades en les fitxes? Molt difícil $\square \quad$ Difícil $\square \quad$ Normal $\square \quad$ Fàcil $\square \quad$ Molt fàcil $\square$

2. Creus que es compleix l'objectiu proposat? Sí $\square \quad$ No $\square$

3. Has introduït les activitats al contingut curricular assenyalat o en algun altre?

T emes indicats $\square \quad$ Altres $\square$ (indica quins:

4. Has utilitzat altres recursos a part dels que apareixen a la fitxa? Sí $\square \quad$ No $\square$

5. ¿Faries alguna modificació de millora en les fitxes per assolir els objectius de manera més òptima? Sí $\square \quad$ No $\square$

(en cas afirmatiu, indica quina:

6. Com s'han sentit els alumnes en realitzar les activitats? (motivació, implicació, interacció amb altres, ....)

7. Hi ha algun aspecte que consideres oportú comenta per a la millora del programa? 


\section{ASSERTIVITAT}

Capacitat diexpressar els propis sentiments, necessitats $i$ drets al mateix temps que es respecten els sentiments, drets $i$ necessitats dels altres.

\section{Objectins.}

$\checkmark$ Defendre i expressar els nostres drets.

$\checkmark$ Saber com elogiar i expressar afecte i com rebre-ho. 
CURS: 5è PRIMÀRIA

FITXA: 4

ASSIGNATURA: CIÈNCIES SOCIALS

ACTIVITAT:ELS MEUS DRETS

CONTINGUTS: POBLACIÓ D'ESPANYA I D'EUROPA I ASSERTIVITAT

\section{OBJECTIUS CURRICULARS}

- Descriure característiques de la població espanyola i de la UE.

- Conèixer drets dels ciutadans espanyols.

\section{OBJECTIUS SOBRE LA TEMÀTICA}

- Reconèixer els nostres drets.

- Defendre i expressar els nostres drets.

\section{METODOLOGIA / PROCEDIMENT}

En aquesta activitat treballarem continguts relacionats amb la població d'Espanya i d'Europa, i també continguts d'assertivitat. L'activitat l'encontrarem desenvolupada a la fitxa 4.

1. Introducció en grup de l'activitat:

Hem estat estudiant la població d'Espanya i d'Europa, $i$ hem conegut algunes de les seues característiques. Com per exemple que l'esperança de vida és Ilarga, la població viu majoritàriament a zones urbanes, l'edat de la població és alta, la taxa de natalitat és baixa, etc. Quines altres característiques coneixeu de la població espanyola i europea?

(Comentem tots en gran grup les característiques de la població.)

A més d'aquestes característiques, la població espanyola té més coses en comú, i una d'elles és que tots tenim uns drets que són molt importats per a tots. Anem a llegir en veu alta alguns dels drets que tenim els ciutadans espanyols des de la constitució espanyola de 1978.

(Els alumnes llegeixen en veu alta aquests drets.)

2. Realització individual de la primera activitat:

Ja ens hem vist que tots els ciutadans espanyols compartim una sèrie de drets. Ara anem a pensar, a més dels drets ciutadans que hem comentat, quins creieu que són els vostres drets? Per exemple, jo considero que tinc dret a que em respecten i si un company m'agafa coses sense demanar-me permís o em colpeja per darrere jo li tindré que fer saber que caldria que canviés la seua actitud perquè jo tinc dret a que em respecte, $i$ en aquest cas és important que defensi el meu dret perquè així comuniqui al meu company que no estic disposat a que em faja això.

Anoteu a la fitxa un dret que vosaltres considereu que teniu i també perquè creieu que és important defendre els vostres drets.

(Els alumnes treballen individualment una estona anotant un dret.) 


\section{Comentem en grup les respostes de la primera activitat:}

Digueu-me, quins drets haveu anotat? I, per què és important defendre els nostres drets? Quins avantatges i inconvenients té expressar-los?

(Anotem a la pissarra tots aquells drets que els alumnes van anomenant a una columna i a l'altra el motiu pel que consideren que és important defendre els seus drets.)

4. Introducció en grup i realització individual de la segona activitat:

D'acord, doncs ja sabem que tots tenim drets i que és important defendre'ls però sense oblidar que cal defendre els nostres drets adequadament. Cal que ho fem educadament, amb tranquil-litat, amb un to de veu correcte, comunicant als altres el que sentim, mitjançant el diàleg i la conversa.

Aleshores, llegiu ara la segona activitat i escrigueu com respondríeu a aquesta situació, es a dir, que li diríeu al vostre amic per a defendre els vostres drets adequadament.

\section{TEMPORALITZACIÓ}

Temps aproximat de l'activitat 20 minuts:

1. Introducció de l'activitat: 5 minuts

2. Realització de la primera activitat: 5 minuts

3. Comentem les respostes de la primera activitat: 5 minuts

4. Introducció i realització de la segona activitat: 5 minuts

\section{ORIENTACIONS}

- La finalitat és que recorden característiques de la població espanyola i que coneguin els drets ciutadans.

- En aquesta part volem que els alumnes siguin capaços d'adonar-se que tots tenim drets $\mathrm{i}$ que sàpiguen reconèixer quins són els seus drets. Entre altres poden ser: equivocar-se, expressar la seua opinió, utilitzar adequadament les coses, rebre ajuda, queixar-se quan no s'està d'acord, etc.

- També és molt important que els alumnes sàpiguen que aquests drets que tenen els deuen defendre ells mateixos, i ho poden fer reclamant els seus drets demanant educadament que els altres canvien la seua conducta ja que està perjudicant la nostra. Aquestes són algunes de les frases amb les que es pot completar:

És important defendre els nostres drets perquè...

- Comuniques a les altres persones quins són els teus drets i el que no estàs disposat a fer.

- Així informes que no estàs d'acord amb alguna conducta.

- Si no defens els teus drets viuràs situacions que no t'agraden.

- Evitaràs que altres persones s'aprofiten de tu.

- Ens ajudarà a tenir millors relacions amb les altres persones. 
- Expressar i defendre els nostres drets adequadament és fonamental, per això els alumnes deuen saber que quan volem comunicar als altres alguna cosa cal fer-ho dialogant, tranquil-lament, relaxat i explicant clarament el que no estem disposats a deixar passar i el que caldria que canviés l'altra persona per a que es respecten els nostres drets.

\section{RECURSOS}

- Fitxa número 4 del quadern de 5è de primària. 


\section{ELS MEUS DRETS}

Els ciutadans d'Espanya tenim, entre altres, els següents drets:

- Tota persona té dret a la llibertat i a la seguretat.

- Es garanteix el dret a l'honor, a la intimitat personal i familiar i a la pròpia imatge.

- Tots tenen dret a expressar i difondre lliurement els pensaments, idees i opinions per mitjà de la paraula, l'escrit o qualsevol altre mitjà de reproducció.

- Tots tenen el dret a l'educació.

\section{Completa les següents frases:}

- Jo tinc dret a...

- És important defendre els meus drets perquè...

2. El teu amic i tu esteu al pati jugant, haveu quedat que cada volta colpejarà u la pilota però el teu amic l'està colpejant tota l'estona i no et deixa fer-ho a tu. Tu tens dret a colpejar la pilota igual que ell.

- Què li diràs al teu amic?

\section{RECORDA...}

Defensa els teus drets adequadament comunicant com et sents així evitaràs que els altres s'aprofiten de tu i aconseguiràs que canvien la seua conducta i que no et perjudiqui. 
CURS: 5è PRIMÀRIA

FITXA: 5

ASSIGNATURA: CIÈNCIES SOCIALS

ACTIVITAT:CONTA'M QUÈ T'AGRADA

CONTINGUTS: ESPANYA I ASSERTIVITAT

\section{OBJECTIUS CURRICULARS}

- Situar a Espanya com un país de la Unió Europea.

- Descriure característiques d'Espanya.

\section{OBJECTIUS SOBRE LA TEMÀTICA}

- Aprendre a fer o rebre elogis.

- Expressar grat o afecte.

\section{METODOLOGIA / PROCEDIMENT}

En aquesta activitat treballarem diferents continguts relacionats amb l'assertivitat i també amb aspectes relacionats amb Espanya. L'activitat la trobarem a la fitxa 5 del quadern.

1. Introducció en grup a l'activitat:

Com bé sabem, nosaltres vivim a Espanya, i Espanya junt amb altres països forma la Unió Europea. Es tracta d'una associació econòmica i política que avarca gran part del continent europeu. Aquests països es ajunten per un propòsit en comú $i$ comparteixen moltes coses però també tenen d'altres diferents, ja que cada país té la seua cultura i les seues costums. A veure, digueu-me quines costums coneixeu d'Espanya i quines coses de la seua cultura destacaríeu.

(Els alumnes fan les seues aportacions dels aspectes culturals i de costums que considerem més rellevants del nostre país. Podem anar anotant a la pissarra les idees que aporten els alumnes, ja que els ajudarà a realitzar la primera activitat. A l'apartat d'orientacions trobarem informació.)

2. Realització individual de la primera activitat:

D'acord, doncs ja haveu vist que hi ha moltes coses que caracteritzen a Espanya i la diferencien d'altres països de la Unió Europea. Com a ciutadans espanyols tenim que aprendre a valorar el que tenim i a comunicar a la gent tot allò que ens agrada del nostre país, es a dir, tenim que fer elogis del que és nostre. Ara el que farem és pensar que tenim un amic que viu a un altre país i ens pregunta si val la pena vindre de viatge al nostre país. Ens demana que li escriguem una carta de poques línies contant-li tot allò que ens agrada, i què podria veure si visita el nostre país. Hem d'aprendre a elogiar amb sinceritat tot el que tenim al nostre voltant, tan a les coses com a les persones, perquè a les altres persones igual que a nosaltres els agrada escoltar coses i opinions agradables i positives sobre les seues coses o sobre ells mateixos.

(Els alumnes treballen individualment escrivint un xicotet paràgraf on destacaran i elogiaran aspectes del nostra país.) 


\section{Introducció en grup i realització en parelles de la segona activitat:}

Ja sabeu com d'important és valorar i saber expressar adequadament l'estima o el que ens agrada alguna cosa. Bé, doncs ara anem a veure com respondre a un elogi, anem a posar-nos per parelles i un serà l'amic que ha escrit la carta i l'altre l'amic que viu fora i que rep la carta, i després canviarem els papers. Aleshores, primer intercanviareu la carta que haveu escrit. A continuació, començarà a parlar l'amic dient-li que ha llegit la carta que ha rebut i opinant sobre Espanya positivament. L'altre té que respondre a l'elogi que li està fent per la seua carta donant-li les gràcies per les paraules. Després farem el mateix però intercanviant els papers.

Per a agrair els elogis cal que ho fem adequadament, es a dir, els tracta d'agrair a l'altra persona l'elogi i les paraules positives que ens dedica. Considerarem per tant adequat el donar les gràcies $i$ inadequat totes aquelles expressions amb les quals llevem rellevància al que ens diu o les obviem.

4. Reflexió final en grup de l'activitat:

Com haveu viscut aquesta activitat? Vos ha resultat fàcil elogiar i respondre a aquests elogis? Com ho haveu fet?

(Els alumnes reflexionen sobre l'activitat, si els ha resultat fàcil o complicat i com ho han fet.)

Segurament us haureu adonat que no és difícil elogiar i mostrar afecte a les coses $i$ les persones que tenim al nostre voltant. És un acte molt fàcil que ens ajudarà a tenir millor relacions amb la gent perquè és molt positiu transmetre als altres el que sentim, $i$ els altres també volen saber $i$ que els transmetem el que sentim, $i$ segur que ho valoraran positivament i aixi aconseguirem que les relacions amb els nostres amics i companys siguem millors.

\section{TEMPORALITZACIÓ}

Temps aproximat de l'activitat 20 minuts:

1. Introducció a l'activitat: 5 minuts.

2. Realització primera activitat: 5 minuts.

3. Introducció i realització de la segona activitat: 5 minuts.

4. Reflexió final: 5 minuts.

\section{ORIENTACIONS}

- Aspectes culturals i costums que podem destacar:

- Gastronomia: oli d'oliva, paella, truita de creïla, pa amb tomaca, botifarra, vi, pernil, pinxos, formatges, etc.

- Vestuari: vestits regionals de fallers, aragonesos, sevillans, etc.

- Costums: la migdiada, celebració de les campanades de nou any, festes populars als pobles, eixir de tapes, etc.

- Idiomes: català, gallec i basc.

- Balls i música: flamenc, jotes, sardanes, sevillanes, etc.

- Festes: falles, sant fermí, fira d'abril, festa del pilar, sant Jordi etc. 
- La finalitat d'aquesta activitat és que aprenguin a veure les coses positives i bones que tenim al nostre voltant i sobre tot que sàpiguen expressar i elogiar tot allò que els agrada amb sinceritat i d'una forma correcta.

- Tant important és saber fer un elogi com respondre a un elogi que ens facin a nosaltres. Quan algú ens elogia cal contestar adequadament, agrair les seues paraules, i ho podem fer amb expressions com: moltes gràcies per les teues paraules, molt agraïda per que em comentes, etc. Pel contrari cal evitar altres expressions com: això no té importància, no em digues eixes coses, no tens raó, etc. També la reacció ha de ser adequada, evitant no canviar de tema, obviar el que ens diuen, etc.

\section{RECURSOS}

- Fitxa número 5 del quadern de 5 è de primària. 


\section{CONTA'M QUÈ T'AGRADA}

1. Escriu una carta a un amic contant-li aspectes culturals i costums que més t'agraden d'Espanya per tractar de convèncer-lo perquè visiti el nostres país.

2. Per parelles, conversa amb el teu company on un farà de l'amic que rep la carta i l'altre el que l'envia. Converseu utilitzant elogis sobre el que ha escrit $\mathbf{i}$ contestant a aquests adequadament.

- Paraules i expressions que podeu utilitzar per fer elogis:

Et felicito

Em pareix molt bé

És preciós

- Per donar les gràcies:

Adequat: moltes gràcies, molt agraït i gràcies per les teues paraules.

X No adequat: no digues tonteries, això no importa i tens raó sóc genial.

RECORDA...

Expressar un elogi és dir alguna cosa positiva o mostrar agraïment a una altra persona, i ho devem fer amb sinceritat i adequadament. Quan responem a un elogi cal agrair-lo i fer veure que t'agrada el que et diuen. 


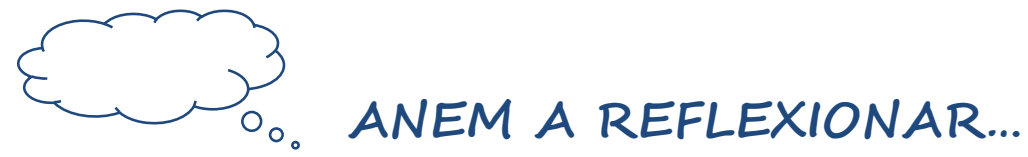

Després d'haver realitzat les activitats anteriors, reflexionarem sobre els aspectes que hem treballat. Per a això, contesta les següents qüestions:

1. És important defendre els teus drets?
$\square \quad$ sí
NO

\section{Com devem expressar els nostres drets?}

Adequadament, utilitzant un to de veu correcte i un vocabulari adequat.

Amb un to de veu elevat i sense deixar parlar a l'altra persona.

Altres:

\section{Escriu a continuació:}

- Dos paraules o expressions adequades per a expressar elogis.

- Dos paraules o expressions adequades per a respondre a un elogi. 
FITXA D'AVALUACIÓ PER AL PROFESSOR/A DE LES ACTIVITATS

1. Com t'ha resultat dur a terme les tasques segons les indicacions exposades en les fitxes?

Molt difícil $\square \quad$ Difícil $\square \quad$ Normal $\square \quad$ Fàcil $\square \quad$ Molt fàcil $\square$

2. Creus que es compleix l'objectiu proposat? Sí $\square \quad$ No $\square$

3. Has introduït les activitats al contingut curricular assenyalat o en algun altre?

T emes indicats $\square \quad$ Altres $\square$ (indica quins:

4. Has utilitzat altres recursos a part dels que apareixen a la fitxa? Sí $\square \quad$ No $\square$

5. ¿Faries alguna modificació de millora en les fitxes per assolir els objectius de manera més òptima? Sí $\square \quad$ No $\square$

(en cas afirmatiu, indica quina:

6. Com s'han sentit els alumnes en realitzar les activitats? (motivació, implicació, interacció amb altres, ....)

7. Hi ha algun aspecte que consideres oportú comenta per a la millora del programa? 


\section{CIBERBULLYING}

Quan un xiquet $\sigma$ adolescent és turmentat, amenaçat, assetjat, humiliat, molestat d'una manera $\sigma$ una altra, per un altre new $\sigma$ adolescent mitjançant l'ús d'internet, tecnologies interactives $i$ digitals $\sigma$ telèfon mòbil.

\section{Objectins.}

$\checkmark$ Conèixer què és el ciberbullying i les seues conseqüències.

$\checkmark$ Reconèixer com es produeix el ciberbullying. 
CURSO: 5ㅇ PRIMARIA

FICHA: 7

ASIGNATURA: LENGUA CASTELLANA Y LITERATURA

ACTIVIDAD: CARLOS Y EL CIBERBULLYING

CONTENIDOS: RESUMEN Y CIBERBULLYING

\section{OBJETIVOS CURRICULARES}

- Interpretar el contenido de un texto del ámbito social.

- Planificar y escribir un resumen a partir de un texto.

\section{OBJETIVOS SOBRE LA TEMÁTICA}

- Conocer qué es el ciberbullying.

- Ser conscientes de las consecuencias reales y legales que conlleva el ciberbullying.

\section{METODOLOGÍA / PROCEDIMIENTO}

En esta actividad se trabajarán contenidos como la planificación y escritura de un resumen así como también contenidos relacionados con el ciberbullying. Para ello se ha elaborado una actividad que encontraremos en la ficha 7.

1. Introducción en grupo a la actividad:

Vamos a realizar una actividad en la que pondremos en práctica la realización de un resumen. Para ello sabemos que lo más importante es leer bien el texto que vamos a resumir y fijarnos bien y escoger las ideas principales, es decir, aquellas ideas que consideremos más importantes. Una vez leído el texto y seleccionadas las ideas debemos planificar el resumen y ver como lo vamos a escribir, qué ideas queremos plasmar y cómo lo haremos.

2. Realización y reflexión en grupo de la primera actividad:

Vamos a leer en voz alta el texto.

(Pedimos voluntarios para leer el texto en voz alta y elegimos a cuatro, cada uno leerá un párrafo.)

¿Qué me podríais decir del texto? ¿Cuál creéis que es la idea que nos quiere transmitir, es decir, las ideas principales?

(Los alumnos van aportando sus opiniones sobre el texto, e iremos reflexionando sobre la información que se nos proporciona en el texto. Podemos revisar el apartado de orientaciones para ver qué aspectos sería interesante remarcar.)

3. Reflexión en grupo de la segunda actividad:

De acuerdo, ahora que ya sabemos bien qué trata el texto, decidme cuales son las ideas principales que transmite el texto que hemos leído y que deberían estar en el resumen, pues sabemos que un resumen debe transmitir las ideas más importantes del texto.

(En el apartado de orientaciones encontramos el texto con las ideas más importante subrayadas, para que a partir de estas los alumnos elaboren el resumen.) 
4. Realización individual de la segunda actividad:

Como ya hemos comentado las ideas principales y sabemos lo que habría que transmitir, vamos a realizar cada uno de nosotros un resumen del texto en la ficha.

(Los alumnos trabajan individualmente realizando el resumen.)

\section{TEMPORALIZACIÓN}

Tiempo aproximado de la actividad 20 minutos:

1. Introducción a la actividad: 5 minutos.

2. Realización y reflexión de la primera actividad: 5 minutos.

3. Reflexión de la segunda actividad: 5 minutos.

4. Realización de la segunda actividad: 5 minutos.

\section{ORIENTACIONES}

- En esta actividad es muy importante que los alumnos escojan como información importante los datos que se ofrecen sobre el ciberbullying, tanto la definición del concepto como las consecuencias que conlleva padecer ciberbullying. También hay que remarcar lo graves que son estas consecuencias y sobretodo la importancia de avisar a un adulto y comunicarle lo que ocurre si detectamos un caso así para tratar que no vaya a más la situación. Lo más importante es hacer una reflexión global sobre esta problemática para que la lleguen a entender y sean conscientes de la importancia que tienes estas situaciones, y también que nos transmitan sus inquietudes y conocimientos sobre el ciberbullying.

- Para el resumen del texto presentamos a continuación subrayadas sobre el texto original las ideas que sería interesante que se plasmaran en el resumen pues son las que sería necesario que asumieran en dicha temática:

Carlos, un niño de 11 años tiene problemas con compañeros de clase. Desde hace unas semanas recibe mensajes al móvil y correos electrónicos donde algunos compañeros de clase lo amenazan y lo insultan, y en los grupos de clase de whatsapp no le dejan participar. Carlos es víctima de ciberbullying, que es cuando un niño o adolescente es amenazado, acosado, humillado, molestado de una manera u otra reiteradamente, por otro niño o adolescente mediante el uso de Internet, tecnologías interactivas $y$ digitales o teléfono móvil.

La gente cercana a Carlos se ha dado cuenta que desde hace un tiempo Carlos ha cambiado mucho su carácter pues siempre está triste, sus notas escolares han empeorado, no quiere asistir a clase ni salir a jugar por las tardes y dice que le duele mucho el estómago y que se encuentra mareado. Todo esto son consecuencias del ciberbullying, pues debemos saber que este problema es muy frecuente y que las consecuencias que conlleva son muy importantes.

Durante mucho tiempo Carlos no ha querido contar lo que estaba sufriendo a sus padres ni a sus profesores, y sus compañeros, aunque sí lo sabían tampoco se lo han comunicado a ningún adulto. Mientras tanto, Carlos ha sufrido todas las consecuencias que comentábamos, y lo ha pasado muy mal, puesto que el ciberbullying es un problema muy grave con consecuencias legales muy importantes para las personas 
que envían estos mensajes que son los agresores, pues se trata de un delito.

Por eso es necesario que sepamos lo qué es y que cuando veamos que algún compañero lo está sufriendo avisemos a algún adulto, para así tratar de solucionar esta situación lo antes posible y que nuestros amigos y compañeros no lleguen a sufrir lo que está viviendo Carlos.

\section{RECURSOS}

- Ficha número 7 del cuaderno de 5o de primaria. 


\section{CARLOS Y EL CIBERBULLYING}

\section{Lee el texto.}

Carlos, un niño de 11 años tiene problemas con compañeros de clase. Desde hace unas semanas recibe mensajes al móvil y correos electrónicos donde algunos compañeros de clase lo amenazan y lo insultan, y en los grupos de clase de WhatsApp no le dejan participar. Carlos es víctima de ciberbullying, que es cuando un niño o adolescente es amenazado, acosado, humillado, molestado de una manera u otra reiteradamente, por otro niño o adolescente mediante el uso de Internet, tecnologías interactivas y digitales o teléfono móvil.

La gente cercana a Carlos se ha dado cuenta que desde hace un tiempo Carlos ha cambiado mucho su carácter pues siempre está triste, sus notas escolares han empeorado, no quiere asistir a clase ni salir a jugar por las tardes y dice que le duele mucho el estómago y que se encuentra mareado. Todo esto son consecuencias del ciberbullying, pues debemos saber que este problema es muy frecuente y que las consecuencias que conlleva son muy importantes.

Durante mucho tiempo Carlos no ha querido contar lo que estaba sufriendo a sus padres ni a sus profesores, y sus compañeros, aunque sí lo sabían tampoco se lo han comunicado a ningún adulto. Mientras tanto, Carlos ha sufrido todas las consecuencias que comentábamos, y lo ha pasado muy mal, puesto que el ciberbullying es un problema muy grave con consecuencias legales muy importantes para las personas que envían estos mensajes que son los agresores, pues se trata de un delito.

Por eso es necesario que sepamos lo qué es y que cuando veamos que algún compañero lo está sufriendo avisemos a algún adulto, para así tratar de solucionar esta situación lo antes posible y que nuestros amigos y compañeros no lleguen a sufrir lo que está viviendo Carlos. 
2. Haz un resumen en el que se expresen las ideas principales que transmite el texto que has leído.

RECUERDA...

El ciberbullying es cuando un niño o adolescente es amenazado, acosado, humillado, molestado de una manera u otra reiteradamente, por otro niño o adolescente mediante el uso de Internet, tecnologías interactivas y digitales o teléfono móvil. Las consecuencias que conlleva son muy importantes por eso es necesario que cuando sepamos que alguien lo está sufriendo avisemos a un adulto. 
CURSO: 5ㅇ PRIMARIA

FICHA: 8

ASIGNATURA: LENGUA CASTELANA Y LITERATURA

ACTIVIDAD: ¿QUÉ NECESITAS SABER?

CONTENIDOS: ENTREVISTA Y CIBERBULLYING

\section{OBJETIVOS CURRICULARES}

- Planificar y escribir de forma reflexiva una entrevista.

- Participar en un debate oral sobre temáticas cercanas.

\section{OBJETIVOS SOBRE LA TEMÁTICA}

- Conocer los canales por los que se produce el ciberbullying y los tipos que existen.

- Ser conscientes de los peligros del mal uso de las nuevas tecnologías.

\section{METODOLOGÍA / PROCEDIMIENTO}

En esta actividad trabajaremos contenidos relacionados con el ciberbullying junto con la entrevista. Para ello hemos elaborado la ficha 8.

1. Introducción en grupo a la actividad:

Vamos a realizar una actividad en la que trabajaremos la entrevista, que como ya sabemos la entrevista es una conversación entre varias personas acerca de un tema. También sabemos que en una entrevista hay personas que hacen el papel del entrevistador, que es la persona que hace las preguntas, y también el papel de entrevistado que es la persona experta del tema a la que se le hacen las preguntas y que responde a ellas.

Ahora que ya sabemos bien qué son las entrevistas, vamos a realizar una entrevista nosotros. En este caso el tema que vamos a trabajar es el ciberbullying, que como ya vimos el otro día el ciberbullying es cuando un niño o adolescente es amenazado, acosado, humillado, molestado de una manera $u$ otra $y$ reiteradamente, por otro niño o adolescente mediante el uso de Internet, tecnologías interactivas y digitales o teléfono móvil.

Pero, ¿sabéis exactamente cómo se produce el ciberbullying? Es decir, ¿por qué canales o medios se produce? o ¿sabéis qué es o no es ciberbullying? Seguro que tenéis muchas dudas sobre el ciberbullying, por exactamente vamos a realizar la entrevista.

Cada uno de vosotros preparará unas preguntas, pues vosotros haréis de entrevistadores, y yo haré de entrevistado y experto en ciberbullying, y os daré las respuestas a las preguntas que planteéis.

2. Realización individual de la actividad:

Ahora cada uno en la ficha anotará dos preguntas que quiera plantear sobre el ciberbullying.

(Los alumnos trabajan individualmente escribiendo dos preguntas en las cuales plantean dudas sobre el ciberbullying. Encontraremos en el apartado de orientaciones algunas preguntas que se pueden plantear por si algún alumno tiene 
dudas sobre las preguntas que pueda hacer y también encontramos allí las respuestas que nos ayudarán a responder a estas preguntas así como también a conocer en general que es el ciberbullying de modo que nos darán orientaciones generales.)

3. Realización grupal de la actividad:

Ahora con las preguntas que habéis planteado vamos a realizar una entrevista donde vosotros seréis los entrevistadores y yo el entrevistado, de modo que iréis haciéndome las preguntas y yo iré respondiendo. Cuando hagáis las preguntas anotad debajo las respuestas.

(Los alumnos van planteando las preguntas y nosotros como expertos en ciberbullying vamos respondiendo a las preguntas. Nos podemos guiar por la información que tenemos en el apartado de orientaciones. Debemos usar siempre un vocabulario entendible para ellos, de modo que si resulta complicado algún concepto lo podemos explicar con ejemplos de casos posibles en los que se produciría ciberbullying.)

4. Reflexión final en grupo:

Con todas las respuestas conoceréis mejor lo que es el ciberbullying, que como ya dijimos el otro día es un problema muy grave que debemos de evitar, y cuando conozcamos algún caso avisar a un familiar o un profesor para que nos ayuden a resolverlo. Hemos visto que el ciberbullying se lleva a cabo mediante el uso de las nuevas tecnologías por eso es importante que aprendamos a hacer un buen uso de los móviles, ordenadores, tabletas, etc. Así, haciendo un buen uso evitaremos sufrir ciberbullying, porque enviar mensajes amenazantes, excluir a alguien de un grupo, difundir videos o imágenes de otros, suplantar la identidad, difundir secretos o rumores de otros niños o adolescentes es ciberbullying.

\section{TEMPORALIZACIÓN}

Tiempo aproximado de la actividad 20 minutos:

1. Introducción a la actividad: 5 minutos.

2. Realización individual de la actividad: 5 minutos.

3. Realización grupal de la actividad y 4. Reflexión final: 10 minutos.

\section{ORIENTACIONES}

- Preguntas que sería interesante que se plantearan sobre el ciberbullying, algunas puede que nos las formulen directamente de este modo o de modo similar mediante ejemplos. Utilizaremos siempre un lenguaje entendible para ellos.

- 1. ¿Cómo se produce el ciberbullying?

- Mensaje de texto

- Acoso telefónico

- Fotografías-vídeos

- Correos electrónicos

- Sesiones de chat

- Programas de mensajería instantánea (como WhatsApp) 
- Páginas web

- 2. ¿Qué tipos de ciberbullying existe?

- Envío y difusión de mensajes ofensivos.

- Envío de mensajes amenazantes

- Difusión de rumores con intención de desacreditar.

- Difusión de secretos o imágenes.

- Exclusión de grupos en la red.

- Suplantación de identidad: con mensajes maliciosos.

- 3. ¿Cómo se llaman los que participan en el ciberbullying?

- Agresor: persona que acosa.

- Víctima: persona que recibe el acoso.

- Los espectadores: otras personas cercanas al agresor y a la víctima que conocen y ven que existe ciberbullying.

\section{RECURSOS}

- Ficha número 8 del cuaderno de 5으 de primaria. 


\section{¿QUÉ NECESITAS SABER?}

Escribe a continuación dos preguntas para la entrevista que realizaremos en clase sobre el ciberbullying.

1.

Respuesta:

2.

Respuesta:

RECUERDA...

Realizar acciones como enviar mensajes amenazantes, excluir a alguien de un grupo, difundir videos o imágenes de otros, suplantar la identidad, difundir secretos o rumores de otros niños o adolescentes es ciberbullying. 


\section{VAMOS A REFLEXIONAR...}

Después de haber realizado las actividades anteriores, vamos a reflexionar sobre los aspectos que hemos trabajado. Para ello, contesta las siguientes cuestiones:

1. ¿Qué es el ciberbullying?

2. Las consecuencias del ciberbullying no son muy graves por eso no es importante avisar a un adulto si nos ocurre a nosotros o si vemos que alguien lo está sufriendo.

Verdadero

Falso

3. Nombra tres ejemplos de acciones que son ciberbullying.

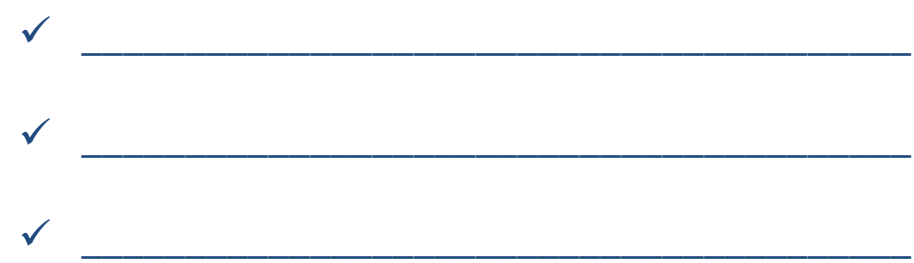


FITXA D'AVALUACIÓ PER AL PROFESSOR/A DE LES ACTIVITATS

DEL BLOC DE CIBERBULLYING

1. Com t'ha resultat dur a terme les tasques segons les indicacions exposades en les fitxes?

Molt difícil $\square \quad$ Difícil $\square \quad$ Normal $\square \quad$ Fàcil $\square \quad$ Molt fàcil $\square$

2. Creus que es compleix l'objectiu proposat? Sí $\square \quad$ No $\square$

3. Has introduït les activitats al contingut curricular assenyalat o en algun altre?

T emes indicats $\square \quad$ Altres $\square$ (indica quins:

4. Has utilitzat altres recursos a part dels que apareixen a la fitxa? Sí $\square \quad$ No $\square$

5. ¿Faries alguna modificació de millora en les fitxes per assolir els objectius de manera més òptima? Sí $\square \quad$ No $\square$

(en cas afirmatiu, indica quina:

6. Com s'han sentit els alumnes en realitzar les activitats? (motivació, implicació, interacció amb altres, ....)

7. Hi ha algun aspecte que consideres oportú comenta per a la millora del programa? 


\section{PREVENCIÓ I RESOLUCIÓ DE CONFLICTES}

Evitar i solucionar discrepancies entre dos $\sigma$ més interessos simultanis que algunes voltes donen lloc a un estat de tensió emocional que comporta estats dansietat $i$ comportaments impulsius.

\section{Objectius.}

$\checkmark$ Identificar les situacions conflictives i les seues causes.

$\checkmark$ Valorar les respostes possibles front a un conflicte i les seues conseqüències. 
CURS: 5è PRIMÀRIA

FITXA: 10

ASSIGNATURA: CIÈNCIES SOCIALS

ACTIVITAT: ELS CONFLICTES

CONTINGUTS: EDAT MITJA I PREVENCIÓ I RESOLUCIÓ DE CONFLICTES

\section{OBJECTIUS CURRICULARS}

- Descriure alguns processos i fets històrics.

- Conèixer les etapes de l'edat mitja.

\section{OBJECTIUS SOBRE LA TEMÀTICA}

- Descriure què és un conflicte.

- Detectar situacions conflictives.

\section{METODOLOGIA / PROCEDIMENT}

En aquesta activitat es treballaran continguts relacionats amb la prevenció i resolució de conflictes així com altres relacionats amb el al-Àndalus. L'activitat la trobarem a la fitxa 10.

1. Introducció de l'activitat en grup:

Recordeu els canvis que ha ocorregut a l'edat mitja, es a dir, les diferents invasions que s'han produït a la península al llarg dels anys? Digueu-me que quines invasions es van produir des dels temps dels romans.

(Recordem tots junts les diferents invasions que es produïren a la península i els canvis que es van produir per les lluites. Trobarem més informació a l'apartat d'orientacions.)

Doncs bé, hem vist que a la península es van sofrir molts canvis degut a les lluites que els van produir per les invasions de la península ibèrica per on passaren els romans, visigots, musulmans, etc. Aquestes eren lluites que es produïen perquè tots volien conquistar aquestes terres. Penseu que eren conflictes?

(Valorem tots junts si es poden considerar o no conflictes. En aquest cas es pot considerar com a conflicte ja que es produeix un problema, una lluita, una diferència d'idees, discordança d'interessos, etc.)

2. Realització primer individual i després en grup de la primera activitat:

Aleshores podem dir que durant l'edat mitja es van produir molts conflictes per conquistar la península ibèrica. Però, què enteneu vosaltres per conflicte? Llegiu la primera activitat i responeu i després ho comentarem junts.

(Els alumnes responen a la primera activitat, senyalant si consideren que es un conflicte i també podem afegir a l'últim espai el que ells consideren que és un conflicte.)

Digueu-me, quines de les frases creieu que defineixen bé el que és un conflicte? I si algú ha escrit alguna altra cosa, anem a comentar-ho també!

(Comentem tots junts el que considerem que podria ser un conflicte, que com ja hem comentat es tractaria de tot allò que produeix lluita, problemes, discordança d'idees, etc.) 
3. Realització individual de la segona activitat i reflexió conjunta d'aquesta:

Ara que ja sabem el que és un conflicte, anem a escriure a l'activitat 3 per què creieu que es produeixen els conflictes. Responeu a la pregunta de la fitxa i després ho comentem tots junts.

(Els alumnes responen individualment a la pregunta 3 i a continuació es comenta en grup les respostes que aniran encaminades a respostes com: perquè no es posen d'acord, tenen pensaments diferents, els dos lluiten per alguna cosa, etc.

4. Reflexió final en grup i realització individual de la tercera activitat:

Ja em vist que les situacions que ocorrien fa anys a l'edat mitja eren conflictes que ocorrien perquè diferents grups lluitaven per conquista la península ibèrica. Igual que els ocorria a ells, hui en dia ens ocorren coses paregudes a nosaltres. Ara anem a pensar una situació en la qual nosaltres haguem viscut un conflicte, i l'escriurem a la fitxa.

Hem de saber que tenir problemes es bastant freqüent a casa, a l'escola, amb els amics, etc. I tot i sent una cosa normal, hem d'aprendre a evitar-los doncs no ens aporten res positiu, i és molt important que en eixos moments ens parem a pensar $i$ ens adonem que fent les coses d'una altra forma sense entrar en conflicte solucionarem les coses millor i les relacions que tindrem amb els altres també seran millors.

(Els alumnes treballen individualment escrivint alguna situació en la que hages viscut algun fet conflictiu.)

\section{TEMPORALITZACIÓ}

Temps aproximat de l'activitat 20 minuts:

1. Introducció inicial: 5 minuts.

2. Realització de la primera activitat: 5 minuts.

3. Realització de la segona activitat: 5 minuts.

4. Realització de la tercera activitat i reflexió final: 5 minuts.

\section{ORIENTACIONS}

- Durant l'edat mitja es van produir moltes invasions a la península ibèrica: els visigots van entrar a la península per la cridada d'ajuda dels romans per l'atac dels Bàrbars i després de la seua lluita els visigots es van quedar a la península, posteriorment els musulmans en la batalla de Guadalete varen entrar a la península pel sud i sense quasi lluitar van conquista i dominar pràcticament tota la península Ibèrica. Després de la invasions d'aquests, va passar a anomenar-se Al-andalús i va passar anys després d'emirat a califat i després als regnes de taifes.

- Aquestes activitats permeten als alumnes ser conscients de què són els conflictes, poder adonar-se que fa milers d'anys que aquests ocorren i a nosaltres també ens ocorren molt a sovint per això és important distingir les situacions conflictives i adonar-se que aquest tipus de reaccions no ens porten a cap lloc ni ens aporten cap cosa positiva per això cal prestar atenció i tractar de solucionar les situacions que ens 
ocorren de la millor forma possible sense arribar als conflictes perquè així aconseguirem tenir unes relacions més positives amb les persones del nostre voltant.

\section{RECURSOS}

- Fitxa número 10 del quadern de 5è de primària. 


\section{ELS CONFLICTES}

Les situacions que vos plantegem a continuació són conflictes:

- La lluita dels visigots contra els vàndals, alans i sueus.

- La invasió musulmana en la batalla del Guadalete.

1. Què és un conflicte per a tu? Senyala la resposta.

Quan hi ha una lluita per una cosa.

Dos persones que es criden perquè no s'entenen.

Fer coses que molesten als altres.

2. Per què creus que es produeixen els conflictes?

3. Pensa alguna situació conflictiva que hagis viscut i escriu-la.

\section{RECORDA...}

Tenir problemes es bastant freqüent però hem d'aprendre a evitar-los, doncs no ens aporten res positiu. És molt important que en eixos moments ens parem a pensar i ens adonem que fent les coses d'una altra forma, sense entrar en conflicte, solucionarem les coses millor i les relacions que tindrem amb els altres també seran més bones. 
ASSIGNATURA:CIÈNCIES SOCIALS

\section{ACTIVITAT:SOLUCIONEM ELS CONFLICTES}

CONTINGUTS: LA RECONQUISTA DELS CRISTIANS I PREVENCIÓ I RESOLUCIÓ DE CONFLICTES

\section{OBJECTIUS CURRICULARS}

- Descriure els canvis a l'edat mitja a la península.

- Reconèixer la reconquista cristiana de la península.

\section{OBJECTIUS SOBRE LA TEMÀTICA}

- Reconèixer un conflicte i les causes d'aquests.

- Valorar les solucions possibles per a resoldre els conflictes i reflexionar sobre les conseqüències.

\section{METODOLOGIA / PROCEDIMENT}

En esta activitat treballarem continguts relacionats amb els regnes cristians així com també continguts per a la prevenció i resolució de conflictes. La fitxa que correspon a aquesta activitat és la 11.

1. Introducció a la primera activitat en grup i realització individual d'aquesta:

Sabem que a la península ibèrica va haver molts canvis durant l'edat mitja, doncs va ser ocupada inicialment pels romans, visigots, musulmans i finalment pels cristians. Els cristians foren els últims en ocupar la península, $i$ aquests ho feren després de guanyar la batalla de las Navas de Tolosa, on els musulmans foren vençuts i quasi tot el Al-Àndalus fou reconquistat pels cristians, $i$ anys després al 1492 va quedar totalment conquistat.

Una volta hem recordat tots aquests fets, digueu-me, quin fou el conflicte que va ocórrer entre els musulmans $i$ els cristians? Anem a comentar-ho i després ho anotarem a la primera activitat de la fitxa.

(Comentem tots junts el procés de reconquista dels cristians que finalment aconseguiren tornar a conquistar tota la península al derrotar als musulmans. El conflicte és la lluita dels cristians i musulmans. Després anoten individualment la resposta a la primera activitat de la fitxa.)

2. Realització individual de la segona activitat i després ho comentem en grup:

D'acord, doncs ja sabem quin és el conflicte que es produeix entre musulmans $i$ cristians, però sabríeu dir-me perquè es produeix eixe conflicte?

(Els alumnes anoten individualment la resposta a la pregunta a la fitxa i després ho comentem tots junts on cadascú dona la seua opinió i aporta la seva resposta que tractarem d'encaminar-la a que el conflicte és que tots dos volien establir-se a la península i dominar-la. Per aquest motiu lluiten per aconseguir-ho.)

3. Realització individual de la tercera activitat:

Com que hem determinat ja quin és el conflicte que ha ocorregut i també perquè es produeix, el que farem ara és pensar cada u de vosaltres què penseu que hagueren 


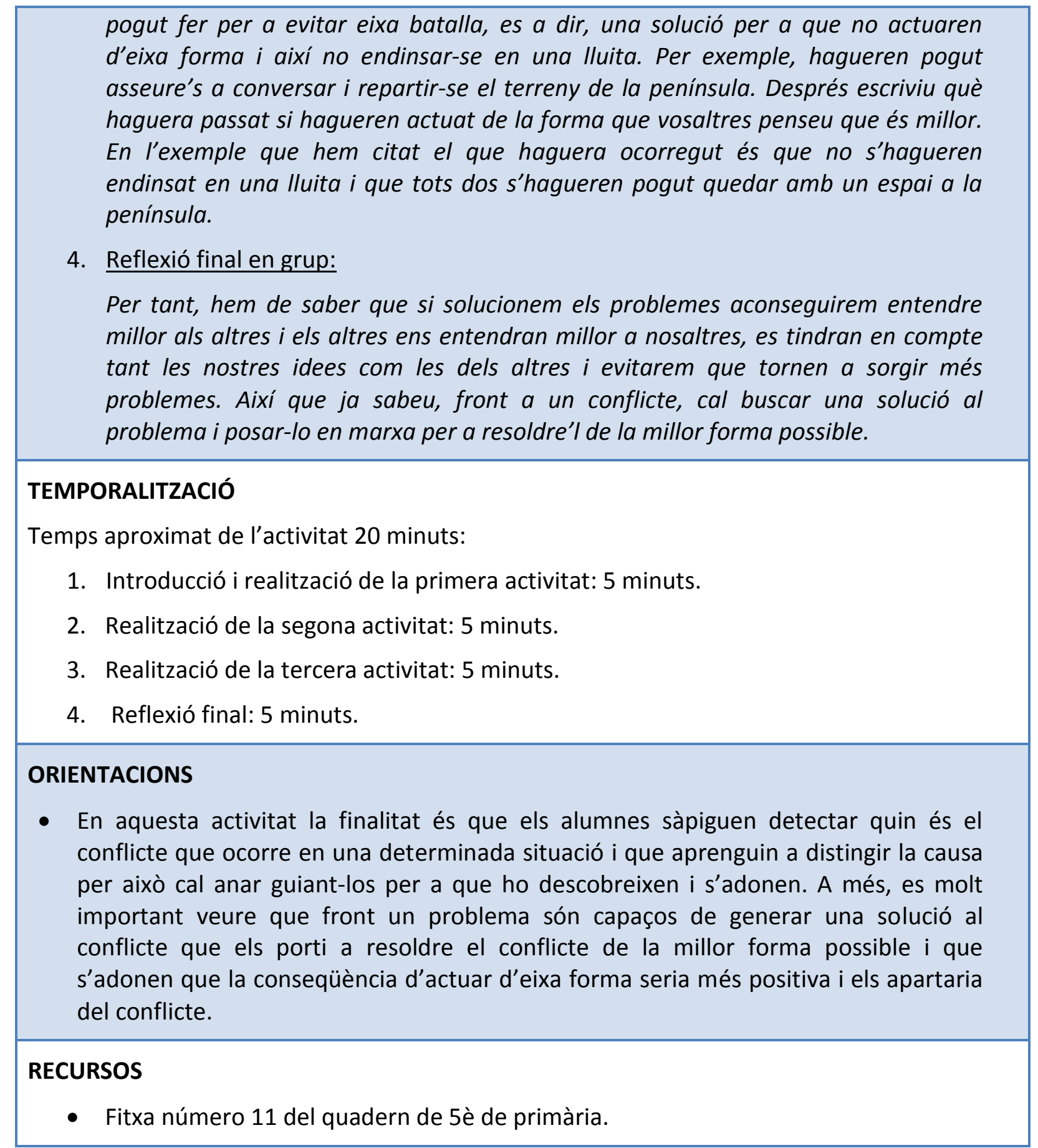




\section{SOLUCIONEM ELS CONFLICTES}

1. Quin és el conflicte?

\section{Per què s'ha produït el conflicte?}

3. Pensa i escriu la solució que consideres més adient i digues que haguera passat si hagueren actuat d'eixa forma.

RECORDA...

Si solucionem els problemes aconseguirem entendre millor als altres i els altres ens entendran millor a nosaltres, es tindran en compte tant les nostres idees com les dels altres i evitarem que tornen a sorgir més problemes per tant les relacions amb els altres seran millors. 


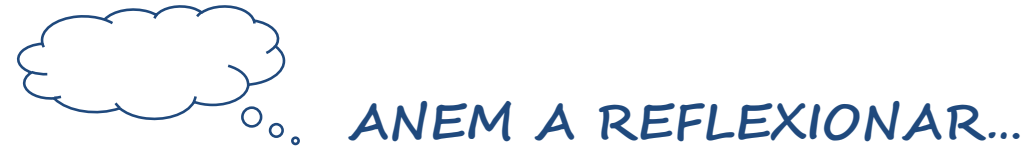

Després d'haver realitzat les activitats anteriors, reflexionarem sobre els aspectes que hem treballat. Per a això, contesta les següents qüestions:

1. Tenir problemes és una cosa freqüent; doncs a casa, amb els amics o companys tenim conflictes perquè no estem d'acord amb alguna cosa, pensem diferent, etc.

Vertader

Fals

2. Senyala la resposta correcta.

El més important quan ens trobem amb un conflicte és ...

Seguir amb el conflicte i sense pensar en les conseqüències.

Parar-nos a pensar i tractar de resoldre'l buscant la forma correcta d'actuar.

Fugir del conflicte i deixar a l'altra persona parlant.

3. Què aconseguirem si solucionem els problemes? 
FITXA D'AVALUACIÓ PER AL PROFESSOR/A DE LES ACTIVITATS DEL BLOC DE PREVENCIÓ I RESOLUCIÓ DE CONFLICTES

1. Com t'ha resultat dur a terme les tasques segons les indicacions exposades en les fitxes? Molt difícil $\square \quad$ Difícil $\square \quad$ Normal $\square \quad$ Fàcil $\square \quad$ Molt fàcil $\square$

2. Creus que es compleix l'objectiu proposat? Sí $\square \quad$ No $\square$

3. Has introduït les activitats al contingut curricular assenyalat o en algun altre?

T emes indicats $\square \quad$ Altres $\square$ (indica quins:

4. Has utilitzat altres recursos a part dels que apareixen a la fitxa? Sí $\square \quad$ No $\square$

5. ¿Faries alguna modificació de millora en les fitxes per assolir els objectius de manera més òptima? Sí $\square \quad$ No $\square$

(en cas afirmatiu, indica quina:

6. Com s'han sentit els alumnes en realitzar les activitats? (motivació, implicació, interacció amb altres, ....)

7. Hi ha algun aspecte que consideres oportú comenta per a la millora del programa? 


\section{BON ÚS DE LES TIC}

\section{Utilitzar adequadament $i$ amb responsabilitat Internet $i$ les noves tecnologies.}

\section{Objectivs.}

$\checkmark$ Reflexionar sobre l'ús responsable de les noves tecnologies com a mitjà de comunicació.

$\checkmark$ Ser conscients dels perills que comporta l'ús de les noves tecnologies a la nostra salut. 
ASSIGNATURA:CIÈNCIES DE LA NATURALESA

ACTIVITAT:ENS RELACIONEM PER INTERNET

CONTINGUTS: LA FUNCIÓ DE RELACIÓ I EL BON ÚS DE LES NOVES TECNOLOGIES

\section{OBJECTIUS CURRICULARS}

- Reconèixer i expressar què és la funció de relació.

- Identificar i localitzar els principals òrgans implicats en la funció de relació del cos humà.

\section{OBJECTIUS SOBRE LA TEMÀTICA}

- Sensibilitzar als alumnes sobre la necessitat de fer un ús responsable de les noves tecnologies com a mitjà de comunicació.

- Promoure el coneixement dels perills que comporta comunicar-se mitjançant les noves tecnologies.

\section{METODOLOGIA / PROCEDIMENT}

En aquesta activitat anem a treballar continguts relacionats amb la funció de relació humana conjuntament amb continguts sobre el bon ús de les noves tecnologies. Aquesta activitat la podrem realitzar a la fitxa 13.

\section{Introducció en grup a l'activitat:}

Anem a realitzar una activitat on treballarem la funció de relació. Sabeu què és la funció de relació? De segur que sí! A veure que em podeu dir!

(Comentem tots junts què és la funció de relació. Amb les aportacions dels alumnes anem realitzant una definició que s'aproximi al concepte de funció de relació. Podem trobar més informació sobre aquest concepte a l'apartat d'orientacions.)

D'acord, doncs la funció de relació consisteix en captar informació de l'exterior mitjançant els òrgans dels sentits, interpretar eixa informació al cervell i després actuar de la forma més convenient. Aleshores, per a captar aquesta informació necessitarem òrgans dels sentits. Quins són aquests òrgans dels sentits?

(De nou tots junts anem aportant idees sobre quins són els òrgans dels sentits que actuen en la funció de relació. Aquests es trobarem a l'apartat d'orientacions.)

Perfecte, així hem quedat que els òrgans dels sentits que intervenen són cinc: l'oïda, el gust, el tacte, la vista i l'olfacte. I sabeu què ocorre després? Doncs que els receptors dels sentits que són els que perceben els estímuls com poden ser la llum, el so...envien la informació al cervell per terminacions nervioses, el cervell processa la informació i decideix com actuar enviant senyals mitjançant el sistema nerviós $i$ l'aparell locomotor rep les ordres i actua realitzant els moviments adequats.

2. Realització en grup de la primera activitat:

Ja sabem què és la funció de relació i els sentits que intervenen, és important que conegueu que una de les accions més important de les relacions humanes és la 
comunicació, ja que és la que ens permet relacionar-nos amb altra gent. Així, quan ens comuniquem posem en marxa la funció de relació, els nostres sentits reben uns estímuls com són paraules que podem escoltar, gestos que podem veure, textos que podem llegir, olors de les persones que podem olorar, etc. i després el nostre cervell al processar la informació és el que envia la senyal de com actuar. Digueume per quins canals ens podem comunicar amb els altres? Per exemple, per telèfon. Quines més? Mentre ho comentem anem anotant-ho a la fitxa.

(Fem un llistat a la pissarra de formes mitjançant els quals ens podem comunicar amb altres persones. Trobarem diferents opcions orientatives a l'apartat d'orientacions.)

3. Realització en grup de la segona activitat:

Com hem pogut veure són molts els canals pels que ens podem relacionar $i$ comunicar amb altra gent, però si ho pensem bé... quins són els que utilitzem més hui per hui? Doncs tots aquells relacionats amb les noves tecnologies, es a dir, ens comuniquem més per l'ordinador, mòbil o tableta que per exemple cara a cara, perquè hem canviat la forma de relacionar-nos i de comunicar-nos, ja que abans aquests dispositius no existien i la gent parlava quan es veia o per carta.

A través d'Internet podem comunicar-nos amb amics sense la necessitat d'estar prop d'ells, el que ens permet estar en contacte amb gent que està lluny de nosaltres, es a dir, que ens aporta moltes coses bones. Digueu-me més coses bones que de relacionar-nos per correu electrònic, missatgeria instantània, fòrums, xats, xarxes socials, etc. Anem a anotar-les a la pissarra i després a la fitxa.

(Anotem a la pissarra totes aquelles idees que ens transmeten els alumnes sobre tot allò positiu que ens aporta la comunicació i entaular relacions per Internet i les noves tecnologies. Trobarem un llistat a l'apartat d'orientacions.)

Perfecte, haveu vist que són molts els beneficis de comunicar-se amb les noves tecnologies, però són tot beneficis o creieu que també hi ha perills i que cal anar en compte? Què hem de fer per a prevenir aquests perills? Els anotarem primer a la pissarra i després escolliu els tres que vos pareguin més importants i els escriviu a la fitxa.

(Comentem i reflexionem tots junts sobre aquesta qüestió i fem un llistat a la pissarra amb les pautes que cal prendre per a que comunicar-se per Internet o altres dispositius no sigui perillós. Trobem un llistat d'accions de prevenció a l'apartat d'orientacions.)

4. Reflexió final en grup:

Com hem vist en aquesta activitat una funció de relació molt important és la comunicació. A la funció de relació els sentits prenen un paper molt important doncs són els que reben els estímuls del que ocorre al nostre voltant i informen al cervell $i$ aquest és qui diu com reaccionar. Hui en dia nosaltres ens comuniquem principalment per dispositius electrònics que ens faciliten molt la comunicació però també sabem que cal anar molt en compte i posar tots els nostres sentits alerta $i$ seguir els consells que hem après per a actuar correctament. Així aconseguirem comunicar-nos per Internet amb responsabilitat i sense perills! 


\section{TEMPORALITZACIÓ}

Temps aproximat de l'activitat 20 minuts:

1. Introducció a l'activitat: 5 minuts.

2. Realització de la primera activitat: 5 minuts.

3. Realització de la segon activitat: 5 minuts.

4. Reflexió final:5 minuts.

\section{ORIENTACIONS}

- Considerem la funció de relació com aquella acció que consisteix en captar informació de l'exterior mitjançant els òrgans dels sentits, interpretar eixa informació al cervell i després actuar de la forma més convenient.

- Els òrgans implicats en la funció de relació són: l'oïda, el gust, el tacte, la vista i l'olfacte.

- Alguns canals de comunicació són: la carta, telèfon, cara a cara, correu electrònic, missatgeria instantània, fòrums, xats, xarxes socials, etc.

- Relacionar-nos i comunicar-nos per les noves tecnologies ens permet:

- Escriure missatges que pots manar a l'instant i que en pocs segons poden arribar a la seva destinació.

- Tenir converses i enviar arxius en temps real.

- Parlar amb els teus amics, si tens micròfon i altaveus o mitjançant converses escrites.

- Parlar i veure's a temps reial per càmeres.

- Poden ajudar-nos a mantenir comunicació en gent llunyana.

- És important que els alumnes se n'adonen que comunicar-nos amb aquests dispositius electrònics ens aporta moltes coses bones però que també cal utilitzar-les bé $\mathrm{i}$ amb responsabilitat i per tant cal conèixer pautes que cal aplicar quan fem ús d'elles:

- Mai responguis a telefonades o a missatges de números desconeguts.

- No proporciones el teu número de telèfon o el correu electrònic a gent que no coneguis.

- No envies missatges ni fages telefonades que a tu no t'agradaria rebre.

- No escriguis missatges ofensius o desagradables.

- No fages fotos ni vídeos a altres persones sense el seu consentiment.

- No difonguis informació d'altres persones.

\section{RECURSOS}

- Fitxa número 13 del quadern de 5è de primària. 


\section{ENS RELACIONEM PER INTERNET}

1. Per quins canals de comunicació ens podem relacionar?

2. Escriu tres aspectes positius de relacionar-se amb les noves tecnologies.

- Escriu tres consells que cal seguir per a comunicar-nos positivament amb les noves tecnologies.

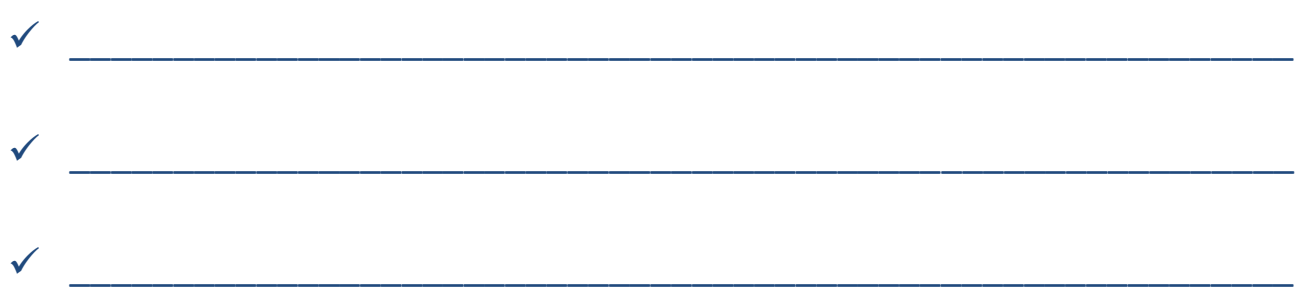

RECORDA...

Hui en dia ens comuniquem principalment per dispositius electrònics que ens faciliten molt la comunicació però també cal anar molt en compte, posar tots els nostres sentits alerta i seguir els consells que hem après com no respondre a desconeguts, no enviar missatges ofensius, no proporcionar el nostre telèfon a desconeguts, etc. 
ASSIGNATURA:CIÈNCIES DE LA NATURALESA

ACTIVITAT:FEM UN ÚS SALUDABLE

CONTINGUTS: LA SALUT I EL BON ÚS DE LES NOVES TECNOLOGIES

\section{OBJECTIUS CURRICULARS}

- Reflexionar sobre el concepte salut i la seua importància.

- Ser conscients dels factors que afecten la salut.

\section{OBJECTIUS SOBRE LA TEMÀTICA}

- Afavorir el debat amb els alumnes sobre I'ús saludable de les TIC.

- Sensibilitzar als alumnes sobre les conseqüències de fer un ús inadequat de les TIC.

\section{METODOLOGIA / PROCEDIMENT}

En aquesta activitat treballarem conceptes relacionats amb la salut i també altres relacionat amb el bon un de les noves tecnologies. Aquesta activitat la trobarem a la fitxa 14.

1. Introducció en grup a l'activitat:

Un dels aspectes més importats per als humans és tindre salut i trobar-nos bé, moltes voltes haureu escoltat la frase "mentre hi haja salut tot la resta no importa"...esteu d'acord amb aquesta frase? Què és la salut i perquè creieu que és tant important?

(Reflexionem i debatrem tots junts sobre la importància de la salut per a les persones i sobre el concepte de salut. Trobarem indicacions per a desenvolupar aquest debat a l'apartat d'orientacions.)

2. Realització en grup de la primera activitat:

Doncs com acabem de veure, és molt important per a tots tenir una bona salut, però digueu-me, què podem fer o que tenim que tenir en compte per a tenir una bona salut? Anoteu a la fitxa tres accions hàbits que ens ajudaran a tenir una bona salut.

(Debatrem tots junts sobre quines coses hem de fer per a que la nostra salut sigui bona i anotem els hàbits i accions que comporten a un estat saludable a la pissarra remarcant i nomenant l'ús de les noves tecnologies. Trobarem indicacions a l'apartat d'orientacions.)

3. Realització en grup de la segona activitat:

Aleshores, ja sabem com d'important és seguir hàbits de vida saludables per a tenir una bona salut. Hem dit que cal alimentar-se bé, fer esport, descansar bé...però vos haveu adonat que també hi ha altres aspectes que afecten a la salut com per exemple I ús de les noves tecnologies? Com creieu que ens poden afectar i per què?

(Reflexionem tots junts a aquesta qüestió, ja que molts coneixeran els altres aspectes que alteren la nostra salut però no són conscients dels perills de l'ús de les noves tecnologies a la salut. A l'apartat d'orientacions trobarem indicacions de 


\section{com desenvolupar aquesta reflexió.)}

Ens hem adonat com d'important és tenir cura de l'ús que fem de les noves tecnologies, ja que fer un mal ús d'elles ens pot portar problemes de salut i també problemes amb la gent del nostre voltant. A més, si fem un mal ús també és perillós per a la salut del nostre ordinador perquè ens podem infectar amb virus, spam, malware, etc. que ens pot danyar l'ordinador i els arxius. I què podem fer per a evitar aquests perills al nostre ordinador i també a la nostra salut?

(De nou debatrem i fem un llistat a la pissarra amb aquelles accions que cal seguir per prevenir aquests riscos que comporten un ús inadequat de les noves tecnologies. Trobarem indicacions a l'apartat d'orientacions.)

Anotem ara a la fitxa dos perills dels que hem comentat per un mal ús de les noves tecnologies $i$ dos hàbits saludables que podem seguir per a evitar que ens ocorri.

4. Reflexió final en grup:

Per tant, cal que recordeu que la salut és el més important que tenim i per això cal tenir cura i seguir hàbits saludables, com la bona alimentació, practicar esports, descansar bé, etc. però també cal tenir en compte altres aspectes que poden afectar a la nostra salut com és l'ús de les noves tecnologies, ja que si fem un ús inadequat pot ser perillós per a nosaltres i també per al nostre ordinador, tableta o mòbil. Així és important que respectem els horaris que ens marquen els pares, no comunicar-nos amb desconeguts, respectar als altres, pensar bé la informació que compartim a les xarxes, utilitzar un antivirus a l'ordinador, i altres més aspectes que hem comentant. Si seguim aquests hàbits amb l'ús de les noves tecnologies aconseguirem que la nostra salut sigui millor i ens sentirem millor!

\section{TEMPORALITZACIÓ}

Temps aproximat de l'activitat 20 minuts:

1. Introducció a l'activitat i 2 . Realització de la primera activitat: 10 minuts.

3. Realització de la segona activitat i 4 . Reflexió final: 10 minuts.

\section{ORIENTACIONS}

- És molt important que en aquesta activitat els alumnes reflexionen sobre el concepte de salut, que el poden definir com "I'estat complet de benestar físic, psicològic $i$ social; i no solament la absència d'infermetat". Els alumnes han de reconèixer que és molt important tenir una bona salut, ja que ens ajudarà en la resta de coses. Si tenim una bona salut podrem jugar, estudiar, estar amb la nostra família, etc. I com diu la definició, no es tracta nomes d'estar bé a nivell físic sinó també mentalment i també tenir bones relacions amb la gent que ens rodeja, com són els nostres amics, companys, família i tots aquells amb els que convivim a diari.

- Per a tenir una bona salut, i prevenir així també infermetats, cal seguir uns hàbits saludables com són: la higiene, el descans, l'esport, l'alimentació saludable, la postura correcta i les revisions mèdiques.

A més dels hàbits saludables, que són els que hem comentat abans i els que ens ajudaran a prevenir, també cal tenir en compte altres aspectes que suposen grans 
riscos per a la nostra salut com: l'obesitat, els accidents de tràfic, el tabac, l'alcohol, les drogues, l'ús inadequat de les noves tecnologies, etc.

- Com ja hem comentat, moltes voltes quan parlem de salut als més menuts ens centrem en aspectes com són l'alimentació, el descans, practicar esports, etc. o inclús les drogues o l'alcohol, però no són conscients que hi ha moltes altres coses que cal tenir cura per a tenir una bona salut. Un d'aquests és l'ús que fem de les noves tecnologies, ja que les tenim tant incorporades al nostre dia a dia, $\mathrm{i}$ ho veiem tant normal, que no ens adonem que a part de tot allò positiu que ens aporten també hi ha riscos. Per tant, cal que se n'adonen dels perills que comporta en la salut les noves tecnologies:

○ Ús inadequat d'elles:

- Ciberbulliyng, que és l'assetjament entre menors mitjançant les noves tecnologies. Aquestes accions són molt perilloses ja que rebre burles, amenaces i humiliacions a través d'Internet o telèfon mòbil pot causar molt de sofriment i dolor a la persona que ho rep, i per tant afectar-li psicològicament i també socialment.

- Sexting: tenir en compte que les imatges o vídeos que enviem a un amic o publiquem a les xarxes socials poden acabar en qualsevol lloc del món i les poden rebre qualsevol persona, i per tant pot ser perillós per a nosaltres.

- Grooming: cal anar en compte amb la gent que coneixem a la xarxa perquè alguns adults en males intencions tracten de guanyar-se la confiança dels menors per a finalitats il-lícites.

- Ús abusiu quan s'utilitzen aquests dispositius més temps del recomanat.

- Addicció quan la vida del xiquet gira entorn a la utilització de les noves tecnologies.

- Per prevenir aquests perills de l'ús inadequat de les noves tecnologies, que ens poden afectar a la nostra salut i també al nostre ordinador, cal:

- A l'ordinador: instal-lar antivirus i tallafocs, no obrir ni acceptar correus o arxius de persones desconegudes.

- Per a nosaltres: evitar relacionar-se amb gent desconeguda, ser respectuós amb les altres persones, tenir en compte la informació que publiquem a la xarxa o que enviem pel mòbil, no respondre a provocacions d'altres persones, respectar els horaris d'ús dels dispositius electrònics, etc.

\section{RECURSOS}

- Fitxa número 14 del quadern de 5è de primària. 


\section{FEM UN ÚS SALUDABLE}

1. Escriu tres hàbits que cal seguir per a seguir una vida saludable.

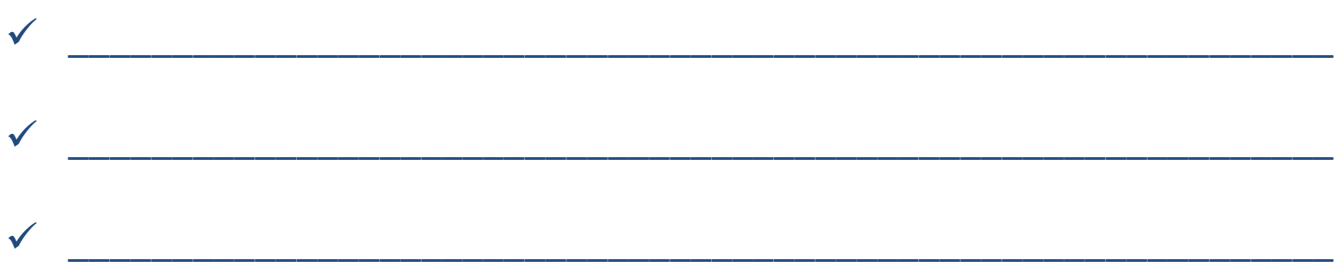

2. Anota dos accions perilloses que podem sofrir per l'ús de les noves tecnologies i que poden afectar a la nostra salut.

- I dos accions que hàbits saludables que podem seguir quan utilitzem les noves tecnologies per a prevenir aquests perills.

$\checkmark$

$\checkmark$

RECORDA...

L'ús inadequat i irresponsable de les noves tecnologies pot ser perillós per a la nostra salut. Per això cal que respectem els horaris que ens marquen els pares, no comunicar-nos amb desconeguts, respectar als altres, pensar bé la informació que compartim a les xarxes, entre altres. Si seguim aquests hàbits saludables amb l'ús de les noves tecnologies aconseguirem que la nostra salut sigui millor i ens sentirem millor! 


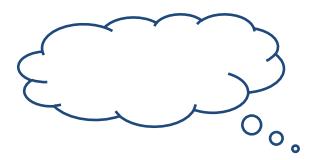

ANEM A REFLEXIONAR...

Després d'haver realitzat les activitats anteriors, reflexionarem sobre els aspectes que hem treballat. Per a això, contesta les següents qüestions:

1. Les noves tecnologies ens permeten comunicar-nos i relacionar-nos amb altra gent, però cal fer un bon ús d'elles.

Vertader

Fals

\section{Senyala les opcions correctes.}

Quan utilitzem les noves tecnologies per a comunicar-nos cal fer un bon ús d'elles i per tant cal...

No respondre a telefonades o missatges de números que no coneixem.

Donar el número de telèfon a tots aquells que ens el demanen.

Escriure missatges ofensius a altres persones.

No difondre imatges d'una altra persona sense el seu consentiment.

3. Quines accions poden ser perilloses per a la nostra salut? 
FITXA D'AVALUACIÓ PER AL PROFESSOR/A DE LES ACTIVITATS DEL

BLOC DE BON ÚS DE LES TIC

1. Com t'ha resultat dur a terme les tasques segons les indicacions exposades en les fitxes? Molt difícil $\square \quad$ Difícil $\square \quad$ Normal $\square \quad$ Fàcil $\square \quad$ Molt fàcil $\square$

2. Creus que es compleix l'objectiu proposat? Sí $\square \quad$ No $\square$

3. Has introduït les activitats al contingut curricular assenyalat o en algun altre?

T emes indicats $\square \quad$ Altres $\square$ (indica quins:

4. Has utilitzat altres recursos a part dels que apareixen a la fitxa? Sí $\square \quad$ No $\square$

5. ¿Faries alguna modificació de millora en les fitxes per assolir els objectius de manera més òptima? Sí $\square \quad$ No $\square$

(en cas afirmatiu, indica quina:

6. Com s'han sentit els alumnes en realitzar les activitats? (motivació, implicació, interacció amb altres, ....)

7. Hi ha algun aspecte que consideres oportú comenta per a la millora del programa? 


\section{QÜESTIONARI FINAL}

\section{Alumnat 5è de Primària}

Edat:

Gènere: Xic $\square \quad$ Xica $\square$

A continuació trobaràs una sèrie de qüestions amb tres possibles respostes. Llegeix detingudament i assenyala l'opció que s'acosti més al que tu penses. No et preocupis per les respostes que marques, no hi ha respostes correctes o incorrectes, només ens interessa la teva opinió.

1. Quan un amic es sent trist nosaltres hem de...

No fer-li cas, ja li passarà.

$\square$ Pensar com estaríem nosaltres si ens passés el mateix que a ell i així sabrem millor què li passa.

$\square$ Dir-li que no es preocupi, que això no és important, que això els passa a tots.

2. Compartir els nostres sentiments amb els altres...

$\square$ És bo perquè ajuda a que ens entenguin millor quan ens sentim malament.

$\square$ És un error perquè el millor és no contar a ningú com ens sentim.

$\square$ No és bo perquè pot ser es riguin de nosaltres.

3. Si un amic o company et diu que fages alguna cosa que no vols fer...

Ho faig perquè és el meu amic o company i m'ho ha demanat.

Li dic que no em pareix bé però després faig el que hem diu.

$\square$ Li dic que no ho faré per què no estic d'acord i li explico els motius.

4. Quan una persona ens diu alguna cosa bonica sobre nosaltres cal...

$\square$ No contestar-li res, mirar-li i ja està.

$\square$ Agrair el comentari bo i fer-li veure que t'agrada el que et diu.

Dir-li que segur que ens ho està dient per a quedar bé.

5. Estarem davant d'un cas de ciberbullying quan ...

Parlem per WhatsApp o altres aplicacions amb companys i amics.

Compartim informació nostra a les xarxes socials.

Compartim vídeos o imatges gracioses però humiliants d'algú pel mòbil 
6. Si sofrim ciberbullying o coneixem alguna persona que ho està sofrint hem de...

No contar-li a ningú el que passa perquè ningú s'assabenti.

Contar-li a un amic o company el que està passant.

Avisar a un adult i contar-li el que està passant.

7. Quan tenim problemes amb els companys o els amics i ens barallem...

Hem d'aprendre a evitar eixes situacions perquè no ens aporten res positiu.

És una situació comuna i és normal que diguem el primer que se'ns passi pel cap.

$\square$ És bo que discutim i ens barallem perquè així mostrem a tots el que pensem.

8. Solucionar els problemes que tenim parlant amb l'altre...

Parlant amb l'altre aconseguirem que el problema sigui més gran. És millor deixar-ho passar.

Ens ajudarà a entendre millor als altres i que els altres ens entenguin millor a nosaltres.

No serveix per a res perquè si jo penso d'una manera i l'altre d'una altra, parlant sorgiran més problemes.

9. Quan parlem amb gent per l'ordinador, la tableta o el mòbil, fem coses que ens poden posar en un problema. Una cosa que no hem de fer és...

Ignorar a algú que no coneixem encara que ell ens digui que sí que ens coneix. Això és de mala educació.

Dir el nostre nom, on estudiem, on vivim, ..., ja que com més ens coneguin, més amics tindrem a Internet.

Demanar permís a algú abans de penjar una foto seva graciosa, ens dirà que no i no podrem penjar-la.

10. Quan estem amb l'ordinador, la tauleta o el mòbil, hem de tenir en compte que...

No passa res per estar connectat més estona del que ens diuen els nostres pares. Són uns exagerats.

Si tots ens burlem d'una foto d'un company, per a nosaltres serà divertit, però per al company serà molt dur i ho passarà malament. A Internet és impossible que una persona es faci passar per una altra persona que no és. 


\section{RECURSOS}

\section{GUIES}

* Junta de Castilla y León (2011). Manual de uso inteligente de las nuevas tecnologías para los alumn@s. De 8 a 10 años. Recuperado de: http://www.cyldigital.es/sites/default/files/library/manual810anosprogramaaprende.pdf

* Junta de Castilla y León (2011). Manual de uso inteligente de las nuevas tecnologías para los alumn@s. De 10 a 12 años. Recuperado de: https://www.cyldigital.es/sites/default/files/library/manual10-

12anosprogramaaprende.pdf

Concepte de noves tecnologies, informació sobre els videojocs, televisió, ordinador i Internet. També ens ofereixen informació sobre els riscs que podem trobar en la xarxa. A més, ens proporcionen informació sobre els e-drets dels xiquets i xiquetes i una sèrie de regles que es necessari que els menors coneguin a I'hora d'utilitzar les noves tecnologies.

* INTECO (2013). Guía de actuación contra el ciberacoso. Padres y educadores. Recuperado de: http://www.injuve.es/sites/default/files/2013/46/publicaciones/Gu\%C3\%ADa\%20 de\%20actuaci\%C3\%B3n\%20contra\%20el\%20ciberacoso.pdf

Concepte de ciberbullying, pautes de detecció, prevenció i actuació, i comportar a cap el procés de denuncia i el delicte que comporta. També trobarem una sèrie d'experiències de casos de ciberbullying i altres riscos de l'ús de les TIC, així com consells bàsics sobre l'ús de les noves tecnologies.

* Centro se Seguridad en Internet Protégeles (s.f.). Ciberbullying y privacidad. Guía para profesores. Recuperado de: http://www.yocontrolo.es/descargas/PROYECTO DAPHNE ES.pdf

Continguts teòrics relacionats amb el ciberbullying: concepte, qui intervé, prevenció, etc., i també altres sobre la privacitat: drets i deures, protecció de dades i delictes. També trobarem a aquests document una sèrie d'activitats per a treballar el ciberbullying i la privacitat en Internet. 
* Comisión de libertades e informática (2009). Proyecto CLI Prometeo. Manual práctico de uso de las tecnologías de la información. 9 a 11 años. Recuperado de:http://www.madrid.org/dat oeste/descargas/08 09/cli prometeo/Manual 9 11 castellano.pdf

Conjunt d'activitats on es treballen els diferents aspectes relacionats en l'ús de les tecnologies de la comunicació i la informació a partir d'històries relacionades amb I'ús que els menors fan d'aquestes tecnologies.

* Collell, J. y Escudé, C. (2008). No te enredes en la red. Guía para conocer el ciberbullying y algunos peligros de internet y las nuevas tecnologías. Recuperado de: http://www.xtec.cat/ jcollell/ZGuia\%20Ciber.pdf

Informació teòrica com el concepte de ciberbullying i conductes relacionades amb el ciberbullying. Presenta un conjunt d'activitats on a partir d'una sèrie d'històries es presenten qüestions per a debatre en grup sobre les conductes que es presenten a les històries.

Luengo, J. A. (2014). Ciberbullying. Prevenir y actuar. Guía de recursos didácticos para Centros Educativos. Recuperado de: http://www.copmadrid.org/webcopm/recursos/CiberbullyingB.pdf

Situació de l'ús de les TIC en els últims anys, conceptes teòrics sobre el ciberbullying i informació sobre diferents tècniques de treball del ciberbullying. En aquesta guia ens proporcionen també pautes i materials per la prevenció a partir de l'alfabetització digital des de l'educació primària. A més, la guia ens proporciona moltes activitats didàctiques per a portar a terme a les aules $i$ un protocol d'intervenció ben desenvolupat amb materials i pautes tan per a pares com per a professors i alumnes. Finalitza amb una sèrie de referències normatives per a la reflexió i acció en el centre escolar.

* Fundación Dédalo (2012). Por un uso seguro de internet. Primaria. Recuperado de:http://www.disfrutalared.com/images/yootheme/fichas didacticas/FichasDida cticasPrimaria es.pdf

Conjunt d'activitats relacionades amb l'ús segur d'Internet on es treballen aspectes com els valors, el ciberbullying, la privacitat, etc. 


\section{PÀGINES WEB}

* PANTALlaS AMIgAS (http://www.pantallasamigas.net).És la web més completa, i la pionera en la temàtica, que existeix on encontrarem recursos relacionats amb l'ús segur i saludable de les noves tecnologies de tot tipus: articles, vídeos, definicions de conceptes, materials i recursos didàctics, etc.

* CIBERBULlyING (http://www.ciberbullying.com). A la web trobarem informació sobre el ciberbullying, recursos de prevenció, consells contra el ciberbullying, noticies, articles, entrevistes, etc. tot relacionat amb aquesta temàtica.

* PROTEGeleS.COM (http://www.protegeles.com). Organització de protecció al menor en Internet que proporciona informació a la seua web com pot ser com actuar front a un problema, recursos, guies, estudis, vídeos, etc. I informació concreta dirigida a pares i mares, alumnes o professors amb una sèrie de normes, responsabilitats, activitats, etc.

* YO CONTROLO (http://www.yocontrolo.es/).Trobarem informació sobre casos de pèrdua de privacitat o ciberbullying, recursos com guies, webs, vídeos, estudis, etc.

\section{VÍDEOS}

* Ciberacoso (Childnet International - Cyber Bullying). Caso de ciberbullying subtitulado español. https://www.youtube.com/watch?v=9bgdOuBn4Q4

* Ciberbullying: ciberacoso en redes sociales, videogames, smartphones... y su prevención.https://www.youtube.com/watch?v=SEC dOWFN5M\&index=1\&list= PLC186BF9FE0418ED2

* ¿Cómo actuar ante el ciberacoso? Ignora, bloquea, pide ayuda y denuncia. https://www.youtube.com/watch?v=tVAjiyNzYq0\&list=PLC186BF9FE0418ED2\&in $\underline{\operatorname{dex}=7}$

* Recomendaciones para el Uso Seguro de Internet y las Redes Sociales. https://www.youtube.com/watch?v=t$\underline{x 73 w 1 N 10 s \& l i s t=P L C 186 B F 9 F E 0418 E D 2 \& \text { index }=12}$

* ¿Cómo evitar ser víctima de ciberbullying por suplantación de identidad? https://www.youtube.com/watch?v=XQeFYgedVZg\&list=PLC186BF9FE0418ED2\& index $=15$

* Decálogo por la ciberconvivencia positiva y contra la violencia digital. https://www.youtube.com/watch?v=gXvG53ccyJY\&index=17\&list=PLC186BF9FE 0418ED2 
ANEXO 11. CUADERNO DEL PROFESOR DE $6^{\circ}$ DE EDUCACIÓN PRIMARIA DEL PROGRAMA "CONVIURE EN UN MÓN REAL I DIGITAL"

Conviure en un món real $i$ digital

QUADERN DEL PROFESSOR SISÈ DE PRIMÀRIA

CENTRE:

PROFESSOR/A:

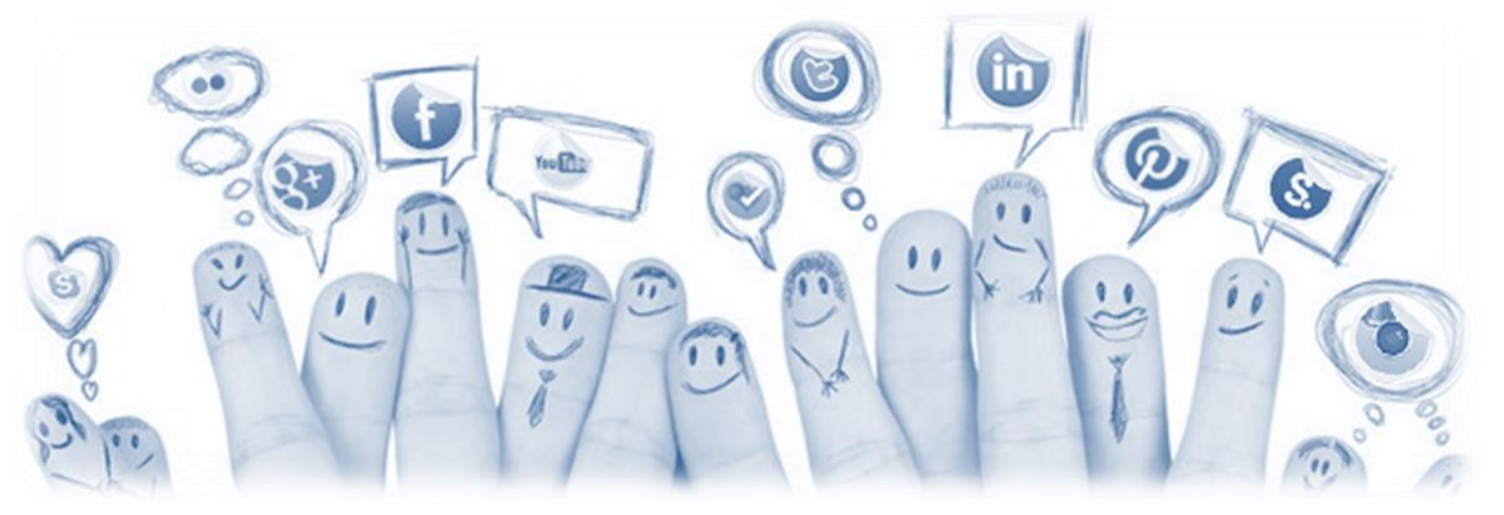




\section{ÍNDEX}

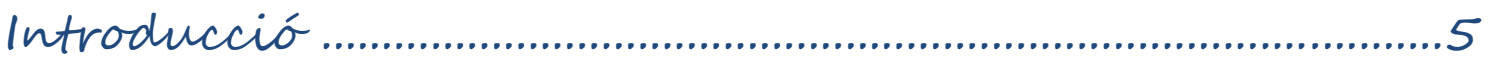

Objectiu general del programa ......................................................6

Caracteristiques $i$ configuració del programa ..........................6

Procediment per a l'aplicació del programa ..............................9

Taula de distribució de les activitats ...............................11

Activitats.

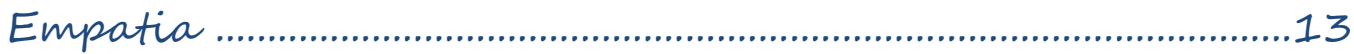

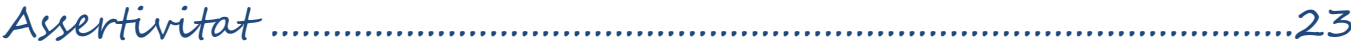

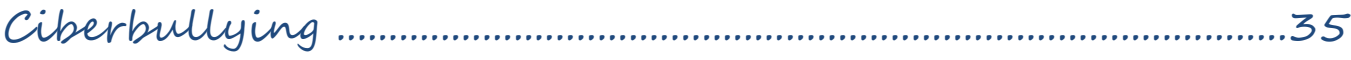

Prevenció $i$ resolució de conflictes ............................................47

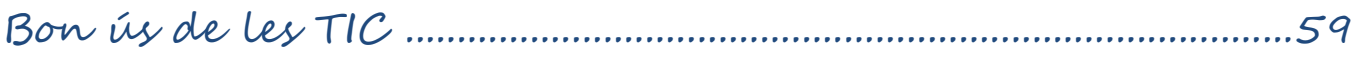

Qüestionari final ................................................................. 71

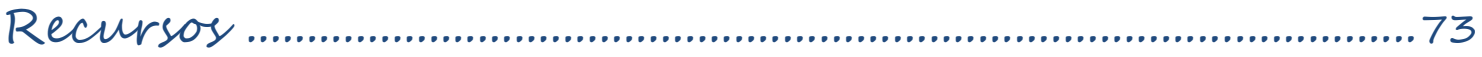




\section{INTRODUCCIÓ}

La infantesa, la pre-adolescència i l'adolescència són etapes crucials en el desenvolupament de les persones, tant a nivell personal com social i acadèmic/professional. Açò dona lloc a que els més joves siguin molt vulnerables davant l'entorn que els envolta i als continus canvis que caracteritzen la nostra societat actual. Els nostres joves han nascut en la era de les TIC, i fan ús d'elles des de edats molt primerenques.

En l'actualitat, els xiquets i les xiquetes, anomenats natius digitals, comencen a utilitzar les Tecnologies de la Informació i de la Comunicació (Tics) partir dels 3 anys d'edat, malgrat això, no saben com fer-ho de forma responsable i com protegir-se de les possibles amenaces. Així, sovint es troben amb una sèrie de dificultats com són l'accés a informació inadequada per a l'edat, sobretot continguts pornogràfics o violents, els riscos tècnics, la pèrdua de privacitat, la suplantació d'identitat, els fraus econòmics i l'addicció a pantalles, entre altres (Salmerón, Campillo i Casas, 2013). Aspectes com aquests provoquen que s'acreixi l'alarma social, doncs aquests riscos són desconeguts per als educadors, els pares i les mares, que han crescut en un context no digital (Del Riu, Sádaba i Bringué, 2010).

Un dels riscos que formen part dels anteriorment citats, és el ciberbullying. Parlem de Ciberbullying "quan un nen o adolescent és turmentat, amenaçat, assetjat, humiliat, molestat d'una manera o una altra, per un altre nen o adolescent mitjançant l'ús d'Internet, tecnologies interactives i digitals o telèfon mòbil" (Collell i Escudé, 2008).

Aquest tipus de maltractament entre iguals s'ha convertit en un problema complex entre els nostres adolescents, que sol tenir repercussions indesitjables en la convivència escolar (Avilés, 2013), i encara que la violència no és cap cosa nova, ja que a la fi dels anys 70 el noruec Olweus es va iniciar en l'estudi de la violència entre escolars mundialment conegut amb l'expressió bullying, les formes de materialització de la mateixa han anat evolucionant amb el temps, ideant noves formes de dur-la a terme (Hernández i Solano, 2007).

Considerant l'anteriorment citat, els centres educatius de tots els nivells tenen en l'actualitat el deure incloure dins de la formació integral aspectes com el sensibilitzar i prevenir que entre el mateix alumnat sorgeixin situacions de maltractament $\mathrm{i}$ intimidació, encara que es sap que el ciberbullying no succeeix precisament dins de l'escola, és aquí on ha d'abordar-se com a part de l'educació integral (Ortega, 2010).

La nova educació que cal realitzar en l'àmbit de les TIC també ha de procurar capacitar en determinades destreses i habilitats, que suscitarà unes actituds i disposicions. Entre aquestes últimes és imprescindible la necessitat de formar en una actitud sanament crítica davant les TIC. És a dir, saber distingir en què ens ajuden i en què ens limiten, 
per poder actuar en conseqüència. Aquest procés ha d'estar present i donar-se de manera integrada en la família, a l'escola i en la societat (Berríos i Buxarris, 2005).

Per tot això, és convenient destacar la necessitat de dur a terme accions de prevenció a edats primerenques, per oferir una informació i formació adequada als nens, progenitors i professorat, en l'àmbit de les TIC. Aquesta formació ha de basar-se en dues perspectives, una tecnològica i una altra humanística. És a dir, que atengui als mitjans, però també a les finalitats de l'educació (Naval, Sábada i Bringué, 2003).

* objectiu general del programa

L'objectiu principal d'aquest programa no es altre que realitzar accions de prevenció del ciberbullying als centres escolars en el segon i tercer cicle de l'educació primària mitjançant activitats inserides en el currículum escolar, de manera que l'alumne tingui la possibilitat d'adquirir aquests coneixements $\mathrm{i}$ aptituds relacionades amb la prevenció del ciberbullying progressivament durant els quatre últims cursos de l'educació primària.

\section{* característiques I configuració del programa}

El programa de prevenció del ciberbullying ha sigut dissenyat a partir d'un conjunt d'activitats inserides al currículum escolar, concretament a les següents assignatures:

- Ciències socials

- Ciències de la naturalesa

- Llengua castellana i literatura

Aquesta inserció curricular no solament va a cobrir la prevenció en quant a aspectes tecnològics, sinó també en aspectes humanístics. És a dir, per aconseguir els objectius proposats és necessari treballar aspectes tecnològics no obstant això, treballar únicament aquests aspectes no seria suficient, doncs per poder assumir aquesta informació i aplicar-la correctament és necessari que certes habilitats personals i socials estiguin ben desenvolupades, per així prevenir l'aparició de problemes com el ciberbullying. En concret les habilitats centrades en el bon ús de les TIC i les relacionades amb la resolució de conflictes seran aspectes centrals en el nostre projecte doncs treballant-los des d'edats primerenques creiem que són aspectes clau en la prevenció del ciberbullying.

Per tant les temàtiques que es treballaran en aquest programa es classifiquen del següent mode. En els cursos de tercer i quart de primària es treballaran un conjunt d'activitats relacionades amb habilitats tecnològiques i personals com són:

- Bon ús de les TIC

- Prevenció i resolució de conflictes 
- Autoestima

- Emocions

- Autocontrol

A continuació en cinquè $i$ sisè curs de primària es seguiran treballant aspectes tecnològics i introduirem habilitats socials, atès que aquests últims s'han de desenvolupar amb posterioritat a les habilitats més personals. Així els continguts a treballar els dos últims cursos de l'educació primària són:

- Bon ús de les TIC

- Resolució de conflictes

- Empatia

- Assertivitat

- Ciberbullying

El programa disposa d'un dossier que inclou totes les activitats a desenvolupar al llarg del programa. Aquestes activitats es troben classificades per cursos escolars (tercer, quart, cinquè i sisè de primària).

El dossier de cada curs escolar, al mateix temps, està format per cinc blocs temàtics amb tres activitats per cada bloc (dos relacionades amb el contingut curricular i una d'avaluació) sent un total de quinze activitats per curs escolar.

\begin{tabular}{|c|c|c|}
\hline CURS & TEMÀTICA & ACTIVITAT \\
\hline \multirow{5}{*}{$3 r$} & Autoestima & $\begin{array}{l}\text { 1. Així sóc jo. } \\
\text { 2. Em quede amb tot allò bo. } \\
\text { 3. Anem a reflexionar. }\end{array}$ \\
\hline & Emocions & $\begin{array}{l}\text { 4. El que sentim. } \\
\text { 5. Dime com et sents. } \\
\text { 6. Anem a reflexionar. }\end{array}$ \\
\hline & Autocontrol & $\begin{array}{l}\text { 7. Què passarà? } \\
\text { 8. Pren-te el teu temps. } \\
\text { 9. Anem a reflexionar. }\end{array}$ \\
\hline & $\begin{array}{l}\text { Prevenció i resolució de } \\
\text { conflictes }\end{array}$ & $\begin{array}{l}\text { 10. Ens relacionem. } \\
\text { 11. Fa un temps. } \\
\text { 12. Anem a reflexionar. }\end{array}$ \\
\hline & Bon ús de les TIC & $\begin{array}{l}\text { 13. Un día cualquiera } \\
\text { 14. ¿Tú qué opinas? } \\
\text { 15. Vamos a reflexionar. }\end{array}$ \\
\hline $4 t$ & Autoestima & $\begin{array}{l}\text { 1. Autorretrato. } \\
\text { 2. Así es mi compañero. } \\
\text { 3. Vamos a reflexionar. }\end{array}$ \\
\hline
\end{tabular}




\begin{tabular}{|c|c|c|}
\hline & Emocions & $\begin{array}{l}\text { 4. Els altres també senten. } \\
\text { 5. Sentim diferent. } \\
\text { 6. Anem a reflexionar. }\end{array}$ \\
\hline & Autocontrol & $\begin{array}{l}\text { 7. Anem a imaginar. } \\
\text { 8. ¿Què ocorre? } \\
\text { 9. Anem a reflexionar. }\end{array}$ \\
\hline & $\begin{array}{l}\text { Prevenció i resolució de } \\
\text { conflictes }\end{array}$ & $\begin{array}{l}\text { 10. ¿Hablamos? } \\
\text { 11. ¿Qué ocorre? } \\
\text { 12. Anem a reflexionar. }\end{array}$ \\
\hline & Bon ús de les TIC & $\begin{array}{l}\text { 13. A internet ho trobarem. } \\
\text { 14. Siguem responsables. } \\
\text { 15. Anem a reflexionar. }\end{array}$ \\
\hline \multirow{5}{*}{5 è } & Empatia & $\begin{array}{l}\text { 1. Ponte en mi lugar. } \\
\text { 2. Si tú estás feliz yo estoy feliz. } \\
\text { 3. Vamos a reflexionar. }\end{array}$ \\
\hline & Assertivitat & $\begin{array}{l}\text { 4. Els meus drets. } \\
\text { 5. Conta'm què t'agrada. } \\
\text { 6. Anem a reflexionar. }\end{array}$ \\
\hline & Ciberbullying & $\begin{array}{l}\text { 7. Carlos y el ciberbullying. } \\
\text { 8. ¿Qué necesitas saber? } \\
\text { 9. Vamos a reflexionar. }\end{array}$ \\
\hline & $\begin{array}{l}\text { Prevenció i resolució de } \\
\text { conflictes }\end{array}$ & $\begin{array}{l}\text { 10. Els conflictes. } \\
\text { 11. Solucionem els conflictes. } \\
\text { 12. Anem a reflexionar. }\end{array}$ \\
\hline & Bon ús de les TIC & $\begin{array}{l}\text { 13. Ens relacionem per internet. } \\
\text { 14. Fem un ús saludable. } \\
\text { 15. Anem a reflexionar. }\end{array}$ \\
\hline \multirow{5}{*}{$6 \grave{~}$} & Empatia & $\begin{array}{l}\text { 1. Buscando la reacción adecuada. } \\
\text { 2. ¿Tú cómo lo ves? } \\
\text { 3. Vamos a reflexionar. }\end{array}$ \\
\hline & Assertivitat & $\begin{array}{l}\text { 4. Algunes voltes cal dir que no. } \\
\text { 5. Queixar-se com cal. } \\
\text { 6. Anem a reflexionar. }\end{array}$ \\
\hline & Ciberbullying & $\begin{array}{l}\text { 7. Así sí. } \\
\text { 8. ¿Y ahora qué hago? } \\
\text { 9. Vamos a reflexionar. }\end{array}$ \\
\hline & $\begin{array}{l}\text { Prevenció i resolució de } \\
\text { conflictes }\end{array}$ & $\begin{array}{l}\text { 10. Prenem la decisió. } \\
\text { 11. Jo decideixo per mi. } \\
\text { 12. Anem a reflexionar }\end{array}$ \\
\hline & Bon ús de les TIC & $\begin{array}{l}\text { 13. Compartim informació. } \\
\text { 14. Utilitzem el temps com cal. } \\
\text { 15. Anem a reflexionar. }\end{array}$ \\
\hline
\end{tabular}


Al inici de cada bloc temàtic es presenta una sèrie d'informació on s'especifica el concepte de la temàtica a treballar, els objectius que es persegueixen i una taula resum amb les activitats que inclou el bloc classificades per les assignatures curriculars per a facilitar així la seua inserció.

Respecte al material que es presenta a cada bloc per al professorat inclou, a més de les fitxes dels alumnes, una fitxa tècnica per a cadascuna de les activitats que conté els següents camps informatius:

- Assignatura: indica l'assignatura en la qual cal inserir l'activitat.

- Contingut curricular: matèria de l'assignatura amb la que està relacionada l'activitat.

- Objectius curriculars i objectius de la temàtica: remarca els objectius tant curriculars com de la temàtica que es treballen a l'activitat.

- Metodologia i procediment: determina com i de quina forma portar a cap l'activitat.

- Temporalització: temps aproximat de la realització de l'activitat.

- Orientacions: dades relacionades amb l'activitat que faciliten al professorat l'aplicació de l'activitat, tant a nivell teòric com a pràctic.

- Recursos: materials necessaris per a desenvolupar adequadament l'activitat.

Després de cada un dels blocs temàtics, es troba una fitxa d'avaluació per ser emplenada pel professor/a sobre les activitats corresponents a aquest bloc. Aquesta avaluació serà d'ajuda per millorar el programa.

A més del programa, al final d'aquest document hi ha un apartat amb una fitxa d'avaluació final del programa per a l'alumnat per a aquest curs educatiu, i també un petit document amb recursos extra com guies, enllaços de pàgines web i vídeos amb els que es poden ampliar els coneixements relacionats amb la temàtica principal del programa, el ciberbullying.

\section{procediment per a l'aplicació del programa}

Aquest programa està dissenyat per a ser aplicat als quatre cursos que corresponen al segon i tercer cicle de l'educació primària de forma progressiva al llarg d'aquests cursos, de forma que al finalitzar el tercer cicle els alumnes hagen assolit tots els objectius del programa de prevenció.

L'aplicació del programa correspon als professors tutors, ja que es considera important que es relacioni l'aspecte educatiu d'aquest programa amb la tasca quotidiana que realitzen els alumnes en les diferents assignatures curriculars. Així, per a que l'aplicació sigui adequada i satisfactòria és necessària la constància del professorat al llarg del curs. 


\section{SISÈ DE PRIMÀRIA}

\begin{tabular}{|c|c|c|c|c|}
\hline ASSIGNATURA & $\begin{array}{c}\text { TEMÀTICA } \\
\text { CURRICULAR }\end{array}$ & $\begin{array}{c}\text { TEMÀTICA } \\
\text { TRANSVERSAL }\end{array}$ & \multicolumn{2}{|c|}{$\begin{array}{l}\text { REGISTRE } \\
\text { DE FITXES } \\
\text { FETES }\end{array}$} \\
\hline \multirow{3}{*}{$\begin{array}{c}\text { CIËNCIES DE } \\
\text { LA } \\
\text { NATURALESA }\end{array}$} & L'aparell digestiu & \multirow{3}{*}{ Bon ús de les TIC } & 13 & \\
\hline & La respiració & & 14 & \\
\hline & Anem a reflexionar & & 15 & \\
\hline \multirow{6}{*}{$\begin{array}{l}\text { CIENNCIES } \\
\text { SOCIALS }\end{array}$} & $\begin{array}{c}\text { Intervenció de l'ésser } \\
\text { humà en el medi }\end{array}$ & \multirow{3}{*}{ Assertivitat } & 4 & \\
\hline & Sectors econòmics & & 5 & \\
\hline & Anem a reflexionar & & 6 & \\
\hline & Industrialització & \multirow{3}{*}{$\begin{array}{c}\text { Prevenció i resolució } \\
\text { de conflictes }\end{array}$} & 10 & \\
\hline & Espanya al segle $X X$ & & 11 & \\
\hline & Anem a reflexionar & & 12 & \\
\hline \multirow{6}{*}{$\begin{array}{c}\text { LENGUA } \\
\text { CASTELLANAY } \\
\text { LITERATURA }\end{array}$} & Texto argumentativo & \multirow{3}{*}{ Empatia } & 1 & \\
\hline & El diálogo & & 2 & \\
\hline & Vamos a reflexionar & & 3 & \\
\hline & El eslogan & \multirow{3}{*}{ Ciberbullying } & 7 & \\
\hline & Dramatización & & 8 & \\
\hline & Vamos a reflexionar & & 9 & \\
\hline
\end{tabular}




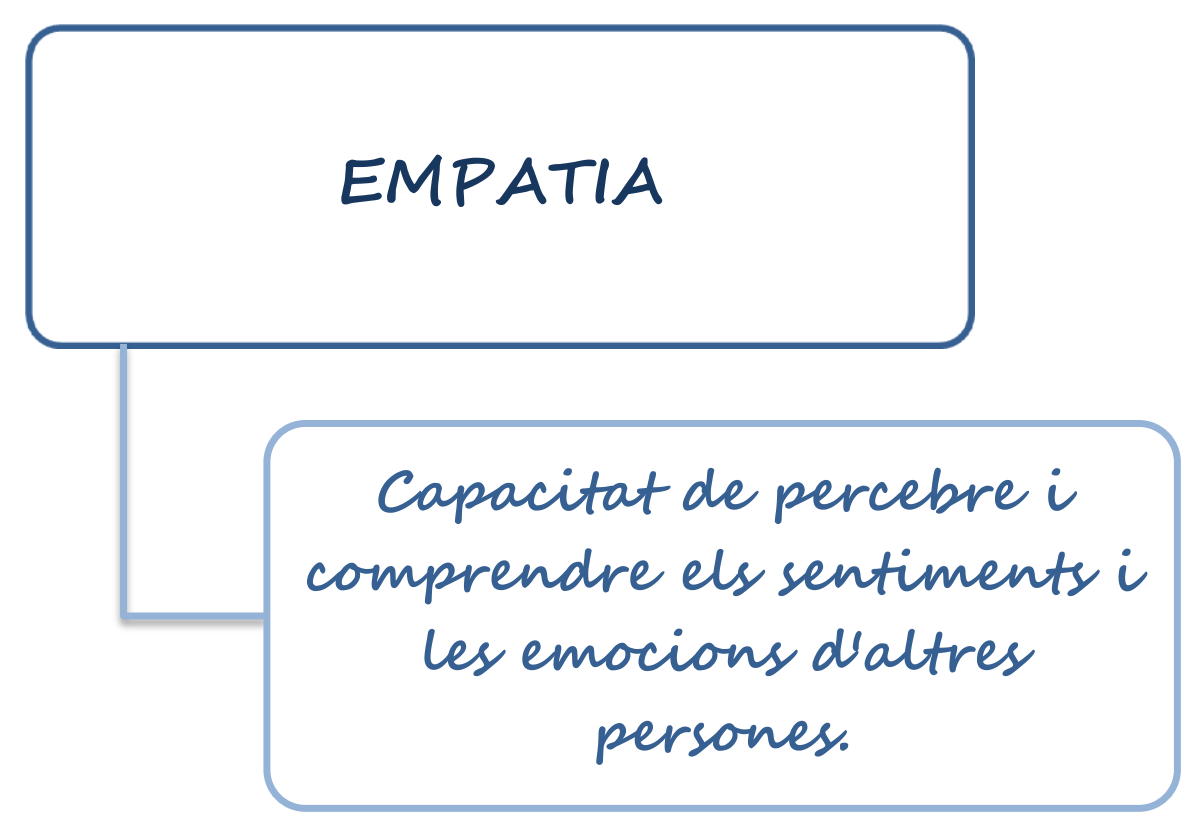

\section{Objectivs.}

$\checkmark$ Tenir competència social per a transmetre als altres que comparteixen les seues emocions i que compten amb la seua ajuda.

$\checkmark$ Prendre una actitud tolerant i positiva amb els altres. 
CURSO: 6ㅇ PRIMARIA

FICHA:1

ASIGNATURA: LENGUA CASTELLANA Y LITERATURA

ACTIVIDAD: BUSCANDO LA REACCIÓN ADECUADA

CONTENIDOS: TEXTO ARGUMENTATIVO Y EMPATIIA

\section{OBJETIVOS CURRICULARES}

- Organizar la información obtenida durante la escucha activa.

- Planificar y redactar un texto expositivo.

\section{OBJETIVOS SOBRE LA TEMÁTICA}

- Idear estilos de aproximación comunicativa.

- Desplegar comportamientos eficaces para la ayuda y apoyo social.

\section{METODOLOGÍA / PROCEDIMIENTO}

Esta actividad engloba contenidos relacionados con el texto argumentativo, así como también contenidos en los que se trabaja la empatía. La actividad que detallamos a continuación la encontramos en la ficha 1 del cuaderno.

1. Introducción actividad 1 grupal:

En nuestro día a día surgen muchas situaciones en las que personas de nuestro alrededor nos cuentan cómo se sienten o lo que les ocurre. Sabemos que es muy importante compartir con los demás nuestros sentimientos y que ellos lo hagan con nosotros, porque eso nos ayuda a tener mejores relaciones. Para compartirlos el mejor modo es aprender a ponerse en su lugar, así sabremos bien cómo se sienten, y una vez lo compartamos hay que saber reaccionar adecuadamente.

2. Realización grupal de la actividad 1:

En la primera actividad nos presentan dos diálogos. Carmen le está contando a su amigo Andrés que hace días que no se habla con una amiga porque discutieron. En cada apartado vemos dos diálogos que se producen teniendo en cuenta esa situación. Vamos a leerlos.

(Los alumnos leen el diálogo en voz alta, elegimos a cuatro alumnos, podemos hacer que cada personaje sea leído por un alumno, que uno haga de Andrés y otro de Carmen.)

¿Habéis notado alguna diferencia entre ambos diálogos? ¿En cuál de los dos creéis que la reacción de Andrés ha sido más adecuada y por qué? Señaladlo en la ficha y lo comentamos.

(Dejamos que los alumnos vayan aportando sus opiniones al respecto.)

Entonces, vemos que Andrés muestra una reacción más adecuada ante Carmen. $Y$ decidme, ¿qué ventajas tiene esa reacción ante la otra reacción que hemos dicho que no es adecuada? Por ejemplo, en ese diálogo Andrés muestra que es consciente de lo mal que lo está pasando Carmen. ¿Qué más ventajas tiene? ¿Y qué desventajas tiene la reacción que consideramos que no es adecuada? 
(Hacemos un listado en la pizarra con todas las ventajas y desventajas que aporten los alumnos.)

3. Introducción grupal y realización individual de la actividad 2:

Hemos visto que reaccionar de un modo adecuado cuando alguien nos expresa sus sentimientos tiene muchas ventajas. Entonces lo que vamos a hacer ahora es redactar cada uno un texto argumentativo en el que vamos a argumentar por qué es tan importante que reaccionemos adecuadamente ante situaciones así. Podemos partir de las ventajas y desventajas que hemos comentado.

(Los alumnos trabajan individualmente redactando el texto de la actividad 2.)

\section{TEMPORALIZACIÓN}

Tiempo aproximado de la actividad 20 minutos:

1. Introducción de la actividad 1: 3 minutos

2. Realización de la actividad 1: 5 minutos

3. Introducción y realización de la segunda actividad: 12 minutos

\section{ORIENTACIONES}

- La finalidad de la primera actividad es que sean conscientes de las reacciones que son adecuadas o inadecuadas cuando dialogamos con un compañero o amigo que nos expresa sus sentimientos. Es muy importante compartir los sentimientos con los demás pero también es muy importante saber reaccionar adecuadamente.

Algunas de las ventajas que podemos citar de la situación 2:

- Es consciente de lo mal que lo está pasando la otra persona.

- Comparte sus sentimientos.

- Le ofrece su ayuda.

Y entre las desventajas de la situación 1 podemos comentar:

- Que no se da cuenta de lo que está pasando la otra persona.

- No comparte sus sentimientos.

- No le ofrece su ayuda.

- Puede que le haga sentir mal.

- La finalidad de la segunda actividad es que redacten un texto argumentativo que les haga reflexionar sobre la importancia de adoptar reacciones adecuadas y de los beneficios que ello conlleva a comparación con la otra reacción.

\section{RECURSOS}

- Ficha número 1 del cuaderno de 60 de primaria. 


\section{BUSCANDO LA REACCIÓN ADECUADA}

\section{Lee y señala en qué situación la reacción de Andrés es adecuada:}

Carmen le está contando a su amigo Andrés que hace días que no se habla con una amiga porque discutieron.

\section{Situación 1:}

Andrés: Vamos Carmen, no creo que sea para tanto. Seguro que encuentras otras amigas.

Carmen: Ya, pero ella es mi amiga y no quiero estar discutida con ella. ¡No entiendo por qué está tan enfadada!

Andrés: Yo no entiendo tu preocupación. ¿Qué ganas poniéndote así? ¡Yo de ti me olvidaría ya de ella!

\section{Situación 2:}

Andrés: No me esperaba nunca que estuvieseis tantos días sin hablaros con lo amigas que sois. Entiendo que te encuentres mal porque estas cosas duelen mucho.

Carmen: Ella es mi amiga. ¡No entiendo por qué está tan enfadada!

Andrés: ¡Cómo te comprendo! Sabes que me tienes para lo que necesites, podemos quedar esta tarde o ir a hablar con tu amiga para tratar de arreglar las cosas.

2. Escribe un texto argumentativo sobre la importancia de reaccionar adecuadamente ante situaciones como la anterior.

RECUERDA...

Cuando alguien comparte sus sentimientos debemos responder adecuadamente, y eso implica: reconocer lo que le pasa a la otra persona, compartir sus sentimientos y ofrecerle nuestra ayuda en la medida de lo posible. 
CURSO: 6 PRIMARIA

FICHA: 2

ASIGNATURA: LENGUA CASTELLANA Y LITERATURA

ACTIVIDAD: ¿TÚ CÓMO LO VES?

CONTENIDOS: DIÁLOGO Y EMPATÍA

\section{OBJETIVOS CURRICULARES}

- Utilizar lenguaje no discriminatorio y respetuoso.

- Escribir un diálogo adaptándose a la situación comunicativa.

\section{OBJETIVOS SOBRE LA TEMÁTICA}

- Ser positivos y tolerantes con los demás.

- Tener competencia social para adoptar ciertas actitudes teniendo en cuenta a los demás.

\section{METODOLOGÍA / PROCEDIMIENTO}

En la presente actividad trabajaremos contenidos relacionados con el diálogo y la empatía. Dicha actividad la podemos encontrar en la ficha 2 del cuaderno.

1. Introducción de la primera actividad en grupo:

Cada uno de nosotros vive las situaciones de un modo diferente y siente diferente. Sabemos que es muy importante compartir las emociones con los demás porque esto favorece y mejora las relaciones, y además esto nos ayudará a aceptar a los demás positivamente algo que es muy importante.

Ahora vamos a realizar la actividad 1 y para ello nos pondremos por parejas, leeremos las frases y anotaremos debajo el sentimiento que nos produce esa frase a nosotros y el de nuestro compañero de pareja. Por ejemplo si nos dice: Tu amigo hace una fiesta de cumpleaños pero no te invita, puede que nosotros sintamos tristeza y nuestro compañero sorpresa. $Y$ es que debemos saber que de la misma manera que sentimos emociones, los demás también las sienten y posiblemente sean vividas por cada uno de manera diferente. Es muy importante saber que aceptar a los demás significa entender los sentimientos ajenos, lo que nos llevará a mantener unas buenas relaciones.

2. Realización de la primera actividad por parejas:

Sabiendo lo importante que es aceptar a los demás, pues esto nos ayuda a tener relaciones positivas, sabemos que el primer paso es entender sus sentimientos, por ello vamos a trabajarlo por parejas y anotándolo y reflexionando sobre ello.

(Los alumnos trabajaran por parejas la primera actividad anotando las respuestas a las preguntas.)

Una vez ya hemos comentado con nuestro compañero qué sentiría él si le ocurriese eso, debemos reflexionar sobre ello y darnos cuenta que todos somos diferentes y sentimos diferentes, y debemos aceptarnos tal y como somos.

3. Introducción en grupo y realización individual de la segunda actividad:

Ahora que ya sabemos lo importante que es comprender y tolerar los sentimientos de los demás, como ya hemos visto en otra actividad, debemos aprender también 


a reaccionar adecuadamente cuando otra persona nos cuenta cómo se siente.
Por eso vamos a escoger una de las tres situaciones que se plantean en la primera
actividad, y nos centramos en cómo nos ha dicho el compañero que se sentirí, y
con esa información vamos a elaborar un diálogo en el que le mostremos a él que
reconocemos lo que le ocurre, compartimos sus sentimientos y le ofrecemos
nuestra ayuda.
(Cada alumno trabaja individualmente elaborando el diálogo a partir de la
información que ha recopilado en la actividad anterior.)
TEMPORALIZACióN
Tiempo aproximado de la actividad 20 minutos:
1. Introducción de la primera actividad: 4 minutos
2. Realización de la actividad $1: 6$ minutos
3. Introducción y realización de la segunda actividad: 10 minutos
- La finalidad de la primera actividad es que los alumnos lleguen a ser conscientes de
que una misma situación puede provocar diferentes emociones, y que es muy
importante comprenderlas. Además, así conseguiremos la aceptación de todos, pues
comprender los sentimientos de los demás nos ayuda a aceptarlos y con ello a
mantener relaciones más positivas.
aprender a reconocer cuál es la actitud que deben adoptar y qué les dían al
compañero si se plantease esa situación conociendo cómo se siente, es deciron
aprender a adoptar una actitud adecuada teniendo presentes las emociones de los
demás.




\section{¿TÚ CÓMO LO VES?}

1. Lee las siguientes frases e indica cómo te sentirías tú si te ocurriese esa situación. Pregúntale a tu compañero cómo se sentiría él y anótalo también.

- Tu amigo hace una fiesta de cumpleaños pero no te invita.

- ¿Cómo te sientes tú?

- ¿Cómo se siente tu compañero?

- Quedas para ir a patinar con un amigo pero no acude a la cita.

- ¿Cómo te sientes tú?

- ¿Cómo se siente tu compañero?

- Un compañero de clase te coge siempre el material.

- ¿Cómo te sientes tú?

- ¿Cómo se siente tu compañero?

2. Escoge una de las situaciones anteriores y escribe un diálogo teniendo en cuenta el sentimiento de la otra persona y lo importante que es compartir los sentimientos y ofrecer ayuda en situaciones como las que hemos planteado en la actividad anterior.

RECUERDA...

Aceptar a los demás significa entender los sentimientos ajenos, lo que nos llevará a mantener unas buenas relaciones. 


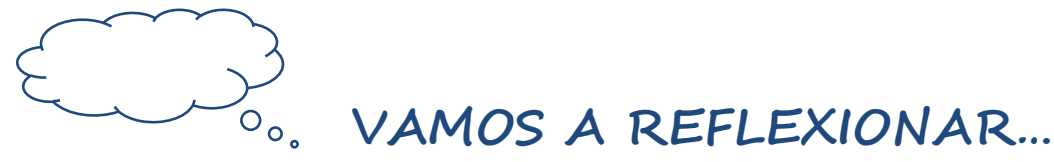

Después de haber realizado las actividades anteriores, vamos a reflexionar sobre los aspectos que hemos trabajado. Para ello, contesta las siguientes cuestiones:

\section{Lee y señala cuál sería la reacción más adecuada de Sofía:}

Marcos le cuenta a Sofía que está muy contento porque su amigo Luís le ha regalado una entrada para ir a ver un partido de fútbol.

¡Vaya rollo! Seguro que ese partido no vale nada y por eso te ha regalado la entrada.

$\square$ iQué bien! Entiendo que estés tan contento, con lo que te gusta a ti el fútbol seguro que lo pasas genial.

2. ¿Qué debemos tener en cuenta a la hora de reaccionar cuando un amigo o compañero nos expresa sus sentimientos? Razona tu respuesta. 
FITXA D'AVALUACIÓ PER AL PROFESSOR/A DE LES ACTIVITATS DEL BLOC D'EMPATIA

1. Com t'ha resultat dur a terme les tasques segons les indicacions exposades en les fitxes? Molt difícil $\square \quad$ Difícil $\square \quad$ Normal $\square \quad$ Fàcil $\square \quad$ Molt fàcil $\square$

2. Creus que es compleix l'objectiu proposat? Sí $\square \quad$ No $\square$

3. Has introduït les activitats al contingut curricular assenyalat o en algun altre?

T emes indicats $\square \quad$ Altres $\square$ (indica quins:

4. Has utilitzat altres recursos a part dels que apareixen a la fitxa? Sí $\square \quad$ No $\square$

5. ¿Faries alguna modificació de millora en les fitxes per assolir els objectius de manera més òptima? Sí $\square \quad$ No $\square$

(en cas afirmatiu, indica quina:

6. Com s'han sentit els alumnes en realitzar les activitats? (motivació, implicació, interacció amb altres, ....)

7. Hi ha algun aspecte que consideres oportú comenta per a la millora del programa? 


\section{ASSERTIVITAT}

Capacitat d'expressar els propis

sentiments, necessitats $i$ drets al mateix temps que es respecten els sentiments, drets $i$ necessitats dels altres.

\section{Objectivs.}

$\checkmark$ Saber dir que no en el moment adequat.

$\checkmark$ Tenir recursos per a queixar-se adequadament i acceptar les queixes que són justes. 
CURS: 6è PRIMÀRIA

FITXA: 4

ASSIGNATURA: CIÈNCIES SOCIALS

ACTIVITAT: ALGUNES VOLTES CAL DIR NO

CONTINGUTS: INTERVENCIÓ ÉSSER HUMÀ EN EL MEDI I ASSERTIVITAT

\section{OBJECTIUS CURRICULARS}

- Reconèixer la necessitat de protegir el medi ambient.

- Ser conscient del consum excessiu de recursos naturals i del reciclatge de residus.

\section{OBJECTIUS SOBRE LA TEMÀTICA}

- Identificar les situacions en les que hem de dir no.

- Aprendre a dir que no quan convé.

\section{METODOLOGIA / PROCEDIMENT}

En aquesta activitat treballem diferents continguts relacionats amb la intervenció de l'ésser humà en el medi i també continguts on treballarem l'assertivitat. La fitxa on trobarem aquesta activitat és la 4.

1. Introducció en grup a l'activitat:

Anem a realitzar una activitat en la que hem de posar en pràctica tot allò que hem après sobre la intervenció de l'ésser humà en el medi. Què em sabríeu dir del consum dels recursos naturals i del reciclatge dels residus domèstics? Com d'important és per a vosaltres i què podríem fer per a protegir el medi ambient?

(Els alumnes comenten i reflexionen sobre la importància de protegir el medi ambient i sobre com nosaltres devem actuar per a tractar-lo i protegir-lo com cal. Quines accions són adequades i quines inadequades.)

2. Reflexió inicial en grup de l'activitat:

Doncs bé, ja sabem quant d'important és tenir cura del medi ambient, i la importància que tenen les accions que nosaltres realitzem per protegir el medi ambient el millor possible.

Ara anem a llegir les situacions que ens plantegen en aquesta activitat, dos situacions relacionades amb el medi ambient. Teniu que imaginar que són dos situacions que ens ocorren a nosaltres $i$ tenim que pensar com respondriem a aquestes situacions.

(Elegim alguns alumnes que lliguen la primera conversa que presentem en l'activitat.)

Què us ha paregut el que ens diu aquesta persona? Què li respondríeu? Esteu d'acord en actuar com ell us diu?

(Els alumnes opinen sobre la situació que els presenten aportant el seu punt de vista.)

Haureu vist que la petició que ens fan, de complir-la estariem tractant malament el medi ambient doncs no és correcte utilitzar un be tant apreciat com el paper 
d'aquesta forma, ja que estem fem que talen més arbres i estem utilitzant recursos naturals innecessàriament. Quan ens ocorren coses com aquestes en les que algú ens demana que fem una cosa que nosaltres no considerem adequada, hem d'aprendre a rebutjar fer el que ens diuen, hem de dir que no ho volem fer, perquè si aprenem a dir que no amb educació aprendrem a dominar la situació tal i com nosaltres volem i evitarem actuar d'una forma en la que no estem d'acord. I com podem dir que no a una petició així però amb educació?

(Els alumnes aporten opcions de resposta. Trobarem algunes idees a l'apartat d'orientacions.)

3. Realització individual de l'activitat:

Aleshores, pensant ben bé com actuaria, si ens trobarem en aquesta situació, completeu el diàleg amb la resposta que li donarieu a la persona que us digués això, i farem el mateix amb la segona situació que ens plantegen.

(Els alumnes realitzaran individualment l'activitat completant els diàlegs de les dos situacions que els presentem.)

4. Reflexió final en grup de l'activitat:

Hem vist en aquesta activitat com d'important és aprendre a dir que no. Moltes voltes ens trobem en situacions en les que altres persones es volen aprofitar de nosaltres $i$ hem de saber dir no. Segurament vos resultarà complicat, però cal dir que no quan no estem d'acord i si diem que sí després ens sentirem malament, els altres estaran contínuament demanant-te coses inadequades i ens podem posar en molts problemes. Per això, quan tinguem clar que no volem fer alguna cosa, cal expressa-ho amb claredat, dir no amb educació i així aconseguirem sentir-nos bé amb nosaltres mateix $i$ els altres ens coneixeran tal $i$ com som.

\section{TEMPORALITZACIÓ}

Temps aproximat de l'activitat 20 minuts:

1. Introducció a l'activitat: 5 minuts

2. Reflexió inicial: 5 minuts

3. Realització de l'activitat: 5 minuts

4. Reflexió final: 5 minuts

\section{ORIENTACIONS}

- La primera part introductòria de l'activitat té com a finalitat que els alumnes reconeguem la importància de protegir el medi ambient, i siguin conscients que ells amb les seues accions poden ajudar a cuidar i millorar-lo. Hem de tenir cura del consum de recursos naturals i també quant d'important és el reciclatge dels residus domèstics.

- És important que els alumnes s'adonen que en aquestes situacions que els plantegem no es respecta el medi ambient i que si els ocorregués una situació així deurien rebutjar actuar tal i com els diuen, doncs de fer-ho no estarien protegint el medi ambient com cal. 
- Quan no s'està d'acord amb una petició que ens fan cal rebutjar-la adequadament, que implica fer-ho amb educació i amb claredat. Expressions com: no estic segur, igual bé, doncs no ho sé, etc. no serien correctes doncs no ho transmetem amb claredat i ens faran passar una mala estona. Algunes expressions correctes serien: ho sento però no ho puc fer, entenc la teua posició però jo no la compartisc, no me pareix una bona idea, no em pareix just, etc.

- Els alumnes tenen que aprendre a diferenciar aquelles situacions en les que és necessari donar un no com a resposta, on es planteja una situació en la qual la persona no està disposada a actuar com li ho indiquen, doncs considera que no és apropiat. Normalment ens consta dir no en certes situacions, però han d'aprendre a no sentir-se malament ni avergonyits, sinó deuen mostrar el que pensen i actuar com volen sense sentir que s'aprofiten d'ells. Pel contrari, si accepten fer alguna cosa que no volen es sentiran malament $\mathrm{i}$ es poden posar en problemes per actuar inadequadament.

\section{RECURSOS}

- Fitxa número 4 del quadern de 6è de primària. 


\section{ALGUNES VOLTES CAL DIR NO}

\section{Respon a aquestes propostes.}

\section{Situació 1:}

Anem a empaperar tota la paret amb fulls blancs per escriure un missatge per l'aniversari de Carme.

Pots anar a comprar cinc paquets de folis blancs a la papereria?
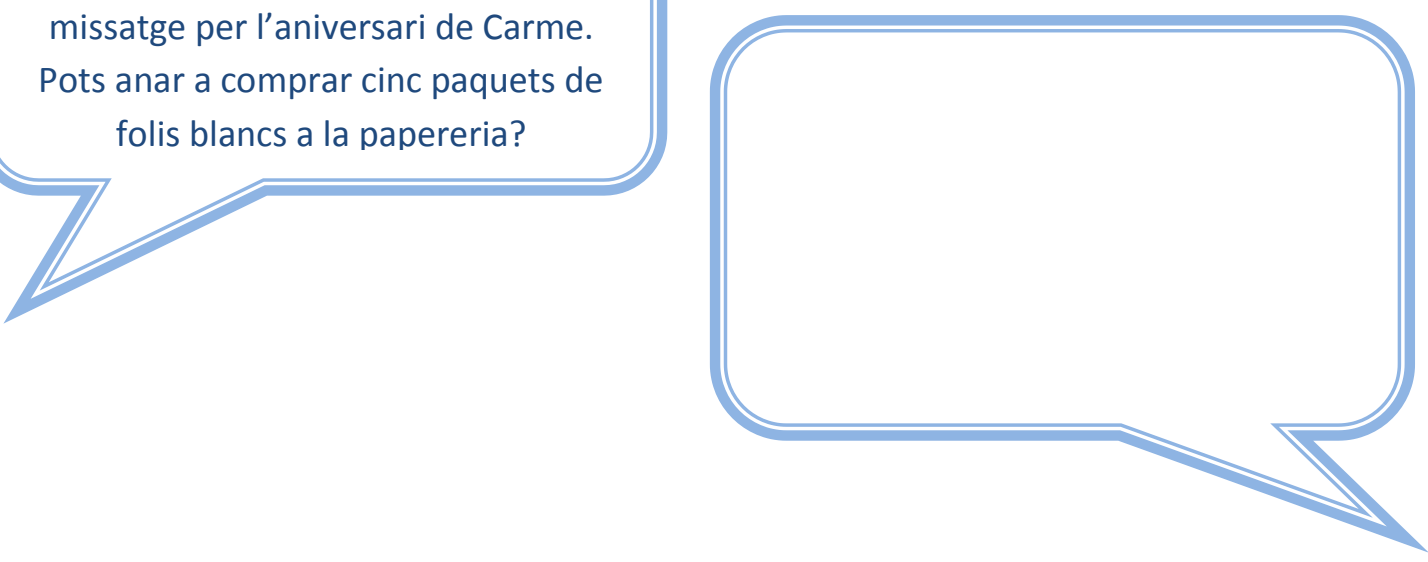

\section{Situació 2:}
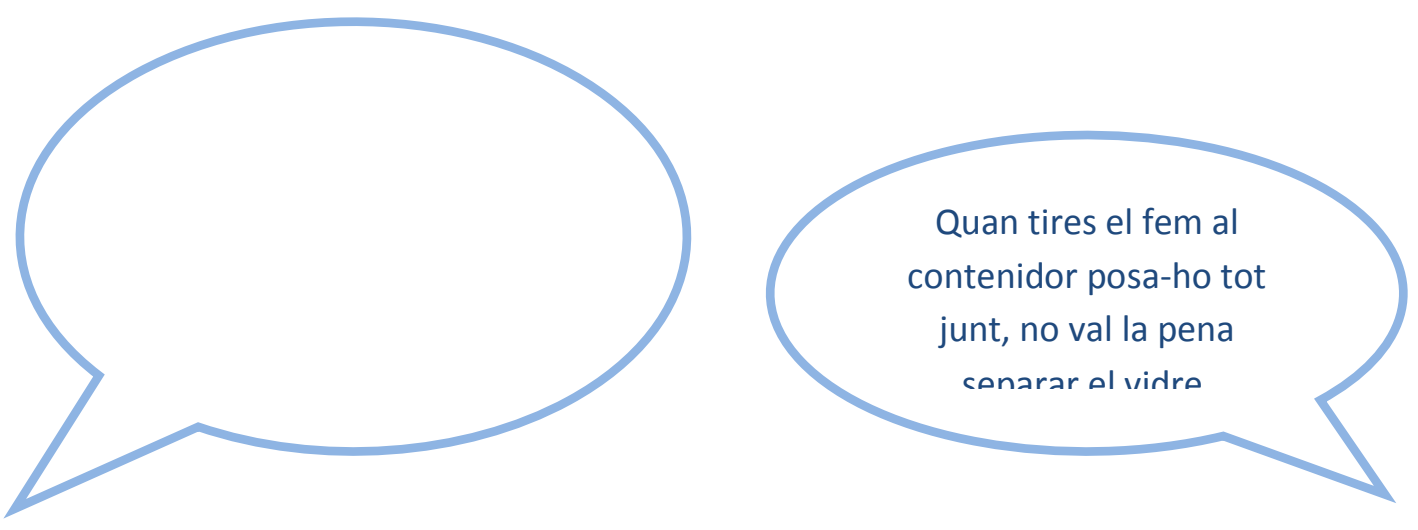

RECORDA...

Moltes voltes ens consta dir no en certes situacions, però no ens tenim que sentir malament ni avergonyits per fer-ho, devem mostrar el que pensem i actuar com volem. Si accepten fer alguna cosa que no volem, ens sentirem malament i ens podem posar en problemes per actuar inadequadament. 
CURS: 5è PRIMÀRIA

FITXA: 5

ASSIGNATURA: CIÈNCIES SOCIALS

ACTIVITAT:QUEIXAR-SE COM CAL

CONTINGUTS: SECTORS ECONÒMICS I ASSERTIVITAT

\section{OBJECTIUS CURRICULARS}

- Classificar oficis en funció del sector econòmic al que pertanyen.

- Interessar-se pel concepte de treball i tot el que comporta.

\section{OBJECTIUS SOBRE LA TEMÀTICA}

- Expressar una queixa adequadament.

- Acceptar una queixa quan és justa.

\section{METODOLOGIA / PROCEDIMENT}

En aquesta activitat treballarem continguts relacionats amb el treball i també amb I'assertivitat. La fitxa en la qual trobarem aquesta activitat és la 5.

1. Introducció en grup a l'activitat:

Hem estat treballant què són els sectors econòmics i el treball. Ja sabem que el treball és tota aquella activitat on una persona realitza una tasca determinada a canvi d'una remuneració econòmica, a canvi de diners. Coneixem molts tipus de treball en diferents sectors econòmics com són el primari, secundari i terciari. Quins oficis coneixeu de cadascun d'aquests sectors?

(Donem la paraula als alumnes per a que vaguen dient treballs que pertanyen a cada sector.)

Doncs bé, tot treball com hem comentat implica realitzar una tasca que és remunerada. Quasi sempre quan una persona treballa està en contacte amb altres persones, ja siguin companys, clients, cap de l'empresa, etc.

En el nostre dia a dia en general, sabem com d'important és tenir una bona relació amb la gent, i al nostre lloc de treball també ho és doncs és un dels llocs on passem més hores del dia. Per tant, viurem allí coses bones i no tan bones, coses que ens agraden $i$ d'altres que no ens agraden, $i$ hem d'aprendre a viure totes elles de la millor forma possible.

2. Realització en grup de la primera activitat:

Ara ens anem a fixar en dos situacions que ens presenten a la fitxa. En cadascuna d'elles representen una situació en un lloc de treball, on un cambrer està servint a uns clients $i$ un d'ells es queixa perquè li ha donat malament el canvi. I és que moltes voltes al treball ens trobarem en situacions en la que alguna persona es queixa d'alguna cosa o nosaltres mateixos ens tindrem que queixar. La diferència entre els dos diàlegs és que en cada situació la queixa que transmet el client és diferent. Fixem-nos bé! Algú em pot llegir en veu alta els dos diàlegs?

(Els alumnes lliguen en veu alta els dos diàlegs.)

A quin sector pertany el ofici de cambrer? Què ocorre als diàlegs? Són iguals o hi ha 
diferència entre ells? Podríem dir que una de les dos queixes és adequada i l'altra inadequada?

(Escoltem les opinions dels alumnes i debatem tots junts en quin dels dos diàlegs es produeix una queixa inadequada.)

3. Reflexió en grup de la primera activitat:

I si ens fixem en la queixa adequada, sabríeu dir-me si considereu que és justa $i$ perquè?

(Valorem junts si en aquest cas que es presenta seria just o no queixar-se. En aquest cas seria just queixar-se doncs aquesta persona té dret a que li retornen bé el canvi i queixar-se és una forma d'expressar als altres que hi ha alguna cosa que nos ens agrada i que està perjudicant els nostres drets.)

4. Realització en grup de la segona activitat:

Aleshores, ara ja hem vist que podem dir que hi ha maneres adequades $i$ inadequades de queixar-se, i moltes voltes les queixes són justes. Però digueu-me, penseu que és convenient queixar-se? Per què ens hem de queixar o per què no? Digueu-me avantatges o inconvenients de queixar-se, per exemple si no expresso la meua queixa segurament no em sentiré bé amb mi mateixa.

(Anem anotant a la pissarra els avantatges i inconvenients d'expressar les queixes.)

5. Reflexió final de l'activitat:

Realitzant aquesta activitat ens hem adonat que hi ha diferents formes de queixarnos, unes són adequades $i$ altres inadequades, $i$ evidentment la forma correcta de queixar-se és la que implica fer-ho educadament, utilitzant un vocabulari adequat, to de veu correcte... I quan alguna persona es queixa, devem aprendre a valorar si la queixa és justa o no. Per exemple, en el cas que ens presentaven és just que aquesta persona es queixo doncs el cambrer no li ha tornat bé el canvi i ella té dret a que li tornen els diners bé.

A més, sabem que queixar-se és una forma d'expressar el que sentim que utilitzem moltes voltes i necessitem saber perquè ho hem de fer... Ja hem vist els avantatges que suposa queixar-se, $i$ és que si ho fem aconseguirem sentir-nos millor amb nosaltres mateixos, expressar als altres com ens sentim, que els altres sàpiguen com ens sentim i que sàpiguen que estan fent malament. No ens oblidem que saber expressar adequadament les nostres queixes és molt important, i que quan algú es queixa justament, cal acceptar la queixa i utilitzar-la per a tractar de millorar els nostres actes.

\section{TEMPORALITZACIÓ}

Temps aproximat de l'activitat 20 minuts:

1. Introducció a l'activitat: 3 minuts

2. Realització de la primera activitat: 4 minuts

3. Reflexió primera activitat: 4 minuts

4. Realització de la segona activitat: 5 minuts 
5. Reflexió final: 4 minuts

\section{ORIENTACIONS}

- Alguns dels oficis dels tres sectors són:

Primari: agricultor, ramader, pescador, etc.

Secundari: electricista, obrer, fontaner, fuster, etc.

Terciari: mestre, metge, infermer, secretari, conductor, etc.

- Els dos diàlegs que es presenten són diferents doncs la queixa es transmet de forma diferent. En el primer diàleg la queixa és expressada inadequadament doncs la forma de comunicar-la no és l'adient: vocabulari inadequat, s'intueix un to de veu alt, i les formes en general no serien les correctes. Pel contrari, en el segon diàleg la queixa és més adequada, ja que el client ho expressa amb educació i amb un vocabulari adequat.

- Els avantatges que podem comentar són: que el que es queixa es sent millor, transmet als altres com es sent, els altres poden conèixer millor a eixa persona, pot ajudar a algú amb la meua queixa, ajudar a resoldre un problema, etc. Els inconvenients podrien ser que si no ens queixem pot ser ens posem més nerviosos, no transmeten a l'altra persona el que estem sentint, etc.

- En aquesta part el que volem és que els alumnes vegin que queixar-se està bé sempre i quan sigui justa, es a dir, és bo queixar-se quan tractem d'expressar el que sentim d'una forma adequada $\mathrm{i}$ amb un argument coherent, perquè hi ha alguna cosa que no ens agrada $\mathrm{i}$ aquesta ens està perjudicant els nostres drets.

- La finalitat d'aquesta activitat és que els alumnes se n'adonen que saber expressar adequadament una queixa és una habilitat social molt important, ja que ens permet sentir-nos millor amb nosaltres mateixos, expressar al altres com ens sentim, que els altres sàpiguen com ens sentim i que sàpiguen que estan fent malament. I també és important que nosaltres reconeguem quan una queixa és justa i que ens permeti veure que acció devem canviar ja que està perjudicant a altres.

\section{RECURSOS}

- Fitxa número 5 del quadern de 6 è de primària. 


\section{QUEIXAR-SE COM CAL}

1. Llegeix els següents diàlegs i senyala si la queixa és adequada o inadequada.

Carles, el cambrer del bar, serveix a una taula el menjar i a l'hora de pagar el client s'adona que li ha cobrat malament.

Disculpa, crec que ha hagut un error amb el canvi. El dinar eren 12 euros i t'he donat 15, per tant em faltarien 3 euros. Si ets tant amable de comprovar-ho...
Adequat

Inadequat
Escolta, m'has tornat malament el canvi, em falten 3 euros! Eres un despistat, et deuries fixar més!

2. Digues quins avantatges i inconvenients té expressar una queixa.

Avantatges

Adequat

Inadequat
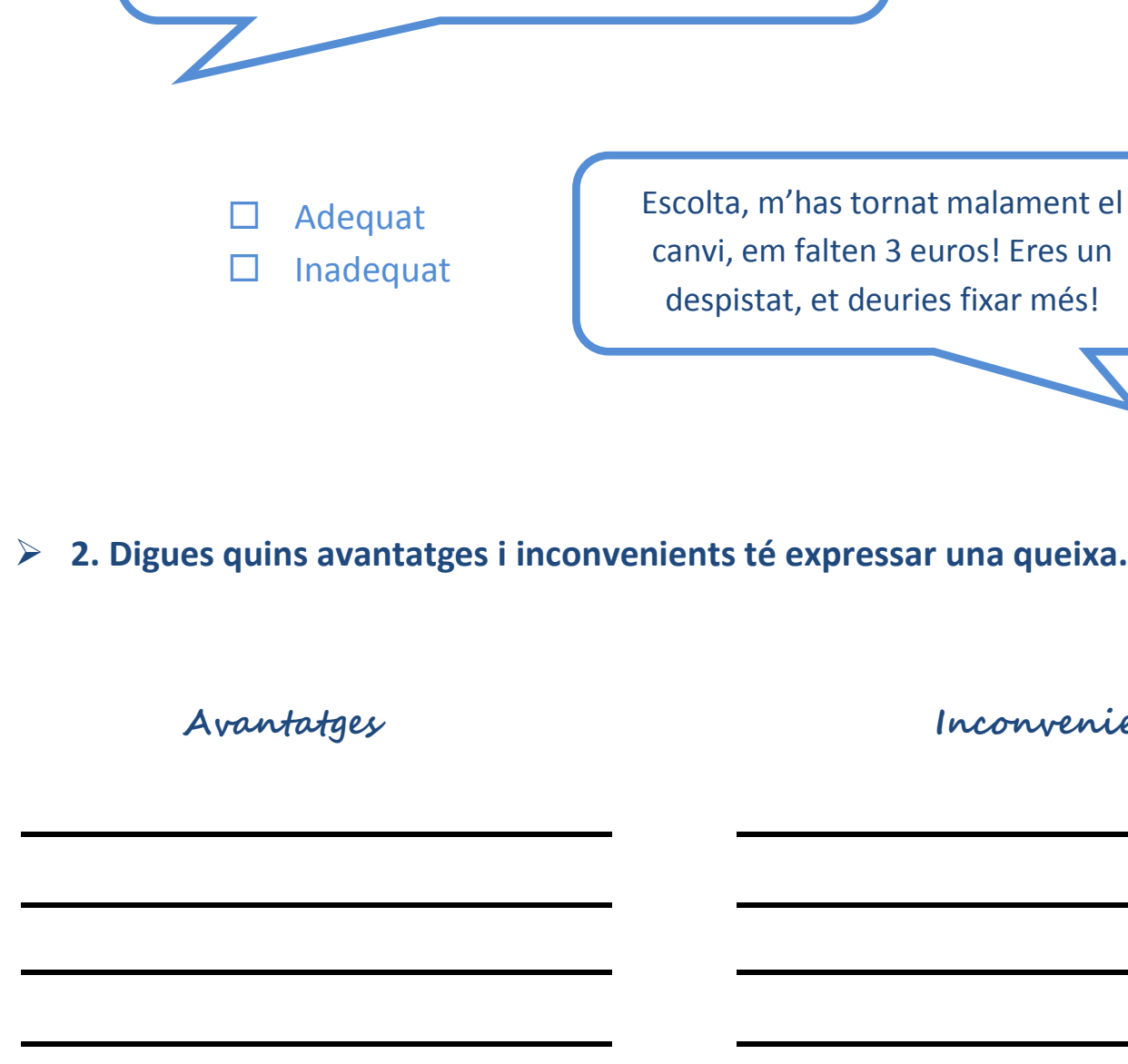

Inconvenients

RECORDA...

Saber expressar adequadament les nostres queixes és molt important, es tracta d'expressar alguna cosa que no ens agrada i que ens perjudica amb educació $i$ bones formes. Quan una queixa és justa, cal acceptar-la i utilitzar-la per tractar de millorar els nostres actes. 


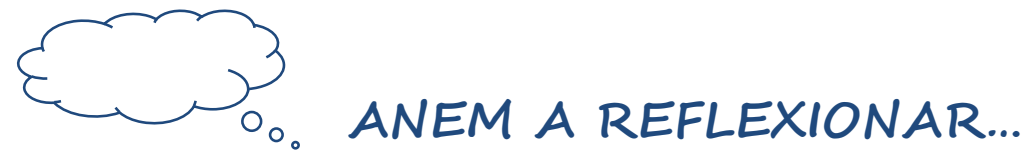

Després d'haver realitzat les activitats anteriors, reflexionarem sobre els aspectes que hem treballat. Per a això, contesta les següents qüestions:

1. Què ens pot ocórrer si no fem alguna cosa que no volem fer però no diem que NO? Senyala la resposta correcta.

Estarem contents de fer-ho.

Ens sentirem malament per fer una cosa que no volem fer.

Es bo que sempre diguem sí a tot el que ens demanen.

2. Senyala si aquesta queixa és justa o no ho és.

$\square$ sí $\quad \square \quad$ NO

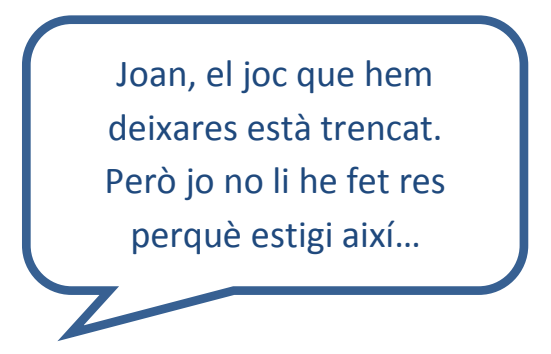

Deuries haver tingut més cura, quan et vaig deixar

el joc estava bé. No et podré deixar més coses meıses una altra voltal

\section{Quan ens queixem adequadament, com ho devem expressar?}


FITXA D'AVALUACIÓ PER AL PROFESSOR/A DE LES ACTIVITATS DEL BLOC D'ASSERTIVITAT

1. Com t'ha resultat dur a terme les tasques segons les indicacions exposades en les fitxes? Molt difícil $\square \quad$ Difícil $\square \quad$ Normal $\square \quad$ Fàcil $\square \quad$ Molt fàcil $\square$

2. Creus que es compleix l'objectiu proposat? Sí $\square \quad$ No $\square$

3. Has introduït les activitats al contingut curricular assenyalat o en algun altre?

T emes indicats $\square \quad$ Altres $\square$ (indica quins:

4. Has utilitzat altres recursos a part dels que apareixen a la fitxa? Sí $\square \quad$ No $\square$

5. ¿Faries alguna modificació de millora en les fitxes per assolir els objectius de manera més òptima? Sí $\square \quad$ No $\square$

(en cas afirmatiu, indica quina:

6. Com s'han sentit els alumnes en realitzar les activitats? (motivació, implicació, interacció amb altres, ....)

7. Hi ha algun aspecte que consideres oportú comenta per a la millora del programa? 


\section{CIBERBULLYING}

Quan un xiquet $\sigma$ adolescent és turmentat, amenaçat, assetjat, humiliat, molestat d'una manera o una altra, per un altre nen o adolescent mitjançant l'ús d'nternet, tecnologies interactives $i$ digitals o telèfon mòbil.

\section{Objectins.}

$\checkmark$ Conèixer pautes de detecció i d'evitació de situacions de ciberbullying.

$\checkmark$ Aprendre a actuar i afrontar situacions de ciberbullying. 
CURSO: 6ㅇ PRIMARIA

FICHA: 7

ASIGNATURA: LENGUA CASTELLANA Y LITERATURA

ACTIVIDAD: ASÍ SÍ

CONTENIDOS: ESLOGAN Y CIBERBULLYING

\section{OBJETIVOS CURRICULARES}

- Favorecer el debate entre los alumnos sobre temas escolares y sociales.

- Planificar y escribir textos publicitarios.

\section{OBJETIVOS SOBRE LA TEMÁTICA}

- Analizar e identificar situaciones en las que el uso de las TICS puede ser peligroso.

- Conocer las pautas de evitación del ciberbullying.

\section{METODOLOGÍA / PROCEDIMIENTO}

En esta actividad trabajaremos contenidos relacionados con el ciberbullying así como también la escritura de un eslogan publicitario. Para trabajar dichos contenidos hemos elaborado la actividad 7.

1. Introducción en grupo a la actividad:

Vamos a realizar una actividad en la que trabajaremos cómo saber qué acciones son ciberbullying y cómo evitarlo. Pero antes vamos a ver qué es el ciberbullying. ¿Alguien sabría decirme qué es el ciberbullying?

(Hacemos la pregunta al grupo clase de modo que con las respuestas de los alumnos construimos el concepto. Dirigiremos sus respuestas hacía la definición de ciberbullying que encontraremos en el apartado de orientaciones.)

\section{Realización en grupo e individual de la primera actividad:}

De acuerdo, entonces ahora que ya sabemos qué es el ciberbullying vamos a ver cómo creéis vosotros que podemos evitar sufrir ciberbullying, es decir, qué acciones debemos realizar para disminuir el riesgo de sufrir o de ejercer ciberbullying. Por ejemplo, un modo de evitar el ciberbullying es hacer un buen uso de las nuevas tecnologías. ¿Qué otras acciones creéis que ayudarían a evitar el ciberbullying?

(Los alumnos responden a la pregunta planteando acciones que serían buenas realizar para evitar que se produzca ciberbullying. Hacemos en la pizarra un listado con estas acciones que los alumnos nombran. En el apartado de orientaciones encontramos posibles respuestas.)

Todas estas acciones que hemos anotado a la pizarra son acciones que debemos llevar a cabo todos nosotros para evitar tener problemas con el uso de las nuevas tecnologías: móvil, tableta, ordenador, etc. Anotad en la ficha tres acciones de las que hemos anotado en la pizarra, aquellas que consideréis más importantes.

3. Realización en grupos de cuatro de la segunda actividad:

Ahora que ya tenemos anotadas las acciones que debemos tener en cuenta para evitar tener problemas con los otros a través de las nuevas tecnologías, y que ya 
conocemos bien qué es el ciberbullying, vamos a realizar una actividad por grupos de cuatro.

(Dividimos la clase en grupos de cuatro alumnos.)

Tal y como estamos en grupo vamos a realizar cada grupo un eslogan utilizando la información sobre el ciberbullying que hemos trabajado en la anterior actividad. Sabemos que un eslogan es una frase corta y original utilizada en publicidad para llamar la atención y que recordemos ese producto.

Por grupos vamos a pensar un eslogan para una campaña publicitaria de prevención del ciberbullying, en el que queremos transmitir lo importante que es actuar adecuadamente para evitarlo. Para ello fijaros bien en las frases que hemos trabajado y recordad que un eslogan debe ser corto, claro, original y debe reflejar bien la idea que queremos transmitir. Un ejemplo sería: Cuando utilices internet, piensa bien antes de escribir. iNo al ciberbullying!

(Dejamos a los alumnos trabajar en grupo escribiendo el eslogan.)

\section{Reflexión final en grupo:}

Vamos a leer en voz alta los eslóganes...

(Cada grupo nombra a un miembro del grupo que será el encargado de leer el eslogan de grupo a la clase.)

Perfecto, pues como habéis escrito en los eslóganes, todo ello son acciones que debemos realizar nosotros y ser conscientes de que el ciberbullying es un problema muy grave, pues afecta mucho a la persona que lo sufre, y que no se trata de bromas ni algo sin importancia sino que puede tener consecuencias muy graves para quien lo sufre y consecuencias legales también graves para quien lo realiza. Por eso es muy importante que nos concienciemos sobre ello y que aprendamos a actuar adecuadamente cuando hacemos uso de las nuevas tecnologías pues así evitaremos tener problemas tan graves como el ciberbullying.

\section{TEMPORALIZACIÓN}

Tiempo aproximado de la actividad 20 minutos:

1. Introducción a la actividad: 5 minutos

2. Realización de la primera actividad: 5 minutos.

3. Realización de la segunda actividad: 5 minutos

4. Reflexión final: 5 minutos.

\section{ORIENTACIONES}

- Definición de ciberbullying. El ciberbullying es cuando un niño o adolescente es amenazado, acosado, humillado, molestado de una manera u otra reiteradamente, por otro niño o adolescente mediante el uso de Internet, tecnologías interactivas y digitales o teléfono móvil.

- Podemos evitar situaciones de ciberbullying: 
- Minimizar el uso de las nuevas tecnologías.

- Hacer un buen uso de las nuevas tecnologías.

- No publicar información personal que después puedan utilizar en tu contra.

- Revisar bien las fotos o videos que se comparten pues pueden conllevar comentarios indeseados por parte de otras personas.

- Hacer un buen uso de las redes sociales (no agregar a contactos desconocidos, utilizar nicks, guardar bien las contraseñas, no publicar datos personales, no enviar fotos o imágenes a gente desconocida, etc.)

- Contar hasta 10 antes de responder a un mensaje que te moleste o te afecte.

- Lo que no dirías a la cara, no lo digas por internet.

\section{RECURSOS}

- Ficha número 7 del cuaderno de 6ㅇ de primaria. 


\section{Así sí}

1. Escribe tres acciones que es importante realizar para evitar el ciberbullying.

2. Escribe un eslogan para una campaña publicitaria para la prevención del ciberbullying.

RECUERDA...

Es muy importante que aprendamos a utilizar adecuadamente las nuevas tecnologías, no publicar información personal en las redes sociales, compartir fotos e imágenes solo con personas conocidas, no responder a mensajes ofensivos, etc. pues así evitaremos tener problemas tan graves como el ciberbullying. 
CURSO: 6 PRIMARIA

FICHA: 8

ASIGNATURA: LENGUA CASTELLANA Y LITERATURA

ACTIVIDAD: ¿Y AHORA QUÉ HAGO?

CONTENIDOS: DRAMATIZACIÓN Y CIBERBULLYING

\section{OBJETIVOS CURRICULARES}

- Fomentar la comunicación grupal favoreciendo el desarrollo de hábitos de escucha activa.

- Representar los diferentes papeles mediante la construcción de personajes acordes a esos roles.

\section{OBJETIVOS SOBRE LA TEMÁTICA}

- Identificar pautas de afrontamiento en situaciones de ciberbullying.

- Potenciar la capacidad de ponerse en el lugar de los diferentes roles existentes en una situación de acoso.

\section{METODOLOGÍA / PROCEDIMIENTO}

En esta actividad vamos a trabajar contenidos relacionados con el ciberbullying y también contenidos relacionados con la dramatización de situaciones sociales y escolares cercanas. Para ello hemos elaborado la ficha 8 del cuaderno.

1. Introducción grupal a la actividad:

Vamos a realizar una actividad en la que vamos a seguir trabajando el ciberbullying. ¿Os acordáis el otro día lo que decíamos del ciberbullying? Vimos lo que es el ciberbullying y también trabajamos lo importante que es utilizar bien las nuevas tecnologías para prevenir el ciberbullying, pues se trata de un problema que tiene consecuencias muy graves, tanto para el que lo sufre que es la víctima como para quien lo realiza que es el agresor.

2. Realización grupal de la primera actividad:

De acuerdo, como ya sabemos qué acciones podemos hacer para evitar el ciberbullying, ahora lo que vamos a hacer es ver qué podemos hacer si nosotros o alguien que conocemos ya está sufriendo ciberbullying. Para ello vamos a leer un texto de una historia de un niño llamado Juan que sufría ciberbullying.

(Leemos el texto en voz alta.)

Como os habréis dado cuenta, Juan ha sufrido mucho y las consecuencias a las que le ha llevado sufrir ciberbullying han sido muy graves para él, y además todas las personas de su alrededor han sufrido mucho...

Decidme, ¿cómo creéis que se podría afrontar una situación así? Es decir, ¿qué podría haber hecho Juan o la gente de su entorno para actuar ante una situación como la que él está viviendo?

(Los alumnos aportan sus ideas mediante la técnica del torbellino de ideas. Anotamos en la pizarra sus aportaciones respecto a los modos de afrontamiento. En el apartado de orientaciones encontramos información respecto a acciones de afrontamiento que se pueden plantear y que sería interesante que conocieran.) 


\section{Realización en grupos de tres de la segunda actividad:}

Cómo habéis visto, ante situaciones así podemos actuar de diferentes modos, según la gravedad de la situación actuaremos de un modo u otro.

Ahora nos pondremos en grupos de tres, y seleccionaréis en cada grupo el modo de afrontamiento que creéis que sería más eficaz o que consideráis más importante. Una vez lo tengáis vais a representar la situación donde uno hará el papel de la víctima, otra del acosador y otra de una persona que conoce la situación, que se llama el observador.

(Dividimos la clase en grupos de tres. Cada grupo irá trabajando en la elección del modo de afrontamiento que consideran más eficaz de los comentados en el grupoclase y posteriormente escenificaran la situación. Mientras el maestro pasará por los grupos para ver las representaciones que van haciendo.)

4. Reflexión final en grupo:

En esta actividad os habréis dado cuenta de lo importante que es conocer cómo actuar cuando alguien sufre ciberbullying. Todos estos modos de actuar los debéis recordar bien, y ante cualquier dato que os haga ver que estáis sufriendo acoso o que algún compañero lo está sufriendo; debéis avisar a un adulto, no contestar a las provocaciones, dejar de utilizar los dispositivos con los que os molestan, guardar bien todos los mensajes y avisar a la persona que acosa que lo que está haciendo os molesta y que está cometiendo un delito grave. Si seguís todos estos consejos lograréis afrontar la situación correctamente y evitaréis muchos problemas graves.

\section{TEMPORALIZACIÓN}

Tiempo aproximado de la actividad 20 minutos:

1. Introducción a la actividad: 5 minutos.

2. Realización de la primera actividad: 5 minutos.

3. Realización de la segunda actividad: 5 minutos.

4. Reflexión final: 5 minutos.

\section{ORIENTACIONES}

- Algunas de las pautas de afrontamiento que es interesantes que los alumnos conozcan son las siguientes:

- Pide ayuda a un adulto y tomad medidas legales.

- No respondas a las provocaciones.

- Trata de evitar el uso de aquellos dispositivos mediante los cuales eres acosado.

- No compartas información personal, cuanta más información tengan de ti más vulnerable serás.

- Guarda pruebas del acoso durante todo el tiempo, es decir, los mensajes, videos, imágenes, etc. mediante los cuales te increpan.

- Hazles saber a aquellos que te acosan que lo que están haciendo no te gusta y te molesta.

- Avisa a los que te acosan que lo que están haciendo es un delito con 
consecuencias legales graves.

RECURSOS

- Ficha número 8 del cuaderno de 60 de primaria. 


\section{¿Y AHORA QUÉ HAGO?}

\section{Lee el texto y responde a la siguiente pregunta.}

Juan es un chico de 11 años, tiene móvil y perfil de WhatsApp y participa en muchos grupos de WhatsApp con amigos y compañeros de clase. Un día Juan envió a un grupo de WhatsApp donde participa mucha gente una foto suya y Carlos, uno de los chicos que estaba en el grupo de WhatsApp, empezó a enviar mensajes riéndose de la foto y metiéndose con Juan. El resto de compañeros leían los mensajes pero nadie decía nada y Juan seguía respondiendo a los mensajes que le enviaba Carlos. Juan empezó a encontrarse mal, siempre le dolía la cabeza, sus notas empezaron a bajar y dejó de ir al colegio porque les decía a sus padres que estaba enfermo. Juan perdió un curso entero y tuvo que cambiarse de colegio.

- ¿Cómo podría haber afrontado Juan esta situación?

2. Representa esta historia en grupos de tres, siendo uno Juan, otro Carlos y el tercero un compañero que está en el grupo de WhatsApp. Ponte en su lugar y piensa bien cómo se siente cada uno y qué podría hacer para afrontar el problema.

RECUERDA...

Ante cualquier acto que os haga ver que estáis sufriendo acoso o que algún compañero lo está sufriendo; debéis avisar a un adulto, no contestar a las provocaciones, dejar de utilizar los dispositivos con los que os molestan, guardar bien todos los mensajes y avisar a la persona que acosa que lo que está haciendo os molesta y que está cometiendo un delito grave. 


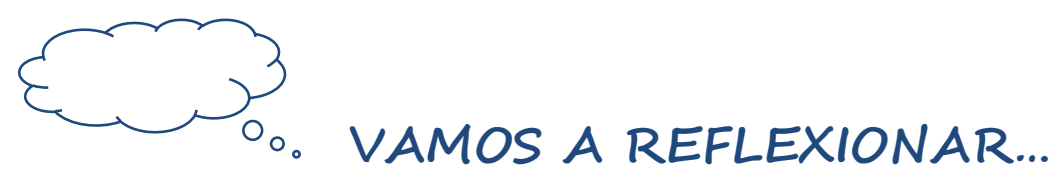

Después de haber realizado las actividades anteriores, vamos a reflexionar sobre los aspectos que hemos trabajado. Para ello, contesta las siguientes cuestiones:

1. Señala acciones que debemos realizar para evitar situaciones de ciberbullying.

Hacer un buen uso de las nuevas tecnologías.

Responder a los mensajes ofensivos que nos envían.

No publicar información personal que después puedan utilizar en tu contra.

Enviar fotos y mensajes a gente desconocida.

Guardar bien las contraseñas de nuestras cuentas de redes sociales.

2. Escribe qué harías si alguien te manda un mensaje como este.

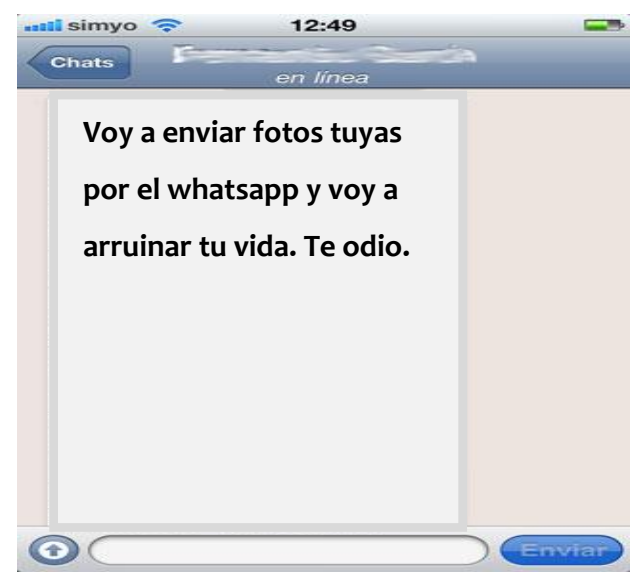


FITXA D'AVALUACIÓ PER AL PROFESSOR/A DE LES ACTIVITATS DEL BLOC DE CIBERBULLYING

1. Com t'ha resultat dur a terme les tasques segons les indicacions exposades en les fitxes? Molt difícil $\square \quad$ Difícil $\square \quad$ Normal $\square \quad$ Fàcil $\square \quad$ Molt fàcil $\square$

2. Creus que es compleix l'objectiu proposat? Sí $\square \quad$ No $\square$

3. Has introduït les activitats al contingut curricular assenyalat o en algun altre?

T emes indicats $\square \quad$ Altres $\square$ (indica quins:

4. Has utilitzat altres recursos a part dels que apareixen a la fitxa? Sí $\square \quad$ No $\square$

5. ¿Faries alguna modificació de millora en les fitxes per assolir els objectius de manera més òptima? Sí $\square \quad$ No $\square$

(en cas afirmatiu, indica quina:

6. Com s'han sentit els alumnes en realitzar les activitats? (motivació, implicació, interacció amb altres, ....)

7. Hi ha algun aspecte que consideres oportú comenta per a la millora del programa? 


\section{PREVENCIÓ I RESOLUCIÓ DE CONFLICTES}

Evitar i solucionar discrepancies entre dos $\sigma$ més interessos simultanis que algunes voltes donen lloc a un estat de tensió emocional que comporta estats dansietat i comportaments impulsius.

\section{Objectius.}

$\checkmark$ Aprendre a com prendre decisions adequades.

$\checkmark$ Ser conscients que cadascú és lliure d'actuar per si mateix. 
ASSIGNATURA:CIÈNCIES SOCIALS

ACTIVITAT:PRENEM LA DECISIÓ

CONTINGUTS: INDUSTRIALITZACIÓ I PREVENCIÓ I RESOLUCIÓ DE CONFLICTES.

\section{OBJECTIUS CURRICULARS}

- Analitzar els canvis de la revolució industrial.

- Distingir entre la societat agrícola i la industrial.

\section{OBJECTIUS SOBRE LA TEMÀTICA}

- Conèixer el procés per a prendre decisions.

- Aprendre a prendre les decisions més adequades.

\section{METODOLOGIA / PROCEDIMENT}

En aquesta activitat treballarem continguts relacionats amb la industrialització espanyola i també continguts per a la prevenció i resolució de conflictes. La fitxa d'aquesta activitat és la 10.

\section{Introducció en grup a l'activitat:}

Recordem els canvis que vàrem sofrir a Espanya quan va ocórrer la revolució industrial, que va produir uns canvis en la forma de treballar i de viure la gent, gràcies a la utilització de les màquines. Es va passar d'un predomini de societat rural dominada per la noblesa a una societat urbana moderna basada en la industria i dominada per la burgesia. El primer invent va ser la màquina de vapor, $i$ aquesta va permetre que després aparegueren altres màquines que facilitaren $i$ augmentaren la producció, $i$ així els productes que feien a les fàbriques eren més econòmics i estaven més a l'abast de més gent.

Doncs bé, ja sabem que la societat ha sofert molts canvis al llarg dels anys, però indiscutiblement el invent de les màquines fou un fet molt important, ja que va facilitar i millorar molt la producció.

A l'activitat que anem a realitzar ens plantegen una situació, en la que tenim que pensar que ens situem en aquella època. Som un treballador del camp, comencem a tenir molta feina, i com que ja s'han començat a treballar amb màquines, doncs la societat es basa en la industria, hem de pensar si seguim treballant amb les mateixes ferramentes que fins ara o comprem màquines noves que han sorgit per a treballar el camp. Hem de prendre una decisió.

2. Realització de la primera activitat en grup:

En primer lloc, anem a pensar quin és el problema que se'ns planteja. Quin creieu que és?

(Deixem que els alumnes ho reflexionen i que responguin tant a la fitxa com en veu alta a la pregunta sobre quin és el problema. A l'apartat d'orientacions trobarem indicacions.) 
3. Realització de la segona activitat primer individualment i després reflexió en gran grup:

Ja sabem quin és el problema, però el més important quan ens trobem amb una situació així és que sapiguem quines solucions possibles tenim. Penseu cadascú algunes solucions possibles a aquest problema i anoteu-ho, $i$ una volta ho tinguem ho comentem tots junts per a veure les solucions que hem pensat.

(Primer deixem que cadascú anoti a la fitxa les possibles solucions que ha pensat per al problema que es planteja, després comentarem tots junts el que han anotat i dirigirem les respostes amb l'ajuda de les indicacions que trobarem a l'apartat d'orientacions.)

4. Realització de la tercera activitat individualment i després reflexió en grup:

Ara, igual que hem fet amb la pregunta anterior, tenim que pensar per a cada una de les solucions que hem pensat, en el cas que ho férem, quines serien les conseqüències. Es a dir, si actuem com hem dit que seria una solució, què ocorreria? Anotem per tant una conseqüència de cada una de les solucions i quan ho tinguem ho comentem en grup.

(De la mateixa forma que ho hem fet a l'activitat anterior, ara també treballarà cada alumne individualment a la fitxa anotant la conseqüència que ells creuen que ocorrerà per a cada solució que han anotat, després comentarem en grup el que han escrit.)

5. Reflexió final en grup i realització individual de la quinta activitat:

Després de respondre a aquestes preguntes, us haureu adonat que quan se vos plantegi un problema el primer que heu de fer és parar-vos a pensar i reflexionar ben bé què ocorre, una volta tenim ben definit el problema, el que farem és pensar com ho podem solucionar, es a dir, què podem fer. Busquem les solucions i després tractem d'endevinar les conseqüències que ens portarien si posarem en marxa eixes solucions. Una volta ja estem en eixe punt és hora de valorar bé quina de les solucions plantejades seria la més adequada, i així és com actuaríem.

Hem de saber que prendre una decisió es tracta de buscar varies solucions al problema, pensar i reflexionar bé sobre les conseqüències que comporten cada una d'elles i després elegir la que considerem millor i més adequada.

Així, que ara és el moment de pensar amb quina de les solucions que haveu pensat us quedaríeu i ho anoteu a la fitxa.

(Deixem que cada alumne anoti a la fitxa quina de les solucions plantejades és l'elegida.)

\section{TEMPORALITZACIÓ}

Temps aproximat de l'activitat 23 minuts:

1. Introducció a l'activitat: 4 minuts

2. Realització de la primera activitat: 5 minuts.

3. Realització de la segona activitat: 5 minuts. 


\section{Realització de la tercera activitat: 5 minuts.}

5. Reflexió final i realització de la quarta activitat: 4 minuts.

\section{ORIENTACIONS}

- En aquesta activitat pretenem que els alumnes aprenguin a prendre decisions quan es troben amb un conflicte o problema. En aquest cas partim d'una situació en la qual el problema és que, al cas plantejat, es té el dubte si és millor seguir endavant treballant el camp amb ferramentes més tradicionals o es passa a treballar amb màquines i gastar-se diners. Per tant orientarem les respostes d'aquesta pregunta cap a aquesta resposta.

- Les possibles solucions que comentin els alumnes poden ser diverses però aquestes dues poden ser de les més comuns en aquest cas: una de les solucions és quedar-se igual que estan treballant amb ferramentes tradicionals, l'altra opció és comprar algunes màquines $i$ utilitzar algunes voltes les ferramentes de sempre $i$ altres les màquines segons la feina que tinguin, $i$ la tercera seria comprar totes les màquines que els facin falta per a poder treballar-ho tot amb elles.

- Les conseqüències que poden aportar a cada solució proposada també poden ser diverses però per a les solucions que hem plantejat abans les conseqüències poden ser les següents: si segueixen amb el material que tenen estalviaran diners però seguiran treballant al mateix ritme pel que no podran augmentar la producció, si compren nomes algunes aconseguiran amb pocs diners treballar una mica més apresa i produir més, i si compres totes les màquines necessàries produiràs molt més apresa però et gastaràs molts diners.

\section{RECURSOS}

- Fitxa número 10 del quadern de 6è de primària. 


\section{PRENEM LA DECISIÓ}

Fa molts anys, amb la industrialització espanyola, la nostra societat va canviar molt sobretot laboralment. Pensa en aquesta situació que et plantegem a continuació i respon a les preguntes.

Treballes al camp i tens que prendre la decisió de seguir treballant amb ferramentes tradicionals, o bé comprar unes màquines noves que han sortit, perquè t'ha sorgit molta feina i necessites produir més però en aquests moments tens problemes econòmics $i$ no et pots permetre gastar-te molts diners.

1. Pensa quin és el problema.

2. Quines són les possibles solucions?

3. Quines seran les conseqüències de cada solució?

4. Elegeix una de les solucions prenent la decisió que consideres més adequada.

RECORDA...

Prendre una decisió es buscar varies solucions al problema, pensar i reflexionar bé sobre les conseqüències que comporten cada una d'elles i després elegir la que considerem millor i més adequada. 
ASSIGNATURA:CIÈNCIES SOCIALS

ACTIVITAT:JO DECIDEIXO PER MI

CONTINGUTS: ESPANYA AL SEGLE XX I PREVENCIÓ I RESOLUCIÓ DE CONFLICTES

\section{OBJECTIUS CURRICULARS}

- Analitzar un dels principals canvis experimentats per la societat del segle $\mathrm{XX}$.

- Reconèixer què és el sufragi femení i què va significar.

\section{OBJECTIUS SOBRE LA TEMÀTICA}

- Ser conscient que cadascú és lliure i pot decidir per si mateix com actuar.

- Ser capaç de reconèixer situacions en les que cal prendre una decisió.

\section{METODOLOGIA / PROCEDIMENT}

En aquesta activitat treballarem continguts relacionats amb aspectes d'Espanya al segle $X X, i$ també altres continguts relacionats amb la prevenció i resolució de conflictes. A la fitxa 11 trobarem aquesta activitat.

1. Introducció en grup a l'activitat:

A Espanya, al segle XX, van haver molts canvis. La societat, l'economia, la política era molt diferent a com ho coneixem nosaltres ara. En aquell moment Espanya va passar d'una monarquia a una república, la societat va sofrir una guerra $i$ el franquisme es va instaurar durant molts anys... Amb el pas del temps, ha hagut canvi, i majoritàriament aquests processos de canvi ens han permès que hui ens trobem amb un país i una societat millor, i sobretot que tinguem molts més drets dels que tenien els nostres avantpassats. I sabeu quin fou un dels canvis més significatius referents a drets al segle XX? Doncs que les dones pogueren votar, ja que abans nomes els homes ho podien fer, i fins la Constitució del 1931 no es va aconseguir i reconèixer el dret a vot de les dones.

2. Realització de la primera activitat en grup:

Així es va aconseguir que tots tinguem actualment els mateixos drets, i que tan homes com dones puguem votar i decidir pel futur del nostre país. Què opineu vosaltres d'aquest fet? Creieu que tots tenim els mateixos drets a decidir?

(Reflexionem tots junts sobre el que va comportar a la nostra societat un canvi tant gran de drets com és que s'equipari el dret de vot de les dones amb els dels homes. Trobarem algunes indicacions a l'apartat d'orientacions.)

3. Realització de la segona activitat primer individualment i després ho comentem en grup:

Bé, doncs com hem comentat, gràcies al sufragi femení les dones aconseguiren poder votar i decidir el que consideraven que era més convenient per al nostre país, igual que els homes ho havien fet fins aquell moment.

Aquest canvi, junt a molts altres que s'han produït al llarg del temps, en ha permès que tots actualment tinguem els mateixos drets, siguem d'un sexe o d'un altre, 
pertanyem o no a ètnies o cultures diferents... Per tant, tots som lliures de prendre les nostres decisions i d'elegir el que volem per nosaltres mateixos.

Digueu-me alguna cosa que vosaltres hagueu decidit fer per vosaltres mateixos. Per exemple, l'altre dia em vaig trobar amb dos amigues que anaven a passar la vesprada de compres i hem van proposar anar amb elles, però de sobte vaig pensar que tenia que fer feina a casa i els vaig dir que no podia acompanyar-les perquè tenia molta feina a casa important i que un altre dia les acompanyaria. Aleshores en aquell moment el que faig fer és prendre una decisió que jo considerava que era la més adient per a mi, perquè era més important per a mi en aquell moment finalitzar la feina de casa, i que ja podria un altre dia acompanyar-les. En quin moment vosaltres haveu pres una decisió? Escriviu a la fitxa un exemple i ara ho comentem tots junts.

(Els alumnes treballen individualment escrivint una situació en la qual ells van tenir que elegir entre diferents opcions que els van presentar i per tant va ser necessari que prengueren una decisió. Posteriorment comentarem tots junts el que han escrit els companys. A l'apartat d'orientacions trobarem més informació sobre aquest aspecte a tractar.)

4. Realització en grup de la tercera activitat:

Ja haveu escoltat que són moltes les situacions en les que ens presenten diferents opcions i nosaltres som els que hem de prendre una decisió i escollir, perquè tots som lliures de fer-ho. Però quan prenem una decisió què cal fer abans?

(Reflexionem tots junts sobre com cal actuar abans de prendre una decisió. A l'apartat d'orientacions podem consultar cap on dirigir aquest debat.)

5. Reflexió final en grup:

Aleshores, després de finalitzar aquesta activitat vos haureu adonat que gràcies a tots els canvis produïts al llarg dels anys, en un moment com l'actual tots tenim els mateixos drets $i$ tots podem prendre les decisions per nosaltres mateixos. Però per a prendre bé una decisió cal pensar ben bé les opcions que tenim i escollir sempre aquella que ens aporti coses bones $i$ positives, i no ens hem de deixar influenciar pels altres, la decisió de com actuar nosaltres és sempre nostra i mai hem de fer una cosa amb la que no estem d'acord o no ens fa sentir bé. Si nosaltres pensem bé abans de decidir i som capaços d'escollir la opció més adequada, la gent del nostre voltant confiarà amb nosaltres!

\section{TEMPORALITZACIÓ}

Temps aproximat de l'activitat 25 minuts:

1. Introducció a l'activitat: 4 minuts

2. Realització de la primera activitat: 4 minuts.

3.Realització de la segona activitat: 8 minuts.

4. Realització de la tercera activitat: 4 minuts

5. Reflexió final: 5 minuts. 


\section{ORIENTACIONS}

- Aquesta activitat té la finalitat que els alumnes se n'adonen que actualment en termes legals tots tenim dret a votar, i per tant a prendre una decisió, i que fa uns anys nomes els homes tenien aquest dret cosa que era discriminatori cap a les dones simplement pel fet de ser dones.

- En aquesta part de l'activitat $i$ al comentar tots junts moments que han viscut on han pres decisions, ens permetrà que els alumnes vegin que front a determinades situacions en les quals els se plantegen diferents opcions, ells són lliures d'elegir allò que consideren més adequat en aquell moment per a ells i capaços de fer-ho sense que ningú els condicioni perquè són lliures de fer-ho.

- A la tercera activitat els alumnes han de reflexionar sobre què han de fer abans de prendre una decisió, i la resposta més adient és pensar abans de decidir-nos, es a dir, saber ben bé les opcions que tenim, valorar les conseqüències i elegir la més adequada, la que ens aportarà més coses positives, com ja varem treballar a l'activitat anterior.

\section{RECURSOS}

- Fitxa número 11 del quadern de 6è de primària. 


\section{JO DECIDEIXO PER MI}

1. Què opines del sufragi femení? Creus que tots, homes i dones, tenim els mateixos drets a votar? Raona la teua resposta.

2. Escriu una situació que hagis viscut on has pres una decisió per tu mateix.

3. Què hem de fer abans de prendre una bona decisió?

RECORDA...

Cada u té l'oportunitat i pot decidir per si mateix. Si prens bones decisions, la gent del teu voltant confiarà més amb tu perquè s'adonaran que penses bé les coses abans de fer-les $\mathrm{i}$ decideixes fer les coses com cal. 


\section{ANEM A REFLEXIONAR...}

Després d'haver realitzat les activitats anteriors, reflexionarem sobre els aspectes que hem treballat. Per a això, contesta les següents qüestions:

1. Quins passos cal seguir per a prendre una bona decisió?

2. Quan hem de prendre una decisió nosaltres no podem decidir com actuar, els altres ens diran que hem de fer i com hem d'actuar.

Vertader

Fals

- Justifica la teua resposta. 
FITXA D'AVALUACIÓ PER AL PROFESSOR/A DE LES ACTIVITATS DEL BLOC DE PREVENCIÓ I RESOLUCIÓ DE CONFLICTES

1. Com t'ha resultat dur a terme les tasques segons les indicacions exposades en les fitxes? Molt difícil $\square \quad$ Difícil $\square \quad$ Normal $\square \quad$ Fàcil $\square \quad$ Molt fàcil $\square$

2. Creus que es compleix l'objectiu proposat? Sí $\square \quad$ No $\square$

3. Has introduït les activitats al contingut curricular assenyalat o en algun altre?

T emes indicats $\square \quad$ Altres $\square$ (indica quins:

4. Has utilitzat altres recursos a part dels que apareixen a la fitxa? Sí $\square \quad$ No $\square$

5. ¿Faries alguna modificació de millora en les fitxes per assolir els objectius de manera més òptima? Sí $\square \quad$ No $\square$

(en cas afirmatiu, indica quina:

6. Com s'han sentit els alumnes en realitzar les activitats? (motivació, implicació, interacció amb altres, ....)

7. Hi ha algun aspecte que consideres oportú comenta per a la millora del programa? 


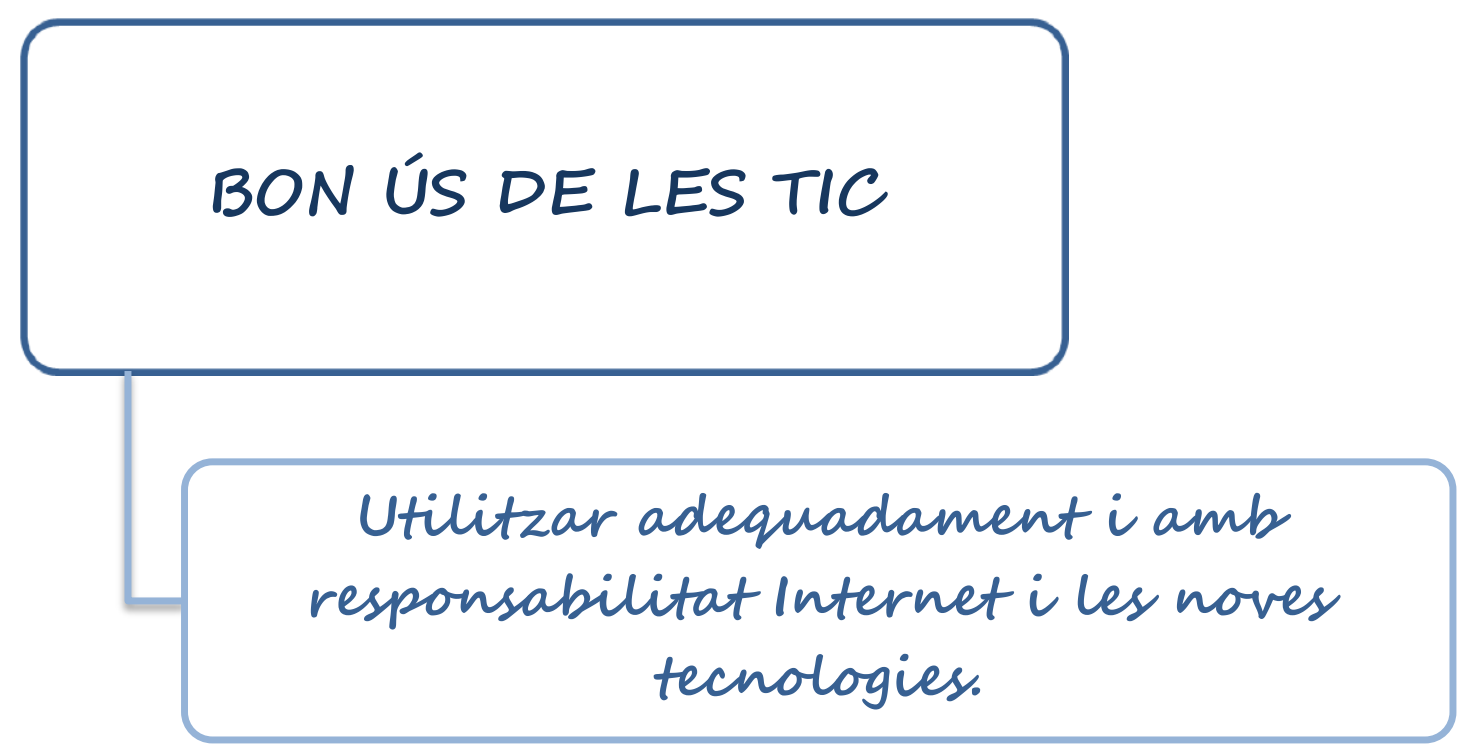

\section{Objectius.}

$\checkmark$ Aprendre a utilitzar adequadament les Tic com eina per a compartir informació.

$\checkmark$ Sensibilitzar sobre els perills que comporta fer un ús abusiu de les Tic. 
ASSIGNATURA:CIÈNCIES DE LA NATURALESA

ACTIVITAT:COMPARTIM INFORMACIÓ

CONTINGUTS: L'APARELL DIGESTIU I EL BON ÚS DE LES NOVES TECNOLOGIES

\section{OBJECTIUS CURRICULARS}

- Identificar l'aparell digestiu i les seues funcions.

- Reconèixer quins són els òrgans que formen part de l'aparell digestiu i les infermetats relacionades amb aquest.

\section{OBJECTIUS SOBRE LA TEMÀTICA}

- Reflexionar sobre l'ús de les Tic com a eina per compartir informació.

- Generar en els alumnes una visió crítica sobre com utilitzar adequadament les Tic per compartir informació.

\section{METODOLOGIA / PROCEDIMENT}

En aquesta activitat treballarem continguts relacionats amb l'aparell digestiu i també altres relacionats amb el bon ús de les noves tecnologies. Aquesta activitat la trobarem a la fitxa 13.

1. Introducció en gran grup a la primera activitat:

Estem treballant a classe l'aparell digestiu, hem estudiat què és l'aparell digestiu, les funcions que fan, els òrgans que formen part d'ell, etc.

D'acord, doncs ara el que anem a fer és un petit resum de tot allò que sabem de l'aparell digestiu. Ho farem en grups de 4 alumnes on cadascú s'encarregarà de recollir informació d'un aspecte determinat i realitzar una part del resum.

2. Realització en grups de quatre de la primera activitat:

Aleshores ens anem a posar a treballar en grups de quatre. El 1 definirà què és l'aparell digestiu, el 2 quina és la seua funció, el 3 quins òrgans formen part d'ell $i$ el 4 com tenir cura de l'aparell digestiu i les infermetats de l'aparell digestiu.

(Dividim el grup classe en grups de quatre alumnes i adjudiquem a cada alumne un número de l'u al quatre, on cadascú s'encarregarà de recollir informació sobre l'aspecte del tema al que correspon el número.)

Ara tenim un temps per a que cadascú treballi l'apartat que li ha tocat. Podeu utilitzar el llibre o preguntar a algun company o a mi si teniu algun dubte. Anoteu cadascú a la primera activitat la informació que tingueu per a aportar després al grup i en un full apart escriviu el resum que m'entregareu després a mi.

(Els alumnes es troben situats en grup on cadascú està realitzant la seua part del resum sobre l'aparell digestiu però al mateix temps poden consultar uns amb els altres dubtes, es poden ajudar, etc. i junts realitzen el resum que inclourà tots els apartats que corresponen a la informació que han buscat els membres del grup. Quan tots tinguin el resum passem al següent punt.)

3. Realització en gran grup de la segona activitat:

Ja tenim tots els components del grup la informació que havíeu de buscar i el resum de l'aparell digestiu. El que haveu fet ha sigut compartir informació uns amb 
altres i relacionar-vos amb la finalitat de realitzar junts una acció que en aquest cas es tractava d'un resum. Aleshores la informació l'haveu compartit ràpidament $i$ cara a cara perquè vos trobeu tots al mateix lloc però imagineu que cadascú estigués en un lloc diferent i necessiteu conèixer la informació dels altres per a poder fer el resum. Com podríeu compartir aquesta informació? Quines eines electròniques utilitzaríeu?

(En aquest apartat és on treballarem i reflexionarem sobre l'ús de les noves tecnologies con a mitjà per a compartir informació. A l'apartat d'orientacions trobarem més informació sobre com desenvolupar aquest debat.)

Segur que molts de vosaltres ja ha utilitzat algun d'aquests dispositius i eines per a compartir informació, però ho haveu fet de forma segura? Compartir informació el mòbil o ordinador és molt còmode però també comporta riscos i per tant cal prendre certes mesures i tenir cura quan ho utilitzem. Què podem fer per exemple per a crear i utilitzar un compte de correu electrònic o un perfil a una xarxa social segur? Anem a anotar a la pissarra el que anem dient i després cadascú anotarà aquelles tres que consideri més adequades.

(En aquest punt debatrem sobre les accions que hem de tenir en compte abans de crear-nos un compte de correu electrònic, perfil a una xarxa social o utilitzar una App de missatgeria instantània i com utilitzar-lo adequadament, ja que com hem dit hi ha perills que cal evitar. Anotarem aquestes precaucions a la pissarra per a que els alumnes les anoten després a la fitxa. Trobarem pautes a l'apartat d'orientacions.)

\section{Reflexió final de l'activitat:}

Vos haveu adonat que la comunicació i el compartir informació d'uns als altres quan estem al mateix lloc és molt fàcil i també ho és si estem lluny, ja que actualment disposem de molts dispositius com l'ordinador i el mòbil amb Internet que ens permeten comunicar-nos i compartir informació amb gent que no tenim prop. Però cal tenir molta cura de com utilitzem aquestes eines, com creem els nostres comptes, amb qui compartim aquesta informació i quina informació de la que rebem és segura i quina no. Per tant, cal seguir una sèrie de recomanacions com les que hem comentat, així aconseguirem compartir informació d'una forma segura i sense perills, ja que Internet és una xarxa molt gran i tot el que difonem per ella pot ser vista per molta gent, per això és important utilitzar filtres de seguretat i privacitat, i saber bé amb qui estem compartint aquesta informació. Si seguim aquests consells compartirem informació ràpidament i amb seguretat!

\section{TEMPORALITZACIÓ}

Temps aproximat de l'activitat 25 minuts:

1. Introducció a l'activitat: 5 minuts

2. Realització de la primera activitat: 10 minuts.

3. Realització de la segona activitat: 5 minuts

4. Reflexió final: 5 minuts. 


\section{ORIENTACIONS}

- En aquesta activitat treballarem les diferents formes que hi ha per a compartir informació. En els últims anys els mitjans de comunicació han avançat molt i són molts els dispositius i programes que ens ajuden a comunicar-nos amb més facilitat $i$ també a compartir informació. Alguns d'aquests són: el mòbil mitjançant missatges, whatsApp i altres aplicacions de missatgeria instantània, l'ordinador a partir de xats, xarxes socials (facebook, tuenti, twiter, etc.), correus electrònics, etc. Aquests permeten enviar-nos imatges, documents, textos, àudios, vídeos, etc., i per tant ens faciliten molt compartir dades i informació, ja que són molt ràpids i ens permeten comunicar-nos amb gent que està lluny de nosaltres.

- Els alumnes comencen a utilitzar molt prompte les Tic com a forma de comunicació; es descarreguen aplicacions als mòbils com el whatsApp, es creen comptes de correu electrònic i perfils a les xarxes socials, però és necessari que coneguin molt bé com ho han de fer correctament per a evitar perills. Aquests consells són interessants que els coneguin quan facin ús d'aquestes eines de comunicació:

- Per a identificar-se (adreça electrònica, xat, xarxes socials, etc.) no es convenient utilitzar el nom o l'edat ni cap altra dada personal.

- La contrasenya que utilitzem ha de ser segura, i mai l'hem de compartir amb amics o companys i menys amb gent desconeguda, nomes amb els nostres pares.

- Cal evitar obrir correus, arxius, missatges, etc. de gent que no coneixem perquè poden infectar el nostre ordinador o mòbil amb virus.

- És important no reenviar correus o missatges en cadena que prometen tenir bona sort o aconseguir alguna cosa a canvi perquè són tot invencions i mai es compleix el que prometen.

- Si accedim als nostres comptes des d'un ordinador o mòbil que no són els nostres o els que tenim a casa, cal assegurar-se bé de tancar la sessió després d'utilitzarla.

- No hem d'acceptar a contactes o gent que no coneguem, i si has agregat a algú que et molesta cal bloquejar-lo per a que no pugi posar-se de nou en contacte amb nosaltres i avisar a una persona adulta.

- A les xarxes socials és important configurar el perfil de privacitat per a que nomes puguin veure la nostra informació $i$ allò que compartim les persones que nosaltres volem.

- Cal tenir cura doncs pot ser hi hagin perfils falsos perquè hi ha gent que crea perfils amb dades falses i pot ser darrere d'aquest estigi una persona que no sigui la que creiem.

\section{RECURSOS}

- Fitxa número 13 del quadern de 6è de primària. 
1. Anota a continuació la informació sobre l'aparell digestiu que t'ha pertocat.

2. Imagina que els teus companys es troben lluny, com podríeu compartir la informació per a fer un resum conjunt?

- Quins consells cal seguir per a compartir informació per l'ordinador, mòbil, etc.?

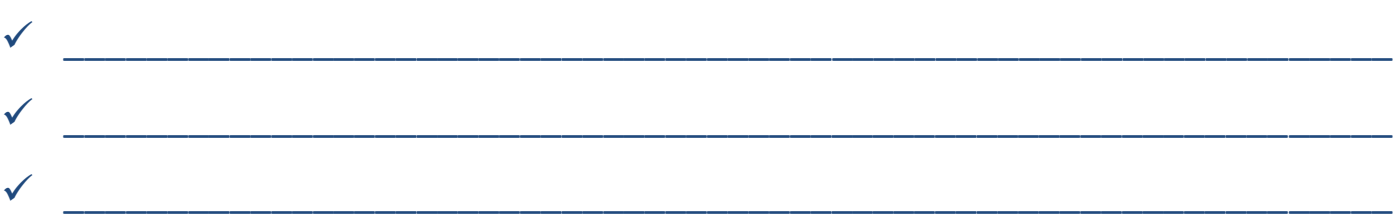

\section{RECORDA...}

Compartir informació d'uns als altres quan estem lluny és molt fàcil, però cal tenir molta cura quan utilitzem aquestes eines perquè Internet és una xarxa molt gran i tot

el que difonem ho pot veure molta gent. Per això, és important utilitzar filtres de seguretat i privacitat, i saber bé amb qui estem compartint aquesta informació entre altres. Si seguim aquests conselles que hem après, compatir serà més segur! 
ASSIGNATURA:CIÈNCIES DE LA NATURALESA

ACTIVITAT:UTILITZEM EL TEMPS COM CAL

CONTINGUTS: LA RESPIRACIÓ I EL BON ÚS DE LES NOVES TECNOLOGIES

\section{OBJECTIUS CURRICULARS}

- Reconèixer les funcions del sistema respiratori.

- Adoptar hàbits de vida saludables i mesures preventives relacionades amb els sistema respiratori.

\section{OBJECTIUS SOBRE LA TEMÀTICA}

- Reflexionar sobre quin és l'ús adequat de cadascuna de les Tic.

- Sensibilitzar als alumnes dels perills de l'ús abusiu de les Tic.

\section{METODOLOGIA / PROCEDIMENT}

En aquesta activitat treballarem continguts relacionats amb l'aparell respiratori i també altres relacionats amb el bon ús de les noves tecnologies. A la fitxa 14 trobarem aquesta activitat.

1. Introducció en gran grup a l'activitat:

La respiració és la funció per la qual els essers vius prenem del medi ambient l'oxigen que necessiten les nostres cèl/lules i desprenem diòxid de carboni. Així el conjunt d'òrgans que ens permet posar en comunicació l'aire atmosfèric amb la sang s'anomena el sistema respiratori. El sistema respiratori fa una funció importantíssima i per tant cal tenir cura d'ell i seguir unes normes higièniques que ens permeten que arribi als nostres pulmons tot l'oxigen que necessitem i per a prevenir qualsevol tipus de malaltia respiratòria.

2. Realització en grup de la primera activitat:

Aleshores, quins hàbits d'higiene creieu que cal seguir per a que el sistema respiratori funcioni correctament? Anoteu a la fitxa dos hàbits saludables per a mantenir sa el sistema respiratori i prevenir infermetats $i$ ara ho comentem tots junts.

(Comentem tots junts en grup quines accions sèrie convenient portar a terme per a tenir una bona higiene al nostre sistema respiratori. Trobarem algunes indicacions a l'apartat d'orientacions.)

3. Realització en grup de la segona activitat:

D'acord, aleshores ja sabem quina és la funció del sistema respiratori i també la importància de seguir hàbits saludables. Però a més de la funció principal del sistema respiratori, també té una altra funció, i és que ens ajuda a relaxar-nos. Si respirem lentament, concentrant-nos en la inspiració i l'expiració, aquesta acció ens relaxarà i ens ajudarà a superar molts moments d'angoixa o malestar.

Per exemple, anem a imaginar que estem a casa jugant a l'ordinador, portem més de dues hores, i el nostre pare ens diu que ja és hora d'anar a sopar, aleshores ens posem una mica nerviosos i li fem un crit al pare. Per què creieu que ens hem pogut posar nerviosos i què podríem fer en aquest moment? 
(Debatim tots junts a què es deu el nerviós en aquest moment i què podem fer en aquest moment per a tranquil.litzar-nos. A l'apartat d'orientacions hi ha algunes indicacions per a seguir en aquest debat.)

Aleshores, veient que el fet d'utilitzar que ens diguin que deixem l'ordinador ens porta a una situació de nerviosisme... Creieu que és convenient utilitzar dispositius electrònics com pot ser l'ordinador, la tableta, el mòbil, etc.? Quins problemes ens pot causar el seu ús?

(Reflexionem tots junts sobre la conveniència o no d'utilitzar els dispositius electrònics i les conseqüències que poden comportar un mal ús. A l'apartat d'orientacions trobarem indicacions sobre aquest aspecte.)

4. Reflexió final en grup:

Com ja hem vist, cal que fem un ús responsable de les noves tecnologies $i$ això implica no fer un ús abusiu d'elles, es a dir, cal respectar els horaris que ens marquen a casa $i$ utilitzar cada dispositiu per a la seua finalitat. Si alguna volta deixar d'utilitzar les Tic vos provoca angoixa o vos posa de mal humor, és perquè alguna cosa va malament, per tant cal mantenir la calma, relaxar-nos $i$ adonar-nos que hi ha coses molt importants a fer com jugar amb els amics, sortir a practicar un esport, estar amb la nostra familia, i que si ens organitzem hi ha temps per a tot, que l'ordinador i el mòbil no ho són tot a la nostra vida i que tot el que ens ocorre no pot girar al voltant d'ells. Les noves tecnologies ens ajuden a moltes coses però cal utilitzar-les nomes quan sigui necessari, és més important que gaudim del temps fent allò que ens agradi, així ens sentirem millor!

\section{TEMPORALITZACIÓ}

Temps aproximat de l'activitat 22 minuts:

1. Introducció a l'activitat: 4 minuts

2. Realització de la primera activitat: 5 minuts.

3. Realització de la segona activitat: 8 minuts

4. Reflexió final: 5 minuts.

\section{ORIENTACIONS}

- Algunes de les recomanacions que cal tenir en compte per a una bona higiene del nostre sistema respiratori són, entre altres:

- Respirar pel nas i no per la boca.

- Fer exercicis respiratoris de tant en tant, per ventilar totalment els pulmons.

- Practicar esports i exercicis gimnàstics doncs desenvolupen la capacitat toràcica.

- No fumar, el tabac perjudica especialment al sistema respiratori.

- L'aire de les ciutats té impureses. En ell suren milions de microbis i gasos, fums, etc.

- L'aire del mar i de la muntanya és el mes puro i sa.

- La ventilació de les habitacions és necessària per donar sortida a l'aire viciat i entrada a l'aire pur. 
- En aquest punt és important que els alumnes se n'adonen que l'ús de les noves tecnologies ens pot causar situacions estressants per voler i necessitar seguir utilitzant-les molta estona, i que en moments com aquests cal deixar el dispositiu que estiguem utilitzant i relaxar-nos, realitzant exercicis d'expiració i inspiració i canviar d'activitat.

- Aquest punt de reflexió és molt important, ja que els alumnes han de veure $\mathrm{i}$ reconèixer que les noves tecnologies com la televisió, els videojocs, l'ordinador, la tableta, el mòbil, etc. ens aporten moltes coses bones, però cal fer un ús responsable d'elles, ja que si l'utilitzem moltes hores estem fent un ús abusiu i ens pot causar problemes greus físics i psicològics, i més greu seria si es creés una addicció, que és quan la vida gira entorn a un dispositiu electrònic. Per això cal conscienciar que l'ús abusiu pot portar a problemes com el nerviosisme o ansietat o inclús a problemes més greus d'addicció o dependència a aquests dispositius.

Així, és important fer un ús controlat, seguir els horaris que ens marquen els nostres pares i no fer mai un ús de més de dues hores al dia utilitzant dispositius. Per exemple, el mòbil és una eina de comunicació que ens pot resultar útil quan estem lluny de casa, però si estem a casa, a l'escola o amb la família no és necessari perquè en eixes situacions, si necessitem alguna cosa, estem protegits pels professors i la família. La televisió per a distraure'ns una estona i passar-ho bé, Internet per a buscar informació per a realitzar algun treball de l'escola... Aquestes són les funcions dels dispositius.

Per tant, han de ser conscients que cal fer un ús raonable, seguir les normes que dicten els pares a casa i utilitzar les noves tecnologies per a la finalitat que té cadascuna. Passar molt de temps amb elles no ens aporta res bo, al contrari, ens lleva temps d'altres coses més important que sí ens aporten moltes coses bones.

\section{RECURSOS}

- Fitxa número 14 del quadern de 6è de primària. 


\section{UTILITZEM EL TEMPS COM CAL}

1. Escriu dos hàbits saludables que cal seguir per a tenir cura del nostre sistema respiratori i prevenir malalties.

2. Imagina que estàs a casa jugant a l'ordinador, portes més de dues hores jugant, i el nostre pare ens diu que ja és hora d'anar a sopar, aleshores ens posem una mica nerviosos i li fem un crit al pare.

- Per què creus que ens t'has pogut posar nerviós i què podries fer en aquest moment?

- Creus que és convenient utilitzar dispositius electrònics com l'ordinador, la tableta, el mòbil, etc.? Raona la teua resposta.

- Quins problemes ens pot causar l'ús inadequat de les noves tecnologies?

RECORDA...

Les Tic ens aporten moltes coses bones però cal respectar els horaris que ens marquen a casa i utilitzar cada dispositiu per a la seua finalitat. Si alguna volta deixar d'utilitzar les Tic vos provoca angoixa o vos posa de mal humor, és perquè alguna cosa va malament, per tant cal mantenir la calma, relaxar-nos i adonar-nos que hi ha moltes altres coses importants a fer. 


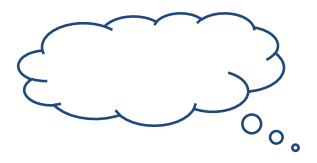

ANEM A REFLEXIONAR...

Després d'haver realitzat les activitats anteriors, reflexionarem sobre els aspectes que hem treballat. Per a això, contesta les següents qüestions:

1. Senyala les frases correctes.

Quan utilitzem les noves tecnologies com per a compartir informació cal...

Utilitzar una contrasenya segura, i mai l'hem de compartir amb amics o companys i menys amb gent desconeguda, nomes amb els nostres pares.

$\square$ Obrir tots els correus, arxius, missatges, etc. que rebem, també de gent que no coneixem.

No reenviar correus o missatges en cadena que prometen tenir bona sort o aconseguir alguna cosa a canvi.

Assegurar-se bé de tancar la sessió després d'utilitzar-la.

Acceptar a contactes o gent que no coneguem.

2. Consideres que utilitzar els dispositius tecnològics moltes hores i fer un ús abusiu d'aquests, ens pot causar problemes d'addicció molt greus? Raona la teua resposta. 
FITXA D'AVALUACIÓ PER AL PROFESSOR/A DE LES ACTIVITATS DEL

BLOC DEL BON ÚS DE LES TIC

1. Com t'ha resultat dur a terme les tasques segons les indicacions exposades en les fitxes? Molt difícil $\square \quad$ Difícil $\square \quad$ Normal $\square \quad$ Fàcil $\square \quad$ Molt fàcil $\square$

2. Creus que es compleix l'objectiu proposat? Sí $\square \quad$ No $\square$

3. Has introduït les activitats al contingut curricular assenyalat o en algun altre?

T emes indicats $\square \quad$ Altres $\square$ (indica quins:

4. Has utilitzat altres recursos a part dels que apareixen a la fitxa? Sí $\square \quad$ No $\square$

5. ¿Faries alguna modificació de millora en les fitxes per assolir els objectius de manera més òptima? Sí $\square \quad$ No $\square$

(en cas afirmatiu, indica quina:

6. Com s'han sentit els alumnes en realitzar les activitats? (motivació, implicació, interacció amb altres, ....)

7. Hi ha algun aspecte que consideres oportú comenta per a la millora del programa? 


\section{QÜESTIONARI FINAL}

\section{Alumnat 6è de Primària}

Edat:

Gènere: Xic $\square \quad$ Xica $\square$

A continuació trobaràs una sèrie de qüestions amb tres possibles respostes. Llegeix detingudament i assenyala l'opció que s'acosti més al que tu penses. No et preocupis per les respostes que marques, no hi ha respostes correctes o incorrectes, només ens interessa la teva opinió.

1. Quan un company o un amic ens diu que està trist o preocupat hem de...

Dir-li que no té perquè sentir-se així, que el seu problema no és tant important.

Dir-li que entenem el que li passa i animar-li.

No dir res, ja se li passarà. Nosaltres no podem fer res.

2. Quan a un company de classe li treuen l'entrepà, li trenquen el material o no el conviden a una festa d'aniversari,...

A mi em seria igual així que a ell segur que també li és igual.

No podem saber mai com se sent, això només ho sap cada un, i llavors no li podem dir res.

Si se sent malament hem de animar-lo i ajudar-lo encara que per nosaltres sigui una ximpleria el que li ha passat.

3. Si un company et demana que facis alguna cosa que no vols fer i no la fas...

$\square$ Em sento avergonyit per no haver-ho fet.

$\square$ Em sento bé perquè no estava bé fer-ho i tant me fa el que ell em digui.

$\square$ Em sento preocupat per si s'enfada amb mi i em diu alguna cosa.

4. Quan estic parlant amb els meus amics per Internet, he de tindre en compte que...

Quan envio un missatge o penjo alguna foto, després el puc esborrar i ningú ho podrà veure.

Abans de penjar fotos meves he de comprovar que només ho comparteixo amb amics i coneguts meus.

He de respondre a tots els missatges que m'envien, sobretot els ofensius.

5. Quan estem en el nostre grup d'amics o companys i no estem d'acord amb alguna cosa que diuen o volen fer...

$\square$ Cal queixar-nos i dir-los tranquil.lament el que no ens agrada.

És millor no dir cap cosa, segur que si diem alguna cosa es fiquen amb nosaltres.

$\square$ Cal queixar-nos i cridant i enfadats perquè sàpiguen que no ens agrada. 


\section{Si algú s'està ficant amb tu $\mathrm{o}$ amb un amic teu a Internet hem de ...}

Contestar els missatges on es fiquen amb nosaltres perquè vegin que no tenim por.

Esborrar tots els missatges que ens han enviat i no contar-ho a ningú, així tot s'acabarà.

Explicar-li a un adult el que ens està passant.

7. Si quan tens un problema et costa molt decidir què és el millor que pots fer...

$\square$ Actuar de manera ràpida, fent el que se'ns passi primer pel cap, si triguem a fer alguna cosa després és més difícil.

Has de buscar varies solucions al problema i pensar quina és la més adequada. El millor és no fer res i esperar que tot passi.

8. Si pensem bé les coses abans de prendre una decisió...

La gent pensarà que sóc indecís o ximple perquè trigo molt a decidir què faig.

$\square$ Encara que pensem les coses no podem saber mai què serà millor, no podem endevinar què passarà.

$\square$ La gent confiarà més en mi perquè s'adonaran que penso bé les coses abans de fer-les.

9. Utilitzar Internet per compartir coses amb altra gent és molt fàcil i divertit, però una cosa important que hem de fer és...

Comprovar amb qui estic compartint la informació, és a dir, qui pot veure el que penjo.

Donar-li la nostra contrasenya a algun amic o company per si se'ns oblida.

$\square$ Si algú em molesta o m'envia missatges estranys, no està bé bloquejar-perquè a mi no m'agradaria que em bloquegessin.

10. Les noves tecnologies (l'ordinador, la tauleta o el mòbil) són molt divertides i cal tenir en compte que ...

Si algú està tot el dia connectat i quan no està se sent angoixat i té mal humor, és normal perquè és el que més li agrada.

Si estem tot el dia connectats podem tenir problemes de salut i problemes amb la gent que ens envolta.

Hem d'estar sempre connectats si no podem no contestar a algú a temps i perdre amics. 


\section{RECURSOS}

\section{GUIES}

* Junta de Castilla y León (2011). Manual de uso inteligente de las nuevas tecnologías para los alumn@s. De 8 a 10 años. Recuperado de: http://www.cyldigital.es/sites/default/files/library/manual810anosprogramaaprende.pdf

* Junta de Castilla y León (2011). Manual de uso inteligente de las nuevas tecnologías para los alumn@s. De 10 a 12 años. Recuperado de: https://www.cyldigital.es/sites/default/files/library/manual10-

12anosprogramaaprende.pdf

Concepte de noves tecnologies, informació sobre els videojocs, televisió, ordinador i Internet. També ens ofereixen informació sobre els riscs que podem trobar en la xarxa. A més, ens proporcionen informació sobre els e-drets dels xiquets i xiquetes i una sèrie de regles que es necessari que els menors coneguin a I'hora d'utilitzar les noves tecnologies.

* INTECO (2013). Guía de actuación contra el ciberacoso. Padres y educadores. Recuperado de: http://www.injuve.es/sites/default/files/2013/46/publicaciones/Gu\%C3\%ADa\%20 de\%20actuaci\%C3\%B3n\%20contra\%20el\%20ciberacoso.pdf

Concepte de ciberbullying, pautes de detecció, prevenció i actuació, i comportar a cap el procés de denuncia iel delicte que comporta. També trobarem una sèrie d'experiències de casos de ciberbullying i altres riscos de l'ús de les TIC, així com consells bàsics sobre l'ús de les noves tecnologies.

* Centro se Seguridad en Internet Protégeles (s.f.). Ciberbullying y privacidad. Guía para profesores. Recuperado de: http://www.yocontrolo.es/descargas/PROYECTO DAPHNE ES.pdf

Continguts teòrics relacionats amb el ciberbullying: concepte, qui intervé, prevenció, etc., i també altres sobre la privacitat: drets i deures, protecció de dades i delictes. També trobarem a aquests document una sèrie d'activitats per a treballar el ciberbullying i la privacitat en Internet. 
* Comisión de libertades e informática (2009). Proyecto CLI Prometeo. Manual práctico de uso de las tecnologías de la información. 9 a 11 años. Recuperado de:http://www.madrid.org/dat oeste/descargas/08 09/cli prometeo/Manual 9 11 castellano.pdf

Conjunt d'activitats on es treballen els diferents aspectes relacionats en l'ús de les tecnologies de la comunicació i la informació a partir d'històries relacionades amb I'ús que els menors fan d'aquestes tecnologies.

* Collell, J. y Escudé, C. (2008). No te enredes en la red. Guía para conocer el ciberbullying y algunos peligros de internet y las nuevas tecnologías. Recuperado de: http://www.xtec.cat/ jcollell/ZGuia\%20Ciber.pdf

Informació teòrica com el concepte de ciberbullying i conductes relacionades amb el ciberbullying. Presenta un conjunt d'activitats on a partir d'una sèrie d'històries es presenten qüestions per a debatre en grup sobre les conductes que es presenten a les històries.

Luengo, J. A. (2014). Ciberbullying. Prevenir y actuar. Guía de recursos didácticos para Centros Educativos. Recuperado de: http://www.copmadrid.org/webcopm/recursos/CiberbullyingB.pdf

Situació de l'ús de les TIC en els últims anys, conceptes teòrics sobre el ciberbullying i informació sobre diferents tècniques de treball del ciberbullying. En aquesta guia ens proporcionen també pautes i materials per la prevenció a partir de l'alfabetització digital des de l'educació primària. A més, la guia ens proporciona moltes activitats didàctiques per a portar a terme a les aules $\mathrm{i}$ un protocol d'intervenció ben desenvolupat amb materials i pautes tan per a pares com per a professors i alumnes. Finalitza amb una sèrie de referències normatives per a la reflexió i acció en el centre escolar.

* Fundación Dédalo (2012). Por un uso seguro de internet. Primaria. Recuperado de:http://www.disfrutalared.com/images/yootheme/fichas didacticas/FichasDida cticasPrimaria es.pdf

Conjunt d'activitats relacionades amb l'ús segur d'Internet on es treballen aspectes com els valors, el ciberbullying, la privacitat, etc. 


\section{PÀGINES WEB}

* PANTALlaS AMIgAS (http://www.pantallasamigas.net).És la web més completa, i la pionera en la temàtica, que existeix on encontrarem recursos relacionats amb l'ús segur i saludable de les noves tecnologies de tot tipus: articles, vídeos, definicions de conceptes, materials i recursos didàctics, etc.

* CIBERBULlyING (http://www.ciberbullying.com). A la web trobarem informació sobre el ciberbullying, recursos de prevenció, consells contra el ciberbullying, noticies, articles, entrevistes, etc. tot relacionat amb aquesta temàtica.

* PROTEGeleS.COM (http://www.protegeles.com). Organització de protecció al menor en Internet que proporciona informació a la seua web com pot ser com actuar front a un problema, recursos, guies, estudis, vídeos, etc. I informació concreta dirigida a pares i mares, alumnes o professors amb una sèrie de normes, responsabilitats, activitats, etc.

* YO CONTROLO (http://www.yocontrolo.es/).Trobarem informació sobre casos de pèrdua de privacitat o ciberbullying, recursos com guies, webs, vídeos, estudis, etc.

\section{VÍDEOS}

* Ciberacoso (Childnet International - Cyber Bullying). Caso de ciberbullying subtitulado español.https://www.youtube.com/watch?v=9bgdOuBn4Q4

* Ciberbullying: ciberacoso en redes sociales, videogames, smartphones... y su prevención.https://www.youtube.com/watch?v=SEC dOWFN5M\&index=1\&list= PLC186BF9FE0418ED2

* ¿Cómo actuar ante el ciberacoso? Ignora, bloquea, pide ayuda y denuncia. https://www.youtube.com/watch?v=tVAjiyNzYq0\&list=PLC186BF9FE0418ED2\&in $\underline{\operatorname{dex}=7}$

* Recomendaciones para el Uso Seguro de Internet y las Redes Sociales. https://www.youtube.com/watch?v=t$\underline{x 73 w 1 N 10 s \& l i s t=P L C 186 B F 9 F E 0418 E D 2 \& \text { index }=12}$

* ¿Cómo evitar ser víctima de ciberbullying por suplantación de identidad? https://www.youtube.com/watch?v=XQeFYgedVZg\&list=PLC186BF9FE0418ED2\& index $=15$

* Decálogo por la ciberconvivencia positiva y contra la violencia digital. https://www.youtube.com/watch?v=gXvG53ccyJY\&index=17\&list=PLC186BF9FE 0418ED2 
ANEXO 12. CUADERNO DE ACTIVIDADES COMPLEMENTARIAS PARA EL PROFESORADO DE EDUCACIÓN PRIMARIA DEL PROGRAMA "CONVIURE EN UN MÓN REAL I DIGITAL".

ACTIVITATS

COMPLEMENTARIES

del programa

Conviure en un món real $i$ digital

CENTRE:

PROFESSOR/A:

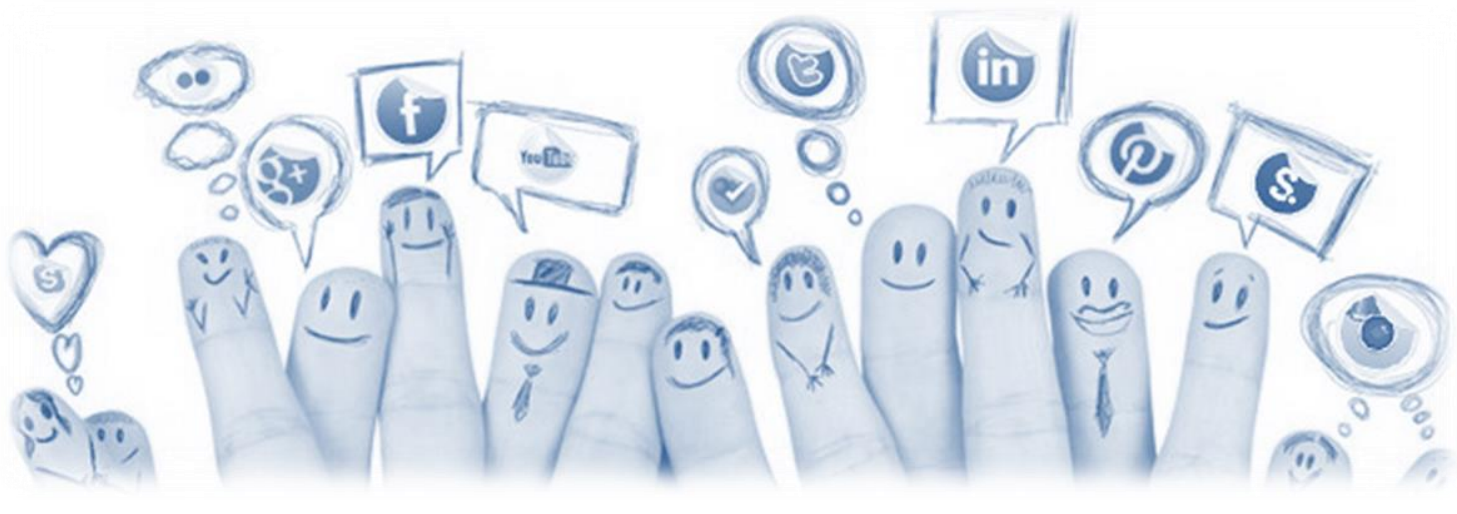

1 


\section{ÍNDEX}

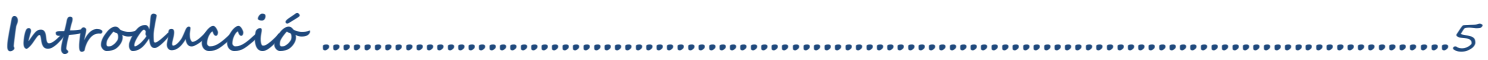

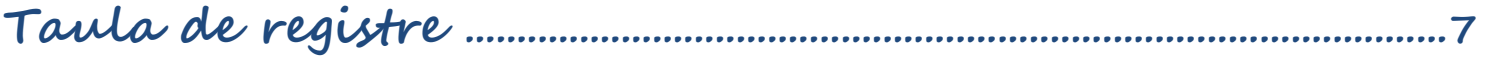

\section{Activitats.}

Autoestima

Emocions

Autocontrol

Prevenció $i$ resolució de conflictes

Empatia

Assertivitat

Ciberbullying 25

Recursos

Fitxa de registre. 


\section{INTRODUCCIÓ}

Aquest document recull un conjunt d'activitats complementaries al programa Conviure en un món real i digital. Es tracta d'un total de quaranta activitats, classificades en huit temàtiques, que són les que es treballen al programa classificades, segons el curs educatiu en el que s'imparteixen, de la següent forma:

Tercer i quart de primària:

- Autoestima.

- Emocions.

- Autocontrol.

- Prevenció i resolució de conflictes.

- Bon ús de les TIC.

Cinquè i sisè de primària:

- Empatia.

- Assertivitat.

- Ciberbullying.

- Prevenció i resolució de conflictes.

- Bon ús de les TIC.

Aquest conjunt d'activitats complementaries van dirigides a tots aquells professors i professores del centre, sobretot a aquells que treballen amb els alumnes de tercer, quart, cinquè $\mathrm{i}$ sisè de primària, doncs són aquests els que estan treballant el programa.

Les activitats es troben classificades per temàtiques. Al principi de cadascuna d'elles es pot veure una definició del concepte que s'està treballant, i al principi del document es presenta una taula on es pot anar anotant quines activitats s'han realitzat i a quin curs educatiu.

El document finalitza amb un apartat de recursos específicament de ciberbullying: guies, enllaços de pàgines web i vídeos, amb els que es pot completar més la temàtica del ciberbullying, doncs és l'eix central del programa Conviure en un món real i digital. A més d'un document anomenat fitxa de registre per a anotar les activitats que es realitzen, a quina assignatura i curs. 


\begin{tabular}{|c|c|c|c|}
\hline $\begin{array}{c}\text { TEMÀTICA } \\
\text { TRANSVERSAL }\end{array}$ & $\begin{array}{l}\text { REG } \\
\text { FITX }\end{array}$ & $\begin{array}{l}\text { REDE } \\
\text { FETES }\end{array}$ & CURS \\
\hline \multirow{5}{*}{ Autoestima } & 1 & & \\
\hline & 2 & & \\
\hline & 3 & & \\
\hline & 4 & & \\
\hline & 5 & & \\
\hline \multirow{5}{*}{ Emocions } & 6 & & \\
\hline & 7 & & \\
\hline & 8 & & \\
\hline & 9 & & \\
\hline & 10 & & \\
\hline \multirow{5}{*}{ Autocontrol } & 11 & & \\
\hline & 12 & & \\
\hline & 13 & & \\
\hline & 14 & & \\
\hline & 15 & & \\
\hline \multirow{5}{*}{$\begin{array}{l}\text { Prevenció i resolució de } \\
\text { conflictes }\end{array}$} & 16 & & \\
\hline & 17 & & \\
\hline & 18 & & \\
\hline & 19 & & \\
\hline & 20 & & \\
\hline \multirow{5}{*}{ Bon ús de les TIC } & 21 & & \\
\hline & 22 & & \\
\hline & 23 & & \\
\hline & 24 & & \\
\hline & 25 & & \\
\hline \multirow{5}{*}{ Empatia } & 26 & & \\
\hline & 27 & & \\
\hline & 28 & & \\
\hline & 29 & & \\
\hline & 30 & & \\
\hline \multirow{5}{*}{ Assertivitat } & 31 & & \\
\hline & 32 & & \\
\hline & 33 & & \\
\hline & 34 & & \\
\hline & 35 & & \\
\hline \multirow{5}{*}{ Ciberbullying } & 36 & & \\
\hline & 37 & & \\
\hline & 38 & & \\
\hline & 39 & & \\
\hline & 40 & & \\
\hline
\end{tabular}




\section{AUTOESTIMA}

Acceptació, valoració $i$ estima cap a un mateix.

\section{* aCTIVITAT 1:}

Objectiw. Elaborar una imatge positiva i realista de si mateix.

Descripció. Cada alumne realitza un dibuix d'ell, on es veu la seua cara, el seu cos, el seu voltant... Després de tenir els dibuixos finalitzats cada alumne es posa al centre de la classe i ensenya el seu dibuix i els companys han de destacar allò bo que té el seu company i que veuen reflectit al dibuix, i li recorden també els aspectes positius que té $\mathrm{i}$ que no ha reflectit al dibuix.

Recursoy. Fulls blancs, llapis i colors.

\section{* ACTIVITAT 2:}

Objectiw. Ser conscients de la importància de les nostres valoracions en l'autoestima dels altres.

Descripció. En grup, escollim a un alumne que es situarà al centre d'un cercle que formarem nosaltres. A aquest alumne l'enrotllarem amb paper de forma que no es puga moure, i explicarem que així és com ens sentim quan no ens sabem valorar bé, ens sentim atrapats, sense poder fer res, menuts, fràgils... Cada alumne s'aproximarà a aquest alumne i escriurà a un full de paper que està al seu costat alguna cosa positiva relacionada amb aquest, per exemple, sempre escolta quan algú li conta alguna cosa, és molt bon amic, és simpàtic, etc. Una volta tots han escrit alguna cosa sobre eixe company, el professor anirà llegint totes les frases que han escrit sobre eixe alumne i ell poc a poc s'anirà lliurant del paper. El professor els fa reflexionar sobre com es sentia quan estava enrotllat amb el paper, i la importància i el benestar que causa en nosaltres les paraules positives que els altres ens diuen i com així augmenta la nostra autoestima.

Recursoy: Roll gran de paper, bolígrafs o llapis i fulls de paper blanc. 


\section{* ACTIVITAT 3:}

Objectiu. Conèixer quines coses afecten positivament o negativament a la nostra autoestima.

Descripció. Cada alumne escriu a un full coses que li han ocorregut durant l'última setmana i les classificarà en dos columnes segons si els ha fet sentir bé o malament, per exemple ha quedat amb un amic per a jugar, ha ajudat a la mare en casa, s'ha barallat amb un amic, etc. Després llegirem tots en veu alta les coses que ens han ocorregut i que ens han fet sentir bé i les que ens han fet sentir malament, i el professor els ajudarà a reflexionar sobre aquestes situacions de forma que se n'adonen sobre què poden fer per a solucionar i canviar allò que els fa sentir malament i afecta negativament a la seua autoestima amb la finalitat de sentir-se millor.

Recursoy:Fulls blancs i llapis.

\section{* aCTIVITAT 4:}

Objectiw. Reflexionar sobre tots aquells aspectes que tenim oblidats i que són importants en la nostra autoestima.

Descripció. Cada alumne realitzarà una descripció on proporcionarà informació sobre el seu aspecte físic, habilitats físiques, manera de ser, com es relaciona amb els altres, capacitat d'estudi, coneixements de certs aspectes com música o dibuix, com et veuen els altres, etc. Es a dir, una descripció on es detallaran molts aspectes de forma que quan acaben reflexionaran tots junts comentant si els ha resultat fàcil o difícil fer aquesta descripció, si alguna volta havia pensat en tots aquests aspectes abans, si fer la descripció li ha ajudat a conèixer-se millor...

Recursos. Fulls blancs i llapis.

* ACTIVITAT 5:

Objectiw. Aprendre a comunicar als companys tot allò que pensem d'ells i que els ajudarà a augmentar la seua autoestima.

Descripció. Imaginem que ens en tenim que anar de viatge, i abans d'emprendre el viatge cal parar-nos a pensar i recordar quins aspectes dels nostres companys recordaríem si hui viatjarem a un altre lloc. Fem grups de cinc alumnes $i$ cadascú ha d'escriure una cosa que recordaria de cadascun dels altres quatre companys. Després tots junts ho comentaran de forma que se n'adonaran de com 
els recordarien els companys, si ells també es veuen així, si tots coincideixen més o menys en les mateixes coses... Emfatitzarem els aspectes positius i els farem veure que si són recordats per alguna cosa que els consideren negativa, estan a temps de canviar-la, perquè es tracta d'un viatge simulat i està en les seues mans canviar allò d'ells que no els agrada.

Recursos: Fulls blancs i llapis. 


\section{EMOCIONS}

\section{Estat complex de L'organisme caracteritzat per una}

excitació o pertorbació que predisposa a una resposta organitzada

\section{ACTIVITAT 6:}

Objectiw. Adonar-se de com expressem el que sentim a través del nostre cos i ser conscient del que ens transmet.

Descripció. Per parelles, un dels dos fa d'artesà i l'altre d'escultura. Així l'escultor ha de plasmar en l'escultura el que ell sent canviant-li la posició del cos, el gest de la cara, etc. Una volta l'escultor ha transmès com es sent a través de l'escultura, l'alumne que ha fet d'escultura ha d'endevinar com creu que es sent l'escultor per la postura, gestos, etc. que li ha fet prendre. Després es canvien els rols.

Recursoy: Espai ampli.

\section{ACTIVITAT 7:}

Objectiu. Diferenciar les emocions i expressar-les artísticament.

Descripció. Parlem de les emocions en gran grup i escollim sis emocions. Dividim la classe en sis grups, de forma que a cada grup li pertany una emoció. A partir de l'emoció que els pertoqui, a una cartolina i amb l'ajuda de retalls de revistes, periòdics, colors, etc. aniran formant un collage on es representi eixa emoció. Quan ho finalitzen, un membre de cada grup explicarà a la classe què representa el seu collage i perquè ho han elegit així.

Recursoy: Cartolines, revistes, periòdics, tisores, pegament, colors, etc. 


\section{* ACTIVITAT 8:}

Objectiw. Associar i representar emocions de successos de la vida diària.

Descripció. Cada alumne escriu a un foli una situació que li ha fet sentir una determinada emoció, per exemple, un dia es va barallar amb el seu germà i es va sentir trist. Una volta tinguin tots escrita la situació, eixiran d'un en un i representaran sense parlar eixa escena,es a dir, nomes amb gests, moviments, etc. de forma que els companys han d'endevinar quina emoció ha sentit.

Recursos: Foli blanc i llapis.

\section{* aCTIVITAT 9:}

Objectiw. Expressar emocions a partir d'una imatge i acceptar la diversitat d'emocions.

Descripció. Elegim quatre fotografies que transmeten alguna emoció i les anirem ensenyant als alumnes. Ensenyarem les fotografies d'una en una i els alumnes ens han de dir quina emoció els transmet i ho anotarem a la pissarra així quan ja haguem mostrat les quatre fotografies podrem veure la diversitat de sentiments que ha generat cadascuna i reflexionarem sobre aquest fet. Es a dir, ens adonarem que front a una mateixa situació cadascú pot sentir diferent, i que no és millor ni pitjor que la resta dels sentiments.

Recursos: Quatre fotografies, pissarra i clarió.

\section{* ACTIVITAT 10:}

Objectiv. Identificar emocions i regular la seua expressió.

Descripció. Escollim una noticia que sigui propera als alumnes, alguna cosa que ha ocorregut prop, gent de la seua edat implicada, etc. Llegim aquesta noticia en veu alta i els alumnes han de dir com creuen que es senten les persones que ho han sofert o que estan implicades. Després debatrem tots junts les reaccions emocionals que ens ha fet sentir aquesta noticia i tractem de regular aquesta emoció. Per exemple si és una noticia d'esport on el nostre equip ha perdut hem de saber que no sempre es pot guanyar i que algunes voltes es perd i no per això ens tenim que posar tristos. Es a dir, cal donar respostes emocionals reflexives que ens ajuden a encontrar el benestar personal i en grup.

Recursos: Noticia del periòdic. 


\title{
AUTOCONTROL
}

\author{
Gestionar de forma adequada les emocions $i$ els \\ impulsos conflictius.
}

\section{* ACTIVITAT 11:}

Objectiw. Reflexionar sobre les reaccions de situacions viscudes i sobre com es poden millorar aquestes reaccions.

Descripció. Cada alumne ha de pensar una situació en la que s'haja enfadat. El professor planteja unes qüestions sobre les que han de reflexionar, com són: per què em vaig enfadar, com em vaig sentir, que vaig aconseguir enfadant-me? o haguera aconseguit alguna cosa millor si no m'haguera enfadat?. Comentem tots junts els casos de cadascú i les respostes a aquestes preguntes amb les que ens adonarem que moltes voltes ens enfadem i reaccionem instintivament però que si ens pararem a pensar en com podríem actuar per a beneficiar-nos segurament no ho faríem de la mateixa forma que quan actuem sense pensar.

Recursoy. Cap material concret, encara que es pot escriure en paper i llapis i després comentar-ho.

* ACTIVITAT 12:

Objectiw. Aprendre a controlar els nostres impulsos front a actuacions dels altres.

Descripció: Anem a fer un joc que consisteix en que els alumenes es posen per parelles i un dels dos ha de quedar-se quiet mentre que l'altre fa cares, es riu d'ell, li diu coses, etc. L'altre alumne s'ha de mantenir immòbil i en silenci, es a dir ha que controlar la seua reacció front a una provocació. Reflexionarem que moltes voltes ens resulta complicat aguantar certs comportaments dels altres però hem d'aprendre a controlar els nostres perquè així aconseguirem que els altres no ens tracten així.

Recursoy: No es necessari cap material. 


\section{* ACTIVITAT 13:}

Objectiw. Aprendre a treballar reflexivament i relaxadament, evitant la impulsivitat.

Descripció. Pintar un dibuix que sigui complex, amb la finalitat de pintar-lo tot per dins sense eixir-se'n. Així aconseguirem a controlar la nostra impulsivitat de treballar apresa. Ens podem plantejar preguntes com el que volem és pintar bé el dibuix aleshores que puc fer? Aconseguiré alguna cosa si em posi nerviós? Com ho he de fer?, És millor començar a pintar els bordes i després per dins més apresa així eviti eixir-me'n?... Es tracta de controlar els nostres actes per a aconseguir allò que busquem, en aquest cas pintar bé el dibuix.

Recursos. Un dibuix per a pintar i colors.

\section{* ACTIVITAT 14:}

Objectiv. Exercitar l'autocontrol amb el joc.

Descripció. Fem un llistat de paraules i posem normes, per exemple: vaig dient paraules i cada volta que digui la paraula ma cal pegar una palmada, dir una sèrie de paraules i quan aparegui la paraula taula cal asseure.... Es tracta d'un joc on juga tota la classe i on mitjançant les instruccions del professor els alumnes han de seguir unes normes que estableix.

Recursos: Preparar un llistat de paraules i de normes.

\section{* ACTIVITAT 15:}

Objectiv. Aprendre a reaccionar controladament.

Descripció. Els alumnes es posen en situació de fer una cursa de velocitat, on guanya el que aplega abans a la meta, però han de tenir molta cura per a fer l'eixida, ja que el professor serà el que la marcarà, i nomes serà vàlida l'eixida quan es digui la paraules JA, però si el professor diu una altra paraula com Jaume, jaciment, jazz, javelina, etc. Es a dir, paraules que comencen en ja però que no són ja, i aquestos eixen, aquests seran eliminats.

Recursoy. Espai ampli i llistat de paraules que comencen per ja. 


\title{
PREVENCIÓ I RESOLUCIÓ DE CONFLICTES
}

\author{
Evitar i solucionar discrepancies entre dos $\sigma$ més \\ interessos simultanis que algunes voltes donen lloc \\ a un estat de tensió emocional que comporta estats \\ d'ansietat $i$ comportaments impulsius.
}

\section{* ACTIVITAT 16:}

Objectiw. Aprendre a detectar la causa del conflicte i veure quina és la millor solució.

Descripció. Fem una dramatització d'una acció conflictiva entre diverses persones. Realitzem la dramatització a l'aula i en el moment en el que s'exposa el problema, es a dir, quan surt el conflicte, aturem l'escena i estudiem com podríem reaccionar a aquesta situació i quina seria la que més ens beneficiaria.

Recursoy. Escenes on es produeix un conflicte.

\section{* ACTIVITAT 17:}

Objectiw. Desenvolupar la capacitat collectiva de prendre decisions i resoldre conflictes.

Descripció. Fem una tela d'aranya amb cordes o gomes, i diem als alumnes que es troben atrapats i necessiten eixir perquè dins hi ha una bomba que pot esclatar. Nomes es salvaran si aconsegueixen sortir tots per la tela d'aranya, per això és molt important que s'ajuden els uns als altres. La reflexió final és que quan ens trobem amb un problema cal pensar bé que fer i si tenim ajuda dels altres i confiem amb ells segur que ens poden ajudar a resoldre'l millor, no cal enfadar-nos ni actuar precipitadament.

Recursoy: Corda o goma llarga i un lloc on nugar-los. 
* ACTIVITAT 18:

Objectiw. Aprendre paraules i expressions per a evitar conflictes.

Descripció. Per grups de 4 o 5 alumnes fem un mural amb paraules i expressions que inciten o no al conflicte. Per exemple, demanar les coses per favor, no cridar, donar les gràcies, parlar amb un to correcte, etc. Amb aquesta activitat aprenem quines accions faciliten o eviten els conflictes entre els companys.

Recursoy: Cartolines blanques, llapis i colors.

\section{ACTIVITAT 19:}

Objectiw. Analitzar una situació conflictiva i aprendre a resoldre-la adequadament.

Descripció: Presentem una situació conflictiva i tots junts la comentem: què ocorre?, com reaccionen els personatges?, quina és la causa?, com actuen?, hi hauria una forma millor d'actuar?, què aconsegueixen actuant així?, i si actuen d'una altra forma que aconseguirien?, etc. Els alumnes han de reflexionar sobre la situació i veure que les accions es produeixen per unes raons però que hi ha moltes formes d'actuar front a un problema i que sempre cal evitar el conflicte.

Recursoy: No es necessari cap material.

* ACTIVITAT 20:

Objectiu. Descobrir quines situacions conflictives són més freqüents i aprendre a resoldre-les adequadament.

Descripció. Fer un llistat cadascú dels conflictes que més a sovint s'encontren, i pensar cadascú com reaccionen en eixos moments i si hi hauria una forma millor de reaccionar per a aconseguir una relació més positiva amb els altres. Després es posen totes les situacions en comú per a veure si solen coincidir i així uns ajuden als altres a trobar la millor forma d'actuar quan es troben en una situació així.

Recursos. Fulls de paper i llapis. 


\section{BON ÚS DE LES TIC}

Utilitzar adequadament $i$ amb responsabilitat Internet i les noves tecnologies.

* ACTIVITAT 21:

Objectiw. Conèixer els avantatges i desavantatges de l'ús d'Internet.

Descripció. Visualitzar tots junts el següent vídeo (Las 10 claves para utilizar Internet con seguridad: https://www.youtube.com/watch?v=2TferQprZOgO) i comentar els avantatges i desavantatges de la utilització d'Internet. Fem un llistat a la pissarra del avantatges i desavantatges que considerem que té l'ús d'Internet.

Recursoy.

\section{* ACTIVITAT 22:}

Objectiw. Ser conscients de la funcionalitat real de l'ordinador.

Descripció. Realitzarem un treball a ordinador, que després portaran imprès, en el que tindran que buscar a casa informació sobre una temàtica concreta. Així aprenen a buscar informació en la xarxa i a realitzar un treball amb el processador de textos, de forma que reflexionen que l'ordinador no serveix únicament per a l'oci sinó també per a aprendre.

Recursos: Ordinador amb connexió a Internet i impressora.

\section{* ACTIVITAT 23:}

Objectiw. Crear un blog.

Descripció. Crear tots junts a classe un blog sobre una temàtica que als alumnes els resulte interessant, i cada setmana actualitzar-la a classe amb informació que els alumnes aporten nova. Algunes de les pàgines per a crear blogs són; Blogger, WordPress, Tumblr, entre altres

Recursoy. Pantalla i accés a Internet. 


\section{* ACTIVITAT 24:}

Objectiu. Adonar-se de l'ús que fem en el nostre dia a dia de les TIC i racionalitzar el seu ús.

Descripció. Tots junts realitzem un llistat d'activitats que realitzem en el nostre dia a dia utilitzant les Tecnologies de la Informació i la Comunicació i com ens sentim quan no les podem utilitzar, primer fem cadascú un llistat individual i després ho posem en comú. Ens adonem que són moltes les activitats i hores que passem al dia amb aquests dispositius, i que caldria fer un horari amb el temps que devem utilitzar al dia amb aquests dispositius i la importància del seu ús adequat.

Recursoy. Foli de paper i llapis.

\section{ACTIVITAT 25:}

Objectiv. Ser conscients de la importància que els adults coneguin l'ús que fem de les TIC.

Descripció: Cal utilitzar les Tic en companyia d'un adult i que ells sàpiguen en tot moment que estem utilitzant-les i què estem fent, i també poder acudir a ells si ens trobem amb alguna cosa que no ens agrada a la xarxa o necessitem ajuda per a fer alguna cosa. Per això realitzarem un debat entre els alumnes en que debatrem la importància que els adults estiguen assabentats del que fem quan utilitzem les TIC, i perquè creuen que és important tenir a un adult al costat.

Recursos: No és necessari cap material. 


\section{EMPATIA}

\section{Capacitat de percebre $i$ comprendre els sentiments $i$ les emocions dialtres persones.}

\section{* ACTIVITAT 26:}

Objectiu. Reconèixer la possible distorsió de les emocions quan ens comuniquem.

Descripció. Aquesta activitat es tracta d'un joc on els alumnes han de fer una o varies files de unes deu persones. Es situen un enrere l'altre tots mirant cap al mateix lloc, de forma que el que es queda l'últim a de transmetre amb gestos corporal i facials una emoció al de davant però cap més mira. Després és el segon el que transmet al tercer, i així successivament, nomes mira el que està davant, ningú més. Una volta han arribat al primer de la fila aquest transmet en veu l'emoció que li han transmès $i$ tots junts veuen si coincideix o no amb la primera. Amb aquest joc es pot reflexionar que moltes voltes un gest es pot distorsionar $i$ que per això és molt important fixar-nos bé en el que els altres fan per a conèixer bé com es senten.

Recursoy: Espai ampli.

\section{ACTIVITAT 27:}

Objectiw. Compartir emocions amb els companys.

Descripció. Per parelles, cadascú li conta a l'altre company alguna historia o anècdota que ha viscut. A partir d'aquest, l'altre company fa un dibuix mostrant en ell les emocions que li ha transmès el company i que comparteix amb ell quan li ho ha contat.

Recursoy: Folis blancs, llapis, colors, etc. 


\section{- ACTIVITAT 28:}

Objectiw. Aprendre a distingir els sentiments del altres.

Descripció. Cadascú dels alumnes escriu un missatge contant alguna cosa. Posem tots els missatges junts a una caixa i cada alumne aleatòriament en agafa un. Cada alumne llig el missatge que li ha pertocat $\mathrm{i}$ anota vaig quin sentiment creu que ha sentit la persona que ha escrit eixe missatge a l'escriure'l o quan va viure el que ha escrit. Eixiran un per un i llegiran en veu alta el missatge i el sentiment que a ell si ha transmès.

Recursoy. Folis blancs i llapis.

\section{* ACTIVITAT 29:}

Objectiw. Distingir les emocions que es transmeten als escrits.

Descripció. El professor escull poesies curtes que expressen un sentiment, les conta en veu alta a tota la classe i tots junts comenten com creuen que es sentia l'autor o el protagonista d'eixa poesia en eixe moment.

Recursoy: Poesies curtes adequades al nivell dels alumnes.

\section{* ACTIVITAT 30:}

Objectiw. Aprendre a posar-se en diferents punts de vista.

Descripció. El professor escull una escena curta amb dos personatges, on hi haja una confrontació d'opinions. Els alumnes treballen per parelles de forma que cada alumne representarà a un dels dos personatges, i després canviaran els papers. Així els alumnes se n'adonen que quan pensem i opinem alguna cosa és difícil posar-se en el lloc de l'altra persona però al mateix temps és molt important perquè alguna volta ens podem trobar nosaltres en eixa situació.

Recursoy. Escrit d'una escena curta de dos personatges. 


\title{
ASSERTIVITAT
}

\author{
Capacitat d'expressar els propis sentiments, \\ necessitats $i$ drets al mateix temps que es respecten \\ els sentiments, drets $i$ necessitats dels altres.
}

\section{* ACTIVITAT 31:}

Objectiw. Afavorir les expressions individuals i en grup.

Descripció: Es fa un cercle i es collloca un baló al mig. Un alumne que vulgui agafa el baló i fent un gest com una acaricia, una rialla, un bes al baló, etc. i després li passa el baló a la persona a la que va dirigit aquest gest. Aquesta persona torna a respondre amb un gest a la pilota a la persona que inicialment li ha transmès el gest, quan acaba torna el baló al centre i serà un altre company el que l'agafi per a tornar a enviar un missatge a un altre company.

Recursoy: Espai ampli i un baló.

* ACTIVITAT 32:

Objectiw. Expressar la opinió lliurement sense atendre les opinions dels altres.

Descripció. Dibuixar a la pissarra una línea i preguntar a cadascú dels alumnes quina creuen que és la seua mesura. Cada alumne dirà una mesura, tal volta alguns coincidiran, i altres diran el que han dit uns altres per por a expressar el que senten. En aquesta activitat el que es pretén és que cadascú expressi el que opini, sense por a res, ja que tots tenim dret a opinar i no aquella resposta que és la que més coincideix és la correcta o més adequada, per això sempre cal confiar en nosaltres i expressar adequadament el que pensem.

Recursos: Clarió i pissarra.

\section{* ACTIVITAT 33:}

Objectiw. Aprendre a respondre assertivament en diferents situacions.

Descripció. Plantejar als alumnes diferents situacions en les que ocorren coses com: dos alumnes es topen de cara i a un li cau el que portava a la mà, dos companys es troben a un aniversari i sense voler agafa el tros de patís de l'altre, un 
xiquet li agafa un joguet a l'altre, etc. Plantegem aquestes situacions que podem representar, i entre tots fem un llistat de paraules a la pissarra que podríem utilitzar en situacions com aquestes, per exemple per favor, ho senc, no era la meua intenció, gràcies, etc. Han d'aprendre que front a situacions com aquestes cal respondre assertivament i així aconseguirem millorar les relacions amb els altres.

Recursos:Pissarra i clarió.

\section{ACTIVITAT 34:}

Objectiw. Aprendre a dir que no quan no estan d'acord en realitzar certa acció.

Descripció. Fem individualment un mural on els alumnes expressaran allò que volen i els agrada fer i allò que no volen i que no els agrada fer. Poden realitzar-lo amb frases, imatges de revistes, dibuixant amb colors... Una volta ho tenen finalitzat ho ensenyen a la resta de la classe i els explica quines coses li agraden i quines no, de les coses que no els agrada fer el professor li plantejarà una pregunta. Per exemple si un alumne diu que no li agrada que algun company li digui el que ha de fer, aleshores li preguntarem, què faries si Carles et diu el que has de fer? Li respondries que si o no? A partir d'aquesta pregunta els fem reflexionar que han de aprendre a defendre les seues idees i que quan algú els pregunti o els digui fer alguna cosa en la que no estan d'acord i que els portarà conseqüències negatives ells tenen el dret a defendre les seues idees i dir que no estan disposats a fer-ho perquè els perjudica.

Recursoy: Cartolina blanca, revistes, colors, llapis, tisores, pegament, etc.

\section{ACTIVITAT 35:}

Objectiw. Expressar un elogi i respondre assertivament a aquest.

Descripció. Cada alumne escriu una carta a un company on expressa el que opina positivament d'eixe company. Amb aquesta activitat aprenen a elogiar als companys i després hauran de donar resposta a aquest elogi utilitzant un vocabulari assertiu i adequat a la situació, per a agrair les paraules del company.

Recursos: Foli blanc i llapis. 


\section{CIBERBULLYING}

Quan un xiquet $\sigma$ adolescent és turmentat, amenaçat, assetjat, humiliat, molestat d'una manera o una altra, per un altre nen $\sigma$ adolescent mitjançant l'ús d'lnternet, tecnologies interactives $i$ digitals $\sigma$ telèfon mòbil.

\section{* ACTIVITAT 36:}

Objectiw. Aprendre a distingir què és el ciberbullying.

Descripció. Es fan grups de 4 alumnes, on cada grup té que elaborar un mural amb informació relacionada amb el ciberbullying com què és; quins tipus hi ha, que és i que no és ciberbullying, etc. Per exemple enviar fotos de companys per a riures d'ells, enviar missatges ofensius, etc. serien conductes de ciberbullying. Aquests murals poden ser un collage amb retalls de revistes, junt amb dibuixos, etc. Després cada grup presenta a la classe el seu treball i l'explica. Els es fa saber que certes accions incorrectes poden portar a estar exercint ciberbullying que es molt perillós i cal evitar aquest tipus d'accions.

Recursoy: Cartolines, revistes, tisores, pegament, colors, etc.

\section{* ACTIVITAT 37:}

Objectiw. Analitzar una situació on es produeix ciberbullying.

Descripció. Visualitzar el video: Ciberacoso (Childnet International - Cyber Bullying). Caso de ciberbullying subtitulado español. https://www.youtube.com/watch?v=9bgdOuBn4Q4. Després tots junts analitzar què ocorre al vídeo: què ocorre, quins són els protagonistes, que li ocorre a cadascú, quin problema hi ha, a qui cal acudir quan ens troba amb el problema, com resolen el problema, com d'important és, etc.

Recursoy. Pantalla i accés a Internet. 


\section{* ACTIVITAT 38:}

Objectiw. Crear un campanya contra el ciberbullying.

Descripció. Crear per grups una campanya publicitària contra el ciberbullying. Cal buscar primer informació, i després crear un eslògan i una imatge, que publicite que estan en contra del ciberbullying i que cal eradicar aquesta problemàtica social. Per a arribar a aquest punt seria important fer-los abans una xicoteta xerrada explicant-los ben bé què és, què implica, com de perillós és, etc. Els poden posar aquest vídeo: https://www.youtube.com/watch?v=lbVoGm9k0cl on s'explica què és el ciberbullying i la seua importància.

Recursoy: Pantalla, accés a Internet, cartolines, llapis, imatges, etc.

\section{ACTIVITAT 39:}

Objectiv. Ser conscients de la importància del ciberbullying.

Descripció. Llegir als alumnes una noticia de ciberbullying on es reflexen les conseqüències que aquestes accions tenen en els agressors i les víctimes, com per exemple aquesta: Detenido un menor que amenazaba a una joven con difundir sus fotos

http://www.elmundo.es/elmundo/2010/08/10/madrid/1281433812.html. A partir d'aquesta noticia reflexionem tots junts sobre la importància i el perill del ciberbullying, tan per a la víctima com per a l'agressor, i la necessitat de previndrelo o d'avisar a un adult si sabem que algú ho està sofrint.

Recursos: Noticia relacionada amb el ciberbullying.

\section{* ACTIVITAT 40:}

Objectiu. Conèixer als implicats en el ciberbullying i el paper d'aquests.

Descripció. Realitzar un còmic cadascú en el que es mostri una situació de ciberbullying, per a fer-lo tenen que imaginar abans quin és el sentiment que experimenten les tres parts implicades: víctima, agressor i observador. A partir d'aquestos tres personatges crear un còmic que simule una escena de ciberbullying. Reflexionaran una volta realitzat sobre el paper de cada un i el perill que comporta el ciberbullying i la necessitat d'eradicar-lo i prevenir-lo.

Recursos: Folis, llapis, colors, etc. 


\section{RECURSOS}

\section{GUIES}

* Junta de Castilla y León (2011). Manual de uso inteligente de las nuevas tecnologías para los alumn@s. De 8 a 10 años. Recuperado de: http://www.cyldigital.es/sites/default/files/library/manual810anosprogramaaprende.pdf

* Junta de Castilla y León (2011). Manual de uso inteligente de las nuevas tecnologías para los alumn@s. De 10 a 12 años. Recuperado de: https://www.cyldigital.es/sites/default/files/library/manual10-

12anosprogramaaprende.pdf

Concepte de noves tecnologies, informació sobre els videojocs, televisió, ordinador i Internet. També ens ofereixen informació sobre els riscs que podem trobar en la xarxa. A més, ens proporcionen informació sobre els e-drets dels xiquets i xiquetes i una sèrie de regles que es necessari que els menors coneguin a I'hora d'utilitzar les noves tecnologies.

* INTECO (2013). Guía de actuación contra el ciberacoso. Padres y educadores. Recuperado de: http://www.injuve.es/sites/default/files/2013/46/publicaciones/Gu\%C3\%ADa\%20 de\%20actuaci\%C3\%B3n\%20contra\%20el\%20ciberacoso.pdf

Concepte de ciberbullying, pautes de detecció, prevenció i actuació, i comportar a capel procés de denuncia i el delicte que comporta. També trobarem una sèrie d'experiències de casos de ciberbullying i altres riscos de l'ús de les TIC, així comconsells bàsics sobre l'ús de les noves tecnologies.

* Centro se Seguridad en Internet Protégeles (s.f.). Ciberbullying y privacidad. Guía para profesores. Recuperado de: http://www.yocontrolo.es/descargas/PROYECTO DAPHNE ES.pdf

Continguts teòrics relacionats amb el ciberbullying: concepte, qui intervé, prevenció, etc., i també altres sobre la privacitat: drets i deures, protecció de dades i delictes. També trobarem a aquests document una sèrie d'activitats per a treballar el ciberbullying i la privacitat en Internet. 
* Comisión de libertades e informática (2009). Proyecto CLI Prometeo. Manual práctico de uso de las tecnologías de la información. 9 a 11 años. Recuperado de: http://www.madrid.org/dat oeste/descargas/08 09/cli prometeo/Manual 911 castellano.pdf

Conjunt d'activitats on es treballen els diferents aspectes relacionats en l'ús de les tecnologies de la comunicació i la informació a partir d’històries relacionades amb I'ús que els menors fan d'aquestes tecnologies.

* Collell, J. y Escudé, C. (2008). No te enredes en la red. Guía para conocer el ciberbullying y algunos peligros de internet y las nuevas tecnologías. Recuperado de: http://www.xtec.cat/ jcollell/ZGuia\%20Ciber.pdf

Informació teòrica com el concepte de ciberbullying i conductes relacionades amb el ciberbullying. Presenta un conjunt d'activitats on a partir d'una sèrie d'històries es presenten qüestions per a debatre en grup sobre les conductes que es presenten a les històries.

Luengo, J. A. (2014). Ciberbullying. Prevenir y actuar. Guía de recursos didácticos para Centros Educativos. Recuperado de: http://www.copmadrid.org/webcopm/recursos/CiberbullyingB.pdf

Situació de l'ús de les TIC en els últims anys, conceptes teòrics sobre el ciberbullying i informació sobre diferents tècniques de treball del ciberbullying. En aquesta guia ens proporcionen també pautes i materials per la prevenció a partir de l'alfabetització digital des de l'educació primària. A més, la guia ens proporciona moltes activitats didàctiques per a portar a terme a les aules i un protocol d'intervenció ben desenvolupat amb materials i pautes tan per a pares com per a professors i alumnes. Finalitza amb una sèrie de referències normatives per a la reflexió i acció en el centre escolar.

* Fundación Dédalo (2012). Por un uso seguro de internet. Primaria. Recuperado de:http://www.disfrutalared.com/images/yootheme/fichas didacticas/FichasDida cticasPrimaria es.pdf

Conjunt d'activitats relacionades amb l'ús segur d'Internet on es treballen aspectes com els valors, el ciberbullying, la privacitat, etc. 


\section{PÀGINES WEB}

* PANTAllas aMigas (http://www.pantallasamigas.net). És la web més completa, i la pionera en la temàtica, que existeix on encontrarem recursos relacionats amb l'ús segur i saludable de les noves tecnologies de tot tipus: articles, vídeos, definicions de conceptes, materials i recursos didàctics, etc.

* CIBERBUllying (http://www.ciberbullying.com). A la web trobarem informació sobre el ciberbullying, recursos de prevenció, consells contra el ciberbullying, noticies, articles, entrevistes, etc. tot relacionat amb aquesta temàtica.

* PROTEgeles.COM (http://www.protegeles.com). Organització de protecció al menor en Internet que proporciona informació a la seua web com pot ser com actuar front a un problema, recursos, guies, estudis, vídeos, etc. I informació concreta dirigida a pares i mares, alumnes o professors amb una sèrie de normes, responsabilitats, activitats, etc.

* yo controlo (http://www.yocontrolo.es/).Trobarem informació sobre casos de pèrdua de privacitat o ciberbullying, recursos com guies, webs, vídeos, estudis, etc.

\section{VIIDEOS}

* Ciberacoso (Childnet International - Cyber Bullying). Caso de ciberbullying subtitulado español.https://www.youtube.com/watch?v=9bgdOuBn4Q4

* Ciberbullying: ciberacoso en redes sociales, videogames, smartphones... y su prevención.https://www.youtube.com/watch?v=SEC dOWFN5M\&index=1\&list= PLC186BF9FE0418ED2

* ¿Cómo actuar ante el ciberacoso? Ignora, bloquea, pide ayuda y denuncia. https://www.youtube.com/watch?v=tVAjiyNzYq0\&list=PLC186BF9FE0418ED2 \&index $=7$

* Recomendaciones para el Uso Seguro de Internet y las Redes Sociales. https://www.youtube.com/watch?v=t$\underline{x 73 w 1 N 1 \text { os\&list=PLC186BF9FE0418ED2\&index }=12}$

* ¿Cómo evitar ser víctima de ciberbullying por suplantación de identidad? https://www.youtube.com/watch?v=XQeFYgedVZg\&list=PLC186BF9FE0418ED2 \&index $=15$

* Decálogo por la ciberconvivencia positiva y contra la violencia digital. https://www.youtube.com/watch?v=gXvG53ccyJY\&index=17\&list=PLC186BF9FE 0418ED2 
Fitxa de registre

\begin{tabular}{|c|c|c|}
\hline $\begin{array}{c}\text { Número de activitat } \\
\text { realitzada }\end{array}$ & Assignatura & Curs \\
\hline & & \\
\hline & & \\
\hline & & \\
\hline & & \\
\hline & & \\
\hline & & \\
\hline & & \\
\hline & & \\
\hline & & \\
\hline & & \\
\hline & & \\
\hline & & \\
\hline & & \\
\hline & & \\
\hline & & \\
\hline
\end{tabular}




\section{ÍNDICE}

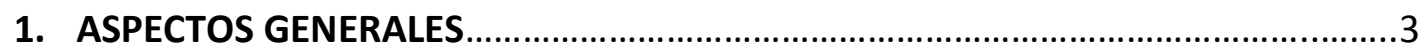

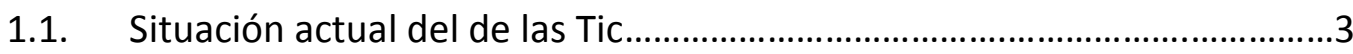

1.2. Conductas de riesgo en el uso de las Tic....................................................4

1.3. Uso de las Tic por parte de los jóvenes.....................................................4

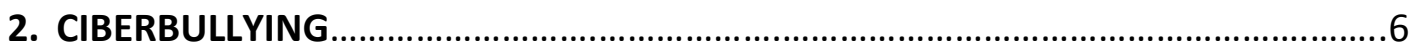

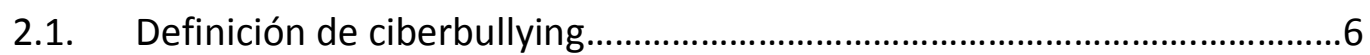

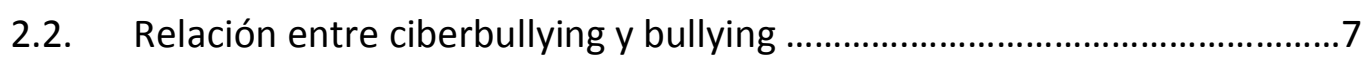

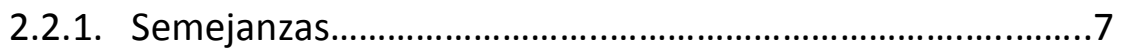

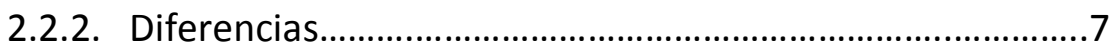

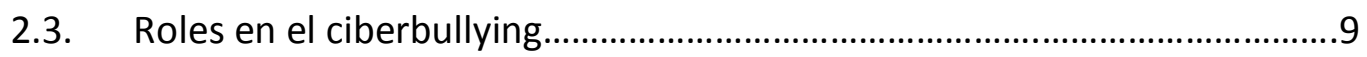

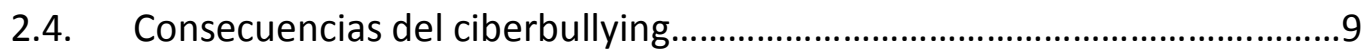

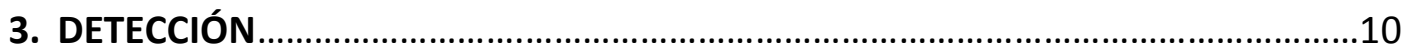

3.1. Formas de acoso que se pueden concretar en el ciberbullying ...............10

3.2. Manifestaciones más frecuentes en el ciberbullying................................10

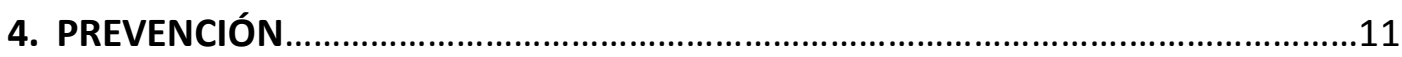

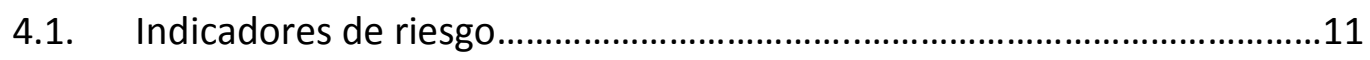

4.2. Ayudar a los menores en la prevención......................................................12

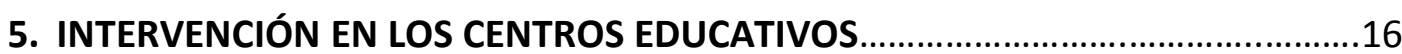

6. PROTOCOLO DE ACTUACIÓN EN EL CENTRO EDUCATIVO...................................20 
ANEXO 14. CUESTIONARIO CEE PARA EL SEGUNDO CICLO DE EDUCACIÓN PRIMARIA.

\section{Cuestionario de Educación Emocional (CEE)}

$3^{3}$ y $4 \stackrel{0}{ }$ Educación Primaria

Nombre y apellidos:

Edad: $\quad$ Género: Chico $\square \quad$ Chica $\square$

Centro:

Curso:

Responde con sinceridad a las siguientes preguntas. Para ello, piensa en ti antes de responder. Coloca una $\mathrm{X}$ en la casilla que tú consideres más adecuada.

\begin{tabular}{|c|c|c|c|c|c|}
\hline & & Nunca & $\begin{array}{l}\text { Algunas } \\
\text { veces }\end{array}$ & $\begin{array}{c}\text { Con } \\
\text { frecuencia }\end{array}$ & Siempre \\
\hline 1 & Estoy satisfecho de lo que aprendo en la escuela. & & & & \\
\hline 2 & Cuando tengo un problema intento resolverlo. & & & & \\
\hline 3 & $\begin{array}{l}\text { Me vienen ideas a la cabeza que no me dejan } \\
\text { dormir por la noche. }\end{array}$ & & & & \\
\hline 4 & $\begin{array}{l}\text { Me gusta explicar mis problemas a otras personas } \\
\text { de confianza }\end{array}$ & & & & \\
\hline 5 & Me siento bien conmigo mismo. & & & & \\
\hline 6 & $\begin{array}{l}\text { Cuando tengo un problema valoro todas las } \\
\text { posibles soluciones para poder escoger la mejor. }\end{array}$ & & & & \\
\hline 7 & Pienso que mi salud es buena. & & & & \\
\hline 8 & $\begin{array}{l}\text { Si mis amigos están preocupados yo también me } \\
\text { siento preocupado. }\end{array}$ & & & & \\
\hline 9 & $\begin{array}{l}\text { Cuando resuelvo un problema pienso cosas como: } \\
\text { ¡Estupendo!, ilo he conseguido!, ihe sido capaz } \\
\text { de..., etc. }\end{array}$ & & & & \\
\hline 10 & $\begin{array}{l}\text { Cuando cometo una estupidez, me siento tan mal } \\
\text { que deseo que me trague la tierra. }\end{array}$ & & & & \\
\hline 11 & $\begin{array}{l}\text { Cuando tengo un problema, procuro tener claro qué } \\
\text { es lo que pasa. }\end{array}$ & & & & \\
\hline 12 & $\begin{array}{l}\text { Me siento muy mal cuando los demás "critican" lo } \\
\text { que hago. }\end{array}$ & & & & \\
\hline 13 & Me gusto tal y como soy físicamente. & & & & \\
\hline 14 & $\begin{array}{l}\text { Antes de tomar una decisión pienso en sus ventajas } \\
\text { e inconvenientes. }\end{array}$ & & & & \\
\hline 15 & Me siento triste sin ningún motivo. & & & & \\
\hline 16 & A mi familia les gusta cómo soy. & & & & \\
\hline 17 & $\begin{array}{l}\text { Aprendo de cómo los demás resuelven sus } \\
\text { problemas. }\end{array}$ & & & & \\
\hline 18 & Pienso seriamente que no vale la pena vivir. & & & & \\
\hline 19 & $\begin{array}{l}\text { Cuando tengo un problema pienso en diversas } \\
\text { soluciones para resolverlo. }\end{array}$ & & & & \\
\hline 20 & $\begin{array}{l}\text { Tengo miedo a equivocarme cuando hago cualquier } \\
\text { cosa. }\end{array}$ & & & & \\
\hline 21 & Noto fácilmente si tengo un problema. & & & & \\
\hline 22 & $\begin{array}{l}\text { Me parece que soy culpable cuando algo no me } \\
\text { sale bien. }\end{array}$ & & & & \\
\hline 23 & Noto si los demás están de buen o mal humor & & & & \\
\hline 24 & Estoy satisfecho con lo que tengo. & & & & \\
\hline
\end{tabular}


ANEXO 14. CUESTIONARIO CEE PARA EL SEGUNDO CICLO DE EDUCACIÓN PRIMARIA.

\begin{tabular}{|l|l|l|l|l|l|}
\cline { 3 - 5 } \multicolumn{2}{l|}{} & Nunca & $\begin{array}{l}\text { Algunas } \\
\text { veces }\end{array}$ & $\begin{array}{l}\text { Con } \\
\text { frecuencia }\end{array}$ & Siempre \\
\hline 25 & $\begin{array}{l}\text { Me tomo el tiempo suficiente para analizar con } \\
\text { detalle cada problema que me preocupa. }\end{array}$ & & & & \\
\hline 26 & $\begin{array}{l}\text { Me siento unas veces alegre y otras tristes, sin } \\
\text { saber por qué. }\end{array}$ & & & & \\
\hline 27 & Me desanimo mucho cuando algo me sale mal. & & & & \\
\hline 28 & $\begin{array}{l}\text { Acostumbro a saber qué pasos dar para } \\
\text { solucionar mis problemas. }\end{array}$ & & & & \\
\hline 29 & Me siento harto de todo. & $\begin{array}{l} \\
\text { problema a la que no haya podido resolver un busco otras soluciones } \\
\text { para conseguirlo. }\end{array}$ & & & \\
\hline 31 & Tengo en cuenta los sentimientos de los demás. & & & & \\
\hline 32 & Me siento satisfecho de las cosas que hago. & & & & \\
\hline 33 & Pienso que la vida es triste. & & & & \\
\hline 34 & $\begin{array}{l}\text { Me considero popular entre los chicos y chicas } \\
\text { de mi clase. }\end{array}$ & & & & \\
\hline 35 & Me pongo muy nervioso fácilmente. & & & & \\
\hline 36 & $\begin{array}{l}\text { Me siento cansado y desanimado sin ningún } \\
\text { motivo. }\end{array}$ & & & & \\
\hline 37 & Me siento una persona feliz. & & & & \\
\hline
\end{tabular}

\section{Gracias por tu participación.}


ANEXO 15. CUESTIONARIO CEE PARA EL TERCER CICLO DE EDUCACIÓN PRIMARIA.

\section{Cuestionario de Educación Emocional (CEE)}

5 ํ y $6^{\circ}$ Educación Primaria

Nombre y apellidos:

Edad: $\quad$ Género: Chico $\square \quad$ Chica $\square$

Centro:

Curso:

Responde con sinceridad a las siguientes preguntas. Para ello, piensa en ti antes de responder. Coloca una $\mathrm{X}$ en la casilla que tú consideres más adecuada.

\begin{tabular}{|c|c|c|c|c|c|}
\hline & & Nunca & $\begin{array}{l}\text { Algunas } \\
\text { veces }\end{array}$ & $\begin{array}{c}\text { Con } \\
\text { frecuencia }\end{array}$ & Siempre \\
\hline 1 & Cuando tengo un problema intento resolverlo. & & & & \\
\hline 2 & $\begin{array}{l}\text { Me vienen ideas a la cabeza que no me dejan } \\
\text { dormir por la noche. }\end{array}$ & & & & \\
\hline 3 & Soy cariñoso con los demás. & & & & \\
\hline 4 & $\begin{array}{l}\text { Me gusta explicar mis problemas a otras personas } \\
\text { de confianza }\end{array}$ & & & & \\
\hline 5 & $\begin{array}{l}\text { Tengo facilidad para empezar a hablar con alguien } \\
\text { a quien quiero conocer. }\end{array}$ & & & & \\
\hline 6 & $\begin{array}{l}\text { Tengo la sensación de que a mis compañeros/as } \\
\text { les gusta estar conmigo. }\end{array}$ & & & & \\
\hline 7 & $\begin{array}{l}\text { Cuando tengo un problema valoro todas las } \\
\text { posibles soluciones para poder escoger la mejor. }\end{array}$ & & & & \\
\hline 8 & $\begin{array}{l}\text { Cuando me dicen que he hecho algo muy bien me } \\
\text { quedo cortado. }\end{array}$ & & & & \\
\hline 9 & $\begin{array}{l}\text { Si mis amigos están preocupados yo también me } \\
\text { siento preocupado. }\end{array}$ & & & & \\
\hline 10 & $\begin{array}{l}\text { Cuando cometo una estupidez, me siento tan mal } \\
\text { que deseo que me trague la tierra. }\end{array}$ & & & & \\
\hline 11 & $\begin{array}{l}\text { Me pongo muy nervioso cuando tengo que hablar } \\
\text { delante de toda la clase. }\end{array}$ & & & & \\
\hline 12 & $\begin{array}{l}\text { Cuando tengo algún problema, pido ayuda a mis } \\
\text { padres. }\end{array}$ & & & & \\
\hline 13 & $\begin{array}{l}\text { Cuando tengo un problema, procuro tener claro } \\
\text { qué es lo que pasa. }\end{array}$ & & & & \\
\hline 14 & $\begin{array}{l}\text { Me siento muy mal cuando los demás "critican" lo } \\
\text { que hago. }\end{array}$ & & & & \\
\hline 15 & $\begin{array}{l}\text { Cuando veo que he molestado a alguien procuro } \\
\text { pedir perdón. }\end{array}$ & & & & \\
\hline 16 & $\begin{array}{l}\text { Antes de tomar una decisión pienso en sus } \\
\text { ventajas e inconvenientes. }\end{array}$ & & & & \\
\hline 17 & Me siento triste sin ningún motivo. & & & & \\
\hline 18 & $\begin{array}{l}\text { Estoy satisfecho de las relaciones que tengo con } \\
\text { mis familiares. }\end{array}$ & & & & \\
\hline 19 & $\begin{array}{l}\text { Aprendo de cómo los demás resuelven sus } \\
\text { problemas. }\end{array}$ & & & & \\
\hline 20 & Pienso seriamente que no vale la pena vivir. & & & & \\
\hline 21 & Soy una persona amable. & & & & \\
\hline 22 & $\begin{array}{l}\text { Cuando tengo un problema pienso en diversas } \\
\text { soluciones para resolverlo. }\end{array}$ & & & & \\
\hline
\end{tabular}


ANEXO 15. CUESTIONARIO CEE PARA EL TERCER CICLO DE EDUCACIÓN PRIMARIA.

\begin{tabular}{|c|l|l|l|l|l|}
\cline { 3 - 5 } \multicolumn{2}{l|}{} & Nunca & $\begin{array}{l}\text { Algunas } \\
\text { veces }\end{array}$ & $\begin{array}{l}\text { Con } \\
\text { frecuencia }\end{array}$ & Siempre \\
\hline 23 & $\begin{array}{l}\text { En general, me cuesta dirigirme a los profesores } \\
\text { para comentarles alguna cosa. }\end{array}$ & & & & \\
\hline 24 & $\begin{array}{l}\text { Tengo miedo a equivocarme cuando hago } \\
\text { cualquier cosa. }\end{array}$ & & & & \\
\hline 25 & Noto fácilmente si tengo un problema. & & & & \\
\hline 26 & Noto si los demás están de buen o mal humor & & & \\
\hline 27 & $\begin{array}{l}\text { Me tomo el tiempo suficiente para analizar con } \\
\text { detalle cada problema que me preocupa. }\end{array}$ & & & \\
\hline 28 & $\begin{array}{l}\text { Me siento unas veces alegre y otras tristes, sin } \\
\text { saber por qué. }\end{array}$ & & & \\
\hline 29 & Participo bastante en los trabajos en grupo. & & & \\
\hline 30 & $\begin{array}{l}\text { Acostumbro a saber qué pasos dar para } \\
\text { solucionar mis problemas. }\end{array}$ & & & \\
\hline 31 & Me siento harto de todo. & & & \\
\hline 32 & $\begin{array}{l}\text { En el caso de que no haya podido resolver un } \\
\text { problema a la primera, busco otras soluciones } \\
\text { para conseguirlo. }\end{array}$ & & & \\
\hline 33 & Tengo en cuenta los sentimientos de los demás. & & & \\
\hline 34 & Pienso que la vida es triste. & & & \\
\hline 35 & Cuando pienso diferente a los demás me callo. & & & \\
\hline 36 & Si me enfado con alguien se lo digo. & & & \\
\hline 37 & $\begin{array}{l}\text { Participo en las actividades que se organizan en } \\
\text { la población donde vivo. }\end{array}$ & & & & \\
\hline 38 & $\begin{array}{l}\text { Hablar con los demás me resulta bastante } \\
\text { complicado, hablo poco y encima me da "corte". }\end{array}$ & & & & \\
\hline 39 & $\begin{array}{l}\text { Si alguien que no conozco se intenta colar, le } \\
\text { digo educadamente que espere su turno. }\end{array}$ & & & & \\
\hline 40 & $\begin{array}{l}\text { Me cuesta hablar con personas a quienes } \\
\text { conozco poco. }\end{array}$ & & & \\
\hline 41 & Me pongo muy nervioso fácilmente. & & \\
\hline 42 & $\begin{array}{l}\text { Procuro felicitar a los demás cuando hacen algo } \\
\text { bien. }\end{array}$ & & & \\
\hline 43 & $\begin{array}{l}\text { Me siento cansado y desanimado sin ningún } \\
\text { motivo. }\end{array}$ & & & \\
\hline 44 & $\begin{array}{l}\text { Sonrío o saludo a los conocidos que me } \\
\text { encuentro. }\end{array}$ & & & \\
\hline 45 & $\begin{array}{l}\text { Me cuesta hablar de mis sentimientos con } \\
\text { amigos o amigas. }\end{array}$ & & & \\
\hline 46 & Me siento una persona feliz. & & \\
\hline
\end{tabular}

\section{Gracias por tu participación.}


ANEXO 16. CUESTIONARIO ESCACIBER.

\section{Escala de evaluación de la Calidad de la Ciberconducta: EsCaCiber}

(Del Rey, Sánchez, Ortega y Casas, 2011)

\begin{tabular}{|l|}
\hline Fecha: \\
\hline Centro: \\
\hline Curso: \\
\hline Sexo: $\quad \square$ Chico $\square$ Chica \\
\hline
\end{tabular}

¿Qué plataformas sociales y herramientas utilizas?
Facebook
Tuenti
Twitter
Instagram $\square$ WhatsApp

Si utilizas otras, escribe cuales:

\begin{tabular}{|l|c|c|c|}
\hline $\begin{array}{l}\text { 1. Cuando publico algo de una persona (fotos, videos, nombres), } \\
\text { le pido permiso. }\end{array}$ & SI & A VECES \\
\hline $\begin{array}{l}\text { 2. Antes de comentar o criticar sobre alguien pienso en el daño } \\
\text { que puedo hacerle. }\end{array}$ & SI & NO & A VECES \\
\hline $\begin{array}{l}\text { 3. Me dirijo a los demás con respeto. } \\
\text { 4. Mis profesores nos ayudan a hacer un uso adecuado de las } \\
\text { redes sociales. }\end{array}$ & SI & NO & A VECES \\
\hline $\begin{array}{l}\text { 5. Mis padres me ayudan a hacer un uso adecuado de las redes } \\
\text { sociales. }\end{array}$ & SI & NO & A VECES \\
\hline $\begin{array}{l}\text { 6. Mi perfil está abierto solo para mis amigos. } \\
\text { 7. Cuando estoy enfadado con algún amigo me desconecto o no } \\
\text { le contesto. }\end{array}$ & SI & NO & A VECES \\
\hline $\begin{array}{l}\text { 8. Subo fotos mías para que mis contactos sepan cómo estoy y } \\
\text { lo que hago. }\end{array}$ & SI & NO & A VECES \\
\hline \begin{tabular}{l} 
9. Me enfado cuando no puedo usar Internet. \\
10. Utilizo la seguridad que existe en las redes sociales. \\
\hline generan en las redes sociales.
\end{tabular} & SI & NO & A VECES \\
\hline
\end{tabular}


ANEXO 16. CUESTIONARIO ESCACIBER.

\begin{tabular}{|c|c|c|c|}
\hline $\begin{array}{l}\text { 12. Estoy en permanente contacto con mis amigos para } \\
\text { sentirme apoyado. }\end{array}$ & $\mathrm{SI}$ & NO & A VECES \\
\hline $\begin{array}{l}\text { 13. Mis profesores hacen actividades para que usemos las } \\
\text { nuevas tecnologías. }\end{array}$ & SI & NO & A VECES \\
\hline 14. Cuando no puedo utilizar Internet me aburro. & $\mathrm{SI}$ & NO & A VECES \\
\hline $\begin{array}{l}\text { 15. Mis padres controlan el uso que hago de las nuevas } \\
\text { tecnologías. }\end{array}$ & SI & NO & A VECES \\
\hline 16. Actualizo el perfil de mi red social. & $\mathrm{SI}$ & NO & A VECES \\
\hline $\begin{array}{l}\text { 17. Mis padres me ayudan a resolver problemas que me } \\
\text { suceden en las redes sociales. }\end{array}$ & $\mathrm{SI}$ & NO & A VECES \\
\hline $\begin{array}{l}\text { 18. Hago cosas con mis padres en Internet (búsqueda de } \\
\text { información, jugar, visitar perfiles,...). }\end{array}$ & $\mathrm{SI}$ & NO & A VECES \\
\hline 19. Dejo las cosas sin hacer por conectarme a las redes sociales. & SI & NO & A VECES \\
\hline 20. Utilizo las redes sociales para hablar con mis amigos. & SI & NO & A VECES \\
\hline $\begin{array}{l}\text { 21. No acepto todas las solicitudes de amistad o invitaciones } \\
\text { que me llegan. }\end{array}$ & $\mathrm{SI}$ & NO & A VECES \\
\hline 22. Hablo con mis amigos a través de las redes sociales. & $\mathrm{SI}$ & NO & A VECES \\
\hline 23. Subo a las redes sociales fotografías de mis amigos. & $\mathrm{SI}$ & NO & A VECES \\
\hline 24. Necesito ver mi perfil todos los días. & $\mathrm{SI}$ & NO & A VECES \\
\hline $\begin{array}{l}\text { 25. Mis profesores controlan el uso que hacemos de las nuevas } \\
\text { tecnologías. }\end{array}$ & $\mathrm{SI}$ & NO & A VECES \\
\hline 26. Mis amigos están agregados a todas mis redes sociales. & SI & NO & A VECES \\
\hline $\begin{array}{l}\text { 27. Visito todos los días los perfiles de mis amigos para ver sus } \\
\text { novedades. }\end{array}$ & SI & NO & A VECES \\
\hline 28. Visito solo el perfil de gente que conozco. & $\mathrm{SI}$ & NO & A VECES \\
\hline $\begin{array}{l}\text { 29. Si me siento agredido, trato de responder de forma calmada } \\
\text { y no violenta. }\end{array}$ & SI & NO & A VECES \\
\hline 30. Utilizo un buen antivirus para proteger mi ordenador. & $\mathrm{SI}$ & NO & A VECES \\
\hline
\end{tabular}


ANEXO 17. INSTRUMENTO DE EVALUACIÓN PEDAGÓGICA PARA EL ALUMNADO DE 3 DE EDUCACIÓN PRIMARIA.

\section{QÜESTIONARI FINAL}

\section{3r de Primària}

Edat:

Gènere: Xic $\square \quad$ Xica $\square$

A continuació trobaràs una sèrie de qüestions amb tres possibles respostes. Llegeix detingudament i assenyala l'opció que s'acosti més al que tu penses. No et preocupis per les respostes que marques, no hi ha respostes correctes o incorrectes, només ens interessa la teva opinió.

1. A l'hora de conèixer a algú és important ...

Tots som igual de bons i importants encara que siguem diferents.

$\square$ Si algú té una característica diferent a la resta no pot ser igual de bo i important que ells.

Alguns són millors que altres.

2. Per a sentir-te bé amb tu mateix cal...

$\square$ Fixar-te només en les coses bones que t'agraden de tu.

$\square$ No fer cas a les coses que no t'agraden de tu.

$\square$ Fixar-te en les coses bones que tens i intentar canviar, si vols, les que no t'agraden.

3. Quan estàs en una situació que no t'agrada res...

$\square$ Estar trist o enfadat està malament, hem d'estar sempre contents.

$\square$ Estar trist o enfadat és una cosa normal i no passa res.

$\square$ Tots estaran igual que jo perquè tots sentim el mateix.

4. Quan estàs molt enfadat/da...

$\square$ He d'explicar als altres com em sento i així podran entendre com estic.

$\square$ He de cridar o plorar perquè tots sàpiguen que estic enfadat.

$\square$ No he de explicar-ho a ningú, no cal parlar amb la resta de com em sento.

5. Quan estàs en una situació desagradable o et passa una cosa dolenta...

$\square$ He de fer el primer que se m'acut sense pensar, l'important és fer alguna cosa ràpid.

$\square$ He de pensar en quines coses puc fer i pensar que passaria si les faig.

$\square$ En eixes situacions difícils totes les respostes són adequades. 
6. En una situació en què sents molta ràbia per alguna cosa que t'han fet..

Cal discutir amb la persona que ens ha fet sentir ràbia perquè li quedi clar el que ha fet.

Cal expressar amb crits la ràbia perquè tots sàpiguen el que ha passat.

$\square$ He de relaxar-me i estar tranquil/tranquil.la abans de dir o fer alguna cosa.

7. Quan estic amb el meu grup de companys al pati...

A vegades hi ha situacions difícils perquè alguns pensen o volen fer alguna cosa diferent que la resta

Tot és fàcil sempre perquè sempre estem d'acord en tot.

$\square$ Sempre hi ha situacions difícils perquè cada un vol fer una cosa.

8. Quan ens barallem entre els companys...

$\square$ Ens fa sentir bé perquè diem el que volem.

$\square$ Ens posem nerviosos i ens sentim malament.

$\square$ Fem nous amics d'entre els companys que estan del nostre costat.

9. Quan estàs amb l'ordinador, la tauleta o el mòbil...

$\square$ És bo estar totes les hores lliures que tinc amb ells perquè és molt divertit.

$\square$ Utilitzar-tota l'estona no és bo perquè fa que no pugui quedar amb els meus amics.

Utilitzar-los a totes hores és bo perquè podem parlar amb els nostres amics per missatges i no cal quedar amb ells.

10. Les noves tecnologies com l'ordinador, la tauleta o el mòbil...

Són sempre positives perquè fa que ens concentrem més i que siguem més creatius.

Són molt negatives per a nosaltres, no hem d'utilitzar-les mai.

$\square$ Tenen coses bones per a nosaltres però cal anar amb compte perquè també poden ser dolentes per a la salut. 
ANEXO 18. INSTRUMENTO DE EVALUACIÓN PEDAGÓGICA PARA EL ALUMNADO DE 4 DE EDUCACIÓN PRIMARIA.

\section{QÜESTIONARI FINAL}

4rt de Primària

Edat: $\quad$ Gènere: Xic $\square \quad$ Xica $\square$

A continuació trobaràs una sèrie de qüestions amb tres possibles respostes. Llegeix detingudament i assenyala l'opció que s'acosti més al que tu penses. No et preocupis per les respostes que marques, no hi ha respostes correctes o incorrectes, només ens interessa la teva opinió.

\section{Quan ens fixem en com som ...}

Hi ha companys que només tenen coses bones i altres que només tenen coses que no m'agraden.

Tots tenim coses bones però també coses que no ens agraden.

$\square$ Els defectes o coses que no ens agraden (com ser antipàtic) no es poden canviar mai.

2. Quan algú ens diu coses bones sobre nosaltres...

Cal escoltar-los bé perquè ens ajuden a recordar tot allò bo que tenim.

No és important, només és important si ens diuen coses que no els agrada de nosaltres

No hem de fer cas, segur que és mentida i ho diuen perquè estiguem contents.

3. Quan estic amb un company o un amic ...

Mirant la cara i els moviments d'algú no podem saber com se sent. Ens ho ha de dir.

$\square$ És important saber si està trist o content per comprendre el que fa o el que diu.

No té res a veure com se sent un company amb el seu comportament a classe $o$ al pati.

4. Les persones tenim emocions diferents però...

Tots ens sentim sempre igual, si jo estic content els meus companys estan contents, si jo estic trist tots estan tristos també.

Quan algun amic o company se sent malament, està trist, enfadat o té por, nosaltres no podem dir-li res que pugui fer-li sentir millor.

Si penso que em passa a mi el que li ha passat a algun company podré entendre millor com se sent.

5. Quan sentim ràbia o estem molt enfadats...

Responem sempre malament (cridant, insultant o plorant), i no es pot evitar.

Si em tranquil|litzo abans de dir o fer alguna cosa, podré respondre d'una millor manera.

És normal sentir-se malament i no podem fer res per a canviar-ho. 
ANEXO 18. INSTRUMENTO DE EVALUACIÓN PEDAGÓGICA PARA EL ALUMNADO DE 4 DE EDUCACIÓN PRIMARIA.

6. Quan parlo amb algú ...

És important el que li dic, és igual la cara i els gestos que faig mentre l'hi dic.

$\square$ És el mateix que jo li digui alguna cosa a algú cridant o en veu baixeta, la qüestió és dir-li-ho.

$\square$ Si dic una cosa bonica però poso mala cara mentre ho dic, a l'altra persona li pot sentar malament.

7. Quan estic parlant amb el meu grup d'amics o de companys ...

Si no m'interessa el tema del que parlen, m'espero a que acabin i ja després parlarem d'una altra cosa.

$\square$ Quan m'ha passat alguna cosa interessant I'hi explico a tots sense deixar que ningú més parli perquè no em interrompin.

Sempre parlem els mateixos perquè no deixem que parlin els que només diuen tonteries.

8. Quan busques informació a Internet hi ha que...

Consultar les primeres pàgines web que surten perquè són les més fiables.

Ser conscients que no tota la informació que hi ha a la xarxa és real.

No cal explicar als pares tot el que busquem, no ens deixarien entrar en alguns llocs i ens perdríem informació.

9. Quan estem en Internet cal...

Contestar els missatges de gent que no coneixem és una bona manera de fer amics nous.

Posar les nostres dades personals en els jocs perquè sigui més real i ens acceptin més ràpidament

Si ens toca un premi a l'entrar en alguna pàgina, pensar que pot ser una manera d'enganyar-nos.

10. Si mentre estàs a Internet hi ha alguna cosa que et fa sentir malament o algú et demana alguna cosa...

Cal explicar-ho a un adult.

Si no ho expliquem a ningú, ningú ho sabrà i serà com que no ha passat.

Contar-li a un amic o company el que el que ha passat. 
ANEXO 19. INSTRUMENTO DE EVALUACIÓN PEDAGÓGICA PARA EL ALUMNADO DE 5 DE EDUCACIÓN PRIMARIA.

\section{QÜESTIONARI FINAL}

\section{5è de Primària}

Edat: $\quad$ Gènere: Xic $\square \quad$ Xica $\square$

A continuació trobaràs una sèrie de qüestions amb tres possibles respostes. Llegeix detingudament i assenyala l'opció que s'acosti més al que tu penses. No et preocupis per les respostes que marques, no hi ha respostes correctes o incorrectes, només ens interessa la teva opinió.

1. Quan un amic es sent trist nosaltres hem de...

No fer-li cas, ja li passarà.

$\square$ Pensar com estaríem nosaltres si ens passés el mateix que a ell i així sabrem millor què li passa.

Dir-li que no es preocupi, que això no és important, que això els passa a tots.

2. Compartir els nostres sentiments amb els altres...

$\square$ És bo perquè ajuda a que ens entenguin millor quan ens sentim malament.

$\square$ És un error perquè el millor és no contar a ningú com ens sentim.

$\square$ No és bo perquè pot ser es riguin de nosaltres.

3. Si un amic o company et diu que fages alguna cosa que no vols fer...

Ho faig perquè és el meu amic o company i m'ho ha demanat.

Li dic que no em pareix bé però després faig el que hem diu.

$\square$ Li dic que no ho faré per què no estic d'acord i li explico els motius.

4. Quan una persona ens diu alguna cosa bonica sobre nosaltres cal...

No contestar-li res, mirar-li i ja està.

Agrair el comentari bo i fer-li veure que t'agrada el que et diu.

Dir-li que segur que ens ho està dient per a quedar bé.

5. Estarem davant d'un cas de ciberbullying quan ...

Parlem per WhatsApp o altres aplicacions amb companys i amics.

Compartim informació nostra a les xarxes socials.

$\square$ Compartim vídeos o imatges gracioses però humiliants d'algú pel mòbil 
ANEXO 19. INSTRUMENTO DE EVALUACIÓN PEDAGÓGICA PARA EL ALUMNADO DE 5 DE EDUCACIÓN PRIMARIA.

6. Si sofrim ciberbullying o coneixem alguna persona que ho està sofrint hem de...

$\square$ No contar-li a ningú el que passa perquè ningú s'assabenti.

Contar-li a un amic o company el que està passant.

Avisar a un adult i contar-li el que està passant.

7. Quan tenim problemes amb els companys o els amics i ens barallem...

$\square$ Hem d'aprendre a evitar eixes situacions perquè no ens aporten res positiu.

És una situació comuna i és normal que diguem el primer que se'ns passi pel cap.

$\square$ És bo que discutim i ens barallem perquè així mostrem a tots el que pensem.

8. Solucionar els problemes que tenim parlant amb l'altre...

Parlant amb l'altre aconseguirem que el problema sigui més gran. És millor deixar-ho passar.

$\square$ Ens ajudarà a entendre millor als altres i que els altres ens entenguin millor a nosaltres.

No serveix per a res perquè si jo penso d'una manera i l'altre d'una altra, parlant sorgiran més problemes.

9. Quan parlem amb gent per l'ordinador, la tableta o el mòbil, fem coses que ens poden posar en un problema. Una cosa que no hem de fer és...

Ignorar a algú que no coneixem encara que ell ens digui que sí que ens coneix. Això és de mala educació.

Dir el nostre nom, on estudiem, on vivim, ..., ja que com més ens coneguin, més amics tindrem a Internet.

Demanar permís a algú abans de penjar una foto seva graciosa, ens dirà que no i no podrem penjar-la.

10. Quan estem amb l'ordinador, la tauleta o el mòbil, hem de tenir en compte que...

No passa res per estar connectat més estona del que ens diuen els nostres pares. Són uns exagerats.

Si tots ens burlem d'una foto d'un company, per a nosaltres serà divertit, però per al company serà molt dur i ho passarà malament.

$\square$ A Internet és impossible que una persona es faci passar per una altra persona que no és. 
ANEXO 20. INSTRUMENTO DE EVALUACIÓN PEDAGÓGICA PARA EL ALUMNADO DE 60 DE EDUCACIÓN PRIMARIA.

\title{
QÜESTIONARI FINAL
}

6è de Primària

\author{
Edat: $\quad$ Gènere: Xic $\square \quad$ Xica $\square$
}

A continuació trobaràs una sèrie de qüestions amb tres possibles respostes. Llegeix detingudament i assenyala l'opció que s'acosti més al que tu penses. No et preocupis per les respostes que marques, no hi ha respostes correctes o incorrectes, només ens interessa la teva opinió.

1. Quan un company o un amic ens diu que està trist o preocupat hem de...

Dir-li que no té perquè sentir-se així, que el seu problema no és tant important.

Dir-li que entenem el que li passa i animar-li.

No dir res, ja se li passarà. Nosaltres no podem fer res.

2. Quan a un company de classe li treuen l'entrepà, li trenquen el material o no el conviden a una festa d'aniversari,...

A mi em seria igual així que a ell segur que també li és igual.

No podem saber mai com se sent, això només ho sap cada un, i llavors no li podem dir res.

Si se sent malament hem de animar-lo i ajudar-lo encara que per nosaltres sigui una ximpleria el que li ha passat.

3. Si un company et demana que facis alguna cosa que no vols fer i no la fas...

Em sento avergonyit per no haver-ho fet.

Em sento bé perquè no estava bé fer-ho i tant me fa el que ell em digui.

Em sento preocupat per si s'enfada amb mi i em diu alguna cosa.

4. Quan estic parlant amb els meus amics per Internet, he de tindre en compte que...

Quan envio un missatge o penjo alguna foto, després el puc esborrar i ningú ho podrà veure.

Abans de penjar fotos meves he de comprovar que només ho comparteixo amb amics i coneguts meus.

He de respondre a tots els missatges que m'envien, sobretot els ofensius.

5. Quan estem en el nostre grup d'amics o companys i no estem d'acord amb alguna cosa que diuen o volen fer...

Cal queixar-nos i dir-los tranquil.lament el que no ens agrada.

És millor no dir cap cosa, segur que si diem alguna cosa es fiquen amb nosaltres.

Cal queixar-nos i cridant i enfadats perquè sàpiguen que no ens agrada. 
ANEXO 20. INSTRUMENTO DE EVALUACIÓN PEDAGÓGICA PARA EL ALUMNADO DE 60 DE EDUCACIÓN PRIMARIA.

6. Si algú s'està ficant amb tu $\mathrm{o}$ amb un amic teu a Internet hem de ...

Contestar els missatges on es fiquen amb nosaltres perquè vegin que no tenim por.

Esborrar tots els missatges que ens han enviat i no contar-ho a ningú, així tot s'acabarà.

Explicar-li a un adult el que ens està passant.

7. Si quan tens un problema et costa molt decidir què és el millor que pots fer...

$\square$ Actuar de manera ràpida, fent el que se'ns passi primer pel cap, si triguem a fer alguna cosa després és més difícil.

$\square$ Has de buscar varies solucions al problema i pensar quina és la més adequada.

$\square$ El millor és no fer res i esperar que tot passi.

8. Si pensem bé les coses abans de prendre una decisió...

La gent pensarà que sóc indecís o ximple perquè trigo molt a decidir què faig.

Encara que pensem les coses no podem saber mai què serà millor, no podem endevinar què passarà.

La gent confiarà més en mi perquè s'adonaran que penso bé les coses abans de fer-les.

9. Utilitzar Internet per compartir coses amb altra gent és molt fàcil i divertit, però una cosa important que hem de fer és...

Comprovar amb qui estic compartint la informació, és a dir, qui pot veure el que penjo.

Donar-li la nostra contrasenya a algun amic o company per si se'ns oblida.

Si algú em molesta o m'envia missatges estranys, no està bé bloquejar-perquè a mi no m'agradaria que em bloquegessin.

10. Les noves tecnologies (l'ordinador, la tauleta o el mòbil) són molt divertides i cal tenir en compte que ...

$\square$ Si algú està tot el dia connectat i quan no està se sent angoixat i té mal humor, és normal perquè és el que més li agrada.

$\square$ Si estem tot el dia connectats podem tenir problemes de salut i problemes amb la gent que ens envolta.

Hem d'estar sempre connectats si no podem no contestar a algú a temps i perdre amics. 
ANEXO 21. INSTRUMENTO DE EVALUACIÓN PEDAGÓGICA DOCENTE.

\section{FITXA D'AVALUACIÓ PER AL PROFESSOR/A DE LES ACTIVITATS DEL BLOC D'AUTOESTIMA}

1. Com t'ha resultat dur a terme les tasques segons les indicacions exposades en les fitxes? Molt difícil $\square \quad$ Difícil $\square \quad$ Normal $\square \quad$ Fàcil $\square \quad$ Molt fàcil $\square$

2. Creus que es compleix l'objectiu proposat? Sí $\square \quad$ No $\square$

3. Has introduït les activitats al contingut curricular assenyalat o en algun altre? T emes indicats $\square \quad$ Altres $\square$ (indica quins:

4. Has utilitzat altres recursos a part dels que apareixen a la fitxa? Sí $\square \quad$ No $\square$

5. ¿Faries alguna modificació de millora en les fitxes per assolir els objectius de manera més òptima? Sí $\square \quad$ No $\square$ (en cas afirmatiu, indica quina:

6. Com s'han sentit els alumnes en realitzar les activitats? (motivació, implicació, interacció amb altres, ....)

7. Hi ha algun aspecte que consideres oportú comenta per a la millora del programa? 
ANEXO 22. RESULTADOS DE LA EVALUACIÓN PEDAGÓGICA DEL ALUMNADO DE 3 DE EDUCACIÓN PRIMARIA.

\begin{tabular}{|c|c|c|c|c|c|c|c|c|c|c|c|}
\hline \multirow{2}{*}{ Alumno } & \multicolumn{10}{|c|}{ Items } & \multirow[b]{2}{*}{ Nota } \\
\hline & 1 & 2 & 3 & 4 & 5 & 6 & 7 & 8 & 9 & 10 & \\
\hline 1 & C & 1 & C & C & C & C & $C$ & $C$ & C & C & 9 \\
\hline 2 & C & $C$ & C & C & $C$ & C & 1 & $C$ & C & C & 9 \\
\hline 3 & $C$ & $C$ & $C$ & $C$ & $C$ & $C$ & $C$ & $C$ & $C$ & $C$ & 10 \\
\hline 4 & C & C & C & C & 1 & C & C & C & C & C & 9 \\
\hline 5 & $\mathrm{C}$ & $\mathrm{C}$ & $\mathrm{C}$ & $\mathrm{C}$ & $\mathrm{C}$ & $C$ & $C$ & $C$ & $C$ & $C$ & 10 \\
\hline 6 & $C$ & $C$ & 1 & $C$ & 1 & $C$ & 1 & $C$ & $C$ & $C$ & 7 \\
\hline 7 & $C$ & C & C & 1 & $C$ & $C$ & 1 & C & $C$ & $C$ & 8 \\
\hline 8 & $\mathrm{C}$ & $C$ & $C$ & $\mathrm{C}$ & $C$ & $C$ & $C$ & $C$ & $\mathrm{C}$ & $C$ & 10 \\
\hline 9 & $C$ & $C$ & $C$ & $C$ & $C$ & $C$ & $C$ & $C$ & 1 & $C$ & 9 \\
\hline 10 & $C$ & $C$ & $C$ & $C$ & $C$ & $C$ & 1 & $C$ & $C$ & $C$ & 9 \\
\hline 11 & $C$ & $C$ & $C$ & $\mathrm{C}$ & 1 & $\mathrm{C}$ & $\mathrm{C}$ & $\mathrm{C}$ & $C$ & $\mathrm{C}$ & 9 \\
\hline 12 & $C$ & $C$ & $C$ & 1 & $C$ & $C$ & $C$ & $C$ & $C$ & $C$ & 9 \\
\hline 13 & $C$ & C & 1 & $C$ & $C$ & $C$ & $C$ & $C$ & $C$ & $C$ & 9 \\
\hline 14 & $C$ & $C$ & 1 & $C$ & $C$ & $C$ & 1 & $C$ & $C$ & $C$ & 8 \\
\hline 15 & C & $C$ & $C$ & $C$ & $C$ & C & $C$ & 1 & $C$ & $C$ & 9 \\
\hline 16 & $C$ & $C$ & $C$ & $C$ & 1 & $C$ & $C$ & $C$ & 1 & $C$ & 8 \\
\hline 17 & $C$ & $C$ & $C$ & $C$ & 1 & $C$ & $C$ & $C$ & $C$ & $C$ & 9 \\
\hline 18 & $C$ & $C$ & $C$ & $C$ & $C$ & 1 & $C$ & $C$ & $C$ & $C$ & 9 \\
\hline $\begin{array}{l}\% \\
\text { Correctas }\end{array}$ & $100 \%$ & $94 \%$ & $83 \%$ & $89 \%$ & $72 \%$ & $94 \%$ & $72 \%$ & $94 \%$ & $89 \%$ & $100 \%$ & \\
\hline \multicolumn{11}{|c|}{ Nota media } & 8,89 \\
\hline
\end{tabular}


ANEXO 23. RESULTADOS DE LA EVALUACIÓN PEDAGÓGICA DEL ALUMNADO DE 4 DE EDUCACIÓN PRIMARIA.

\begin{tabular}{|c|c|c|c|c|c|c|c|c|c|c|c|}
\hline \multirow{2}{*}{ Alumno } & \multicolumn{10}{|c|}{ Items } & \multirow[b]{2}{*}{ Nota } \\
\hline & 1 & 2 & 3 & 4 & 5 & 6 & 7 & 8 & 9 & 10 & \\
\hline 1 & $C$ & C & $C$ & C & C & C & $C$ & $C$ & $C$ & C & 10 \\
\hline 2 & C & C & C & C & C & C & C & C & C & C & 10 \\
\hline 3 & $C$ & $C$ & 1 & $C$ & $C$ & $C$ & $C$ & $C$ & $C$ & $C$ & 9 \\
\hline 4 & $C$ & $C$ & 1 & $C$ & $\mathrm{C}$ & $\mathrm{C}$ & $\mathrm{C}$ & $C$ & $C$ & $\mathrm{C}$ & 9 \\
\hline 5 & 1 & $C$ & $C$ & C & C & 1 & 1 & $C$ & $C$ & C & 7 \\
\hline 6 & $C$ & $C$ & $C$ & $C$ & $C$ & $C$ & $C$ & 1 & $C$ & $C$ & 9 \\
\hline 7 & $C$ & $\mathrm{C}$ & $C$ & 1 & $C$ & $C$ & 1 & $C$ & $\mathrm{C}$ & $C$ & 8 \\
\hline 8 & 1 & $C$ & 1 & $C$ & $\mathrm{C}$ & 1 & $C$ & $C$ & $C$ & $C$ & 7 \\
\hline 9 & $C$ & $C$ & $C$ & 1 & $C$ & $C$ & $C$ & $C$ & $C$ & $C$ & 9 \\
\hline 10 & C & C & C & $C$ & $C$ & $\mathrm{I}$ & $\mathrm{I}$ & C & $C$ & $C$ & 8 \\
\hline 11 & $C$ & $C$ & $\mathrm{C}$ & $C$ & $C$ & $C$ & $\mathrm{C}$ & $C$ & $\mathrm{C}$ & $C$ & 10 \\
\hline 12 & $C$ & $C$ & $C$ & 1 & C & $C$ & $C$ & $C$ & $C$ & $C$ & 9 \\
\hline 13 & C & C & C & C & C & C & 1 & C & C & C & 9 \\
\hline 14 & 1 & $C$ & $C$ & $C$ & $\mathrm{C}$ & $C$ & 1 & 1 & $C$ & $C$ & 7 \\
\hline 15 & $C$ & $C$ & $C$ & $C$ & $C$ & 1 & $C$ & 1 & $C$ & $C$ & 8 \\
\hline 16 & C & C & 1 & $C$ & $C$ & $\mathrm{I}$ & $C$ & $C$ & $C$ & $C$ & 8 \\
\hline 17 & $C$ & $C$ & $C$ & $\mathrm{C}$ & $\mathrm{C}$ & $\mathrm{C}$ & $\mathrm{C}$ & 1 & $C$ & $\mathrm{C}$ & 9 \\
\hline 18 & $C$ & $C$ & $C$ & 1 & $C$ & $C$ & $C$ & $C$ & $C$ & $C$ & 9 \\
\hline 19 & C & C & C & 1 & $C$ & $C$ & $C$ & $\mathrm{I}$ & $\mathrm{I}$ & $C$ & 7 \\
\hline 20 & $C$ & $C$ & $\mathrm{C}$ & $C$ & $C$ & 1 & $C$ & $C$ & 1 & $C$ & 8 \\
\hline $\begin{array}{l}\% \\
\text { Correctas }\end{array}$ & $85 \%$ & $100 \%$ & $80 \%$ & $75 \%$ & $100 \%$ & $70 \%$ & $75 \%$ & $75 \%$ & $90 \%$ & $100 \%$ & \\
\hline \multicolumn{11}{|c|}{ Nota media } & 8,5 \\
\hline
\end{tabular}

$\mathrm{C}=$ correcta

$\mathrm{I}=$ incorrecta 
ANEXO 24. RESULTADOS DE LA EVALUACIÓN PEDAGÓGICA DEL ALUMNADO DE 5 DE EDUCACIÓN PRIMARIA.

\begin{tabular}{|c|c|c|c|c|c|c|c|c|c|c|c|}
\hline \multirow{2}{*}{ Alumno } & \multicolumn{10}{|c|}{ Items } & \multirow[b]{2}{*}{ Nota } \\
\hline & 1 & 2 & 3 & 4 & 5 & 6 & 7 & 8 & 9 & 10 & \\
\hline 1 & C & 1 & C & C & C & C & C & C & 1 & C & 8 \\
\hline 2 & $C$ & $C$ & $C$ & C & C & $C$ & 1 & C & C & $C$ & 9 \\
\hline 3 & C & C & C & C & C & 1 & C & C & C & C & 9 \\
\hline 4 & C & C & 1 & $C$ & $C$ & C & C & $C$ & $C$ & C & 9 \\
\hline 5 & $C$ & $C$ & $C$ & $C$ & $C$ & C & C & C & C & I & 9 \\
\hline 6 & C & C & 1 & C & C & C & C & $\mathrm{I}$ & C & C & 8 \\
\hline 7 & C & C & C & C & C & C & C & $C$ & C & $C$ & 10 \\
\hline 8 & 1 & C & C & C & C & C & C & C & 1 & C & 8 \\
\hline 9 & C & 1 & C & C & C & C & C & C & C & C & 9 \\
\hline 10 & C & $C$ & $C$ & $C$ & $\mathrm{C}$ & $C$ & $C$ & $\mathrm{C}$ & $C$ & $\mathrm{C}$ & 10 \\
\hline 11 & C & C & C & C & C & C & 1 & C & C & C & 9 \\
\hline 12 & $\mathrm{I}$ & C & C & C & C & C & C & $\mathrm{I}$ & C & C & 8 \\
\hline 13 & C & 1 & 1 & C & C & C & C & C & 1 & C & 7 \\
\hline 14 & C & C & C & C & C & C & C & C & C & C & 10 \\
\hline 15 & C & C & C & C & C & C & C & 1 & C & C & 9 \\
\hline 16 & $C$ & $C$ & $C$ & $C$ & $C$ & $C$ & $C$ & $C$ & $C$ & $C$ & 10 \\
\hline 17 & 1 & C & C & C & C & C & C & C & 1 & C & 8 \\
\hline 18 & C & C & C & C & C & C & C & C & C & C & 10 \\
\hline 19 & $C$ & $C$ & $C$ & C & C & C & $C$ & C & 1 & $C$ & 9 \\
\hline 20 & C & C & C & C & C & C & C & 1 & C & C & 9 \\
\hline 21 & $C$ & $C$ & $C$ & C & $C$ & C & C & C & $C$ & $C$ & 10 \\
\hline 22 & $C$ & $C$ & 1 & $C$ & $C$ & $C$ & $C$ & $C$ & $C$ & $C$ & 9 \\
\hline 23 & C & C & C & C & C & C & 1 & I & C & C & 8 \\
\hline $\begin{array}{l}\text { \% } \\
\text { Correctas }\end{array}$ & $87 \%$ & $87 \%$ & $83 \%$ & $100 \%$ & $100 \%$ & $96 \%$ & $87 \%$ & $78 \%$ & $78 \%$ & $96 \%$ & \\
\hline \multicolumn{11}{|c|}{ Nota media } & 8,91 \\
\hline
\end{tabular}

$\mathrm{C}=$ correcta

$\mathrm{I}=$ incorrecta 
ANEXO 25. RESULTADOS DE LA EVALUACIÓN PEDAGÓGICA DEL ALUMNADO DE 60 DE EDUCACIÓN PRIMARIA.

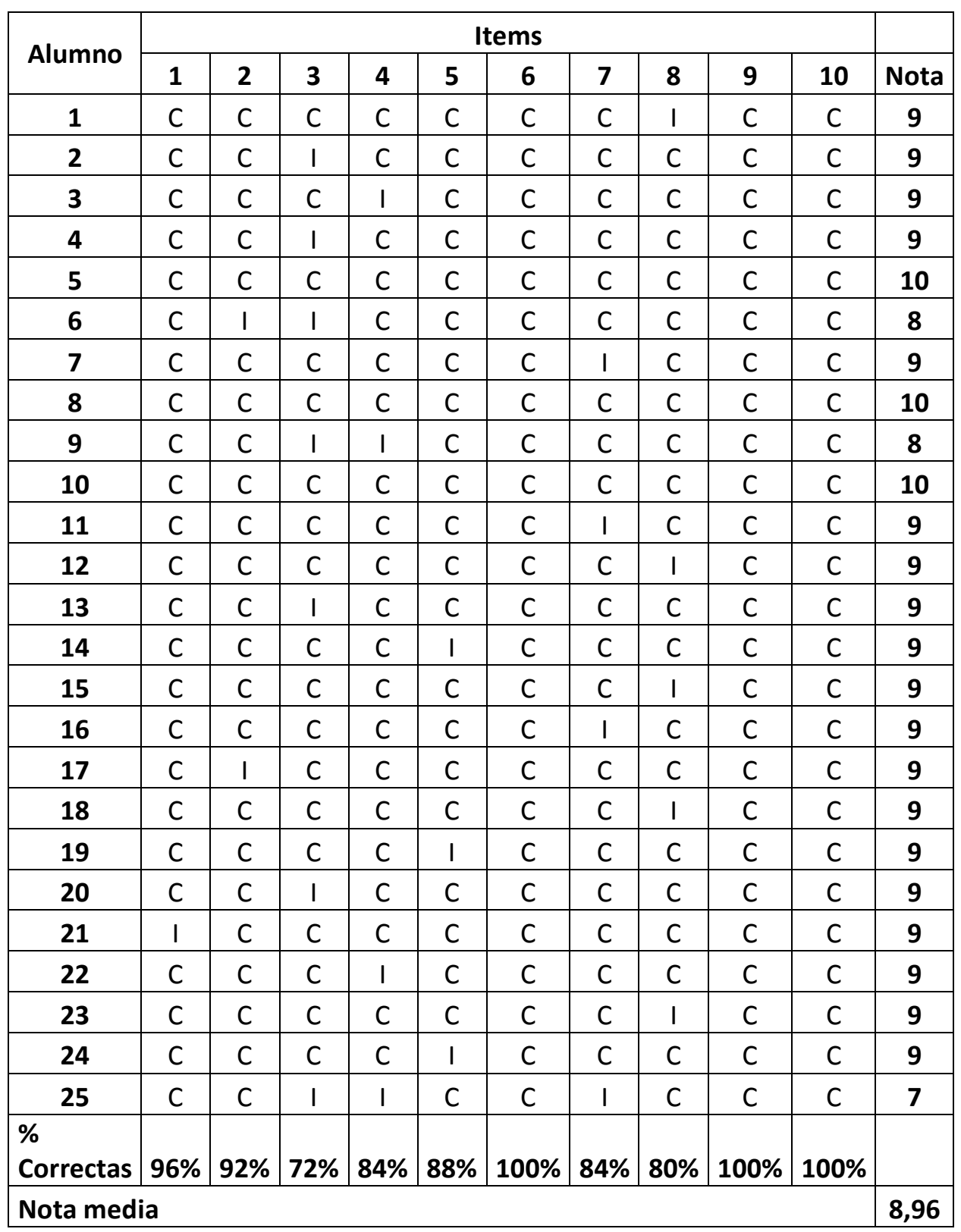

$\mathrm{C}=$ correcta

$\mathrm{I}=$ incorrecta 